Pontifícia Universidade Católica

Ana Cristina Prado de Oliveira

\title{
As relações entre Direção, Liderança e Clima Escolar em escolas municipais do Rio de Janeiro
}

Tese de Doutorado

Tese apresentada como requisito parcial para obtenção do título de Doutor pelo Programa de Pós-Graduação em Educação da PUC-Rio.

Orientadora: Prof ${ }^{a}$. Cynthia Paes de Carvalho Co-Orientadora: Prof ${ }^{a}$ Fátima Cristina de Mendonça Alves

Rio de Janeiro Setembro de 2015 


\section{Ana Cristina Prado de Oliveira}

\section{“As relações entre Direção, Liderança e Clima Escolar em escolas municipais do Rio de Janeiro"}

Tese apresentada como requisito parcial para obtenção do grau de Doutor pelo Programa de Pósgraduação em Educação do Departamento de Educação do Centro de Teologia e Ciências Humanas da PUC-Rio. Aprovada pela Comissão Examinadora abaixo assinada.

Prof‥ Cynthia Paes de Carvalho

Orientadora Departamento de Educação - PUC-Rio

Profª. Fátima Cristina de Mendonça Alves

Co-Orientadora Departamento de Educação - PUC-Rio

Profa . Maria Inês G. F. Marcondes de Souza Departamento de Educação - PUC-Rio

Profa . Alícia Maria Catalano de Bonamino Departamento de Educação - PUC-Rio.

Prof ${ }^{a}$. Mariana Campelo Koslinski UFRJ

Prof. Ângelo Ricardo Souza UFPR

Profa Denise Berruezo Portinari

Coordenadora Setorial do Centro de Teologia e Ciências Humanas da PUC-Rio

Rio de Janeiro, 15 de Setembro de 2015 
Todos os direitos reservados. É proibida a reprodução total ou parcial do trabalho sem autorização da universidade, da autora e do orientador.

\section{Ana Cristina Prado de Oliveira}

Graduou-se em Pedagogia pela Universidade Federal de Minas Gerais e possui Especialização em Teoria e Prática Piagetiana pela Unicamp. Concluiu o Mestrado em Educação na Pontifícia Universidade Católica do Rio de Janeiro em 2012. Na área educacional, sua experiência e atuação se relacionam principalmente aos seguintes temas: currículo, avaliação, aprendizagem, letramento, gestão e clima escolar. Desde 2012 é pesquisadora do grupo de pesquisa Gestão e Qualidade da Educação - GESQ com o foco em gestão da escola e qualidade do ensino público, tendo publicado artigos nesta temática, nacional e internacionalmente. Atuou profissionalmente na Educação Básica por 17 anos, como professora, Coordenadora Pedagógica e tutora em cursos de Formação Continuada para professores.

Ficha Catalográfica

Oliveira, Ana Cristina Prado de

As relações entre direção, liderança e clima escolar em escolas municipais do Rio de Janeiro / Ana Cristina Prado de Oliveira ; orientadora: Cynthia Paes de Carvalho ; co-orientadora: Fátima Cristina de Mendonça Alves. - 2015.

284 f. : il. (color.) ; $30 \mathrm{~cm}$

Tese (doutorado)-Pontifícia Universidade Católica do Rio de Janeiro, Departamento de Educacão, 2015. 
Àqueles diretores e professores das escolas públicas brasileiras que conseguem, a despeito dos inúmeros desafios que enfrentam, garantir que seus alunos aprendam. 


\section{Agradecimentos}

Inicialmente, agradeço à minha orientadora, Prof. ${ }^{a}$ Cynthia Paes de Carvalho, pelo cuidado, estímulo e confiança na condução desse trabalho, que se traduziu em tantas outras parcerias; e à minha co-orientadora, Prof. a Fátima Alves, que de longe, conseguiu ser presença essencial para as nossas reflexões.

Às Professoras Mariane Koslinski, Alícia Bonamino e Maria Inês Marcondes que compuseram a minha banca, pela oportunidade de interlocução e reflexões sobre este trabalho. Especialmente agradeço ao Professor Ângelo Souza, presente desde a qualificação do Projeto, pela leitura atenta e valiosas contribuições, fundamentais para este trabalho.

Aos professores do Programa de Pós-Graduação em Educação da PUC-Rio, pela competência do trabalho desenvolvido no âmbito da pesquisa em educação compartilhada em um rico ambiente acadêmico.

Ao CNPq e à PUC-Rio, pelos auxílios concedidos, sem os quais este trabalho não poderia ter sido realizado.

Aos amigos pesquisadores do GESQ, parceiros em tantos desafios e reflexões.

Aos gestores das Coordenadorias Regionais de Educação da SME/RJ, diretores, coordenadores e professores das escolas que participaram desta pesquisa, pela receptividade e ricas experiências compartilhadas.

Às professoras Maria de Lourdes Pessoa Carloni e Mércia Almeida, por terem sido referências importantes para minhas primeiras reflexões sobre a importância da gestão escolar.

Aos meus pais, por tudo! Especialmente por terem me proporcionado oportunidades infinitas de crescimento emocional e intelectual. Aos meus sogros, Gilda, Nelson e Lígia, pelo apoio acadêmico e estrutural. E aos meus irmãos, cunhados e amigos pela torcida.

Especialmente, agradeço meu marido, André, pelo companheirismo, parceria e incentivo (sem os quais eu não teria conseguido concluir este trabalho), pelas reflexões e leituras cuidadosas e, sobretudo, por estar sempre por perto! E à Luiza, Felipe e Marina, pela ajuda, paciência e, nos momentos mais difíceis da escrita, por cuidarem uns dos outros e por me lembrarem que há um mundo além do computador... Amo vocês infinito! 


\section{Resumo}

Oliveira, Ana Cristina Prado de Oliveira; Paes de Carvalho, Cynthia. As relações entre Direção, Liderança e Clima Escolar em escolas municipais do Rio de Janeiro. Rio de Janeiro, 2015. 284 p. Tese de Doutorado - Departamento de Educação, Pontifícia Universidade Católica do Rio de Janeiro.

Considerando a centralidade do papel desempenhado pelo diretor escolar na condução da tarefa educativa da escola, este trabalho procura ampliar a discussão sobre as relações que podem ser estabelecidas entre a atuação do diretor e o trabalho docente, considerando os resultados dos alunos. A função do diretor escolar é analisada desde sua expressão política e de suas atribuições legais, tomando como referência analítica os conceitos de gestão escolar, liderança e clima escolar. Para tanto, uma ampla revisão bibliográfica sobre o tema foi realizada. O campo definido para a pesquisa considerou as escolas municipais do Rio de Janeiro que atendiam, em 2014, aos dois segmentos do ensino fundamental. A realização de um estudo exploratório com os dados disponibilizados pela Prova Brasil apontou possíveis relações entre a liderança do diretor e os resultados de aprendizagem dos alunos, porém, foram levantadas algumas limitações na utilização destes dados. Assim, este trabalho propõe a complementaridade das metodologias quantitativa e qualitativa em uma abordagem teórico-conceitual do tema. Com o objetivo de ampliar a possibilidade de acesso a informações que levassem à reflexão sobre as questões propostas por esta pesquisa, foram elaborados novos questionários dirigidos a diretores, coordenadores e professores. Os questionários foram testados e aplicados a uma amostra de 42 escolas, sendo sua validação completada a partir da construção de índices adequados para a mensuração dos diferentes aspectos que compõem as relações entre a atuação do diretor e o trabalho docente, considerando os resultados dos alunos. Com estes índices, uma modelagem exploratória foi realizada para averiguar as possíveis associações entre as dimensões estudadas, apontando a importância da percepção dos professores sobre a direção escolar (em diferentes variáveis) para a qualidade de seu trabalho e para a aprendizagem dos alunos. A partir da análise dos dados, foram selecionadas duas escolas da amostra para um retorno ao campo em uma abordagem qualitativa, envolvendo entrevistas e observação do cotidiano da 
gestão da escola (shadowing) e possibilitando o aprofundamento das relações apontadas pelo estudo quantitativo com vistas ao aprimoramento dos nossos instrumentos de pesquisa. Destaca-se que, no caso desta pesquisa, os dados pareceram indicar que a atuação presente do diretor, especialmente na construção e manutenção de um clima adequado ao trabalho escolar, é um fator significativo para a qualidade do trabalho docente e para a proficiência dos alunos. A fase qualitativa da pesquisa apontou duas diferentes formas de atuação do diretor na construção deste clima escolar, envolvendo suas estratégias de gestão e suas características de liderança construídas em cada contexto. Em síntese, o trabalho procura contribuir para a discussão sobre as características do trabalho do diretor e suas possíveis relações com o trabalho docente e a proficiência discente por três vias: 1) na realização de uma meta-análise, incluindo a revisão estruturada das recentes pesquisas sobre o tema; 2) da proposição e testagem de um novo instrumento de coleta de dados quantitativos sobre a gestão e o clima escolar; 3) da apresentação dos resultados de um estudo exploratório com os dados coletados, indicando importantes indícios para futuras pesquisas sobre as questões levantadas.

\section{Palavras Chave}

Direção escolar; Liderança; Gestão Escolar; Clima Escolar. 


\section{Abstract}

Oliveira, Ana Cristina Prado de Oliveira; Paes de Carvalho, Cynthia (Advisor). The relationship between Principals, Leadership and School Environment in the municipal schools of Rio de Janeiro. Rio de Janeiro, 2015. 284 p. Doctoral Thesis - Departamento de Educação, Pontifícia Universidade Católica do Rio de Janeiro.

Given the pivotal role played by the school principal in conducting the school's educational task, this study aimed at broadening the discussion on the relationships that can be established between the principals' activity and both the teachers' work and the students' achievement. The role of the school principal was analyzed from the perspective of his/her political role and his/her legal duties, having as analytical reference the concepts of school management, leadership, and school climate. Therefore, a wide literature review on the topic was conducted. The proposed scope of research encompassed the municipal schools of Rio de Janeiro which in 2014 catered to both segments of elementary school. An exploratory study with data provided by Prova Brazil indicated possible relationships between the principal's leadership and the students' achievement; however, potential limitations in the use of this data were raised. This work used complementary quantitative and qualitative methodologies in a theoretical and conceptual approach to the topic. To broaden the access to information that supports the discussion of the questions posed by this research, new questionnaires targeted at principals, coordinators, and teachers were developed. The questionnaires were tested and subsequently applied to a sample of 42 schools, having then been validated through the construction of indices that adequately synthesize the different aspects of the relationships between the principals' activity and both the teachers' work, considering students' achievement. With these indices, an exploratory modeling was conducted to investigate possible associations between the dimensions studied, indicating the importance of the teachers' perception of school principalship (through different variables) for the quality of their work and for student achievement. From the data analysis, two schools in the sample were selected for a return to the field in a qualitative approach involving interviews and observation of the school 
management (shadowing), enabling a deeper understanding of the relationships identified by the quantitative study as well as gathering information for the improvement of the questionnaires. It is noteworthy that, in the case of this research, the data seemed to indicate that a proactive principal, specially creating a positive environment to academic practices, is an important element for both teaching quality and student learning. The qualitative approach pointed out two different ways in which the principal's actions build this "school climate", involving their leadership characteristics developed in each space. In summary, this study seeks to contribute to the discussion of the characteristics of the principal's work and its possible relationship with the teachers' work and student learning by: 1) conducting a meta-analysis, including the structured review of recent research on the topic; 2) proposing and testing a new quantitative data collection instrument, focused on school management and school climate; 3) presenting the results of an exploratory study with the data collected, having found important clues that help address the issues in future researches on the field.

\section{Keywords}

School Principals; School Leadership; School Management; School Climate. 


\section{Sumário}

1- Direção escolar e relações na escola: uma aproximação.

1.1 - O trabalho do diretor escolar em foco: gestão como fator de eficácia escolar

1.2 - Revisão de literatura: o que dizem as recentes pesquisas sobre o tema (e o que falta dizer)

1.3 - A complexidade do trabalho da direção escolar em contexto ............ 31

1.4 - Hipóteses, questões e objetivos: um desenho de pesquisa .............. 37

\section{2- O papel do Diretor na escola: a Gestão, a Liderança e o Clima}

Escolar.

2.1 - O diretor escolar: seus papéis e suas atribuições

2.2 - A Gestão e a Liderança no trabalho do diretor: a construção do Clima Escolar

3 - O campo: definindo o recorte de pesquisa

3.1 - Por que estudar as escolas que atendem os dois segmentos do ensino fundamental?

3.2 - Quantas e quais escolas?.

3.3 - Como são as escolas e quem são os seus diretores?

4 - Os instrumentos disponíveis: avanços e limitações

4.1 - Quem responde aos questionários contextuais da Prova Brasil dirigidos aos professores.

4.2 - Estrutura e evolução dos instrumentos e sua abordagem dos temas relacionados a esta pesquisa.

4.3 - Diretores e professores: o que é possível saber a partir dos dados disponíveis?

\section{5 - A construção dos questionários}

5.1 - Quadro de referência conceitual e operacionalização dos instrumentos

5.2 - Validação do instrumento

5.2.1 - O Pré-teste assistido

5.2.2 - A Validação dos pares: grupo de pesquisa

5.2.3 - A Validação de face

5.3 - Entre questionários online e impressos

6 - Diretores e Professores: novos olhares para esta relação

6.1 - Por dentro das escolas: primeiros contatos

6.2 - Entre o possível e o esperado: desafios na aplicação dos questionários e a construção de uma Subamostra.

6.3 - Dos itens aos índices: ampliando as possibilidades de mensuração

a partir dos dados coletados

6.4 - Diretores e professores: novos olhares a partir de um estudo exploratório 
7 - De volta ao campo: aprofundando a análise ................................. 160

7.1 - As Escolas L e S ....................................................................... 164

7.2 - Entre a "disciplina e a "acolhida": a construção do ambiente de aprendizagem ........................................................................................ 168

7.2.1 - O foco na disciplina …....................................................... 169

7.2.2 - A escola acolhedora ........................................................... 174

7.2.3 - Disciplinar ou acolher: um falso dilema? ................................. 182

7.3 - O direito de aprender: qual o olhar do diretor? ............................. 187

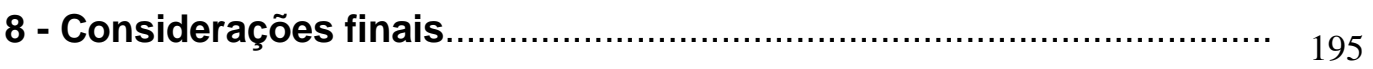

Referências Bibliográficas........................................................... 203

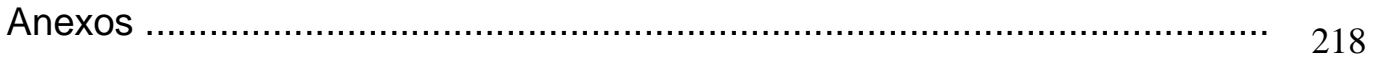




\section{Listas de Tabelas}

Tabela 1 - Distribuição, por dependência administrativa, das escolas avaliadas na

Prova Brasil 2013: Rio de Janeiro, São Paulo e Belo Horizonte.

Tabela 2 - Nível de Escolaridade dos Pais como proxy de NSE: Escolas

Selecionadas X Escolas municipais do Rio de Janeiro X Todas as escolas, Brasil

Tabela 3 - Nível de Proficiência em Matemática: Brasil X Escolas que atendem a somente um segmento do EF no município do Rio de Janeiro X Escolas Selecionadas

Tabela 4 - Tempo do diretor no cargo: Brasil X Escolas que atendem a somente um segmento do EF no município do Rio de Janeiro X Escolas Selecionadas

Tabela 5 - Acesso ao cargo de diretor: Brasil X Município do Rio de Janeiro X Escolas Selecionadas

Tabela 6 - Inexistência de professores: Brasil X Município do Rio de Janeiro X Escolas Selecionadas

Tabela 7 - Correlação entre o Índice de Satisfação no Trabalho (variável dependente) e a Indicação da faixa de idade dos professores (variável de controle)

Tabela 8 - Correlação entre o Índice de Satisfação no Trabalho (variável dependente) e o Índice de Reconhecimento do Trabalho da Direção

Tabela 9 - Correlação entre o Índice de Satisfação no Trabalho (variável dependente) e o Índice de Percepção do Ambiente Escolar

Tabela 10 - Correlação entre o Índice de Satisfação no Trabalho (variável dependente) e os Índices de Intervenção Pedagógica e de Interação do Diretor

Tabela 11 - Correlações entre as variáveis independentes incluídas nos modelos do Grupo 1

Tabela 12 - Síntese dos coeficientes dos modelos do Grupo 1

Tabela 13: Correlação e NSE e a Proficiência Média em Matemática dos alunos do $5^{\circ}$ ano

Tabela 14: Correlação entre o NSE e a Proficiência Média em Matemática dos alunos do $9 \circ$ ano

Tabela 15: Correlação entre a Proficiência Média em Matemática - $5^{\circ}$ ano (variável dependente) e o Índice de Reconhecimento do Trabalho da Direção

Tabela 16: Correlação entre a Proficiência Média em Matemática - 5ํano (variável dependente) e o Índice de Percepção do Ambiente Escolar

Tabela 17: Correlação entre a Proficiência Média em Matemática - 5ํano (variável dependente) e o Índice de Intervenção Pedagógica do Diretor

Tabela 18: Correlação entre a Proficiência Média em Matemática - 5ํano (variável dependente) e o Índice de Satisfação no Trabalho

Tabela 19:Síntese dos Coeficientes dos Modelos do Grupo 2

Tabela 20: Estratificação da amostra a partir da primeira referência: Proxy de NSE

Tabela 21: Referência para estratificação da amostra a partir da distribuição dos professores por escola

Tabela 22: Reestratificação da amostra a partir da segunda referência: 


\section{Listas de Quadros}

$\begin{array}{ll}\text { Quadro 1: Distribuição das escolas selecionadas entre as CREs/RJ } & 67\end{array}$

Quadro 2: Comparação entre o número de repostas aos questionários 77 contextuais da Prova Brasil 2013 e o número de professores por escola

Quadro 3: Comparação evolutiva do questionário contextual da Prova Brasil 78 dirigido aos diretores escolares

Quadro 4: Comparação evolutiva do questionário contextual da Prova Brasil 80 dirigido aos professores

Quadro 5: Cargas Fatoriais das Variáveis Relativas à Liderança do Diretor $\quad 84$

Quadro 6: Cargas Fatoriais das Variáveis Relativas ao Clima Escolar 85

Quadro 7: Variáveis Utilizadas no Modelo $\quad 87$

Quadro 8: Estatística Descritiva das Variáveis Utilizadas no Modelo 87

Quadro 9: Coeficientes do 1ํㅡㄹ Modelo Estimado (5ํano) 87

Quadro 10: Coeficientes do 2ํㅡㄴ Modelo Estimado (9ำ ano) 87

Quadro 11- Temas, conceitos e suas classificações 92

Quadro 12- Gestão e Liderança: suas especificações e operacionalização nos 97 instrumentos (Questionários do Diretor, do Coordenador e dos Professores )

Quadro 13: Clima Escolar: suas especificações e operacionalização nos 104 instrumentos (Questionários do Diretor, do Coordenador e dos Professores )

Quadro 14: Contexto: suas especificações e operacionalização nos instrumentos 108

(Questionário do Diretor, do Coordenador Pedagógico e dos Professores )

Quadro 15: Caracterização sócio demográfica: suas especificações e

operacionalização nos instrumentos (Questionário do Diretor, do Coordenador

Pedagógico e dos Professores )

Quadro 16: Cargas fatoriais das variáveis relativas à Intervenção Pedagógica do Diretor percebida pelo Diretor

Quadro 17: Cargas fatoriais das variáveis relativas à Intervenção Pedagógica do Diretor percebida pelo Professor

Quadro 18: Descrição sintética dos Índices e Indicadores

Quadro 19: Estatística descritiva das variáveis incluídas nos modelos - Grupo 1145

Quadro 20: Estatística descritiva das variáveis incluídas nos modelos - Grupo 2156

Quadro 21: Tempo de interação com os professores, Shadowing o diretor da 173

Escola L

Quadro 22: Tempo de interação com os professores, Shadowing o diretor da Escola S

Quadro 23: Categorização dos artigos selecionados na revisão de literatura 220

Quadro 24: SASS: Temas abordados no questionário dirigido ao diretor escolar 233

Quadro 25: Prova Brasil: Temas abordados no questionário dirigido ao diretor $\quad 234$ escolar

Quadro 26: Categorização do levantamento de Teses e Dissertações 
Quadro 27: Recodificação das respostas: Indicador da tendência da Gestão do Diretor

Quadro 28: Recodificação das respostas: Indicador de Interlocução

Quadro 29: Cargas Fatoriais das variáveis relativas à Participação Docente

Quadro 30: Cargas Fatoriais das variáveis relativas ao Monitoramento da Aprendizagem pelo Diretor

Quadro 31: Cargas Fatoriais das variáveis relativas à Influência do Diretor na

Liderança Pedagógica da Escola

Quadro 32: Cargas Fatoriais das variáveis relativas à Influência do Diretor na Liderança Administrativa da Escola

Quadro 33: Cargas Fatoriais das variáveis relativas à Influência do Professor na Liderança da Escola

Quadro 34: Cargas Fatoriais das variáveis relativas ao Reconhecimento dos Professores quanto ao trabalho da Direção

Quadro 35: Cargas Fatoriais das variáveis relativas à Percepção dos Diretores sobre o Ambiente Escolar

Quadro 36: Cargas Fatoriais das variáveis relativas à Percepção dos Professores sobre o Ambiente Escolar

Quadro 37: Cargas Fatoriais das variáveis relativas à Percepção dos Diretores sobre as Relações Interpessoais

Quadro 38: Cargas Fatoriais das variáveis relativas à Percepção dos Professores sobre as Relações Interpessoais

Quadro 39: Cargas Fatoriais das variáveis relativas à Percepção dos Diretores sobre as coesão e comprometimento dos Professores - EF1

Quadro 40: Cargas Fatoriais das variáveis relativas à Percepção dos Diretores sobre as coesão e comprometimento dos Professores - EF2

Quadro 41: Cargas Fatoriais das variáveis relativas à Percepção dos Professores sobre as coesão e comprometimento Docente

Quadro 42: Cargas Fatoriais das variáveis relativas à Percepção dos Diretores sobre o Alinhamento do trabalho Docente

Quadro 43: Cargas Fatoriais das variáveis relativas à Percepção dos Professore sobre a Interação do Diretor com o corpo docente

Quadro 44: Cargas Fatoriais das variáveis relativas à Percepção dos Diretores sobre sua Satisfação no Trabalho

Quadro 45: Cargas Fatoriais das variáveis relativas à Percepção dos Professores sobre sua Satisfação no Trabalho 


\section{Listas de Gráficos}

Gráfico 1: Número médio de alunos matriculados por escola 63

Gráfico 2: Número médio de turmas por escola 63

Gráfico 3: Número médio de professores por escola $\quad 64$

Gráfico 4: Correlação entre o Índice de Satisfação no Trabalho e variável Idade 136

Gráfico 5: Correlação entre o Índice de Satisfação no Trabalho e o índice de 138

Reconhecimento do Trabalho da Direção

Gráfico 6: Correlação entre o Índice de Satisfação no Trabalho e o Índice de 140

Percepção do Ambiente Escolar

Gráfico 7: Correlação entre o Índice de Satisfação no Trabalho e o Índice de 141 Intervenção Pedagógica do Diretor

Gráfico 8: Correlação entre o Índice de Satisfação no Trabalho e Índice de 142 Interação do Diretor

Gráfico 9: Correlação entre o NSE e a Proficiência Média em Matemática dos alunos do $5^{\circ}$ ano

Gráfico 10: Correlação entre o NSE e a Proficiência Média em Matemática dos alunos do $9^{\circ}$ ano

Gráfico 11: Correlação entre a Proficiência Média em Matemática - 5ํano e o Índice de Reconhecimento do Trabalho do Diretor

Gráfico 12: Correlação entre a Proficiência Média em Matemática - 5ํano e o Índice de Percepção do Ambiente Escolar

Gráfico 13: Correlação entre a Proficiência Média em Matemática - 5ํano e o

Índice de Intervenção Pedagógica do Diretor

Gráfico 14: Correlação entre a Proficiência Média em Matemática - 5ํano e o

Índice de Satisfação no Trabalho

Gráfico 15: Proficiência Média em Matemática (5aa) X NSE: subamostra

Gráfico 16: Proficiência Média em Matemática (5ํano) X Índice de

Reconhecimento do Trabalho da Direção: subamostra

Gráfico 17: Índice de Satisfação no Trabalho X Índice de Percepção do Ambiente

Escolar: subamostra

Gráficos 18 e 19: Evolução do IDEB na Escola L

166

Gráficos 20 e 21: Evolução do IDEB na Escola S

166

Gráficos 22 e 23: Fluxo Escolar, 2013 - 5 e 9o anos (\%)

Gráfico 24: Proficiência Média em Matemática - 5ำ ano: Brasil, Rio de Janeiro,

Escolas L e S

Gráfico 25: Proficiência Média em Matemática - 9o ano: Brasil, Rio de Janeiro, 


\section{Listas de Figuras}

Figura 1: Síntese da abordagem do tema nas recentes pesquisas nacionais, $2010-2014$

Figura 2: Síntese da abordagem do tema nas recentes pesquisas

internacionais, 2010 - 2014

Figura 3: Desenho geral da pesquisa

Figura 4: Os "mundos" do diretor

Figura 5: Síntese dos resultados do estudo exploratório: Survey GESQ 2014, subamostra 


\section{1.}

\section{Direção escolar e relações na escola: uma aproximação}

Que relações podem ser estabelecidas entre o trabalho desempenhado pelo diretor, o trabalho desenvolvido pelos professores e o desempenho escolar dos alunos? A apresentação deste trabalho se inicia com esta questão pois é a partir dela que toda a pesquisa foi estruturada. As características do trabalho do diretor escolar, especialmente sua relação com o corpo docente, é tema de meu interesse pessoal desde a minha própria experiência profissional (como integrante da equipe de gestão e professora na educação básica por vários anos) e acadêmica. A pesquisa desenvolvida durante o mestrado, que focalizou a prática docente no contexto da recente política educacional do município do Rio de Janeiro, apontou a atuação da equipe de gestão da escola (diretora, diretora adjunta e coordenadora pedagógica) como determinante na intermediação entre as orientações da Secretaria Municipal de Educação - SME/RJ e os professor, garantindo a adaptação à nova organização curricular e didática a serem incorporadas pela escola (OLIVEIRA, 2012). Algumas pistas e questões sobre a atuação da equipe responsável pela gestão da escola foram trazidas desta experiência, assim como o desejo de aprofundar o estudo sobre o tema. A inquietação e o desejo encontraram espaço de diálogo e aprofundamento nas leituras e discussões no âmbito do grupo de pesquisa Gestão e Qualidade da Educação - GESQ ${ }^{1}$, do qual passei a ser integrante em 2012 e no qual esta pesquisa se insere.

Proponho uma análise sobre o trabalho do diretor escolar a partir de sua relação com os professores, considerando sua função na gestão da escola e seu papel de liderança na condução do trabalho escolar. O primeiro movimento foi a partir da reflexão sobre os conceitos de liderança, gestão e clima escolar e sua articulação com os objetivos desta pesquisa. Um detalhado levantamento bibliográfico nos aproximou das pesquisas nacionais e internacionais que recentemente abordaram a relação descrita acima, objeto desta pesquisa. Esta aproximação nos apresentou diferentes formas de abordagem e operacionalização dos conceitos citados através de metodologias diversas de pesquisa. As contribuições deste estudo (apresentado nesta introdução e detalhadamente exposto nos

\footnotetext{
${ }^{1}$ O GESQ é um grupo de pesquisa do Departamento de Educação da PUC-Rio coordenado pela Prof. Dra. Cynthia Paes de Carvalho. Seu foco principal é estudar a gestão nas redes públicas de ensino, buscando analisar os fatores que contribuem para a melhoria da qualidade da educação. Suas atividades são desenvolvidas em duas frentes: políticas educacionais e arranjos institucionais das redes públicas de ensino; e a gestão das escolas em termos das relações entre os agentes escolares, alunos e famílias. Para mais informações: http://www.gesqpucrio.com.br/ .
} 
Anexos deste documento) constituem importante referência para futuras pesquisas sobre a temática.

Para o desenvolvimento desta pesquisa, nossa intenção foi investigar este tema (o trabalho do diretor escolar a partir de sua relação com os professores, considerando sua função na gestão da escola e seu papel de liderança) a partir de um amplo levantamento de dados. Assim, interessou-nos saber como os atuais surveys educacionais de alcance nacional o abordam. Para tanto, realizamos uma análise dos questionários dos questionários contextuais que acompanham as edições d Prova Brasil e desenvolvemos um estudo exploratório a partir de seus dados. Tendo em vista as limitações destes instrumentos no acesso às informações sobre o trabalho do diretor escolar (considerando sua dimensão de liderança, sua função na gestão da escola e sua relação com os professores) tomamos como decisão metodológica desenvolver um novo survey, elaborando novos instrumentos de coleta de dados. Desta forma, esta pesquisa optou por uma abordagem quanti-quali com um pressuposto conceitual-metodológico, ou seja, pretendemos discutir conceitualmente as questões levantadas mas, também, construir novos instrumentos metodológicos de pesquisa, elaborando, testando e aplicando novos questionários desenhados especificamente para este fim. Os questionários foram aplicados em um campo previamente definido de 42 escolas municipais do Rio de Janeiro. O trabalho estatístico com os dados construídos apontou importantes associações entre a percepção dos professores sobre o ambiente escolar, o nível de satisfação dos professores no trabalho e o resultado de aprendizagem dos alunos, entre outras. Para aprofundar a compreensão sobre estas associações, retornamos ao campo para o desenvolvimento de uma pesquisa qualitativa em duas unidades escolares (entrevistas e observação), que gerou insumos para aprimorarmos os instrumentos de pesquisa recém criados.

Esta pesquisa pretendeu, assim, trazer uma contribuição conceitual e metodológica para o campo, discutindo uma questão central ao campo educacional e apresentando novos instrumentos de coleta de dados. Ao analisarmos os dados coletados frente às questões levantadas, pretendemos também apontar novas formas para investigá-las. Esta tese de doutoramento apresenta este amplo percurso acadêmico e, mais do que apresentar seus resultados, propõe uma nova agenda de pesquisa sobre o trabalho do diretor no contexto escolar.

Esta introdução apresenta uma aproximação ao tema central da pesquisa, destacando sua relevância no campo educacional, incluindo os resultados da revisão de literatura realizada para esta pesquisa e o contexto político-educacional de atuação do diretor escolar na rede municipal de ensino do Rio de Janeiro, justificando a adequação da 
escolha do nosso campo. Em seguida, trazemos nossas questões, hipóteses e objetivos e apresentamos o desenho desta pesquisa.

\section{1 O trabalho do diretor escolar em foco: gestão como fator de eficácia escolar}

Desde a década de 1950, as pesquisas em Sociologia da Educação têm priorizado a busca de compreensão das desigualdades escolares. Diferentes fases orientaram as investigações no campo nas últimas décadas: o otimismo pedagógico, no período Pós II Guerra (todos têm igual oportunidade de aprender, o sucesso depende do mérito individual); o pessimismo pedagógico, alimentado pela leitura dos grandes surveys educacionais da década de 1960, como o Relatório Coleman (as características da origem social determinam o futuro acadêmico dos alunos e a escola não faz diferença); as teorias da reprodução, a partir dos anos 1960 e 1970 (o sistema escolar reproduz e legitima as diferenças sociais). Sobre esta fase, Nogueira (1990) nos alerta a respeito da distinção entre as teorias de reprodução cultural e as teorias de reprodução das relações sociais. O primeiro grupo (tendo como representantes Bourdieu, Passeron e seguidores) considera que a escola, em seu funcionamento reprodutor, tem certa independência em relação à vida material. Já o segundo grupo enfatiza a escola como aparelho de reprodução das relações sociais de produção (tem como representantes Althusser, Baudelot e Establet, entre outros) (op. cit., p.50).

De acordo com Forquin (1995), após passar por um período de crise em seus paradigmas teóricos e metodológicos, o campo da Sociologia da Educação passa a incorporar novos objetos e metodologias, especialmente na área educacional (estudos de caso em salas de aula, por exemplo). Algumas pesquisas começam, então a questionar as conclusões tomadas em estudos anteriores e a observar diferenças entre escolas. A partir de 1980/1990 se fortalecem as críticas ao determinismo e ao "hiperfuncionalismo" das teorias das fases anteriores. As investigações, neste caso, têm como alvo a identificação das diferenças relacionadas ao efeito das escolas nos resultados dos alunos, principalmente analisando suas características organizacionais e os processos escolares relacionados à aprendizagem. Esse conjunto de pesquisas fica conhecido como pesquisas em eficácia escolar e apontam que, se o background familiar tem um peso importante na definição do desempenho acadêmico do aluno, alguns fatores intraescolares poderiam minimizar o efeito da origem social, promovendo a eficácia e a equidade na oferta 
educacional (BROOKE e SOARES, 2008). Há, então, uma mudança de perspectiva do olhar sobre a escola: se antes ela não fazia diferença, diversos estudos (MORTIMORE et al., 1998; RUTTER et al., 1979; WILLMS,1992; entre outros) identificaram escolas que, apesar de atenderem alunos de origem social semelhante, apresentavam resultados discrepantes. Assim, reforçavam a hipótese de que o trabalho realizado pelas escolas poderia fazer, sim, diferença. E mais ainda, levantaram a expectativa de que aquelas escolas que atendem populações menos privilegiadas economicamente poderiam diminuir as diferenças decorrentes da origem familiar.

$\mathrm{Na}$ análise de possíveis relações entre o trabalho da escola e os resultados dos alunos há que se ressaltar a necessidade de controlar as características de Nível Socioeconômico - NSE do alunado. Contudo, ainda que se isolem as características de origem sociodemoráfica dos alunos, são inúmeras as outras variáveis extraescolares (de estrutura familiar, suporte dos pais aos estudos, território e convivência social do aluno, entre outras) que interferem na sua aprendizagem escolar ${ }^{2}$. Assim, ao analisar o trabalho escolar controlando a variável indicativa do NSE, isolamos um dos fatores extraescolares que, ainda que muito importante, não responde sozinho pelo sucesso ou fracasso escolar. A contribuição dos estudos sobre eficácia escolar consiste em focalizar os fatores intraescolares que poderiam incidir sobre o resultado de aprendizagem dos alunos, embora caiba assinalar que isolar completamente as características sociais dos alunos é tarefa improvável, inclusive porque elas interagem com os demais fatores.

Ainda que consideremos estes desafios postos à pesquisa, autores que buscaram mensurar o efeito dos fatores intraescolares indicam que entre 10 e $20 \%$ da variância nos resultados dos alunos poderia ser explicada por aspectos escolares, tendo controlado as variáveis indicativas das características de origem dos aluno (CREEMERS and REEZGIT, 1996, p. 203). Os autores, contudo, ressaltam que estes valores são referência para o hemisfério ocidental, sendo considerados percentuais indicativos. (op. cit. p. 203). Consideramos, assim, que o contexto socioeconômico em que a escola (ou conjunto de escolas) está inserida produz alterações na influência que os fatores escolares produzem para a aprendizagem de seus alunos. Um exemplo desta adaptação contextual foi apontado por Alves e Franco (2008) ao apresentarem a infraestrutura escolar como um importante fator de eficácia escolar no caso brasileiro, diferentemente do contexto norteamericano ou europeu:

Em muitos países, recursos escolares não são fatores de eficácia escolar. A razão disso é que o grau de equipamento e conservação das escolas não varia muito de

\footnotetext{
${ }^{2}$ Alguns trabalhos abordaram a influência deste fatores extraescolares para os resultados dos alunos. Ver, por exemplo, Ribeiro et al., 2010; Silva, 2013; Felipe, 2013.
} 
escola para escola. No Brasil, ainda temos bastante variabilidade nos recursos escolares com que contam as escolas [...].

A interpretação sobre o que caracteriza a escola como eficaz (normalmente esta eficácia vem sendo mensurada a partir dos resultados dos alunos em avaliações de larga escala), contudo, não é um consenso. Conceitos como eficácia, efetividade e eficiência vêm sendo utilizados no campo educacional, especialmente das políticas públicas, muitas vezes sem uma definição clara sobre a sua compreensão. Neste sentido, a tese de Isabelle Silva (2014), recém defendida na UFPR, traz uma importante contribuição para a discussão, ao realizar uma completa abordagem evolutiva do uso destes conceitos na área educacional. Sander (2005) faz uma crítica à busca exacerbada pela eficiência na prática escolar e questiona "o movimento internacional no campo das ciências sociais e administrativas que preconiza conceitos e práticas que muitas vezes valorizam a eficiência e a produtividade acima do próprio processo educativo que se realiza na escola e na sala de aula" (op. cit., p. 110). O autor chama a atenção para a tendência de se interpretar a eficácia ou a efetividade do trabalho escolar a partir de um parâmetro único, o resultado em uma avaliação ou índice de desempenho, ignorando outros aspectos fundamentais do trabalho escolar relacionados à formação humana e social dos alunos. Sander propõe uma interpretação da efetividade escolar relacionada à gestão educacional, a partir de uma perspectiva política e participativa "[...] segundo a qual a administração responde pelos seus atos em função das políticas e prioridades estabelecidas pelos participantes da comunidade" (SANDER, 2007, p. 80). Esta é uma importante consideração para pensarmos sobre a caracterização de uma escola enquanto eficaz: o que estamos considerando como característica de efetividade ou eficácia corresponde à expectativa de pais e alunos sobre o que é uma escola eficaz? A elevação na média dos resultados de aprendizagem dos alunos é uma comprovação de sua eficácia? Concordamos com Sander (2005, p. 111) em sua expectativa de que a consolidação de novas alternativas às práticas tradicionais de avaliação permitirá o desenvolvimento de metodologias mais compreensivas e participativas de avaliação institucional e de medida da eficácia escolar.

Ainda que a avaliação de desempenho dos alunos em escala nacional tenha sido um grande avanço para conhecermos o trabalho escolar desenvolvido no sistema educacional do país, é preciso ler os resultados apontados por estas avaliações como um dos indicativos da efetividade do trabalho escolar. Urge pensar em estratégias para verificar o quanto a elevação do resultado médio dos alunos repercute também em uma distribuição mais equitativa dos níveis de aprendizagem na escola, ou seja, a melhoria do índice de desempenho médio da escola é o resultado de melhores resultados de todos os alunos (ou 
a maior parte deles)? Conforme sugere I. Silva (2014), é preciso pensar sobre a eficácia/efetividade dos fins e meios do trabalho escolar "alinhados à noção de justiça social, de busca de garantia ao direito à educação a todos os cidadãos, fazendo valer a legislação vigente e seus objetivos e metas anunciadas" (op. cit., p. 115). Contando com os recursos metodológicos hoje disponíveis, algumas pesquisas já estão caminhando neste sentido ao olharem a distribuição do nível de proficiência entre os alunos da escola testados em avaliações de larga escala (para além da proficiência média da escola), com base na concepção de que não basta elevar o índice médio da escola, é preciso que mais alunos aprendam adequadamente. Para tanto, estes estudos consideram a porcentagem de alunos da escola que atingiram um nível de proficiência adequado ${ }^{3}$ à sua série.

A reflexão sobre a eficácia e efetividade do trabalho escolar apresentada se faz necessária para evitar uma leitura causalística ou prescritiva das pesquisas que levantaram fatores escolares associados à eficácia do trabalho escolar. A identificação de alguns fatores escolares que poderiam influenciar os resultados dos alunos não pode deixar de considerar as outras dimensões não consideradas e nem ser interpretada como um efeito direto daquela característica do trabalho da escola. Faz-se necessário esclarecer, também, as diferenças entre pesquisas sobre o efeito-escola e pesquisas sobre escolas eficazes. Bonamino e Oliveira (2013) esclarecem que as primeiras buscam analisar o impacto das escolas geralmente através de análises multiníveis (necessitando, para isso, de uma medida de proficiência inicial dos alunos). Brooke e Soares (2008) complementam: entende-se por efeito-escola "o quanto um dado estabelecimento escolar, por suas políticas e práticas internas, acrescenta ao aprendizado do aluno" (op. cit., p.10).

Por sua vez, as pesquisas sobre as escolas eficazes analisam os processos organizacionais e pedagógicos de escolas que apresentam bons resultados independente da condição socioeconômica de seu público. "Esses estudos utilizam tanto de metodologias quantitativas, tais como modelos de correlação, de regressão e multiníveis, quanto de metodologias qualitativas como estudo de caso e etnografia, que envolvem a análise simultânea das escolas e das salas de aula". (BONAMINO e OLIVEIRA, 2013, p. 39)

Os resultados dos alunos em testes e avaliações, utilizados por estas pesquisas como indicativos da aprendizagem dos alunos, também merecem esclarecimento. Brooke e Soares consideram que

\footnotetext{
${ }^{3}$ O Ministério da Educação utiliza as indicações da organização não-governamental “Todos Pela Educação" Com base na escala construída pelo professor José Francisco Soares a partir de estudos sobre a escala do SAEB e o PISA. A escala é composta de quatro níveis (Insuficiente, Básico, Proficiente e Avançado) com valores de referência específicos para cada série e conteúdo avaliado. A aprendizagem Adequada engloba os Níveis Proficiente e Avançado. (Informação disponível em www.qedu.com.br).
} 
a medida do aprendizado exige o acompanhamento longitudinal dos alunos, com o registro de sua proficiência no ponto inicial de uma trajetória escolar e, depois, em outros pontos subsequentes. A diferença entre o desempenho do aluno nesses dois ou mais pontos é uma medida do seu aprendizado, e a média dos aprendizados é definida como o valor agregado da escola. (2008, p. 222)

Portanto, cabe esclarecer que esta pesquisa, em uma linha mais próxima aos estudo sobre as escolas eficazes, propõe investigar uma possível relação entre o trabalho do diretor e a manutenção de um clima escolar favorável na escola com o trabalho docente e, através dele, com o desempenho dos alunos. Não se pretende, neste estudo, verificar ou medir o efeito destes fatores uma vez que, para tanto, necessitaríamos desenvolver um estudo longitudinal como descrito na citação acima. Para as análises que propomos, tomaremos como referência da aprendizagem dos alunos o seu nível de proficiência na avaliação nacional (Prova Brasil). Conforme lembram Bonamio e Oliveira (2013), estes resultados são seccionais, ou seja, "o mesmo teste é aplicado a grupos de alunos da série avaliada e estes alunos são diferentes a cada ano de avaliação" (op. cit., p. 38). Apesar de serem um "retrato" pontual do nível de desempenho do aluno, os resultados nos testes expressam seu aprendizado acumulado ao longo dos últimos anos escolares. Contudo, apontam as autoras, as medidas contextuais da escola, geralmente calculadas a partir dos dados disponibilizados pelos questionários contextuais eu acompanham as edições das avaliações, são pontuais, isto é, expressam a situação da escola (infraestrutura, organização, características dos profissionais, entre outras) no momento da aplicação do teste. Assim, as relações estabelecidas entre as características escolares e os resultados dos alunos devem ser analisadas com rigor e cuidado.

Em um levantamento de pesquisas que identificaram fatores escolares que poderiam explicar a variação de resultados entre alunos de diferentes escolas, Creemers e Reezgit (1996, p. 199-203) chamam a atenção para a importância de conhecer como atuam os diferentes fatores escolares e qual a correlação entre eles.

Recentemente foram realizados outros levantamentos de pesquisas que se dedicaram a identificar fatores de eficácia escolar (características escolares associadas à variação nos resultados dos alunos, tendo sido controladas as características sociodemográficas das populações atendidas pelas escolas). Estes levantamentos sintetizaram alguns fatores que foram encontrados, sistematicamente, como promotores de ummelhor desempenho escolar. Destacamos, entre eles, o trabalho de Sammons (1999) e o levantamento nacional realizado por Franco et al. (2005), reeditado mais tarde por Alves e Franco (2008). 
Em meio a um debate sobre a colaboração entre a pesquisa acadêmica e a ação governamental na Inglaterra, Sammons (1999), participou de um estudo encomendado pelo governo inglês para levantar fatores relacionados à eficácia escolar. Uma primeira condição do trabalho foi a substituição do termo "determinantes-chave" por "características-chave" considerando que "a natureza correlacional da evidência da pesquisa em eficácia escolar significava que um enfoque determinístico era inapropriado" (SAMMONS, $2008^{4}$, p. 336). O estudo levou em consideração as evidências e achados de pesquisas realizadas em vários países e recebeu considerável atenção da mídia e dos profissionais da área educacional na ocasião de sua publicação (1995). A autora sintetizou 11 fatores-chave de eficácia, que devem ser analisados conjuntamente, ou seja, considerando as várias associações possíveis entre eles: Liderança profissional; Objetivos e visões compartilhados; Um ambiente de aprendizagem; Concentração no ensino e na aprendizagem; Ensino e objetivos claros; Altas expectativas; Incentivo positivo; Monitoramento do progresso; Direitos e responsabilidades do aluno; Parceria casa-escola; Uma organização orientada à aprendizagem. A autora chama a atenção para as questões referentes ao contexto onde estas características foram identificadas, lembrando que os estudos não são diretamente transferíveis para outro contexto (SAMMONS, 2008, p. 348, grifos meus).

No campo da pesquisa educacional nacional, esta discussão é mais recente. Alves e Franco (2008) analisam o contexto e os avanços da pesquisa em eficácia escolar no Brasil e apresentam uma revisão da literatura brasileira sobre o tema. Consideram que, naquele momento, enquanto o campo da pesquisa em equidade e eficácia escolar se encontrava bem consolidado no cenário internacional, os estudos nesta linha ainda eram recentes e pouco numerosos no Brasil. A partir do levantamento realizado, os autores sintetizam quais seriam os fatores intraescolares associados à eficácia escolar nos estudos nacionais: Recursos escolares; Organização e gestão da escola; Clima acadêmico; Formação e Salário docente; Ênfase pedagógica (op. cit., p. 494, grifos meus). De acordo com Alves e Franco (2008), a literatura brasileira tem achado indícios significativos sobre o efeito positivo dos três primeiros fatores no desenvolvimento acadêmico dos alunos. Os dois fatores seguintes trazem indicativos mais esparsos, mas também com efeito positivo na aprendizagem dos alunos.

Tanto no levantamento nacional quanto no internacional apresentados, a gestão/liderança da escola e o clima acadêmico aparecem como importantes fatores associados à eficácia escolar. Destacamos que a liderança, especialmente aquela

\footnotetext{
${ }^{4}$ Esta data se refere à versão resumida e em português do trabalho, publicada na coletânea "Pesquisa em eficácia escolar: origem e trajetórias" (BROOKE e SOARES, 2008). O texto original, contudo, data de 1999: SAMMONS, P. School Effectiveness: Coming of Age in the Twenty-First Century. Lisse: Swets e Zeitlinger, 1999.
} 
desenvolvida pelo diretor escolar, tem um lugar de destaque. Alves e Franco (2008, p. 495) citam pesquisas realizas com dados sobre as escolas brasileiras que apontam a percepção sobre a liderança do diretor e a dedicação do mesmo como características associadas à eficácia escolar. Sammons (2008) aponta que:

Quase todos os estudos de eficácia escolar mostram a liderança como fator-chave, tanto na escola primária quanto na secundária. Gray (1990) diz que 'a importância da liderança dos diretores é uma das mensagens mais claras da pesquisa em eficácia escolar'. [...] o estudo da literatura revela que três características foram encontradas frequentemente associadas à liderança de sucesso: propósito forte, envolvimento de outros funcionários no processo decisório, e autoridade profissional nos processos de ensino e aprendizagem (p. 351-352).

A autora, porém, pondera que ainda que a liderança do diretor seja uma característica marcante da pesquisa sobre eficácia escolar nos Estados Unidos e Inglaterra, sua importância depende do contexto, especialmente em razão dos diversos padrões de organização escolar existentes nos diferentes países ${ }^{5}$.

Tendo dedicado as duas últimas décadas aos estudos sobre a liderança escolar e o trabalho do diretor, Leithwood (2009) ressalta a atenção dada ao tema:

A liderança escolar é atualmente objeto de uma atenção sem precedentes. A agenda da reforma educacional, em sua permanente evolução, parece haver captado que o papel da liderança escolar é em si mesmo uma importante meta para a reforma e, simultaneamente, um veículo para que outras coisas se sucedam. (op. cit., p. 17).

Ainda que o termo "liderança escolar" não seja frequente na rotina escolar brasileira, e mesmo nas pesquisas acadêmicas nacionais (como será discutido mais adiante), vale ressaltar a dimensão política que o papel da direção escolar assume. As políticas educacionais têm considerado, cada vez mais, a importância desta função, tanto na tarefa de mediar as definições do órgão central junto aos professores, funcionários e comunidade escolar quanto na responsabilização pelos resultados de aprendizagem na escola. Ao longo deste trabalho discutiremos mais detalhadamente as implicações desta relevância para a rotina de trabalho do diretor no contexto desta pesquisa, tanto no levantamento das especificidades de suas funções quanto na análise dos dados levantados.

Leithwood (2009) destaca a relevância das práticas em sala de aula entre os fatores que podem influenciar os resultados dos estudantes, mas ressalta que a atuação dos diretores também traz um efeito sobre o desempenho dos alunos, embora sua ação seja

\footnotetext{
${ }^{5}$ A autora cita pesquisa realizada na Holanda que não identificou aspectos específicos da liderança escolar como fatores de eficácia naquele contexto. Ainda sobre este aspecto, Leithwood (1999) aponta algumas pesquisas que encontraram um maior efeito das características de liderança escolar em escolas que atendiam alunos menos favorecidos.
} 
indireta. Considerando os recentes estudos sobre os efeitos do trabalho do diretor para a eficácia escolar, Leithwood destaca que, ainda que a liderança escolar somente explique entre 3\% e 5\% da variância de aprendizagem dos alunos entre escolas, ela representa um quarto da variância total quando controladas as variáveis de origem dos alunos e analisados somente os fatores intraescolares (2009, p. 23).

Soares (2007) também realça a importância da gestão da escola entre os fatores intraescolares relacionados à eficácia escolar. Ele considera que "dentro da escola há dois importantes processos que interagem para a produção do desempenho dos alunos: a gestão escolar e o ensino" (SOARES, 2007, p.153). De acordo com o autor, a gestão, responsabilidade da direção da escola, tem como função administrar o projeto pedagógico da escola, as pessoas que constituem a comunidade escolar e os aspectos físicos e financeiros da organização escolar. Isso vincula sua atuação à garantia do funcionamento da escola "de forma que os recursos nela existentes possam ser usados para atender às necessidades de aprendizagem dos alunos" (op. cit). Como veremos ao longo do próximo capítulo, esta é uma possível definição sobre a gestão escolar e suas responsabilidades, mas não é a mais abrangente. De fato, alguns autores têm discutido a multidimensionalidade da gestão escolar quando esta assume funções administrativas, representativas, pedagógicas e políticas (BARROSO, 2012; SOUZA, 2006 e 2012). Ainda assim, para a discussão sobre a gestão escolar enquanto fator promotor de eficácia, destacamos o enfoque apontado por Soares (2007) que realça como sua ação organizacional pode repercutir nos resultados dos alunos. De fato, as tarefas de conciliar e manter um ambiente propício para a aprendizagem, compartilhar as metas entre a equipe e favorecer o desenvolvimento de um trabalho coletivo (onde os agentes escolares se sintam incluídos no processo) têm sido apontadas como estratégias de uma gestão eficaz. Sammons (2008, p. 351) também considera que o impacto do trabalho da gestão escolar na melhora dos resultados acadêmicos dos alunos não se dá de maneira direta, mas envolve um verdadeiro trabalho de bastidores, que procura garantir o desenvolvimento de outras características apontadas como essenciais para a eficácia escolar: objetivos e visões compartilhados, ambiente de aprendizagem, incentivos positivos, parceria casa-escola, organização orientada à aprendizagem e monitoramento do progresso acadêmico dos alunos. Entre estas características, o estudo ora proposto busca aprofundar o conhecimento sobre a relação entre o trabalho do diretor e o clima escolar (envolvendo a manutenção de um ambiente de aprendizagem) com o trabalho docente e o desempenho dos alunos. 


\section{2 \\ Revisão de literatura: o que dizem as recentes pesquisas sobre 0 tema (e o que falta dizer)}

O papel do diretor escolar tem recebido grande atenção de recentes pesquisas na área educacional e algumas indicações sobre a relação entre seu trabalho e o trabalho docente aparecem em recentes publicações de pesquisas internacionais e nacionais. $\mathrm{Na}$ revisão de literatura feita para este trabalho, além de sistematizar os principais achados de pesquisas nacionais e internacionais, buscamos também identificar as metodologias utilizadas por seus autores ${ }^{6}$. Para conhecer as tendências das pesquisas realizadas sobre o tema proposto, foram desenvolvidos trabalhos com vistas à revisão de sua abordagem no campo. O primeiro se refere ao levantamento bibliográfico das recentes publicações sobre o tema desta pesquisa, em 4 importantes periódicos nacionais e internacionais (Revista Brasileira de Educação, Revista Brasileira de Política e Administração da Educação, Educational Administration Quarterly e Americam Educational Research Journal ). Nos 78 volumes destes periódicos publicados entre 2010 e 2014 (últimos 5 anos), foram selecionados 44 artigos. Apesar de todos os artigos terem sido selecionados por abordarem, de alguma forma, a relação entre a gestão do diretor escolar e o trabalho dos professores, a temática central das pesquisas era diversa. Assim, estes artigos foram categorizados a partir de seu tema central em 4 grupos: Diretores e Professores: a construção de uma relação; Políticas educacionais e o trabalho da gestão escolar; Tipos de Liderança e Tarefas do Diretor; e A gestão escolar e os resultados de aprendizagem. Todos os artigos foram lidos na íntegra, tornando-se importante interlocutores para este trabalho, conceitual e metodologicamente.

Entre as pesquisas nacionais e internacionais publicadas sobre o tema nos últimos 5 anos, notou-se a relevância atribuída ao trabalho da gestão escolar para o funcionamento da escola, incluindo o trabalho docente e o desempenho dos alunos. A leitura integral dos artigos foi uma contribuição valiosa para o desenvolvimento desta pesquisa, tanto do ponto de vista metodológico quanto conceitual. Esta interlocução e suas contribuições serão apresentadas ao longo dos próximos capítulos, mas, em linhas gerais, podemos afirmar que os estudos apontam que o trabalho do diretor, através de diversas estratégias de gestão da escola, se relaciona com o trabalho do professor de diferentes maneiras. Estas relações foram percebidas, em alguns casos, numa dimensão pedagógica (através de interferências e orientações curriculares ou metodológicas, do monitoramento da aprendizagem dos alunos e do incentivo na formação docente). Em outros casos, em uma

\footnotetext{
${ }^{6}$ O detalhamento dos procedimentos adotados para a revisão de literatura realizada para esta pesquisa se encontram no Anexo 1, incluindo a apresentação e categorização dos artigos selecionados.
} 
dimensão relacional ou afetiva (através do fortalecimento de vínculos com a instituição, da manutenção de um clima favorável no ambiente escolar, influenciando tanto na decisão do professor de continuar trabalhando naquela escola como na qualidade de seu trabalho). Considerando as diferenças contextuais de origem das pesquisas (Brasil e diversos outros países, especialmente Estados Unidos), os estudos ressaltaram diferentes abordagens para o trabalho do diretor escolar, as quais buscamos sintetizar nos dois esquemas que se seguem:

Figura 1: Síntese da abordagem do tema nas recentes pesquisas nacionais, 20102014

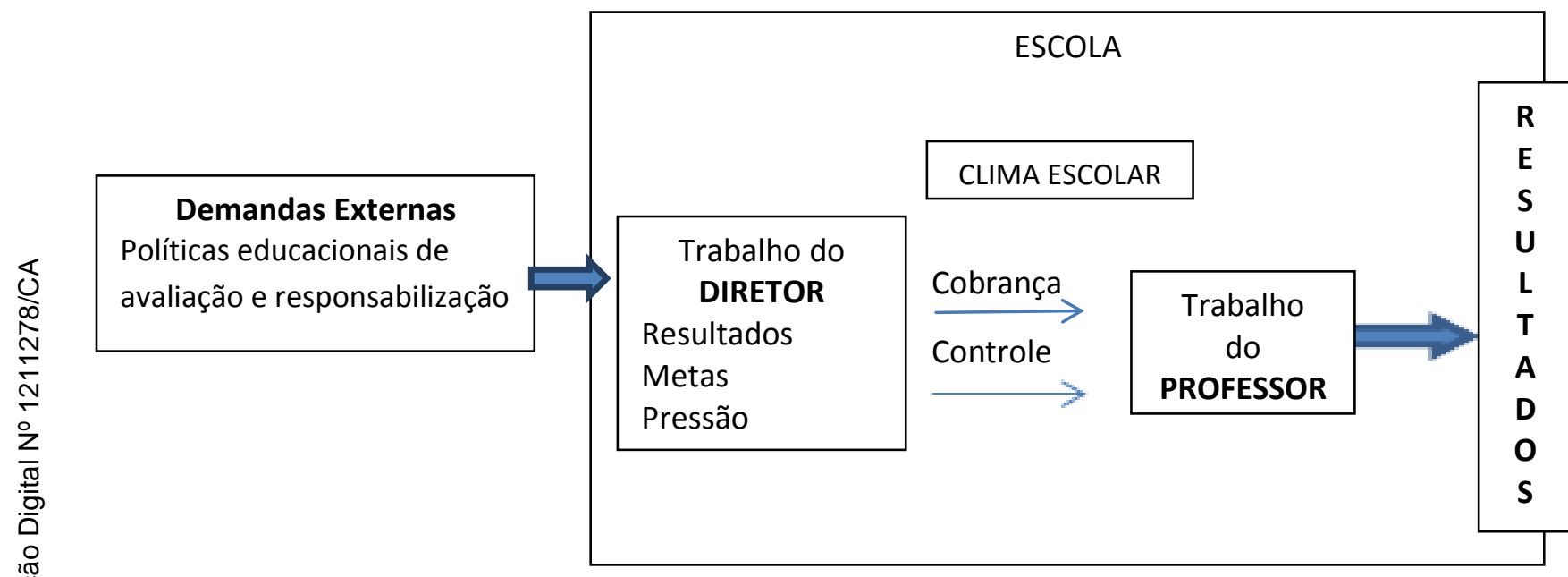

Fonte: Elaborado pela autora.

É importante ressaltar que esta síntese não pretende uma consolidação de resultados, uma vez que trata-se de um conjunto de pesquisas de diferentes naturezas metodológicas, graus de abrangência e possibilidades de generalização. A análise dos artigos possibilitou, contudo, evidenciar a relevância das demandas externas ao trabalho do diretor na escola, ainda que, nos últimos anos, os autores tenham privilegiado uma (Políticas de Avaliação e Responsabilização) entre tantas demandas. Há, também, o destaque para os consequentes reflexos do trabalho do diretor escolar, tanto no trabalho do professor quanto nos resultados dos alunos. 
Figura 2: Síntese da abordagem do tema nas recentes pesquisas internacionais, 2010-2014

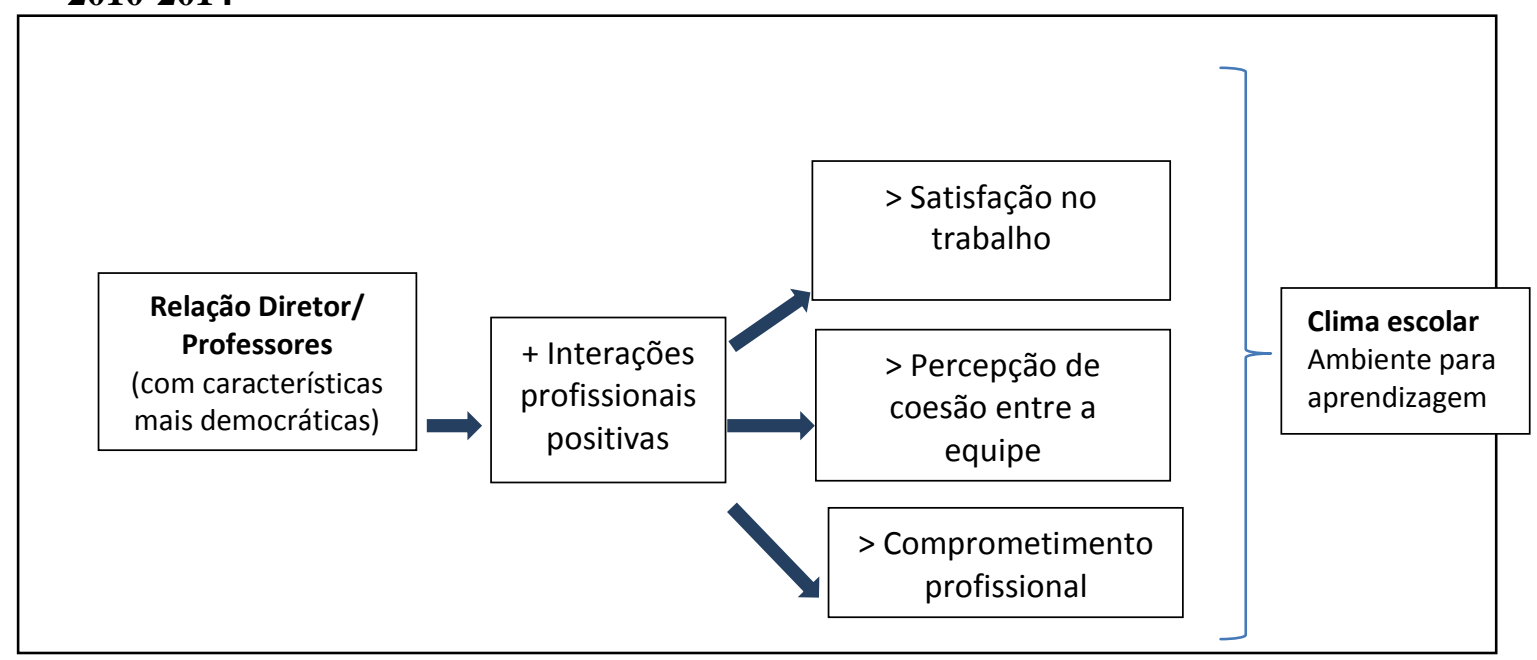

Fonte: Elaborado pela autora.

As pesquisas internacionais selecionadas nesta revisão se voltam, especialmente, para a análise das tarefas do diretor e seus impactos na escola. Os trabalhos compilados tendem a apontar a relação entre o diretor e os demais membros da organização escolar (especialmente os professores) como determinante para a qualidade do trabalho na escola (especialmente aquele desenvolvido nas salas de aula). É importante destacar que no contexto dos Estados Unidos há uma política de responsabilização (accountability) federal e as pesquisas tendem a uma apresentação mais prescritiva dos resultados encontrados, com vistas a fomentar os cursos de formação de diretores naquele país. Os estudos destacaram que o estabelecimento de uma forma de liderança mais participativa/colaborativa/distribuída, que envolve os profissionais das escolas nas decisões importantes relativas à rotina dos estabelecimentos - principalmente as pedagógicas - aparece como fator que influencia o nível de satisfação e comprometimento do professor com seu trabalho, além de aumentar a percepção sobre o nível de coesão da equipe na escola, uma vez que todos são chamados a participar e decidir.

A revisão de literatura nos apontou diferentes abordagens para temas fundamentais para esta pesquisa: o papel do diretor escolar, suas atribuições, perfis de liderança do diretor, interferências externas para seu trabalho, reflexos de sua atuação para o trabalho docente e para o desempenho dos alunos. Contudo, sentimos falta de uma abordagem menos compartimentada a respeito destes temas. Consideramos que seria interessante propor um olhar mais articulado para a temática: diferentes formas de atuação do diretor escolar (tipologias de gestão e de liderança, como veremos) se expressam na priorização de determinadas tarefas que, por sua vez, sofrem determinações contextuais (internas e externas) e irão se refletir de alguma forma, no trabalho do professor e na proficiência dos 
alunos. Identificando esta lacuna, o presente trabalho pretende colaborar para ampliar a discussão, refletindo, especialmente, sobre as formas através das quais o trabalho do diretor pode ser um elemento diferenciador na escola.

Considerando as abordagens metodológicas das pesquisas relatadas nos artigos selecionados, notamos que os estudos quantitativos ainda são minoria (17) e predominam nas publicações internacionais. Entre estas, destacou-se o uso dos dados disponibilizados pelo School and Staffing Survey (SASS), survey aplicado a cada 4 anos com o intuito de prover dados descritivos sobre a condição educacional nos Estados Unidos ${ }^{7}$. É importante destacar que as pesquisas nacionais relativas ao tema de interesse têm sido desenvolvidas em caráter predominantemente qualitativo. Por outro lado, o presente estudo propõe a criação e análise de variáveis quantitativas para investigação neste campo.

Um segundo movimento de atualização sobre as pesquisas desenvolvidas recentemente sobre o tema envolveu o levantamento de teses e dissertações defendidas no Brasil nos anos de 2011 e $2012^{8}$. As 198 pesquisas encontradas foram categorizadas em 11 grupos.

Entre os 26 trabalhos que abordaram a Gestão da escola e resultados acadêmicos, a relação do diretor com os professores aparece como uma importante componente na definição da gestão escolar enquanto corresponsável pelos resultados acadêmicos da escola. Os trabalhos se dedicaram, principalmente, a investigar: experiências de sucesso (ou insucesso) escolar relacionadas ao trabalho da gestão (NEVES, 2012; A. LIMA, 2012; entre outros), as estratégias da gestão escolar para melhorar os resultados da escola (COSTA, 2012; MIRANDA, 2012; entre outros), estudos comparativos entre escolas (MARQUES, 2012; CUNHA, 2012; entre outros), o apoio/intervenção do diretor na gestão da sala de aula (MACHADO, 2012; GOMES, 2012; RODRIGUES, 2012; entre outros), o efeito da gestão (entre outros fatores) para os resultados de aprendizagem em língua portuguesa e matemática (N. LIMA, 2012). Estes trabalhos, ao tratarem do efeito indireto da gestão escolar nos resultados acadêmicos dos alunos, abordam, de alguma forma, a atuação pedagógica do diretor junto aos professores de sua escola. As contribuições destas pesquisas estão presentes ao longo do trabalho.

Os dois levantamentos de pesquisas recentes na área da gestão e liderança escolar, apresentados nesta seção, trouxeram importantes contribuições tanto no que se refere à reflexão teórica, quanto ao trabalho metodológico (levantamento de itens, formas de operacionalização de conceitos, apresentação de resultados). A leitura e categorização dos

\footnotetext{
${ }^{7}$ Considerando a relevância do material disponibilizado por este survey e sua utilização nas pesquisas norte-americanas, apresentamos um estudo sobre o SASS no Anexo 2 deste trabalho. ${ }^{8} \mathrm{O}$ detalhamento deste levantamento, incluindo a descrição do estudo e a categorização das pesquisas, bem como as limitações que incorreram no recorte temporal indesejado, se encontram no Anexo 3 deste trabalho.
} 
textos apontaram para a crescente atenção dada ao tema da gestão escolar e sua influência nos resultados de aprendizagem dos alunos. Há que se destacar a importância da divulgação destes resultados de pesquisa, especialmente para alimentar a discussão, revisão e reelaboração de instrumentos de coletas de dados. A revisão de literatura também revelou uma carência de trabalhos, especialmente no âmbito nacional, que se voltassem mais especificamente para a importância das intervenções do diretor na condução da atividade pedagógica e na manutenção de um clima escolar favorável para a aprendizagem. Percebemos também a necessidade de um olhar mais relacional e abrangente para as diferentes interfaces de um tema complexo, como já mencionado. $\mathrm{O}$ levantamento mais aprofundado de práticas e percepções dos agentes escolares acerca destas questões foi sugestão recorrente dos estudos citados, propondo possíveis aprofundamentos das pesquisas realizadas. Esta pesquisa pretende preencher esta lacuna, especialmente a partir da reflexão sobre novas possibilidades de acessar as percepções de diretores e professores no universo escolar.

\section{3 \\ A complexidade do trabalho da direção escolar em contexto}

Alguns autores consideraram que as estratégias de trabalho do diretor e o clima escolar são delineados e afetados pelo contexto no qual a escola está inserida, incluindo a sua referência política e normativa. Neste sentido, Urick e Bowers (2014, p. 27) observam que os diretores adaptam sua atuação na escola a partir das características contextuais da mesma, incluindo as características do distrito ao qual sua escola pertence e as políticas de responsabilização a que estão sujeitos. No Brasil, Machado e Alavarse (2014) trazem à tona a discussão sobre a responsabilidade do gestor escolar em instruir os professores da escola sobre a melhor utilização dos dados levantados a partir das avaliações externas, incorporando uma nova tarefa decorrente de fatores externos à escola. Parece-nos relevante, então, considerar e explicitar as características da atual organização educacional no Brasil e, especialmente, na cidade do Rio de Janeiro afim de compreendermos alguns determinantes da atuação dos diretores que serão sujeitos desta pesquisa. Assim, a seguir trazemos algumas informações sobre o contexto educacional nacional e local, no intuito de inserir o leitor no cenário onde as estratégias de gestão e liderança dos sujeitos desta pesquisa são construídas e analisadas.

Experimentamos no Brasil, desde o início da década de 1990, mudanças significativas no que se refere à política educacional, relacionadas à avaliação, ao monitoramento e à busca pela qualidade e equidade no sistema educacional. Contamos, hoje, com coleta e disponibilização de dados educacionais nunca antes experimentadas e 
o trabalho de análise destas informações começa a se estruturar de forma mais regular e sistematizada. Antes da utilização das avaliações nacionais em larga escala, tínhamos somente os Censos Demográficos, a Pesquisa Nacional por Amostra de Domicílios (PNAD) e o Censo Escolar como fontes de informações escolares no âmbito não amostral. A reunião destas fontes possibilita o cruzamento de informações significativas sobre os dados educacionais, no que se refere ao acesso e ao fluxo na Educação Básica. Contudo, estas pesquisas não conseguem responder às perguntas sobre o desempenho dos alunos a partir do ensino ministrado na escola, pois, como apontam Alves e Franco (2008, p. 484), tais levantamentos não envolvem pesquisas específicas sobre a qualidade do ensino.

Na América Latina, a adoção das avaliações em larga escala para aferição do rendimento escolar tem sido realizada desde o início da década de 90 do século passado. No Brasil, a criação de um Sistema de Avaliação da Educação Básica - SAEB data do ano de $1990^{9}$. Em 2005, este sistema foi ampliado com a introdução da Prova Brasil, avaliação que envolve testes de Língua Portuguesa e Matemática e é aplicada às séries finais de cada etapa do ensino fundamental, em todas as escolas públicas brasileiras com mais de 20 alunos nas séries avaliadas. Sua intenção diagnóstica é defendida pelo Plano de Metas Todos pela Educação ${ }^{10}$ :

Com os resultados do Prova Brasil, as secretarias e o MEC têm um diagnóstico da Educação brasileira, podendo detectar desigualdades nas escolas e entre elas. A partir disso, esses órgãos devem definir ações e direcionar recursos para corrigir essas distorções e melhorar a qualidade do ensino. ${ }^{11}$

A busca por atingir as metas estabelecidas pelo governo federal gerou a ampliação das iniciativas locais (estaduais e municipais) de avaliação do ensino público, como as experimentadas em Minas Gerais, São Paulo e Rio de Janeiro. Até o ano de 2011, de acordo com o levantamento de Brooke et al.(2011), 19 estados brasileiros já possuíam sistemas próprios de avaliação da aprendizagem. Estas iniciativas, em geral, utilizam testes semelhantes aos utilizados pelo SAEB/Prova Brasil, o que possibilita monitorar o ensino em suas unidades escolares e comparar "os resultados do conjunto dos alunos matriculados nas respectivas redes com o padrão de desempenho do sistema de ensino

\footnotetext{
${ }^{9}$ Implica em avaliações de Língua Portuguesa e Matemática para os estudantes de $5^{\circ}$ e $9^{\circ}$ anos do ensino fundamental e também estudantes do $3^{\circ}$ ano do ensino médio, da rede pública e da rede privada, de escolas localizadas nas áreas urbana e rural. A avaliação é amostral, ou seja, apenas parte dos estudantes brasileiros das séries avaliadas participa da prova. Os resultados de desempenho são gerados em três níveis: Brasil, Regiões e Estados (Unidades da Federação). (Fonte: http://provabrasil.inep.gov.br)

${ }^{10}$ Proposta regulamentada pelo Decreto n ${ }^{\circ} 6.094$, de 24 de abril de 2007.

${ }^{11}$ Disponível em: www.todospelaeducacao.org.br/educacao-no-brasil. Acesso em: 12 jul. 2011.
} 
brasileiro retratado na escala de proficiência do SAEB". (ALVES e FRANCO, 2008, p. 486).

Bonamino e Souza (2012) destacam que a introdução da Prova Brasil, além de outras avaliações estaduais e municipais, e a divulgação de seus resultados inauguram a segunda geração de políticas de avaliação em larga escala no Brasil (a primeira geração foi representada pela sistematização do SAEB, na década de 1990).

Com a divulgação, pelo Governo Federal, de resultados nacionais da Prova Brasil, associada a iniciativas de governos estaduais nessa mesma direção - por exemplo, Minas Gerais, Ceará e Rio Grande do Sul -, passa-se a contar com experiências de avaliação da educação de segunda geração, caracterizadas por inovações que incorporam a divulgação de resultados de modo a permitir comparações não apenas entre redes, mas entre escolas (BONAMINO e SOUZA, 2012, p.380).

No município do Rio de Janeiro, contexto desta pesquisa, a Secretaria Municipal de Educação (SME/RJ ${ }^{12}$ implantou, a partir de 2009, uma nova política educacional, introduzindo gradualmente um conjunto de medidas. Entre elas, destacamos as Avaliações Bimestrais da Rede, que são testes de múltipla escolha de Língua Portuguesa, Matemática e Ciências, aplicados a todas as séries do ensino fundamental bimestralmente. Os testes são elaborados por professores da própria rede de ensino, sendo distribuídos e aplicados em todas as escolas de acordo com o calendário determinado pela SME/RJ. Cada professor regente é responsável pela correção das avaliações de sua turma e pelo registro dos resultados em planilha específica para esse fim. Esses resultados são monitorados pela secretaria, uma vez que as notas dos alunos são inseridas em plataforma digital própria (tarefa normalmente desempenhada pelo Coordenador Pedagógico ou Secretário escolar). As notas atingidas nos testes vão compor a nota média do aluno, ou seja, o resultado do aluno na Avaliação Bimestral da Rede deve ser uma das atividades avaliativas do bimestre, acrescida de outras atividades que os professores desejarem aplicar. Estas avaliações estão articuladas a dois outros instrumentos didáticos introduzidos pela mesma política: os Descritores de Ensino (listas bimestrais de habilidades e conteúdos a serem contemplados nas Avaliações Bimestrais da Rede) e os Cadernos de Apoio Pedagógico (apostilas bimestrais de exercícios das disciplinas avaliadas que visam complementar o trabalho do professor e preparar os alunos para a Avaliação Bimestral da Rede). Estes materiais também são elaborados por professores da

\footnotetext{
${ }^{12}$ A prefeitura do Rio de Janeiro está em seu segundo mandato (2009-2012, 2013-2016). A Secretária de Educação, Cláudia Costin, que iniciou esta nova organização educacional na rede ( a qual denominou "Salto de qualidade da educação") deixou o cargo em 25/04/2014 para assumir a função de Diretora Global de Educação no Banco Mundial. A subsecretária Helena Bomeny assume, então, o cargo de Secretária Municipal de Educação do Rio de Janeiro, dando continuidade aos projetos iniciados na rede.
} 
rede municipal de ensino do Rio de Janeiro e tomam como referência a Matriz de Descritores do SAEB e os Parâmetros Curriculares Nacionais.

Em consonância com a política nacional, a SME/RJ também instituiu uma nova modalidade avaliativa: a Prova Rio. Trata-se de uma avaliação externa anual, aplicada a alguns anos do ensino fundamental $\left(3^{\circ}, 4^{\circ}, 7^{\circ}\right.$ e $8^{\circ}$ anos foram avaliados na edição de 2013$)$ da rede municipal. Os testes de Matemática e Língua Portuguesa seguem a mesma matriz de referência (descritores) da Prova Brasil e, a partir de 2012, a Prova Rio passou a incluir a avaliação de Ciências. Para preparar os alunos para participarem da Prova Rio, a secretaria propõe também a realização de Simulados nas séries que serão avaliadas. Os Simulados são testes aplicados também anualmente pela SME/RJ, que seguem os padrões das avaliações externas como treinamento para a Prova Rio.

Assim como os resultados obtidos na Prova Brasil compõem o cálculo do Índice de Desenvolvimento da Educação Básica (IDEB) ${ }^{13}$ de cada escola, os resultados obtidos na Prova Rio são utilizados para o cálculo do Índice de Desenvolvimento da Educação Básica do Rio de Janeiro (IDE-Rio) também por escola. A SME/RJ passou a utilizar estes dois índices como parâmetros de avaliação e definição de metas para as escolas da rede municipal do Rio de Janeiro, além de estabelecer prêmios para escolas, professores e alunos que alcancem as metas esperadas ${ }^{14}$. Em estudo que relacionou as características escolares ao recebimento do prêmio em 2009 e 2011 na rede municipal do Rio de Janeiro, Koslinski (2013) aponta que mesmo as escolas com índices abaixo da média podem vir a receber o prêmio, uma vez que as metas são calculadas para cada escola, considerando o resultado por ela atingido na edição anterior. "Contudo, as metas de evolução no IDEB são mais altas (em proporção ao resultado anterior) para as escolas com baixa performance e para as escolas que atendem aos anos iniciais do ensino fundamental" (op. cit., p. 4). As estratégias adotadas pela atual política educacional da SME/RJ apresentam elementos característicos das políticas de responsabilização, conforme descrito por Brooke (2006, p. 379): divulgação do desempenho das escolas, testes padronizados, aplicação de incentivos e punições de acordo com resultados obtidos. A única característica ausente na política de responsabilização da SME/RJ é a punição de escolas

\footnotetext{
${ }^{13}$ O IDEB é calculado a partir do desempenho dos alunos na Prova Brasil e fluxo escolar aprovação/reprovação/evasão - aferido a partir dos dados do Censo Escolar (Levantamento de dados estatístico-educacionais de âmbito nacional realizado todos os anos e coordenado pelo Inep). O IDEB é calculado para as escolas, municípios, estados, regiões e país. Para maiores detalhes sobre o cálculo do índice, ver: www.portal.mec.gov.br.

${ }^{14}$ De acordo com Decreto 36978 (SME/RJ, 2013) são agraciados com o Prêmio Anual de Desempenho os servidores das escolas que atingirem as metas estabelecidas nos índices do Ideb (anos ímpares) ou IDE-Rio (anos pares). As metas para cada unidade escolar são calculadas em relação ao desempenho anterior na avaliação anterior e só são consideradas para efeito de premiação se houve, no mínimo, $85 \%$ de participação dos alunos nos testes de referência. O prêmio, em dinheiro, é calculado com base no salário do servidor e leva em consideração a assiduidade do mesmo.
} 
por não atingirem as metas estabelecidas (a política de accountability educacional nos Estados Unidos prevê como punição para as escolas que sistematicamente não atingem suas metas, desde demissões ao fechamento da escola). Tais estratégias trazem, para o interior da escola, novos elementos a serem incorporados, tanto na rotina de trabalho, quanto nas relações estabelecidas entre os profissionais. Recentemente, algumas pesquisas têm se dedicado a estudar estas implicações, como o estudo de caso realizado por Oliveira (2012 e 2012b) em uma escola municipal do Rio de Janeiro; o levantamento das condições de trabalho do gestor escolar e das mudanças nas escolas premiadas e não premiadas por esta iniciativa, estudo realizado por Paes de Carvalho, Oliveira e Lima (2014); o estudo qualitativo feito por Rosistolato, Prado e Fernández (2014) com diretores e membros da secretaria sobre suas percepções e utilização dos dados disponibilizados pelas avaliações externas; o estudo exploratório desenvolvido por Koslinski, Cunha e Andrade (2014) sobre as características das escolas municipais do Rio de Janeiro bonificadas por esta política; a dissertação (C. CUNHA, 2015) e a tese (CERDEIRA, 2015) recentemente defendidas sobre a prática docente e a gestão escolar em contexto de políticas de responsabilização. Ainda que o foco deste trabalho não seja um estudo sobre as citadas políticas educacionais, torna-se necessário compreender suas implicações para a escola, uma vez que, como apontam os estudos citados, interferem na sua rotina.

A rede municipal de ensino do Rio de Janeiro é maior rede educacional municipal da América Latina ${ }^{15}$, atualmente atende a 658.508 alunos matriculados em Creches, Unidades de Educação Infantil e Ensino Fundamental (1.457 unidades, no total), onde trabalham 41.661 professores. ${ }^{16}$ A estrutura da rede municipal de ensino do Rio de Janeiro conta com 11 Coordenadorias Regionais de Educação - CREs, instâncias intermediarias entre a SME/RJ e as escolas que abrangem, de acordo com a distribuição territorial. Considerando a extensão da rede, a rotina das escolas da rede reflete uma característica organizacional complexa. Ao longo dos últimos anos diferentes arranjos foram realizados para a organização da oferta escolar (séries atendidas por cada unidade). Conforme informado pela própria $\mathrm{SME} /{ }^{17}$, a determinação sobre o atendimento de cada escola seguia uma lógica de demanda de matrícula e não de oferta de vagas, ou seja, a escola tinha seu atendimento ampliado ou reduzido de acordo com a necessidade contextual. Como resultado, as escolas da rede tiveram, em sua maioria, mudanças constantes na oferta educacional, gerando uma ausência de padrão no atendimento escolar nesta rede. Assim, atualmente encontramos diferentes organizações do atendimento escolar na rede municipal de ensino do Rio de Janeiro: unidades que atendem somente à

\footnotetext{
${ }^{15}$ Segundo a definição da própria SME/RJ, disponível em: www.rio.rj.gov.br/web/sme

${ }^{16}$ Dados disponíveis em: www.rio.rj.gov.br/web/sme/educacao-em-numeros .

${ }^{17}$ Apresentação da Subsecretaria de Ensino da SME/RJ na PUC-Rio, em 28/11/2014.
} 
educação infantil; unidades que atendem à educação infantil e primeiro segmento do ensino fundamental ( $1^{\circ}$ ao $5^{\circ}$ ano); unidades que atendem somente ao primeiro segmento do ensino fundamental; unidades que atendem somente ao segundo segmento do ensino fundamental ( $6^{\circ}$ ao $9^{\circ}$ ano); as Casas de Alfabetização, atendendo aos alunos de $1^{\circ}$ ao $3^{\circ}$ ano; unidades que atendem os alunos do $4^{\circ}$ ao $6^{\circ}$ ano; unidades que atendem alunos do $7^{\circ}$ ao $9^{\circ}$ ano; unidades que atendem a todas as séries do ensino fundamental com ou sem oferta também de educação infantil.

Esta distribuição passa, desde 2014, por uma reorganização estruturada a partir de um estudo territorial amplo, como será discutido mais adiante no detalhamento do recorte de pesquisa proposto. Pretende-se organizar, até 2030, o atendimento de toda a rede em unidades de atendimento padronizadas de três tipos: Educação Infantil, Primário $\left(1^{\circ}\right.$ ao $6^{\circ}$ ano) e Ginásio ( $7^{\circ}$ ao $9^{\circ}$ anos). Esta reorganização das escolas da rede, que está em curso, propõe a retomada de uma segmentação do ensino fundamental, nos moldes da Lei de Diretrizes e Bases da Educação Nacional (LDB) Lei no 4024/61, que organizava a escola em: ensino primário, ginásio e colegial. A unificação do ensino de $1^{\circ}$ grau como conhecemos hoje, atendendo alunos de 7 a 14 anos (considerando a relação idade-série adequada) ${ }^{18}$ foi proposta inicialmente pela Lei $n^{\circ} 5692 / 71$ (que altera a LDB de 1961) e foi mantida pela LDB Lei $\mathrm{n}^{\circ}$ 9394/96, renomeada como Ensino Fundamental. Esta unificação foi articulada em algumas redes com a oferta de todas as séries do ensino fundamental em uma mesma unidade escolar, com a justificativa de garantir unidade no trabalho pedagógico. Na rede municipal do Rio de Janeiro, o número de escolas com esta característica vem diminuindo progressivamente considerando este processo de reorganização, conforme será discutido no Capítulo 3 deste trabalho. Esta pesquisa pretendeu pensar a gestão escolar a partir destas unidades que, de acordo com os dados coletados, envolve considerável complexidade de tarefas. Uma escola que atende diferentes segmentos da educação básica (podendo incluir a educação infantil, os dois segmentos do ensino fundamental e a Educação de Jovens e Adultos - EJA) lida com as demandas específicas de cada segmento e mais as demandas gerais da escola. E, conforme comprovamos em campo, há um elemento que torna a gestão destas escolas ainda mais complexa: a insuficiência de recursos humanos na equipe de gestão das escolas. Na rede municipal de ensino do Rio de Janeiro estas equipes contam, quando completas, com três profissionais: o diretor, o diretor adjunto e o coordenador pedagógico, independente do número de séries que a escola atende ${ }^{19}$. Os dados disponibilizados pelos questionários contextuais da Prova Brasil de 2011 indicaram que a maioria dos diretores

\footnotetext{
${ }^{18}$ A partir de 2006, a referência de idade para o atendimento é: alunos de 6 a 14 anos.

${ }^{19}$ A SME/RJ aloca um profissional a mais na gestão da escola (um assistente) em casos excepcionais, especialmente quando a escola tem um número de matriculas superior a 1000 alunos.
} 
da cidade do Rio de Janeiro reconhece que a falta de pessoal técnico/administrativo é um problema grave na escola (PAES de CARVALHO et al., 2014):

Os dados sinalizam que a sobrecarga de trabalho dos diretores já era acentuada, notadamente diante do volume das atribuições da gestão, ampliado em decorrência da proliferação de programas e projetos educacionais e da interface social da escola na última década. A indução à melhoria da qualidade requer, além de novos conhecimentos técnicos, tempo para planejar, executar despesas, prestar contas, manter reuniões com a comunidade escolar e acompanhar o processo de ensinoaprendizagem desenvolvido pela escola (op. cit., p. 63).

A complexidade do tralho da gestão escolar, especialmente na rede municipal do Rio de Janeiro, tem sido apontada pelas pesquisas, no que se refere ao papel mediador que desempenham (OLIVEIRA, 2012), às mudanças nas características e demandas de seu trabalho (OLIVEIRA, 2012b), à diversidade em seu trabalho e a articulação com elementos externos à escola (F. LIMA, 2011), às demandas específicas das políticas de avaliação e responsabilização (SILVA, 2013; CERDEIRA, 2015). Ao propor esta reestruturação da oferta educacional na rede municipal de ensino, a SME/RJ traz à tona a discussão sobre a complexidade do trabalho da gestão escolar e a possibilidade de se pensar as especificidades da gestão para cada um dos três tipos de escola propostos.

A oferta de todas as séries do ensino fundamental em uma mesma unidade escolar, ao invés de garantir uma unidade no trabalho parece ter produzido vários "universos" diferentes em uma mesma escola, sob a responsabilidade de um único diretor com uma equipe de gestão restrita. Para esta pesquisa, o cenário educacional da rede municipal do Rio de Janeiro trazia a possibilidade (ainda) de conhecer a complexidade da gestão destas escolas que atendem aos dois segmentos do ensino fundamental, considerando a importância metodológica de acessar um grupo maior de professores por escola. Deste ponto de vista, a escolha do campo e o recorte da pesquisa (que será detalhado no Capítulo 3) se justificaram e, na verdade, amplificaram as questões levantadas.

\section{4 \\ Hipóteses, questões e objetivos: um desenho de pesquisa}

Reconhecendo o papel central que os diretores escolares desempenham na articulação de toda a rotina e funcionamento da escola, fazendo inclusive a mediação entre os órgãos centrais (SME/RJ e CREs) e os demais educadores - especialmente os professores, o interesse desta pesquisa se volta para a atuação pedagógica do diretor. 
Entre as tarefas desempenhadas pela direção escolar, coloca-se a necessidade de acompanhar, orientar, avaliar o trabalho docente, além de manter um clima escolar adequado para o trabalho acadêmico. A atenção e o tempo dedicado para tais tarefas variam entre os diretores. Consideramos que possivelmente sua formação profissional e a que tenha adquirido especialmente para o cargo, bem como seu contexto de trabalho e experiência profissional influenciem tais práticas. A partir dessas considerações, indagamos quais seriam as consequências, para o trabalho dos professores, de o diretor adotar de estratégias pedagógicas ou voltadas para a manutenção do clima acadêmico. Minha experiência de anos de trabalho na educação básica (lecionando e coordenando), as leituras e o estudo sobre o tema, além do constante diálogo com profissionais da área, trouxeram algumas indicações e muitos questionamentos, que foram sintetizadas nas hipóteses e questões desta pesquisa.

Ressaltando o lugar e o papel central do diretor na gestão escolar e seus reflexos no trabalho docente, este trabalho considerou as seguintes hipóteses:

a) existem algumas tarefas, posicionamentos e iniciativas do diretor que influenciam diretamente no clima escolar e interferem no trabalho do professor;

b) algumas destas tarefas são relacionadas ao processo de ensino e à aprendizagem dos alunos e poderiam ser chamadas de "gestão pedagógica";

c) os instrumentos de coleta de dados atualmente disponíveis para a pesquisa acadêmica nacional podem não estar captando estas informações.

A partir destas hipóteses, apresenta-se como questão central de pesquisa:

- Que relações podem ser estabelecidas entre as características do trabalho do diretor, as percepções dos professores sobre o clima escolar e o desempenho dos alunos? Como mensurá-las?

Em decorrência deste questionamento central, outras perguntas se delinearam:

- Como os questionários que acompanham as edições da Prova Brasil abordam as características do trabalho do diretor e as relações construídas na escola? O que é possível saber a partir deles?

- Que características descrevem as relações entre os diretores e professores no contexto estudado? 
- Quais os diferentes perfis de liderança do diretor que podem ser capturadas através da análise destas relações?

- Existem, nas relações estabelecidas entre diretores e professores, intervenções pedagógicas?

- Em que medida as políticas de avaliação e responsabilização influenciam a atuação do diretor na unidade escolar?

Para investigar as questões acima, optamos por iniciar com uma abordagem metaanalítica sobre o tema, ou seja, sintetizar e integrar diferentes estudos a partir de seus achados. Para isso, procuramos inventariar o que se conhece sobre o assunto. A revisão de literatura e o levantamento das teses e dissertações defendidas recentemente sobre o tema, apresentada nesta introdução e presente ao longo do trabalho, se justificam por apresentar, como definem Figueiredo Filho et al. (2014, p. 207), "o atual status do conhecimento sobre um determinado problema de pesquisa". Além dos cuidados na seleção e análise dos dados para cumprir este propósito, procuramos também levantar os procedimentos metodológicos utilizados nestes estudos. Neste aspecto, interessou-nos, também, conhecer como as pesquisas têm utilizado os dados educacionais disponíveis (especialmente considerando as edições da Prova Brasil). Realizamos, então, uma verificação sobre as possibilidades e limitações metodológicas dos instrumentos de coleta de dados hoje disponíveis para pesquisas quantitativas no Brasil, sobre nosso tema de interesse.

O esquema a seguir procura sintetizar os caminhos percorridos, apresentando o desenho da pesquisa: 


\section{Figura 3: Desenho geral da pesquisa}

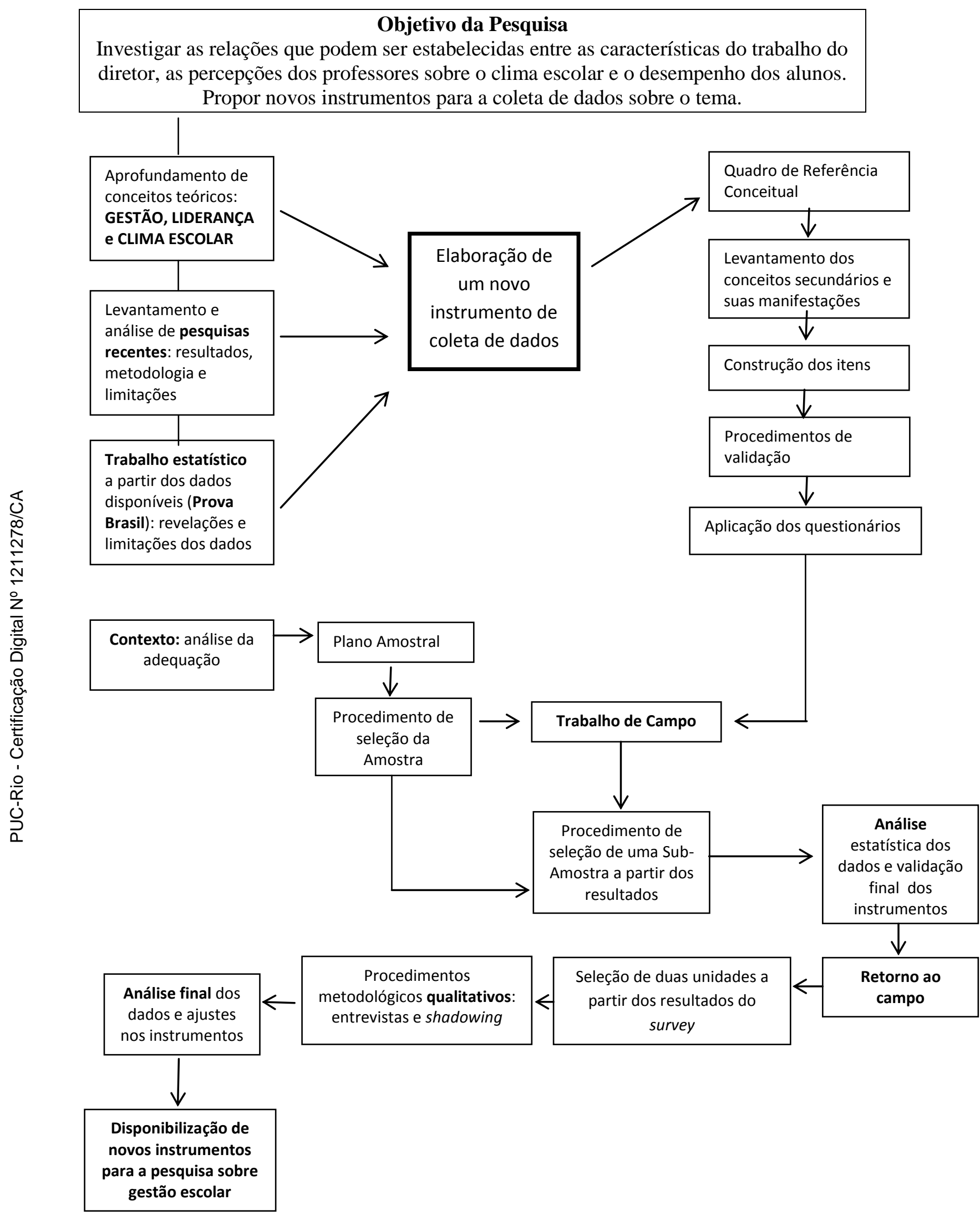


Seguindo a organização apresentada pelo esquema, esta tese está organizada em 8 capítulos, incluindo esta introdução. No capítulo 2 apresentamos alguns pontos da reflexão teórica que norteou a pesquisa, cujo desenvolvimento mais detalhado será apresentado de forma diluída em todos os capítulos do trabalho.

O capítulo 3 apresenta o campo de realização desta pesquisa, justificando as escolhas realizadas e indicando a seleção amostral realizada para o estudo.

O capítulo 4 traz uma análise detalhada dos instrumentos de coleta de dados disponíveis para o levantamento de dados sobre diretores e professores nas escolas públicas brasileiras, discutindo as alterações realizadas nos questionários contextuais das edições de 2007 a 2013 da Prova Brasil. Apresenta, ainda, um estudo estatístico exploratório realizado com os dados disponibilizados pela última edição acessível da Prova Brasil. Neste estudo, procuramos analisar a relação entre a percepção dos professores sobre a liderança dos diretores e sobre o clima escolar com os resultados dos alunos nos testes de matemática.

Considerando as limitações e fragilidades dos construtos utilizados no estudo desenvolvido com os dados dos questionários contextuais da Prova Brasil, em decorrência da pouca abrangência dos itens e do acesso a poucos professores em cada escola, optamos por desenvolver, testar e aplicar um novo questionário contextual para diretores, coordenadores e professores, que pudesse captar com mais detalhes elementos da gestão da escola e das relações no ambiente escolar. O capítulo 5 relata então o processo de criação destes novos questionários contextuais estruturados e articulados com o quadro referencial desta pesquisa, assim como sua validação e metodologia de aplicação.

A aproximação ao campo delimitado para o trabalho, os procedimentos de aplicação dos questionários (incluindo os desafios encontrados) são apresentados no capítulo 6, onde também trazemos a análise estatística exploratória dos dados levantados, na perspectiva de oferecer elementos para ampliar a discussão sobre o trabalho da direção escolar.

No capítulo 7 narramos o retorno ao campo a partir de procedimentos metodológicos qualitativos que foram desenvolvidos com a intenção de aprofundar as informações levantadas pelo survey e subsidiar o refinamento dos instrumentos de pesquisa. Finalmente, o capítulo 8 apresenta as nossas considerações finais. 


\title{
2. \\ O papel do Diretor na escola: a Gestão, a Liderança e o Clima Escolar
}

\begin{abstract}
Diretor: /ô/ adj. s.m. que ou aquele que dirige, dirigente, chefe. 1. ADM que ou aquele que ocupa o cargo mais alto na administração de escolas, hospitais, empresas etc. [...] 4. que ou o que orienta, fundamenta; norteador.
\end{abstract}

(HOUAISS, 2001)

O título de diretor remete, a princípio, às definições de chefia, comando, administração, àquele que está à frente de uma instituição. A definição do verbete, citada acima. teve o intuito de introduzir a reflexão sobre as possíveis definições e representações que o cargo ou função de diretor pode assumir ao definirmos a escola enquanto seu espaço de atuação. Especialmente para os fins deste trabalho, tornou-se fundamental compreender a função do diretor escolar em suas diversas nuances, para além da gestão ou administração de sua unidade. Neste sentido, a segunda definição do verbete amplia o papel do diretor enquanto aquele que também orienta e norteia o trabalho e a equipe pela qual é responsável. Em se tratando do ambiente escolar, o diretor assume diferentes demandas e tarefas: administrativas, burocrática, relacionais, pedagógicas, entre outras. Entendendo que elas não são excludentes ou antagônicas, como argumentaram Paro (2015) e Souza (2006), discutiremos na primeira seção deste capítulo o papel do diretor da escola pública, iniciando pela definição de seu cargo enquanto funcionário público e destacando a centralidade política da direção escolar. Souza (2012, p.160) considera que não se pode isolar a ação administrativa do poder que está presente nela. Neste sentido, discutiremos a partir da legislação e das atribuições do cargo de diretor escolar sua natureza política e representativa. Pereira (1976) já destacava a combinação do conhecimento técnico e das relações políticas no desempenho do trabalho do diretor, em uma pesquisa realizada no final da década de 1950, no interior de São Paulo. Tomando como objetivo de pesquisa focalizar as relações entre escola e comunidade, o autor dedica parte de seu trabalho a narrar as representações que as pessoas construíam sobre os indivíduos que constituem a escola então investigada (diretor, auxiliar, professores, funcionários, alunos e famílias). Entendendo a escola a partir de uma concepção weberiana, o autor destacou sua estrutura social, formal e racionalmente organizada: 
Nessa organização há um sistema de cargos e posições hierarquizadas, aos quais correspondem obrigações e privilégios precisamente definidos por normas específicas. Cada um desses cargos abrange uma área de competência e responsabilidade atribuídas. A autoridade, ou seja, o poder de controle que deriva de status reconhecido, está no cargo e não na pessoa que o ocupa. (PEREIRA, 1976, p. 58)

Neste sentido, podemos considerar que todas as relações estabelecidas entre o diretor e os professores são pautadas por esta dinâmica de poder, na qual o diretor estabelece suas estratégias para conduzir a gestão da escola. Concordamos com Pereira (1976) no sentido de que a referência de autoridade está no cargo da direção escolar, e não em determinado diretor em si mesmo. Contudo, consideramos que as formas de exercer esta autoridade são as mais variadas e refletem a trajetória pessoal do diretor, sua formação acadêmica e sua experiência no exercício do cargo ou em outros setores educacionais. As estratégias adotadas na condução da escola envolvem negociações, diálogos e decisões. Acreditamos que o nível de participação e abertura estabelecidas nesta relação definirão diferentes estilos de liderança do diretor na escola.

Após discutirmos o papel político e as atribuições do diretor escolar, as últimas seções deste capítulo apresentam como os conceitos de gestão, liderança e clima escolar nos ajudaram a analisar o trabalho do diretor e suas relações na escola, tema central desta pesquisa.

\section{1 \\ O diretor escolar: seu papel e suas atribuições}

O diretor escolar da rede pública de ensino no Brasil é um funcionário público, vinculado à União, Estado ou Município, dependendo do pertencimento de sua unidade escolar. Há uma questão de definição legal em relação à compreensão da natureza do vínculo do diretor escolar: enquanto cargo comissionado, o diretor escolar se enquadra como servidor de carreira, de acordo com os Incisos II e V do Artigo 37 de nossa Constituição Federal. Os planos de remuneração e as políticas de admissão ficam a cargo dos respectivos poderes: “(Art. 39) A União, os Estados, o Distrito Federal e os Municípios instituirão conselho de política de administração e remuneração de pessoal, integrado por servidores designados pelos respectivos Poderes" (BRASIL, 1998). Assim, estando legalmente investido em um cargo público, o diretor escolar cumpre um papel administrativo que o vincula tanto ao Poder que o nomeou quanto à instituição que dirige e representa. Sobre o seu papel enquanto funcionário público, Souza (2006, p.171) 
considera: "Como servidor público, o diretor é um burocrata, no sentido weberiano do termo. E é sua função, dentre outras questões, fazer a interlocução entre o Estado e a comunidade escolar e, como tal, exerce um papel de uma liderança local". A burocracia, conforme visualizada e descrita por Weber é um tipo ideal de organização que, provavelmente não encontra réplica na realidade, mas funciona como importante modelo de análise sociológica e política. A burocracia weberiana nos remete à natureza de dever do funcionário que ocupa um cargo:

O acesso a um cargo, incluídos os da economia privada, considera-se como a aceitação de um dever particular de fidelidade à administração, em troca de uma existência segura. Para o caráter específico da moderna fidelidade a um cargo é essencial o fato de que, no tipo puro, o cargo não determine uma relação com uma pessoa, como a fé do vassalo ou o discípulo nas relações de autoridade feudal ou patrimonial. A lealdade moderna adere-se a finalidades impessoais e funcionais. (WEBER, 1977, p.11)

Enquanto funcionário público, burocrata, o diretor assume seu cargo ou ocupa sua posição investido pelo poder que o nomeou, o que significa que um dos papéis que desempenha é o de representante do Estado e também dos profissionais da escola e da comunidade na instituição escolar. Esta representação remete ao caráter político que confere centralidade à direção escolar. E no caso da escolha dos diretores para as escolas públicas brasileiras há uma descentralização na definição de como tais funcionários acessam seu cargo. A Constituição Federal de 1988 e a Lei de Diretrizes e Bases da Educação Nacional - LDBN 9394/96, apesar de defenderem o princípio da gestão democrática nas escolas, não estendem este princípio para a escolha do diretor escolar. De fato, a legislação deixa a cargo de cada ente federado as definições referentes à carreira de diretor escolar, inclusive o seu acesso ao cargo. Como resultado, temos que hoje, entre as escolas participantes da Edição da Prova Brasil $2013^{20}, 50,7 \%$ dos diretores assumiram seu cargo através de indicação política ou técnica. Recentemente (de 2005 a 2014) tramitaram no Senado Federal dois Projetos de Lei que buscavam ampliar o Artigo 14 da LDBN 9394/96, definindo formas de escolha de diretores para as escolas públicas. O primeiro (BRASIL, 2005) propunha três formas de escolha de dirigentes, a critério de cada sistema de ensino: indicação do responsável pela administração do ensino, escolha pela comunidade escolar e concurso público. O segundo (BRASIL, 2007) defendia a eleição direta pela comunidade escolar como forma única de escolha dos ocupantes do cargo ou função de dirigente de escolas de ensino fundamental, médio e técnico das redes federal, estaduais e municipais. Após votação, o relatório foi favorável ao primeiro

${ }^{20} \mathrm{~N}=52310$ escolas/diretores respondentes. 
Projeto de Lei, que apenas normatizava o que de fato já ocorre na maioria das redes. Contudo, a recente aprovação do Plano Nacional da Educação - PNE retoma a discussão sobre a escolha dos diretores escolares nas escolas públicas a partir da eleição. Em sua Meta 19, o plano reforça a efetivação da gestão democrática nas escolas, propondo como uma das estratégias, que se "considere, conjuntamente, para a nomeação dos diretores e diretoras de escola, critérios técnicos de mérito e desempenho, bem como a participação da comunidade escolar" (BRASIL, 2014). Ainda sobre o tema, a estratégia 19.8 prevê o estabelecimento de critérios objetivos para o provimento de cargos de diretores escolares, incluindo cursos de formação e provas nacionais específicas. Considerando o prazo previsto para o cumprimento da meta ( 2 anos), as redes de ensino devem se organizar para efetivar a gestão democrática em suas unidades escolares até 2016.

No que tange ao provimento do cargo de diretor, a rede municipal de ensino do Rio de Janeiro, âmbito desta pesquisa, adota um processo misto de escolha, já em consonância com o proposto pelo atual PNE. Este processo acontece a cada três anos e vem sendo atualizado ao longo de suas edições. A Lei 5623/2013, que dispõe sobre o Plano de Cargos, Carreiras e Remuneração dos funcionários da Secretaria Municipal de Educação, define:

Art. 23. A escolha do Diretor das Unidades Escolares far-se-á por intermédio de consulta à comunidade escolar, da qual somente participarão os profissionais habilitados em etapa anterior.

Parágrafo único. A habilitação a que se refere o caput será obtida mediante critérios a serem definidos em regulamento próprio. (SECRETARIA MUNICIPAL DE EDUCAÇÃO DO RIO DE JANEIRO, 2013)

A Resolução 1133/2011 detalha o processo de habilitação mencionado na legislação citada acima sintetizado em nota publicada pela SME/RJ na mídia ${ }^{21}$. Os critérios para concorrer ao cargo de diretor em uma escola da rede em 2014 foram:

1- O candidato para inscrever-se deve ser professor da Rede Municipal do Rio, possuir Curso Superior e/ou Pós-Graduação na área de Educação, Curso de Gestão e MBA em Gestão ou ser Líder Carioca.

2- Os interessados deverão apresentar à Banca Avaliadora, composta por professores da Secretaria, um Plano de Gestão para a escola pretendida, que será avaliado por essa Banca.

3- Após a aprovação do Plano de Gestão pela Banca Avaliadora, a chapa composta por diretor e diretor-adjunto é submetida à avaliação da Comunidade Escolar, pelo voto direto de pais, alunos, professores e funcionários, além de um representante da Associação de Moradores. O voto é facultativo.

4- Todo o processo é acompanhado pelas Comissões Eleitorais de cada escola.

\footnotetext{
${ }^{21}$ Disponível em: http://extra.globo.com/emprego/servidor-publico/eleicao-para-diretores-deescolas-municipais-do-rio-gera-polemica-14392369.html\#ixzz3h0VitDcQ
} 
Assim, para atuar como diretor escolar em uma escola da rede municipal do Rio de Janeiro, há a exigência de formação mínima específica (e, neste sentido, a SME/RJ estabeleceu recentemente parcerias com instituições para a oferta de cursos de formação em Gestão Escolar, presenciais e online) e de uma proposta de trabalho para os três anos de mandato, expressa num Plano de Gestão (que deve enfocar, especialmente, estratégias para melhorar a aprendizagem dos alunos ${ }^{22}$ ). Tendo sido comprovado o preenchimento de tais pré-requisitos, os candidatos passam pelo processo de eleição na comunidade escolar, que legitima um dos candidatos cuja capacidade técnica foi aferida pelo órgão central. Assim, retomamos a complexa questão da representatividade no exercício do cargo de diretor escolar, que será fundamental para pensarmos sua relação com os professores na escola e o cumprimento de suas atribuições: ele é um representante legítimo do Estado, por ele empoderado e à ele devedor, no sentido weberiano do termo, de seu cargo e lealdade. E é, ao mesmo tempo, representante dos seus pares professores, tendo vindo desta classe e tendo sido por eles (entre outros representantes da comunidade escolar) eleito. A definição de funcionário burocrata na obra de Weber nos ajuda a pensar nesta dupla representatividade:

O tipo puro de funcionário burocrático é nomeado por uma hierarquia superior. Um funcionário escolhido pelos governados não é uma figura puramente burocrática. É claro que a existência formal de uma eleição não implica que esta não dissimule uma nomeação; no Estado, principalmente, nomeação pelos chefes de partido. [...] Em qualquer circunstância, a designação de funcionários por meio de uma eleição entre os governados altera o rigor da subordinação hierárquica. Um funcionário assim eleito tem, em princípio, uma posição autônoma com relação ao funcionário superior. A posição do funcionário escolhido veio "de baixo" e não "de cima" [...] (WEBER, 1977, p. 14-15).

Essa tensão identitária, cujo cerne procuramos descrever, tornou-se central na nossa reflexão ao longo do trabalho e será aprofundada no texto.

Uma vez empossado no cargo, o que se espera de um diretor escolar nas escolas públicas brasileiras? Na ausência de uma definição nacional para as atribuições do cargo, que como já mencionado é de responsabilidade de cada ente federado, tomamos como referência o Programa Nacional Escolas de Gestores da Educação Básica, desenvolvido pelo MEC em parceria com as Instituições Federais de Ensino Superior. O Programa propõe a formação continuada e pós-graduada de dirigentes da educação básica das escolas públicas e, assim sendo, pode-se dizer que representa o que se espera, a nível nacional, da atuação do dirigente escolar. O Programa (BRASIL, 2010, p.11) pretende formá-lo para, entre outras tarefas:

\footnotetext{
${ }^{22}$ De acordo com a consulta realizada na $3^{\text {a }}$ CRE da SME/RJ, em 07/05/2015.
} 


\begin{abstract}
Atuar na gestão da educação e da escola visando a efetivação do direito à educação básica com qualidade social, por meio de práticas caracterizadas pela transparência, pelo trabalho coletivo, pela participação da comunidade nas decisões e pela postura ética, crítica e criativa, pelo compromisso com a elevação do IDEB de sua escola e da educação escolar.

Realizar e fortalecer a gestão democrática do ensino como princípio legal e formativo fundamental sustentada em práticas e processos que conduzam ao trabalho coletivo e à participação nos processos decisório da educação e da escola.
\end{abstract}

Nota-se, em toda a apresentação e objetivos do Programa, a relevância dada a dois aspectos. O primeiro se refere ao princípio da gestão democrática (especialmente expressa através da expectativa de que o dirigente escolar amplie a participação e a coletividade na escola, envolvendo alunos, pais, funcionários e demais membros da comunidade na qual a escola está inserida). E o segundo se refere à melhoria na qualidade da educação escolar (expressa pela expectativa de que o dirigente escolar esforços para garantir a elevação do IDEB de sua escola). No município do Rio de Janeiro, foi estabelecido pela Lei Ordinária 2619/1998, que dispõe sobre a estrutura organizacional, pedagógica e administrativa da rede pública municipal de educação, uma lista das atribuições do diretor ${ }^{23}$ escolar. A lista inclui uma série de atribuições que passam por tarefas administrativas, de desenvolvimento das relações interpessoais, de articulação com a comunidade e aquelas relacionadas ao processo de aprendizagem dos alunos. Mais recentemente, a Resolução 1074/2010 da SME/RJ reforça a melhoria da qualidade da educação como foco central do trabalho do diretor escolar:

Art. 13. A Direção é responsável pela coordenação do processo de planejamento, supervisão e avaliação das ações pedagógica, comunitária e administrativa, de acordo com as normas emanadas do Nível Central, garantindo a qualidade da educação oferecida para todos os alunos (SECRETARIA MUNICIPAL DE EDUCAÇÃO DO RIO DE JANEIRO, 2010).

Como descrito na introdução deste trabalho, a atual política da SME/RJ, em vigor desde 2009, estabeleceu instrumentos de acompanhamento e monitoração da aprendizagem escolar, vinculados à uma política de responsabilização. Foi, assim, estabelecida a assinatura anual de um Acordo de Resultados e Termo de Compromisso, que define metas para os gestores (centrais, intermediários e locais) e funcionários dos diferentes órgãos da administração direta e entidades da administração pública indireta da Prefeitura (SECRETARIA MUNICIPAL DE EDUCAÇÃO DO RIO DE JANEIRO,

${ }^{23} \mathrm{O}$ documento completo encontra-se no Anexo 4. 
2009). No caso das escolas, as metas são previamente pactuadas mediante o Termo de Compromisso de Desempenho Educacional, assinado pelo diretor de cada unidade que se compromete a elevar o IDEB e o IDE-Rio, parâmetros utilizados como medidas do desempenho acadêmico da escola. Fica claro, assim, o compromisso assumido por cada diretor em relação aos resultados de seus alunos, o que implica em uma dedicação às questões pedagógicas em sua tarefa e a compreensão de que a aprendizagem dos alunos é a finalidade primeira da escola. Saviani (1996) descreve esta centralidade da seguinte forma:

A escola é uma instituição de natureza educativa. Ao diretor cabe, então, o papel de garantir o cumprimento da função educativa que é a razão de ser da escola. Nesse sentido, é preciso dizer que o diretor de escola é, antes de tudo, um educador; antes de ser administrador ele é um educador (op. cit., p. 208).

A questão que se coloca ao adentrarmos o universo de trabalho do diretor escolar neste contexto é: o que é feito por ele para garantir o "cumprimento da função educativa" em sua escola e como ele articula as diferentes demandas que lhe cabem para priorizar este aspecto? Aqui temos um segundo ponto central sobre o papel do diretor escolar que acompanhou todo o processo desta pesquisa: a articulação de diferentes prioridades em seu trabalho e o foco na aprendizagem dos alunos, através da direção do trabalho docente. Assim, reconhecendo seu papel de representante público de quem se espera algumas atribuições, especialmente relacionadas ao desempenho dos alunos (enfática e explicitamente no caso do município do Rio de Janeiro), passamos ao estudo sobre os conceitos de gestão, liderança e clima escolar. A seção que se segue introduz nossa abordagem dos conceitos, que serão aprofundados ao longo de todo o texto, especialmente na elaboração do Quadro de Referência Conceitual para a construção dos questionários propostos (Capítulo 5), reforçando o caráter conceitual-metodológico que esta pesquisa propôs.

\section{2}

\section{A Gestão e a Liderança no trabalho do diretor: a construção do Clima Escolar}

Compreendendo o trabalho do diretor na perspectiva de relação social que seu cargo exige e entendendo que estas relações estão pautadas por dinâmicas de poder definidas tanto a priori (referências de autoridade que o cargo implica) como a posteriori (perfil do diretor no exercício da autoridade), iniciamos esta seção refletindo sobre a inspiração que o conceito lutas concorrenciais, de Bourdieu, pode trazer ao tema. Através 
delas, os agentes participam nos campos visando manter ou melhorar suas posições relativas aos outros agentes. Bourdieu (1994) trouxe este conceito para o universo educacional em um estudo sobre as Grandes Écoles ${ }^{24}$. Metodologicamente, o autor justifica a importância de privilegiar na pesquisa a análise das relações entre os sujeitos ante aos elementos diretamente visíveis, considerando necessário

deduzir as leis de funcionamento desses diferentes campos, os objetivos específicos que eles propõem, os princípios de divisão segundo os quais se organizam, as forças e as estratégias dos diferentes campos que se opõem; tudo isto sem esquecer que, por maior que seja sua autonomia relativa, cada um deve suas propriedades mais fundamentais à posição que ocupa no campo do poder: só pensando como tal a estrutura de relações objetivas entre os diferentes universos e a luta para manter ou subverter essa estrutura, quer dizer, para impor o princípio dominante de dominação é possível compreender completamente as propriedades específicas de cada um dos subcampos. (BOURDIEU, 1994, p. 42)

A compreensão das relações estabelecidas no espaço escolar, especialmente entre diretores e professores, requer a observação sobre a capacidade destes agentes de se adaptarem ao funcionamento do campo - lógica da organização escolar e demandas externas. Em se tratando de relações hierárquicas, ou seja, quando uns (diretores) detém mais poder de decisão do que outros (professores), esse sens du jeu se torna mais complexo. As estratégias de ação do diretor, para manter ou conquistar sua posição de liderança no campo, têm que considerar as adaptações necessárias para corresponder às diferentes expectativas que envolvem o espaço escolar. A esta capacidade de adaptação, Bourdieu (1996, p.144) acrescenta a habilidade de antevisão: “[...] ter o sentido do jogo é ter o jogo na pele; é perceber no estado prático o futuro do jogo. É ter o senso histórico do jogo. [...] o bom jogador é aquele que antecipa, que está adiante do jogo". Enquanto gestor responsável por sua unidade escolar e exercendo o papel de líder entre os demais sujeitos da escola, o diretor exercita, constantemente, sua capacidade de adaptação. A partir desta reflexão, discutiremos os conceitos gestão escolar e liderança a partir do trabalho do diretor na escola, especialmente na construção de um clima escolar propício à aprendizagem.

O uso do termo gestão escolar foi, ao longo das últimas décadas, substituindo e ressignificando o conceito de administração escolar nas políticas educacionais e nos estudos no campo da política e da sociologia da educação. Como aponta Souza (2006), esse processo de alternância no uso do conceito data da década de 1980 e está relacionado à valorização da natureza política da gestão escolar. Há que se considerar o contexto

\footnotetext{
${ }^{24}$ A educação superior na França é caracterizada pela coexistência de dois sistemas: as Universidades e as Grandes Ecoles. Estas últimas são instituições de pequeno e médio porte, que têm sólido apoio administrativo e financeiro, são altamente seletivas, proporcionam educação de alta qualidade e mantém laços próximos com o mundo corporativo. (Fonte: www.bsbu.eu)
} 
político-social deste período, pautado pelos movimentos em defesa da democratização (inclusive da escola), legalmente assegurada pelas legislações (Constituição Federal de 1988 e Lei de diretrizes e Bases da Educação Nacional, 1996). De acordo com o autor, passa-se a considerar como objeto da gestão escolar a coordenação da política escolar. Em consonância com esta consideração, Paes de Carvalho (2012, p.80) aponta que

pode-se aventar, então, a hipótese de que, ao menos naquele momento, o termo "administração escolar" permaneceu vinculado à perspectiva mais tecnocrática anteriormente vigente, enquanto o termo "gestão" teria sido assumido pelos críticos àquela perspectiva, que valorizavam o conteúdo político da gestão da escola, atribuindo ao diretor um papel de mediação e liderança política potencialmente transformadora.

Aprofundar a discussão sobre a construção histórica do uso do conceito está além das pretensões deste trabalho. ${ }^{25}$ Por hora, é relevante destacar que sua utilização no cenário educacional brasileiro surge em um momento de extensa discussão de propostas democratizadoras no cenário político do fim do regime militar na década de 1980, assumindo, simultaneamente, traços das teorias administrativas e organizacionais.

Compreendendo que a gestão escolar se dá através de relações de disputa de poder entre os seus agentes, entendendo a escola enquanto organização e um sistema em si próprio (LIMA, 2001) e reconhecendo a escola enquanto contexto de multirregulação das reformas educacionais (BARROSO, 2006b), cabe questionar: quem, de fato, é responsável pela gestão da escola? A relevância dada à democratização dos processos escolares em nosso país, inclusive da gestão, data do final da década de 1980, mais especificamente com a promulgação da Constituição Federal de 1988 que estabeleceu a "gestão democrática do ensino público, na forma da lei” (BRASIL, 1988, Art. 206, Inciso VI). Mais tarde, a Lei de Diretrizes e Bases da Educação Nacional (LDBEN 9394/1996) mantém o princípio da gestão democrática como indicação para o ensino público e prevê como as escolas devem garantir o processo de gestão democrática instituindo: "participação dos profissionais da educação na elaboração do projeto pedagógico da escola e participação das comunidades escolar e local em conselhos escolares ou equivalentes" (BRASIL, 1996, Art. 14).

Porém, o que está sendo entendido no contexto escolar como gestão democrática? O que tem sido colocado em prática? Os princípios propostos pela legislação garantem uma gestão realmente democrática no contexto escolar?

Primeiramente, há que se destacar a tendência de se privilegiar a lógica da participação como garantia da gestão democrática da escola. Mendonça (2001)

\footnotetext{
${ }^{25}$ Sobre este aspecto, sugerimos a leitura da Tese de Doutoramento de Souza, 2006.
} 
problematiza esta tendência, apontando uma distribuição desigual da participação no processo de gestão democrática nas escolas:

Ao abordar aspectos da gestão democrática do ensino público ligados à participação, foi possível constatar que, ao contrário do que se idealiza sobre a convivência entre membros da comunidade escolar, os mecanismos adotados pelos sistemas não lograram pôr termo à guerra entre segmentos. Diretores, professores e funcionários, com prevalência dos primeiros, ainda monopolizam os foros de participação. (op. cit., p. 87)

Souza (2006, p.130-131), por sua vez, alerta sobre o risco de se pautar a democratização da gestão pela lógica da maioria:

A instituição de conselhos de escola, eleições para dirigentes escolares, ou outros mecanismos tidos como de gestão democrática que atuam a partir da regra da maioria, per si, portanto, não representam muito a democracia. Se os indivíduos que compõem essas instituições não pautarem suas ações pelo diálogo e pela alteridade, pouco restará de democrático nessas ações coletivas.

A compreensão sobre o processo de operacionalização da gestão democrática nas escolas tem sido interesse de pesquisa na área da sociologia e política educacional, especialmente das pesquisas de natureza qualitativa, conforme apontou o levantamento de Souza (2006). Dada a relevância do tema nesta pesquisa, consideramos a necessidade de ampliar as informações disponíveis sobre a atuação do diretor escolar a partir da demanda legal do exercício da gestão democrática. Para tanto, é preciso compreendê-la para além da lógica da participação, conforme propõe Souza (2006, p. 131):

A gestão democrática é compreendida então como um processo político através do qual as pessoas que atuam na/sobre a escola identificam problemas, discutem, deliberam e planejam, encaminham, acompanham, controlam e avaliam o conjunto das ações voltadas ao desenvolvimento da própria escola na busca da solução daqueles problemas. Esse processo, sustentado no diálogo, na alteridade e no reconhecimento às especificidades técnicas das diversas funções presentes na escola, tem como base a participação efetiva de todos os segmentos da comunidade escolar, o respeito às normas coletivamente construídas para os processos de tomada de decisões e a garantia de amplo acesso às informações aos sujeitos da escola.

Pretendemos, assim, discutir o conceito de gestão democrática tanto a partir do que é legalmente esperado do trabalho de gestão do diretor escolar, assim como a partir de sua compreensão sobre o que é uma gestão democrática e como se deve operacionalizá-la. Tendo em vista a questão do papel político do diretor escolar, discutido na seção anterior, algumas estratégias características à gestão democrática como a compreendemos (diálogo em equipe, deliberações, planejamentos, participação nas 
decisões) podem ficar comprometidas. O estudo propõe então uma reflexão sobre como o diretor lida com esta dupla demanda - operacionalizar a gestão democrática na escola e garantir que as determinações externas sejam cumpridas - garantindo (ou não) que a escola cumpra sua função de ensino. Esta dupla demanda está entre as múltiplas funções do diretor escolar, muitas delas decorrentes das mudanças nas atribuições e no contexto da gestão da escola nos últimos anos. Barroso (2012) analisou o contexto de atuação da gestão escolar, sintetizando os "mundos" do diretor conforme o esquema a seguir:

Figura 4: Os "mundos" do diretor.

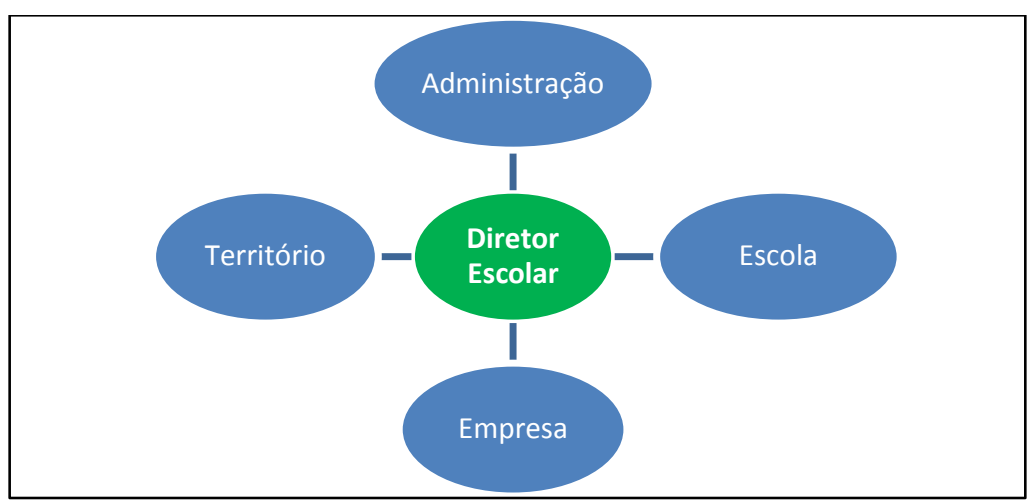

Fonte: BARROSO, 2012

De acordo com o autor, o diretor escolar se encontra, atualmente, no centro de quatro dimensões referenciais para realizar a gestão escolar. Na dimensão Administração o diretor representa o elo entre a administração educacional central e a escola; na dimensão Escola o diretor é o representante dos demais, o primeiro entre os iguais; na dimensão Empresa o diretor representa o gestor de empresas, que deve se preocupar com a eficiência e a eficácia dos resultados; na dimensão território, o diretor é o negociador político, que se conecta com as especificidades e demandas locais. $\mathrm{O}$ autor acrescenta que estas quatro dimensões foram se estruturando na escola e atualmente todos os diretores escolares em Portugal (e outros países) se veem transitando entre estes "mundos" para realizar seu trabalho. Elas se referem às expectativas em relação à atuação do diretor como gestor da escola. Nesta leitura, as expectativas com relação à garantia da aprendizagem dos alunos estariam a cargo da dimensão "empresa", onde o diretoradministrador é o responsável pela eficiência e eficácia da escola. Os estereótipos dirigidos ao diretor escolar a partir da sua múltipla atuação (Administrador, Representante, Diretor executivo, Mediador) expressam seus diferentes posicionamentos enquanto líder da instituição e trazem ainda mais complexidade ao tema. Cabe indagar então: como o diretor equilibra esta complexidade ao exercer sua liderança na escola? 
O termo liderança é, conforme aponta Leithwood (2009, p. 18), complexo e de difícil definição. Antes de explorá-lo no contexto escolar, assumimos alguns pressupostos-chave do conceito adotados pelo autor (ib., ibidem.): a) a liderança existe dentro de relações sociais e serve a fins sociais; b) a liderança implica em um propósito e uma direção; c) a liderança é um processo de influência; d) a liderança é uma função; e) a liderança é contextual e contingente. A partir destes pressupostos, podemos considerar: a) o diretor escolar é um líder em uma teia de relações sociais, onde geralmente atua como mediador; b) sua liderança na escola se baseia em uma meta comum para todos os envolvidos, que a princípio seria garantir a aprendizagem escolar de todos os alunos; c) a extensão de sua liderança na escola dependerá da sua capacidade de influenciar os seus liderados em torno do objetivo da escola; d) Ao tomar posse do cargo de diretor escolar, liderar (no sentido de estar a frente) a escola se torna sua função; e) sua liderança e a forma que ela assume depende do contexto (incluindo o processo de seu acesso ao cargo) e tem um tempo limitado de duração.

Apesar de ser um conceito pouco frequente na literatura acadêmica brasileira sobre a direção escolar, trabalhos que se pautam nos estudos sobre as escolas eficazes, utilizam o termo liderança (ou liderança forte) como uma das características da gestão escolar eficaz (ALVES e FRANCO, 2008; SOARES e TEIXEIRA, 2006; SOARES, 2007; BONAMINO,2012).

Em seus estudos sobre a liderança escolar, Leithwood a define como: "o trabalho de mobilizar e influenciar outros para articular e alcançar as intenções e metas compartilhadas na escola" (2009, p. 20, minha tradução). O autor afirma que as pesquisas recentes têm apontado que uma liderança efetiva na escola abrange funções e características tais como: uma orientação não conformista; selecionar e substituir de maneira rigorosa os professores; garantir que o foco do trabalho da escola seja a aprendizagem; monitorar frequentemente as atividades escolares; valorizar, investir tempo e energia na melhora escolar; apoiar os professores; garantir a participação dos pais dos alunos; monitorar o progresso dos estudantes; desenvolver processos exitosos de agrupamento dos alunos; coordenar as definições curriculares e avaliativas da escola; entre outras. Em geral, de acordo com os estudos de Leithwood (2009, p. 22), as estratégias de liderança escolar mais voltadas para as questões pedagógicas e de aprendizagem são mais fortemente relacionadas à melhora acadêmica dos alunos do que aquelas relacionadas às questões administrativas e organizacionais, naquele contexto. Contudo, vale questionar: tais estratégias ou iniciativas de liderança podem ser analisadas isoladamente? Seriam excludentes?

Souza (2006), ao analisar a natureza do trabalho do diretor escolar, considera as suas faces administrativas e pedagógicas, destacando a tendência de que o diretor se 
dedique mais às questões de cunho administrativo do que àquelas que se relacionam à aprendizagem dos alunos. E qual seria sua motivação (ou desmotivação) para esta priorização? O autor levanta algumas hipóteses, inclusive a da falta de formação ou preparo do diretor para intervir em questões pedagógicas, ainda que reconheça a importância de fazê-lo. Souza ressalta a relação não excludente entre as duas faces e conclui que "os conhecimentos sobre os elementos pedagógicos e administrativos são, os dois, fundamentais para o exercício da função do diretor escolar" (SOUZA, 2006, p. 173).

As discussões sobre as tipologias de liderança escolar são frequentes e, muitas vezes, não consensuais. Nos Estados Unidos, os estudos têm destacado a Liderança Transformacional (focada no desenvolvimento humano e organizacional), a Liderança Instrucional (focada no trabalho dos professores para o cumprimento do currículo e a aprendizagem) e a Liderança Instrucional Distribuída (focada na instrução e aprendizagem, mas envolvendo a participação dos professores). Marks e Printy (2003) propõem como síntese uma Liderança Integrada (Integrated Leadership) que reconhece tanto a importância da liderança ser compartilhada entre os demais agentes educacionais (para usar um termo da nossa literatura) quanto a necessidade de uma referência central atuante e reconhecida para garantir o sucesso do trabalho instrucional na escola. Recentemente, Urick e Bowers (2014) problematizam esta tipologia de perfis de liderança, propondo uma classificação que contemple a interação com o contexto onde a escola está inserida e a relação com os outros agentes escolares.

No cenário europeu, em se tratando das pesquisas sobre o tema, destaca-se o trabalho de Cousin (1998). Olivier Cousin desenvolve um estudo comparativo entre 12 escolas da região em torno de Bordeaux, envolvendo observação e entrevistas e abrangendo um universo de agentes representativo desse conjunto. $\mathrm{O}$ autor identifica três tipos de liderança: um estilo administrativo, que remete a uma atitude burocrática, distinguindo a esfera pedagógica do domínio administrativo e valorizando as regras; um estilo laisser-faire, que privilegia as funções administrativas, mas pouco ou nada intervém no domínio pedagógico, e tende a 'amolecer' as regras; um estilo intervencionista, que tenta alargar seu campo de ação, intervindo em todos os setores do estabelecimento de ensino. Para o autor "o que distingue fundamentalmente os três tipos de gestão não está nas características da equipe de gestão, mas na definição de seu domínio de intervenção" (COUSIN, 1998, p. 132, minha tradução).

No contexto nacional, Polon (2012) buscou identificar diferentes perfis de liderança entre escolas no Rio de Janeiro ${ }^{26}$, sua ocorrência de acordo com a rede de ensino a que pertencia a escola e sua relação com os resultados acadêmicos dos alunos. A

\footnotetext{
${ }^{26}$ Escolas participantes do Projeto Geres - Estudo Longitudinal Geração Escolar 2005, Polo PUCRJ.
} 
autora identificou três perfis de liderança: Pedagógica, que privilegia tarefas de orientação e acompanhamento do planejamento escolar; Organizacional, que prioriza tarefas relacionadas a garantir suporte estrutural ao trabalho acadêmico) e Relacional, cujo foco está nas tarefas relacionadas ao atendimento de alunos, famílias e organização de eventos. No caso estudado, controladas as características socioeconômicas do alunado, a gestão escolar caracterizada predominantemente pela Liderança Pedagógica preponderou nas escolas com melhores resultados acadêmicos. Para Polon (2012, p. 74), tal resultado indica

a necessidade de valorização da dimensão pedagógica da gestão escolar, considerada aqui como aquela que leva os gestores escolares a assumirem um papel de liderança na discussão sobre o que se ensina e como, na construção do projeto pedagógico da escola.

A atenção aos aspectos da aprendizagem no cotidiano escolar está entre os fatoreschave para que a atuação do diretor tenha um efeito positivo no rendimento dos alunos, apontados pelas escolas eficazes e sintetizados por Bonamino (2012, p. 125). Tais fatores envolvem a capacidade de compartilhar a autoridade com a equipe, o acompanhamento sistemático e pessoal das atividades escolares, a capacidade de identificação e articulação de metas e prioridades, a participação e o envolvimento nas questões relacionadas ao aprendizado dos alunos, entre outras. A dimensão pedagógica é considerada uma das características chave dos diretores nos estudos sobre as escolas eficazes. "Eles são líderes que estão envolvidos em atividades pedagógicas e não somente em atividades administrativas, porque entendem que o pedagógico interfere diretamente na aprendizagem dos alunos" (BONAMINO, 2012, p. 124).

Soares e Teixeira (2006) também se dedicaram a identificar perfis de liderança ao analisar a postura dos diretores escolares a partir das seguintes tendências de gestão escolar:

a tendência conservadora, que diz respeito ao papel tradicional do diretor; a tendência democrática, que procura construir um espaço coletivo para a articulação dos diferentes interesses presentes na escola; e a tendência gerencial, que, procurando garantir a autonomia administrativa da escola, mantém o controle sobre os seus resultados e introduz a preocupação com a eficácia das ações escolares. (op. cit., p. 158)

A partir do estudo, que envolveu a aplicação de questionários a professores e diretores de uma amostra das escolas estaduais de Minas Gerais, a análise dos dados possibilitou a identificação destas tendências nos perfis dos diretores. Porém, elas não se categorizaram diretamente nestes três grupos. Há um número significativo de fatores que 
podem ser associados mais ou menos a esse modelo. Percebe-se assim uma fusão de características na construção do perfil de liderança do diretor escolar.

Uma importante questão que não pode deixar de ser mencionada ao estudarmos a liderança escolar é a de que, como foi visto, os estudos realizados tendem a categorizar as atitudes, estratégias e posturas do diretor escolar (muitas vezes a partir das percepções dos professores) em perfis de liderança. E, em alguns casos, apontam formas de liderar a escola mais fortemente relacionadas com a melhora nos resultados de aprendizagem dos alunos. Não podemos tomar estas referências como uma "prescrição" para a atuação dos diretores na escola ou as categorias construídas para atuação em determinados contextos como um enquadramento para todos os outros diretores. Como aponta Paes de Carvalho (2012, p. 89): “como qualquer tipologia, devemos considerá-la um insumo para reflexão e não uma moldura na qual se possa se encaixar univocamente cada gestor escolar".

Para compreender as dimensões do trabalho do diretor escolar, esta pesquisa propôs uma reflexão sobre seu trabalho enquanto gestor escolar e enquanto líder desta instituição, aproximando os conceitos gestão e liderança. Enquanto gestor escolar, o diretor assume a responsabilidade pela instituição que representa e as características do seu trabalho podem revelar diferentes perfis de liderança que se refletirão na manutenção do ambiente escolar, com condições de trabalho para os professores e, consequentemente, para a aprendizagem dos alunos. Assim, a sua atuação na gestão e liderança da escola são elementos fundamentais para a construção do clima escolar.

O conceito de clima escolar tem sua origem nos estudos sobre clima organizacional e sua definição não é consenso entre os estudos na área . Brunet (1992, p. 125) aponta que atualmente os estudos sobre o clima organizacional o definem como medida perceptiva dos atributos organizacionais. "Neste caso, o elemento principal é a percepção que um indivíduo tem do seu ambiente de trabalho. [...] A percepção surge, então, como um filtro que serve para interpretar a realidade e as componentes da organização" (BRUNET, 1992, p. 126). Neste sentido, entendemos que a medida do clima de uma organização se dá pela percepção dos seus sujeitos.

O trabalho de Aguerre (2004) é, sem dúvida, referência fundamental para o estudo de clima organizacional nas escolas, tanto por sua abrangência quanto por sua profundidade. $\mathrm{O}$ autor destaca a importância do conceito clima organizacional para os estudos educacionais e o enfoque que o mesmo vem recebendo, sobretudo nas pesquisas sobre a eficácia escolar. Ao fazer um levantamento histórico da abordagem do tema nos estudos educacionais, Aguerre (2004) cita os autores que foram referência na definição do tema e apresenta uma construção evolutiva do termo, desde a introdução do conceito de clima nos estudos organizacionais (década de 1930), passando pela ênfase no plano metodológico (1960/1970) e pela crise epistemológica dos anos 1980, até uma síntese de 
quatro enfoques sobre o clima na escola: o sistema autoritário explorador; o sistema autoritário paternalista; o sistema consultivo e o sistema de participação em grupo. A partir dos anos 1980, tendo como ponto de partida o trabalho de Bryk e Driscoll, várias pesquisas desenvolveram instrumentos para investigar o clima organizacional na escola, considerando-a uma comunidade e polarizando dois modelos de organização: "o comunitário e o burocrático" (AGUERRE, 2004, p. 50, minha tradução).

Mais tarde, nos anos 1990, Hoy e Feldman desenvolvem um novo instrumento voltado para a análise da "saúde do clima escolar", o Organizational Health Inventory for High Schools (OHI), conforme aponta Aguerre (2004, p. 49). Esta abordagem se fundamenta nos estudos de Parsons e reflete a crescente preocupação com a qualidade do clima organizacional para os resultados escolares.

Em nossa revisão de literatura os estudos de Rodney Ogawa e Steven Bossert foram citados em algumas pesquisas como referência para a definição do conceito de clima escolar. Os autores trabalham com dois conceitos importantes: liderança escolar como qualidade organizacional e clima escolar. Partindo dos estudos sobre as teorias das organizações, Ogawa e Bossert (1995) discutem a compreensão sobre a liderança nas duas perspectivas da teoria técnico-racional e da teoria institucional das organizações. $\mathrm{Na}$ perspectiva técnico-racional, considerada pelos autores como a visão dominante nos estudos sobre a liderança escolar, os líderes "operam dentro de culturas organizacionais e afetam a interpretação dos outros participantes sobre os eventos organizacionais assim como influenciam a maneira como estes se comportam" (OGAWA e BOSSERT, 1995, p. 229, grifo dos autores, minha tradução). Já na concepção institucional, a liderança é uma qualidade sistêmica das organizações, um fenômeno cultural, e "não está confinada a certos papéis nas organizações" (op. cit., p. 238). A compreensão da liderança escolar como uma qualidade organizacional implica, de acordo com os autores, em se compreender os micro-contextos escolares, as relações que se constroem na escola. Os pesquisadores, nesta perspectiva, devem analisar a liderança "monitorando seu fluxo para cima para baixo nas organizações e entre os seus níveis" (OGAWA e BOSSERT, 1995, p. 239, minha tradução). Quanto aos parâmetros para a liderança, a perspectiva técnicoracional destaca a performance organizacional e cumprimento de metas, enquanto a perspectiva institucional enfoca legitimidade social e a sobrevivência organizacional. Ogawa e Bossert (1995) destacam que os possíveis efeitos causais da liderança atuam sobre a sobrevivência organizacional dependendo de dois fatores: "a adoção de estruturas institucionalizadas no nível administrativo e o desenvolvimento de mecanismos coordenados no nível técnico" (op. cit. p. 234, minha tradução). E, mais importante (considerando o enfoque deste trabalho), os autores apontam que os professores 
estabelecem suas estratégias de ensino a partir das contingências que encontram no nível técnico das organizações escolares.

Ogawa e Bossert (1995) analisaram a compreensão de liderança a partir de diferentes perspectivas que influenciaram os estudos sobre o clima escolar. É interessante notar que o foco está no trabalho do diretor escolar e nele a liderança assume diferentes variações, tanto em sua forma como em sua substância (op. cit., p. 239). Quanto a possível associação entre as características do trabalho do diretor e as dimensões do clima escolar, Brunet (1992, p. 128) chama a atenção para a impossibilidade de generalizar os resultados, uma vez que "o estilo de liderança só indica uma das dimensões possíveis do clima [organizacional]".

Cousin (1998) também aponta, em seu estudo, um conjunto de indicadores para estudar as escolas, entre os quais destaca as "políticas da equipe de gestão". Estas se desdobram em aspectos que abrangem: estrutura interna de funcionamento da escola, fluxos decisórios e relações com professores, funcionários, alunos e famílias: "Formalmente, a equipe de gestão organiza a vida do estabelecimento" (COUSIN, 1998, p. 129, minha tradução). Compreendendo as relações entre a equipe de gestão escolar e os professores como um indicador da política de liderança na escola, Cousin (1998, p.134) aponta que as relações são percebidas como positivas pelos professores, quando eles enxergam no diretor um representante, quando há espaço para a discussão coletiva sobre os objetivos do estabelecimento de ensino e quando a gestão apoia os professores nas resoluções dos problemas de disciplina, entre outras. $\mathrm{O}$ autor valoriza a dimensão relacional da gestão escolar, que passa tanto pela participação e coletividade, quanto pelo suporte da autoridade escolar para as decisões do professor. No trabalho com os dados da pesquisa, Cousin (1998) concluiu que além da alta correlação entre origem social e desempenho escolar, o estabelecimento também é uma variável explicativa importante para a compreensão dos resultados escolares, em consonância com os trabalhos sobre a eficácia escolar. O autor desenvolve um conjunto de indicadores para caracterizar as escolas no que se refere às suas diferentes políticas institucionais. enfatizando a mobilização dos professores na relação com os índices acadêmicos das escolas. Cousin (1998) ressalta que uma das pré-condições fundamentais para que tais "políticas de sucesso" possam perdurar e incrementar é, logicamente, a estabilidade do corpo docente e da equipe administrativa.

Nesta pesquisa, propomos o estudo sobre a relação entre o trabalho do diretor escolar (incluindo a gestão da escola e a liderança que exerce) e possíveis alterações ou manutenções no clima escolar, considerando as definições apresentadas acima. Toma-se como referência a tendência apresentada pelos autores citados de compreender o clima escolar como o resultado do compartilhamento de ações individuais e coletivas. Sua 
leitura se faz possível através da percepção narrada por seus agentes, no caso, os próprios diretores e os professores das escolas pesquisadas. 


\section{3 \\ O campo: Definindo o recorte de pesquisa}

A rede de escolas municipais da cidade do Rio de Janeiro é a maior rede municipal da América Latina ${ }^{27}$. Atualmente, atende a 664.384 alunos matriculados em Creches, Unidades de Educação Infantil e Ensino Fundamental (1677 unidades, no total), onde trabalham 42.529 professores. ${ }^{28}$ Conforme determina o Artigo 11 da Constituição Federal, é de responsabilidade dos municípios a oferta da educação infantil (creches e pré-escolas) e do ensino fundamental:

A União, os Estados, o Distrito Federal e os Municípios organizarão em regime de colaboração seus sistemas de ensino.

$\S 1^{\circ}$ A União organizará o sistema federal de ensino e o dos Territórios, financiará as instituições de ensino públicas federais e exercerá, em matéria educacional, função redistributiva e supletiva, de forma a garantir equalização de oportunidades educacionais e padrão mínimo de qualidade do ensino mediante assistência técnica e financeira aos Estados, ao Distrito Federal e aos Municípios;

$\S 2^{\circ}$ Os Municípios atuarão prioritariamente no ensino fundamental e na educação infantil.

$\S 3^{\circ}$ Os Estados e o Distrito Federal atuarão prioritariamente no ensino fundamental e médio.

$\S 4^{\circ} \mathrm{Na}$ organização de seus sistemas de ensino, a União, os Estados, o Distrito Federal e os Municípios definirão formas de colaboração, de modo a assegurar a universalização do ensino obrigatório.

$\S 5^{\circ}$ A educação básica pública atenderá prioritariamente ao ensino regular. (BRASIL, 1988)

No caso do ensino fundamental, considerava-se, ainda, a possibilidade de repartir a responsabilidade da oferta com o estado federado a que pertence o município, uma vez que os municípios são espaços de atendimento das demandas educacionais da sociedade por meio da colaboração entre as três esferas de governo. Contudo, a Emenda Constitucional nº 14 de 1996, mantém a orientação para o regime de colaboração entre os entes federados, e orienta a municipalização do ensino fundamental, delegando aos Estados a competência pelo Ensino Médio, de forma gradativa. Assim, os municípios brasileiros passam a ser os principais responsáveis pela oferta do ensino fundamental ${ }^{29}$. No estado do Rio de Janeiro, esta indicação constitucional vai ao encontro do Programa de Municipalização da Educação Infantil e Ensino Fundamental - PROMURJ, a partir de

\footnotetext{
${ }^{27}$ Segundo a definição da própria SME/RJ, disponível em: www.rio.rj.gov.br/web/sme

${ }^{28}$ Dados disponíveis em: www.rio.rj.gov.br/web/sme/educacao-em-numeros.

${ }^{29}$ Aprofundar as questões relacionadas ao federalismo educacional brasileiro, ou seja, os aspectos do regime de colaboração entre os governos municipal, estadual e federal na oferta educacional (conforme previsto na Constituição Federal de 1988) foge ao escopo deste trabalho. Contudo, para uma reflexão detalhada sobre o tema, sugerimos as obras de Arretche, 2000 e 2012, indicadas nas referências bibliográficas.
} 
1988. O programa foi criado originalmente pela Resolução da SEE n. 1.411, de 03 de dezembro de 1987, e alterado pelas Resoluções SEE n. 1.488, de 08 de março de 1989 e n. 1658 de 25 de março de 1992 (SECRETARIA ESTADUAL DE EDUCAÇÃO DO RIO DE JANEIRO, 1987, 1989 e 1992). O programa prevê a transferência gradual e progressiva da responsabilidade pela Educação Infantil e pelo Ensino Fundamental para os municípios. Esta transferência, além de visar cumprir a indicação legal, procura racionalizar a oferta do ensino público, tornando mais eficiente a aplicação dos recursos financeiros para a educação de qualidade. A meta do programa, em 2011, era a de que até 2015 todo o primeiro segmento do ensino fundamental, $\left(1^{\circ}\right.$ ao $5^{\circ}$ ano), fosse de responsabilidade dos municípios, em todo o estado. (ALERJ, 2011). Os municípios fluminenses vêm absorvendo este processo de municipalização em diferentes ritmos e alguns estudos vêm sendo desenvolvidos nesta área ${ }^{30}$. O município do Rio de Janeiro absorve este processo de forma mais acelerada, tornando-se, como já foi dito, a maior rede municipal de ensino da América Latina. Quando comparamos a distribuição entre as dependências administrativas (federal, estadual e municipal) das escolas avaliadas na edição de 2011 da Prova Brasil nas três maiores capitais do país, nota-se no município do Rio de Janeiro a supremacia da rede municipal no que concerne à oferta e gestão do ensino fundamental:

Tabela 1: Distribuição, por dependência administrativa, das escolas avaliadas na Prova Brasil 2013: Rio de Janeiro, São Paulo e Belo Horizonte.

\begin{tabular}{lrrrr}
\hline \hline & Rio de Janeiro & São Paulo & Belo Horizonte \\
\hline Federal & $15(1,7 \%)$ & $1(0,1 \%)$ & $2(0,5 \%)$ \\
Estadual & $29(3,2 \%)$ & $978(67,5 \%)$ & $198(54,7 \%)$ \\
Municipal & & $853(\mathbf{9 5 , 1 \%})$ & $489(32,4 \%)$ & $162(44,8 \%)$ \\
& Total & $897(100 \%)$ & $1448(100 \%)$ & $362(100 \%)$ \\
\hline \hline
\end{tabular}

Fonte: INEP, 2015.

A opção pela realização da pesquisa na rede municipal de ensino do Rio de Janeiro se justifica, então, pela dimensão do seu atendimento, que concentra quase toda a oferta do ensino fundamental público na cidade. Além disso, a oferta educacional (séries atendidas) das escolas nesta rede apresenta, atualmente, uma grande diversidade de configurações e arranjos, como foi comentado na introdução deste trabalho. Entre estas diferentes configurações, encontram-se as escolas que atendem aos dois segmentos do ensino fundamental, recorte escolhido para esta pesquisa.

\footnotetext{
${ }^{30}$ A este respeito, vem sendo desenvolvida a Tese de Doutoramento de Andreia Martins de Oliveira Santo, integrante do GESQ.
} 


\section{1 Por que estudar as escolas que atendem aos dois segmentos do ensino fundamental?}

Nesta pesquisa propomos investigar a atuação da gestão escolar em unidades que atendem, simultaneamente, ao $5^{\circ}$ e ao $9^{\circ}$ anos, ou seja, que oferecem os dois segmentos do ensino fundamental. Esta escolha se deu por diferentes razões: o interesse em analisar as estratégias de gestão adotadas pelos diretores de unidades que atendem um público potencialmente maior, com uma maior diversidade no corpo discente (alunos de diferentes idades e com diferentes demandas) e no corpo docente (grupo mais numeroso, professores com diferente formação acadêmica, licenciados em pedagogia ou em disciplinas específicas). O gerenciamento de uma escola com estas características demanda, por parte do diretor da unidade, estratégias específicas que, nos parece, merecem ser estudadas. Brunet $(1992,1987)$ e Aguerre (2004), nos estudos sobre clima organizacional nas escolas, destacaram a influência do tamanho da escola:

Do ponto de vista da relação causal, podem aqui recuperar-se algumas das hipóteses levantadas por Brunet (1987), sobre a existência de uma relação linear inversa entre clima e tamanho da escola. (AGUERRE, 2004, minha tradução)

A revisão de literatura realizada sobre o tema desta pesquisa demonstrou que esta não é uma característica da gestão escolar que tem merecido a atenção dos pesquisadores. Entre as teses e dissertações levantadas sobre o tema nenhuma utilizou este recorte e entre os 42 artigos analisados, apenas um estudo menciona o tamanho da escola como um fator determinante para o trabalho da gestão escolar. Trata-se do estudo de Donaldson (2013) sobre as principais barreiras que os diretores encontram nas tarefas de selecionar/contratar, avaliar, atribuir tarefas e favorecer o desenvolvimento profissional dos professores: "Líderes de escolas que eram substancialmente maiores (pelo menos 15\%) do que a média estadual para seu segmento de atendimento apresentaram maior frequência em identificar barreiras nas funções de capital humano discutidas" (op. cit., p. 866, minha tradução). De acordo com o estudo, o diretor nestas escolas não tem tempo hábil para interagir com um elevado número de alunos e staff.

Além de possibilitar um olhar para um campo pouco estudado, há, principalmente, uma justificativa metodológica para esta escolha: a possibilidade de ampliar o volume e a diversidade de informações sobre o corpo docente em cada escola. A opção por estudar as escolas que atendem um maior número de séries do ensino fundamental nos permitirá uma visão mais ampliada das características da gestão do diretor e de sua relação com o trabalho docente. Para a construção destas informações é preciso acessar as respostas dos 
professores para questões relacionadas ao tema e, quanto maior for o número de respondentes em cada unidade, maior será a possibilidade de que as informações levantadas correspondam a uma percepção representativa do grupo docente da escola.

Os gráficos que se seguem apresentam informações sobre o número de alunos, professores e turmas das escolas selecionadas, comparando-as com a média das escolas que atendem somente a um dos segmentos do ensino fundamental ${ }^{31}$ e com a média de todas as escolas municipais do Rio de Janeiro.
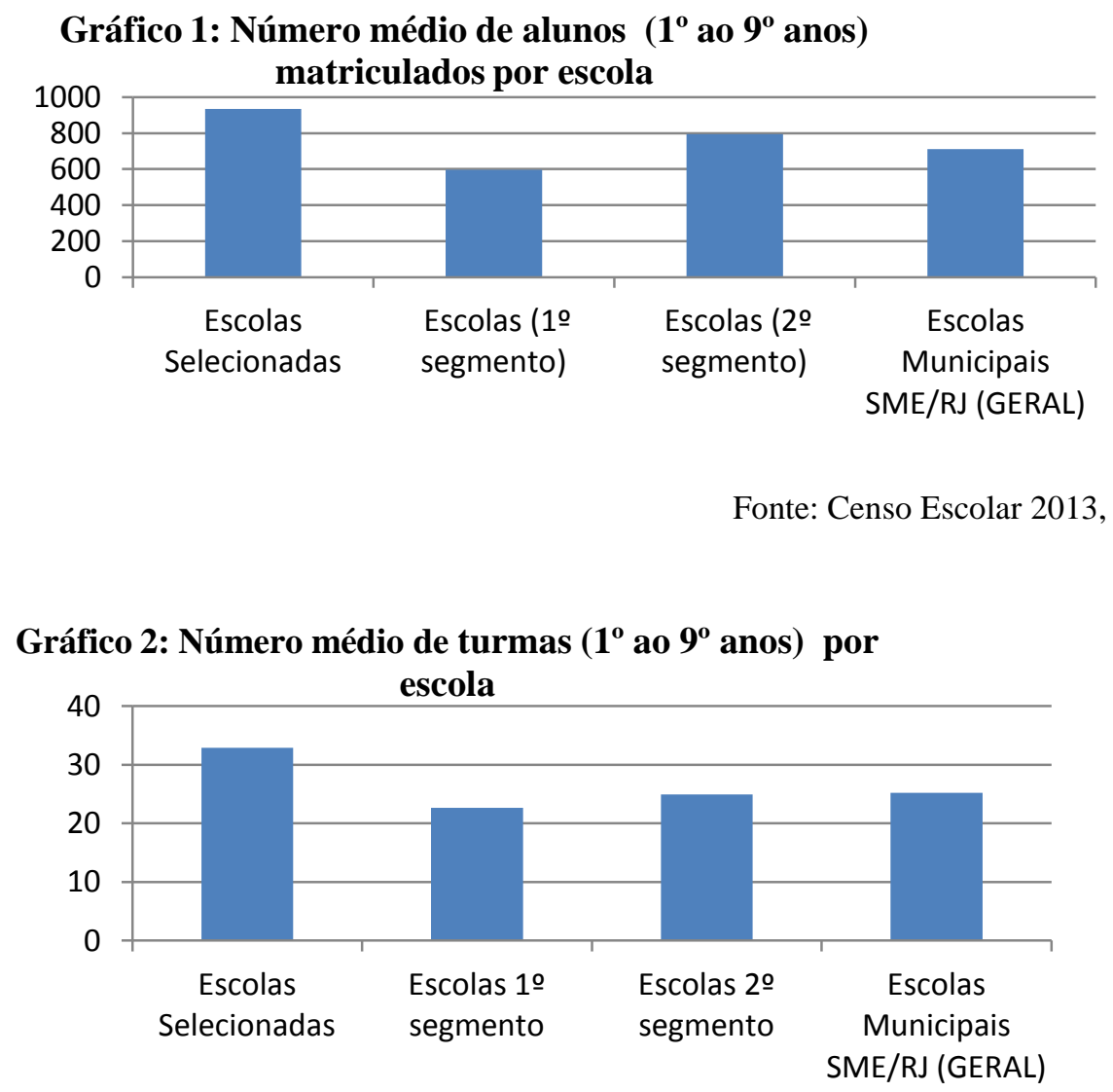

Fonte: Censo Escolar 2013, INEP 2014.

\footnotetext{
${ }^{31}$ Consideramos aqui as escolas que foram testadas na Prova Brasil 2013 somente no $5^{\circ}$ ano como "Escolas de $1^{\circ}$ segmento" e as escolas que foram testadas somente no $9^{\circ}$ ano como "Escolas de $2^{\circ}$ segmento".
} 
Gráfico 3: Número médio de professores por escola

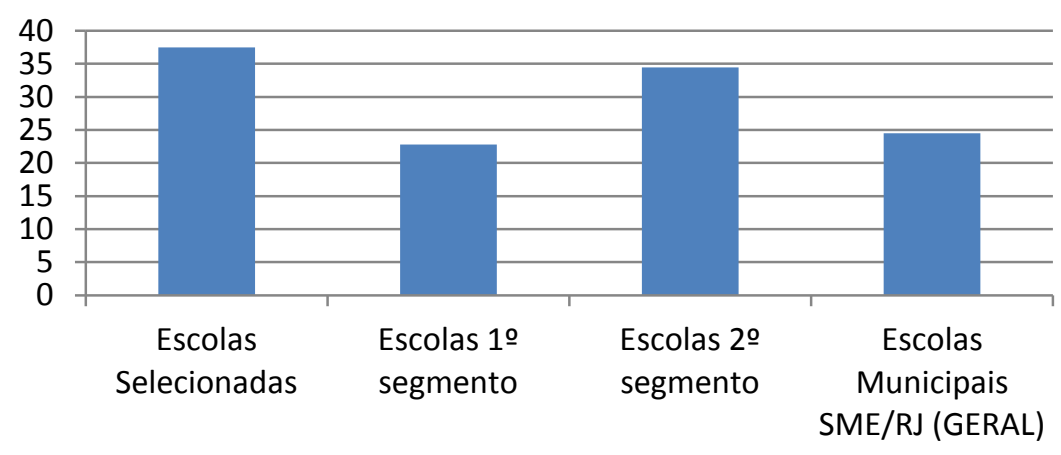

Fonte: Censo Escolar 2013, INEP 2014.

Como podemos observar a partir dos dados apresentados, os diretores das escolas selecionadas para esta pesquisa lidam com um universo ampliado em comparação à realidade das escolas municipais do Rio de Janeiro que atendem somente a um dos segmentos do ensino fundamental ou em relação à rede como um todo: suas escolas têm, em média, mais alunos matriculados, distribuídos em um número maior de turmas, assistidas por um número maior de professores. Especificamente com relação ao número médio de professores, nas escolas selecionadas temos aproximadamente 37,47 professores por escola, enquanto a média no município é de 24,46 professores por escola. Em se tratando da gestão da unidade escolar, pode-se inferir que estes diretores lidam com uma realidade mais complexa comparada às outras escolas da rede municipal do Rio de Janeiro. As questões relacionadas aos alunos (matrícula, enturmação, acompanhamento, atendimento às famílias, problemas disciplinares e de aprendizagem, entre outras) e aos professores (alocação por turma, acompanhamento do trabalho, atendimento, faltas, entre outras) passam a ter uma dimensão maior considerando a diferença quantitativa e qualitativa neste universo.

Portanto, optamos por aplicar os questionários construídos a diretores, coordenadores pedagógicos e professores em escolas que atendem aos dois segmentos do ensino fundamental, principalmente por possibilitar um acesso mais ampliado aos dados dos professores e incorporar à análise outros agentes que participam da gestão da escola. 


\section{2 Quantas e quais escolas?}

Para selecionar o grupo de escolas que atendiam aos dois segmentos do ensino fundamental, realizamos uma análise dos dados disponibilizados pelas edições da Prova Brasil e pelo Censo Escolar.

No ano de 2009, 227 escolas da rede municipal do Rio de Janeiro foram avaliadas tanto no $5^{\circ}$ quanto no $9^{\circ}$ ano, ou seja, ofereciam turmas para esses anos, atendendo assim aos dois segmentos do ensino fundamental (trabalhamos aqui com uma aproximação considerando que estas escolas, possivelmente, atenderiam a todas as séries do ensino fundamental $-1^{\circ}$ ao $9^{\circ}$ anos). Já na edição de 2011 da Prova Brasil, este número cai para 204 escolas $^{32}$. Considera-se que algumas escolas deixaram e poucas passaram a fazer parte deste grupo, indicando um movimento de redução do número de escolas deste tipo na rede municipal do Rio de Janeiro. Optamos, então, por trabalhar com as 197 escolas da rede municipal do Rio de Janeiro que atendiam tanto o $5^{\circ}$ como o $9^{\circ}$ ano desde a edição de 2009 da Prova Brasil.

Como o interesse desta pesquisa se dirige para as escolas que se encaixam neste perfil, tornou-se importante entender se existe alguma política ou indicação da SME/RJ para a determinação do atendimento de cada unidade escolar (uma vez que os dados indicavam uma redução no número de escolas atendendo os dois segmentos do ensino fundamental). Segundo a Coordenadoria de Educação da SME/RJ (informação verbal) ${ }^{33}$, o critério para redução ou ampliação do atendimento feito pelas unidades escolares tradicionalmente era a demanda de cada localidade. Recentemente, foi desenvolvido um amplo projeto de reorganização do atendimento das unidades escolares da rede municipal do Rio de Janeiro em parceria com o Instituto Pereira Passos - IPP, procurando atender a orientação da Lei Municipal 5225, de 05/11/2010 que define a adoção do turno único de 7 horas para todas as escolas da rede municipal. O projeto envolve o desenvolvimento de uma metodologia para divisão da cidade em áreas, para as quais são estimadas a oferta e demanda existentes, visando à definição da quantidade de salas necessárias e a reorganização da atual oferta de turmas e segmentos para implementação do turno único. As escolas começaram então a ser reorganizadas desde 2013, considerando as unidades existentes e a necessidade de construção de novas unidades. De acordo com a divulgação do estudo pelo IPP "O mapeamento dessas informações possibilita planejar de forma

\footnotetext{
${ }^{32}$ Como este estudo para a seleção das escolas foi realizado em 2014, antes dos dados da Prova Brasil 2013 serem liberados (o que só aconteceu, em sua versão definitiva, em maio de 2015), tomamos como referência para esta seleção os dados disponibilizados pela Prova Brasil 2011.

${ }^{33}$ Entrevista realizada na Coordenadoria de Educação da SME/RJ, em 02/06/2014.
} 
integrada a construção de novas unidades escolares, de forma a se alcançar uma melhor distribuição espacial da oferta de ensino na rede municipal, diminuindo as distâncias a serem percorridas pelos alunos" ${ }^{34}$. Pretende-se, assim, gerar uma territorialização das matrículas, uma vez que cada uma das 232 áreas da cidade deverá contar com as seguintes unidades de atendimento: 3 Escolas de Desenvolvimento Infantil - EDI, 2 Primários Carioca ( $1^{\circ}$ ao $6^{\circ}$ anos) e 1 Ginásio Carioca $\left(7^{\circ}\right.$ ao $9^{\circ}$ anos). As unidades vem sendo reorganizadas gradativamente para esta funcionalidade e prevê-se que, futuramente, todas atenderão em turno único de 7 horas. Esta reorganização da rede municipal extinguirá as escolas que atendem aos dois segmentos A complexidade da gestão destas escolas, que procuramos ilustrar anteriormente, é reconhecida pela SME/RJ (informação verbal) ${ }^{35}$, que destaca a dificuldade em gerenciar um número grande de alunos e professores, com demandas bastante diversas. A definição do turno único de 7 horas escolares prevê, também, uma progressiva vinculação dos professores com a unidade escolar, estabelecendo uma gradual migração dos profissionais para o regime de 40 horas semanais na mesma escola. O aumento do tempo dedicado às atividades escolares, considerado uma conquista importante para elevar a qualidade da aprendizagem, requer uma reestruturação curricular que vem sendo estudada pelas equipes da SME/RJ, de acordo com a Subsecretaria de Ensino da SME/RJ (Informação verbal) ${ }^{36}$. Ao final de 2011, havia 171 escolas da rede já funcionando em turno único e a meta da SME/RJ é de que todas as escolas da rede já tenham incorporado o turno único até 2020 (SECRETARIA MUNICIPAL DE EDUCAÇÃO DO RIO DE JANEIRO, 2010).

A proposta de reorganização das unidades escolares da SME/RJ abrange especialmente as escolas que compõem o universo desta pesquisa. Tornou-se necessário, então, atualizar nossas informações e verificar se as escolas que ofereciam os dois segmentos do ensino fundamental em 2013 ainda continuavam com esta oferta educacional no período da aplicação dos questionários (2014). Para esta verificação, utilizamos a base de dados do Censo Escolar de 2013 e informações coletadas no contato com as Coordenadorias de Ensino (CREs) para o encaminhamento da autorização de pesquisa. Constatamos que 34 das 197 escolas selecionadas haviam deixado de atender os dois segmentos do ensino fundamental desde 2011 até 2014, comprovando a tendência da redução da oferta de unidades com estas características na rede municipal do Rio de Janeiro. Assim, nosso universo de pesquisa passou a ser composto por 163 escolas da rede municipal do Rio de Janeiro que atendiam, em 2014, aos dois segmentos do ensino fundamental. É importante registrar que, em médio prazo, prevê-se que as escolas que

\footnotetext{
${ }^{34}$ Informação disponível http://www.rio.rj.gov.br/web/ipp

${ }^{35}$ Entrevista realizada na Coordenadoria de Educação da SME/RJ, em 02/06/2014.

36 "Seminário SME/RJ e PUC-Rio" Apresentação da Gerência Educacional (GED) da SME/RJ na PUC-Rio, em 28/11/2014
} 
atendem aos dois segmentos do ensino fundamental não mais existirão nesta rede. Contudo, manter esta seleção na nossa pesquisa se justificou pelos seguintes motivos: a) a possibilidade de aplicar o questionário a um número maior de professores por escola, obtendo maior representatividade na construção de nossas análises sobre a percepção docente em cada escola (unidades de análise); b) a possibilidade de captar a complexidade da gestão de uma escola com este perfil para comparar com outras modalidades de organização escolar, em estudos futuros; c) o reconhecimento de que como o foco central dos questionários é construir medidas sobre o trabalho do diretor e o clima escolar em qualquer escola, a flexibilidade dos instrumentos construídos possibilitará que sejam facilmente adaptados para a aplicação em outros contextos escolares; d) apesar do movimento de reestruturação das unidades escolares na rede municipal do Rio de Janeiro, a oferta dos dois segmentos do ensino fundamental é opção de outras redes, como na rede privada de ensino, por exemplo.

A seguir, passamos a delinear as características destas unidades escolares e o perfil dos seus diretores, a partir das informações disponibilizadas pelos questionários contextuais da Prova Brasil ${ }^{37}$ e pelos dados do Censo Escolar.

\section{3 Como são as escolas e quem são os seus diretores?}

As 163 escolas da rede municipal do Rio de Janeiro que atendiam ao $5^{\circ}$ e ao $9^{\circ}$ anos simultaneamente em 2014 (doravante denominadas "escolas selecionadas para a pesquisa"), estão distribuídas em todas as CREs:

Quadro 1: Distribuição das escolas selecionadas entre as CREs/RJ

\begin{tabular}{|c|c|c|c|c|c|c|c|c|c|c|}
\hline $1^{\mathrm{a}}$ & $2^{\mathrm{a}}$ & $3^{\mathrm{a}}$ & $4^{\mathrm{a}}$ & $5^{\mathrm{a}}$ & $6^{\mathrm{a}}$ & $7^{\mathrm{a}}$ & $8^{\mathrm{a}}$ & $9^{\mathrm{a}}$ & $10^{\mathrm{a}}$ & $11^{\mathrm{a}}$ \\
$\mathrm{CRE}$ & $\mathrm{CRE}$ & $\mathrm{CRE}$ & $\mathrm{CRE}$ & $\mathrm{CRE}$ & $\mathrm{CRE}$ & $\mathrm{CRE}$ & $\mathrm{CRE}$ & $\mathrm{CRE}$ & $\mathrm{CRE}$ & CRE \\
\hline 11 & 21 & 18 & 22 & 18 & 5 & 12 & 23 & 6 & 15 & 12 \\
\hline
\end{tabular}

Fonte: INEP, 2012 e dados da SME

$\mathrm{Na}$ análise das características socioeconômicas destas escolas consideramos como proxy do Nível Socioeconômico (NSE) a máxima escolaridade dos pais dos alunos. Optamos por utilizar a escolaridade dos pais como referência de NSE por considerar a estreita relação entre o estrato socioeconômico e trajetória de escolarização, como já foi

\footnotetext{
${ }^{37}$ Para as análises que se seguem, as informações forma atualizadas a partir da disponibilização dos dados da edição de 2013 da Prova Brasil.
} 
apontado em diversos estudos (HASEMBALG e SILVA, 2000; SILVA e BARBOSA, 2012; CURY e MENEZES-FILHO, 2006; MENEZES-FILHO, 2007; entre outros). Esta variável foi criada a partir das respostas dos alunos sobre a escolaridade dos pais (NSE = 1 quando ao menos um dos pais havia completado o Ensino Médio), sendo agregada por escola em valores percentuais $($ NSE_Escola $=$ porcentagem de alunos cujos pais - ao menos um deles - completou o Ensino Médio). Esta variável será usada e discutida em outras etapas deste trabalho. Para comparar as escolas, foram criadas faixas ${ }^{38}$ : Escolas em que até $27 \%$ dos pais possuem escolaridade maior que o ensino médio (Baixo NSE), Escolas em que de $28 \%$ a $40 \%$ dos pais possuem escolaridade maior que o ensino médio (Médio NSE) e Escolas em que mais de $41 \%$ dos pais possuem escolaridade maior que o ensino médio (Alto NSE). A tabela abaixo apresenta a distribuição das escolas selecionadas entre estas faixas e denuncia a predominância de pais com nível de escolaridade abaixo do ensino médio (faixa Baixo NSE + faixa Médio NSE) nos três grupos de análise. Contudo, no grupo das escolas selecionadas percebe-se uma maior concentração de alunos cujos pais apresentam escolaridade acima do ensino médio (Alto NSE):

Tabela 2: Nível de Escolaridade dos Pais como proxy de NSE - Escolas Selecionadas $X$ Escolas Municipais do Rio de Janeiro X Escolas no Brasil

\begin{tabular}{lrrr}
\hline \hline & $\begin{array}{r}\text { Escolas } \\
\text { Selecionadas } \\
(\mathbf{N}=\mathbf{1 6 3})\end{array}$ & $\begin{array}{r}\text { Escolas } \\
\text { Municipais do } \\
\text { Rio de Janeiro } \\
\mathbf{( N = 8 5 2 )}\end{array}$ & $\begin{array}{r}\text { Todas as Escolas, } \\
\text { Brasil }^{\mathbf{3 9}} \\
(\mathbf{N = \mathbf { 5 2 8 2 9 } )}\end{array}$ \\
\hline Baixo NSE & $20,6 \%$ & $31,6 \%$ & $59,6 \%$ \\
Médio NSE & $56 \%$ & $67 \%$ & $38,5 \%$ \\
Alto NSE & $23,4 \%$ & $1,4 \%$ & $1,9 \%$ \\
\hline \hline
\end{tabular}

Fonte: Elaborado pela autora. INEP, 2015

Há que se considerar nesta análise que a distribuição da porcentagem da proxy de NSE utilizada, quando consideradas todas as escolas do Brasil, admite novos valores para as faixas (ver NR 39). Dada a grande desigualdade social do país, há uma maior concentração de alunos cujos pais possuem baixa escolaridade quando consideramos todos os estados e dependências administrativas.

\footnotetext{
${ }^{38}$ Estas faixas foram criadas tendo como referência os dados descritivos da variável sobre a porcentagem de pais com escolaridade acima do ensino médio (mínima $=0,14$ e máxima $=0,53$ ). ${ }^{39}$ Para este universo de escolas as faixas criadas foram: Escolas em que até $28 \%$ dos pais possuem escolaridade maior que o ensino médio (Baixo NSE), Escolas em que de $29 \%$ a $56 \%$ dos pais possuem escolaridade maior que o ensino médio (Médio NSE) e Escolas em que mais de 57\% dos pais possuem escolaridade maior que o ensino médio (Alto NSE), tomando como base a distribuição da porcentagem (mínima $=0$ e máxima $=0,88$ )
} 
No que tange ao desempenho acadêmico destas escolas, consideramos o resultado de seus alunos nos testes de matemática da edição de 2013 da Prova Brasil. Esta medida será utilizada como indicativa da proficiência na escola. Optamos pelo resultado da avaliação de matemática por considerar a dimensão mais escolar deste componente curricular em relação à Língua Portuguesa, como têm feito diversas pesquisas nesta área (FRANCO, 2007; RUTTER et al. 2008). Rutter et al. (2008) apontam:

[...] a escolha das disciplinas escolares pode influenciar os resultados [da pesquisa]. Consequentemente, os estudos do IEA- International Educational Achievement Survey (Postlethwaite, 1975; Coleman, 1975), o Project Talent americano (Shaycoft, 1967) e a pesquisa britânica (Brimer et al., 1977) indicaram que disciplinas como, por exemplo, Matemática ou Ciências, que geralmente são aprendidas principalmente escola, mostram maiores diferenças entre escolas do que a leitura, que pode ser aprendida em parte em casa com a ajuda dos pais; ou outras, como Literatura Inglesa ou Estudos Sociais, em que a aprendizagem dos alunos através da televisão ou de livros disponíveis em casa, e também em conversas com a família, provavelmente terá influência (op. cit., p.145-146).

A fim de situarmos os resultados médios deste grupo de escolas, consideramos pertinente compará-los com os resultados médios nacionais e os resultados médios das escolas municipais do Rio de Janeiro que atendem somente ao primeiro ou ao segundo segmento do ensino fundamental (escolas avaliadas somente no $5^{\circ}$ ano ou somente no $9^{\circ}$ ano). Os resultados desta comparação são apresentados na tabela a seguir.

Tabela 3: Nível de Proficiência em Matemática - Brasil X Escolas que atendem a somente um segmento do EF no município do Rio de Janeiro X Escolas Selecionadas

\begin{tabular}{lccr}
\hline \hline & Brasil & $\begin{array}{c}\text { Escolas municipais } \\
\text { do Rio de Janeiro } \\
\text { avaliadas somente } \\
\text { em um segmento }\end{array}$ & $\begin{array}{c}\text { Escolas } \\
\text { Selecionadas }\end{array}$ \\
\hline $\begin{array}{l}\text { Nota média dos participantes } \\
\text { em Matemática, } \mathbf{5}^{\mathbf{0}} \text { ano }\end{array}$ & $\mathbf{2 0 7 , 4 9}$ & $\mathbf{2 2 2 , 5 3}$ & $\mathbf{2 1 7 , 7 8}$ \\
$\begin{array}{l}\text { Nota média dos participantes } \\
\text { em Matemática, } \mathbf{9}^{\mathbf{0}} \text { ano }\end{array}$ & $\mathbf{2 4 4 , 1 8}$ & $\mathbf{2 5 7 , 3 2}$ & $\mathbf{2 5 2 , 7 9}$ \\
\hline \hline
\end{tabular}

Fonte: Elaborado pela autora. INEP, 2015.

A análise dos dados apresentados nos aponta, inicialmente, que as médias dos resultados das escolas selecionadas estão acima da média nacional, tanto para o $5^{\circ}$ quanto para o $9^{\circ}$ ano do ensino fundamental. Contudo, ao compará-los com os resultados das escolas municipais do Rio de Janeiro que atendem somente a um dos segmentos do ensino fundamental, notamos que a nota média das escolas selecionadas é inferior para os alunos do $5^{\circ}$ e do $9^{\circ}$ anos. Tal comparação nos leva a inferir a possibilidade de que estudar em uma escola que oferece os dois segmentos do ensino fundamental tem um 
reflexo negativo para os alunos, em comparação com a possibilidade de estudar em escolas que oferecem somente o primeiro segmento do ensino fundamental. Acompanhar os resultados dos alunos nas avaliações externas é uma das demandas da gestão escolar, e no caso das escolas que atendem aos dois segmentos do ensino fundamental, este monitoramento é dobrado. Esta é uma das complexidades da gestão destas escolas, como buscamos discutir no início deste capítulo, que poderia auxiliar na interpretação destes resultados. Sobre este aspecto, Koslinski et al. (2013) identificaram que, no município do Rio de Janeiro, as escolas que atendiam aos dois segmentos do ensino fundamental tinham menor probabilidade de atingir as metas de desempenho estipuladas pela SME/RJ. "É preciso notar que as escolas que atendem os dois segmentos (do $1^{\circ}$ ao $9^{\circ}$ ano) não somente são maiores e mais complexas, mas têm que atingir duas metas simultaneamente [5 $5^{\circ}$ e $9^{\circ}$ anos]" (op. cit., p. 8).

E quem são os diretores que assumem este desafio? Em se tratando do perfil dos diretores das escolas selecionadas, temos que 99,4\% deles possuem Ensino Superior completo (porcentagem superior à média nacional para todos os diretores, 93\% e à média das escolas municipais do Rio de Janeiro, 98,2\%). Sobre a especificidade desta formação, há entre os diretores das escolas selecionadas uma porcentagem maior de respondentes que cursaram licenciaturas diferentes de Pedagogia $(47,8 \%)$ do que na média nacional para todos os diretores $(35,9 \%)$ mas comparável à média dos diretores das escolas municipais do Rio de Janeiro (48\%). Este dado parece apontar que ser uma característica desta rede a frequência com que professores especialistas (formados em licenciaturas diferentes de Pedagogia - Letras, Matemática, Biologia, História, entre outras- e habilitados a lecionar no segundo segmento do ensino fundamental) assumam a direção de escolas.

A análise das respostas referentes ao tempo na direção da escola avaliada mostrou que $63,8 \%$ dos diretores das escolas selecionadas estão neste cargo a menos de 5 anos, o que se justifica tendo em vista as eleições para diretores escolares que ocorreram em 2008 e 2011.

Tabela 4: Tempo do diretor no cargo - Brasil X Escolas que atendem a somente um segmento do EF no município do Rio de Janeiro X Escolas Selecionadas

\begin{tabular}{lrrrr}
\hline \hline & Brasil & $\begin{array}{r}\text { Escolas municipais } \\
\text { do Rio de Janeiro } \\
\text { avaliadas somente } \\
\text { no 50 ano }\end{array}$ & $\begin{array}{r}\text { Escolas municipais } \\
\text { do Rio de Janeiro } \\
\text { avaliadas somente } \\
\text { no 9 } \mathbf{9}^{\mathbf{0}} \text { ano }\end{array}$ & $\begin{array}{r}\text { Escolas } \\
\text { selecionadas }\end{array}$ \\
\hline $\begin{array}{l}\text { Diretores exercendo a } \\
\text { função a menos de 5 } \\
\begin{array}{l}\text { anos na escola avaliada } \\
(\%)\end{array}\end{array}$ & $77 \%$ & $54,1 \%$ & $62,2 \%$ & $63,8 \%$ \\
\hline \hline
\end{tabular}

* Porcentagem válida

Fonte: Elaborado pela autora. INEP, 2015. 
Contudo, comparando esta informação (conforme a tabela acima), notamos que há uma indicação de que a rotatividade no cargo da direção é mais significativa no contexto nacional geral $(77 \%)$ e mais baixa nas escolas que atendem somente ao primeiro segmento do ensino fundamental da rede municipal do Rio de Janeiro $(54,1 \%)$. Como a decisão de continuar exercendo o cargo passa, inicialmente, pelo desejo do diretor (as eleições acontecem a cada 3 anos, com consulta à comunidade escolar, como vimos no Capítulo 2, e os diretores podem ser reeleitos indefinidamente neste contexto), os dados apresentados parecem indicar que os diretores das escolas municipais do Rio de Janeiro que atendem somente os anos iniciais do ensino fundamental tendem a permanecer no cargo por mais tempo do que seus colegas.

O acesso ao cargo se deu, para a maioria dos diretores das escolas selecionadas, através de processos de eleição e/ou seleção (somando 84,2\%), um índice bem acima da porcentagem nacional, mas compatível com média das escolas municipais do Rio de Janeiro, como se vê na tabela que se segue.

Tabela 5: Acesso ao cargo de diretor - Brasil X Município do Rio de Janeiro X Escolas Selecionadas

\begin{tabular}{lcrr}
\hline \hline & Brasil & $\begin{array}{r}\text { Escolas } \\
\text { Municipais do Rio } \\
\text { de Janeiro }\end{array}$ & $\begin{array}{r}\text { Escolas } \\
\text { selecionadas }\end{array}$ \\
\hline Seleção e/ou Eleição (\%)* & $44,3 \%$ & $94,8 \%$ & $84,2 \%$ \\
\hline \hline & & Fonte: Elaborado pela autora. INEP, 2015.
\end{tabular}

Esta diferença se justifica pela política específica para a atribuição do cargo de diretor escolar adotada no município do Rio de Janeiro, já mencionada neste trabalho.

As diferenças nas formas de provimento do cargo de diretor escolar e seus possíveis reflexos nos resultados escolares tem sido alvo de investigações na área da gestão educacional $^{40}$. Para os objetivos desta pesquisa interessa-nos registrar que a maioria dos diretores das escolas selecionadas acessam seu cargo através de uma dinâmica mista com caráter democrático (eleição) e meritocrático (seleção através de projeto apresentado à SME/RJ/formação continuada).

No que concerne à relação entre o trabalho do diretor e os professores de sua escola, a análise exploratória a partir dos dados provenientes dos questionários contextuais da Prova Brasil 2013 nos possibilitou as seguintes informações: 88,7\% dos diretores das escolas selecionadas afirmam que a maior parte de seus professores (mais de 76\%) têm vínculo de trabalho estável na escola. Com relação à presença dos professores na escola,

\footnotetext{
${ }^{40}$ A este respeito ver, por exemplo, Paes de Carvalho et al. (2012) e Oliveira et al. (2013).
} 
$16,3 \%$ dos diretores tiveram problemas de alta rotatividade de professores e $29,1 \%$ afirmaram que houve alto índice de faltas de professores na sua escola. A tabela a seguir apresenta os dados sobre a inexistência de professores para uma disciplina ou série da escola, comparando-os à média municipal e nacional:

Tabela 6: Inexistência de Professores - Brasil X Município do Rio de Janeiro X Escolas Selecionadas

\begin{tabular}{lccr}
\hline \hline & Brasil & $\begin{array}{c}\text { Escolas Municipais } \\
\text { do Rio de Janeiro }\end{array}$ & $\begin{array}{r}\text { Escolas } \\
\text { selecionadas }\end{array}$ \\
\hline $\begin{array}{l}\text { Inexistência de professores } \\
\text { para algumas disciplinas ou } \\
\text { séries (\%)* }\end{array}$ & $49,7 \%$ & $47,6 \%$ & $58,6 \%$ \\
\hline \hline
\end{tabular}

Fonte: Elaborado pela autora. INEP, 2015.

Conforme apresentado a porcentagem de diretores das escolas selecionadas que afirmaram que em sua escola houve, naquele ano, problema com a inexistência de professores $(58,8 \%)$ foi superior à porcentagem encontrada para todas as escolas municipais do Rio de Janeiro e para a média nacional. Há que se considerar que a gestão de pessoal, que está entre as atribuições do diretor, é uma das dimensões que potencialmente afeta o trabalho da gestão escolar, o funcionamento das escolas e o desempenho dos alunos (LIMA, ALCÂNTARA e ALMEIDA, 2013). Pode-se concluir a partir destes dados que a inexistência de professores para assumirem turmas ou disciplinas é um grave problema para a gestão escolar, que não é exclusivo dos diretores das escolas que atendem aos dois segmentos do ensino fundamental. Entretanto, pode-se considerar que o impacto é provavelmente maior neste contexto, onde um número maior de turmas ou alunos pode estar desassistido em cada escola (informação não captada pelos dados, mas que pôde ser verificada no trabalho de campo e será discutida no capítulo 7).

Tendo apresentado uma análise geral sobre os 163 diretores das escolas da rede municipal do Rio de Janeiro que atendem aos dois segmentos do ensino fundamental, passamos por um processo de amostragem que foi necessário nesta pesquisa, uma vez considerando a inviabilidade de estar presente em 163 escolas (ao menos 2 visitas em cada unidade). O processo de amostragem ${ }^{41}$ seguiu procedimentos estatísticos que consideraram as características relevantes deste universo de escolas (NSE e Número de professores por escola) para garantir sua representatividade no grupo de 42 escolas em que resultou a amostragem definida para este estudo.

\footnotetext{
${ }^{41} \mathrm{O}$ processo de construção da amostra é detalhadamente descrito no Anexo 5.
} 


\section{4. \\ Os instrumentos disponíveis: avanços e limitações}

O levantamento das recentes pesquisas desenvolvidas sobre o trabalho do diretor escolar em relação ao trabalho docente e aos resultados dos alunos identificou a ainda escassa porém crescente produção de pesquisas quantitativas nesta direção. Um dos desafios impostos para o desenvolvimento de pesquisas quantitativas se configura no levantamento e/ou acesso às informações desejadas, seja através da elaboração e aplicação de surveys específicos, seja através do acesso às bases de dados já disponíveis. Nesse capítulo analisamos e abrangência dos dados educacionais disponíveis em escala nacional sobre a gestão escolar. Tomando como referência os dados dos questionários contextuais das edições da Prova Brasil, nossa principal intenção é identificar se e até que ponto os dados disponíveis podem nos ajudar a pensar sobre as questões levantadas nesta pesquisa.

Contamos hoje com uma ampla gama de dados educacionais disponíveis em nosso país. O Censo Demográfico, a Pesquisa Nacional por amostra de Domicílio - PNAD e o Censo Escolar são exemplos de bases de dados que reúnem informações sobre a escolaridade, o nível sócio econômico, os arranjos familiares, entre outras. A instituição do SAEB/Aneb, em 1990, agrega às informações disponíveis a avaliação da proficiência dos alunos de forma amostral (resultados por unidades da federação, regiões e país), além dos dados contextuais gerados pela aplicação dos questionários que acompanham os testes. Com a introdução da Prova Brasil (Anresc), em 2005, estes dados passam a ser censitários para as escolas públicas brasileiras. Passaram, assim, a possibilitar uma análise a partir de um universo mais abrangente, envolvendo informações sobre diretores, professores e alunos de todas as escolas públicas brasileiras e os resultados apresentados ao nível da escola. Os questionários contextuais aplicados nas escolas participantes de cada edição do SAEB (Aneb e Prova Brasil/Anresc) vêm sendo revisados e modificados desde a década de 1990. De acordo com o estudo de Bonamino e Franco (1999), os questionários contextuais do SAEB/Aneb já abordavam, desde a edição de 1993, os tópicos gestão escolar e competência dos professores na elaboração de seus itens. Destacam, contudo, que apenas a partir do terceiro ciclo (edição de 1995) os questionários contextuais passaram a levantar as características socioculturais dos alunos:

O terceiro ciclo inovou positivamente ao incluir, no escopo dos instrumentos contextuais, questionários sobre as características socioeconômicas e culturais e sobre os hábitos de estudo dos alunos. Até a introdução desses instrumentos, o SAEB tinha tendido a valorizar apenas o papel das variáveis propriamente 
escolares . como a formação de professores e diretores, o estilo docente, o tempo dedicado ao ensino, a infraestrutura escolar . subestimando o peso dos fatores socioeconômicos e culturais e a existência de relações estreitas entre fatores escolares e extra-escolares no desempenho do aluno (BONAMINO e FRANCO, 1999, p. 114).

Esta inovação permitiu as estudos realizados a partir dos dados levantados considera as características sóciodemográficas das escolas, uma vez considerando que esta é a variável que mais interfere na variação dos resultados escolares. Os autores citados destacam, contudo, a limitação dos instrumentos para esta caracterização considerando a alta taxa de não-resposta dos questionários dos alunos, sobretudo do $4^{\circ} / 5^{\circ}$ ano.

O contínuo processo de revisão dos instrumentos contextuais do SAEB foi ressaltado por Franco e colegas (2003) ao apresentarem o quadro contextual construído por eles para a revisão e aprimoramento dos questionários a serem aplicados na edição de 2001. Com relação aos construtos sobre as características escolares, os autores destacam que foram considerados os estudos nacionais e internacionais que levantaram fatores escolares relacionados ao rendimento escolar. A partir dos construtos encontrados no levantamento realizado (os autores citam Willms, 1992; Lee, Bryk e Smith, 1993; Mello, 1994; Sammons, Hillman e Mortmore, 1995; pelo relatório do US National Center for Educational Statistics, 2000) e das conclusões dos primeiros trabalhos nacionais realizados a partir dos dados do SAEB e do SARESP, Franco et al. (2003) discutem os construtos e as especificações dos questionários do SAEB dirigidos à alunos, professores e diretores escolares. No que concerne ao interesse desta pesquisa, os autores já apontavam, naquele momento, os construtos Condições de trabalho (no questionário do professor), Trabalho Colaborativo, Clima Acadêmico e Clima Disciplinar (no questionário do diretor).

A priorização dos construtos relacionados com a direção foi derivada tanto da revisão das pesquisas internacionais quanto da pesquisa qualitativa conduzida pela Fundação Carlos Chagas (2000) em escolas incluídas na amostra do Saeb 99. [...] A maior parte da literatura educacional ressalta a relevância do papel pedagógico do diretor (FRANCO et al., 2003, p. 65).

Apesar dos autores considerarem que "o tema da liderança do diretor e sua atuação facilitadora do trabalho docente é também priorizada e abordada via questionário dos professores" (ob, cit., p. 65), os itens que especificam este construto nas edições mais recentes do questionário não possibilitam uma análise aprofundada sobre o tema, como será discutido em seguida. 
Franco et al. (2003) afirmavam, naquele momento de reflexão e revisão sobre os questionários contextuais do SAEB 2001, a importância da literatura e pesquisa acadêmica para a constante revisão e reelaboração dos instrumentos. É neste sentido e com a intenção de avaliar as possibilidades e limitações no uso dos instrumentos contextuais das recentes edições do SAEB/Prova Brasil que propomos a análise apresentada neste capítulo. A primeira seção aborda a abrangência dos dados no que se refere aos respondentes dos questionários, especialmente os dirigidos aos professores (índices de respostas e caracterização dos respondentes). Quanto à abordagem dos temas relevantes para esta pesquisa (gestão, liderança e clima escolar), a segunda seção apresenta uma análise sobre como eles foram tratados nos questionários contextuais das últimas edições do SAEB/Prova Brasil, com o intuito de delinearmos nossa própria abordagem para o aprofundamento dos conceitos. Finalmente, esta análise é seguida por um estudo estatístico exploratório realizado com os dados disponíveis.

\section{1. Quem responde aos questionários contextuais da Prova Brasil dirigido aos professores?}

Os questionários socioeconômicos que acompanham cada edição da aplicação da Prova Brasil são direcionados aos diretores das escolas, aos professores e alunos das séries avaliadas e aos aplicadores do teste. Na página do Instituto Nacional de Estudos e Pesquisas Educacionais Anísio Teixeira - INEP, encontramos a justificativa e o universo abrangido pelos questionários:

Os Questionários da Prova Brasil servem como instrumentos de coleta de informações sobre aspectos da vida escolar, do nível socioeconômico, capital social e cultural dos alunos. Professores de português e matemática das séries avaliadas e os diretores das escolas, também são convidados a responder questionários que possibilitam conhecer a formação profissional, práticas pedagógicas, nível socioeconômico e cultural, estilos de liderança e formas de gestão. Os questionários destinados aos professores e diretores são entregues pelos aplicadores antes da realização do teste e devem ser recolhidos ao final da prova. ${ }^{42}$

A metodologia de aplicação dos questionários contextuais dirigidos aos professores apresenta algumas limitações. A primeira delas se refere a não identificação do professor no momento de resposta ao questionário (onde se lê o código da escola e da turma). No caso de professores especialistas, específicos de Língua Portuguesa e Matemática, seu

${ }^{42}$ Informação disponível no site do INEP: http://provabrasil.inep.gov.br/questionariossocioeconomicos. Acesso em 18 de novembro de 2012. 
vínculo com a escola é por aula, ou seja, o mesmo professor pode, e é comum acontecer, lecionar para duas ou mais turmas do $9^{\circ}$ ano na mesma escola. Esta informação, que poderia ser importante as pesquisas na área educacional, não é possibilitada pelo questionário. O próprio INEP reconhece que o instrumento não disponibiliza tal identificação:

O Inep orienta que os questionários sejam respondidos apenas pelos professores que lecionam na turma para cujo questionário segue identificado (A identificação do instrumento é o nome/ código da turma e não os dados pessoais do professor). Em caso de ausência do professor, não se recomenda que o questionário da turma seja respondido por professor que não ministre aulas para a turma, mesmo que trabalhe em outra área. ${ }^{43}$

Na edição mais recente da Prova Brasil (2013) o INEP procurou corrigir esta limitação solicitando que o professor preencha o número de seu CPF na página inicial do questionário, como veremos mais adiante.

Outra limitação na aplicação dos questionários contextuais aos professores se refere à representatividade do corpo docente, uma vez que os questionários somente são aplicados aos professores de Língua Portuguesa e Matemática das séries avaliadas $\left(5^{\circ}\right.$ e $9^{\circ}$ anos). Sobre este aspecto, Franco (2001) já apontava as mesmas limitações do questionário contextual que acompanhava a aplicação do SAEB:

Outro ponto importante refere-se à noção de que importantes informações sobre a direção e sobre a escola só podem ser obtidas de modo fidedigno por meio de dados coletados com vários professores da mesma escola. Como o SAEB só prevê a coleta de dados dos professores cujos alunos são testados, apenas são coletados dados de um pequeno número de professores (tipicamente, entre 1 e 4 professores por escola). Finalmente, a coleta de dados de professores em um único dia produz alto percentual de dados faltantes, já que, frequentemente, os contratos de trabalho não preveem a ida diária dos professores à escola (op. cit., p. 130. Grifos meus).

Entre as 163 escolas da rede municipal do Rio de Janeiro selecionadas como universo desta pesquisa, considera-se também o número significativo de missing: em um universo de 1495 questionários de professores, 372 (24,9\%) estavam completamente em branco. No caso de duas escolas, não houve professores respondentes, ou seja, não há nenhuma informação sobre a percepção docente nestas escolas(na edição de 2013 da Prova Brasil, como exemplo). Em outras, as análises estatísticas podem ser feitas a partir

\footnotetext{
${ }^{43}$ Conforme resposta da Central de Atendimento do Ministério da Educação - INEP, protocolo n ${ }^{\circ}$ 9899099, de 04 de dezembro de 2012.
} 
das respostas de 3, 4 ou 5 professores, quando estas escolas provavelmente possuíam um corpo docente muito maior. A título de ilustração, apresentamos o quadro abaixo comparando o número de respondentes ao questionário contextual da Prova Brasil 2013 e o número de professores ativos em 5 das escolas selecionadas para esta pesquisa:

Quadro 2: Comparação entre o número de repostas aos questionários contextuais da Prova Brasil 2013 e o número de professores por escola

\begin{tabular}{|l|r|r|r|r|r|}
\hline & Escola 1 & Escola 2 & Escola 3 & Escola 4 & Escola 5 \\
\hline $\begin{array}{l}\text { Número de respondentes ao } \\
\text { Questionário contextual para } \\
\text { Professores - Prova Brasil, 2013 }\end{array}$ & 3 & 3 & 3 & 3 & 3 \\
\hline $\begin{array}{l}\text { Número de professores ativos na } \\
\text { escola em 2013 }\end{array}$ & 32 & 45 & 33 & 23 & 19 \\
\hline
\end{tabular}

Fonte: Elaborado pela autora. INEP, 2015 e INEP, 2014.

A primeira observação que pode ser feita é a de que o número de respondentes ao questionário de professores da Prova Brasil é o mesmo nas cinco unidades, podendo gerar uma impressão de semelhança entre elas no que se refere à quantidade de professores, $\mathrm{o}$ que não corresponde à realidade. Uma escola que possui um corpo docente com 29 professores possivelmente apresenta uma organização mais complexa (com mais alunos e mais turmas) do que uma escola que conta com 19 professores. O que pretendemos ressaltar, contudo, é a baixa representatividade docente por escola, captada pelo instrumento. As análises possíveis serão construídas a partir das respostas de um reduzido número de professores por escola e podem não representar a percepção de todos os professores naquele contexto. Na escola 1, por exemplo, as respostas dos 3 professores respondentes aos questionários contextuais da Prova Brasil poderiam ser tomadas como uma percepção representativa do quadro docente naquela escola. Mas talvez as respostas dos outros 26 professores da mesma escola sejam muito diferentes, até mesmo divergentes das respostas deste pequeno grupo. Há que se considerar também o risco de enviesamento dos dados considerando que os professores que respondem aos questionários são aqueles das séries/disciplinas testadas. Em um contexto de políticas de responsabilização, a crescente atenção às séries avaliadas pode gerar estratégias de alocação de professores (com características específicas) para estas turmas. Esta não é uma informação disponibilizada pelos questionários contextuais da Prova Brasil e, ainda que fuja ao escopo deste trabalho, merece atenção.

Pensando nesta representatividade, consideramos que as informações sobre as percepções docentes em cada escola, construída a partir dos questionários contextuais que acompanham a Prova Brasil, seriam mais consistentes se contassem com a participação 
de todos os professores da escola (pelo menos aqueles presentes no dia da aplicação da prova).

\section{2. \\ Estrutura e evolução dos instrumentos e sua abordagem dos temas relacionados a esta pesquisa.}

Em estudo sobre as possíveis relações entre o perfil de professores de matemática e os resultados acadêmicos de seus alunos, Aguiar (2001) faz uma importante análise evolutiva sobre o instrumento utilizado na pesquisa (questionário contextual do professor - SAEB, 1997 a 2001). Sua intenção foi captar o aprimoramento do instrumento e a lógica da construção de seus itens, exercício que consideramos relevante e pretendemos replicar nesta pesquisa. Para esta pesquisa, procuramos realizar uma análise parecida com os questionários contextuais que acompanharam a Prova Brasil ao longo de suas edições ${ }^{44}$. Não está explicito, pelo INEP, o que motiva e a partir de quais pressupostos são realizadas as alterações nos questionários contextuais em cada edição.

Analisamos inicialmente a estrutura dos questionários aplicados aos diretores, organizando os itens em blocos temáticos para comparar sua abordagem nas quatro versões. O quadro a seguir sintetiza esta análise:

Quadro 3: Comparação evolutiva do questionário contextual da Prova Brasil dirigido aos diretores escolares

\begin{tabular}{|l|c|c|c|c|}
\hline \multicolumn{1}{|c|}{ Temas } & 2007 & 2009 & 2011 & 2013 \\
\hline $\begin{array}{l}\text { Perfil sociodemográfico (idade, sexo, cor, renda), } \\
\text { formação acadêmica e experiência profissional }\end{array}$ & $\mathrm{X}$ & $\mathrm{X}$ & $\mathrm{X}$ & $\mathrm{X}$ \\
\hline $\begin{array}{l}\text { Oferta e participação de atividades de formação } \\
\text { continuada para docentes }\end{array}$ & $\mathrm{X}$ & $\mathrm{X}$ & $\mathrm{X}$ & $\mathrm{X}$ \\
\hline Percentual de professores com vínculo estável & $\mathrm{X}$ & $\mathrm{X}$ & $\mathrm{X}$ & $\mathrm{X}$ \\
\hline $\begin{array}{l}\text { Conselho Escola Comunidade - CEC, Conselho de } \\
\text { Classe - COC e Projeto Político Pedagógico - PPP }\end{array}$ & $\mathrm{X}$ & $\mathrm{X}$ & $\mathrm{X}$ & $\mathrm{X}$ \\
\hline Lei 11645 de 200855 e suas aplicações na escola & --- & $\mathrm{X}$ & $\mathrm{X}$ & --- \\
\hline $\begin{array}{l}\text { Matrícula, vagas, enturmação de alunos e } \\
\text { atribuição de turmas aos professores }\end{array}$ & $\mathrm{X}$ & $\mathrm{X}$ & $\mathrm{X}$ & $\mathrm{X}$ \\
\hline $\begin{array}{l}\text { Estratégias para reduzir evasão, reprovação e } \\
\text { absenteísmo e de reforço escolar }\end{array}$ & $\mathrm{X}$ & $\mathrm{X}$ & $\mathrm{X}$ & $\mathrm{X}$ \\
\hline $\begin{array}{l}\text { Interação com professores visando melhorar o } \\
\text { ensino }\end{array}$ & --- & --- & --- & $\mathrm{X}$ \\
\hline $\begin{array}{l}\text { Estudantes com necessidades especiais, } \\
\text { infraestrutura e recursos humanos para atendê-los }\end{array}$ & --- & --- & --- & $\mathrm{X}$ \\
\hline
\end{tabular}

\footnotetext{
${ }^{44}$ Foram consideradas as versões de 2007, 2009, 2011 e 2013.

${ }^{45}$ Regulamenta a obrigatoriedade do Ensino da História e Cultura Afro-brasileira e Indígena em todos os níveis de ensino.
} 


\begin{tabular}{|l|c|c|c|c|}
\hline Merenda escolar & --- & --- & $\mathrm{X}$ & $\mathrm{X}$ \\
\hline Possíveis problemas na escola & $\mathrm{X}$ & $\mathrm{X}$ & $\mathrm{X}$ & $\mathrm{X}$ \\
\hline $\begin{array}{l}\text { Condições externas para o exercício do cargo de } \\
\text { diretor }\end{array}$ & $\mathrm{X}$ & $\mathrm{X}$ & $\mathrm{X}$ & $\mathrm{X}$ \\
\hline $\begin{array}{l}\text { Infraestrutura e condições de acessibilidade da } \\
\text { escola }\end{array}$ & ---- & ---- & $\mathrm{X}$ & --- \\
\hline Recursos disponíveis na escola & $\mathrm{X}$ & $\mathrm{X}$ & --- & --- \\
\hline Atividades extracurriculares e comunitárias & $\mathrm{X}$ & $\mathrm{X}$ & $\mathrm{X}$ & $\mathrm{X}$ \\
\hline Apoio financeiro & $\mathrm{X}$ & $\mathrm{X}$ & $\mathrm{X}$ & $\mathrm{X}$ \\
\hline Livro didático & $\mathrm{X}$ & $\mathrm{X}$ & $\mathrm{X}$ & $\mathrm{X}$ \\
\hline Violência e segurança na escola & $\mathrm{X}$ & $\mathrm{X}$ & $\mathrm{X}$ & $\mathrm{X}$ \\
\hline Avaliações externas & $\mathrm{X}$ & $\mathrm{X}$ & --- & $\mathrm{X}$ \\
\hline Projetos & --- & --- & $\mathrm{X}$ & $\mathrm{X}$ \\
\hline Ensino e práticas religiosas na escola & --- & --- & $\mathrm{X}$ & $\mathrm{X}$ \\
\hline
\end{tabular}

Fonte: Elaborado pela autora. INEP, 2008, 2011, 2012 e 2015.

Como é possível perceber, há um núcleo no questionário do diretor que permanece presente e inalterado durante estas quatro edições da Prova Brasil. Esta permanência é fundamental para estudos longitudinais, pois permite a comparabilidade dos dados ao longo dos anos. De modo geral, os itens que compõem esse bloco permanecem inalterados, havendo pequenas mudanças no texto e uma evolução na formatação gráfica. Alguns blocos de questões deixaram de constar no questionário contextual dos diretores, como é o caso das questões sobre recursos didáticos disponíveis (2007 e 2009), e um longo bloco sobre questões relacionadas à infraestrutura e acessibilidade da escola (só aparece na edição de 2011). Curiosamente, uma questão sobre o conhecimento dos diretores acerca dos resultados de sua escola na última edição do SAEB/Prova Brasil deixou de constar do questionário em 2011 e retorna na edição de 2013. No bloco das questões sócio demográficas, a edição de 2013 retoma a opção por trazer o item sobre rendimentos financeiros do diretor em faixas de valores, como em 2007 e 2009. Em 2011 esta questão foi no modelo "aberta" o que possivelmente justifica o elevado número de não resposta. Como ressaltam Bradburn et al. (2004, p.272-273) esta é uma questão sempre complicada, por se tratar de um tema sensível aos respondentes, que tendem a reportar valores acima ou abaixo da real renda familiar, seja intencionalmente ou por desconhecimento. Os mesmos autores comentam que o uso de faixas de valores tende a reduzir o constrangimento e aumentar o retorno da questão, uma vez que nesta versão pede-se ao respondente para simplesmente escolher uma entre as opções apresentadas. 
A edição de 2011 é a versão do questionário contextual para diretores que mais apresentou inserções. Já a edição de 2013 trouxe novidades no que se refere ao texto das questões, que se apresenta mais amigável e com introduções explicativas em cada bloco. Esta edição inova também ao trazer, entre as questões sócio demográficas, 5 itens sobre os motivos que levaram o diretor a não participar de atividades de desenvolvimento profissional nos últimos anos (questões 21 a 25). Observa-se um possível aumento na atenção conferida à formação continuada do diretor. A edição de 2013 também traz, como novidade, uma única questão sobre a interação do diretor com os professores com objetivo pedagógico (questão 44) e a redução nos itens sobre violência na escola e sobre o ensino religioso.

Tendo destacado as principais alterações nos questionários contextuais da Prova Brasil aplicados aos diretores escolares, passamos a analisar os questionários dirigidos aos professores, nas mesmas edições de 2007, 2009, 2011 e 2013 da Prova Brasil.

\section{Quadro 4: Comparação evolutiva do questionário contextual da Prova Brasil} dirigido aos professores

\begin{tabular}{|l|c|c|c|c|}
\hline \multicolumn{1}{|c|}{ Temas } & 2007 & 2009 & 2011 & 2013 \\
\hline $\begin{array}{l}\text { Perfil sociodemográfico (idade, sexo, cor, } \\
\text { renda), formação acadêmica, experiência } \\
\text { profissional, carga horária e vínculos }\end{array}$ & $\mathrm{X}$ & $\mathrm{X}$ & $\mathrm{X}$ & $\mathrm{X}$ \\
\hline Hábitos culturais & -- & -- & $\mathrm{X}$ & $\mathrm{X}$ \\
\hline $\begin{array}{l}\text { Conselho de Classe - COC e Projeto Político } \\
\text { Pedagógico - PPP }\end{array}$ & $\mathrm{X}$ & $\mathrm{X}$ & $\mathrm{X}$ & $\mathrm{X}$ \\
\hline Lei 11645 de 2008 e suas aplicações na escola & --- & $\mathrm{X}$ & $\mathrm{X}$ & --- \\
\hline $\begin{array}{l}\text { Possíveis causas para os problemas de } \\
\text { aprendizagem dos alunos }\end{array}$ & $\mathrm{X}$ & $\mathrm{X}$ & $\mathrm{X}$ & $\mathrm{X}$ \\
\hline Relação com o diretor e aspectos da liderança & $\mathrm{X}$ & $\mathrm{X}$ & $\mathrm{X}$ & $\mathrm{X}$ \\
\hline Trabalho em equipe, coesão do grupo docente & $\mathrm{X}$ & $\mathrm{X}$ & $\mathrm{X}$ & $\mathrm{X}$ \\
\hline Possíveis problemas na escola & $\mathrm{X}$ & $\mathrm{X}$ & $\mathrm{X}$ & $\mathrm{X}$ \\
\hline Violência e segurança & $\mathrm{X}$ & $\mathrm{X}$ & $\mathrm{X}$ & $\mathrm{X}$ \\
\hline Conhecimento sobre a Prova Brasil/SAEB & $\mathrm{X}$ & $\mathrm{X}$ & $\mathrm{X}$ & --- \\
\hline Uso de recursos didáticos & $\mathrm{X}$ & $\mathrm{X}$ & $\mathrm{X}$ & $\mathrm{X}$ \\
\hline Cumprimento do currículo previsto & $\mathrm{X}$ & $\mathrm{X}$ & $\mathrm{X}$ & $\mathrm{X}$ \\
\hline Aproveitamento do tempo em sala de aula & --- & --- & --- & $\mathrm{X}$ \\
\hline Expectativa em relação ao futuro dos alunos & $\mathrm{X}$ & $\mathrm{X}$ & $\mathrm{X}$ & $\mathrm{X}$ \\
\hline Livro Didático (escolha e uso) & $\mathrm{X}$ & $\mathrm{X}$ & $\mathrm{X}$ & $\mathrm{X}$ \\
\hline Metodologia de trabalho na sala de aula & $\mathrm{X}$ & $\mathrm{X}$ & $\mathrm{X}$ & $\mathrm{X}$ \\
\hline
\end{tabular}


Em se tratando dos questionários contextuais dirigidos aos professores das séries avaliadas ( $5^{\circ}$ e $9^{\circ}$ anos), percebemos poucas alterações ao longo das edições da Prova Brasil. A versão aplicada em 2011 acrescenta um bloco de perguntas sobre os hábitos culturais dos professores fora do ambiente escolar. Há uma mudança na formatação e apresentação do questionário ao longo dos anos e, no que se refere ao texto das questões, pouquíssimas modificações. Vale ressaltar que o bloco de questões sobre os procedimentos didáticos está dividido em duas partes: uma destinada aos professores de Língua Portuguesa e outra destinada aos professores de Matemática. Na instrução específica para este bloco, as versões de 2007 e de 2011 explicitam que os professores devem responder às questões do quadro que se refere à disciplina que lhe compete. A versão de 2009 não traz esta instrução, o que pode ter colaborado para o alto índice de missing nos dados desta edição, como apontam Oliveira e Waldhelm (2012). A edição de 2013 trouxe algumas modificações, entre elas, o detalhamento das questões sobre a formação continuada dos professores (incluindo questão sobre o investimento financeiro nestas atividades); os blocos de questões sobre liderança e relação com o diretor e sobre o trabalho em equipe foram alterados (questões modificadas e acrescentadas); inserção de um bloco de questões sobre o aproveitamento do tempo em sala de aula; as questões sobre procedimentos metodológicos ganharam mais alguns itens comuns aos professores de Matemática e Língua Portuguesa; como no questionário do diretor, foi retirado o bloco de questões sobre a Lei 11645 de 2008. Entre as modificações, consideramos a mais importante a solicitação do preenchimento do CPF do respondente, logo na página inicial do questionário. Esta iniciativa com certeza trará ganhos no que se refere a uma análise mais aprofundada sobre o universo dos respondentes. Esta era uma limitação importante do instrumento, conforme discutido na seção anterior. A introdução desta informação possibilitará a agregação dos respondentes em caso de um professor para múltiplas turmas, além da possibilidade de vincular os dados disponibilizados à outras bases, como a do Censo Escolar. Contudo, esta identificação do respondente não é disponibilizada pelo INEP, ainda, junto aos microdados da Prova Brasil. Esperamos que este avanço na elaboração dos instrumentos seja mantido, acessível à pesquisa acadêmica e que o preenchimento do número do CPF não intimide o respondente. Sobre este aspecto, cabe ressaltar que não há no texto introdutório dos questionários dirigidos aos professores (e também aos diretores) nenhum comentário sobre o uso que será feito dos dados coletados no questionário ou sobre a identificação do respondente.

O levantamento sobre os itens dos questionários contextuais aplicados à diretores e professores das escolas avaliadas em cada edição da Prova Brasil, apresentado nesta seção, nos aponta duas possíveis análises. A primeira se refere às poucas modificações 
nas questões dos questionários relacionadas à gestão, liderança e clima escolar. Esta consistência mantém a comparabilidade dos dados ao longo dos anos mas, por outro lado, ela também indica que não houve movimento de ampliação das possibilidades de discussão sobre o tema a partir da coleta de dados destes instrumentos. A limitação dos itens nos leva à segunda interpretação: primeiramente, o questionário do diretor não traz nenhuma questão sobre possíveis intervenções pedagógicas da gestão escolar; as questões relacionadas ao trabalho docente se restringem à oferta de formação continuada $\mathrm{e}$ participação da equipe docente em Conselhos de Classe, Conselho de Escola e elaboração do Projeto Político Pedagógico (temas contemplados pela LDB 9394/96 como implicações necessárias do princípio da gestão democrática). Porém, como discutido no capítulo anterior, a lógica da participação nestas instâncias não garante, por si só, o estabelecimento e vivência de uma gestão democrática na unidade escolar. Como as questões tratam somente da composição dos grupos que participam deste fóruns, não é possível captar outras informações a respeito da sua dinâmica e nem os níveis de participação dos sujeitos. Para melhor compreender como (e se) acontece a gestão democrática na escola, seriam necessários itens que abordassem mais detalhadamente a rotina e as relações escolares. É interessante observar que os itens sobre a gestão e liderança no trabalho do diretor aparecem somente no questionário dos professores, ou seja, o próprio diretor não responde sobre tarefas relacionadas à gestão e sobre sua relação com os professores. Vale destacar ainda que outros educadores que compõem a equipe de gestão na escola (diretores adjuntos, coordenadores, supervisores e/ou orientadores pedagógicos, dependendo da rede de ensino) não participam deste levantamento.

Reconhecer estas limitações não impede ou invalida o uso dos dados disponibilizados pelos questionários contextuais que acompanham as edições da Prova Brasil. A pesquisa educacional em educação vem se valendo, nas duas últimas décadas, destas informações, ampliando a possibilidade de desenvolver trabalhos de cunho quantitativo com uma amplitude que envolve praticamente todo o sistema de educação pública no país. No caso da pesquisa sobre a gestão, liderança e clima escolar, os itens apontados podem nos trazer indicações importantes captadas em um universo abrangente, uma vez que praticamente todas as escolas públicas que oferecem as séries avaliadas participam da avaliação. Para esta pesquisa, realizamos um estudo estatístico exploratório com os dados referentes a alguns destes itens cujos resultados serão apresentados a seguir. 


\section{3 \\ Diretores e professores: o que é possível saber a partir dos dados disponíveis?}

Os dados provenientes dos questionários contextuais da Prova Brasil aplicados aos diretores e professores das séries avaliadas nos trazem, como apresentado acima, alguns poucos itens sobre como os respondentes percebem a gestão do diretor e o clima de trabalho em suas escolas ${ }^{46}$, questão fundamental para esta pesquisa. Sobre as relações na escola, envolvendo a liderança e gestão do diretor e o clima escolar, algumas associações podem ser observadas a partir do trabalho estatístico com as respostas às questões citadas. Paes de Carvalho et al. (2012), por exemplo, utilizaram como medida o Índice de Liderança do Diretor, criado a partir da análise fatorial das respostas dos professores aos itens que abordam o trabalho da gestão. O estudo analisou a possível relação entre a liderança do diretor (percebida pelo corpo docente) e os resultados escolares dos alunos e encontrou uma associação estatisticamente positiva e significativa entre o índice criado e os resultados dos alunos do $5^{\circ}$ ano nos testes de matemática, no Rio de Janeiro. Paes de Carvalho e Oliveira (2014) analisaram esta mesma relação (incluindo outras variáveis) considerando os dados de todas as escolas públicas brasileiras participantes nas edições de 2007, 2009 e 2011 da Prova Brasil. As autoras encontraram uma associação significativamente positiva entre o Índice de Liderança do Diretor e os resultados acadêmicos dos alunos, sendo que esta relação apresentou-se gradativamente crescente ao longo das 3 edições, tanto nas escolas municipais quanto nas escolas estaduais.

Procurando refletir sobre a operacionalização dos dados disponibilizados pelos questionários contextuais da Prova Brasil e no intuito de levantar algumas indicações sobre o trabalho do diretor e as relações nas escolas, realizamos um estudo estatístico exploratório com estas informações. Para tanto, utilizamos as dados disponibilizados pela edição de 2013 da Prova Brasil considerando as respostas obtidas nas 163 escolas da rede municipal do Rio de Janeiro selecionadas nesta pesquisa. Entre os itens, selecionamos um bloco de questões ${ }^{47}$ que media a percepção dos professores sobre situações que envolviam o trabalho do diretor escolar ou as relações na escola. Na análise fatorial encontramos 2 fatores que foram denominamos de Índice de Liderança do Diretor e Índice de Clima Escolar. Sobre a relação entre as variáveis que compõem os fatores e os nomes dos índices criados, vale ressaltar que a escolha se baseou na literatura sobre liderança e clima escolar e na limitação dos itens disponíveis.

\footnotetext{
${ }^{46}$ Refiro-me às questões 53 a 67, do questionário do Professor. (INEP, 2015)

47 As questões são apresentadas em uma escala de frequência onde a resposta do professor pode variar de Nunca (1) a Sempre (4). (INEP, 2015)
} 
Assim, no que se refere ao Índice de Liderança do Diretor, temos questões que abrangem as relações pessoais entre professores e diretores e outras que tratam das iniciativas do diretor relacionadas ao trabalho pedagógico ou administrativo da escola. Neste momento e com estes dados, estas variáveis (que poderiam indicar diferentes perfis de liderança do diretor) se agruparam em um mesmo fator, possivelmente indicando que as respostas do grupo analisado tendem a aproximar características relacionais, pedagógicas e administrativas ao analisar a liderança do diretor. Contudo, cabe ressaltar que ainda que os itens não abordem todas as dimensões de liderança desempenhadas pelo diretor no contexto escolar, possibilitaram criar uma medida da percepção global do professor sobre a liderança do diretor, ainda que sem especificar as possíveis tendências desta liderança. O quadro a seguir apresenta as cargas fatoriais dos itens que compuseram o índice:

\section{Quadro 5: Cargas Fatoriais das Variáveis Relativas à Liderança do Diretor}

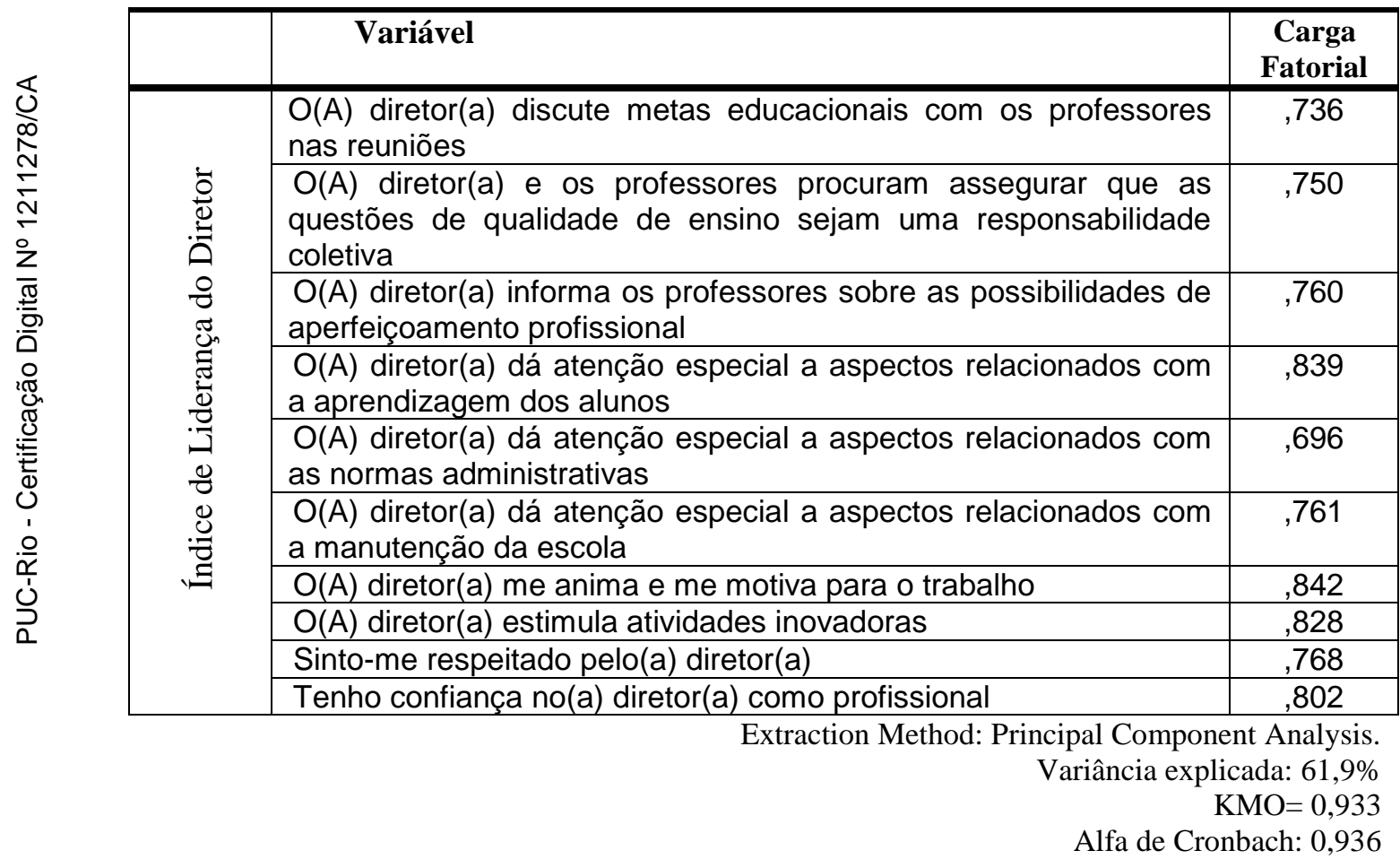

Fonte: Elaborado pela autora. INEP, 2015.

Quanto ao Índice do Clima Escolar ressaltamos que as variáveis que o compõem também não contemplam todos os elementos que constituem o clima de uma escola. $\mathrm{O}$ questionário contextual da Prova Brasil traz outros itens relacionados à violência e à disciplina que fogem ao escopo deste trabalho. Interessa-nos conhecer a percepção dos professores sobre os fatores que interferem na construção de um clima escolar propício ao 
trabalho acadêmico, o que explica a seleção dos itens que entraram na análise. Como lembram Brito e Costa (2010) a ideia de que a "atmosfera" ou o ambiente circundante percebido pelos indivíduos na escola exerce significativa influência sobre o comportamento e a qualidade do trabalho desenvolvido é um consenso nos estudos neste campo. Assim, as variáveis que compõem este índice trazem algumas pistas sobre a coesão e a colaboração entre a equipe, elementos indicadores do clima escolar e geralmente relacionados ao trabalho do diretor, mas não esgotam o tema. O quadro a seguir apresenta suas cargas fatoriais:

Quadro 6: Cargas Fatoriais das Variáveis Relativas ao Clima Escolar

\begin{tabular}{|c|c|c|}
\hline & Variável & $\begin{array}{l}\text { Carga } \\
\text { Fatorial }\end{array}$ \\
\hline \multirow{5}{*}{ 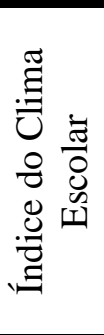 } & Participou do planejamento do currículo escolar ou parte dele & ,618 \\
\hline & Trocou materiais didáticos com seus colegas &, 758 \\
\hline & $\begin{array}{l}\text { Participou de reuniões com colegas que trabalham com a mesma } \\
\text { série (ano) para } a(0) \text { qual leciona }\end{array}$ & ,787 \\
\hline & $\begin{array}{lllll}\text { Participou em discussões sobre o desenvolvimento } & \text { da } \\
\text { aprendizagem de determinados alunos } & & & \\
\end{array}$ & ,771 \\
\hline & $\begin{array}{l}\text { Envolveu-se em atividades conjuntas com diferentes professores } \\
\text { (por exemplo, projetos interdisciplinares) }\end{array}$ & ,719 \\
\hline
\end{tabular}

Extraction Method: Principal Component Analysis.

Variância explicada: $61,9 \%$

$\mathrm{KMO}=0,923$

Alfa de Crombach: 0,802

Fonte: Elaborado pela autora. INEP, 2015.

Os dois índices criados foram posteriormente agregados por escola (Índice Médio de Liderança do Diretor - IMLD e Índice Médio de Clima Escolar - IMCL), indicando a percepção média dos professores da escola a respeito dos dois tópicos.

A título de estudo exploratório, foi organizada uma análise multivariada, com vistas a identificar a associação dos índices criados com o desempenho dos alunos de $5^{\circ} \mathrm{e}$ $9^{\circ}$ anos das 163 escolas selecionadas nesta pesquisa. Para tanto, ajustamos um modelo de regressão linear, cuja variável dependente foi a média da proficiência em Matemática (dos alunos do $5^{\circ}$ ano no primeiro modelo, e do $9^{\circ}$ ano no segundo modelo) e a variável de controle foi uma proxy do Nível Socioeconômico-NSE médio por escola. Esta medida do NSE foi estimada a partir da informação sobre a máxima escolaridade dos pais dos alunos $^{48}$.

\footnotetext{
${ }^{48}$ Conforme explicado no Capítulo 3, p. 66-67.
} 
Como esta pesquisa optou por estudar as relações entre diretores e professores nas escolas que atendem aos dois segmentos do ensino fundamental, consideramos que seria interessante acrescentar ao modelo as variáveis relativas ao número de professores por escola e ao número de turmas que a escola atende (informação disponibilizada pelo Censo Escolar). Esta opção levou em consideração a hipótese de que um maior número de turmas e de professores na escola traz maior complexidade à sua gestão e à constituição de um ambiente próprio para a aprendizagem, com possíveis reflexos no resultado acadêmico dos alunos. As duas variáveis apresentaram uma associação negativa com o resultado dos alunos nos dois modelos, porém estas associações não foram significativas $(p>0,3)$, e as variáveis foram retiradas da análise.

O Índice de Clima Escolar apresentou uma relação pequena e não significativa com os resultados de aprendizagem dos alunos nos dois modelos, e também foi retirado da análise. Optamos, contudo, por manter no texto a descrição da construção do índice com suas variáveis, uma vez que este processo nos referenciou na construção dos novos itens para medir o conceito, apresentados no capítulo próximo.

A não significância das variáveis retiradas do modelo (N_TURMAS, N_PROFESSORES e IMCE) poderia se justificar por uma correlação significativa com a outra variável do modelo (IMLD). Tal hipótese é plausível considerando estudos na área que apontam a relação entre elas: o tamanho da escola é um fator determinante para a complexidade do trabalho da gestão escolar (DONALDSON, 2013); as relações estabelecidas na escola e o trabalho coletivo estão relacionados à iniciativas da gestão escolar (MACHADO, 2012; GOMES, 2012; RODRIGUES, 2012; THOONEM et al., 2011; PRICE, 2011, entre outros). Porém, os testes de correlação entre as variáveis (scatterplot e coeficiente de Pearson) não apresentaram resultados significativos, provavelmente em decorrência do tamanho relativamente reduzido da base $(\mathrm{N}=163$ escolas), uma vez que o teste de correlação entre estas mesmas variáveis é significativo para o universo de todas as escolas testadas em 2013 (Brasil, $\mathrm{N}=52829$ escolas).

Assim, reconhecendo estas possíveis colinearidades entre as variáveis (não significativas em um universo menor de respondentes) e considerando que o Índice Médio de Liderança do Diretor (IMLD) poderia estar captando elementos das outras três variáveis, justificamos a exclusão destas da análise de regressão linear, sem contudo invalidar sua importância.

A equação da regressão tomada como referência para a análise seguiu a fórmula:

Nota_Média_Matemática $=\beta 0+\beta 1($ NSE $)+\beta 2($ IMLD) $+e$ 
Os quadros a seguir apresentam a definição e a estatística descritiva das variáveis utilizadas no modelo.

Quadro 7: Variáveis Utilizadas no Modelo

\begin{tabular}{|c|c|c|}
\hline Variável & $\begin{array}{c}\text { Tipo de } \\
\text { variável }\end{array}$ & Descrição \\
\hline DEPENDENTE & \multicolumn{2}{|c|}{} \\
\hline Nota_Média_Matemática & Contínua & $\begin{array}{l}\text { Proficiência Média em Matemática dos alunos (do } \\
5^{\circ} \text { e 9ªnos) na Prova Brasil-2013, nas 163 escolas } \\
\text { municipais do Rio de Janeiro selecionadas nesta } \\
\text { pesquisa. }\end{array}$ \\
\hline INDEPENDENTES & Contínua & $\begin{array}{l}\text { Nível socioeconômico (NSE)- Percentual de pais } \\
\text { cuja escolaridade é Ensino Médio ou Superior. }\end{array}$ \\
\hline NSE & Contínua & $\begin{array}{l}\text { Índice Médio de Liderança do Diretor (Q58, Q59, } \\
\text { Q60, Q61, Q62, Q63, Q64, Q65, Q66, Q67) }\end{array}$ \\
\hline IMLD
\end{tabular}

Fonte: Elaborado pela autora. INEP, 2015.

Quadro 8: Estatística Descritiva das Variáveis Utilizadas no Modelo

\begin{tabular}{|c|c|c|c|c|}
\hline Variáveis & Mínimo & Máximo & Média & $\begin{array}{l}\text { Desvio } \\
\text { Padrão }\end{array}$ \\
\hline Nota_Média_Matemática( $5^{\circ}$ ano $)$ & 165,30 & 273,03 & 217,79 & 16,74 \\
\hline Nota_Média_Matemática $\left(9^{\circ}\right.$ ano $)$ & 200,17 & 334,35 & 252,79 & 18,80 \\
\hline NSE & 0,14 & 0,56 & 0,35 & 0,81 \\
\hline IMLD $^{49}$ & $-2,55$ & 2,26 & 0,0 & 1,0 \\
\hline
\end{tabular}

Fonte: Elaborado pela autora. INEP, 2015.

Os resultados dos dois modelos estimados a partir da regressão linear, considerando os resultados médios do $5^{\circ}$ e $9^{\circ}$ anos separadamente, são apresentados nos quadros abaixo e discutidos em seguida.

Quadro 9: Coeficientes do $1^{\circ}$ Modelo Estimado ( $5^{\circ}$ ano)

\begin{tabular}{|l|r|r|}
\hline & Coeficiente ( $\beta$ ) & Significância \\
\hline (Constante) & $* * *$ & 0,000 \\
\hline NSE & 0,514 & 0,000 \\
\hline IMLD & 0,091 & 0,217 \\
\hline
\end{tabular}

Fonte: Elaborado pela autora. INEP, 2015.

Quadro 10: Coeficientes do $2^{\circ}$ Modelo Estimado ( $\left(9^{\circ}\right.$ ano)

\begin{tabular}{|c|c|c|}
\hline & Coeficiente $(\beta)$ & Significância \\
\hline (Constante) & $* * *$ & 0,000 \\
\hline NSE & 0,466 & 0,000 \\
\hline IMLD & 0,118 & 0,108 \\
\hline
\end{tabular}

Fonte: Elaborado pela autora. INEP, 2015.

\footnotetext{
${ }^{49}$ Variável padronizada.

${ }^{50} \mathrm{R}^{2}$ ajustado.

51 (idem)
} 
As variáveis que entraram no modelo apresentaram relação significativamente positiva em relação ao resultado dos alunos do $5^{\circ}$ e do $9^{\circ}$ anos na avaliação de matemática da Prova Brasil 2013, apesar de não significativas. Como esperado, o nível socioeconômico dos alunos foi a variável que apresentou a maior relação positiva com o resultado dos alunos no teste de matemática, em conformidade com os estudos que analisam as relações entre escolaridade e desigualdades sociais (FERNANDES, 2005; HASENBALG e SILVA, 2000; PASTORE e SILVA, 2000, entre outros) e as pesquisas já desenvolvidas sobre as relações entre os resultados de aprendizagem e a origem socioeconômica dos alunos (ALVES e SOARES, 2007; F. ALVES, 2012; F. ALVES e FRANCO, 2012; PAES DE CARVALHO et al., 2012; SOARES e ANDRADE, 2006, entre outros). Neste estudo, os resultados confirmam esta tendência (desconsiderando a significância representativa da amostra).

As pesquisas em eficácia escolar apontam que, se o background familiar tem um peso importante na definição do desempenho acadêmico do aluno, alguns fatores intraescolares poderiam minimizar o efeito da origem social, promovendo a eficácia na oferta educacional (BROOKE e SOARES, 2008; SAMMONS, 2008; FRANCO et al., 2007). Neste estudo, o Índice Médio de Liderança do Diretor (IMLD) apresentou relação positiva com o resultado de aprendizagem dos alunos (de $5^{\circ}$ e $9^{\circ}$ anos). $\mathrm{O}$ índice criado buscou medir a percepção dos professores sobre a liderança do diretor no que se refere à diferentes dimensões do seu trabalho, como intervenções pedagógicas, relacionais e administrativas na escola. Estes fatores já foram apontados como fatores-chave para que o diretor exerça um efeito positivo (ainda que indireto, como ressalta a literatura na área) no rendimento dos alunos (BONAMINO, 2012; SAMMONS, 2008; ALVES e FRANCO, 2008).

O modelo estimado para a amostra desta pesquisa explicou $25,9 \%$ da variabilidade dos resultados dos alunos do $5^{\circ}$ ano do ensino fundamental em matemática e $22,3 \%$ da variabilidade dos resultados dos alunos do $9^{\circ}$ ano, nas 163 escolas que fazem parte deste estudo. O modelo sugere que, controlado pelo NSE, o trabalho do diretor (percebido pelos professores) associa-se positivamente (porém, não significativamente, muito provavelmente em decorrência do tamanho da amostra) ao desempenho dos estudantes das escolas que atendem aos dois segmentos do ensino fundamental.

A análise dos resultados ora apresentados corrobora os achados de trabalhos anteriores. Paes de Carvalho et al (2012), Oliveira et al (2013) e Oliveira e Waldhelm (2015) encontraram um efeito positivo para o mesmo índice em relação aos resultados de matemática dos alunos de $5^{\circ}$ ano no estado ou município do Rio de Janeiro. Em um estudo mais amplo, Paes de Carvalho e Oliveira (2014) encontraram também um efeito 
positivo do Índice de Liderança do Diretor nos resultados dos alunos do $5^{\circ}$ ano em todo o país, nas três últimas edições da Prova Brasil (2007, 2009 e 2011).

Apesar de esta análise exploratória nos apresentar pistas interessantes que merecem ser aprofundadas, é importante considerar que seus resultados podem estar comprometidos pela possível imprecisão das variáveis que compõem o modelo. A medida dos índices (IMLD e IMCE) torna-se comprometida, tanto pela fragilidade quanto pela pouca abrangência dos itens que os compõem. Como discutido anteriormente, os itens disponibilizados pelos questionários contextuais da Prova Brasil nos permitiram criar estas medidas que, contudo, estão longe de captar toda a dimensão do trabalho do diretor e do clima escolar. Junta-se a esta limitação a questão da baixa representatividade docente por escola e o alto número de dados faltantes, como foi discutido no início deste capítulo. As limitações apresentadas comprometem as conclusões a partir dos resultados obtidos nas análises estatísticas utilizando estes dados. Soares et al. (2012), em um estudo a partir dos dados das edições da Prova Brasil de 2005, 2007 e 2009, também apontam para esta dificuldade:

[...] os dados colhidos por meio dos questionários da Prova Brasil, aplicados a professores e diretores, permitem o cálculo dos fatores que exploramos aqui, mas não foram especificamente elaborados para tanto, além de apresentarem um alto índice de não resposta. Como resultado, temos medidas frágeis de construtos, tais como ambiente escolar, qualidade das instalações e outros (op. cit., p. 55).

Assim, podemos considerar que os itens sobre liderança e gestão escolar propostos pelos questionários contextuais da Prova Brasil não se traduzem em bons preditores para a análise dos resultados escolares. Concluímos este capítulo tendo apresentado uma análise das limitações no uso dos dados disponibilizados pelos questionários contextuais da Prova Brasil para os fins desta pesquisa. Estas limitações e o desejo de ampliar a discussão sobre o tema justificaram a construção de um novo instrumento de pesquisa que pudesse ser aplicado a diretores, coordenadores e todos os professores de uma escola, especialmente escolas que possuem diferentes perfis de professores (ampliando e diferenciando o público respondente). Assim, esta pesquisa propõe a aplicação de um survey que dê um passo adiante na coleta de dados a respeito do trabalho da direção escolar, considerando as dimensões de gestão, liderança e clima escolar, através da proposição de novos itens construídos para a mensuração destes conceitos. O capítulo a seguir apresenta o processo de elaboração destes instrumentos. 


\section{5 \\ A construção dos questionários}

Neste capítulo apresentamos o processo de elaboração dos questionários construídos nesta pesquisa. A construção de um questionário é um processo complexo, que envolve o cuidado com a redação das questões e a garantia de manter o foco da pesquisa. Bradburn et al. (2004), em um trabalho que se tornou referência para pesquisadores na área da metodologia de survey, lembram que um questionário é um processo de interação entre duas pessoas que estão limitadas por normas específicas. Os autores orientam que durante todo o processo de produção das questões, os pesquisadores devem ter cuidado ao levantá-las, afim de não utilizar o instrumento para perguntas desnecessárias e não perder o foco da pesquisa, perguntando-se sempre: por que estou perguntando isso? (op. cit., p. 21).

Este foi um cuidado constante no processo de criação dos instrumentos, diálogo estendido para o grupo de pesquisa do qual este trabalho faz parte.

Inicialmente, é importante esclarecer a motivação para definir os respondentes desta pesquisa. Em se tratando de investigar as relações estabelecidas entre diretores e professores, estes se tornam, naturalmente, informantes privilegiados para o trabalho. Em algumas pesquisas, opta-se pelo levantamento de dados somente dos diretores ou somente dos professores. Contudo, trabalhos como o de Goldring et al (2008), por exemplo, tem mostrado que há significativas diferenças entre os relatos sobre a liderança do diretor reportados pelos próprios diretores ou pelos professores. No caso deste estudo, que pretende olhar para as relações que se estabelecem na escola, torna-se fundamental investigar os posicionamentos dos responsáveis pela gestão na escola (notadamente os diretores) mas, também, a percepção dos professores sobre a gestão da escola onde trabalham. Decidimos incluir também os diretores adjuntos (respondendo o mesmo questionário do diretor) e o coordenador pedagógico (nesse caso, com instrumento específico) como respondentes que poderiam trazer novas perspectivas desta relação e das práticas escolares. Tomamos como referência para esta decisão a própria organização da gestão escolar nas escolas municipais do Rio de Janeiro, que conta com os três personagens na condução das tarefas que compõem a gestão de uma escola (embora, como sabemos e confirmamos durante as visitas, esta estrutura se organiza das mais diferentes maneiras no que tange à divisão de tarefas e hierarquia). Sobre a articulação necessária no trabalho desta equipe, Marcondes et al. (2012) destacam a importância do coordenador pedagógico: 
o coordenador é peça chave na mediação entre a Secretaria de Educação e os professores da escola, desenvolvendo funções pedagógicas relacionadas ao desenvolvimento profissional do corpo docente e um trabalho político de implementação dos princípios da reforma educacional proposta pela gestão política no momento (op. cit., p.194)

A interação das informações disponibilizadas pelos respondentes responsáveis pela gestão escolar possibilitará um contraponto, uma triangulação dos dados. Assim, como se verá, várias questões foram adaptadas para constarem nas três versões dos instrumentos.

A apresentação do processo de elaboração dos questionários neste capítulo inclui a definição dos conceitos a serem medidos, sua operacionalização e sua construção enquanto associação de informações. Por fim, as últimas seções descrevem os processos de validação incluindo a pré-testagem dos instrumentos. As versões finais e completas dos questionários que foram criados e utilizados nesta pesquisa podem ser consultadas nos Anexos 10, 11 e 12.

\section{1 Quadro de Referência Conceitual e operacionalização dos instrumentos}

Como assinalou Babbie (1999), a construção de um questionário envolve, primeiramente, a decisão do pesquisador sobre os conceitos que se quer medir. Com base nesta referência teórica, Cazelli (2005) apresentou o processo de construção e aplicação de questionários contextuais em sua pesquisa. A autora considerou que a fase seguinte à definição dos conceitos seria a sua classificação quanto a sua operacionalização: os conceitos são observáveis (podem ser medidos diretamente) ou latentes (não são observados diretamente e passam por um processo de construção do pesquisador, que convenciona quais especificações irão compor seu conceito latente)? Seguindo esta organização, o quadro a seguir apresenta a listagem dos conceitos definidos como fundamentais para este trabalho, especificados em conceitos secundários, bem como a classificação quanto à sua operacionalização. 
Quadro 11: Temas, conceitos e suas classificações

\begin{tabular}{|c|c|c|}
\hline Conceitos & Conceitos secundários & Classificação \\
\hline \multirow{13}{*}{$\begin{array}{l}\text { Gestão } \\
\text { Liderança }\end{array}$} & Perfil de liderança do Diretor/Foco da direção escolar & Latente \\
\hline & Perfil de liderança do Coordenador/ Foco da & Latente \\
\hline & Coordenação pedagógica & \\
\hline & Perfil do corpo docente & Latente \\
\hline & $\begin{array}{l}\text { Percepção dos professores sobre a liderança do diretor e } \\
\text { da equipe de gestão da escola }\end{array}$ & Latente \\
\hline & Interlocução com a equipe & Latente \\
\hline & Interações pedagógicas & Latente \\
\hline & Monitoramento da aprendizagem & Latente \\
\hline & Influência como medida da liderança do diretor & Latente \\
\hline & $\begin{array}{l}\text { Influência como medida da liderança do coordenador } \\
\text { pedagógico }\end{array}$ & Latente \\
\hline & Influência como medida da participação do professor & Latente \\
\hline & Descentralização da gestão escolar & Latente \\
\hline & Avaliação do trabalho docente & Latente \\
\hline \multirow[t]{5}{*}{ Clima Escolar } & Ambiente próprio para aprendizagem & Latente \\
\hline & Relações interpessoais & Latente \\
\hline & $\begin{array}{l}\text { Coesão do corpo docente comprometimento com a } \\
\text { escola }\end{array}$ & Latente \\
\hline & Comunicação & Latente \\
\hline & Satisfação no trabalho & Latente \\
\hline \multirow[t]{2}{*}{ Contexto } & Interação com a CRE/SME & Latente \\
\hline & Avaliações externas: reflexos para o trabalho escolar & Latente \\
\hline \multirow{7}{*}{$\begin{array}{c}\text { Caracterização } \\
\text { Sociodemográfica }\end{array}$} & Gênero & Observável \\
\hline & Idade & Observável \\
\hline & Formação Acadêmica & Observável \\
\hline & Experiência profissional & Observável \\
\hline & Acesso ao cargo & Observável \\
\hline & Jornada de trabalho & Observável \\
\hline & Regime de trabalho do professor & Observável \\
\hline
\end{tabular}

Elaborado pela autora.

Os grandes conceitos que estruturam o corpo dos questionários, "gestão, liderança e clima escolar", correspondem aos conceitos definidos como centrais para esta pesquisa, cuja discussão teórica iniciou-se no capítulo 2 deste trabalho. A definição da abordagem teórica destes temas se referencia principalmente na leitura dos estudos de Barroso (2006a, 2006b), Lima (2001) e Souza (2006, 2012) sobre organizações escolares e gestão; nos estudos de Coisin (1998), Leithwood (2009) e Polon (2012) sobre práticas de liderança na escola; e nos trabalhos de Nóvoa (1992), Aguerre (2004) e Brunet (1992) sobre clima organizacional e clima escolar. Esta fundamentação, apresentada anteriormente e retomada neste capítulo, incluindo as contribuições conceituais e metodológicas da revisão bibliográfica sobre o tema, sustentaram a definição dos conceitos secundários apresentados acima.

A partir desta listagem e classificação dos conceitos, buscamos delinear os itens do questionário. Os conceitos observáveis, que no nosso caso estão ligados à caracterização 
sociodemográfica dos respondentes, são facilmente operacionalizáveis no questionário. Já os conceitos latentes envolvem uma compreensão ampla do que está sendo medido, através das referências que norteiam a pesquisa. Além desta compreensão teórica sobre o que se pretende medir, é necessário esclarecer a metodologia de medida deste conceito latente, o que envolve pensar em escalas, dimensões, reduções e outras inferências estatísticas. Muitas vezes, a operacionalização de um conceito latente envolve a compilação de mais de uma variável, a construção de um índice ou a recodificação em faixas analíticas das medidas apresentadas. No caso desta pesquisa, foi possível empreender investimentos específicos para a formação necessária à esta reflexão ${ }^{52}$.

Considerando o caráter conceitual-metdológico que esta pesquisa propõe para abordar as questões levantadas, apresentamos a seguir as reflexões conceituais que nos levaram à construção dos itens do questionário. O caminho que escolhemos seguir foi: 1) Definição dos conceitos e conceitos secundários (o que queremos medir?); 2) Identificação de como estes conceitos se manifestam no contexto observado; 3) Especificação dos itens (como medir?); 4) Operacionalização dos itens em variáveis (o que conseguimos medir?). Esta última etapa será discutida no capítulo 6.

A seguir, discutimos este percurso de construção dos conceitos secundários em cada grande conceito abordado por esta pesquisa. Nos quadros que acompanham esta discussão, optamos por relacionar a numeração dos itens dos questionários que foram definidos para medir cada conceito $(\mathrm{D}=$ Questionário do Diretor, $\mathrm{C}=$ Questionário do Coordenador e $\mathrm{P}=$ Questionário do Professor). Os instrumentos podem ser consultados nos Anexos 10, 11 e 12 deste trabalho.

\section{- Gestão e Liderança escolar}

Os conceitos gestão e liderança, se relacionam a aspectos muito próximos quando analisados em referência ao trabalho do diretor. Assim, nos deparamos com a dificuldade em separar conceitos e suas manifestações nestas duas dimensões. Sobre o uso das terminologias (gestão e liderança), Lück (2009) considera:

\footnotetext{
${ }^{52}$ Refiro-me aqui às disciplinas "Métodos Quantitativos" e "Indicadores Educacionais" (ambas ministradas pela professora Fátima Alves, na PUC-Rio); "Lego I" (ministrada pelo professor Nelson do Valle Silva, no IESP/UERJ) e ao curso "Metodologia de Survey e a Construção de Questionários" (Realizado no Programa de Treinamento Intensivo em Metodologia Quantitativa MQ/UFMG, sob a responsabilidade da Professora Solange Gomes) As experiências citadas em muito contribuíram para a fundamentação na definição dos tipos de questões adequados a cada medida pretendida.
} 
o conceito de gestão não diverge do entendimento proposto sobre liderança. Muito pelo contrário, guarda em relação a ele muitas ideias em comum [...]. Os conceitos de liderança e de gestão se complementam e até mesmo, em certa medida, confundem-se por apresentarem vários elementos importantes e básicos em comum (p. 96).

Tomando então como referência esta aproximação entre os conceitos, propomos a discussão conjunta sobre as definições de gestão e liderança escolar e sua operacionalização nesta pesquisa.

A análise da escola enquanto organização educacional, proposta por Lima (2001), nos ajuda a pensar sobre como se estabelece e como atua a gestão escolar, trazendo novas questões: Como as características dos indivíduos que estão à frente da gestão da escola se articulam aos modelos organizacionais? Qual papel cada um assume? Como os professores se colocam nessa organização? Há diferenças nos posicionamentos dos professores dos distintos segmentos do ensino fundamental? A pesquisa pretende tratar estas questões a partir da investigação sobre as estruturas, regras e ações encontradas na organização escolar.

Neste cenário, o conceito de liderança escolar torna-se fundamental para a compreensão do trabalho do diretor na gestão da escola. As reflexões sobre os tipos de liderança escolar, assim como a identificação das tarefas relevantes no desempenho de sua função, auxiliarão no reconhecimento dos perfis de liderança do diretor que serão trabalhados na análise estatística dos dados. Assim, o conceito de liderança escolar será adotado neste trabalho para se referir ao papel central do diretor na escola, na função de favorecer e mobilizar um trabalho coletivo entre os agentes educacionais em busca das metas comuns da escola, especialmente as que se referem à aprendizagem dos alunos. Embora saibamos que a atuação do diretor não tem um impacto direto nos resultados acadêmicos dos alunos, há que se considerar os meios através dos quais se constroem estas associações indiretas. Como afirmam Soares e Teixeira (2006, p. 170),

dele depende a organização interna da unidade escolar e a criação de condições adequadas para o trabalho docente. [...] Sua função envolve atividades de mobilização, de motivação e de coordenação. Dirigir uma escola implica colocar em ação os elementos do processo organizacional (planejamento, organização, avaliação) de forma integrada e articulada.

Por isso, entre os conceitos secundários relacionados à gestão e liderança, se encontram: interlocução com a equipe, interações pedagógicas, monitoramento da aprendizagem, avaliação do trabalho docente. Tais conceitos secundários serão observados a partir das respostas de diretores, coordenadores e professores das escolas. A operacionalização de cada um se dará, principalmente a partir da construção de índices: 
no caso do primeiro conceito secundário, por exemplo, prevê-se a criação do Índice de Frequência da Interlocução, o Índice de Interação em situações-problema e o Índice da Percepção da cooperação. Para o conceito secundário Interações Pedagógicas, vários itens foram pensados para tentar captar qual é o nível de intervenção pedagógica do diretor. Em contraponto, questões sobre a intervenção do diretor na rotina de trabalho docente foram propostas aos professores para medir a sua percepção (média por escola) da intervenção pedagógica do diretor. A análise destes índices, incluindo suas correlações, será uma importante medida do volume de interações entre diretores e professores com um foco pedagógico.

Para operacionalizarmos uma medida para o Monitoramento da aprendizagem pensamos em alguns itens para verificar a divisão desta tarefa entre a equipe (diretores e coordenadores) possibilitando a criação do Índice de Frequência do monitoramento da aprendizagem (pelo diretor e pelo coordenador). Uma questão similar do questionário dos professores servirá de contraponto para a prática declarada pelos diretores, ou seja, permitirá identificar se a percepção que o diretor tem sobre sua dedicação ao monitoramento da aprendizagem dos alunos coincide com a percepção dos professores sobre o mesmo tema.

Buscando aprofundar o conhecimento sobre as relações de liderança e gestão da escola, buscamos identificar o grau de influência dos agentes envolvidos (diretor, coordenador e professores). Independentemente da tipologia de liderança adotada ou da pessoa a exercê-la na escola, a capacidade de influência é uma importante medida. O nível de influência nas atitudes e comportamentos dos atores escolares tem sido usado como proxy da medida de liderança escolar em diferentes pesquisas na área. Como sugerem Supovitz et al (p. 36), isto implica em compreender a liderança para além do importância atribuída ao cargo, mas estando diretamente relacionada ao exercício de influenciar pessoas. Os autores tomam como referência "a literatura que indica que [os diretores] tendem a influenciar a performance dos alunos indiretamente, através da influência aos professores" (op. cit., p. 39, minha tradução). O modelo criado e testado por Jackson e Marriot (2012) utilizando a influência como proxy da liderança, indicou que quanto maior o nível de influência do diretor e do professor (simultaneamente) maior é o nível de satisfação do professor na escola e, também, maior é a performance escolar percebida pelo diretor. As escolas onde tanto o diretor quanto os professores possuem baixo índice de influência apresentaram clima de desagregação e apatia. Para este estudo, propomos alguns itens para captar a percepção dos respondentes sobre o seu próprio nível de influência e sobre a influência de seus pares em situações da rotina escolar. Os dados gerados por estes itens também serão trabalhados a partir da análise fatorial e da criação de índices por escola. 
O último conceito secundário relacionado à Gestão e Liderança se refere à avaliação do trabalho docente por parte da equipe de gestão da escola. Vários estudos tem apontado a importância da estratégia do diretor em oferecer retorno ou feedback sobre o trabalho do professor, o que funcionaria como um potencializador da qualidade do trabalho docente. Nesta linha, May e Supovitz (2011) procuraram medir qual é a frequência das tarefas do diretor que visam instruir e avaliar o trabalho desenvolvido pelos professores na escola e, ainda, como os professores reagem a esta intervenção. Supovitz et al. (2010) também levantam quais são as principais atividades dos diretores, incluindo a avaliação, que produzem mudanças nas salas de aula, a partir do comportamento dos professores. Em nossos questionários para diretores e coordenadores, propomos algumas questões para identificar as estratégias adotadas na escola no processo de avaliação do trabalho docente. Nos questionários dos professores incluímos duas questões para que ele expressasse sua percepção sobre a frequência com que o diretor avalia seu trabalho. O quadro a seguir apresenta a operacionalização dos conceitos secundários referentes à liderança e gestão nos três questionários construídos. 
Quadro 12: Gestão e Liderança: suas especificações e operacionalização nos instrumentos (Questionários do Diretor, do Coordenador e dos Professores ${ }^{53}$ )

\begin{tabular}{l}
\hline \multicolumn{1}{c}{ Conceito } \\
Perfil do Diretor/Foco \\
da direção escolar
\end{tabular}

da direção escolar

- Entre as metas elencadas abaixo, selecione aquela que você consi

que você considera mais importante para o seu trabalho na

direção da escola: (lista com 9 opções)

- Em sua opinião, qual é o principal papel da escola na sociedade?

D33/C33

- Entre os aspectos abaixo, com qual você gasta mais do seu tempo de trabalho na escola? Gestão de Pessoal/Gestão D34/ C34

Administrativa/ Aspectos Pedagógicos/Relações externas

- Em sua opinião, qual é o maior desafio do trabalho na direção/ coordenação pedagógica?

D60/ C60

Perfil do corpo docente $\quad$ - Em sua opinião, qual é o principal papel da escola na sociedade? P27

- Em sua opinião, qual é o maior desafio do seu trabalho na docência, nesta escola?

Interlocução com a - Qual é a frequência dos seguintes tipos de reuniões na sua escola? Somente entre a equipe gestora/Equipe gestora

equipe e professores do primeiro segmento/Equipe gestora e professores do segundo segmento/ Equipe gestora e todos os professores.

- Em caso de questionamento de pais sobre a correção de provas, com que frequência você consulta: a CRE/ a

Equipe Gestora/os professores.

- Em caso de baixo desempenho acadêmico de uma turma/série, com que frequência você consulta: a CRE/ a

Equipe Gestora/os professores.

- Em caso de faltas de professores, com que frequência você consulta: a CRE/ a Equipe Gestora/os professores.

- Nas diferentes questões da rotina escolar, apresentadas abaixo, com que frequência você é consultado para tomar

decisões? Questões Didáticas (calendário de avaliações, distribuição de pontos, volume de exercícios e atividades)/

Questões Curriculares (definição dos conteúdos a serem trabalhados em cada série, planejamento anual dos

conteúdos)/ Questões Administrativas (decisões financeiras, alocação de pessoal).

- Indique o seu nível de concordância com cada uma das afirmativas abaixo: Há um senso de cooperação entre todos que trabalham nesta escola.

- Indique com que frequência você realiza as seguintes atividades no seu trabalho na direção escolar: Eu assisto às aulas (ou parte delas)/ Eu acompanho os "Passeios Pedagógicos"/ Eu acompanho a aplicação de provas/ Eu dou sugestões aos professores sobre como eles podem melhorar suas aulas/ Eu dialogo com os professores sobre os problemas que surgem em suas turmas/ Eu informo os professores sobre possíveis formas de ampliarem sua formação para o trabalho na escola/ Eu dou aulas quando algum professor falta/ Eu acompanho a escolha do material didático adotado pelos professores na escola.

\footnotetext{
${ }^{53}$ Para a operacionalização da pesquisa todos os dados provenientes dos questionários aplicados aos professores serão agrupados por unidade escolar.
} 
- Quando um professor lhe relata uma briga de alunos em sua turma, qual é o encaminhamento mais comumente adotado?

- Quando um professor lhe relata uma situação em que foi desrespeitado em sua turma, qual é o encaminhamento mais comumente adotado?

- Quando um professor lhe relata uma dificuldade no manejo de sua turma, qual é o encaminhamento mais comumente adotado?

- Quando um professor lhe relata um problema de aprendizagem de seus alunos qual é o encaminhamento mais comumente adotado? sugiro alguma estratégia de trabalho a ser realizado/ dou-lhe autonomia para resolver a

situação/ o encaminho à Coordenação Pedagógica (Direção)/ proponho uma reunião com a Equipe de Gestão/ levo o tema para a reunião de professores.

- Ao início do ano letivo, qual é o principal critério para distribuir os professores dos anos iniciais do ensino fundamental nas séries em que vão atuar?

- Ao início do ano letivo, qual é o principal critério para distribuir os professores dos anos finais do ensino fundamental nas séries em que vão atuar?

- Ao início do ano letivo, qual é o principal critério para distribuir os professores do seu segmento nas séries em que vão atuar?

- A seguir estão alguns itens que se referem ao trabalho de gestão da escola. Indique a frequência das seguintes atividades no trabalho do diretor de sua escola: O diretor assiste às aulas (ou parte delas)/ O diretor dá sugestões aos professores sobre como eles podem melhorar suas aulas.

Monitoramento da aprendizagem

on monitoramento dos resultados acadêmicos dos alunos, indique a frequência com que ocorrem

situações abaixo: Eu solicito ao coordenador uma descrição do desempenho acadêmico bimestral de cada turma/ Eu C16 (a-f)
D10/C10/P12

D11/C11/ P13

D12/C12/P14

$\mathrm{D} 13 / \mathrm{C} 13$

$\mathrm{D} 22 / \mathrm{C} 22$

D24 /C24

$\mathrm{P} 18$

$\mathrm{P} 21(\mathrm{a}, \mathrm{b})$

converso com os professores sobre o desempenho de seus alunos nas avaliações internas da escola/ Eu converso

com os professores sobre a preparação de seus alunos para as avaliações externas/ Eu solicito à equipe gestora que

acompanhe os resultados internos dos alunos $(\mathrm{O}$ diretor solicita que eu...)/ Eu solicito à equipe gestora que

acompanhe os resultados dos alunos nas avaliações externas (O diretor solicita que eu...)/ Eu utilizo o argumento da

bonificação para estimular os professores a melhorar os resultados dos alunos nas avaliações externas.

- A seguir estão alguns itens que se referem ao trabalho de gestão da escola. Indique a frequência das seguintes atividades no trabalho do diretor de sua escola: O diretor monitora os resultados dos alunos.

Influência como medida - Em sua opinião, atualmente qual é o seu nível de influência enquanto DIRETOR na rotina desta escola, em cada

da liderança do

DIRETOR

um dos seguintes aspectos: Definição de metas de desempenho para os alunos da escola/ Definição e organização de turmas regulares da unidade escolar/ Definição de projetos de correção de fluxo na unidade escolar/ Definição dos conteúdos a serem trabalhados em cada série-disciplina/ Definição dos temas a serem trabalhados nas reuniões com professores/ Sistemas de avaliação dos professores/ Decisões sobre a matrícula de alunos/ Decisões sobre a aprovação ou reprovação de alunos/ Decisões sobre o encaminhamento de alunos para outras unidades.

- (Percebida pelo Coordenador): Em sua opinião, atualmente qual é o nível de influência do DIRETOR na rotina desta escola, em cada um dos seguintes aspectos: (mesmos aspectos.

- Sinto-me pouco apoiado (a) em relação aos recursos financeiros e pessoais necessários para manter o pleno funcionamento da escola. (escala de concordância)

P21 (d)

D19 (a-i)

D32(h) 
Influência como medida - Em sua opinião, atualmente, qual é o seu nível de influência na rotina desta escola, enquanto COORDENADOR da liderança do PEDAGÓGICO, em cada um dos seguintes aspectos: Definição de metas de desempenho para os alunos da escola/

COORDENADOR Definição e organização de turmas regulares da unidade escolar/ Definição de projetos de correção de fluxo na unidade escolar/ Definição dos conteúdos a serem trabalhados em cada série-disciplina/ Definição dos temas a serem trabalhados nas reuniões com professores/ Sistemas de avaliação dos professores/ Decisões sobre a matrícula de alunos/ Decisões sobre a aprovação ou reprovação de alunos/ Decisões sobre o encaminhamento de alunos para outras unidades.

-(Percebida pelo Diretor): Em sua opinião, atualmente, qual é o nível de influência do COORDENADOR PEDAGÓGICO na rotina desta escola, em cada um dos seguintes aspectos: (mesmos aspectos)

-Sobre o seu trabalho na coordenação pedagógica desta escola, marque qual é o seu nível de concordância com cada uma das afirmativas abaixo: Os professores desta escola apoiam meu trabalho/ O diretor apoia meu trabalho.

Influência como medida -Em sua opinião, atualmente, qual é o nível de influência dos PROFESSORES na rotina desta escola, em cada um da participação do dos seguintes aspectos: Definição de metas de desempenho para os alunos da escola/ Definições sobre os conteúdos PROFESSOR curriculares/ Definição dos temas dos programas de desenvolvimento profissional (formação continuada)/ Decisões sobre a aprovação ou reprovação de alunos/ Decisões sobre o encaminhamento de alunos para outras unidades.

- (Percebida pelo Diretor) Em sua opinião, atualmente, qual é o nível de influência dos PROFESSORES na rotina desta escola, em cada um dos seguintes aspectos: (mesmos aspectos)

- (Percebida pelo Coordenador): Em sua opinião, atualmente, qual é o nível de influência dos PROFESSORES na - (Percebida pelo Coordenador): Em sua opinião, atualmente, qual é o nível

Percepção dos -Indique o seu nível de concordância com cada uma das afirmativas abaixo: Nesta escola a equipe de gestão é professores sobre a reconhecida por realizar um bom trabalho/ A equipe de gestão da escola tem uma postura encorajadora e solidária liderança do diretor e da com os professores/ O diretor da escola valoriza e reforça o trabalho desenvolvido pelos professores.

equipe de gestão da

\section{escola}

Avaliação do trabalho
docente

- Qual é a principal estratégia que você utiliza para avaliar o trabalho desenvolvido pelos professores? Observo as aulas/ Analiso os resultados dos alunos/ Discuto sobre o desempenho do professor com o Coordenador Pedagógico (Diretor) e o Diretor Adjunto/ Levo em consideração comentários feitos pelas famílias dos alunos/ Considero as ponderações feitas pela CRE/ Levo em consideração os comentários feitos pelos alunos.

- Como você comunica esta avaliação aos professores? Converso informalmente/ Através de reunião individual de feedback/ Por meio de relatório escrito/ Através de reunião coletiva com os professores/ No momento de alocação de professores para as séries/turmas.

- A seguir estão alguns itens que se referem ao trabalho de gestão da escola. Indique a frequência das seguintes atividades no trabalho do diretor de sua escola: $\mathrm{O}$ diretor avalia o trabalho dos professores/ O diretor desta escola deixa claro para os professores o que é esperado de seu trabalho. 


\section{- Clima Escolar}

Tomando como referência os estudos de Aguerre (2004), consideramos:

o clima constitui o contexto de sentidos compartilhados, pre-compreensões que respaldam aproblematicamemte os acordos e as ações individuais ou coletivas que empreendem os membros de uma organização (professores, administradores e alunos)" (op. cit., p. 55, minha tradução)

Pensando em sua aplicabilidade nos estudos sobre a escola, Hutmacher (1992) destaca as dimensões de coletividade e de mobilização como centrais para os estudos sobre o clima escolar: "Um estabelecimento de ensino, como, aliás, qualquer grupo social, precisa mobilizar os conhecimentos e competências dos seus membros para realizar os seus objetivos e enfrentar os acontecimentos cotidianos" (op. cit., p.68). Brunet (1992), por sua vez, identifica três variáveis determinantes para o clima organizacional: a estrutura (características físicas da organização), o processo organizacional (estilo de gestão, modos de comunicação) e a variável comportamental (funcionamentos individuais e de grupo: atitudes, personalidade, coesão, normas). Segundo o autor, os efeitos destas variáveis na manutenção do clima organizacional trazem resultados individuais, de grupo e organizacionais.

Esta pesquisa vem analisando o clima escolar enquanto construção coletiva que envolve as relações interpessoais e o ambiente da escola para a aprendizagem, especialmente relacionado esta construção ao trabalho do diretor (gestão e liderança). A partir desta compreensão, levantamos alguns dos elementos constituintes do clima escolar, com o intuito de pensar medidas para suas manifestações. Neste sentido, definimos alguns conceitos secundários a partir da literatura utilizada (AGUERRE, 2004; BRUNET, 1992; OGAWA \& BOSSERT, 1995). O primeiro deles se refere ao Ambiente próprio para a aprendizagem. A importância da manutenção de um ambiente adequado à aprendizagem é consenso entre os estudos na área da eficácia escolar. Sammons (2008, p.358) destaca como características de um ambiente propício à aprendizagem: um ambiente ordenado e um ambiente atraente. A autora cita vários estudos que enfatizaram a importância de manter, na escola, um clima de ordem orientado para as tarefas escolares. Além disso, ressalta a importância de oferecer aos alunos um ambiente agradável e estimulante. Estas características estão relacionadas à variável estrutura, proposta por Brunet (1992) na análise do clima organizacional escolar. No caso desse estudo, voltaremos nossa atenção para as atitudes e iniciativas dos agentes (diretores, coordenadores e professores) para a manutenção deste clima. Assim, o primeiro bloco de questões se volta para a solução de um problema comum às escolas públicas (conforme 
reportado pelos diretores nos questionários contextuais da Prova Brasil): a falta de professores. A experiência e atuação em escola nos faz reconhecer que as consequências de uma turma sem aula podem comprometer toda a organização escolar e influenciar o clima acadêmico. Propomos analisar a tendência da solução encontrada pela gestão para este desafio, cotejando com as respostas dos professores para a mesma questão.

Em Relações Interpessoais propomos que os respondentes avaliem as suas próprias relações com os diferentes grupos na escola, assim como as relações de forma geral. Vários estudos levantados pela revisão de literatura realizada para esta pesquisa se dedicaram a estudar as relações interpessoais na escola. Nesta direção, destacam-se principalmente as categorias criadas pelos autores para descrever os comportamentos de diretores e/ou professores no cotidiano escolar e, a partir delas, as medidas utilizadas para analisar as relações estabelecidas entre estes sujeitos. Boyd et al. (2011), por exemplo, dedicam especial atenção aos fatores contextuais/relacionais da escola e seus impactos nas decisões dos professores em permanecer ou deixar a escola. $\mathrm{O}$ fator administração (que em seu trabalho envolve o relacionamento com a equipe de direção da escola) mostrou-se importante preditor da decisão do professor em continuar na escola, assim como a falta de apoio desta equipe foi apontada como aspecto que influenciou a decisão do professor em deixar a escola. Ainda que as relações trabalhistas e de hierarquia no contexto brasileiro sejam diferentes, é importante nos atentarmos para as altas taxas de rotatividade de professores entre as escolas e para os fatores que as motivam. Sobre este aspecto, M. Cunha (2015) apresenta um estudo sobre as associações entre a rotatividade docente e características da escola e de seus agentes. A relação com o diretor da escola (ou equipe de direção) foi analisada levando em consideração primordialmente as respostas dos professores para questões sobre respeito, reconhecimento e instrução para o trabalho na escola. Thoonem et al. (2011), por sua vez, analisam o impacto das práticas de liderança, das condições organizacionais da escola e de fatores motivacionais (incluindo as relações estabelecidas na escola) nas práticas dos professores. Reconhecendo a importância da qualidade das relações interpessoais para a construção do clima escolar, pretendemos, a partir dos dados levantados para a construção deste conceito, classificar as relações reportadas utilizando uma escala (de muito ruim a muito boa) para cada grupo de respondentes.

O conceito secundário Coesão do corpo docente e Comprometimento com a escola expressa a relevância da colaboração dos professores entre si na construção de um trabalho coletivo e no comprometimento com a escola em que trabalham. Entre os trabalhos que se voltaram especialmente para analisar a relação entre diretores e professores no contexto escolar, é percebida especialmente a preocupação em se levantar os impactos desta relação no comprometimento do professor (em continuar na escola ou 
não, no envolvimento com a escola, na adoção de novas estratégias, medido através de itens de questionários). Price (2012), por exemplo, analisa as relações organizacionais na escola e como elas se manifestam em diferentes níveis de satisfação, coesão e comprometimento entre diretores e professores. A autora busca, também, medir como as atitudes dos diretores contribuem para atitudes positivas dos professores. Marcondes et al. (2012), por sua vez, ressaltam a importância do comprometimento docente com a escola para a aprendizagem dos alunos, considerando que a equipe de gestão da escola (especialmente o coordenador pedagógico) pode influenciar o nível desse comprometimento:

Escolas, como as pesquisadas neste estudo, em que os coordenadores conseguem manter culturas colaborativas, processos de práticas reflexivas e decisões partilhadas têm maior probabilidade de manter o comprometimento dos professores com a aprendizagem dos alunos. (op. cit., p. 206)

As pesquisas quantitativas, utilizando como referência para a aprendizagem dos alunos a proficiência alcançada nos testes padronizados, também têm buscado interpretar esta relação. Em pesquisa sobre fatores escolares e sua relação com a política de bonificação no município do Rio de Janeiro, Koslinski et al. (2013) encontraram que as escolas onde os professores reportam maior frequência de práticas colaborativas têm maior probabilidade de atingir a meta de desempenho estipulada pela SME/RJ.

Nesta pesquisa decidimos medir a percepção dos professores sobre a coesão e o comprometimento com a escola, mas também a participação de diretores e coordenadores na construção desta coesão e comprometimento. Os itens foram pensados para dialogarem entre os diferentes respondentes e para a criação de índices de Percepção de coesão e de Percepção de comprometimento com a escola.

Um aspecto importante a ser analisado sobre o clima escolar é o fluxo de comunicação que se estabelece na escola. Estudos que destacam práticas mais democráticas na gestão escolar (MARKS \& PRINTY, 2003; LEITHWOOD \& SUN, 2012; HULPIA et al., 2011; SOARES \& TEIXEIRA, 2006; SILVA \& ALVES, 2012) apontam como estratégias de trabalho fundamentais do diretor, a habilidade de comunicar-se em geral e, especialmente, de comunicar as metas do trabalho na escola para a equipe. Assim, propomos uma medida geral sobre a percepção de cada respondente acerca da qualidade da comunicação estabelecida na escola. Além de comparar as percepções dos diferentes respondentes em uma mesma escola, pretende-se criar uma medida sintética da percepção sobre a comunicação de cada escola.

Fechando o bloco de conceitos escolhidos para compor a medida do Clima Escolar, o conceito secundário Satisfação no trabalho, traz algumas questões para captar o nível 
de satisfação dos respondentes com relação ao seu trabalho na escola. A preocupação com os níveis de satisfação do professor no desempenho de sua função, explicitada em algumas pesquisas (MAY \& SUPOVITZ, 2011; PRICE, 2012; SCANLAN, 2012; SHEN et al., 2012; SOMECH, 2010; SUPOVITZ et al., 2010; THOONEM et al., 2011, entre outros), reflete mais do que a preocupação com as condições de trabalho docente. O nível de satisfação no trabalho relatado pelo professor é cada vez mais associado à qualidade de sua instrução e à performance de seus alunos, e, ainda, aos índices de absenteísmo, abandono e rotatividade de professores, questões desafiantes para a gestão escolar. Os estudos citados indicam que o diretor escolar pode influenciar o nível de satisfação de seu corpo docente, através das estratégias de liderança que adota. Os itens propostos por esta pesquisa abordam a intensidade da satisfação dos respondentes em relação a vários fatores da rotina escolar. Alguns deles foram inspirados nos itens do questionário destinado ao diretor do School and Staff Survey - SASS ${ }^{54}$. Propomos agrupá-los a partir da análise fatorial, criando índices de satisfação do Diretor, do Coordenador e do Grupo de Professores em cada escola e relacioná-los entre si e com outras variáveis. Entre os itens propostos para diretores e coordenadores, achamos por bem indagá-los sobre sua percepção acerca das influências externas em seu trabalho, uma vez que estas são identificadas na literatura como fatores de stress que interferem no seu nível de satisfação (KARANXHA, 2013; SILVA \& ALVES, 2012; SUN et al., 2013, entre outros). A operacionalização dos conceitos secundários propostos para tentar captar o Clima Escolar nas unidades investigadas é apresentada no quadro que se segue.

\footnotetext{
${ }^{54}$ Conforme apresentado no Capítulo 1, esta base de dados educacionais dos Estados Unidos é bastante utilizada na pesquisa educacional. Sobre ela, ver Anexo 2.
} 
Quadro 13: Clima Escolar: suas especificações e operacionalização nos instrumentos (Questionários do Diretor, do Coordenador e dos Professores $^{55}$ )

$\begin{array}{cc}\text { Conceito } & \text { Especificação }\end{array}$

Ambiente próprio para

- Quando um professor dos anos iniciais do ensino fundamental falta, sem avisar, qual é o

D14/ C14/ P16

aprendizagem

encaminhamento mais comumente adotado? Eu o substituo/O Coordenador Pedagógico (Diretor) o

substitui/ O Diretor Adjunto o substitui/ Um funcionário administrativo o substitui/ Um professor

especializado o substitui/Os alunos realizam tarefas autonomamente/ Os alunos permanecem na escola

fazendo outras atividades/ Os alunos são dispensados da aula e encaminhados para retornarem às suas

casas/ Os alunos são distribuídos em outras turmas.

- Quando um professor dos anos finais do ensino fundamental falta, sem avisar, qual é o encaminhamento

mais comumente adotado? (as mesmas opções acima)

- Como você avalia os seguintes aspectos da sua escola: Disciplina/ comportamento dos alunos.

- No início do atual ano letivo, quantos professores eram novatos na escola?

- Você considera a qualidade do ensino na sua escola: Muito boa/ Boa/ Regular/ Ruim/ Muito ruim.

- Como você avalia os seguintes aspectos da sua escola: Disciplina e comportamento dos alunos.

Relações Interpessoais

- Sobre o seu trabalho na direção (coordenação) desta escola, marque qual é o seu nível de concordânci com cada uma das afirmativas abaixo: Sinto-me satisfeito (a) com as relações estabelecidas no meu local de trabalho/ Os professores desta escola gostam de trabalhar aqui, eu os descreveria como um grupo satisfeito.

- Como você avalia a sua relação com: Os professores/ O coordenador pedagógico/ Os funcionários da escola/ Os alunos/ Os pais dos alunos/

$\mathrm{D} 15 / \mathrm{C} 15 / \mathrm{P} 17$

O Conselho Escolar.

- Como você avalia os seguintes aspectos da sua escola: A convivência entre as pessoas/ Relação dos alunos com os professores/ Relação dos professores com os alunos/ Relação entre os professores do mesmo segmento/ Relação entre os professores de uma forma geral/ Relação entre os professores e a direção da escola/ Relação entre os professores e a coordenação pedagógica/ Relação entre os professores e os funcionários/ Relação entre os alunos e os funcionários.

- A seguir estão alguns itens que se referem ao trabalho de gestão da escola. Indique a frequência das seguintes atividades no trabalho do diretor de sua escola: O diretor desta escola oferece suporte individual aos professores/ O diretor desta escola se preocupa com o bem estar dos professores.

- Como você avalia a sua relação com: Os outros professores/ O diretor/ O coordenador pedagógico/ os $\quad$ P22 (a-e) funcionários da escola/ Os seus alunos.

- Como você avalia a sua relação com: Os pais dos alunos/O Conselho Escolar/ As escolas do entorno

P23 (a-e)

${ }^{55}$ Para a operacionalização da pesquisa todos os dados provenientes dos questionários aplicados aos professores serão agrupados por unidade escolar. 


\begin{tabular}{|c|c|c|}
\hline \multirow[t]{8}{*}{$\begin{array}{l}\text { Coesão do corpo docente } \\
\text { comprometimento com a } \\
\text { escola }\end{array}$} & $\begin{array}{l}\text { - Como você avalia os professores dos anos iniciais do ensino fundamental da sua escola com relação à } \\
\text { capacidade de: Compartilhar responsabilidades/ Formar um grupo coeso/ Comprometer-se com a política } \\
\text { da escola/ Motivar os alunos para a aprendizagem/Confiar na capacidade dos alunos/Buscar novas } \\
\text { estratégias que melhorem a aprendizagem dos alunos. }\end{array}$ & $\begin{array}{l}\text { D37 (a-e,g)/ } \\
\text { C37 (a-e,g) }\end{array}$ \\
\hline & $\begin{array}{l}\text { - Como você avalia os professores dos anos iniciais do ensino fundamental da sua escola com relação à } \\
\text { capacidade de: (mesmos itens). }\end{array}$ & $\begin{array}{l}\text { D38 (a-e,g) / } \\
\text { C38 (a-e,g) }\end{array}$ \\
\hline & - Como você avalia os professores da sua escola com relação à capacidade de: (mesmos itens). & P25 (a-e,g) \\
\hline & - Você considera que os professores desta escola estão alinhados com o PPP? & D39/C39 \\
\hline & $\begin{array}{l}\text { - Você considera que os professores desta escola estão alinhados com o trabalho desenvolvido pela equipe } \\
\text { de gestão (direção e coordenação)? }\end{array}$ & $\mathrm{D} 40 / \mathrm{C} 40$ \\
\hline & $\begin{array}{l}\text { - Você considera que, nesta escola, o trabalho desenvolvido pelos professores dos anos iniciais está } \\
\text { alinhado com o trabalho desenvolvido pelos professores dos anos finais do ensino fundamental? }\end{array}$ & D41 /C41 \\
\hline & $\begin{array}{l}\text { - A seguir estão alguns itens que se referem ao trabalho de gestão da escola. Indique a frequência das } \\
\text { seguintes atividades no trabalho do diretor de sua escola: O diretor desta escola me encoraja a melhorar o } \\
\text { meu trabalho em sala de aula/ O diretor desta escola garante que existam momentos para discussões } \\
\text { coletivas sobre o trabalho desenvolvido na escola. }\end{array}$ & P21 (j,k) \\
\hline & $\begin{array}{l}\text { - Indique o seu nível de concordância com cada uma das afirmativas abaixo: Em equipe, trabalhamos para } \\
\text { melhorar a imagem da escola. }\end{array}$ & P26 (b) \\
\hline \multirow[t]{4}{*}{ Comunicação } & $\begin{array}{l}\text { - Como você avalia os seguintes aspectos da sua escola: Comunicação e divulgação de informações (da } \\
\text { SME, sobre as avaliações externas e outras) entre todos os funcionários da escola. }\end{array}$ & $\begin{array}{l}\mathrm{D} 36(\mathrm{k}) / \mathrm{C} 36 \\
(\mathrm{k}) / \mathrm{P} 24(\mathrm{k})\end{array}$ \\
\hline & $\begin{array}{l}\text { - Como você avalia os professores dos anos iniciais do ensino fundamental da sua escola com relação à } \\
\text { capacidade de: Comunicar-se com os alunos }\end{array}$ & D37 (f)/ C37 (f) \\
\hline & $\begin{array}{l}\text { - Como você avalia os professores dos anos finais do ensino fundamental da sua escola com relação à } \\
\text { capacidade de: Comunicar-se com os alunos }\end{array}$ & D38 (f)/ C38 (f) \\
\hline & - Como você avalia os professores da sua escola com relação à capacidade de: Comunicar-se com os alunos & P25 (f) \\
\hline \multirow[t]{2}{*}{ Satisfação no trabalho } & $\begin{array}{l}\text { - Sobre o seu trabalho na direção (coordenação pedagógica) desta escola, marque qual é o seu nível de } \\
\text { concordância com cada uma das afirmativas abaixo: As demandas de trabalho na direção (coordenação } \\
\text { pedagógica) são razoáveis/ Sinto-me estressado (a) com o volume de demandas que o trabalho na direção } \\
\text { (coordenação pedagógica) me exige/ Sinto-me insatisfeito (a) com a irregularidade da rotina e com as } \\
\text { constantes mudanças que interferem na gestão escolar/ Eu não tenho o mesmo entusiasmo que eu tinha } \\
\text { quando comecei a trabalhar na direção (coordenação pedagógica)/ Sinto-me frustrado (a) pelo pouco } \\
\text { controle e baixa interferência que tenho sobre os projetos encaminhados pela CRE/SME para a escola/ } \\
\text { Sinto-me pouco apoiado (a) em relação aos recursos financeiros e pessoais necessários para manter o } \\
\text { pleno funcionamento da escola. }\end{array}$ & $\begin{array}{l}\text { D32 (b-f,i) } \\
\text { C32 (b-f,j) }\end{array}$ \\
\hline & $\begin{array}{l}\text { - Indique o seu nível de concordância com cada uma das afirmativas abaixo: Eu estou satisfeito com o } \\
\text { tamanho da minha turma/ Às vezes considero perda de tempo dar o melhor de mim nesta escola/ Eu me } \\
\text { sinto satisfeito em trabalhar nesta escola/ Eu penso em me transferir para outra escola/ Se eu pudesse, } \\
\text { escolheria outra carreira. }\end{array}$ & $\mathrm{P} 26(\mathrm{c}, \mathrm{e}, \mathrm{f}, \mathrm{j}, \mathrm{k})$ \\
\hline
\end{tabular}




\section{- Contexto}

O contexto sócio temporal vivenciado pelos respondentes da pesquisa foi um dos temas de interesse abarcados pelos questionários propostos, uma vez que influências externas à escola, especialmente aquelas relacionadas às demandas das avaliações externas, interferem na rotina escolar. A revisão bibliográfica encontrou alguns estudos que se dedicaram à relação do trabalho do diretor escolar com as políticas e legislações educacionais, alguns focalizando mais suas características administrativas, outros abordando as mudanças no trabalho da gestão escolar a partir das mudanças no cenário educacional. Estes estudos trazem como tônica central a relação entre as alterações nas políticas educacionais e o trabalho de gestão das escolas, essencialmente desempenhado pelo diretor. Russo (2011) destaca que se, por um lado nota-se uma relativa autonomia da escola na consecução e ação de seu projeto escolar, por outro lado se assiste a uma crescente postura intervencionista do Estado na educação. Silva e Alves (2012) também apontam este paradoxo nas atuais determinações para a gestão escolar: apesar de propagar a abertura para maior participação e democracia nos processos escolares, percebe-se a intensificação da responsabilização pelos resultados alcançados. Paes de Carvalho et al. (2014) discutem os desafios e as tensões cada vez mais presentes na pauta da gestão escolar, considerando o contexto de múltiplas avaliações externas e política de responsabilização no município do Rio de Janeiro. As autoras destacam "a sobrecarga de trabalho burocrático num contexto de precariedade de condições de administração, a uma mediação tensa das políticas junto aos agentes escolares e ainda as tendências de mudanças na gestão pedagógica” (op. cit., p. 50).

Para os questionários desta pesquisa, os itens sobre o Contexto foram elaborados com a intenção de captar a percepção dos três grupos de respondentes (diretores, coordenadores e professores) sobre os reflexos destas interferências no trabalho escolar. Considerou-se a intenção de criar variáveis comparáveis e complementares a partir destas informações e, especialmente, levantar a possibilidade de uma associação da percepção do diretor sobre estes aspectos ao seu perfil de liderança.

O primeiro conceito secundário que compõe essa análise aborda a Interação com a $C R E / S M E$. Como foi discutido na introdução deste trabalho, a atual gestão da SME/RJ adotou, progressivamente desde 2009, uma série de medidas que incluem a adoção de avaliações externas e o estabelecimento de metas de desempenho para as escolas da rede. As determinações dos agentes externos que regulam o processo educacional exercem uma importante influência nas atitudes e estratégias dos gestores escolares. Spillane e colegas (2011) se dedicaram a estudar este processo e descrevem o processo pelo qual os diretores escolares adaptam a estrutura formal da escola para "casar" as práticas 
administrativas da escola com as regulamentações do governo e a aprendizagem dos alunos. Os autores reportam que, no universo pesquisado (onde a cobrança de resultados escolares é mais intensificada), os diretores escolares estabelecem uma rotina organizacional para estandardizar o currículo, monitorar a performance dos alunos e dos professores e fazer com que as práticas em sala de aula sejam mais transparentes. Para este estudo interessou conhecer a auto avaliação dos gestores a respeito de sua relação com o órgão central e a sua percepção sobre o "alinhamento" dos professores à política educacional atual.

Avaliações externas e seus reflexos para o trabalho escolar compõem o outro conceito secundário utilizado como indicador do Contexto das escolas pesquisadas. Entre os trabalhos que tem enfatizado a interferência das demandas externas para o trabalho do diretor escolar (BRUGGENCATE et al., 2012; FULLER et al., 2011; SPILLANE et al., 2011; SEBASTIAN \& ALLENSWORTH, 2012; PAES de CARVALHO et al., 2014; ROSISTOLATO et al., 2014; KOSLINSKI, 2014, por exemplo), há um destaque especial para as políticas educacionais de avaliação e de divulgação de resultados. Os estudos destacam o redirecionamento das prioridades e estratégias do trabalho do diretor, responsabilizando-se pelos resultados acadêmicos da escola e aumentando o controle sobre o trabalho dos professores. A preocupação com os resultados dos alunos nos testes de larga escala passou a figurar nas demandas do diretor escolar com mais força a partir das políticas de responsabilização. Os diretores escolares têm um papel central neste contexto, respondendo diretamente pelo resultado atingido por seus alunos, especialmente no contexto desta pesquisa (rede municipal de ensino do Rio de Janeiro). Procuramos incluir no bloco de itens direcionados a este tema, questões sobre a percepção dos respondentes sobre os resultados de sua escola nas avaliações externas (Prova Brasil) e o levantamento de possíveis causas que, de seu ponto de vista, justificam esses resultados. Esta última questão é aberta, o que implicará em uma categorização das respostas para o trabalho com a variável. Entre os efeitos das políticas de avaliação externa para o contexto escolar, nos voltamos para a política de alocação de professores para as séries avaliadas (dados a serem triangulados entre os respondentes) e para as alterações metodológicas no trabalho do professor. Os índices criados a partir destes dados serão, possivelmente, relacionados aos resultados das escolas nas avaliações externas, em análises futuras. Por hora, apresentamos no quadro a seguir as especificações dos conceitos levantados para analisar o Contexto de trabalho dos sujeitos desta pesquisa. 
Quadro 14: Contexto: suas especificações e operacionalização nos instrumentos (Questionário do Diretor, do Coordenador Pedagógico e dos Professores ${ }^{56}$ )

\begin{tabular}{|c|c|c|}
\hline Conceito & & Item \\
\hline \multirow[t]{3}{*}{ Interação com a CRE/SME } & - Como você avalia a sua relação com: a CRE & D35 (h) /C35(g) \\
\hline & $\begin{array}{l}\text { - Você considera que os professores dos anos iniciais do ensino fundamental desta escola } \\
\text { estão alinhados e comprometidos com a política educacional da SME? }\end{array}$ & $\mathrm{D} 42 / \mathrm{C} 42$ \\
\hline & $\begin{array}{l}\text { - Você considera que os professores dos anos finais do ensino fundamental desta escola } \\
\text { estão alinhados e comprometidos com a política educacional da SME? }\end{array}$ & D43/ C43 \\
\hline $\begin{array}{l}\text { Avaliações externas: reflexos para o trabalho } \\
\text { escolar }\end{array}$ & $\begin{array}{l}\text { - Sobre os resultados da sua escola na última avaliação externa (Prova Brasil), indique o } \\
\text { seu grau de concordância com as afirmativas abaixo: O conteúdo cobrado nas avaliações } \\
\text { corresponde ao conteúdo ensinado na escola/ Foram feitas adaptações nos planejamentos } \\
\text { das séries avaliadas visando preparação para as avaliações/ A Direção escolar } \\
\text { (coordenação pedagógica) tem usado os dados destas avaliações para avaliar o trabalho } \\
\text { pedagógico/ Os professores recebem instrução específica de trabalho para lidar com as } \\
\text { avaliações externas. }\end{array}$ & $\begin{array}{l}\text { D17(a-d)/ C17 } \\
(a-d)\end{array}$ \\
\hline
\end{tabular}

valiações externas.

- Sobre os resultados da sua escola na última avaliação externa (Prova Brasil), indique o

seu grau de concordância com as afirmativas abaixo: O conteúdo cobrado nas avaliações corresponde ao conteúdo ensinado na escola/ Os resultados não traduzem corretamente o que os meus alunos sabem/ Foram feitas adaptações nos planejamentos das séries avaliadas visando preparação para as avaliações/ A equipe da escola está trabalhando para melhorar os resultados/ Acarretaram maior cobrança por parte da direção escolar/ Os professores recebem instrução específica de trabalho para lidar com as avaliações externas.

- Em sua opinião, quais são os principais fatores que influenciam/explicam o resultado

dessa escola nas avaliações externas (Prova Brasil)? Cite até três fatores.

- Existe uma política específica de alocação de professores para as turmas dos anos

iniciais do ensino fundamental que serão submetidas a avaliação externa naquele ano?

- Existe uma política específica de alocação de professores para as turmas dos anos finais D25/C25 do ensino fundamental que serão submetidas a avaliação externa naquele ano?

- Existe uma política específica de alocação de professores para as turmas do ensino

fundamental que serão submetidas a avaliação externa naquele ano?

- Com que frequência você utiliza os resultados e índices gerados pelas avaliações

P8

externas para: Discutir sobre questões curriculares com a direção escolar/ Discutir sobre

questões didáticas com a direção escolar/ Reformular os planos de ensino das minhas

aulas./ Discutir sobre os planos de ensino com a coordenação pedagógica.

\footnotetext{
${ }^{56}$ Para a operacionalização da pesquisa todos os dados provenientes dos questionários aplicados aos professores serão agrupados por unidade escolar.
} 
- Caracterização sociodemográfica

Neste bloco de questões, buscamos identificar o perfil de nossos respondentes. Cazelli (2005, p.62) considera que “as características dos [respondentes] são discriminantes individuais que permitem a sua divisão em subgrupos com importância teórica e descritiva". Tendo esta possibilidade em vista, levantamos itens que pudessem, além de delinear o perfil do grupo de respondentes, relacionar-se a outras variáveis do estudo. Muitos dos itens são semelhantes aos contemplados pelos questionários contextuais da Prova Brasil, mas optamos por repeti-los considerando a ampliação no universo de respondentes (coordenadores e professores de toda a escola). Esta opção levou em consideração a recomendação de Bradburn et al (2004, p. 262, minha tradução): "Um pesquisador pode gastar muito tempo reinventando a roda ao tentar determinar como perguntar questões sócio-demográficas". No contexto dos Estados Unidos, os autores sugerem que os pesquisadores utilizem as questões sócio-demográficas propostas pelo U.S. Census Bureau. No nosso caso, utilizamos as questões já amplamente testadas pelas edições da Prova Brasil, ampliando algumas delas. O quadro que se segue apresenta a especificação de cada um dos conceitos latentes que compõem a caracterização sóciodemográfica de nossos respondentes: 
Quadro 15: Caracterização sócio demográfica: suas especificações e operacionalização nos instrumentos (Questionário do Diretor, do Coordenador Pedagógico e dos Professores ${ }^{57}$ )

$\begin{array}{ccc}\text { Conceito } & \text { Especificação }\end{array}$

\begin{tabular}{|c|c|c|}
\hline & & \\
\hline Gênero & - Você é: Homem/Mulher & $\mathrm{D} 47 / \mathrm{C} 46 / \mathrm{P} 28$ \\
\hline Idade & - Marque a opção que determina sua faixa etária: (faixas) & D48/ C47/ P29 \\
\hline \multirow[t]{6}{*}{ Formação Acadêmica } & $\begin{array}{l}\text { - Qual é o seu grau máximo de escolarização concluído? ensino fundamental/ ensino médio/ curso } \\
\text { normal de nível médio/ ensino médio técnico/ curso normal de nível superior/ensino superior/ pós- } \\
\text { graduação ou especialização/ mestrado/ doutorado/ pós-doutorado. }\end{array}$ & $\begin{array}{l}\text { D49/C48/ } \\
\text { P30 }\end{array}$ \\
\hline & - Caso tenha feito ensino superior, em que tipo de instituição se graduou? Pública/ Privada. & D50/C49/P31 \\
\hline & - Caso tenha feito ensino superior, você se graduou em curso de: Pedagogia/ Licenciatura/ Outros. & D51/C50/P32 \\
\hline & - Você concluiu algum curso de qualificação na área de gestão escolar/educacional? & D52 /C51 \\
\hline & - Você está participando de algum curso de qualificação na área de gestão escolar/educacional? & D53/ C52 \\
\hline & - Você pretende fazer algum curso de qualificação na área de gestão escolar/educacional? & D54 /C53 \\
\hline \multirow[t]{5}{*}{ Experiência profissional } & $\begin{array}{l}\text { - Você já trabalhou como professor regente de turma na educação básica? Não/Sim - Por quantos } \\
\text { anos? }\end{array}$ & D55/ C54 \\
\hline & - Há quantos anos você trabalha como diretor escolar (coordenador pedagógico)? & D56/ C55 \\
\hline & - Há quantos anos você trabalha como diretor escolar (coordenador pedagógico) nesta escola? & D57/ C56 \\
\hline & - Há quantos anos (completos) você é professor nesta rede de ensino? (faixas) & P34 \\
\hline & - Há quantos anos (completos) você é professor nesta escola? & $\mathrm{P} 35$ \\
\hline \multirow[t]{2}{*}{ Acesso ao cargo } & $\begin{array}{l}\text { - De que forma você foi escolhido para o cargo atual de diretor escolar (coordenador pedagógico)? } \\
\text { indicação/ eleição/ eleição e seleção/ concurso/ escolha através de banca/ Outro (especifique) }\end{array}$ & D58 /C57 \\
\hline & $\begin{array}{l}\text { - De que forma você foi alocado nesta escola? indicação da CRE/ minha solicitação/ solicitação do } \\
\text { diretor/ realocação/ outros }\end{array}$ & P36 \\
\hline \multirow[t]{4}{*}{ Jornada de Trabalho } & - Qual é a sua carga horária semanal de trabalho? até 20h/ até 30h/ até 40h/ mais de 40h & D59/C58/P38 \\
\hline & - Além da função de coordenador pedagógico, está desempenhando função docente? & C59 \\
\hline & $\begin{array}{l}\text { - Em sua jornada de trabalho nesta escola está prevista carga horária remunerada para a realização } \\
\text { de reuniões com a equipe gestora e/ou professores da escola? }\end{array}$ & P39 \\
\hline & - Você possui outro cargo de professor? & $\mathrm{P} 40$ \\
\hline
\end{tabular}

\section{professor)}

Área de atuação (do professor) - Para qual segmento da escola você leciona? Anos iniciais do ensino fundamental $\left(1^{\circ}\right.$ ao $5^{\circ}$ ano $) /$

Anos finais do ensino fundamental $\left(6^{\circ}\right.$ ao $9^{\circ}$ ano $) /$ Os dois segmentos.

- Quais disciplinas você leciona atualmente nesta escola? Todas as disciplinas (professor

polivalente dos anos iniciais do ensino fundamental)/ Língua Portuguesa (anos finais do ensino

fundamental)/ Matemática (anos finais do ensino fundamental)

\footnotetext{
${ }^{57}$ Para a operacionalização da pesquisa todos os dados provenientes dos questionários aplicados aos professores serão agrupados por unidade escolar.
} 


\section{2 \\ Validação dos instrumentos}

O processo de validação de questionários envolve estratégias para testar a aplicabilidade, clareza e validade dos itens propostos para a construção dos dados que se pretende. A aplicação de um survey é um processo demandante (envolvendo grandes esforços de trabalho e financeiros) que justifica cuidados extras na elaboração e testagem dos instrumentos no intuito de evitar que os esforços sejam em vão, ou seja, que os questionários não possibilitem o levantamento das informações desejadas. Assim, o processo de validação dos questionários envolve uma revisão conceitual e técnica que, nesta pesquisa, se deu em três momentos: o pré-teste assistido, validação dos pares e a validação de face, que serão descritos a seguir.

\subsection{1 \\ O Pré-teste assistido}

Um pré-teste ou teste piloto do instrumento de coleta de dados caracteriza-se pelo caráter experimental e é aplicado a uma pequena amostra de participantes.

O pré-teste de um instrumento de coleta de dados tem por objetivo assegurar-lhe validade e precisão. Como é sabido, no caso do questionário, a obtenção desses requisitos é bastante crítica. Todavia, o pré-teste deve assegurar que o questionário esteja bem elaborado, sobretudo no referente a: a) clareza e precisão dos termos; b) forma de questões; c) desmembramento das questões; d) ordem das questões; e e) introdução do questionário (GIL, 2008, p.134).

A intenção de aplicarmos o pré-teste assistido foi, principalmente, analisar a funcionalidade do instrumento (vocabulário, clareza das questões, tempo de preenchimento, dúvidas e sugestões dos respondentes) e, principalmente, analisar a operacionalização de suas respostas considerando o quadro conceitual construído na sua elaboração. De acordo com Babbie (1999), seu principal objetivo é assegurar a criação de itens úteis. Assim, a análise do comportamento dos respondentes e o trabalho com a leitura das respostas do pré-teste podem auxiliar na reestruturação do instrumento.

O primeiro pré-teste assistido foi realizado com os participantes do "Curso de Formação para uso dos Indicadores Educacionais" ${ }^{58}$. A escolha por aplicarmos o préteste a este grupo de diretores se deu pela proximidade com o tema do curso e a partir da

\footnotetext{
${ }^{58} \mathrm{O}$ curso tinha a duração de um semestre com encontros semanais no campus da Praia Vermelha da UFRJ. Os diretores participantes recebiam uma bolsa (ajuda de custo) e um certificado de conclusão. O curso foi uma iniciativa do Projeto de Pesquisa do Observatório Educação e Cidade OEC/2010-2014.
} 
inserção desta pesquisa no âmbito do GESQ, que integrou o Projeto do Observatório Escola e Cidade de 2010 a 2014. Estavam inscritos no curso 18 diretores das escolas municipais do Rio de Janeiro, sendo 14 frequentes. Realizamos a aplicação do questionário no dia 04/06/2014, o penúltimo dia do curso, e os professores pesquisadores da UFRJ participantes do Projeto disponibilizaram parte da aula para a realização desta atividade. Ajudaram na aplicação do teste Andrea Waldhelm e Maria Elisabete Ramos, pesquisadoras do GESQ. Os respondentes preencheram o questionário em um tempo médio de 25 minutos (mínimo de 20 e máximo de 40 minutos).

O segundo pré-teste assistido foi realizado também no dia 04/06/2014 junto aos alunos do Curso de Pós-Graduação Lato Sensu CESPEB- "Politicas Públicas e Projetos Socioculturais em Espaços Escolares"59. A aplicação do questionário ficou a cargo das doutorandas Maria de Fátima Lima e Andréia Martins, também integrantes do GESQ e professoras pelo curso ministrado. Optamos pela realização deste pré-teste pelas características do público envolvido e pela disponibilidade do acesso a ele. Entre os alunos respondentes havia diretores adjuntos, coordenadores e professores, o que ampliou a nossa testagem para os outros instrumentos construídos (Questionário para Coordenadores Pedagógicos e Questionário para Professores). Apesar desta ampliação, vale ressaltar que os respondentes deste pré-teste se distanciam um pouco do perfil a ser trabalhado nesta pesquisa: profissionais de escolas municipais, estaduais e federais; profissionais de Creches e Unidades de Educação Infantil - UEI e de escolas que atendem somente a um dos segmentos do ensino fundamental ${ }^{60}$. Este distanciamento fez com que vários itens dos instrumentos não se aplicassem à realidade dos respondentes. O tempo médio gasto no preenchimento dos questionários foi 40 minutos (com o mínimo de 15 e o máximo de 60 minutos).

O objetivo da aplicação do questionário foi apresentado aos grupos e as aplicadoras solicitaram que os respondentes expressassem sua dúvidas oralmente ou por escrito. Ao final das duas experiências de pré-testagem, forma realizadas e gravadas entrevistas informais com os respondentes focalizando, especialmente, suas impressões sobre os instrumentos. Reproduzo abaixo algumas manifestações e comportamentos dos respondentes, registradas em relatório de aplicação, durante os dois momentos de prétestagem:

\footnotetext{
${ }^{59}$ Este curso é oferecido pela Faculdade de Educação da UFRJ em parceria com a REDES de desenvolvimento da Favela da Maré (Redes da Maré).

${ }^{60}$ Este levantamento não é preciso uma vez que a grande maioria dos respondentes não preencheu a identificação da escola no cabeçalho. Entre os professores, por exemplo, 15 dos 23 não o fizeram. Os restantes estavam assim distribuídos: 3 Escolas Municipais, 2 Escolas estaduais, 1 CIEP, 1 Escola Federal, 1 Creche Municipal.
} 
- No primeiro grupo, todas folhearam o questionário ao recebê-lo, uma das diretoras fez uma cara de susto com o tamanho do instrumento. Todas desenvolveram uma leitura atenta durante o preenchimento, não houve conversa, distração.

- Uma das diretoras entrevistadas demonstrou dúvidas nas questões de escalas de concordância (régua): "Pra que lado vou?"

- Outra diretora entrevistada sugeriu que repensássemos a questão que envolve uma escala de significância positiva e negativa, pois gera margem de dúvidas. Esta observação também apareceu registrada em um questionário de professores no segundo grupo de pré-testagem.

- Entre as entrevistadas do primeiro grupo, uma delas achou o instrumento bem elaborado e de fácil compreensão, não apresentou reação negativa ao tamanho do mesmo. Outra entrevistada ressaltou que as questões refletem o cotidiano do trabalho do gestor escolar.

- No segundo grupo de aplicação foram percebidos comentários sobre o tamanho do questionário no momento de início do preenchimento. Neste grupo houve a solicitação de esclarecimentos e orientações para várias questões, especialmente as que envolviam escalas de concordância.

- Alguns respondentes manifestaram que o questionário tinha um foco muito acentuado nas questões relativas às avaliações externas.

- No segundo grupo de aplicação alguns participantes demonstraram alívio ao terminarem o preenchimento, evidenciando que o acharam extenso. Um deles exclamou: "Ah! Graças a Deus eu terminei!". Outro respondente, em entrevista, definiu o questionário como trabalhoso afirmando que os professores não têm esse tempo disponível e que, se não fosse naquela situação (no curso) talvez "tivesse saído marcando x em qualquer opção."

Procuramos, ao analisar as respostas coletadas na aplicação dos dois pré-testes, testar a operacionalização das mesmas, ou seja, através do uso do software SPSS testamos como poderíamos trabalhar com os dados coletados a fim de acessarmos os conceitos levantados. Para isso, foram realizados alguns testes exploratórios com as questões respondidas pelos diretores.

A transcrição das respostas coletadas nos dois pré-testes realizados para a base de dados e sua exploração inicial, em termos de análise estatística, possibilitou a percepção de que algumas questões necessitavam reformulação, especialmente as que levantavam 
mais de uma opção de respostas. A primeira questão do questionário dos diretores ${ }^{61}$, por exemplo, foi modificada passando a solicitar a identificação de apenas uma principal meta de trabalho do diretor (na pré-testagem era solicitado que o respondente selionasse em ordem as suas três principais metas de trabalho). Esta é uma típica questão de escolha forçada, que traz a possibilidade da criação de "falsos positivos", ou seja, o respondente é levado a escolher entre as opções, não tendo possibilidade de manifestar sua não identificação com nenhuma das alternativas.

No processo de revisão dos instrumentos, levou em consideração as observações acerca do tamanho dos questionários e reduzimos o número de questões que tratavam sobre as avaliações externas, diminuindo significativamente o tamanho do instrumento. Esta redução também teve o intuito de preservar o foco da pesquisa nos instrumentos construídos.

A reflexão sobre os resultados dos pré-testes levaram em consideração três aspectos: as percepções e observações dos respondentes (expressas ou manifestas durante a aplicação e entrevistas), as possibilidades e limitações dos itens construídos no que se refere à sua operacionalização enquanto geradores de informações e a capacidade dos itens de medir os conceitos para os quais foram criados. Das análises e refutações acerca dos instrumentos de pesquisa formatamos novos instrumentos, na expectativa de que sejam mais capazes de informar com clareza as percepções dos respondentes sobre as questões de pesquisa.

\section{2 .2}

\section{A validação dos pares - Grupo de Pesquisa}

A participação em um grupo de pesquisa é sempre valiosa academicamente; as leituras compartilhadas, as produções conjuntas e os esforços coletivos ampliam as reflexões do pesquisador, por vezes solitárias. A inserção desta pesquisa no trabalho desenvolvido pelo GESQ teve uma conotação de coletividade desde o início. Desenvolver um survey sobre gestão nas escolas públicas, com questionários dirigidos à diretores e professores, constava nas intenções do grupo de pesquisa. Os rumos da minha pesquisa levaram a necessidade de aprofundar o levantamento de informações nesta área, o que impulsionou a preparação do survey. Ainda que a elaboração do instrumento tenha como eixo norteador o levantamento de informações sobre as questões desta pesquisa, foram também consideradas as demandas gerais do grupo, uma vez que os questionários criados poderão ser aplicados em outros contextos e os dados levantados estarão disponíveis para

\footnotetext{
${ }^{61}$ D4: "Entre as metas elencadas abaixo, selecione aquela que você considera mais importante para o seu trabalho na direção da escola: (lista com 9 opções)". Ver Anexo 10.
} 
futuros estudos e análises. Também foram incluídas questões específicas da uma pesquisa (em andamento) da doutoranda Fátima Lima, integrante do GESQ e importante colaboradora na elaboração dos itens, considerando sua vasta experiência enquanto diretora escolar na rede municipal do Rio de Janeiro.

Uma primeira versão do quadro conceitual e dos itens propostos para o questionário dos diretores foi apresentada ao grupo na reunião do dia 15/05/2014. Todo a organização da pré-testagem também foi planejada em grupo, bem como a discussão sobre os resultados obtidos. Após os ajustes, uma nova versão dos questionários foi apresentada ao grupo na reunião do dia 04/09/2014. Em todos os momentos as contribuições foram inúmeras, tanto no que se refere à formatação e compreensão das consignas, quanto à abrangência e funcionalidade das questões. Uma rica discussão metodológica marcou este e outros encontros do grupo, quando discutimos escalas de concordância, atribuição de valores, operacionalização das questões, uso de questões abertas, entre outros. Mais do que leitores atentos, os integrantes do GESQ foram fundamentais na construção destes instrumentos, validando sua operacionalização também através do conhecimento empírico sobre o tema, sobre a realidade das escolas da SME/RJ, sobre o trabalho docente e de gestão escolar e sobre a metodologia de survey.

\subsection{3 \\ A validação de face}

O processo de validação de face implica na avaliação conceitual do instrumento. Neste sentido, indica Cazelli (2005, p. 53), “o questionário é enviado a especialistas encarregados de avaliar se os itens propostos operacionalizam os conceitos que se pretende estudar".

Contamos, nessa pesquisa, com o apoio técnico de dois pesquisadores para esta validação. A primeira contribuição veio da Prof ${ }^{a}$. Gilda Olinto de Oliveira (UFRJ IBICT), pesquisadora que possui uma larga experiência na elaboração e aplicação de questionários e na realização de grandes surveys. Através de uma leitura compartilhada ${ }^{62}$ cuidadosa e minuciosa, várias sugestões, correções e comentários se delinearam. A preocupação com a operacionalização das respostas foi uma constante, trazendo a reflexão sobre a necessidade de ir além de perguntar o que se deseja saber para pensar sobre como perguntar de forma a obter respostas que poderão ser operadas em conjunto.

\footnotetext{
${ }^{62}$ Neste caso, optamos por algumas seções de leitura conjunta e discussão, uma vez que minha interlocutora queria compreender melhor o universo escolar e os conceitos que pretendia medir.
} 
A segunda contribuição veio do Prof. Ângelo Ricardo de Souza (UFPR), importante referência na área de gestão educacional, políticas públicas e gestão escolar, cuja produção acadêmica esteve presente em nossas reflexões ao longo de todo trabalho. O Professor realizou uma minuciosa leitura à distância da primeira versão do instrumento e, tendo conhecimento do Projeto desta pesquisa, pôde contribuir com importantes reflexões. Uma delas tratava da ampliação da abrangência das relações institucionais e políticas entre os diretores e professores. Outra observação importante foi sobre a necessidade de expandir a discussão sobre a democratização da gestão escolar, através de itens que se referissem à participação comunitária, aos conselhos escolares e à participação docente nas decisões da vida escolar.

Assim, a validação de face dos instrumentos elaborados nesta pesquisa contou com importantes contribuições tanto técnica e operacional como teórica, relacionada aos conceitos a serem mensurados pelos itens levantados. Realizamos, então, a última revisão nos instrumentos antes de aplica-los no campo delimitado para esta pesquisa. A última etapa de validação dos questionários se dará no tratamento aos dados levantados pelo survey (Capítulo 6). Trata-se de uma validação por construção que envolve a análise estatística da aplicabilidade, confiabilidade e validade dos itens.

\section{3 Entre questionários online e impressos}

Desde o início do planejamento da pesquisa, quando discutimos a necessidade de construir e aplicar um novo instrumento que fosse mais abrangente no que se refere às possibilidades de mensuração dos conceitos estudados, nossa opção foi pela aplicação online de questionários dirigidos a diretores, professores e coordenadores das escolas a serem estudadas. Nas reuniões de trabalho do OEC, vínhamos discutindo sobre a operacionalização deste tipo de coleta de dados, uma vez que havia outras pesquisas em andamento no grupo que propunham metodologia similar. Sobre as vantagens da aplicação de um questionário online, Couper e Miller (2008) apontam:

[...] é justo dizer que os surveys online tem recebido mais atenção metodológica do que outros modelos de coleta de dados. Em parte, isso se deve ao custo reduzido da aplicação de surveys via web, tornando o método mais acessível do que a coleta por telefone ou face-a-face. Além disso, a natureza informatizada de pesquisas na web facilita a realização de experiências e acelera o processo de coleta de dados, possibilitando (seja isso melhor ou pior) a realização de mais trabalhos de pesquisa em um prazo mais curto (op. cit., p.831, minha tradução). 
Como nossa intenção era justamente ampliar o número de respondentes em cada escola, a utilização de um meio digital de aplicação viabilizaria a realização da pesquisa. Sobre o survey online, alguns estudos comparativos sobre metodologias de coletas de dados levantaram possíveis problemas em sua operacionalização. Holbrook, Green e Krosnick (2003), por exemplo, consideraram que nos questionários respondidos via web, os respondentes seriam mais propícios a utilizarem a opção "não sei” (quando disponível) do que aqueles que responderam ao mesmo questionário em uma metodologia "face-aface". Os autores também consideram que respondentes online apresentariam menor diferenciação em suas respostas (uso das alternativas possíveis em escalas) e deixariam mais questões sem respostas (skip) do que os respondentes "face-a-face". Para lidar com estes possíveis vieses de resposta, escolhemos evitar a opção "não sei" como resposta possível para as questões propostas nos questionários. Acreditamos que, desta forma, estaríamos evitando o problema da "escolha automática" pela opção "não sei”, detectada pelos experimentos realizados na análise da aplicação de surveys via web. Esta opção levou em consideração o cuidado em evitar o efeito do "falso negativo" que, conforme Gillhan e Granberg (1993), acontece quando o respondente tem uma opção de resposta mas abre mão de expressar sua opinião.

Para contatar os respondentes, planejamos que na ocasião da visita às escolas selecionadas para apresentação da pesquisa, faríamos o convite para o preenchimento dos questionários e recolheríamos os endereços eletrônicos de todos os professores, coordenadores e diretores das escolas. A partir de então, a aplicação se daria totalmente online, com a disponibilização do convite/link via mensagem eletrônica, direcionando o respondente para o questionário específico (diretor, coordenador ou professor) hospedado na plataforma do Survey Monkey (www.surveymonkey.com). Assim, após os ajustes finais nos três instrumentos (conforme as observações do processo de validação explicitado), inserimos as questões na plataforma escolhida, em três diferentes endereços de acordo com o tipo de questionário.

Contudo, nos primeiros contatos que fizemos (com coordenadores pedagógicos, em uma reunião na $2^{\mathrm{a}} \mathrm{CRE}$ ), já percebemos que teríamos alguns desafios pela frente: os diretores e coordenadores pedagógicos não podiam disponibilizar os endereços eletrônicos de seus funcionários; nas escolas da rede municipal não havia mais os encontros quinzenais (Centros de Estudo) com todos os professores da escola, quando poderíamos realizar a aplicação dos questionários; segundo relatado pelas coordenadoras, poderia haver alguma resistência ao preenchimento online por parte dos professores, com a alegação de que eles não teriam tempo de se sentarem a frente do computador para responder ao questionário durante o dia de trabalho e não fariam isso de casa. 
Frente a esses impasses, tomamos a decisão de oferecer as duas opções de resposta aos questionários: online e impressa. Para tanto, encomendamos a diagramação e formatação de uma versão impressa dos instrumentos já disponibilizados na plataforma do Survey Monkey (apresentadas nos Anexos 10, 11 e 12). Ainda assim, sabíamos que a utilização desta metodologia mista de survey não garantiria, por si só, a completa adesão à pesquisa, conforme lembram Couper e Miller (2008, p.834): "Surveys mistos, envolvendo a aplicação online têm recebido muita atenção nos últimos anos [...] Mas eles não parecem ser a solução para o problema das taxas de não-respostas"

A ausência de reuniões envolvendo todos os educadores da escola nos impediu de apresentar a pesquisa diretamente a todos os professores. Assim, elaboramos um folder explicativo (Anexo 9) convidando os respondentes a aderirem a pesquisa e disponibilizando os links a serem acessados caso o respondente optasse por participar através da versão online. Nas visitas às escolas, panejamos apresentar a pesquisa ao diretor e/ou equipe de gestão da escola e tentaríamos contatar os professores que estivessem disponíveis (recreio, reunião de série) na sala de professores para entrega dos folders e/ou versão impressa dos questionários. Para os professores que não estivessem acessíveis no momento, deixaríamos o material (folders e questionários impressos) com o coordenador ou diretor ou o adjunto, dependendo do combinado em cada contexto. Os respondentes da versão impressa dos questionários deveriam então entrega-lo respondido à equipe de gestão, com quem recolheríamos todo o material em data agendada. Alguns problemas na condução deste processo, enviesando os resultados ou intimidando a participação dos respondentes, puderam ser detectados e necessitam ser reportados, o que faremos no próximo capítulo, ao narrar nossa experiência no campo. 


\section{6 \\ Diretores e professores: novos olhares para esta relação}

Neste capítulo apresentaremos os resultados do survey aplicado nas escolas selecionadas para a pesquisa. O conjunto de dados gerados por este levantamento foi chamado de Survey GESQ 2014, em referência ao grupo de trabalho do qual esta pesquisa faz parte.

A primeira seção narra os primeiros contatos com as escolas, desde o agendamento até as visitas e conversas com diretores, coordenadores e professores. A segunda seção traz uma análise dos desafios encontrados na aplicação dos questionários que, entre outros aspectos, resultou em um retorno abaixo do esperado, levando à criação de uma subamostra de trabalho. Na terceira seção iniciamos o trabalho estatístico com os dados coletados no Survey GESQ 2014, apresentando o processo de construção dos índices que sintetizaram as variáveis elaboradas para mensurar os conceitos que pretendíamos estudar (conforme descrito no processo de criação dos questionários, Capítulo 5). Por fim, a quarta seção apresenta uma análise inferencial exploratória a partir da construção de modelos estatísticos para verificar as possíveis associações entre os índices criados e a condição do trabalho docente (medida pelo seu nível de satisfação no trabalho) e o resultado dos alunos em Matemática (Prova Brasil, 2013).

\section{1 Por dentro das escolas: primeiros contatos}

O contato inicial com as 42 escolas selecionadas se deu por telefone, quando apresentou-se ao diretor/diretora, em linhas gerais, a proposta da pesquisa, agendando um encontro para a entrega da carta de autorização da SME/RJ e a carta de encaminhamento da CRE específica, segundo os trâmites necessários para a realização da pesquisa acadêmica na área educacional ${ }^{63}$. Nesta primeira fase de contato telefônico, 3 escolas saíram do grupo de amostra por já terem sido segmentadas em 2013 e estarem atendendo a apenas um segmento do ensino fundamental no ano de 2014, e 1 outra escola foi retirada da amostra pois a diretora se recusou a participar da pesquisa. Houve, ainda, duas

\footnotetext{
${ }^{63}$ Esse processo envolveu a apresentação à SME/RJ do Projeto de Pesquisa qualificado e aprovado pelo Conselho de Ética em Pesquisa da PUC- Rio. Após análise e aprovação do núcleo de Convênios e Pesquisas da SME/RJ, foi redigida a carta de autorização (Processo ${ }^{\circ}$ 07/00005.510/2014) a qual apresentamos às Gerências de Educação das CREs envolvidas na pesquisa. Estas, por sua vez, redigiram as cartas de apresentação e encaminhamento da pesquisa, para serem entregues a cada escola.
} 
outras recusas durante a apresentação da pesquisa nas escolas. Estas unidades foram substituídas por outras da amostra reserva. Assim, durante aproximadamente 5 meses, estabelecemos o contato com as 42 escolas e realizamos o processo de aplicação dos questionários. Em todas as escolas foram necessários pelo menos duas visitas: uma para a apresentação da pesquisa e outra para recolhimento dos questionários. Porém, na maioria das escolas, houve a necessidade de mais visitas, seja para conseguir contatar os professores, seja pela ausência da equipe na data agendada, ou ainda pelo atraso no preenchimento dos questionários. Uma complexa agenda foi montada, com visitas a três escolas por dia (em média). As reuniões com diretores e coordenadores durante as visitas foram registradas em um diário de campo e trouxeram elementos importantes para a reflexão sobre os contextos escolares em que foi realizada esta pesquisa..

As visitas às escolas aconteciam de acordo com agendamento prévio e, geralmente, a pesquisa era apresentada para o/a diretor/a (algumas vezes acompanhado/a pelo restante da equipe). Nestes primeiros contatos já era possível perceber a receptividade da equipe para participar do survey. Em alguns casos, os gestores relataram boas experiências com situações de pesquisa acadêmica, como na escola que participou do Projeto GERES ${ }^{64}$ ou a diretora que participou do Projeto de Pesquisa Trabalhando o Tempo na Creche ${ }^{65}$.

O pedido por um retorno sobre os resultados da pesquisa foi uma prática comum nestas primeiras reuniões. Alguns gestores, e também professores, mostraram-se genuinamente interessados no tema e nos possíveis resultados da aplicação dos questionários. Em alguns casos, o interesse pela participação na pesquisa se tornava mais evidente quando mencionávamos a parceria pretendida entre o GESQ e as escolas da rede municipal do Rio de Janeiro. Como estava explícito no folder de apresentação da pesquisa, foi planejada a oferta de bolsas de estudo em um curso de extensão sobre gestão escolar e o uso de indicadores avaliativos para os profissionais das escolas onde houvesse a participação de um número significativo de respondentes. $\mathrm{O}$ interesse em participar do curso, explicitado em muitas situações, parece indicar a necessidade de discussão sobre o tema como legítima e atual ${ }^{66}$. Ainda sobre a receptividade à pesquisa, vale ressaltar a iniciativa de alguns gestores que se dispuseram a apresentar a pesquisa para cada grupo

\footnotetext{
${ }^{64}$ Projeto Geres - Estudo Longitudinal Geração Escolar 2005, Polo PUC-RJ coordenado pela Prof ${ }^{a}$. Alícia Bonamino.

${ }^{65}$ Projeto desenvolvido no Departamento de Educação da PUC-Rio, sob a Coordenação da Prof ${ }^{a}$ Zena Eisenberg.

${ }^{66}$ O Curso "Indicadores Educacionais e Gestão da Escola", planejado e oferecido pelo GESQ/PUC-Rio iniciou-se em agosto de 2015. As escolas participantes foram convidadas, com bolsa de estudo para dois representantes, porém, apesar da grande procura por vagas no curso, poucos integrantes das escolas pesquisadas se matricularam.
} 
de professores nos Centros de Estudo ${ }^{67}$ por série ou daqueles que entregaram pessoalmente o folder e o questionário impresso aos professores.

Entretanto nem sempre a apresentação da pesquisa encontrou tal acolhida e receptividade. Em algumas poucas situações (3 casos) os gestores da escola visitada demonstraram resistência e se recusaram participar da pesquisa. Em uma das escolas, no primeiro retorno telefônico após a visita, quando questionada sobre o andamento do preenchimento dos questionários, a diretora diz que não recebeu nenhuma resposta: "eu deixei lá na sala dos professores, mas ninguém pegou...". (Trecho do Diário de Campo, Escola 6, 10/10/2014 e 30/10/2015). Percebendo a situação de pouca adesão, perguntei se podíamos ir à escola falar com os professores e ela autorizou. Após a terceira visita à escola, a diretora comunica através do contato telefônico que "não houve retorno da pesquisa, que nenhum professor havia devolvido o questionário respondido e que a equipe de gestão não tinha tempo para fazê-lo" (idem). Neste caso a escola foi substituída por outra da amostra reserva. Em outros casos, a resistência não era explícita, mas parecia haver pouco interesse ou colaboração, o que se traduziu em um baixo retorno de respostas nestas unidades.

Durante as reuniões com diretores e coordenadores ficou bastante explícita em suas falas a sobrecarga de trabalho e os inúmeros desafios da função de gerenciar a escola. $\mathrm{Na}$ Escola 4, por exemplo, a diretora começa a falar espontaneamente sobre sua rotina de trabalho e sobre o excesso de atribuições que percebe hoje na gestão da escola. Conta que a escola estava em vacância, então participou de um processo seletivo para o cargo (detalha todo o processo). Não pretende continuar no cargo, quer voltar para sala de aula. De acordo com ela, é "a diretora quem paga todas as contas". (Trecho do Diário de Campo, Escola 4, 26/09/2014). Em outra escola, uma funcionária entra na sala e interrompe a nossa reunião para pedir um rolo de papel higiênico. "Até isso.... eu é que tenho que me preocupar...." (Trecho do Diário de Campo, Escola 7, 29/09/2014). Em uma outra situação, a diretora da Escola 8 me recebe em sua sala (pede que eu me assente, mas permanece em pé), aparenta cansaço e atribulação, apesar de ser ainda o início da manhã de uma segunda-feira. Na conversa com a diretora da Escola 13, a diretora diz que está na direção desde 2009 e não vai continuar, pretende voltar para a sala de aula. Comenta que o cargo lhe traz muitas demandas e stress, carga horária muito mais ampla do que 40 horas. Considera que não vale a pena continuar no cargo.

\footnotetext{
${ }^{67}$ Os Centros de Estudo, que antes eram quinzenais e incluíam todos os professores da escola (com dispensa dos alunos) agora acontece durante o período de aula, entre professores da mesma série/disciplina, enquanto os alunos estão em aulas especializadas (são chamados de blocagens).
} 
Algumas pesquisas recentes tem se dedicado a registrar o possível excesso de demandas no trabalho da direção escolar. Spillane e Lee (2014), por exemplo, investigam os desafios que os diretores enfrentam no início da carreira e reportam que o maior deles se refere ao sentimento de "ser responsável por tudo". Este sentimento tende a não diminuir ao longo do tempo e a ser reforçado pelas demandas de um contexto de políticas de responsabilização (SUN et al, 2013; BARRÈRE, 2014; TEROSKY, 2014). A complexidade do trabalho da gestão escolar foi recentemente considerada nos estudos do INEP, que disponibilizou junto aos dados da última edição do SAEB/Prova Brasil, o Índice de Complexidade da Gestão Escolar. Este indicador foi construído a partir das informações do Censo Escolar sobre características da escola, tais como número de matrícula, número de turmas, turnos de atendimento, complexidade e número de modalidades de ensino ofertadas. A análise dos dados, que envolveu a utilização da Teoria da Resposta ao Item - TRI, gerou a classificação das escolas em 6 níveis de complexidade de gestão. Acreditamos que este estudo, além de apontar a atenção ao tema da gestão escolar, possibilitará novas análises sobre o tema.

Entre as demandas da direção e da coordenação escolar, ficou evidente a frequência dos problemas causados na rotina escolar pelo excesso de absenteísmo de professores. Foram várias as queixas em relação às mudanças no procedimento para licença médica na $\mathrm{SME} / \mathrm{RJ}^{68} \mathrm{e}$ às faltas de professores justificadas pelo trabalho nas eleições (convocação do Tribunal Regional Eleitoral - TRE ${ }^{69}$ ). Sobre as dificuldades enfrentadas em decorrência das faltas dos professores, a Diretora Adjunta da Escola comenta que há muita licença médica de professor e que não há um dia em que não tenha, pelo menos, um professor de licença: "Minha mesa fica cheia de atestados". O absenteísmo dos professores, com esta questão das licenças médicas, causa muito transtorno. "Nós não podemos mandar o aluno de volta para casa, ainda mais nesta situação perigosa que a comunidade está vivendo. E ainda houve o agravamento da situação com as dispensas dos professores que trabalharam nas eleições (TRE). Várias turmas acabam ficando sem aulas. (Trecho do Diário de Campo, Escola 24, 20/10/2014). Uma outra diretora fala sobre a dificuldade em gerenciar a questão da falta docente, considerando as regras e recomendações para a escola e sua relação com os professores. Comenta que há uma professora que está faltando há 31 dias e entrou em processo administrativo. A diretora comenta que não pode ser conivente: "o que ela esperava? que

\footnotetext{
${ }^{68}$ No período da pesquisa, os peritos da área de saúde do município estavam em greve há bastante tempo. Então, a SME/RJ encaminhou que os professores que necessitassem de licença médica com prazo menor do que 10 dias deveriam apresentar o atestado médico diretamente na escola, sem necessitar passar pela perícia.

${ }^{69}$ Ao aceitar a convocação para trabalhar no dia das eleições (como mesário, fiscal ou outra função), o funcionário recebe a dispensa de dois dias em seu trabalho para cada dia trabalhado no processo eleitoral, incluindo treinamentos.
} 
eu fosse ficar encobrindo as faltas dela?" (Trecho do Diário de Campo, Escola 7, 29/09/2014)

E o problema da falta de profissionais também atinge a equipe de gestão: entre as escolas visitadas, 2 estavam sem diretor ou adjunto e 7 sem coordenador pedagógico. No caso do coordenador pedagógico existe uma dificuldade, verbalizada por vários deles durante a pesquisa, no que se refere à pouca atratividade do $\operatorname{cargo}^{70}$. Na escola 19 , a coordenadora pedagógica, ao me acompanhar até o portão, comenta sobre as dificuldades do trabalho da coordenação, o excesso de demandas de uma escola daquele tamanho para uma só pessoa. Diz que adoeceu esse ano e pediu remoção do cargo para voltar à sala de aula. Considera que não vale a pena financeiramente e que pretende zelar pela sua saúde. Comenta, ainda, que há vários pedidos semelhantes o seu na SME: "ninguém está querendo esse cargo, é preciso rever isso..." (Trecho do Diário de Campo, Escola 19, 11/11/2014).

A falta de um dos membros da equipe de gestão foi relatada como importante entrave para a complexidade da rotina destas escolas, pois a equipe já é considerada pequena para tantas demandas. Tantas demandas e a coincidência de um período turbulento no calendário das escolas municipais do Rio de Janeiro parecem ter contribuído para a baixa adesão ao Survey, uma vez que dependíamos da colaboração desta equipe de gestão, como narramos na seção a seguir.

\title{
6.2 Entre o possível e o esperado: desafios na aplicação dos questionários e a construção de uma subamostra
}

\author{
"Nós tivemos $52 \%$ de retorno no nosso survey online. Eu estou \\ tão orgulhoso desta taxa, considerando como os diretores \\ escolares são ocupados..." (POLLOCK et al., 2014, minha \\ tradução)
}

O trecho acima se refere ao relato de uma pesquisa realizada no Canadá sobre as prioridades assumidas no trabalho dos diretores escolares. Ao utilizarem um survey online, os pesquisadores obtiveram o retorno relatado e o consideraram satisfatório após conhecerem a rotina estressante destes profissionais. No caso desta pesquisa também consideramos que a taxa de resposta ao survey, apesar de abaixo do esperado, é

\footnotetext{
${ }^{70}$ O Coordenador Pedagógico na rede municipal do Rio de Janeiro vem do corpo docente (normalmente da mesma escola) indicado pelo Diretor (não há concurso ou seleção específica para o cargo). O salário de professor é complementado de uma gratificação que, de acordo com os relatos, não compensa a dedicação de 40 horas.
} 
compreensível. É necessário reconhecer que estávamos introduzindo mais duas demandas na rotina já atribulada dos gestores escolares: responder a um questionário e distribuir/recolher os questionários dos professores. Enfim, é importante registrar que entre as respostas recebidas para o survey proposto, obtivemos $19 \%$ de retorno via web e $81 \%$ via questionários impressos.

Sobre este aspecto, convém mencionar os possíveis vieses na metodologia de aplicação do survey. O primeiro deles trata-se da aplicação de um survey misto, ou seja, contamos com duas ferramentas metodológicas diferentes que, apesar de conduzirem as mesmas questões se operacionalizavam de diferentes formas. Contudo, para a coleta dos dados relativos a esta pesquisa, não foram percebidas diferenças no comportamento dos respondentes dependendo do instrumento utilizado (observamos, por exemplo, se haveria maior número de respostas em branco ou de tendência de respostas nos questionários respondidos online do que nos impressos, o que não foi o caso). A impressão que ficou da análise dos perfis de respostas online ou escritas foi a de que o respondente que se interessou ou se sentiu motivado a participar da pesquisa optou pela versão que the era mais prática. Os que não se interessaram ou não quiseram participar, simplesmente não o fizeram. Enfim, é importante registrar que entre as respostas recebidas para o survey proposto, obtivemos $19 \%$ de retorno via web e $81 \%$ via questionários impressos.

Heerwegh e Loosveldt (2008, p.845) apontam que a tentativa de garantir o retorno de um maior número de respondentes justificaria a adoção de diferentes metodologias de coleta dos dados. Porém, os possíveis vieses devem ser reportados e observados.

Um segundo problema na metodologia de aplicação dos questionários impressos foi a falta de contato direto com a maioria dos professores. A maioria recebia o material da pesquisa pelas mãos do coordenador ou diretor da escola, o que, por si só, já poderia criar uma dúvida sobre a origem da pesquisa. Cabe assinalar aqui que talvez o maior complicador do processo tenha sido o fato de os questionários serem recolhidos ou recebidos pelos gestores da escola. O fato de ter que entregar o questionário preenchido ao diretor ou coordenador parece ter intimidado o professor respondente, como percebemos em uma das visitas. No meu retorno à escola 7, a diretora compromete-se a reforçar o pedido de preenchimento dos questionários aos professores (poucos haviam preenchido) e também a terminar o preenchimento do questionário dela. "Vou aproveitar para falar agora com os professores que estão na sala de reunião" (Trecho do Diário de Campo, Escola 7, 29/10/2014). Pergunto se posso ir junto e ela não faz objeção. Na sala havia 4 professores, a diretora me apresenta e faz uma intervenção inadequada para cobrar o preenchimento dos questionários. Dirige-se a um dos professores e pergunta: "Você já fez, né? Eu vi um lá com a sua letra..." (idem). Fica claro que ela leu os questionários respondidos pelos professores. Após ela sair, continuo na sala conversando 
com os professores. Um deles fala que começou a preencher mas parou, porque ficou constrangido com as questões que abordam as relações na escola, pois teria que entregar o questionário preenchido para a diretora e não se sentia a vontade. Esta foi a única situação explícita do possível constrangimento causado pela forma que adotamos para recolher os questionários. É importante ressaltar que no contexto pesquisado esta foi a única alternativa possível para acessar os professores. Ainda que considerássemos que a melhor opção fosse a aplicação conjunta em um momento de reunião coletiva, por exemplo, este espaço não nos foi oferecido, até porque ele inexiste na atual organização do calendário escolar da rede. Assim, optamos por lidar com esse possível viés reconhecendo-o e considerando que este pode ter sido o motivo para a não adesão de alguns possíveis respondentes. Na situação relatada, sugerimos a opção do preenchimento online.

A opção pela metodologia mista na aplicação dos questionários trouxe, ainda, uma demanda a posteriori: a necessidade de unificar a apresentação dos dados, ou seja, a digitação dos dados na plataforma do Survey Monkey. Para este trabalho contamos com a preciosa contribuição dos pesquisadores bolsistas da Iniciação Científica integrantes do GESQ em 2014, João Pedro Fontes e Catarine Teixeira Ignácio Henrique. Delimitamos alguns procedimentos para garantir a organização do trabalho: digitação seguindo a unidade Escola; registro de preenchimento com data e horário; codificação (por exemplo: usar EM para Escola Municipal, no campo "nome da escola") e compatibilização dos dados (por exemplo, procedimento comum para múltiplas respostas em questões que só aceitariam uma resposta na versão online). Durante o processo de inclusão dos dados na plataforma, os dois bolsistas registraram suas impressões. Entre elas, destacamos: a percepção de possível desinteresse ou falta de tempo no preenchimento, por parte dos professores, ao deixarem questões em branco (especialmente as dissertativas); casos de respostas idênticas para as questões dissertativas entre os questionários da equipe pedagógica da mesma escola (indicando possível preenchimento conjunto); algumas pequenas diferenças entre as versões impressa e digital, implicando em correções necessárias.

O contexto temporal ( $2^{\circ}$ semestre de 2014) também foi considerado um dificultador na aaplicação do survey: as escolas da rede estavam passando por um processo de eleição para a nova direção (o que envolvia várias reuniões na CRE além da apresentação de documentos e relatórios) e houve o período das eleições nacionais (para presidente, governador e senadores) ocasionando a falta de vários professores nas semanas seguintes ao $1^{\circ}$ e ao $2^{\circ}$ turnos eleitorais (em licença pelo TRE). Além disso, o processo de reorganização da oferta de ensino nas escolas da rede municipal do Rio de Janeiro, pressionou a agenda dos diretores com diferentes reuniões na CRE e providências a serem tomadas pela equipe de gestão. Por outro lado, a aplicação do survey também coincidiu 
com o período de preparação e aplicação de avaliações externas (Prova Rio, Alfabetiza Rio, $\mathrm{ANA}^{71}$ ).

No retorno às escolas, foram muitas as situações onde o diretor, adjunto e/ou coordenador, ao me atenderem para a entrega dos questionários preenchidos, mostraramse constrangidos com o baixo retorno no preenchimento por parte dos professores. Era como se sentissem responsáveis pela participação no survey e estivessem desapontados com o resultado.

Neste contexto, mesmo realizando vários retornos à cada unidade escolar, utilizando mecanismos de incentivo à participação (bolsas no curso de extensão), estabelecendo contatos telefônicos e por mensagens eletrônicas, conseguimos um retorno abaixo do esperado, mas uma resposta significativa: 45 respostas de diretores e adjuntos (distribuídos em 27 escolas), 23 respostas de coordenadores pedagógicos (distribuídos em 23 escolas) e 394 respostas de professores (distribuídos em 37 escolas). Em média, estes números correspondem a 55\% de retorno nos questionários destinados aos diretores, 55\% de retorno nos questionários dos coordenadores pedagógicos e $30 \%$ de retorno nos questionários dos professores $^{72}$.

Os instrumentos foram idealizados para serem trabalhados de forma conjunta (resultados de diretores, coordenadores e professores) considerando como unidade de análise a escola. Em uma primeira leitura dos dados, procuramos levantar a frequência das respostas de cada grupo de respondentes por escola. Encontramos que, entre as 42 unidades da amostra, algumas apresentavam somente dados relativos aos professores, em outras havia dados de alguns professores e do coordenador pedagógico. Como explicitamos na apresentação da pesquisa e no processo de construção dos questionários, a possibilidade de triangular as informações sobre a gestão e o clima escolar, utilizando os dados de diretores e professores, era necessária nesta pesquisa. Consideramos que a análise de tais itens torna-se incompleta ou parcial quando não temos a representatividade dos principais grupos envolvidos. Em algumas unidades obtivemos respostas dos três grupos de respondentes, mas com um número muito baixo no que se refere à participação dos professores, o que comprometia a representatividade do corpo docente nas análises propostas. Por isso, consideramos que, para um estudo significativo a partir dos dados obtidos com a aplicação dos questionários seria importante ter, em cada escola, uma

\footnotetext{
${ }^{71}$ As duas primeiras se referem às avaliações municipais do Ensino Fundamental aplicadas aos $3^{\circ}$ e $7^{\circ}$ anos e ao $1^{\circ}$ ano, respectivamente. A ANA é a Avaliação Nacional da Alfabetização, direcionada para as unidades escolares e estudantes matriculados no $3^{\circ}$ ano do Ensino Fundamental, fase final do Ciclo de Alfabetização.

${ }^{72}$ Esta é uma aproximação da quantidade total de professores, uma vez que não temos o número exato de professores atuando nas escolas onde os diretores não responderam ao questionário (esta era uma das questões propostas), assim, trabalhamos com a estimativa a partir da informação do Censo Escolar 2013.
} 
representação expressiva dos professores, pelo menos maior do que a obtida com os dados oriundos da Prova Brasil.

Foi necessário tomar uma decisão em relação a nossa amostragem: excluir as escolas em que não houvesse respostas dos diretores ou diretores adjuntos e, também, excluir as escolas com baixa representatividade docente (de acordo com os critérios comentados acima). Tal decisão reduziu a amostra para 27 unidades escolares, que passamos a chamar de subamostra. Neste grupo havia, em média 12 professores respondentes ao Survey GESQ 2014 por escola. Para este mesmo grupo de escolas, a média de professores respondentes ao questionário contextual da Prova Brasil foi igual a 6. Assim, com a subamostra do Survey GESQ 2014 conseguimos acesso a um quadro representativo dos docentes mais expressivo através dos dados coletados com itens especificamente criados para o tema investigado.

É importante ressaltar que, ao optarmos por esta seleção, privilegiamos garantir a análise estatística da operacionalização dos conceitos através dos dados construídos pela aplicação dos novos questionários. Reconhecemos que esta redução na seleção amostral compromete a representatividade dos resultados para o seu universo (163 escolas da rede municipal que atendiam aos dois segmentos do ensino fundamental em 2014) e, por isso, revisitamos nossos procedimentos de amostragem para garantir que todos os estratos da amostragem estavam sendo representados. Confirmamos que todos os extratos da amostragem estavam devidamente representados na subamostra, contudo, ainda que estatisticamente a subamostra $(n=27)$ pudesse representar o universo das escolas da SME/RJ que atendem aos dois segmentos do ensino fundamental $(\mathrm{N}=163)$, não podemos desconsiderar um importante fator que impõe um viés nesta representatividade: as 27 escolas que compõem a subamostra são aquelas em que obtivemos maior retorno na reposta aos questionários. Ainda que os motivos que levaram os diretores, coordenadores e professores destas escolas a participarem sejam os mais diversos, não podemos deixar de considerar que eles sejam os mais participativos. Assim, estas 27 escolas podem ser aquelas que tenham um nível destacado de participação ou adesão de seus integrantes em relação às outras escolas da amostra (ou este resultado pode ter sido um fato isolado ou aleatório). 


\section{3 \\ Dos itens aos índices: ampliando as possibilidades de mensuração a partir dos dados coletados}

Os dados coletados pela aplicação dos questionários foram extraídos da plataforma do Survey Monkey e organizados em três bases a partir do programa SPSS ${ }^{73}$, software utilizado em nossa análise estatística: Diretores, Coordenadores e Professores.

$\mathrm{Na}$ seleção das escolas que cumpriam os critérios para comporem a subamostra, encontramos a ausência de dados referentes aos coordenadores pedagógicos como dificultador. Ainda que o levantamento das informações referentes aos coordenadores pedagógicos possa ser útil para a triangulação de alguns dados, os dados oriundos destes questionários, quando presentes na subamostra desta pesquisa, não acrescentavam diferenciação aos dados coletados de seus respectivos diretores. Optamos, assim, por trabalhar somente com os dados de diretores e professores na análise estatística exploratória, considerando que a coleta de informações referentes ao trabalho da Coordenação Pedagógica a partir dos questionários propostos deve ser encorajada em pesquisas futuras com grupos amostrais mais amplos.

O trabalho com os dados gerados pelos questionários se iniciou com a construção dos índices criados a partir das questões propostas ${ }^{74}$. Vários índices e indicadores foram criados, conforme planejado na elaboração dos instrumentos (Capítulo 5), considerando a amplitude dos temas abordados. Todos os índices foram testados para verificar a aplicabilidade do questionário na tarefa de medir o conceito que propunham. Esta fase do trabalho é comumente chamada de validação por construção ou validação empírica dos instrumentos, quando procuramos confirmar a validade dos itens operacionalizados em escalas. Como explica Cazelli (2005, p.78), “as variáveis relativas aos conceitos latentes passam por um tratamento analítico que envolve um estudo de dimensionalidade para avaliar se os itens, tidos a priori como os que gerariam as escalas, são confirmados na construção das mesmas". A análise fatorial foi o procedimento estatístico comumente utilizado para a construção e validação (ou descarte) dos índices, idealizados na elaboração dos itens, conforme apresentado no Capítulo 5. A análise de fatores pode ser entendida como "uma técnica para identificar aglomerados de variáveis que se relacionam" (FIELD, 2009, P. 602). A seguir, descrevemos o processo de criação, os itens e as cargas fatoriais de dois dos índices criados a partir dos dados desta pesquisa, a título de exemplo.

\footnotetext{
${ }^{73}$ Statistical Package for the Social Sciences, versão 19.

${ }^{74}$ Ressaltamos que os dados provenientes dos questionários dos professores foram sempre agregados por escola criando um índice médio da percepção dos professores sobre cada conceito, por unidade escolar.
} 
As mesmas informações referentes aos demais índices criados se encontram no Anexo 7 deste trabalho.

Índice de intervenção pedagógica do Diretor (percebida pelo Diretor e pelos Professores)

O questionário destinado aos diretores aborda questões da rotina escolar em que poderiam acontecer intervenções pedagógicas suas, especialmente relacionadas ao trabalho do professor. Os dados foram recodificados (para que a escala de frequência tivesse um sentido de valor positivo) e trabalhados a partir de análise fatorial para a criação do índice. Duas variáveis (Eu dialogo com os professores sobre os problemas que surgem na sua turma e Eu dou aulas quando algum professor falta), que foram elaboradas para compor a medida deste conceito, foram excluídas por apresentarem carga fatorial baixa na relação com os outros itens. A análise resultou em um índice, ao qual nomeamos Índice de Intervenção Pedagógica do Diretor $(D)$. O quadro abaixo apresenta as cargas fatoriais das variáveis que compuseram o índice:

Quadro 16: Cargas Fatoriais das Variáveis Relativas à Intervenção Pedagógica do Diretor percebida pelo Diretor.

\begin{tabular}{|l|r|}
\hline Índice de Intervenção Pedagógica do Diretor (D) \\
\hline Variável & Carga Fatorial \\
\hline Eu assisto às aulas (ou parte delas). & 0,744 \\
\hline Eu acompanho os “Passeios Pedagógicos". & 0,758 \\
\hline Eu acompanho a aplicação de provas. & 0,855 \\
\hline $\begin{array}{l}\text { Eu dou sugestões aos professores sobre como eles podem melhorar } \\
\text { suas aulas. }\end{array}$ & 0,682 \\
\hline $\begin{array}{l}\text { Eu informo os professores sobre possíveis formas de ampliarem sua } \\
\text { formação para o trabalho na escola. }\end{array}$ & 0,593 \\
\hline $\begin{array}{l}\text { Eu acompanho a escolha do material didático adotado pelos } \\
\text { professores na escola. }\end{array}$ & 0,834 \\
\hline
\end{tabular}

Extraction Method: Principal Component Analysis. Fonte: Elaborado pela autora. Survey GESQ 2014

Para mensurar a percepção dos professores sobre este mesmo aspecto, elaboramos o Índice de Intervenção Pedagógica do Diretor $(P)$. Aos itens do questionário dos professores pensados para esta medida (Capítulo 5), incorporamos alguns outros que, também, abordavam a intervenção pedagógica do diretor. Da mesma forma, as repostas foram recodificadas e submetidas à análise fatorial, criando o índice que sintetiza a percepção dos professores sobre as intervenções pedagógicas do diretor. O quadro a seguir apresenta as cargas fatoriais das variáveis que compuseram o índice: 
Quadro 17: Cargas Fatoriais das Variáveis Relativas à Intervenção Pedagógica do Diretor percebida pelo Professor.

Índice de Intervenção Pedagógica do Diretor $(P)$

\begin{tabular}{|l|l|}
\hline Variável & Carga Fatorial \\
\hline
\end{tabular}

\begin{tabular}{|l|r|}
\hline O diretor assiste às aulas (ou parte delas). & 0,537 \\
\hline
\end{tabular}

\begin{tabular}{|l|r|}
\hline O diretor dá sugestões aos professores sobre como eles podem & 0,762 \\
\hline
\end{tabular} melhorar suas aulas.

\begin{tabular}{|c|c|}
\hline O diretor avalia o trabalho dos professores. & 0,782 \\
\hline
\end{tabular}

\begin{tabular}{|l|r|}
\hline O diretor monitora os resultados dos alunos. & 0,696 \\
\hline
\end{tabular}

O diretor desta escola me encoraja a melhorar o meu trabalho em sala $\quad 0,641$ de aula.

Extraction Method: Principal Component Analysis

Fonte: Elaborado pela autora. Survey GESQ 2014

Todos os índices criados foram testados quanto à sua unidimensionalidade enquanto medida possível para os conceitos levantados. "A literatura específica tem informado sobre a fidedignidade de escalas por meio de uma medida denominada Alpha de Cronbach que fornece a consistência interna baseada na média de correlação dos itens." (CAZELLI, 2005, p.80). Normalmente considera-se que um Alpha de Cronbach acima de 0.70 é ótimo e entre 0.70 até 0.60 é aceitável. Os valores do Alpha de Cronbach para os todos os índices criados se apresentaram significativos, indicando que os mesmos se constituem como escalas consistentes. O quadro a seguir sintetiza a descrição dos índices criados e testados para esta amostra, seus itens e os valores de KMO e Alpha de Conbrach de cada um deles. 


\begin{tabular}{|c|c|c|c|c|c|}
\hline Conceito & Variável & Descrição & $\begin{array}{l}\text { Questionário de } \\
\text { Origem e itens }\end{array}$ & KMO & $\begin{array}{l}\text { Alpha de } \\
\text { Conbrach }\end{array}$ \\
\hline \multirow{2}{*}{$\begin{array}{l}\text { Perfil do } \\
\text { Diretor }\end{array}$} & Tendência de Gestão Pedagógica & Indicador de uma Tendência de Liderança Pedagógica do diretor & $\begin{array}{l}\text { Q Diretor: } 4,33,34, \\
60\end{array}$ & --- & --- \\
\hline & Tendência de Gestão Distribuída & Indicador de uma Tendência de Liderança Distribuída do diretor & $\begin{array}{l}\text { Q Diretor: } 4,33,34 \\
60\end{array}$ & --- & --- \\
\hline \multirow{6}{*}{ Interlocução } & $\begin{array}{l}\text { Indicador médio da frequência de } \\
\text { interlocução (D) }\end{array}$ & $\begin{array}{l}\text { Indicador de Frequência da Interlocução com a Equipe (percebida pelo } \\
\text { Diretor) }\end{array}$ & Q Diretor: 5 & --- & --- \\
\hline & $\begin{array}{l}\text { Indicador médio da frequência de } \\
\text { interlocução }(\mathrm{P})\end{array}$ & $\begin{array}{l}\text { Indicador de Frequência da Interlocução com a Equipe (percebida pelo } \\
\text { Professor) }\end{array}$ & Q Professor: 9 & --- & --- \\
\hline & Índice de Participação docente & Índice médio da percepção docente sobre sua participação & Q Professor: 10 & 0,630 & 0,735 \\
\hline & Participação em Questões Didáticas & $\begin{array}{l}\text { Porcentagem de professores que se sentem incluídos nas decisões didáticas } \\
\text { da escola }\end{array}$ & Q Professor: 10a & --- & --- \\
\hline & Participação em Questões Curriculares & $\begin{array}{l}\text { Porcentagem de professores que se sentem incluídos nas decisões } \\
\text { curriculares da escola }\end{array}$ & Q Professor: $10 \mathrm{~b}$ & --- & --- \\
\hline & $\begin{array}{l}\text { Participação em Questões } \\
\text { Administrativas }\end{array}$ & $\begin{array}{l}\text { Porcentagem de professores que se sentem incluídos nas decisões } \\
\text { administrativas da escola }\end{array}$ & Q Professor: 10c & --- & --- \\
\hline \multirow{3}{*}{$\begin{array}{l}\text { Intervenção } \\
\text { pedagógica }\end{array}$} & $\begin{array}{l}\text { Índice de Intervenção Pedagógica do } \\
\text { Diretor (D) }\end{array}$ & Índice de Intervenção pedagógica do diretor (percebida pelo diretor) & Q Diretor: 9 a-d, f, h & 0,824 & 0,841 \\
\hline & $\begin{array}{l}\text { Índice de Intervenção Pedagógica do } \\
\text { Diretor }(\mathrm{P})\end{array}$ & Índice de Intervenção pedagógica do diretor (percebida pelo professor) & Q Professor: $21 \mathrm{a}-\mathrm{d}, \mathrm{j}$ & 0,767 & 0,716 \\
\hline & $\begin{array}{l}\text { Índice de Monitoramento da } \\
\text { aprendizagem (D) }\end{array}$ & Índice de Monitoramento da aprendizagem pelo Diretor & Q Diretor: 16b-e & 0,604 & 0,785 \\
\hline \multirow{4}{*}{ Liderança } & Índice de Liderança Pedagógica & $\begin{array}{l}\text { Índice de Liderança do Diretor em questões pedagógicas (percebido pelo } \\
\text { diretor) }\end{array}$ & Q Diretor:19a,d,f,h & 0,718 & 0,857 \\
\hline & Índice de Liderança Administrativa & $\begin{array}{l}\text { Índice de Liderança do Diretor em questões da organização administrativa } \\
\text { (percebido pelo diretor) }\end{array}$ & Q Diretor: 19b,g,i & 0,718 & 0,659 \\
\hline & Índice de Liderança do Professor & Índice de Participação Docente na Liderança (percebida pelos professores) & Q Professor: 11a-e & 0,787 & 0,790 \\
\hline & $\begin{array}{l}\text { Índice do reconhecimento do trabalho da } \\
\text { direção }\end{array}$ & Índice do reconhecimento do trabalho da direção escolar pelos professores & Q Professor: 26a,g,h & 0,668 & 0,866 \\
\hline
\end{tabular}




\begin{tabular}{|c|c|c|c|c|c|}
\hline Conceito & Variável & Descrição & $\begin{array}{l}\text { Questionário de } \\
\text { Origem e itens }\end{array}$ & KMO & $\begin{array}{l}\text { Alpha de } \\
\text { Conbrach }\end{array}$ \\
\hline \multirow{2}{*}{$\begin{array}{l}\text { Ambiente } \\
\text { próprio para } \\
\text { aprendizagem }\end{array}$} & $\begin{array}{l}\text { Índice de Percepção do Ambiente Escolar } \\
\text { (D) }\end{array}$ & $\begin{array}{l}\text { Índice da percepção dos Diretores sobre o Ambiente Escolar: disciplina e } \\
\text { relações envolvendo alunos }\end{array}$ & Q Diretor 36b,c,d,j & 0,778 & 0,855 \\
\hline & $\begin{array}{l}\text { Índice de Percepção do Ambiente Escolar } \\
(\mathrm{P})\end{array}$ & $\begin{array}{l}\text { Índice da percepção dos Professores sobre o Ambiente Escolar: disciplina } \\
\text { e relações envolvendo alunos }\end{array}$ & Q Professor 24b,c,d,j & 0,784 & 0,851 \\
\hline \multirow{3}{*}{ Relações } & Índice de Relações Interpessoais (D) & $\begin{array}{l}\text { Índice de Relações interpessoais envolvendo professores (percebida pelos } \\
\text { diretores) }\end{array}$ & Q Diretor: $36 \mathrm{e}-\mathrm{i}$ & 0,759 & 0,820 \\
\hline & Índice de Relações Interpessoais (P) & $\begin{array}{l}\text { Índice de Relações interpessoais envolvendo professores (percebida pelos } \\
\text { professores) }\end{array}$ & Q Professor $24 \mathrm{e}-\mathrm{i}$ & 0,829 & 0,891 \\
\hline & Índice de Interação do Diretor (P). & $\begin{array}{l}\text { Índice de Interação do diretor com o corpo docente (percebida pelo } \\
\text { professor) }\end{array}$ & $\begin{array}{l}\text { Q Professor 21e- } \mathrm{g}, \mathrm{i}- \\
\mathrm{k}\end{array}$ & 0,726 & 0,829 \\
\hline \multirow{4}{*}{$\begin{array}{c}\text { Coesão e } \\
\text { comprometi- } \\
\text { mento }\end{array}$} & $\begin{array}{l}\text { Índice de Coesão e Comprometimento } \\
\text { EF1 (D) }\end{array}$ & $\begin{array}{l}\text { Índice de coesão e comprometimento dos professores do EF1 (percebido } \\
\text { pelo diretor) }\end{array}$ & Q Diretor 37a-e, g & 0,742 & 0,913 \\
\hline & $\begin{array}{l}\text { Índice de Coesão e Comprometimento } \\
\text { EF2 (D) }\end{array}$ & $\begin{array}{l}\text { Índice de coesão e comprometimento dos professores do EF2 (percebido } \\
\text { pelo diretor) }\end{array}$ & Q Diretor 38a-e, g & 0,742 & 0,922 \\
\hline & $\begin{array}{l}\text { Índice de Coesão e Comprometimento } \\
\text { (P) }\end{array}$ & $\begin{array}{l}\text { Índice de coesão e comprometimento dos professores (percebido pelo } \\
\text { professor) }\end{array}$ & Q Professor 25a-e, g & 0,882 & 0,916 \\
\hline & $\begin{array}{l}\text { Índice do Alinhamento do Trabalho } \\
\text { Docente (D) }\end{array}$ & Índice de alinhamento no trabalho dos professores (percebido pelo diretor) & Q Diretor 39,40 e 41 & 0,666 & 0,744 \\
\hline \multirow{2}{*}{$\begin{array}{l}\text { Satisfação no } \\
\text { trabalho }\end{array}$} & Índice de Satisfação no Trabalho (D) & Índice de Satisfação no trabalho (percebido pelos diretores) & Q Diretor 32c,f & 0,726 & 0,717 \\
\hline & Índice de Satisfação no Trabalho (P) & Índice de Satisfação no trabalho (percebido pelos professores) & $\begin{array}{l}\text { Q Professor } \\
26 \mathrm{c}, \mathrm{e}, \mathrm{f}, \mathrm{j}, \mathrm{k}\end{array}$ & 0,675 & 0,610 \\
\hline
\end{tabular}

Fonte: Elaborado pela autora. Survey GESQ 2014 
Cabe fazer aqui duas importantes observações: a primeira se refere a generalização da aplicabilidade dos instrumentos. As escalas se mostraram adequadas na utilização para esta amostra específica; ainda que haja uma grande probabilidade de que os índices sejam também adequados para a aplicação em outros grupos semelhantes (diretores, coordenadores e professores), deve-se observar como os índices se comportarão nessas situações. A segunda observação se refere às escolhas que levaram à construção destes índices e não de outros: "O pesquisador seleciona um número de fatores que acredita ser adequado para explicar os relacionamentos entre as variáveis observadas" (AGRESTI e FINLAY, 2012, p.587). As opções pelas variáveis a serem testadas, indicadas no capítulo 5 deste trabalho, assim como a escolha dos nomes dos índices, foram lastreadas nas concepções teóricas da literatura discutida e poderiam ter sido diferentes a partir de outras inspirações. Ressalta-se ainda que outros índices podem ser pensados a partir destes instrumentos, a partir de itens que não foram utilizados nesta pesquisa.

Tendo encerrado a fase de construção e validação dos índices, passamos a utilizálos em um estudo estatístico exploratório que será descrito na seção que se segue.

\section{4 \\ Diretores e professores: novos olhares a partir de um estudo exploratório}

A construção da base de dados final se deu com a agregação dos dados de diretores e adjuntos, criando uma base de escolas, para onde foram transferidos os índices dos professores (agregados por unidade escolar) e as variáveis oriundas do estudo realizado com os dados da Prova Brasil 2013 (NSE e Nota Média de Matemática do $5^{\circ}$ e do $9^{\circ}$ anos). Iniciamos, então, a análise das possíveis associações entre fatores relacionados ao trabalho do diretor (tendência de liderança, intervenções pedagógicas, monitoramento da aprendizagem, liderança pedagógica, interação com os professores) e ao clima escolar (relações interpessoais, interlocução, participação docente nas decisões, coesão e comprometimento da equipe, alinhamento do trabalho realizado na escola) com a condição do trabalho do professor (medida pelo índice de satisfação no trabalho) e os resultados dos alunos da escola (Média dos resultados dos alunos do $5^{\circ}$ e do $9^{\circ}$ anos nos testes de matemática da Prova Brasil 2013 por escola). Assim, foram criados dois grupos de modelos: o primeiro grupo teve como variável dependente o Índice de Satisfação no Trabalho e o segundo grupo teve como variável dependente a Proficiência média em Matemática dos alunos do $5^{\circ}$ ano na Prova Brasil 2013. Pretendemos, assim, discutir a partir dos resultados, quais são as variáveis (relacionadas ao trabalho do diretor e ao clima 
escolar) que apresentam uma relação significativa com a satisfação do professor no trabalho e com a aprendizagem dos alunos.

Em cada um dos grupos, testamos inicialmente um modelo de regressão linear simples onde as variáveis de controle são as únicas variáveis independentes (Modelos 1 de cada grupo $)^{75}$. Em seguida, propomos uma análise em modelos parciais onde cada variável preditora é incluída individualmente, estimando a associação isolada de cada um dos fatores com a variável dependente (Modelos 2 a 6 de cada grupo). Este procedimento nos ajuda a identificar o tamanho da associação de cada fator com as variáveis dependentes e se fez necessário considerando o tamanho reduzido da amostra. Como aponta Field (2009, p.181) "é importante ter dados suficientes para obter um modelo de regressão confiável. [...] Há muitas regras práticas por aí, as duas mais comuns são que você deve ter 10 casos de dados para cada previsor no modelo ou 15 casos de dados por previsor". Com efeito, após este procedimento, tentamos estimar um modelo de regressão incluindo todas as variáveis de cada grupo, através da técnica stepwise ${ }^{76}$ (Modelo Final, em cada grupo) e apenas uma das variáveis permanece no modelo com uma associação significativa. Tal limitação se deve tanto ao tamanho da amostra quanto à possível colinearidade entre as variáveis, como será discutido em cada caso.

É importante ressaltar a natureza exploratória do estudo realizado com os dados disponibilizados pelo Survey GESQ 2014, cujos resultados são limitados à esta amostra e não podem ser interpretados como efeitos causais para as variáveis dependentes selecionadas. A intenção das modelagens propostas foi levantar indícios de possíveis associações entre as variáveis e testar as análises possibilitadas pelos dados disponibilizados pelos questionários. Tendo em conta estas observações, apresentamos a seguir, os resultados dos modelos estimados em dois grupos: o primeiro, tendo como variável dependente a Satisfação no Trabalho do Professor e o segundo grupo tendo como variável dependente o Resultado de Aprendizagem dos alunos.

\footnotetext{
${ }^{75}$ A organização e apresentação dos modelos estimados seguiu o roteiro utilizado por Alves et al. (2013) por considerar sua clareza e relevância metodológica.

${ }^{76}$ Este procedimento consiste em testar as variáveis independentes em diversas combinações e ordenações, até chegar ao melhor ajuste para o modelo, no qual nem todas as variáveis permanecem.
} 


\section{1 grupo: o que pode estar associado ao nível de satisfação do professor no trabalho?}

Talvez seja consenso pensar que professores satisfeitos no trabalho desempenham melhor sua função e, assim, ensinam melhor. Porém, poucos estudos na área educacional tem se dedicado a estudar esse tema, dentre os quais destacamos o trabalho de Price (2011). O estudo buscou compreender como e por que as relações entre os diretores e os professores nas escolas poderiam criar um "desejável clima de satisfação, coesão e comprometimento nas escolas" (PRICE, 2011, p.40), que estaria relacionado às diferenças no clima escolar e na eficácia do trabalho desenvolvido. Utilizando os dados de questionários aplicados a professores e diretores, a autora analisou a relação entre eles a partir das variáveis criadas referentes ao trabalho coletivo, liderança e participação. Para este estudo, incluímos no questionário dos professores itens sobre o volume de trabalho, a valorização da escola, o desejo de continuar trabalhando naquela unidade e na educação em geral. Os itens foram sintetizados no Índice de Satisfação no Trabalho ${ }^{77}$ sendo depois analisado junto às outras variáveis criadas, tentando responder a pergunta: o que pode estar associado ao nível de satisfação do professor no trabalho? Como descrito na introdução desta seção, apresentamos a seguir a construção de cada modelo estimado para esta análise. A Tabela 12, ao final desta explanação, sintetiza os parâmetros obtidos em todos os modelos (coeficientes de regressão das variáveis e coeficientes de determinação$\mathrm{R}^{2}$ de cada modelo ${ }^{78}$ ).

\section{Modelo 1: Variável de controle (Idade do Professor)}

Nossa intenção era analisar se as variáveis relacionadas ao trabalho do diretor (liderança e gestão escolar) e as variáveis relacionadas ao clima escolar estariam relacionadas ao Índice de Satisfação no Trabalho (do professor). Porém, como muitos outros aspectos influenciam o nível de satisfação do professor em trabalhar na escola na qual está alocado, é necessário utilizar uma variável de controle evitando que as demais capturem seu possível efeito. Inicialmente, testamos as variáveis relacionadas ao nível socioeconômico dos alunos da escola (medido a partir da escolaridade média dos pais, do Índice de Desenvolvimento Humano e da renda per capta do bairro onde a escola se localiza, do indicador de território criado - próximo ou não próximo à favela). Tomamos como referência o trabalho desenvolvido por Price (2011), que utilizou como variável de

\footnotetext{
${ }^{77}$ Os itens que compuseram o índice e suas cargas fatoriais são apresentados no Anexo 7.

${ }^{78}$ Este coeficiente nos dá a medida do poder explicativo das variáveis do modelo sobre a variável dependente: a proporção da variância de $Y$ explicada por $X$.
} 
controle a medida de NSE da escola e outras variáveis sociodemográficas. O estudo de Paul e Barbosa (2008) apontou a correlação encontrada entre o NSE da escola e a presença de professores mais experientes, que tinham a oportunidade de escolher a escola onde iriam trabalhar (na amostra utilizada). Porém, no caso desta pesquisa, as variáveis indicativas do nível socioeconômico das escolas pouco ou nada explicavam a variação no Índice de Satisfação no Trabalho entre as escolas, muito provavelmente devido ao tamanho reduzido da amostra. Assim, embora não possamos descartar a possibilidade de que a satisfação em trabalhar em determinada escola possa estar relacionada à sua localização ou ao nível socioeconômico de seus alunos, para esta amostra, resolvemos adotar outra variável de controle. Entre as características sociodemográficas dos professores, a variável que apresentou maior correlação com o Índice de Satisfação no Trabalho foi aquela relacionada à idade dos professores, conforme apresentado pela tabela e gráfico que se seguem:

Tabela 7: Correlação entre o Índice de Satisfação no trabalho (variável dependente) e a variável indicativa da idade dos professores (variável de controle)

\begin{tabular}{llcc}
\hline \hline & & $\begin{array}{c}\text { Índice de Satisfação } \\
\text { no trabalho } \\
\text { (percebido pelos } \\
\text { professores }\end{array}$ & $\begin{array}{c}\text { Porcentagem de } \\
\text { professores } \\
\text { respondentes na } \\
\text { escola que têm } \\
\text { mais de 40 anos }\end{array}$ \\
\hline $\begin{array}{l}\text { Índice de Satisfação no trabalho } \\
\text { (percebido pelos professores }\end{array}$ & Pearson Correlation & 1 &, $484^{*}$ \\
\hline $\begin{array}{l}\text { Porcentagem de professores } \\
\text { respondentes na escola que têm } \\
\text { mais de } 40 \text { anos }\end{array}$ & Pearson Correlation &, $484^{*}$ &, 012 \\
\hline \hline
\end{tabular}

*. A correlação é significativa ao nível 0.05 (2-tailed). Fonte: Elaborado pela autora. Survey GESQ 2014

Gráfico 4: Correlação entre o Índice de Satisfação no trabalho (variável dependente) e a variável indicativa da idade dos professores (variável de controle)

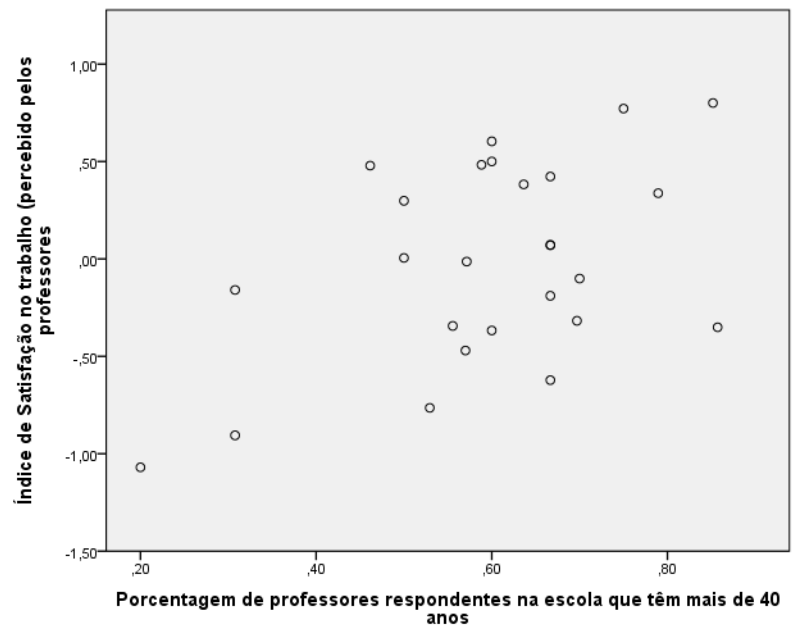

Fonte: Elaborado pela autora. Survey GESQ 2014 
Como se vê pelo gráfico, há uma relação linear positiva entre as duas variáveis, ou seja, nas escolas onde há uma maior porcentagem de professores com mais de 40 anos estes reportam uma maior satisfação no trabalho e, provavelmente, ficam mais tempo na mesma escola. Sobre este aspecto, M. Cunha (2015) apresenta um levantamento sobre os fatores relacionados à mobilidade docente e, dentre eles, destaca os estudos que associaram a idade do professor à sua disponibilidade para mudar de escola:

No que diz respeito à idade dos professores, estudos mostram que profissionais mais jovens possuem maior probabilidade de sair da escola na qual lecionam, quando comparados a professores de maior faixa etária, com exceção daqueles que estão prestes a se aposentar. (M. CUNHA, 2015, p. 49)

Poderíamos ampliar esta análise considerando que os professores mais velhos tendem a permanecer mais tempo na escola por estarem mais satisfeitos no trabalho, como os dados desta pesquisa parecem apontar. A regressão linear simples encontrou para este primeiro modelo um coeficiente de determinação $R^{2}$ igual a 0,20 , indicando que a variável indicativa da idade dos professores explica $20 \%$ da variação no Índice de Satisfação no trabalho reportado pelos professores. Esta tornou-se, então, nossa variável de controle que estará presente em todos os próximos modelos estimados neste grupo de análise.

Modelo 2: O Reconhecimento do trabalho da Direção

Entre todos os índices criados a partir do tratamento dos dados desta pesquisa, apresentados neste capítulo, quatro apresentaram uma associação significativa com o Índice de Satisfação no Trabalho. O primeiro deles foi o Índice de Reconhecimento do Trabalho da Direção ${ }^{79}$, conforme ilustram a tabela e o gráfico a seguir:

\footnotetext{
${ }^{79}$ As variáveis que compuseram este índice foram: Nesta escola a equipe de gestão é reconhecida por realizar um bom trabalho; A equipe de gestão da escola tem uma postura encorajadora e solidária com os professores; $O$ diretor da escola valoriza e reforça o trabalho desenvolvido pelos professores $(\mathrm{KMO}=0,668$ e Alpha de Crombach $=0,866)$. Para mais detalhes, ver Anexo 7 .
} 
Tabela 8: Correlação entre o Índice de Satisfação no Trabalho (variável dependente) e o Índice de Reconhecimento do Trabalho da Direção

\begin{tabular}{|c|c|c|c|}
\hline & & $\begin{array}{c}\text { Índice de Satisfação } \\
\text { no trabalho } \\
\text { (percebido pelos } \\
\text { professores }\end{array}$ & $\begin{array}{c}\text { Índice de } \\
\text { Reconhecimento } \\
\text { do Trabalho da } \\
\text { Direção }\end{array}$ \\
\hline \multirow{2}{*}{$\begin{array}{l}\text { Índice de Satisfação no trabalho } \\
\text { (percebido pelos professores }\end{array}$} & Pearson Correlation & 1 &, $622^{* * *}$ \\
\hline & Sig. (2-tailed) & &, 001 \\
\hline \multirow{2}{*}{$\begin{array}{l}\text { Índice de Reconhecimento do } \\
\text { Trabalho da Direção }\end{array}$} & Pearson Correlation &, $622^{* * *}$ & 1 \\
\hline & Sig. (2-tailed) &, 001 & \\
\hline
\end{tabular}

Gráfico 5: Correlação entre o Índice de Satisfação no Trabalho (variável dependente) e o Índice de Reconhecimento do Trabalho da Direção

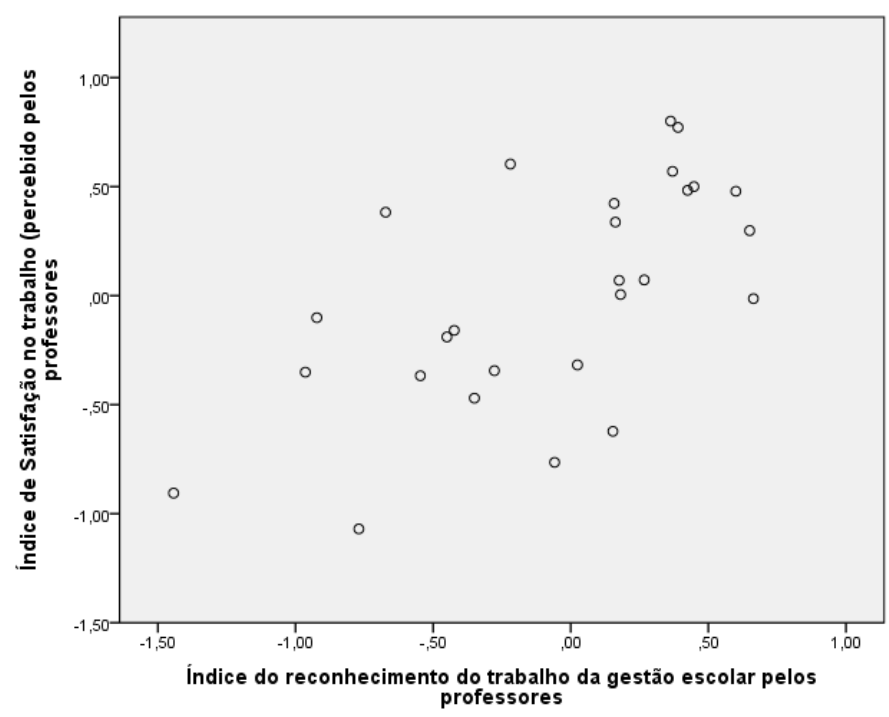

Fonte: Elaborado pela autora. Survey GESQ 2014

Os resultados das correlações, apresentados acima, apontam para uma relação direta e positiva entre o Índice do reconhecimento do trabalho da direção escolar e a variável dependente, ou seja, nas escolas pesquisadas que reportaram uma boa percepção dos professores sobre a direção da escola, estes mesmos professores tenderam a apresentar um maior nível de satisfação no trabalho. Esse resultado aponta para a importante relação entre a percepção dos professores quanto à eficácia do trabalho dos diretores e suas próprias ações na rotina escolar (influenciadas pelo seu nível de satisfação). a regressão linear simples, controlada pela variável indicativa da idade dos professores, encontrou um coeficiente significativo para esta variável, aumentando o 
poder explicativo do modelo para $45 \%\left(\mathrm{R}^{2}=0,45\right)$. Ou seja, parte da satisfação que os professores reportaram em trabalhar nas escolas da amostra, é explicada pelo nível de reconhecimento que têm do trabalho desenvolvido pela direção da escola. Este resultado, ainda que em uma perspectiva exploratória, corrobora os achados de Price (2011). A autora encontra associações positivas entre os índices criados para medir a Autonomia do diretor e sua Capacidade de socializar as expectativas de trabalho (variáveis que expressam o reconhecimento do trabalho desenvolvido pelos diretores) e o nível de satisfação dos professores (op. cit., p. 63-64).

\section{Modelo 3: A percepção sobre o Ambiente Escolar}

Como vimos, o conceito de clima escolar não é consensual entre os estudos no meio acadêmico. Brito e Costa (2010) consideram que, em geral, as principais referências sobre o tema

buscam analisar padrões de interações sociais presentes no contexto escolar que podem facilitar ou dificultar o trabalho coletivo e o diálogo entre os diferentes atores do processo pedagógico, aspectos fundamentais na dinâmica educativa (BRITO e COSTA, 2010, p. 501).

A ampla abrangência conceitual do termo torna difícil sua observação e mensuração. Em sua pesquisa empírica, Aguerre (2004) inicialmente considerou a possibilidade de trabalhar com um único índice para a medida do clima escolar. Contudo, as análises estatísticas demonstraram a multidimensionalidade do conceito, indicando a presença de três dimensões do clima escolar naquele contexto.

Para esta pesquisa, foi possível criar índices válidos para a medida das seguintes dimensões do conceito: Ambiente próprio para a aprendizagem; Relações, Coesão e comprometimento; Percepção do Ambiente Escolar e Satisfação no trabalho. Destes, o único que apresentou uma correlação significativa com a variável dependente foi o Índice de Percepção do Ambiente Escolar (pelos professores) ${ }^{80}$. A tabela e o gráfico a seguir apresentam os dados desta correlação:

\footnotetext{
${ }^{80}$ As variáveis que compuseram este índice foram: Como você avalia os seguintes aspectos da sua escola: Disciplina/comportamento dos alunos; Relação dos alunos com os professores; Relação dos professores com os alunos; Relação dos alunos com os funcionários. (KMO = 0,784 e Alpha de Crombach $=0,851$ ). Para mais detalhes, ver Anexo 7 .
} 
Tabela 9: Correlação entre o Índice de Satisfação no Trabalho (variável dependente) e o Índice de Percepção do Ambiente Escolar

\begin{tabular}{|c|c|c|c|}
\hline & & $\begin{array}{c}\text { Índice de Satisfação } \\
\text { no trabalho } \\
\text { (percebido pelos } \\
\text { professores) }\end{array}$ & $\begin{array}{c}\text { Índice de } \\
\text { Percepção do } \\
\text { Ambiente Escolar }\end{array}$ \\
\hline \multirow{2}{*}{$\begin{array}{l}\text { Índice de Satisfação no trabalho } \\
\text { (percebido pelos professores) }\end{array}$} & Pearson Correlation & 1 &, $616^{* * 6}$ \\
\hline & Sig. (2-tailed) & &, 001 \\
\hline \multirow{2}{*}{$\begin{array}{l}\text { Índice de Percepção do Ambiente } \\
\text { Escolar }\end{array}$} & Pearson Correlation &, $616^{* * *}$ & 1 \\
\hline & Sig. (2-tailed) &, 001 & \\
\hline
\end{tabular}

Gráfico 6: Correlação entre o Índice de Satisfação no Trabalho (variável dependente) e o Índice de Percepção do Ambiente Escolar

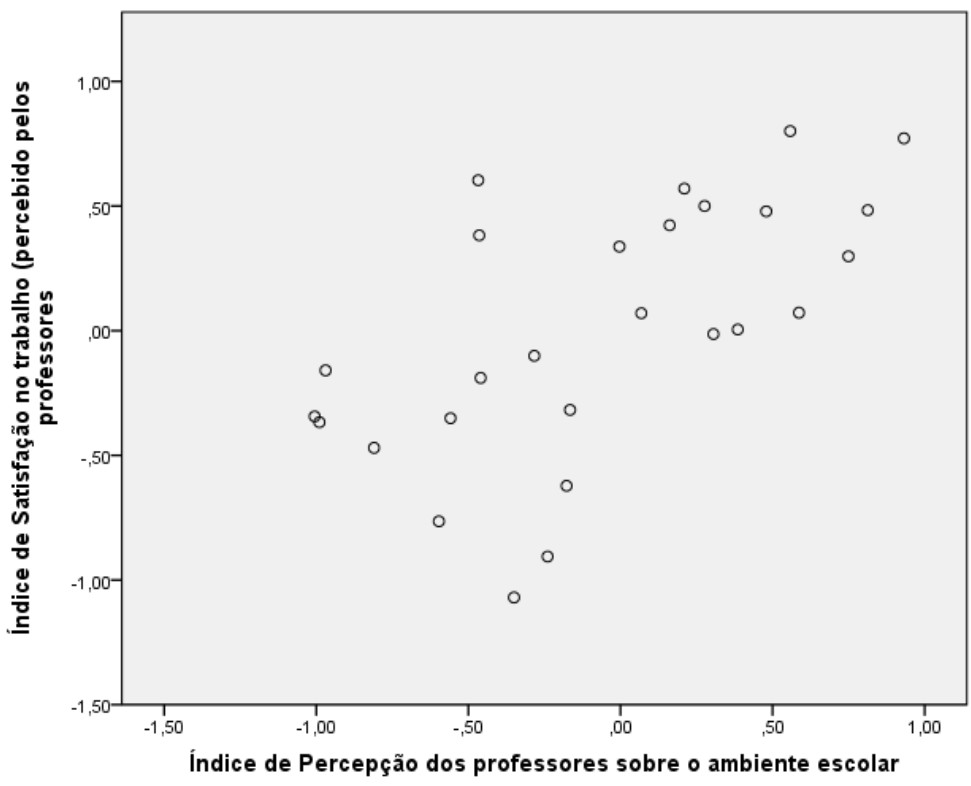

Fonte: Elaborado pela autora. Survey GESQ 2014

O gráfico acima, assim como os dados da tabela, indicam a alta correlação entre as variáveis, em uma relação direta e positiva. Esta indicação foi confirmada pela regressão linear, tendo sido controlada pela variável indicativa da idade dos professores, que resultou em uma associação positiva e significativa entre as variáveis, aumentando o poder explicativo do modelo para 46\%. Assim, na amostra desta pesquisa, encontramos que parte da satisfação reportada pelos professores pode ser explicada pela percepção que eles têm do ambiente escolar. 


\section{Modelos 4 e 5: A intervenção pedagógica e a interação do Diretor}

Discutiremos neste bloco os dois índices criados para sintetizar a percepção dos professores sobre o trabalho do diretor no que se refere às intervenções e interações com o corpo docente. Os itens que compuseram os índices são bastante próximos e abrangem um relacionamento mais direto entre diretores e professores. As correlações entre estes índices e a variável dependente são expressas na tabela e gráficos que se seguem:

Tabela 10: Correlações entre o Índice de Satisfação no Trabalho (variável dependente) e os Índices de Intervenção Pedagógica e de Interação do Diretor

\begin{tabular}{|c|c|c|c|c|}
\hline & & $\begin{array}{c}\text { Índice de } \\
\text { Satisfação no } \\
\text { trabalho }\end{array}$ & $\begin{array}{c}\text { Índice de } \\
\text { Intervenção } \\
\text { Pedagógica do } \\
\text { Diretor }\end{array}$ & $\begin{array}{c}\text { Índice de } \\
\text { Interação do } \\
\text { Diretor }\end{array}$ \\
\hline \multirow{2}{*}{$\begin{array}{l}\text { Índice de Satisfação no trabalho } \\
\text { (percebido pelos professores }\end{array}$} & Pearson Correlation & 1 &,- 279 &,$- 414 *$ \\
\hline & Sig. (2-tailed) & &, 159 &, 045 \\
\hline \multirow{2}{*}{$\begin{array}{l}\text { Índice de Intervenção Pedagógica } \\
\text { do Diretor }\end{array}$} & Pearson Correlation &,- 279 & 1 &, $523 * *$ \\
\hline & Sig. (2-tailed) &, 159 & &, 009 \\
\hline \multirow[t]{2}{*}{ İndice de Interação do Diretor } & Pearson Correlation &,$- 414 *$ &, $523 * *$ & 1 \\
\hline & Sig. (2-tailed) & 045 & ,009 & \\
\hline
\end{tabular}

Gráfico 7: Correlação entre o Índice de Satisfação no Trabalho (variável dependente) e o Índice de Intervenção Pedagógica do Diretor ${ }^{81}$

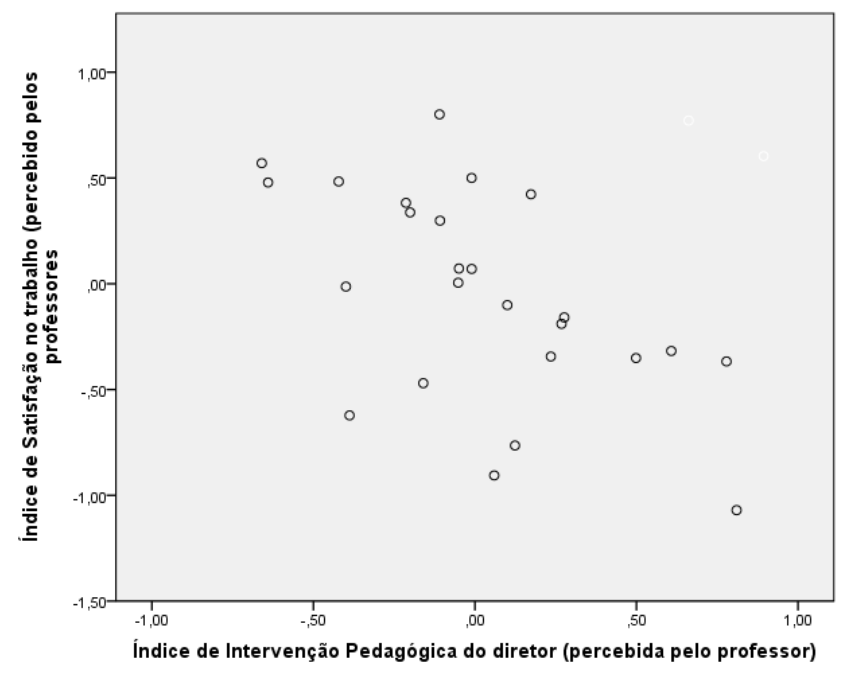

Fonte: Elaborado pela autora. Survey GESQ 2014

\footnotetext{
${ }^{81}$ As variáveis que compuseram o índice foram: $O$ diretor assiste às aulas (ou parte delas; $O$ diretor dá sugestões aos professores sobre como eles podem melhorar suas aulas; $O$ diretor avalia o trabalho dos professores; $O$ diretor monitora os resultados dos alunos; $O$ diretor desta escola me encoraja a melhorar o meu trabalho em sala de aula. (KMO =0,767 e Alpha de Crombach = 0,716). Para mais detalhes, ver Anexo 7.
} 
Gráfico 8: Correlação entre o Índice de Satisfação no Trabalho (variável dependente) e o Índice de Interação do Diretor ${ }^{82}$

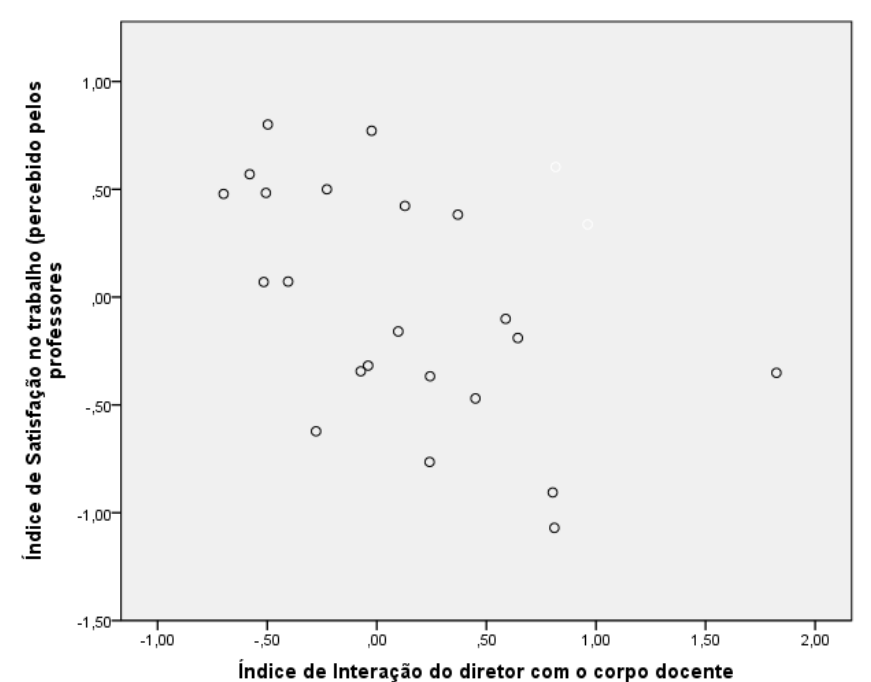

Fonte: Elaborado pela autora. Survey GESQ 2014

Chama a atenção o fato de duas variáveis terem se associado de forma inversa com a variável dependente: nas escolas da amostra, à medida que os índices de intervenção pedagógica do diretor e de interação do diretor com os professores aumenta, o nível de satisfação do corpo docente cai.

No primeiro caso, trata-se de uma dimensão da liderança pedagógica (ou instrucional) do diretor na escola (POLON, 2009; TEROSKY, 2014; NEUMERSKI, 2013). Uma possível hipótese para esse resultado pode estar na compreensão de como os professores percebem esta intervenção e interação do diretor com o corpo docente. Os itens que compuseram os índices abordam a presença do diretor na sala de aula, o monitoramento dos resultados dos alunos, as possíveis sugestões para o professor aplicar em sua sala de aula. Pensando nas diferentes e complexas tarefas da direção escolar, é possível que os professores das escolas que reportaram uma percepção negativa sobre estes aspectos, desaprovem uma gestão pedagógica do diretor, estabelecendo um limite na expectativa de atuação do diretor: a sala de aula. Retomando a leitura de Barroso (2012) sobre os diversos mundos do diretor, seria como se os professores reconhecessem o papel de Administrador, Diretor Executivo ou Mediador e tivessem pouca expectativa de sua atuação enquanto Representante (pedagógico) do grupo. Sobre este aspecto, o estudo de

\footnotetext{
${ }^{82}$ As variáveis que compuseram o índice foram: Quando um professor tem problemas em sua classe, o diretor toma a iniciativa de discutir o problema; Quando um professor leva um problema sobre sua classe à direção escolar, este é resolvido com sua participação; $O$ diretor desta escola se preocupa com o bem-estar dos professores; $O$ diretor desta escola me encoraja a melhorar o meu trabalho em sala de aula; $O$ diretor desta escola garante que existam momentos para a discussões coletivas sobre o trabalho desenvolvido na escola. $(\mathrm{KMO}=0,726 \mathrm{e}$ Alpha de Crombach $=0,829)$. Para mais detalhes, ver Anexo 7 .
} 
Barrère (2014) aborda uma possível "ruptura identitária" no desempenho da tarefa do diretor escolar, que na maioria das vezes, exerceu a função docente antes de assumir a direção: "[...] todos revelam uma espécie de ruptura identitária, desejada ou não, perante seus antigos pares, diante dos quais estão, doravante, numa posição hierárquica" (op. cit., p.288).

A relação estabelecida entre o índice de interação do diretor e a satisfação do professor no trabalho também apresentou um resultado inversamente negativo, ou seja, quanto mais os diretores interagem com os professores, menos satisfação no trabalho eles reportam. As variáveis que compuseram o índice, conforme apresentado, abrangem a preocupação do diretor com o bem estar dos professores, o espaço para discussões coletivas, as expectativas e avaliações do trabalho docente, entre outros. Tais aspectos se referem a uma dimensão mais relacional do trabalho do diretor, também percebida negativamente pelos professores da amostra. Os resultados encontrados pela regressão linear confirmaram esta relação significativa e inversa entre os índices e a variável dependente. Este resultado, ainda que exploratório, talvez indique que a ruptura identitária mencionada por Barrère esteja sendo percebida pelos professores, que não recebem com naturalidade as intervenções pedagógicas e nem a interação do diretor. Uma possível hipótese para esta relação inversa poderia estar relacionada à qualidade do clima escolar, que poderia estar atuando sobre as duas variáveis. Ou seja, poderíamos pensar que em um ambiente escolar com muitos problemas o nível de satisfação dos professores tende a ser mais baixo assim como seria propício para intervenções mais frequentes do diretor. Resultados inversos poderiam ser encontrados em ambientes escolares mais tranquilos. Com efeito, a relação entre a percepção sobre o ambiente escolar e o nível de satisfação dos professores no trabalho foi demonstrada. E entre as variáveis Índice de interação do diretor com o corpo docente e Índice de Percepção dos professores sobre o ambiente escolar encontramos uma correlação significativa, inversamente negativa ( $\alpha=$ $0,519, p=0,009)$. Não podemos deixar de considerar esta correlação e a relevância do Índice de Percepção dos professores sobre seu ambiente de trabalho, ainda que análises com amostras mais abrangentes aprofundariam o estudo.

\section{Modelo Final}

Após analisar as relações individuais de cada índice com a variável dependente, controlados pela variável indicativa da porcentagem de professores acima de 40 anos, tentamos estimar um modelo que incluísse todas as cinco variáveis testadas. Porém, apesar de considerarmos que há uma série de fatores agindo simultaneamente para a determinação dos níveis de satisfação dos professores na escola (inclusive muitos outros 
não medidos neste trabalho), o modelo final manteve apenas uma das variáveis apresentando uma relação significativa com a variável dependente: o Índice de Percepção sobre o Ambiente Escolar (pelos professores). Os coeficientes encontrados repetem, assim, aqueles já apresentados no Modelo 3.

As limitações técnicas na modelagem para esta amostra impedem uma análise do comportamento destas variáveis simultaneamente. Como antecipado na introdução desta seção, esta limitação se deve tanto ao tamanho da amostra quanto à colinearidade entre os índices utilizados, fenômeno no qual cada preditor explica parte da variância da variável dependente que já foi explicada por outro preditor. Nas ciências sociais, em geral (Cohen \& Cohen, 1975), grande parte das variáveis são correlacionadas entre si. Nesse caso, a análise simultânea de fatores correlacionados em uma regressão linear múltipla, pode resultar em coeficientes não significativos. De fato, ao analisarmos as correlações entre os quatro índices que entraram no modelo, notamos a alta colinearidade entre eles:

Tabela 11: Correlações entre as variáveis independentes incluídas nos modelos do Grupo 1

\begin{tabular}{|c|c|c|c|c|c|}
\hline & & $\begin{array}{c}\text { Índice do } \\
\text { reconhecimento } \\
\text { do trabalho da } \\
\text { gestão escolar } \\
\text { pelos professores }\end{array}$ & $\begin{array}{c}\text { Índice de } \\
\text { Percepção } \\
\text { do } \\
\text { Ambiente } \\
\text { Escolar } \\
\end{array}$ & $\begin{array}{l}\text { Índice de } \\
\text { Intervenção } \\
\text { Pedagógica } \\
\text { do Diretor }\end{array}$ & $\begin{array}{l}\text { Índice de } \\
\text { Interação } \\
\text { do Diretor }\end{array}$ \\
\hline \multirow{2}{*}{$\begin{array}{l}\text { Índice do reconhecimento do } \\
\text { trabalho da gestão escolar } \\
\text { pelos professores }\end{array}$} & Pearson Correlation & 1 &, $704 * *$ &,$- 469 *$ & $-754 * *$ \\
\hline & Sig. (2-tailed) & &, 000 &, 014 &, 000 \\
\hline \multirow{2}{*}{$\begin{array}{l}\text { Índice de Percepção do } \\
\text { Ambiente Escolar }\end{array}$} & Pearson Correlation &, $704 * *$ & 1 &,$- 414 *$ &, $519 * *$ \\
\hline & Sig. (2-tailed) &, 000 & &, 032 & ,009 \\
\hline \multirow{2}{*}{$\begin{array}{l}\text { Índice de Intervenção } \\
\text { Pedagógica do Diretor }\end{array}$} & Pearson Correlation &,$- 469 *$ &,$- 414 *$ & 1 &, $523 * *$ \\
\hline & Sig. (2-tailed) &, 014 &, 032 & & ,009 \\
\hline \multirow[t]{2}{*}{ Índice de Interação do Diretor } & Pearson Correlation &,$- 754 * *$ &,$- 519 * *$ &, $523 * *$ & 1 \\
\hline & Sig. (2-tailed) &, 000 & ,009 & ,009 & \\
\hline
\end{tabular}

Assim, ao analisarmos os resultados do Modelo Final, apresentados na última coluna da Tabela 12 que se segue, devemos notar a importância do Índice de Percepção dos professores sobre o Ambiente Escolar para explicar a variância em seu nível de satisfação no trabalho (cada incremento no índice de Percepção do ambiente escolar, equivale ao aumento de 0,27 no valor médio do indicador de satisfação docente no trabalho, e a primeira variável é responsável por $46 \%$ da explicação na variância da segunda). Porém, esta variável explicativa está refletindo, também, as relações estabelecidas pelas outras variáveis testadas. Os índices, apesar de não terem 
permanecido no modelo final, apresentaram coeficientes significativos em relação à variável dependente, quando analisados individualmente (tendo a variável de controle nos modelos individuais), merecendo portanto ser aprofundados. Encerrando as análises neste grupo, apresentamos a seguir as estatísticas descritivas das variáveis e a síntese dos modelos estimados.

Quadro 19: Estatística Descritiva das Variáveis incluídas nos Modelos do Grupo 1

\begin{tabular}{|c|c|c|c|c|}
\hline Variáveis & Mínimo & Máximo & Média & Desvio Padrão \\
\hline \multicolumn{5}{|l|}{ DEPENDENTE } \\
\hline Índice de Satisfação no Trabalho & $-1,07$ &, 80 & ,0045 & ,51447 \\
\hline \multicolumn{5}{|l|}{ INDEPENDENTES } \\
\hline $\begin{array}{l}\text { Porcentagem de } \quad \text { Professores } \\
\text { respondentes com mais de } 40 \text { anos de } \\
\text { idade }\end{array}$ & 20 & ,86 &, 5964 &, 15613 \\
\hline $\begin{array}{l}\text { Índice do reconhecimento do trabalho } \\
\text { da gestão escolar pelos professores* }\end{array}$ & $-2,48$ & 1,34 & 0,0 & 1,0 \\
\hline $\begin{array}{l}\text { Índice de Percepção do Ambiente } \\
\text { Escolar* }\end{array}$ & $-1,63$ & 1,77 & 0,0 & 1,0 \\
\hline $\begin{array}{l}\text { Índice de Intervenção Pedagógica do } \\
\text { Diretor* }\end{array}$ & $-1,73$ & 1,92 & 0,0 & 1,0 \\
\hline Índice de Interação do Diretor* & $-1,42$ & 2,69 & 0,0 & 1,0 \\
\hline
\end{tabular}

Fonte: Elaborado pela autora, com dados do Survey GESQ 2014.

Tabela 12: Síntese dos coeficientes dos modelos do Grupo 1

\begin{tabular}{|c|c|c|c|c|c|c|}
\hline & Modelo 1 & Modelo 2 & Modelo 3 & Modelo 4 & Modelo 5 & $\begin{array}{c}\text { Modelo } \\
\text { Final }\end{array}$ \\
\hline Constante & $-0,963^{*}$ & $-0,709^{*}$ & $-0,734^{*}$ & $-0,936^{*}$ & $-1,062 * *$ & $-0,734^{*}$ \\
\hline $\begin{array}{l}\text { Porcentagem de } \\
\text { Professores } \\
\text { respondentes com mais } \\
\text { de } 40 \text { anos de idade }\end{array}$ & $1,58^{*}$ & $1,17^{*}$ & $1,21^{*}$ & $1,55^{*}$ & $1,71 * *$ & $1,21 *$ \\
\hline $\begin{array}{l}\text { Índice do } \\
\text { reconhecimento do } \\
\text { trabalho da direção }\end{array}$ & & $0,27 * *$ & & & & \\
\hline $\begin{array}{l}\text { Índice de Percepção do } \\
\text { Ambiente Escolar }\end{array}$ & & & $0,27 * *$ & & & $0,27 * *$ \\
\hline $\begin{array}{l}\text { Índice de Intervenção } \\
\text { Pedagógica do Diretor }\end{array}$ & & & & $-0,11 *$ & & \\
\hline $\begin{array}{l}\text { Índice de Interação do } \\
\text { Diretor }\end{array}$ & & & & & $-0,21^{*}$ & \\
\hline $\mathrm{R}^{2}$ Ajustado & 0,20 & 0,45 & 0,46 & 0,21 & 0,35 & 0,46 \\
\hline
\end{tabular}

*.O coeficiente é significativo ao nível 0.05 (2-tailed).

**. O coeficiente é significativo ao nível 0.01 (2-tailed).

Constante: Índice de Satisfação no Trabalho (professores).

Fonte: Elaborado pela autora, com dados do Survey GESQ 2014. 


\section{2 grupo: o que pode estar associado aos resultados de aprendizagem dos alunos?}

Os estudos em eficácia escolar têm se dedicado a levantar elementos escolares que poderiam estar relacionados às diferenças nos resultados escolares, uma vez controladas as características sociodemográficas dos alunos (BROOKE \& SOARES, 2008; SAMMONS, 2008; ALVES e FRANCO, 2008; SAMMONS et al., 1995). Entre os fatores escolares que poderiam ser efetivos para os resultados acadêmicos dos alunos, a gestão escolar - especialmente o trabalho do diretor na escola - é considerado fundamental (BARROSO, 2005 \& 2012; PARO, 2015; LEITHWOOD, 2009; SOUZA, 2012). Pesquisas desenvolvidas em diferentes contextos procuram identificar a relação entre a atuação do diretor escolar e os resultados dos alunos (SOARES, 2007; URICK \& BOWERS, 2013; BRUGGENCATE et al., 2012; GRISSON \& LOEB, 2011; LEITHWOOD et al., 2010; MARQUES, 2012; MIRANDA, 2012; PAES de CARVALHO et al., 2012; entre outros). Parece haver um consenso sobre a relevância da atuação do diretor para os resultados dos alunos em testes de aprendizagem, sendo que esta atuação se dá de maneira indireta. Neste estudo, procuramos desenvolver uma análise a partir dos dados levantados pelos instrumentos de pesquisa elaborados, que permitisse um aprofundamento sobre como o trabalho do diretor torna-se relevante para os resultados escolares. Consideramos especialmente em nossa análise as atividades dos diretores que pudessem estar relacionadas ao trabalho docente com a intenção de avaliar sua associação aos resultados dos alunos em testes de larga escala. Da mesma forma que procedemos no primeiro grupo de análise, após a seleção de uma variável de controle (Modelo 1), testamos a correlação de todas os índices criados com a variável dependente: Proficiência média em Matemática dos alunos do $5^{\circ}$ e $9^{\circ}$ anos, Prova Brasil 2013 (Modelos 2 a 6). Finalmente, testamos a entrada de mais de uma variável no modelo, através do procedimento stepwise do SPSS (Modelo Final). A seguir, cada modelo é explicado a partir de suas correlações e a Tabela 18, ao final da seção, apresenta todos os coeficientes estimados nos modelos. Ainda que possa parecer redundante, cabe ressaltar novamente o caráter experimental desta análise. O tamanho da amostra limita a amplitude das análises estatísticas e a consideração sobre sua representatividade e generalização. Mais uma vez, nosso intuito ao estimar os modelos que se seguem, foi testar a aplicabilidade inferencial dos instrumentos criados. 


\section{Modelo 1: Variável de controle (NSE)}

Como já era previsto, a variável indicativa do NSE médio das escolas ${ }^{83}$, foi o preditor que apresentou a associação mais forte e significativa com os resultados dos alunos. A relação entre a origem socioeconômica e o desempenho escolar é, provavelmente, a mais importante e discutida na Sociologia da Educação. Grandes levantamentos educacionais da década de 1960 confirmaram "que as diferenças socioeconômicas entre os alunos são as grandes responsáveis pelas diferenças no seu desempenho" (BROOKE e SOARES, 2008, p.15). Vários estudos posteriores demonstraram que esta é, também, uma indicação para as diferenças de desempenho encontradas entre as escolas (ALVES, 2012; SOARES e ANDRADE, 2006 e 2007; entre outros). Assim, quanto mais elevado o nível socioeconômico das famílias atendidas pela escola, maior é a probabilidade desta escola apresentar melhores resultados acadêmicos.

Os dados utilizados nesta pesquisa, oriundos da edição de 2013 da Prova Brasil, confirmam esta tendência, justificando a escolha desta como a variável de controle para os modelos de regressão linear desenvolvidos posteriormente. As tabelas e gráficos a seguir apresentam as correlações entre as variáveis dependente e de controle:

Tabela 13: Correlação entre o NSE e a Proficiência Média em Matemática dos alunos do $5^{\circ}$ ano

\begin{tabular}{llccc}
\hline \hline & & $\begin{array}{c}\text { Proficiência Média } \\
\text { em Matemática dos } \\
\text { alunos do 5 }\end{array}$ & $\begin{array}{c}\text { Porcentagem de } \\
\text { pais com } \\
\text { escolaridade acima } \\
\text { do Ensino Médio } \\
\text { (NSE) }\end{array}$ \\
\hline $\begin{array}{l}\text { Proficiência Média em } \\
\text { Matemática dos alunos do 5 }\end{array}$ & Pearson Correlation & 1 &, $723^{* *}$ \\
\hline $\begin{array}{l}\text { Porcentagem de pais com } \\
\text { escolaridade acima do Ensino } \\
\text { Médio (NSE) }\end{array}$ & Sig. (2-tailed) & Searson Correlation &, $723^{* *}$ &, 000 \\
\hline \hline
\end{tabular}

**. A correlação é significativa ao nível 0.01 (2-tailed).

Fonte: Elaborado pela autora. INEP, 2015.

\footnotetext{
${ }^{83}$ Como foi explicado no Capítulo 3, p. 66-67, utilizamos como proxy do NSE a escolaridade média dos pais dos alunos, medida pela porcentagem de pais com escolaridade superior ao Ensino Médio.
} 
Tabela 14: Correlação entre o NSE e a Proficiência Média em Matemática dos alunos do $9^{\circ}$ ano

\begin{tabular}{|c|c|c|c|}
\hline & & $\begin{array}{l}\text { Proficiência Média } \\
\text { em Matemática dos } \\
\text { alunos do } 9^{\circ} \text { ano }\end{array}$ & $\begin{array}{c}\text { Porcentagem de } \\
\text { pais com } \\
\text { escolaridade acima } \\
\text { do Ensino Médio } \\
\text { (NSE) }\end{array}$ \\
\hline \multirow{2}{*}{$\begin{array}{l}\text { Proficiência Média em } \\
\text { Matemática dos alunos do } 9^{\circ} \text { ano }\end{array}$} & Pearson Correlation & 1 &, $540 * *$ \\
\hline & Sig. (2-tailed) & &, 004 \\
\hline \multirow{2}{*}{$\begin{array}{l}\text { Porcentagem de pais com } \\
\text { escolaridade acima do Ensino } \\
\text { Médio (NSE) }\end{array}$} & Pearson Correlation &, $540 * *$ & 1 \\
\hline & Sig. (2-tailed) &, 004 & \\
\hline
\end{tabular}

Gráfico 9: Correlações entre o NSE e a Proficiência Média em Matemática dos alunos do $5^{\circ}$ ano

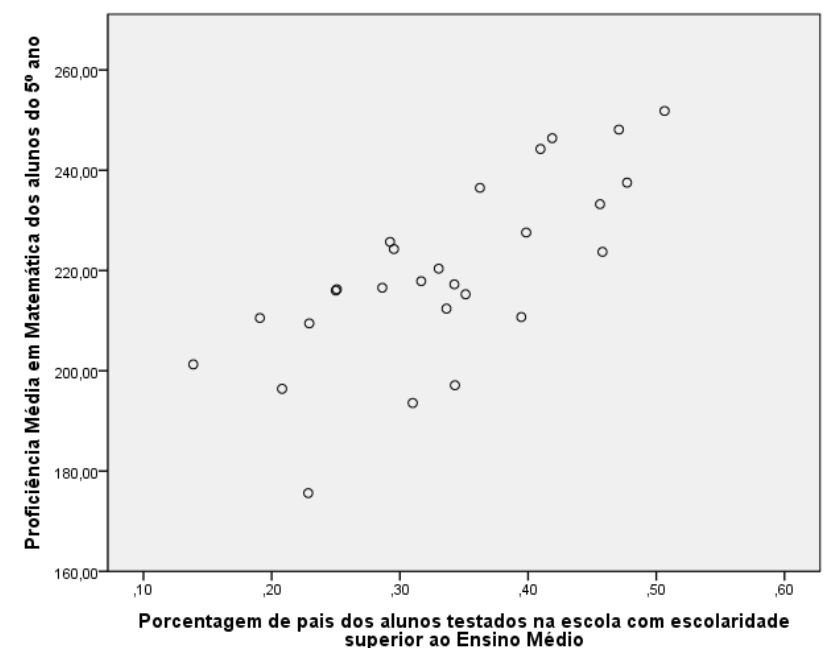

Fonte: Fonte: Elaborado pela autora. INEP, 2015.

Gráfico 10: Correlações entre o NSE e a Proficiência Média em Matemática dos alunos do $9^{\circ}$ ano

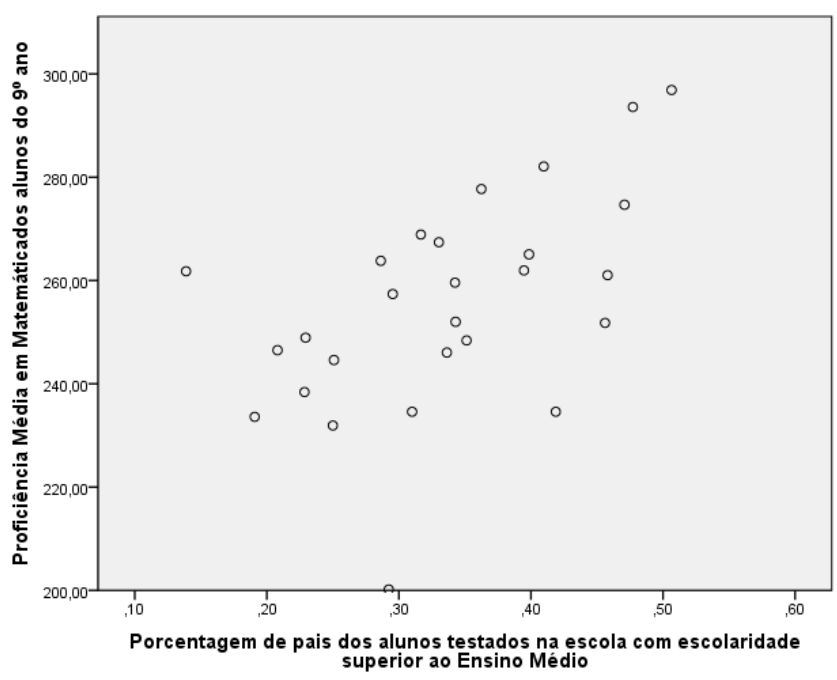

Fonte: Fonte: Elaborado pela autora. INEP, 2015. 
Os altos e significativos coeficientes de correlação apresentados, entre a medida de NSE e os resultados médios dos alunos, foram confirmados na regressão linear simples, quando a variável de controle explicou $52 \%$ da variância nos resultados médios do $5^{\circ}$ ano $\left(R^{2}=0,52\right)$ e $26 \%$ da variância do resultado médio do $9^{\circ}$ ano $\left(R^{2}=0,26\right)$. Há, portanto, uma indicação na amostra estudada de que as características de origem do aluno são mais significativas para explicar as diferenças encontradas nos resultados dos alunos das séries inicias ( $5^{\circ}$ ano).

Entre todas as outras variáveis testadas, nenhuma apresentou uma correlação positiva com o resultado médio dos alunos do $9^{\circ}$ ano, o que pode indicar que as características escolares testadas nesta pesquisa se associam menos aos resultados dos alunos mais velhos. Esta hipótese necessitaria de maiores aprofundamentos. Há que se considerar, também, a possibilidade do tamanho reduzido da amostra não revelar toda a magnitude das relações testadas, como consideramos na apresentação desta seção.

Assim, os modelos apresentados a seguir, consideraram apenas a proficiência média dos alunos do $5^{\circ}$ ano como indicador dos resultados da escola. Foram testadas as correlações desta variável dependente com as variáveis testadas no grupo anterior (Modelos 2 a $4^{84}$ ), no intuito de discutir a relevância do trabalho do diretor para os resultados dos alunos a partir da sua relação com os professores. Acrescentamos um modelo (Modelo 5) estimando a relação entre a satisfação do professor no trabalho e o resultado médio dos alunos, hipótese levantada por esta pesquisa. Todos os modelos de regressão linear consideraram como variável de controle a medida de NSE.

\section{Modelo 2: O Reconhecimento do trabalho da Direção}

Todos os índices associados significativamente com o Índice de Satisfação no Trabalho nas análises do Grupo 1, forma testados em sua correlação com a variável dependente do Grupo2: a proficiência média em Matemática dos alunos do $5^{\circ}$ ano. A seguir, apresentamos os resultados encontrados para o primeiro deles, o Índice de Reconhecimento do Trabalho da Direção:

\footnotetext{
${ }^{84}$ A variável Índice de Interação do Diretor com os professores cuja composição foi apresentada na NR 83 e no Anexo 7, foi excluída da análise neste grupo por apresentar um comportamento instável em relação à variável dependente na estimativa de correlação e na regressão linear.
} 
Tabela 15: Correlação entre a Proficiência Média em Matemática - $5^{\circ}$ ano (variável dependente) e o Índice de Reconhecimento do Trabalho da Direção

\begin{tabular}{llcc}
\hline \hline & & $\begin{array}{c}\text { Proficiência Média } \\
\text { em Matemática dos } \\
\text { alunos do 5 }\end{array}$ & $\begin{array}{c}\text { Indice de } \\
\text { Reconhecimento } \\
\text { do Trabalho da } \\
\text { Direção }\end{array}$ \\
\hline $\begin{array}{l}\text { Proficiência Média em } \\
\text { Matemática dos alunos do 5 } 5^{\text {ano }} \text { ano }\end{array}$ & Pearson Correlation & 1 &, 160 \\
\hline $\begin{array}{l}\text { Índice de Reconhecimento do } \\
\text { Trabalho da Direção }\end{array}$ & Pearson Correlation &, 160 &, 425 \\
\hline \hline & Sig. (2-tailed) &, 425 & 1 \\
\hline \hline
\end{tabular}

Fonte: Elaborado pela autora. INEP, 2015 e Survey GESQ 2014.

Gráfico 11: Correlação entre a Proficiência Média em Matemática - $5^{\circ}$ ano (variável dependente) e o Índice de Reconhecimento do Trabalho da Direção

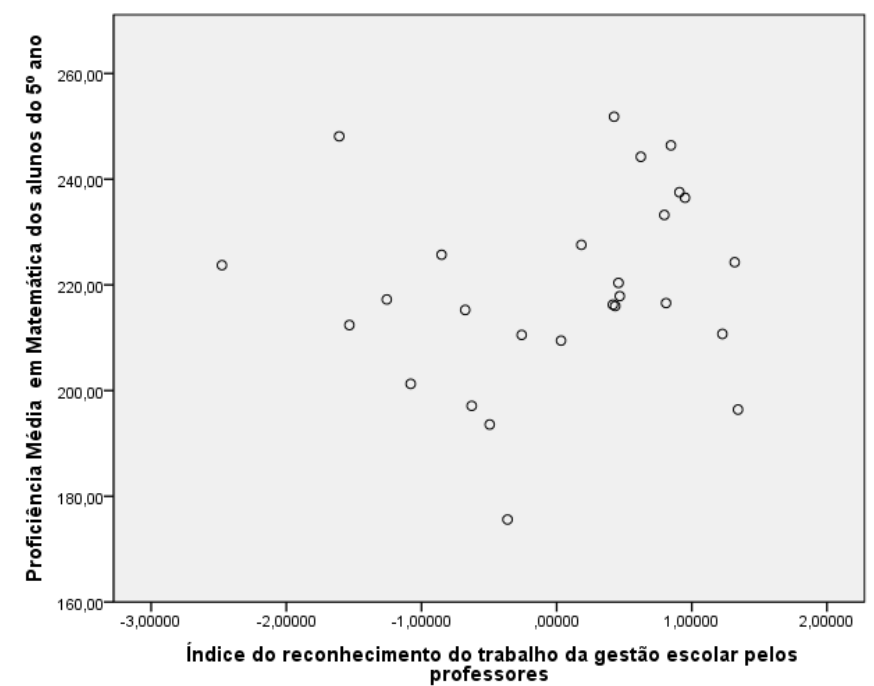

Fonte: Elaborado pela autora. INEP, 2015 e Survey GESQ 2014.

Com base na literatura, podemos considerar a indicação apontada pelos dados de que nas escolas onde os professores reportaram reconhecer o trabalho da direção escolar como um trabalho eficaz, os resultados dos alunos tenderam a ser melhores. Sammons (2008) e Alves e Franco (2008) apontaram a gestão ou liderança escolar como fatores chave para a eficácia escolar. De fato, o trabalho do diretor tem uma relação indireta com o desempenho acadêmico (SAMMONS, 2008) e os resultados deste estudo exploratórios parecem seguir esta premissa. Entretanto, na nossa amostra, observa-se a não significância do coeficiente encontrado, confirmada na regressão linear (a variável acrescenta pouco poder explicativo ao modelo), muito provavelmente em decorrência do tamanho da amostra e da colinearidade das variáveis, discutida anteriormente. 


\section{Modelo 3: A percepção sobre o Ambiente Escolar}

Conforme discutido na apresentação dos modelos do Grupo 1, a definição e a mensuração do conceito clima escolar é um desafio para as pesquisas na área educacional, dada a abrangência de sua interpretação. Entre os índices criados e testados para captar informações sobre este conceito, esta análise estatística continuou considerando o Índice de Percepção do Ambiente Escolar, reportado pelos professores, como indicador do clima escolar. Este índice apresentou uma relação positiva e significativa com o Índice de Satisfação no trabalho reportado pelos professores, sendo o modelo que mais explicou a variância da deste Índice entre as escolas da amostra utilizada. A percepção dos professores sobre o ambiente escolar poderia influenciar, também, os resultados dos alunos? Tentando encontrar indícios desta relação, testamos a correlação entre as variáveis:

Tabela 16: Correlação entre a Proficiência Média em Matemática - $5^{\circ}$ ano (variável dependente) e o Índice de Percepção do Ambiente Escolar

\begin{tabular}{|c|c|c|c|}
\hline & & $\begin{array}{l}\text { Proficiência Média } \\
\text { em Matemática dos } \\
\text { alunos do } 5^{\circ} \text { ano }\end{array}$ & $\begin{array}{c}\text { Índice de } \\
\text { Percepção do } \\
\text { Ambiente Escolar }\end{array}$ \\
\hline Proficiência Média em & Pearson Correlation & 1 &, $558^{* * *}$ \\
\hline Matemática dos alunos do $5^{\circ}$ ano & Sig. (2-tailed) & &, 002 \\
\hline Índice de Percepção do Ambiente & Pearson Correlation &, $558^{* * 3}$ & 1 \\
\hline Escolar & Sig. (2-tailed) &, 002 & \\
\hline
\end{tabular}

Fonte: Elaborado pela autora. INEP, 2015 e Survey GESQ 2014.

Gráfico 12: Correlação entre a Proficiência Média em Matemática - $5^{\circ}$ ano (variável dependente) e o Índice de Percepção do Ambiente Escolar

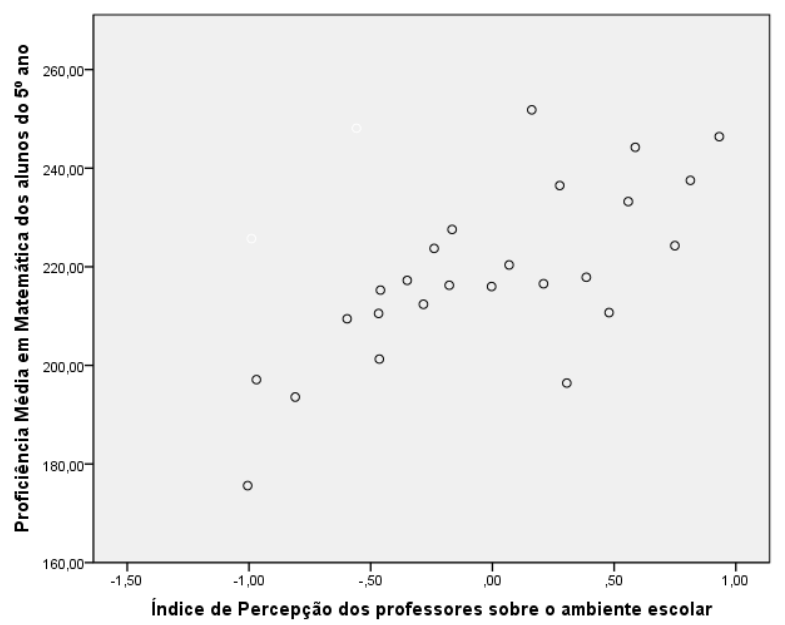

Fonte: Elaborado pela autora. INEP, 2015 e Survey GESQ 2014. 
O coeficientes significativamente positivo bem como o gráfico indicam a associação direta e relevante entre as variáveis, confirmada na regressão linear sendo a variável que mais acrescentou poder explicativo à variável de controle $\left(\mathrm{R}^{2}=0,59\right)$. Podemos inferir da leitura destes dados que as escolas cujos professores reportaram uma percepção mais positiva sobre o ambiente escolar, tenderam a apresentar os melhores resultados médios em matemática dos alunos de $5^{\circ}$ ano. Os itens que compuseram o índice abordavam a percepção dos professores sobre a disciplina e as relações envolvendo os alunos. Compreendemos que em um ambiente onde percebe-se positivamente a disciplina dos alunos e as relações que estes estabelecem com professores e funcionários há um ambiente adequado para a aprendizagem (tranquilo e de colaboração, conforme lembra Sammons, 2008). A associação positiva entre as variáveis reforça a importância da manutenção de um ambiente adequado para a aprendizagem dos alunos. Conforme lembram Brito e Costa (2010), a ideia de que a "atmosfera" ou o ambiente circundante percebido pelos indivíduos na escola exerce significativa influência sobre o comportamento e a qualidade do trabalho desenvolvido é um consenso nos estudos neste campo. Em pesquisa sobre a percepção dos professores acerca do prestígio e do clima escolar em escolas públicas do Rio de Janeiro, os autores apontam que

\begin{abstract}
A literatura sobre clima escolar tem destacado a figura do gestor como um agente crucial na promoção de um clima favorável nas escolas, e os relatos dos professores colaboram para evidenciar a influência da gestão na construção desse bom clima de trabalho. Aspectos como gestão democrática, mobilização comunitária e fortalecimento da equipe parecem contribuir para promover o maior envolvimento dos professores nas atividades escolares, favorecendo o aprendizado escolar dos alunos (BRITO e COSTA, 2010, p. 506).
\end{abstract}

Os dados apresentados neste modelo parecem corroborar a importância da relação destacada pelos autores, ainda que o papel do diretor na manutenção deste ambiente mereça ser mais explorado.

\title{
Modelos 4: A intervenção pedagógica do Diretor
}

Assim como na análise do Grupo 1, discutiremos o modelo estimado com o índice criado para sintetizar a percepção dos professores sobre o trabalho do diretor no que se refere a suas intervenções pedagógicas. Como vimos, o índice apresentou uma associação significativa negativa com o Índice de Satisfação no Trabalho. Testamos, então, como o mesmo índice se comporta na relação com os resultados dos alunos das escolas pesquisadas. A correlação entre eles está expressa na tabela e gráfico que se seguem: 
Tabela 17: Correlação entre a Proficiência Média em Matemática - $5^{\circ}$ ano (variável dependente) e o Índice de Intervenção Pedagógica do Diretor

\begin{tabular}{llcc}
\hline \hline & \multicolumn{1}{c}{$\begin{array}{c}\text { Proficiência } \\
\text { Média em } \\
\text { Matemática dos } \\
\text { alunos do } 5^{\circ} \text { ano }\end{array}$} & $\begin{array}{c}\text { Índice de } \\
\text { Intervenção } \\
\text { Pedagógica do } \\
\text { Diretor }\end{array}$ \\
\hline $\begin{array}{l}\text { Proficiência Média em Matemática } \\
\text { dos alunos do 5 }{ }^{\circ} \text { ano }\end{array}$ & Pearson Correlation & 1 &, 171 \\
& Sig. (2-tailed) &, 394 \\
\hline $\begin{array}{l}\text { Índice de Intervenção Pedagógica } \\
\text { do Diretor }\end{array}$ & Pearson Correlation &, 171 & 1 \\
& Sig. (2-tailed) &, 394 & \\
\hline & Fonte: Elaborado pela autora. INEP, 2015 e Survey GESQ 2014.
\end{tabular}

Gráficos 13: Correlação entre a Proficiência Média em Matemática - $5^{\circ}$ ano (variável dependente) e o Índice de Intervenção Pedagógica do Diretor

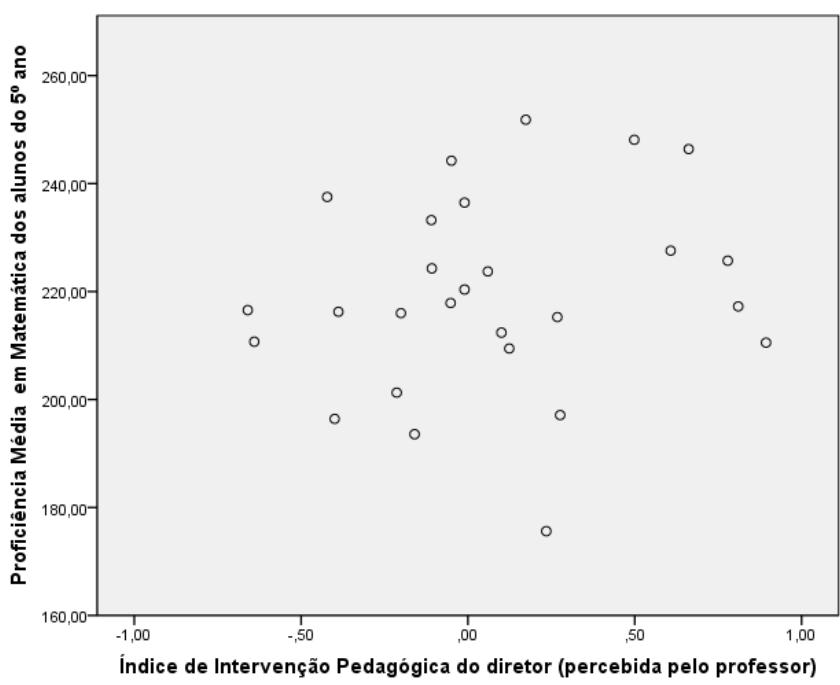

Fonte: Elaborado pela autora. INEP, 2015 e Survey GESQ 2014.

Apesar da correlação não significativa com a variável dependente, é importante observar que a relação do Índice de Intervenção Pedagógica do Diretor assume uma direção positiva. No modelo de regressão linear estimado o índice não acrescenta valor explicativo à variável de controle, demonstrando uma associação de pequena magnitude com a variável dependente. Mais uma vez, cabe ressaltar o caráter exploratório desta análise, onde o tamanho da amostra limita as inferências estatísticas. A título de exploração na leitura dos dados, com base na literatura sobre o tema, poderíamos considerar que nas escolas onde os professores identificam uma maior atuação pedagógica dos diretores, os resultados dos alunos são melhores. Ainda que sem significância estatística, esta relação nos remete aos estudos que consideraram a relevância do foco do trabalho do diretor na aprendizagem. Leithwood aponta que, 
enquanto no passado se os líderes educativos eram valorizados por uma gestão técnica eficiente das escolas ou dos sistemas, atualmente se espera que os líderes escolares privilegiem os processos de ensino e aprendizagem: “[...] que os líderes dirijam sua atenção a assegurar que todos os componentes e ações dentro do sistema educacional apoiem a aprendizagem dos estudantes" (LEITHWOOD, 2009, p.19, minha tradução). Elfers e Stritikus (2014), por sua vez, consideram que uma liderança escolar focada na aprendizagem "implica uma visão ampla abrangendo toda a gama de atividades escolares entre os diferentes níveis do sistema, [...] oferecendo aos professores em sala de aula ideias, orientações ou apoio especificamente dirigido a instrução" (op. cit., p. 309, minha tradução).

O índice criado a partir das respostas dos professores para medir esse conceito aponta algumas possíveis intervenções pedagógicas do diretor, sem contudo esgotar o tema, que merece ser aprofundado (na relação com o nível de satisfação docente no trabalho e com os resultados dos alunos) em pesquisas futuras.

\section{Modelos 5: A Satisfação do professor no trabalho}

Considerando a decisão de usar o Índice de Satisfação do professor no Trabalho como indicativo de seu compromisso com o trabalho desenvolvido na escola, analisamos a correlação deste índice com a variável dependente Proficiência média em Matemática dos alunos do $5^{\circ}$ ano. Nossa intenção foi testar a hipótese levantada inicialmente de que escolas com professores mais satisfeitos tendem a apresentar melhores resultados de seus alunos, partindo do pressuposto de que professores satisfeitos com o trabalho são mais comprometidos com sua função. A tabela e o gráfico a seguir apresentam os resultados encontrados:

Tabela 18: Correlação entre a Proficiência Média em Matemática - $5^{\circ}$ ano (variável dependente) e o Índice de Satisfação no Trabalho

\begin{tabular}{|c|c|c|c|}
\hline & & $\begin{array}{c}\text { Proficiência } \\
\text { Média em } \\
\text { Matemática dos } \\
\text { alunos do } 5^{\circ} \text { ano }\end{array}$ & $\begin{array}{c}\text { Índice de } \\
\text { Satisfação no } \\
\text { Trabalho }\end{array}$ \\
\hline \multirow{2}{*}{$\begin{array}{l}\text { Proficiência Média em Matemática } \\
\text { dos alunos do } 5^{\circ} \text { ano }\end{array}$} & Pearson Correlation & 1 & ,300* \\
\hline & Sig. (2-tailed) & &, 028 \\
\hline \multirow[t]{2}{*}{ Índice de Satisfação no Trabalho } & Pearson Correlation & ,300* & 1 \\
\hline & Sig. (2-tailed) &, 028 & \\
\hline
\end{tabular}




\section{Gráfico 14: Correlação entre a Proficiência Média em Matemática - $5^{\circ}$ ano (variável} dependente) e o Índice de Satisfação no Trabalho

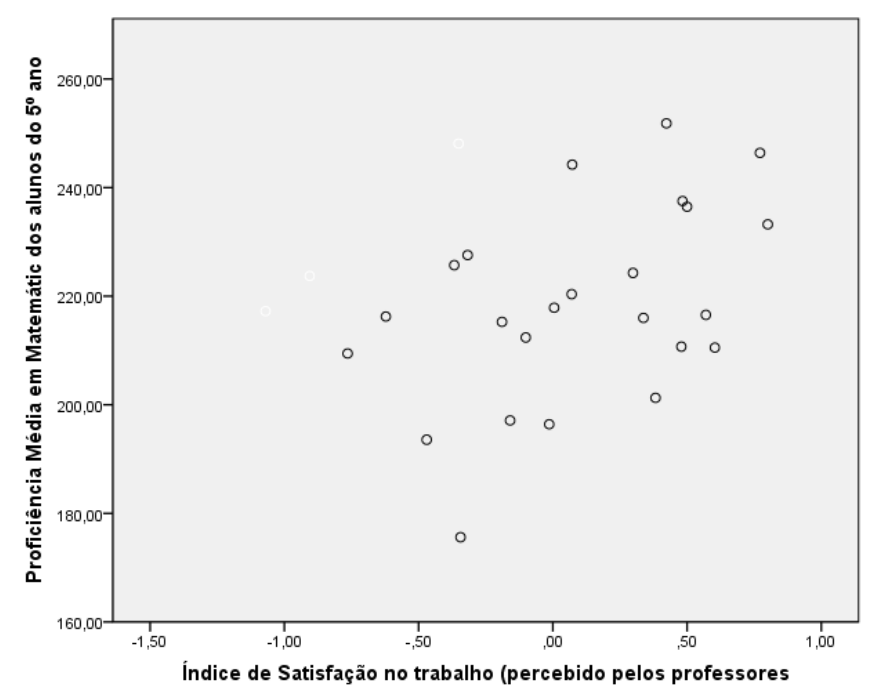

Fonte: Elaborado pela autora. INEP, 2015 e Survey GESQ 2014.

A correlação significativamente positiva, expressa também na direção do gráfico, auxilia a sustentação da hipótese de que nas escolas onde os professores se encontram mais satisfeitos, os alunos apresentam melhores resultados. Devemos considerar também a relação refletida entre as variáveis, isto é, o coeficiente de correlação pode ser interpretado no sentido de que os professores são mais satisfeitos nas escolas que alcançam melhores resultados nas avaliações externas (esta relação foi inclusive testada na definição da variável de controle para os modelos do primeiro grupo de análise). Como nossa intenção neste momento era levantar possíveis associações entre as variáveis relacionadas ao desempenho médio dos alunos nas escolas pesquisadas, estimamos um modelo de regressão linear, tendo esta medida como variável dependente e o indicativo de NSE médio da escola como variável de controle. Os resultados encontrados confirmaram esta associação significativamente positiva, aumentando o poder de explicação do modelo para $56 \%\left(R^{2}=0,56\right)$.

Poucos estudos se dedicaram a analisar o nível de estabilidade e satisfação no trabalho do professor como preditores de uma melhor aprendizagem dos alunos. Destacamos algumas pesquisas internacionais já citadas, como o trabalho de Hulpia et al. (2011), que analisam quais são as características do diretor que mais influenciam o "comprometimento organizacional dos professores"; Thoonem et al. (2011) que estudaram o efeito das condições organizacionais da escola e de fatores motivacionais nas práticas dos professores; o trabalho de Price (2011), comentado no início desta seção, também analisa as relações organizacionais na escola e como elas se manifestam em diferentes níveis de satisfação, coesão e comprometimento entre diretores e professores.

Esta pesquisa pretende ampliar a discussão sobre este tema a nível nacional. Os instrumentos de pesquisa propostos buscaram mensurar aspectos que poderiam estar 
relacionados à Satisfação do professor em trabalhar na sua escola. A análise exploratória dos dados, indicou uma possível associação desta dimensão com fatores relacionados à gestão da escola. E, mais ainda, apontou uma relação significativa entre o Índice de Satisfação no Trabalho e os resultados dos alunos. Talvez esteja aí também uma indicação sobre como o diretor pode influenciar a variância nos resultados dos alunos.

\section{Modelo Final}

Após analisar as relações individuais de cada índice com a variável dependente, controlados pela variável indicativa do NSE médio da escola, tentamos também estimar um modelo que incluísse todas as cinco variáveis testadas em relação à variável dependente. Assim como na modelagem do Grupo 1, o procedimento utilizado foi o stepwise, no SPSS. Da mesma forma, o modelo final manteve apenas uma das variáveis apresentando uma relação significativa com a variável dependente: novamente, foi o Índice de Percepção sobre o Ambiente Escolar (pelos professores). Os coeficientes do Modelo final são, assim, iguais ao do Modelo 3 deste grupo.

Considerando a colinearidade entre as variáveis, anteriormente discutida, e o tamanho da amostra como limitações técnicas para uma análise dos efeitos simultâneos dos índices, consideraremos provisoriamente suas associações individuais. O Modelo Final apresenta a variável Índice de Percepção sobre o Ambiente Escolar como a que melhor se ajustou ao modelo, ampliando seu poder explicativo para a variância no resultado médio das escolas pesquisadas.

Encerrando as análises neste grupo, apresentamos a seguir as estatísticas descritivas das variáveis e a síntese dos modelos estimados.

Quadro 20: Estatística Descritiva das Variáveis incluídas nos Modelos do Grupo 2

\begin{tabular}{|l|r|r|r|r|}
\hline \multicolumn{1}{|c|}{ Variáveis } & Mínimo & Máximo & Média & Desvio Padrão \\
\hline DEPENDENTE & \multicolumn{5}{|l|}{} \\
\hline Proficiência Média em Matemática $-5^{\circ}$ ano & 175,60 & 251,83 & 219,47 & 18,06 \\
\hline INDEPENDENTES & \multicolumn{5}{|l|}{} \\
\hline $\begin{array}{l}\text { NSE (Porcentagem de pais de alunos com } \\
\text { escolaridade acima de Ensino Médio) }\end{array}$ & $-2,05$ & 1,79 & 0,0 & 1,0 \\
\hline $\begin{array}{l}\text { Índice do reconhecimento do trabalho da } \\
\text { gestão escolar pelos professores* }\end{array}$ & $-2,48$ & 1,34 & 0,0 & 1,0 \\
\hline $\begin{array}{l}\text { Indice de Percepção do Ambiente } \\
\text { Escolar* }\end{array}$ & $-1,63$ & 1,77 & 0,0 & 1,0 \\
\hline $\begin{array}{l}\text { Índice de Intervenção Pedagógica do } \\
\text { Diretor* }\end{array}$ & $-1,73$ & 1,92 & 0,0 & 1,0 \\
\hline Índice de Satisfação no Trabalho* & $-2,09$ & 1,55 & 0,0 & \\
\hline
\end{tabular}

*. Os índices foram padronizados para entrar nos modelos de regressão. Fonte: Elaborado pela autora, com dados da Prova Brasil 2013 e do Survey GESQ 2014. 
Tabela 19: Síntese dos coeficientes dos modelos do Grupo 2

\begin{tabular}{|c|c|c|c|c|c|c|}
\hline & Modelo 1 & Modelo 2 & Modelo 3 & Modelo 4 & Modelo 5 & $\begin{array}{c}\text { Modelo } \\
\text { Final }\end{array}$ \\
\hline Constante & $219,47 * *$ & $219,47 * *$ & $219,47 * *$ & $219,47 * *$ & $219,47 * *$ & $219,47^{* * *}$ \\
\hline $\begin{array}{l}\text { Porcentagem de Pais de } \\
\text { alunos com escolaridade } \\
\text { acima do Ensino Médio }\end{array}$ & $13,2 * *$ & $13,3 * *$ & $10,9 * *$ & $13,1 * *$ & $12,8 * *$ & $10,9 * *$ \\
\hline $\begin{array}{l}\text { Índice do } \\
\text { reconhecimento do } \\
\text { trabalho da direção }\end{array}$ & & 3,08 & & & & \\
\hline $\begin{array}{l}\text { Índice de Percepção do } \\
\text { Ambiente Escolar }\end{array}$ & & & $5,8^{*}$ & & & $5,8^{*}$ \\
\hline $\begin{array}{l}\text { Índice de Intervenção } \\
\text { Pedagógica do Diretor }\end{array}$ & & & & $2,11^{*}$ & & \\
\hline $\begin{array}{l}\text { Índice de Satisfação no } \\
\text { trabalho }\end{array}$ & & & & & $4,2^{*}$ & \\
\hline $\mathrm{R}^{2}$ Ajustado & 0,52 & 0,53 & 0,59 & 0,52 & 0,56 & 0,59 \\
\hline
\end{tabular}

Fonte: Elaborado pela autora, com dados da Prova Brasil 2013 e do Survey GESQ 2014.

A análise estatística exploratória, utilizando os dados da subamostra desta pesquisa, indicaram importantes indicativos no que se refere aos fatores associados à satisfação dos professores na escola e aos resultados dos alunos. Os resultados desta análise, ainda que tímidos do ponto de vista da abrangência, confirmam o trabalho docente e a gestão escolar como fatores associados ao desempenho dos alunos (SAMMONS, 2008; ALVES e FRANCO, 2008). No que se refere ao trabalho da gestão escolar, encontramos resultados distintos do Índice de Intervenção Pedagógica do Diretor nos dois modelos: associa-se de forma negativa inversa com o Índice de Satisfação do Professor no Trabalho mas associa-se de forma positiva direta com a Proficiência Média em Matemática na escola. Uma leitura possível para este resultado seria a de que, apesar de ter um impacto negativo para a satisfação dos professores no trabalho (conforme hipóteses já apresentadas), a intervenção pedagógica do diretor pode ter um efeito positivo para os resultados de aprendizagem dos alunos (conforme medidos neste estudo exploratório).

Destaca-se, nos modelos finais estimados, a importância da variável usada para sintetizar a percepção dos professores sobre o ambiente escolar ${ }^{85}$, que melhora significativamente o poder explicativo para a variância das duas variáveis dependentes

\footnotetext{
${ }^{85}$ É importante ressaltar que o índice criado não agrega nenhuma variável referente à infraestrutura da escola, dimensão não analisada por esta pesquisa.
} 
(Satisfação do Professor no Trabalho e Proficiência média em Matemática $-5^{\circ}$ ano). Sobretudo, destaca-se que a entrada deste índice no modelo reduz o coeficiente da associação entre o NSE médio das escolas e os resultados dos alunos. Observando a tabela, nota-se que a variável indicativa do NSE médio da escola explicava, sozinha, 52\% da variância dos resultados das escolas na Proficiência em Matemática do $5^{\circ}$ ano (Modelo1). O modelo que agrega a variável sobre a Percepção do Ambiente Escolar (reportada pelos professores) aumenta o poder de explicação desta variável para 59\%, diminuindo o coeficiente de regressão da variável NSE de 13,2 para 10,9. Isto significa que, o incremento de um desvio padrão na variável de NSE resulta no aumento de 13,2 pontos na média de Proficiência em Matemática - $5^{\circ}$ ano da escola. Mas, quando analisado em conjunto com o Índice de Percepção do Ambiente Escolar, esta relação muda: o incremento de um desvio padrão na variável de NSE resulta no aumento de 10,9 pontos na média de Proficiência em Matemática - $5^{\circ}$ ano da escola e o incremento de 1 desvio padrão no Índice de Percepção do Ambiente Escola resulta no aumento de 5,8 pontos na mesma variável. Poderíamos, assim, explorar a hipótese de que em escolas onde os professores reportam percepções mais positivas sobre o ambiente escolar, os resultados dos alunos tendem a ser melhores independente de sua origem socioeconômica. Torna-se importante aprofundar esta análise e pensar em alternativas de intervenções produtivas no sentido de criar, nas escolas públicas brasileiras, ambientes mais propícios ao trabalho docente e à aprendizagem dos alunos.

Sendo adotado por esta pesquisa como uma dimensão do clima escolar, o ambiente de aprendizagem (medido pelo índice em foco) merece atenção cuidadosa. Como vimos, este índice esteve correlacionado com outros índices que abrangiam aspectos ligados à gestão e liderança do diretor, indicando que a manutenção de um ambiente apropriado à aprendizagem deve estar entre as prioridades do diretor escolar. Com efeito, o estudo de Urick e Bowers (2014) já apontava esta prioridade: "Nos estudos mais recentes, os comportamentos de liderança que contribuem para a criação de um bom clima escolar foram identificados como tendo maior influência nos resultados de professores e alunos em comparação com as tarefas administrativas e gerenciais" (URICK \&BOWERS, 2014, p.98, minha tradução)

Ainda que reportem uma análise realizada a partir de uma amostra reduzida, os dados apresentados neste capítulo apontam importantes indícios para pensarmos sobre as questões levantadas nesta pesquisa. Vários estudos (SAMMONS, 2008; ALVES \& FRANCO, 2008, TORRECILLA, 2008, LEITHWOOD, 2009; SOARES e TEIXEIRA, 2006; entre outros) têm apontado o efeito indireto da gestão escolar para a aprendizagem dos alunos e, como procuramos discutir neste trabalho, esse efeito passa pela relação que o diretor estabelece com os professores. Os dados apresentados indicam pistas sobre a 
direção desta relação, sobretudo ressaltando a importância da manutenção de um ambiente adequado para as atividades escolares. A aplicação dos instrumentos criados e testados nesta pesquisa a amostras mais abrangentes possibilitará uma análise mais consistente das relações encontradas, além de outras associações com os índices e itens não abordados nesta pesquisa.

O capítulo que se segue narra um retorno qualitativo ao campo, com vistas a aprofundar as análises possibilitadas pelo estudo quantitativo e identificar possíveis adequações para aprimorar os questionários. 


\section{7 \\ De volta ao campo: aprofundando a análise}

Esta pesquisa propôs investigar que relações podem ser estabelecidas entre as características do trabalho do diretor, as percepções dos professores sobre o clima escolar e o desempenho dos alunos. Após a aplicação de questionários especialmente desenhados e testados para esse fim, a análise dos resultados do survey trouxe algumas indicações importantes sobre fatores da gestão escolar que podem estar associados à satisfação do professor e/ou aos resultados de aprendizagem dos alunos na amostra estudada. Novas questões se colocaram a partir desta análise: Como o reconhecimento de um ambiente adequado ao trabalho do professor e à aprendizagem dos alunos se constrói na escola? Quais características do trabalho do diretor são reconhecidas pelos professores como eficazes? Como o perfil de liderança adotado na escola se associa à satisfação dos professores no trabalho e aos resultados de aprendizagem dos alunos? Como poderíamos aprimorar os itens dos questionários para ampliar a compreensão sobre a liderança do diretor e suas relações com o trabalho docente?

Com a intenção de validar e aprofundar a análise sobre as questões levantadas pela pesquisa e de possibilitar o aprimoramento dos questionários criados, reforçando o caráter conceitual e metodológico deste trabalho, optamos por um retorno pontual ao campo para um estudo qualitativo exploratório complementar. Este capítulo apresenta os resultados deste estudo, iniciando pela apresentação dos critérios considerados para a escolha das escolas a serem pesquisadas.

Considerando os resultados do survey, selecionamos duas escolas em nossa subamostra para realizar este estudo. Para esta seleção desconsideramos as escolas em que houve mudança na equipe de direção a partir de 2015 (como foi apresentado anteriormente, um novo período de gestão se iniciava em 2015: em 11 das 27 escolas houve mudança de diretores). A partir das informações coletadas no Survey GESQ 2014 e das informações sociodemográficas disponibilizadas pela Prova Brasil $2011^{86}$, organizamos em gráficos os dados referentes às escolas da subamostra para orientar a nossa seleção:

\footnotetext{
${ }^{86}$ A seleção das escolas para o estudo qualitativo foi realizada em março de 2014, quando ainda não haviam sido disponibilizados os dados da Prova Brasil 2013 (o que só aconteceu, em sua versão definitiva, em maio de 2015). Assim, tomamos como referência para esta seleção os dados disponibilizados pela Prova Brasil 2011.
} 


\section{Gráfico 15: Proficiência Média em Matemática ( $5^{\circ}$ ano) X NSE: Subamostra}

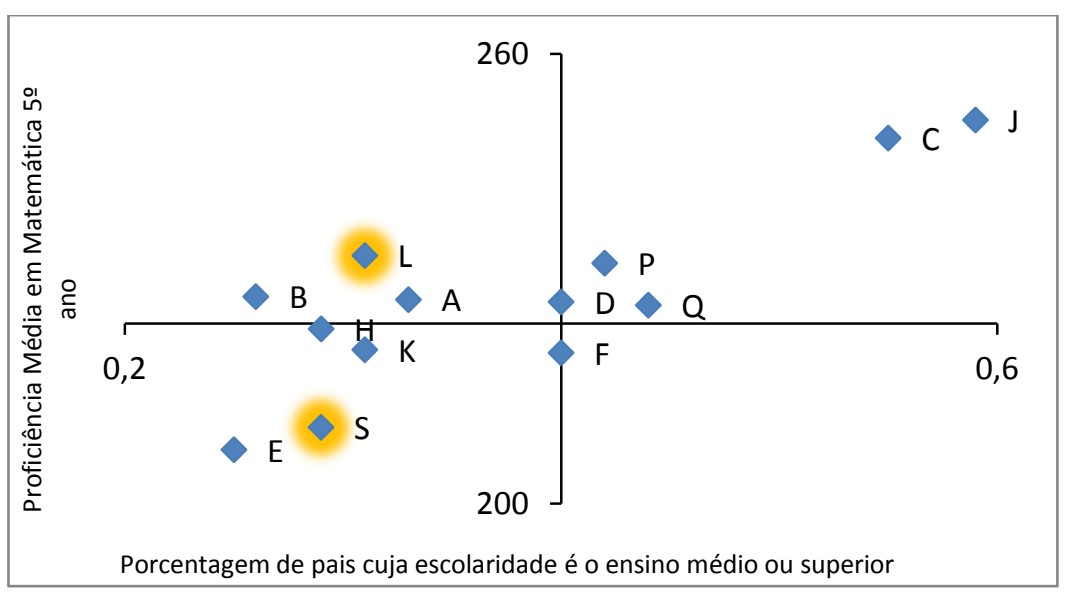

Fonte: Elaborado pela autora. INEP, 2012.

O gráfico acima apresenta o nível socioeconômico médio das escolas (medido pela escolaridade dos pais, como foi apresentado anteriormente) e o desempenho médio dos alunos do $5^{\circ}$ ano em matemática ${ }^{87}$ (proficiência média por escola). Nota-se a tendência, já discutida extensamente na literatura da sociologia da educação e confirmada na análise estatística desta pesquisa, da presença de melhores resultados de aprendizagem em escolas que apresentam um NSE mais elevado. Contudo, destacamos as escolas B, A e L que, apesar de estarem no quadrante das escolas com NSE mais baixo, apresentaram um resultado de proficiência em matemática acima da média do grupo analisado $(224,0)$.

Para a nossa escolha, resolvemos "isolar" esta característica sociodemográfica das escolas, optando por escolher escolas entre aquelas que apresentavam um NSE abaixo da média do grupo (quadrantes à esquerda do gráfico). Entre elas, selecionamos duas que apresentaram resultados discrepantes em termos da proficiência dos alunos do $5^{\circ}$ ano em Matemática, dos alunos, ou seja, uma estava no quadrante superior (resultado de aprendizagem acima da média) e outra no quadrante inferior do gráfico (resultado de aprendizagem abaixo da média). Entre todas as possibilidades, optamos pelas escolas L e S, que apresentavam medidas de NSE próximas (0,31 e 0,29 respectivamente) e medidas de proficiência média em matemática distantes $(233,09 \text { e } 210,18)^{88}$. Esta escolha também levou em consideração o Índice de Reconhecimento do Trabalho da Direção e o Índice de Interação do Diretor, como mostram os gráficos a seguir.

\footnotetext{
${ }^{87}$ Consideramos nesta análise somente os resultados do $5^{\circ}$ ano, uma vez que a Proficiência Média em Matemática do $9^{\circ}$ ano não apresentou associação significativa com os índices (Cf. Capítulo 6). ${ }^{88}$ Nossa primeira opção foi pelas escolas L e K. Contudo, a escola K está localizada em uma favela que tem apresentado persistente resistência à instalação da Unidade de Polícia Pacificadora - UPP, sendo local onde ocorrem vários conflitos que resultam frequentemente no fechamento da escola. As visitas realizadas para o survey precisaram ser reagendadas mais de uma vez por esse motivo e o acesso à escola é complicado (via de mão dupla muito estreita que dá acesso à favela). Portanto, pareceu sensato optar por outra escola do mesmo grupo.
} 


\section{Gráfico 16: Proficiência Média em Matemática $\left(5^{\circ}\right.$ ano $) X$ Índice de Reconhecimento} do trabalho da Direção: Subamostra

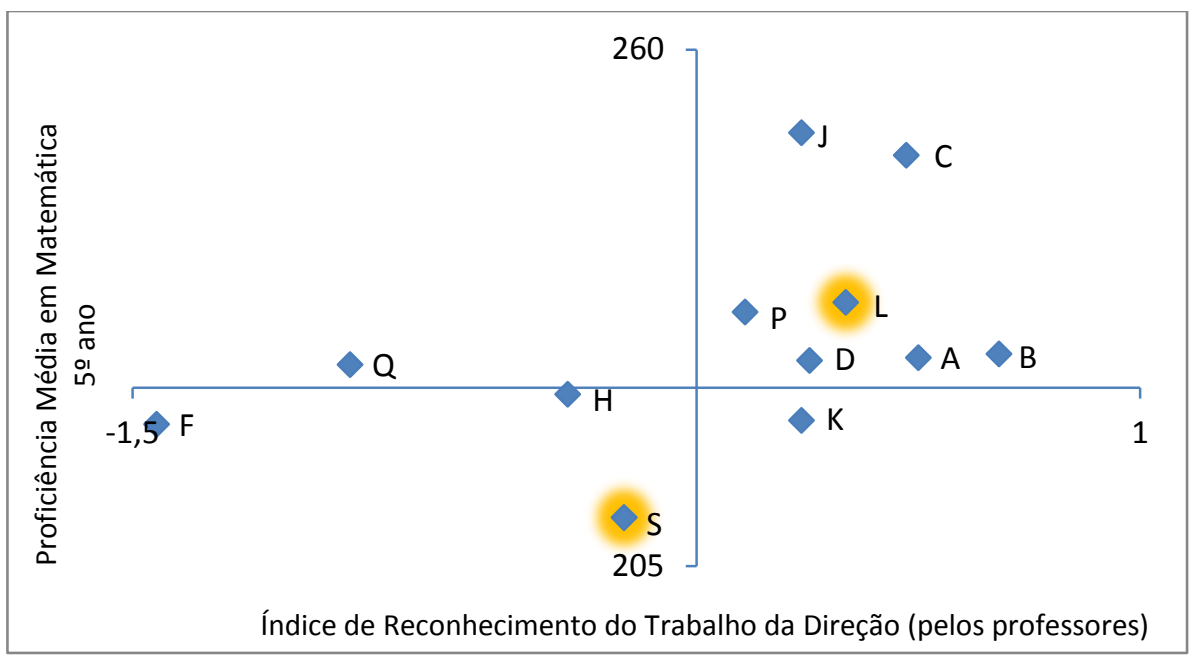

Fonte: Elaborado pela autora. INEP, 2012 e Survey GESQ 2014.

Uma das relações destacadas na análise dos resultados do Survey GESQ 2014 por esta pesquisa foi a relação entre a percepção dos professores sobre o trabalho da direção e a proficiência média em matemática dos alunos do $5^{\circ}$ ano medida pela Prova Brasil $2011^{89}$. De acordo com os resultados, nas escolas em que os professores apresentavam uma melhor percepção sobre o trabalho da equipe de gestão da escola (expressa em valores mais positivos do índice) os resultados de proficiência em matemática dos alunos eram melhores. Esta relação fica aparente no gráfico acima, no qual se nota que as escolas selecionadas ( L e S) estão em quadrantes opostos. Na escola L há uma percepção positiva dos professores a respeito do trabalho de gestão da escola e os alunos apresentaram um resultado acima da média do grupo no teste de matemática para o $5^{\circ}$ ano. Já na escola $\mathrm{S}, \mathrm{o}$ índice de reconhecimento da liderança pelos professores teve um resultado negativo (0,28 ) e os alunos do $5^{\circ}$ ano apresentaram pior resultado na proficiência em matemática. Acreditamos que essa diferença poderia nos possibilitar aprofundar as duas dimensões analisadas: como os professores percebem o trabalho da equipe de direção nas escolas? Como esta percepção pode estar interferindo no resultado de aprendizagem dos alunos?

$\mathrm{O}$ aspecto mais significativamente associado ao nível de satisfação dos professores foi o índice que sintetizava a percepção docente sobre o ambiente escolar. O gráfico a seguir ilustra a relação entre essas variáveis percebidas nas escolas da subamostra:

\footnotetext{
${ }^{89}$ As análises estatísticas apresentadas no Capítulo 6 foram atualizadas com os dados da Prova Brasil 2013 (INEP, 2015).
} 
Gráfico 17: Índice de Satisfação no Trabalho (professores) X Índice de Percepção do Ambiente Escolar: Subamostra

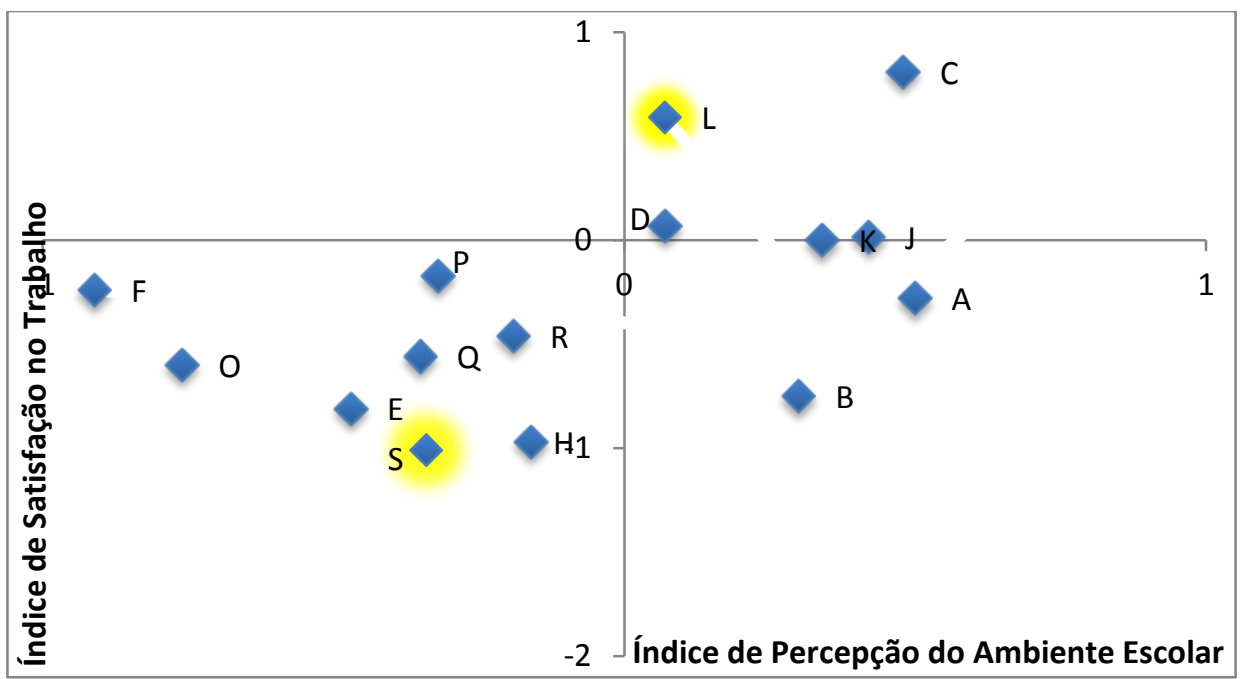

Fonte: Survey GESQ 2014.

$\mathrm{Na}$ escola L, os professores reportaram estar mais satisfeitos com seu trabalho do que na escola $\mathrm{S}$, assim como apresentaram uma percepção mais positiva do ambiente escolar. Um retorno à estas duas escolas poderia nos ajudar a compreender como os professores reportam sua satisfação no trabalho e como constroem a percepção sobre seu ambiente de trabalho. No questionário proposto, os itens que abordavam o primeiro índice se referiram ao desejo de continuar na escola, à satisfação na carreira como um todo, ao engajamento no trabalho, entre outros. O segundo índice sintetizou a percepção dos professores sobre a disciplina e as relações interpessoais de seus alunos. Estes fatores, expressos positivamente em uma escola e negativamente em outra, teriam relação com que aspectos da gestão escolar? Examinar esta questão nos possibilitaria entender melhor esta relação e refinar nossas medidas para estas duas dimensões (satisfação no trabalho e ambiente escolar).

Assim, tendo escolhido as duas escolas e conhecendo suas características sociodemográficas (NSE), seus resultados de aprendizagem e como os índices criados no survey se comportavam nestes espaços, planejamos o retorno ao campo para uma análise qualitativa dos dados coletados.

Para realizar o trabalho, utilizamos três procedimentos metodológicos: entrevistas com professores (5 a 6 professores em cada escola) e diretores; a técnica de shadowing quando um ou mais pesquisadores ficam na escola durante todo o período escolar, acompanhando o trabalho do diretor para identificar possíveis tendências, predominâncias, comportamentos (para mais detalhes, ver SPILLANE et al, 2011; TEROSKI, 2014); a observação de pelo menos uma reunião coletiva entre a equipe de gestão da escola e os 
professores $^{90}$. A proposta tem como principal objetivo, aprofundar e refinar as respostas obtidas no levantamento de dados quantitativos, possibilitando o adensamento de sua interpretação, além de oferecer insumos para uma revisão inicial e aprimoramento dos questionários construídos. Como apontam M. Alves et al. (2013): “O estudo qualitativo permitirá, assim, compreender melhor o sentido das diferentes respostas, analisar as configurações específicas e aproximar-nos do sentido das ações detectadas, neste tratamento estatístico, de modo agregado". O trabalho a ser narrado nas seções que seguem envolveu entrevistas semiestruturadas (Escola L: 1 diretor e 5 professores. Escola S: 1 diretor - junto de sua adjunta - e 6 professores); a observação de uma reunião coletiva (Centro de Estudos) em cada unidade; o acompanhamento ao trabalho do diretor (3 dias de shadowing em cada escola).

\section{1}

\section{As escolas L e S}

As duas escolas se localizam na zona norte da cidade, porém estão distantes uma da outra, pertencendo à diferentes CREs. A escola L se localiza em um bairro de classe média, populoso e movimentado que se localiza entre importantes complexos de favelas (algumas das quais ainda em processo de implementação da Unidade de Polícia Pacificadora - UPP ${ }^{91}$ ), onde moram a grande maioria dos alunos. Como considerou um professor da escola, "a clientela daqui vem de três comunidades muito difíceis, que estão passando por problemas muito difíceis"; "o entorno, essas três comunidades são difíceis de trabalhar. Então, tem tudo pro trabalho dar errado, mas a gente faz tudo pro trabalho dar certo." (Trechos da Entrevista com o Professor 3, Escola L). Na escola L, 50\% dos alunos são beneficiados pelo Programa Bolsa Família ${ }^{92}$. A escola L atende, em 2015, 1215 alunos, distribuídos em 2 turmas de educação infantil, 15 turmas dos anos iniciais e 16 turmas dos anos finais do ensino fundamental, além de 1 turma do Projeto Acelera e 1 turma de Inclusão (recursos). Trabalham na escola 47 professores e 10 funcionários. A

\footnotetext{
${ }^{90}$ Os chamados Centros de Estudo voltaram ao calendário de planejamento da SME/RJ, porém as reuniões agora são bimestrais.

${ }^{91}$ Dos 6.3 milhões de cariocas, 1,4 milhões vivem em favelas - ou seja: um de cada cinco habitantes da cidade. Segundo o censo 2010 do Instituto Brasileiro de Geografia e Estatística (IBGE), o município do Rio tem 763 favelas. Desde 2008, 38 Unidades de Polícia Pacificadora (UPPs) foram instaladas. Cada uma delas atende entre uma e vinte favelas. O número efetivo de policiais nas UPPs também varia.

${ }_{92}$ De acordo com o Ministério de Desenvolvimento Social, “o Bolsa Família é um programa de transferência direta de renda que beneficia famílias em situação de pobreza e de extrema pobreza em todo o país. O Bolsa Família integra o Plano Brasil Sem Miséria, que tem como foco de atuação os milhões de brasileiros com renda familiar per capita inferior a $\mathrm{R} \$ 77$ mensais e está baseado na garantia de renda, inclusão produtiva e no acesso aos serviços públicos" (Fonte: http://www.mds.gov.br ).
} 
diretora está no cargo há 28 anos, ainda que a sua equipe (adjunta e coordenadora pedagógica) tenha sido alterada ao longo dos últimos anos.

A escola $\mathrm{S}$ localiza-se em um bairro tradicional, com maior desigualdade socioeconômica do que o anterior, que além de abrigar residências e infraestrutura de classe média a classe média alta, compreende importantes favelas pacificadas, cujas crianças compõem o público discente da escola. O perfil do alunado é caracterizado pelos professores a partir de seu pertencimento às comunidades do entorno e ao processo de implantação da UPP nestes espaços:

Eles veem basicamente destas duas comunidades. E aí quando a UPP entrou, essa postura mudou. Mudou muito. Eles vinham muito mais calmos, eles passaram a frequentar mais a escola... E agora, de uns tempos pra cá, eu tenho sentido de novo que eles tão começando a ficar agitados de novo. (Trecho da Entrevista com o Professor 2, Escola S).

Na escola S, aproximadamente 39\% dos alunos são beneficiados pelo Programa Bolsa Família. A escola S atende, em 2015, 723 alunos, distribuídos em 2 turmas de educação infantil, 6 turmas dos anos iniciais e 11 turmas dos anos finais do ensino fundamental, além de 6 turmas de Projetos (Realfa e Acelera) e 4 Classes Especiais. A escola conta com 40 professores (incluindo os readaptados) e 12 funcionários em seu quadro. O Diretor e a sua Adjunta estão no cargo há quase três anos, e a atual Coordenadora Pedagógica assumiu a função este ano.

Como foi apresentado na seção anterior, as duas escolas atendem um público cujo indicador de NSE (escolhido para essa pesquisa) é muito parecido e que, de acordo com os dados coletados nas entrevistas, provém de comunidades vizinhas às escolas (nos dois casos os diretores relataram que menos de $10 \%$ dos alunos moram nas proximidades da escola - no "asfalto"). Ainda que reconhecendo diferenças socioeconômicas entre as comunidades atendidas pelas escolas L e S (e mesmo dentro das próprias comunidades), as situações de violência, conflitos, envolvimento com o crime foram apontadas nos dois espaços. Os resultados de aprendizagem nestas duas unidades, contudo, são bastante discrepantes. Apresentamos a seguir um histórico dos resultados das duas escolas desde de 2007 (IDEB, Proficiência em Matemática no $5^{\circ}$ e $9^{\circ}$ anos e Fluxo Escolar). 


\section{Gráficos 18 e 19: Evolução do IDEB na Escola L: $5^{\circ}$ e $9^{\circ}$ anos}
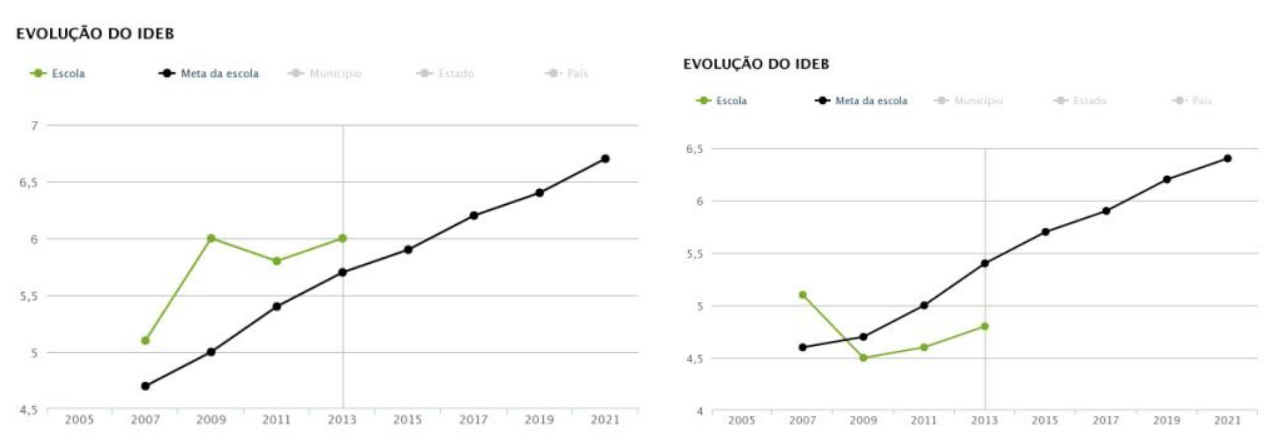

Fonte: $\underline{\text { www.qedu.com.br }}$

\section{Gráficos 20 e 21: Evolução do IDEB na Escola S: $5^{\circ}$ e $9^{\circ}$ anos}
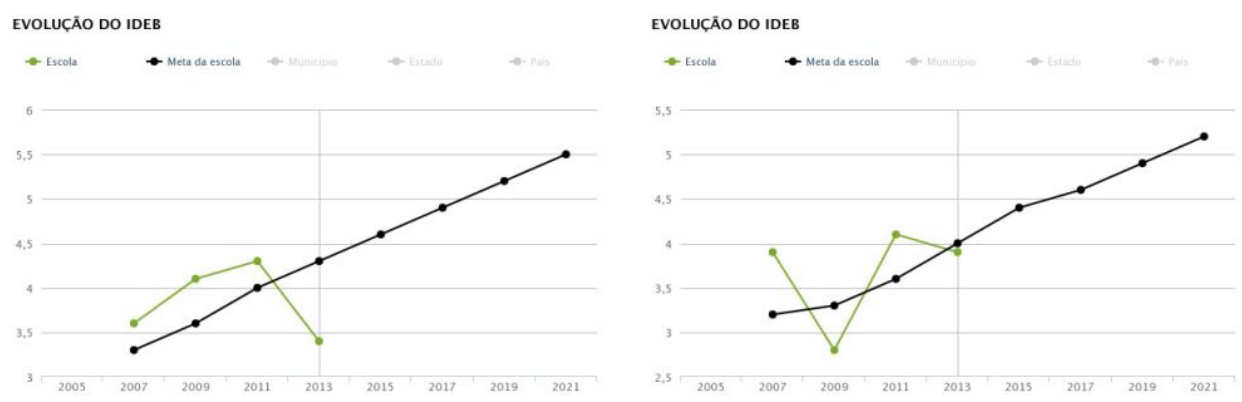

Fonte: www.qedu.com.br

No que se refere à avaliação dos anos iniciais do ensino fundamental, nota-se que, na escola L, o índice IDEB está acima da meta desde 2007, e a indicação para a escola é a manutenção deste resultado. Já a escola $S$ apresentou uma recente significativa involução do índice para este mesmo segmento. $\mathrm{O}$ avanço no IDEB de $9^{\circ}$ ano é um desafio para todo o país e não deixa de ser para as escolas em foco nesta pesquisa. A escola L, apesar de apresentar um índice maior do que o da escola $\mathrm{S}$ para esta série, está abaixo de sua meta, apresentando uma ligeira evolução nas duas últimas edições. A escola $\mathrm{S}$, por sua vez, apresenta uma oscilação nos indicadores desde 2007, tendo tido uma boa recuperação de resultado em 2011, mas voltando a ficar abaixo da meta em 2013. Considerando que o IDEB é calculado a partir da proficiência média dos alunos e do fluxo escolar, convém observar como esses indicadores ${ }^{93}$ têm se apresentado nas duas escolas:

\footnotetext{
${ }^{93}$ Optamos por analisar a evolução da proficiência média em Matemática (e não a de Língua Portuguesa), em conformidade com as justificativas já apresentadas no Capítulo 4.
} 
Gráficos 22 e 23: Fluxo Escolar, 2013 - $5^{\circ}$ ano e $9^{\circ}$ ano (\%)

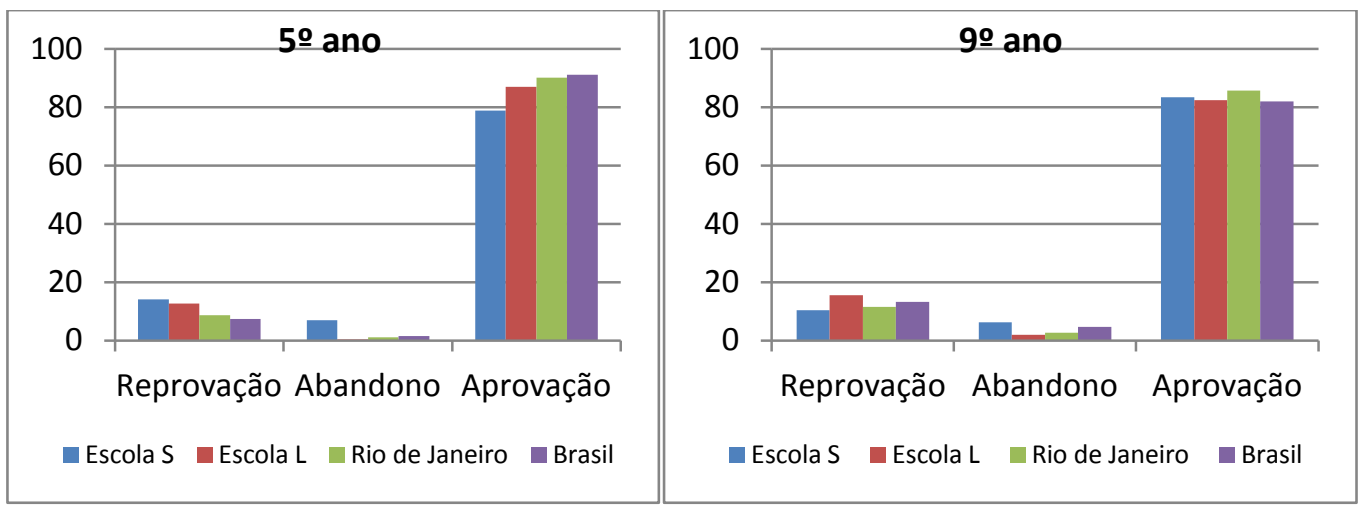

Fonte: Censo Escolar. INEP, 2013.

Gráfico 24: Proficiência média em Matemática - $5^{\circ}$ ano: Brasil, Rio de Janeiro, Escolas L e S.

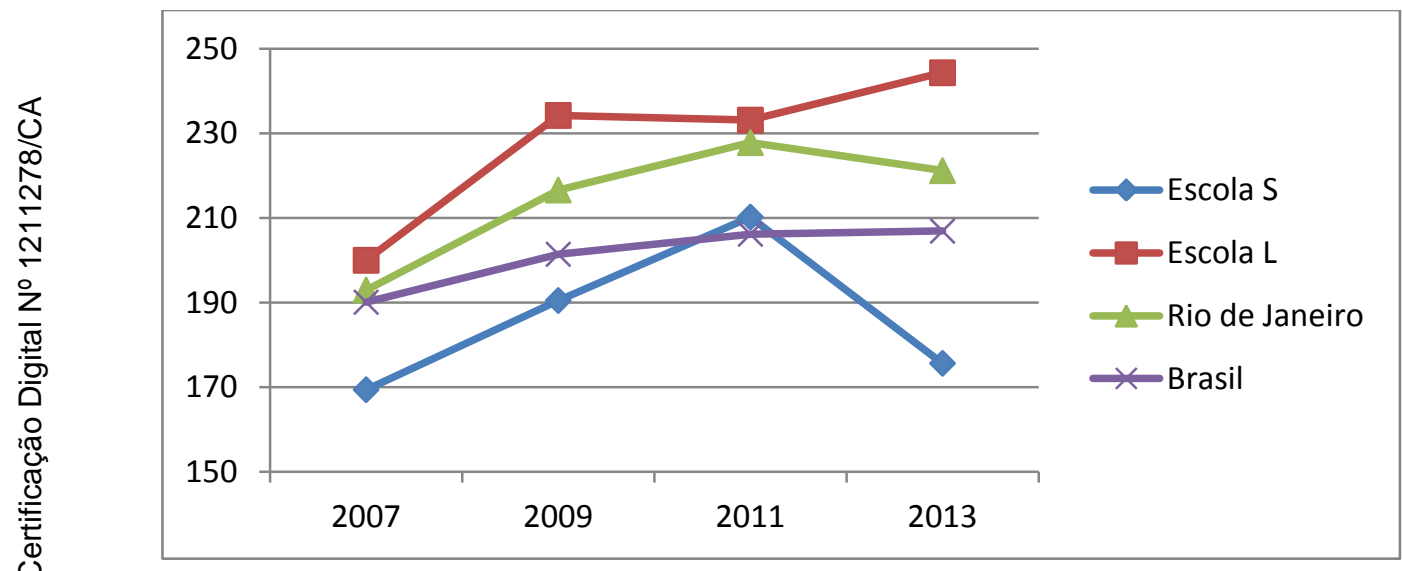

Fonte: INEP, 2008; 2011; 2012; 2015.

Gráfico 25: Proficiência média em Matemática - $9^{\circ}$ ano: Brasil, Rio de Janeiro, Escolas L e S.

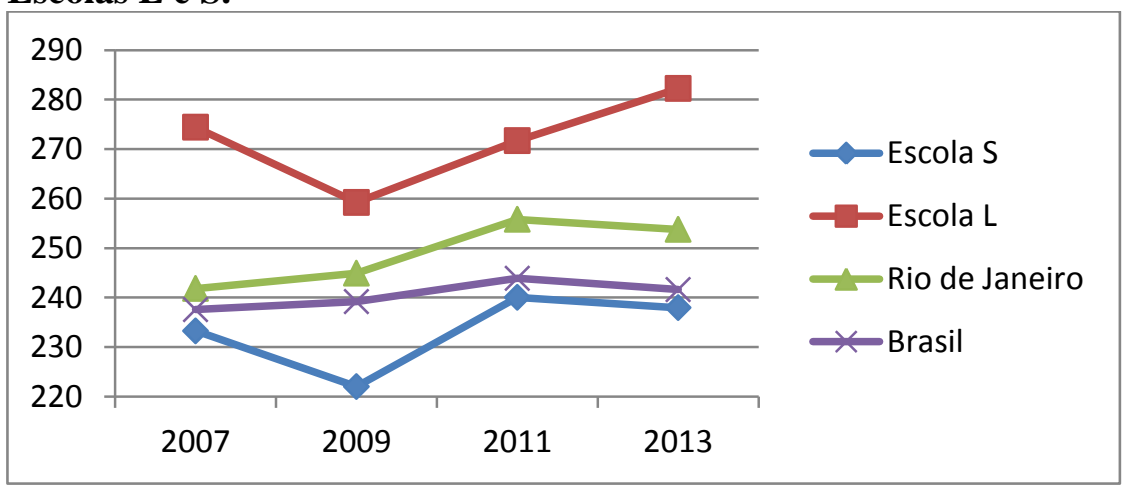

Fonte: INEP, 2008; 2011; 2012; 2015. 
Os indicadores do fluxo escolar apontam uma taxa de abandono significativa nas duas séries da Escola $\mathrm{S}$ (em relação à média nacional e municipal). Em relação ao número de reprovações, nota-se que houve, em 2013, um percentual de reprovações nas duas séries da Escola L acima da média nacional e municipal. Este índice de reprovação é reconhecido pelos professores como um reflexo da não aprendizagem dos alunos e do fato da escola não "maquiar" resultados, como explicitado na fala de um professor: "Se o aluno chega aqui no $6^{\circ}$ ano e não sabe ler nem escrever, não tem como... se não conseguir avançar, vai reprovar. Não estamos preocupados com índices" (Trecho da entrevista com o Professor 3, Escola L). Outro professor considera que o índice de reprovação ainda é baixo: "Se eu pudesse, eu reprovava a metade, dois terços" (Trecho da entrevista com o Professor 5, Escola L). Nota-se, ainda, que nesta escola o índice de reprovação é maior no $9^{\circ}$ do que no $5^{\circ}$ ano, o que parece seguir uma tendência nacional.

Olhando a trajetória da proficiência média em matemática nas duas escolas, percebemos que os resultados dos alunos da escola L estiveram acima da média nacional e municipal em todas as edições, nas duas séries avaliadas. Por outro lado, a média dos alunos da escola $\mathrm{S}$ foi inferior à média nacional e municipal em praticamente todas as edições, tanto no $5^{\circ}$ como no $9^{\circ}$ ano.

E o que poderia explicar esta diferença no desempenho dos alunos nas duas escolas, se considerarmos que foram isoladas as características sociodemográficas? Em que medida o reconhecimento da liderança do diretor e a satisfação do professor em trabalhar na escola interferem nesse resultado? As entrevistas realizadas nas duas escolas ${ }^{94}$ e o período de observação e acompanhamento do trabalho dos diretores trouxeram novos elementos para esta reflexão.

\section{2 \\ Entre a "disciplina" e a "acolhida": a construção do ambiente para a aprendizagem}

Durante esta fase da pesquisa, que envolveu as entrevistas e a observação da rotina dos diretores nas duas escolas, identificamos que a gestão escolar assume diferentes prioridades nas duas unidades. Antes de detalharmos estas diferentes características na gestão das escolas, vale reforçar a diferença de tempo dos diretores no cargo em cada uma delas: a diretora da escola L está há 28 anos a frente da escola,

\footnotetext{
${ }^{94}$ Foram realizadas 13 entrevistas semiestruturadas, totalizando mais de 9 horas de gravação e 171 páginas de transcrição. Os roteiros das entrevistas seguiram o protocolo de um projeto de pesquisa internacional, o International School Leadership Development Network - ISLDN, coordenado pelo Professor Bruce Barnett da University of Texas at San Antonio, do qual o GESQ passou a integrar em 2015. Os dois roteiros (entrevista com diretores e com professores) se encontram nos Anexos 8 e 9 .
} 
enquanto o diretor da escola $\mathrm{S}$ assumiu esta aposição há aproximadamente 3 anos (embora tenha sido diretor adjunto na gestão anterior). O tempo de experiência no cargo da direção é um fator importante na definição do perfil adotado pela gestão da escola. Entre os estudos que se dedicaram ao tema, Spillane e Lee (2014) se dedicaram a analisar s desafios enfrentados pelos diretores ao assumirem seus cargos (os "newcomers"). Os autores ressaltam que "os diretores escolares têm que desempenhar e gerenciar diferentes e conflitantes papéis e, para os novos diretores, este conflito de papéis potencialmente cria dilemas indenitários na sua transição para o novo cargo" (SPILLANE \& LEE, 2014, p. 435 , minha tradução)

Vários autores já ressaltaram a multiplicidade de funções exercidas pelos diretores escolares (COUSIN, 1998; BARROSO, 2012; LEITHWOOD, 2009; GRISSON \& LOEB, 2011; SPILLANE \& LEE, 2014), o que aponta para a dificuldade de equilibrar as diferentes demandas na rotina escolar. Alguns estudos destacaram a tendência do diretor escolar priorizar uma ou mais destas diferentes demandas, identificando perfis ou tipologias de liderança (POLON, 2012; MEDEIROS et al., 2014; URICK \& BOWERS, 2014; TEROSKY, 2014, entre outros). No caso das duas escolas investigadas, ficou clara a predominância de dois destes perfis: uma postura mais disciplinadora (Escola L) e outra mais acolhedora (Escola $S$ ).

As evidências que levaram a esta percepção serão apresentadas e discutidas a seguir, relacionando-as aos resultados do Survey GESQ 2014. As informações construídas a partir deste retorno ao campo de pesquisa trouxeram subsídios para o aprimoramento dos instrumentos de pesquisa. Assim, novos itens para os questionários são sugeridos ao longo das próximas seções. É importante ressaltar que as sugestões de novos itens a serem incorporados aos questionários compõem uma proposta de revisão inicial dos instrumentos e merecem ser testadas.

\subsection{1}

\section{O foco na disciplina}

Nas entrevistas realizadas com os professores da Escola L a importância de manter a disciplina dos alunos e o cumprimento das regras da escola foi unanimemente destacada na questão sobre as principais características da gestão da escola (Questão 17 do Roteiro de Entrevista de Professores, Anexo 9):

Se você precisa de ajuda na sua turma ou pra resolver qualquer tipo de problema, você tem essa ajuda. E como você trabalha com aluno, qual é a maior dificuldade que você tem? É com o aluno, que apresenta indisciplina, ou que apresenta uma 
coisa assim... Então, quando você tem esse apoio, você vai, desenvolver seu trabalho tranquilamente... (Trecho da entrevista com o Professor 1, Escola L).

A característica principal[da direção] pra mim é ser disciplinadora. Não consigo pensar em outra. (Trecho da entrevista com o Professor 2, Escola L).

[A Direção é] Presente. Elas tão sempre aí, coisa que você não vê em outras escolas. Atuante, tá? Incisiva quando tem que ser, tanto com aluno quanto com professor, e, principalmente, com os pais. (Trecho da entrevista com o Professor 3 , Escola L).

Nós temos o apoio da direção. Que tá sempre junto ali com a gente. Trazendo os problemas deles, o que necessitamos ou não e sempre somos atendidos, mas sempre voltado pra uma boa educação. Tanto na parte pedagógica como na parte, também, do social da criança, nos preocupamos muito com isso. A disciplina, né? Dentro da escola... (Trecho da entrevista com o Professor 4, Escola L).

[...] Aqui a [Diretora] é linha dura! Mas para funcionar tem que ser linha dura (Trecho da entrevista com o Professor 5, Escola L).

A atuação firme e disciplinadora da diretora em diferentes situações da rotina escolar foi exemplificada pelos professores, que ressaltaram o seu posicionamento de apoio ao professor. Citaram situações em que a diretora tanto confirmava e aprovava sua intervenção com os alunos (os professores têm autonomia para enviar ficha de ocorrência de comportamento para os pais dos alunos, assim como suspendê-los das aulas seguintes) e situações em que a diretora tinha uma atuação pontual em situações extremas (como no caso do atendimento à mãe do aluno suspenso pelo professor, que compareceu à escola ignorando a suspensão).

Durante o período observado (shadowing) algumas intervenções da diretora nos chamaram a atenção como iniciativas para garantir a disciplina dos alunos, mantendo um ambiente organizado na escola. Uma delas se refere à sua supervisão da entrada dos alunos na escola, quando estes devem se organizar em filas no pátio e subir, turma a turma, a partir de seu comando, junto com seus professores. O mesmo acontece após o recreio e a diretora lembra aos professores sobre o horário: "Vamos lá, gente... já tocou o sinal!" (Trecho do registro Shadowing a Diretora da Escola L). E esta postura, de cobrar o cumprimento do horário também dos professores, parece ser uma constante, como ressaltou o Professor 5: “Ela chama atenção: 'Olha, está chegando atrasado!' ou 'Tuas notas... o combinado das notas, de entregar as notas era dia 20, hoje é dia 21 e você ainda não entregou. E aí?"' (Trecho da entrevista com o Professor 5, Escola L).

Trabalhar em um ambiente onde os alunos cumprem regras (horário, uniforme e comportamento foram as mais citadas nas entrevistas) favorece a aprendizagem, afirmaram os professores ao serem questionados sobre o clima escolar: 
E quanto maior a disciplina e a calmaria do ambiente vai fazer com que eles entendam que aqui é um ambiente... Não é aquele ambiente da bagunça, da violência, da agressão. Aqui a gente vem pra aprender. A gente brinca, a gente se diverte, mas a gente, principalmente, veio pra aprender. (Trecho da entrevista com o Professor 2, Escola L).

O fato de você ter ordem pra mim já é um diferencial [para a aprendizagem], né? Você não ter aquela gritaria, aquela balbúrdia, aquele inferno que é recreio com briga... Você não vê briga aqui, né? Coisa que você vê em outras escolas... (Trecho da entrevista com o Professor 3, Escola L).

Muito provavelmente estas informações sobre a atuação da direção na manutenção da disciplina na escola ajudam a explicar o Índice de Reconhecimento do Trabalho da Direção Escolar, reportado pelos professores no Survey GESQ 2014. De acordo com o Gráfico 16, apresentado anteriormente, a escola $\mathrm{L}$ apresentou um dos maiores valores para este índice entre as escolas analisadas. A Escola L apresentou o segundo maior resultado no Índice de Percepção do Ambiente Escolar entre as escolas da subamostra (Gráfico 17). Esta informação coincide com os dados coletados na escola, que demonstram a valorização dos professores à manutenção da disciplina na escola. Assim, para aprimorar a mensuração neste tópico, propomos a inclusão dos seguintes itens no questionário dos professores (Anexo 12, continuando a questão 26, escala de concordância):

26.12 A equipe de direção desta escola se preocupa com a manutenção de um clima tranquilo para a aprendizagem, reforçando e cobrando que os alunos cumpram as normas da escola (horário, uniforme, deslocamentos pela escola).

26.13 A equipe de direção desta escola intervém no comportamento dos alunos, corrigindo situações de má-conduta e aplicando as medidas corretivas previstas.

$26.14 \mathrm{O}$ diretor desta escola apoia as medidas disciplinares adotadas pelos professores.

A inclusão destas questões teria por objetivo adicionar à medida de reconhecimento do trabalho da direção escolar a percepção dos professores sobre a atuação dos diretores na manutenção da disciplina entre os alunos, trazendo para o survey a relação identificada na Escola L.

O fato de saber que terão o apoio da direção nas intervenções com os alunos e a possibilidade de trabalhar em um ambiente "calmo" e "organizado" é explicitado pelos professores da Escola L como um dos fatores determinantes de sua satisfação em trabalhar (e permanecer) naquela escola. De acordo com os relatos, conseguir aproveitar 
o tempo do aluno na escola e conseguir dar aulas, são motivos para o professor trabalhar mais satisfeito:

Essa disciplina não é uma coisa ruim, ela produz bons frutos. E esses bons frutos que fazem com que a gente queira ficar mais aqui. (Trecho da entrevista com o Professor 3, Escola L).

Em geral sim, eu acho que a grande maioria dos professores aqui está satisfeito. [...] Porque o pessoal, tem muitos professores aqui que dão aula aqui e em outras escolas, e eles percebem: "Nossa! Na outra escola a direção é mais... é mais... frouxa, assim, do tipo, não está nem aí se o professor faltou ou não, se o professor está dando aula direito ou não, muito frouxo em relação aos alunos, tem tráfico na escola, tem coisas acontecendo na escola que são... né? Tipo... nossa, horríveis, tal... (Trecho da entrevista com o Professor 5, Escola L).

Assim, é possível que os itens sugeridos para complementar a questão P26 possam também se associar ao Índice de Satisfação do professor no trabalho, uma vez observada esta relação na pesquisa qualitativa. Os dados coletados pelo Survey GESQ 2014 apontaram que o Índice de satisfação no trabalho reportado pelos professores da Escola L estava ligeiramente acima da média das escolas analisadas. Contudo, devemos lembrar que os índices de Intervenção Pedagógica e de Interação do Diretor se associaram negativamente com o Índice de Satisfação no Trabalho. A partir das entrevistas e observações na escola foi possível aprofundar a análise sobre esta relação através da percepção de que há, na Escola L, uma expectativa relacionada ao comportamento esperado do professor, que define parte do ethos escolar. De acordo com Mafra (2003, p. 113), o conceito de ethos se refere ao "conjunto de valores, atitudes e comportamentos que dão identidade particular à escola". Há uma cobrança, por parte da direção, com relação ao trabalho dos professores (horário, faltas). Adequar-se à esta cobrança foi reportado como uma condição naturalizada na convivência escolar, como aponta uma das professoras: "Geralmente fica aqui quem quer, quem gosta, quem não se importa e quem acha que esse método tá ótimo. Entendeu? (Trecho da entrevista com o Professor 1, Escola L). Porém, talvez não sejam todos os professores que estejam afinados ou tenham uma visão positiva desta forma de interação. Para refinar esta percepção, sugerimos que os próximos surveys ampliem a medida dos índices, com a inclusão de itens como: (Anexo 12, continuando a questão 21, escala de frequência):

21.12 O diretor desta escola está atento à assiduidade e pontualidade dos professores. 
$21.13 \mathrm{O}$ diretor desta escola realiza os procedimentos de registro das faltas e atrasos dos professores, comunicando à instâncias superiores quando é o caso.

21.14 Com relação aos deveres e compromissos dos professores com a escola (horário, assiduidade, prazos, qualidade do trabalho), a equipe de direção segue as indicações da SME.

21.15 No que se refere às questões relacionadas aos deveres e compromissos do corpo docente, a equipe de direção desta escola adota tratamento igual para todos os professores.

Além dos itens sobre a relação de supervisão do cumprimento de regras pelo professor, consideramos que seria interessante entender melhor qual é, predominantemente, o tipo de interação que o professor tem com seu diretor. O tempo de observação nas escolas possibilitou uma impressão pontual desta interação, que pode não traduzir, de forma fidedigna e completa, o cotidiano desta relação, mas que nos oferece importantes indícios sobre a sua tendência. Em um dia de trabalho, a Diretora da Escola L teve um tempo total de interação com os professores de aproximadamente 40 minutos, assim distribuídos:

Quadro 21: Tempo de interação com os professores, Shadowing Diretor da Escola L.

\begin{tabular}{|l|l|}
\hline Tempo & \multicolumn{1}{|c|}{ Interação com professor (es) } \\
\hline $5^{\prime}$ & Resolução de situação disciplinar de aluno, junto ao professor. \\
\hline $2^{\prime}$ & Cumprimentar os professores na sala dos professores. \\
\hline $6^{\prime}$ & Encaminhamento de resoluções referente à aposentadoria de uma professora. \\
\hline $5^{\prime}$ & Localização de um material para professora, consultando os demais professores. \\
\hline $2^{\prime}$ & Cumprimentar os professores na sala dos professores. \\
\hline $8^{\prime}$ & Resolução de situação disciplinar de aluno, junto ao professor. \\
\hline $3^{\prime}$ & $\begin{array}{l}\text { Consulta ao professor sobre a possibilidade de realizar uma festa sugerida pelos } \\
\text { alunos, arranjos necessários. }\end{array}$ \\
\hline $2^{\prime}$ & $\begin{array}{l}\text { Solicitação e encaminhamento de BIM (Boletim de Inspeção Médica) por uma } \\
\text { professora. }\end{array}$ \\
\hline $5^{\prime}$ & $\begin{array}{l}\text { Comentários e encaminhamentos sobre situação de aluno que estará ausente por } \\
\text { um período escolar longo }\end{array}$ \\
\hline $3^{\prime}$ & $\begin{array}{l}\text { Professora apresentando e comentando um recado de uma mãe de alunos sobre } \\
\text { seu trabalho. }\end{array}$ \\
\hline $3^{\prime}$ & Resolução de situação disciplinar de aluno, junto ao professor. \\
\hline
\end{tabular}

O tempo dedicado à interação com professores, seja ele por iniciativa da Diretora ou não, teve diferentes finalidades. Assim, tendo em vista que a interação com os professores possui diversas nuances, ainda que não seja a atividade predominante na rotina do diretor escolar (na escola em foco), consideramos que seria interessante aprofundar esta percepção nos próximos trabalhos. Para isso, propomos a inclusão de um item no questionário dos professores destinado a identificar as situações predominantes nas quais eles interagem com os diretores (Anexo 12, após a questão 21): 
21 (extra) As interações pessoais que tive com o diretor, no último mês, foram predominantemente para (escolha apenas uma opção):

a. Relatar trabalhos desenvolvidos em minha aula/turma, sobre os quais gostaria de conversar com o diretor.

b. Apresentar e comentar os resultados de meus alunos nas últimas avaliações.

c. Resolver alguma situação disciplinar ou de comportamento ocorrido com meus alunos, para a qual solicitei a intervenção do diretor.

d. Conversar sobre assuntos pessoais e diversos.

e. Resolver alguma situação administrativa.

Na Escola L, possivelmente a terceira opção de resposta à esta questão seria a de maior frequência entre os professores, se considerarmos as situações observadas no contexto. Porém, somente a partir da aplicação do item a um número significativo de respondentes poderíamos ter uma leitura mais consistente sobre a percepção dos professores acerca da natureza da interação com seu diretor.

As informações coletadas na pesquisa qualitativa realizada na Escola L mostraram o perfil de uma diretora que valoriza e cuida da disciplina, estabelece uma interação com a equipe atenta às questões organizacionais. Estes aspectos aparecem nas falas dos professores relacionados à satisfação que reportam em trabalhar na escola e, principalmente, no reconhecimento de sua liderança.

Na próxima seção, apresentaremos o perfil encontrado na gestão da outra escola pesquisada, para em seguida refletirmos os condicionantes que levaram a identificação destas características nas duas escolas, considerando o contexto escolar que requer do diretor o desempenho de múltiplos papéis.

\subsection{2}

\section{A escola acolhedora}

$\mathrm{Na}$ Escola S, inúmeras situações e relatos (de professores e diretores) destacaram a característica acolhedora da escola, muitas vezes no intuito de ressaltar que aquela unidade atende a todos os alunos que lhe procuram. Este destaque pode parecer estranho, uma vez que apresenta como exceção um procedimento que esperava-se ser o natural nas escolas públicas: a abertura a todos os alunos. Porém, a afirmação "acolher todos os alunos" encontra duas interpretações possíveis no contexto da Escola S. A primeira se refere ao fato de a escola ter, em seu quadro, 4 turmas de Classes Especiais (para alunos diagnosticados como portadores de necessidades especiais) e 6 turmas de Projetos de Correção de Fluxo (Realfa e Acelera, para alunos com defasagem idade-série superior a 
dois $\operatorname{anos}^{95}$ ). Como a oferta de turmas de Projeto de Correção de Fluxo ou de Classes Especiais não é comum a todas as escolas da rede, a Escola $\mathrm{S}$ absorve os alunos com necessidades especiais e os alunos fora da faixa etária que as outras escolas municipais do entorno não podem atender.

A segunda interpretação decorre de uma consideração feita com frequência pelos profissionais da escola, referindo-se à acolhida aos alunos que não se adaptaram à outras escolas (seja academicamente ou por questões relativas à disciplina; e seja encaminhado pelas famílias ou pela direção de outras escolas):

Mandam... está dando problema na A? Vem pra cá. Está dando problema lá? Entendeu? É isso. Tudo vai para a S. (Trecho da entrevista com a Adjunta, Escola S).

[...] hoje em dia que a gente está nessa batalha, essa briga por não receber. Acho que cada um tem que ficar com os seus problemas. (Trecho da entrevista com o Diretor, Escola S).

[...] então várias escolas por aí, a gente tem ideia de que jogam seus problemas, fazem a limpezinha deles, e manda pra cá, e aqui, como é aquela coisa do paizão, da mãezona, que a gente abraça essa ideia, acaba vindo tudo pra cá, né... (Trecho da entrevista com o Professor 1, Escola S)

As outras escolas que têm, assim, um perfil mais tranquilo, que a clientela é mais tranquila: "Ah, joga na S". Entendeu? Então tava vindo, tava, como é que se diz? Migrando pra cá... Muitos alunos que tinham problemas de disciplina em outras escolas e vindo pra cá. Quer dizer, é uma característica da escola... (Trecho da entrevista com o Professor 3, Escola S)

Esta seleção de alunos em outras unidades, com encaminhamentos para a Escola $\mathrm{S}$, apesar de não ser uma prática reconhecida como legítima nas escolas da rede municipal do Rio de Janeiro (que adota a matrícula digital dos alunos, onde os fatores que determinam a possibilidade de matrícula são a escolha dos pais e a disponibilidade de vaga), parece ser (ou ter sido) recorrente, como relataram professores e a equipe de direção. Costa e Koslinski (2011) já chamavam a atenção para o este procedimento nas escolas do Rio de Janeiro, ao qual chamaram "quase-mercado oculto":

São procedimentos velados que permitem a algumas escolas operar ativamente no mercado, que, do ponto de vista legal e formal, não é, nem pode ser fechado. Há vagas para todos - ao menos no ensino fundamental. A rede estudada, assim como outras redes públicas que conhecemos no país, não dispõe de procedimentos que permitam filtrar claramente seus alunos (testes de acesso ou mecanismos legais de exclusão e seleção). No entanto, há forte seletividade por parte de algumas escolas mais conceituadas, o que ocorre de forma velada. A existência de uma reduzida

\footnotetext{
${ }^{95}$ De acordo com o Censo 2013, 48\% dos alunos na Escola S apresentavam distorção idade-série.
} 
independência da gestão escolar - mesmo que esta não tenha sido estimulada por uma política deliberada - tem levado a artifícios

como o de "esconder vagas", ou à rejeição de alunos. (COSTA e KOSLINSKI, 2011, p. 255-256)

De acordo com os autores, a pesquisa encontrou mecanismos de seleção de alunos nas escolas públicas que incluem a transferência sugerida veemente aos pais do aluno para uma escola que fosse mais condizente ao "perfil escolar indesejado do aluno" (op. cit., p. 261). No caso desta pesquisa, a Escola S, de acordo com os relatos dos profissionais, foi ou tem sido o destino de alguns "alunos com perfil indesejado", que foram, de alguma forma, excluídos de outras unidades. Ainda que fuja ao escopo desta pesquisa aprofundar sobre esta questão, chamou-nos a atenção a relevância dada pelos respondentes a esta característica, ao questioná-los sobre o perfil de sua escola. Percebese aí um indicativo de uma representação coletiva que, ainda que não tenha sido comprovada, está muito fortemente presente no grupo e nos ajuda a entender a valorização à acolhida construída no ethos daquela escola.

Alguns professores comentaram sobre a situação em que esses alunos chegam à escola, com baixa autoestima e sentimento de rejeição. De acordo com o depoimento de uma professora, a escuta e a disponibilização de chances ao aluno é uma prerrogativa da escola:

A gente tem muito essa coisa do conversar com aluno, sabe? Antes de você perder as estribeiras, de chegar num limite... $\underline{\text { A gente conversa, a gente releva muita }}$ coisa. A gente tem essa coisa assim do pegar o aluno mesmo e: "Vamo tentar, vamo melhorar, vamo mudar..." E a gente dá todas as chances. $\underline{\text { A gente vai dando }}$ chance até quando não deve dar... Até a gente esgotar todas as possibilidades. Então assim, a gente tem essa política aqui. (Trecho da entrevista com o Professor 2, Escola $S)$.

A impressão construída a partir das entrevistas e observações nesta unidade é a de que acolher o aluno (no sentido de oferecer carinho, escutar) é o principal objetivo dos profissionais que lá atuam. Para além de uma característica institucional da Escola S, a acolhida também é uma característica marcante do Diretor desta unidade. Nas entrevistas com os professores, ao serem questionados sobre a principal característica da gestão da escola (e em outros pontos da entrevista também), todos destacaram o perfil acolhedor de seu Diretor:

Da gestão? Eu acho que essa parte que Paulo Freire chamava de Pedagogia do Amor. Essa coisa do tratamento mesmo, de você não rotular, de você tentar buscar caminhos que façam com que ele perceba, né? O que é melhor... O que é o certo... (Trecho da entrevista com o Professor 2, Escola S) 
Aqui a gente... Nós somos acolhedores. Quem chega é bem acolhido na escola. (Trecho da entrevista com o Professor 3, Escola S)

Eu sou suspeita pra falar do meu gestor, tá? Que meu diretor é a pessoa mais maravilhosa do planeta. Assim, precisava ter muitos iguais a ele pra que a educação fosse diferente, com um olhar diferente. Só que, como eu te falo, por ele ser tão maravilhoso às vezes lota aqui dos problemas que ninguém quer. (Trecho da entrevista com o Professor 4, Escola $S$ )

Esse diretor é muito bom. Ele é o cara certo para essa comunidade, que a comunidade aceita ele.[...] Ele é o líder democrático aqui. A comunidade, os professores, que tiverem que votar nele, vão votar nele. A comunidade, os pais, eu vou votar nele também. Que é uma pessoa, assim, democraticamente, que a democracia acho que pressupõe isso, pressupõe aceitação. (Trecho da entrevista com o Professor 5, Escola S)

Eu considero o [Diretor], que é o professor diretor, né? Ele consegue, isso que eu sempre digo, eu acho ele um herói nacional, né? Ele consegue dentro do que é essa escola, dentro do que são as comunidades que frequentam a escola, ele consegue manter uma harmonia bastante grande. Esse saber lidar com o modo de ser dos alunos, ele sabe. Os alunos gostam muito dele. (Trecho da entrevista com o Professor 6, Escola S)

Então, característica deles é aquilo: a questão do abraçar a escola, de estar sempre presente. Agora a questão de disciplina, eu acho que isso falta... (Trecho da entrevista com o Professor 1, Escola S)

Durante o período de shadowing, foi possível conhecer um pouco da atuação do diretor, quando esta característica realmente é perceptível. O diretor não recusou nenhum atendimento, seja a pais, funcionários, professores ou, principalmente, alunos, mesmo quando estava realizando outra atividade ou não era seu horário de atendimento (como comentou a secretária, em uma situação). Ouviu os alunos com atenção, solicitou diferentes versões para resolver conflitos, acolheu um aluno que estava chorando: "Ele está com saudade da avó que faleceu, de vez em quando vem chorar na minha sala". Um aluno com necessidades especiais (que já tem 18 anos e, segundo o próprio diretor já não devia estar mais na escola, mas como não tem família e mora na rua, a escola é sua única referência) entra na sala da direção várias vezes durante o dia para cumprimentar o diretor ou lhe pedir algum item de uniforme.

Enquanto se desloca pela escola, o diretor conversa com vários alunos, escuta casos, pergunta, comenta sobre futebol. Os alunos costumam abraçá-lo quando o veem. Este perfil acolhedor do diretor, que foi descrito pela sua parceira de trabalho como "um professor com coração que não dá dentro do peito" (Trecho da entrevista com a Diretora Adjunta, Escola S), é reconhecido pela sua equipe como sua principal característica. Porém, o Índice de Reconhecimento do Trabalho da Direção Escolar nesta unidade está abaixo da média da amostra no Survey GESQ 2014 (ver Gráfico 16). Como já foi 
mencionado, este índice foi construído por itens do questionário relacionados ao reconhecimento pelo trabalho da equipe e ao encorajamento e apoio da equipe de direção ao trabalho dos professores. Considerando a relevância dada pelos professores da Escola $\mathrm{S}$ à característica de acolhimento no perfil do diretor escolar, que não foi abordada no questionário, sugerimos incluir à esta seção os seguintes itens (Anexo 12, continuando a questão 26, em escala de concordância):

$26.15 \mathrm{O}$ diretor desta escola interage com os alunos (na entrada, em sua sala, no recreio).

26.16 O diretor desta escola está sempre disponível para atender quem o procurar.

A inclusão destes itens pretende testar sua associação com os outros itens que compuseram o Índice de Reconhecimento do Trabalho da Direção Escolar, afim de verificar se "o perfil acolhedor do diretor" estaria entre as características que favorecem o reconhecimento de sua liderança na escola ou não. Ao que nos parece, os resultados nesta escola mostraram que não, mas seria interessante investigar como este dado se comporta em outros contextos.

A acolhida é estendida aos professores, que demonstraram ter construído uma relação de intimidade com o Diretor (ele já atuava como Adjunto nesta escola antes de assumir o cargo). Porém, esta proximidade parece não ter sido considerada por nenhum dos professores entrevistados ao serem questionados sobre o nível de satisfação do grupo de professores em trabalhar na escola. As respostas coletadas no Survey GESQ 2014 reportaram um Índice de Satisfação no Trabalho negativo entre os professores da Escola $\mathrm{S}$, sendo um dos mais baixos da amostra (conforme apresentado no Gráfico 16). Nas entrevistas, quando procuramos ampliar nossa percepção sobre que fatores influenciam o nível de satisfação dos professores, encontramos muitas referências à trajetória pessoal do professor, seu comprometimento com a escola e com seus alunos e algumas falas relacionadas à insatisfação com a infraestrutura e organização da escola:

É um pouco complicado. O que a gente tem é assim... as pessoas acabam desestimuladas, porque você está dando aula na sua sala, de repente aí tem esse coisa: de público, uma aula o professor não veio, pá... daqui a pouco tem um chutando tua porta. (Trecho da entrevista com o Professor 1, Escola S)

É, a gente tem de tudo um pouco, né? Mas a grande maioria, que eu falo, que a gente fica aqui, assim, a gente acredita muito no potencial desses meninos. A gente acredita que eles... Que a gente pode melhorar em alguma coisa, a gente sabe que a gente não vai conseguir, não vai alcançar com todos... (Trecho da entrevista com o Professor 2, Escola S) 
Quem tá com a mão na massa sabe fazer, quer fazer. Senão não estava mais com a mão na massa, o salário não justifica. É o pior salário do planeta. Nada justifica isso. Você tem que gostar. Todo mundo gosta. (Trecho da entrevista com o Professor 4, Escola S)

A questão toda com a insatisfação não é a unidade, a questão é o momento que a gente tá vivendo, que a sociedade tá vivendo, de muita violência, de menores...

(Trecho da entrevista com o Professor 3, Escola S).

Eu acho que todo mundo gosta daqui, da escola. É claro que a gente tem as nossas questões, mas dentro disso... (Trecho da entrevista com o Professor 6, Escola S).

Assim, para ampliar nossa medida sobre o nível de satisfação dos professores em seu trabalho na escola, além dos itens já sugeridos na seção anterior, acrescentaríamos algumas questões incluindo a sua percepção sobre a capacidade relacional do diretor, a auto-avaliação de seu trabalho de forma mais localizada (nesta escola) e a apreciação sobre a infraestrutura da escola (Anexo 12, continuando a questão 26, em escala de concordância):

$21.15 \mathrm{O}$ diretor desta escola demonstra abertura e interesse para escutar os professores.

21.16 O diretor desta escola consegue articular as diferentes ideias e opiniões do grupo.

26.17 Sinto-me realizado com o trabalho que desenvolvo nesta escola.

26.18 Encontro na escola a infraestrutura que preciso para realizar minhas aulas.

26.19 A organização da escola favorece meu trabalho.

Para melhor compreender a natureza da interação do Diretor da Escola S com seus professores, registramos no quadro abaixo todas as situações em que ocorreram algum tipo de interação entre eles em um dia de observação (shadowing):

Quadro 22: Tempo de interação com os professores, Shadowing Diretor da Escola S.

\begin{tabular}{|c|c|}
\hline Tempo & Interação com professor (es) \\
\hline 3' & Conversa informalmente com uma professora e alunos. \\
\hline $2^{\prime}$ & $\begin{array}{l}\text { Avisa a uma professora (atrasada) que sua turma está sozinha, após o recreio. Ela } \\
\text { estava se encaminhando para a sala. }\end{array}$ \\
\hline $2^{\prime}$ & $\begin{array}{l}\text { Um professor lhe entrega bandeirinhas de festa junina feitas em sua aula e } \\
\text { comenta sobre o trabalho. }\end{array}$ \\
\hline 3' & Conversa com uma professora sobre sua ausência no dia anterior. \\
\hline 2' & Conversa com uma professora sobre um documento a ser encaminhado à CRE. \\
\hline $1^{\prime}$ & $\begin{array}{l}\text { Entrega um envelope com documento para uma professora que passava em frente } \\
\text { a sua sala. }\end{array}$ \\
\hline 5' & $\begin{array}{l}\text { Vai à uma sala do } 6^{\circ} \text { ano e conversa com os alunos sobre disciplina, na presença } \\
\text { da professora. }\end{array}$ \\
\hline $2^{\prime}$ & $\begin{array}{l}\text { Vai à uma sala do } 9^{\circ} \text { ano e conversa com os alunos sobre disciplina, na presença } \\
\text { do professor. }\end{array}$ \\
\hline
\end{tabular}




\begin{tabular}{|l|l|}
\hline $1^{\prime}$ & Conversa com uma professora sobre o ensaio para a festa junina. \\
\hline $3^{\prime}$ & $\begin{array}{l}\text { Solicita à uma professora do } 9^{\circ} \text { ano que indique alunos para participar do Projeto } \\
\text { Vencer. }\end{array}$ \\
\hline 5 & Atende, junto com o professor, uma mãe de aluna sobre a indisciplina da mesma. \\
\hline $1^{\prime}$ & $\begin{array}{l}\text { A professora do } 9^{\circ} \text { ano vem à sua sala e lhe devolve o documento do Projeto } \\
\text { Vencer preenchido. }\end{array}$ \\
\hline $3^{\prime}$ & $\begin{array}{l}\text { Juntamente com a Adjunta, instrui um professor sobre a condução de uma turma } \\
\text { (indisciplina) }\end{array}$ \\
\hline 4 & Atende, junto com o professor, um responsável sobre faltas dos alunos. \\
\hline 5 & Atende, junto com o professor, dois alunos sobre a indisciplina dos mesmos. \\
\hline
\end{tabular}

É interessante notar que o tempo de interação do Diretor da Escola $\mathrm{S}$ com os professores, em um dia normal de trabalho, foi coincidentemente igual ao tempo que a Diretora da Escola L interagiu com seu corpo docente. Nota-se que, em ambas as escolas, o tempo em que o diretor realiza algum tipo de interação com os professores é equivalente à $8,75 \%$ de seu tempo de trabalho. Considerando-se que as reuniões de Centro de Estudos se tornaram bimestrais, assim como são os Conselhos de Classe, são poucas as oportunidades que a equipe de direção tem para interagir com todos os professores, assim como são raros os momentos de interação entre eles no cotidiano escolar. No caso da Escola $\mathrm{S}$, as situações de interação com os professores também apresentaram finalidades diversas, desde o apoio à intervenções disciplinares com os alunos até questões burocráticas. Assim como foi proposto na seção anterior, reforçamos a importância de captar de forma mais direta a percepção do professor sobre a natureza da sua interação com o diretor, incluindo no questionário do professor a Questão 21 - extra já apresentada.

Nos momentos de interação do diretor da Escola $\mathrm{S}$ com os seus professores, podese perceber uma relação de proximidade. Em alguns casos, esta proximidade se traduzia em maior liberdade com relação à rotina escolar, como na situação em que uma professora não subiu para dar aula após o recreio e, 10 minutos depois, o Diretor a encontra subindo para a sala. Ele comenta que sua turma estava sozinha, fora da sala e a professora sorri e diz que está tudo bem, pois ela já estava indo, encerrando o assunto. $\mathrm{O}$ que poderia ser um comentário em tom de repreensão ou cobrança por parte do Diretor, considerando a hierarquia da relação, pareceu ser um comentário sobre algo rotineiro ou sem importância, considerando a reação da professora. Em uma outra situação, a professora do $3^{\circ}$ ano comentou sobre o período de 5 dias em que havia faltado por estar em período de provas na faculdade (os alunos ficaram em casa, sem aula, durante este tempo). O Diretor confirmou com naturalidade que lembrava do episódio, mostrando que a decisão da professora foi comunicada e aceita pela direção. 
As situações narradas parecem indicar que atrasos ou faltas de professores são práticas naturalizadas na Escola $\mathrm{S}$ sendo, inclusive, tema de discussão na reunião de Centro de Estudos observada pela pesquisa. Nesta ocasião, o diretor parece perceber uma necessidade de mudar a sua postura nesta relação com os professores, considerando os prejuízos que as suas faltas têm acarretado para a escola. Iniciada a reunião, O Diretor avisa que precisarão tratar de um assunto delicado: os atrasos e faltas dos professores. Diz que "a escola é pesada, é punk... não dá para ser punk também com os colegas". (Pareceu-me querer explicar porque costuma ser conivente com faltas e atrasos dos professores) Continuou: "mas tem hora que o bicho pega, tem dia que a escola está sem 3 professores, está ficando complicado... Administrar isso é complicado". Uma professora intervém: "Mas ninguém falta porque quer..." e a secretária comenta: "Ah... tem gente que falta porque está menstruada...." (começa um pequeno tumulto). O Diretor retoma a palavra: "nós sabemos que há casos e casos..." e pede: "Vamos coordenar estas faltas, se já tem um colega faltando, não falta, falte outro dia...Agora, se não tiver atestado, vai ter que levar falta. Eu fiquei sendo bonzinho, mas tem gente abusando..." (Trechos do registro da observação realizada no Centro de Estudo)

Conforme a argumentação do diretor (reforçada pela Coordenadora Pedagógica), as faltas de professores comprometem a organização e a rotina da escola. A tentativa de minimizar a frequência destas situações passa por uma revisão da relação entre o diretor e seus professores (“Agora, se não tiver atestado, vai ter que levar falta"), uma vez que há limites externos pautando o compromisso profissional de todos.

A postura acolhedora do Diretor apareceu como uma característica marcante de sua gestão na Escola S, sendo reconhecida nas relações com os alunos e professores. Sua interação com os professores se dá em diferentes momentos e com diferentes finalidades, como foi apresentado. Em todos eles, destaca-se a disponibilidade e abertura ao professor, ainda que esta relação não tenha aparecido como influente para a satisfação do corpo docente no exercício de sua função. Em algumas falas dos professores, percebe-se um misto de reconhecimento e desaprovação da flexibilização dos limites consequente desta relação acolhedora entre o diretor e os alunos:

Então, característica deles é aquilo: a questão do abraçar a escola, de estar sempre presente. [...] Existem outras coisas. Então eu acho que em relação à gestão, eu acho que tem que ter... porque as coisas se confundem na cabeça de aluno... eu acho que isso fica muito confuso na cabeça deles, entendeu? (Trecho da entrevista com o Professor 1, Escola S)

Então eles consideram a escola um pouco extensão da comunidade deles. E isso é uma coisa positiva. Agora, requer uma adaptação porque a questão da disciplina é mais complicada em função disso, né? Porque eles se consideram os donos do pedaço. [...] É uma escola que tem esse viés democrático, que é peculiar. É mais 
difícil exatamente. Tem pessoas que não conseguem lidar com essa escola porque exatamente não tem tanto aquela disciplina formal. (Trecho da entrevista com o Professor 6, Escola S)

A predominância de um perfil mais acolhedor no trabalho do diretor da Escola S, conforme percepção dos professores entrevistados, não anula as outras características de seu trabalho na gestão da escola, ainda que estas tenham tido menor relevância. Na seção que se segue, discutiremos as impressões coletadas nas duas unidades, relativizando a complexidade do papel do diretor a partir das questões propostas por esta pesquisa.

\subsection{3}

\section{Disciplinar ou acolher: um falso dilema?}

Tomando como referência as reflexões propostas pelas duas seções anteriores, é preciso considerar que ter um perfil predominantemente "disciplinador" ou um perfil predominantemente "acolhedor" como diretor escolar está relacionado com o contexto em que estes diretores atuam. Estudando as diferentes tipologias de liderança escolar nas escolas dos Estados Unidos, Urick e Bowers (2014) comentam, em sua revisão de literatura, que poucos estudos têm dado atenção às variáveis contextuais da escola no estudo sobre perfis de liderança do diretor. De acordo com eles, "a inclusão de variáveis sobre o contexto escolar é importante uma vez que o diretor ajusta sua liderança para ir ao encontro das necessidades dos professores e alunos na escola" (URICK \& BOWERS, 2014, minha tradução). Consideramos relevante, então, analisar o contexto em que foram construídas as representações (disciplinador e acolhedor) sobre a atuação dos dois diretores estudados.

Antes de assumir sua atual função, a Diretora da Escola L foi Coordenadora de Turno da mesma unidade, quando já iniciou um trabalho de "organizar a escola", como ela mesma contou. Era o final da década de 1980 e a escola estava vivendo uma mudança estrutural (prédio), de atendimento (passando a atender os anos finais do ensino fundamental) e de público (passou a atender a mais uma comunidade). O contexto era complexo e a então Coordenadora da Escola L trouxe, de sua experiência anterior (uma escola bastante complexa, segundo seu relato), a característica de "disciplinadora":

Eu entrei em uma escola que era uma loucura, era portão aberto, aqui tinha uma mesa de ping-pong, uma mesa de totó, e era... o aluno da manhã podia ficar aqui a tarde se ele quisesse ficar e os alunos da tarde poderiam chegar de manhã para jogar ping-pong e o maldito do totó. E aquilo era uma loucura. E eu comecei a fazer uma disciplina na escola (Trecho da entrevista com a Diretora, Escola L) 
As famílias e os professores da escola pareceram aprovar esta iniciativa, uma vez que no ano seguinte ela foi eleita diretora da escola. Percebe-se que, ao trazer para a escola a ordem e disciplina em um momento turbulento, a Diretora da Escola L atendeu às expectativas do corpo docente e da comunidade atendida pela escola (pelo menos, de sua maior parte). Desde então, com suas sucessivas reeleições, sua característica disciplinadora vem sendo legitimada à frente da direção.

Na Escola S, como foi comentado anteriormente, há uma representação coletiva negativa sobre o perfil dos alunos que atendem (encaminhados por outras escolas para as turmas de Projetos, Classes Especiais ou por questões disciplinares). Essa percepção está explicitada nas falas dos professores que assumem, como responsabilidade da escola, acolher esses alunos e resgatar seu vínculo com a vida escolar:

A marca dessa escola é inclusão. Essa é uma escola de inclusão. Olha, a gente tem desde as criancinhas até os enormes... Nós temos classe especial, meninos com Síndrome de Down, meninos especiais mesmo, com todas as especialidades. [...] Então, o que a gente tem conversado muito na reunião é um resgate da autoestima dos nossos meninos. Imaginar, assim, você um dia foi matriculado na $S$ porque não te quiseram, mas agora a gente te quer. (Trecho da entrevista com o Professor 4, Escola S)

Foi comum ouvir e presenciar a atenção dada aos alunos, no que se refere a dar prioridade a escutá-los, abraça-los, conversar com eles. A percepção sobre a carência afetiva dos alunos e a necessidade de investir em sua autoestima foi verbalizada pela maioria dos professores, em alguns casos considerada como a questão de maior prioridade no seu trabalho (antes mesmo das funções acadêmicas, como será discutido em seguida). Assim, o contexto da escola, seja ele real ou senso comum coletivo, parece ter construído entre os educadores a necessidade de priorizar a acolhida aos alunos, construindo o que poderia ser chamado de "clima social da escola", onde destaca-se o tom emocional da instituição. (MAFRA, 2003, p. 116). Ao assumir o cargo recentemente, o Diretor da Escola $\mathrm{S}$ já estava inserido neste contexto e, conforme explicitado por alguns professores, foi escolhido provavelmente por ter um perfil que se identificava com essa característica da escola.

A relação do Diretor da Escola $S$ com os professores, como foi visto, também é permeada pela acolhida. Analisá-la para além das características pessoais dos educadores requer que observemos o contexto específico em que estas relações são construídas. Um dos principais problemas da escola é a falta de professores, tanto as faltas esporádicas (como foi assinalado) quanto a inexistência de professores para algumas turmas/disciplinas: 
Por exemplo, a gente tem uma turma que está sem professor de português desde o começo do ano. [...] Eu hoje estou com uma professora de inglês de licença, um de história de licença, professor de geografia de licença. (Trecho da entrevista com o Diretor, Escola $S$ )

Nós somos uma escola punk e depois de 18 anos trabalhando aqui, eu te falo que tem dia que eu acordo e estou muito desanimada, não quero trabalhar... (Professora 7, registro do Centro de Estudo da Escola S)

E, segundo relataram o diretor e a adjunta dessa escola, há uma dificuldade em captar novos professores para a Escola S,

Porque tem que ter o perfil. O perfil de lidar com os garotos. A pessoa tem que ter esse perfil. A gente percebe... (Trecho da entrevista com o Diretor, Escola S)

Assim, parece haver um cuidado com esse professor quando chega à escola, para que ele se adeque à realidade da escola e possa permanecer.

Tem aqueles que são concursados e que vem pra cá, fez concurso, foi escolher a escola, veio... aí não tem jeito. A gente tem alguns assim. Aí esses a gente tenta trazer. Tenta, conversa, traz para conversar. (Trecho da entrevista com o Diretor, Escola S)

Em um espaço onde a acolhida já era um traço marcante do clima organizacional, o Diretor apresenta um perfil acolhedor (possivelmente reforçado pelo contexto vivenciado), atendendo as expectativas nas relações com alunos e professores. Ouvindo a relevância dada pelos professores à este aspecto e considerando o contexto da escola, torna-se mais fácil entender porque o Diretor foi predominantemente reconhecido como "acolhedor". Sobre esta adequação do perfil do diretor ao contexto da escola, Urick e Bowers (2014) argumentam:

os diretores mediam as informações sobre o contexto escolar, tais como as políticas de responsabilização de seu distrito, as características e história dos professores e alunos, entre outras, para decidir a direção de sua liderança na escola. (p. 122, minha tradução)

Ter um perfil mais disciplinador ou mais acolhedor não exclui, como foi discutido anteriormente, as outras características da gestão escolar nas unidades pesquisadas. Presenciamos várias situações em que a Diretora da Escola L demonstrou ter uma relação próxima com seus professores e de acolhida aos alunos: conversando animadamente com os professores antes do início das aulas, preparando uma mesa de lanche para os 
professores no dia da reunião de Centro de Estudos, recebendo os alunos na porta e cumprimentando-os pelo nome, conversando espontaneamente com os alunos na hora do recreio. Como ela mesma frisou em sua entrevista, ela vem construindo esta relação com os alunos ao longo dos anos, de forma que os alunos do $9^{\circ}$ ano são bastante próximos à ela:

Mas eu também sento para conversar com eles, entendeu? $O$ aluno do $9^{\circ}$ ano é aquele que já ficou com você 9 anos, que já te conhece só no olhar: "Posso falar com você?", "Pode, meu filho! Entra â̂", então a gente conversa como se fosse colega mesmo, vem, beija. Então tudo isso para eles era muito importante, é o mundo deles. (Trecho da entrevista com a Diretora, Escola L)

E, com os professores, procura ser uma referência e um apoio para eles, ressaltando o bom clima da relação, ainda que a cobrança esteja presente em sua fala:

O professor é o aluno, ele quer ser visto, ouvido, cobrado, [...] o professor sente falta disso, de ter alguém do lado dele, cobrando também a produção dele, elogiando ele, criticando construtivamente ele.

Eu gosto, eu me sinto muito bem, é vendo as pessoas satisfeitas, conversando com os amigos, somos amigos, profissionais, fizemos um concurso para estar aqui, ninguém entrou aqui de graça, pela janela, estudamos muito para chegar onde nós estamos, sofremos muito, professor ele sofre muito, ele se angustia muito. (Trecho da entrevista com a Diretora, Escola L)

Na Escola S, além da boa relação com os alunos, foram observadas inúmeras situações em que o Diretor interveio em conflitos ou situações de indisciplina. Em algumas delas, precisando alterar a voz e ameaçar alunos de serem suspensos ou mesmo encaminhados à outra escola. Em outras, acompanhou professores em suas reprimendas aos alunos, escutando e reforçando a fala dos professores ou atuou diretamente em sala de aula. Em uma ocasião, o Diretor passa na sala do $6^{\circ}$ ano onde a professora de Português estava dando aula e pede ordem aos alunos, muda alguns de lugar, diz para um aluno que se não melhorar seu comportamento será suspenso.

Após o recreio, constantemente, o Diretor e a Adjunta da Escola S se ocupam em solicitar que os alunos se dirijam para suas salas, seja através do sistema de som da escola ou pessoalmente. Em algumas situações, eles sobem para os corredores das salas de aula e cuidam para que os alunos não fiquem transitando ou deixem de ir para a sala. Vale registrar que, apesar de dedicar boa parte de seu tempo para cuidar de questões disciplinares ou da organização do ambiente, o Diretor deixa, em alguns momentos, prevalecer a flexibilização das regras. Como exemplo, podemos citar a prática dos alunos mais velhos da Escola $\mathrm{S}$ de permanecerem na antessala da direção conversando após o recreio, ou de abraçarem o Diretor encaminhando-o para o caminho oposto às salas de 
aula, em uma clara estratégia de estender o tempo fora de sala. Em outra situação, quando alguns alunos estavam controlando a "Rádio-Escola" no sistema de som interno, após o término do recreio o Diretor solicitou que desligassem a música para tocar o sinal e os alunos insistiram em continuar, conseguindo prolongar o recreio por mais de 10 minutos. Nessas e em outras situações foi possível perceber que a atenção às questões disciplinares está presente na gestão da Escola S, contudo, há uma prevalência das "chances até mesmo quando não deve dar", como considerou uma de suas professoras. E há ainda uma questão estrutural: a escola conta com 2 inspetores que não são profissionais condições de cuidar da disciplina dos alunos (um tem um comprometimento visual e acaba realizando as tarefas de porteiro e auxiliar; o outro não consegue interagir com os alunos para as intervenções necessárias, criando mais atritos do que resolvendo). Profissionais que foram, também, acolhidos em suas dificuldades, mas que deixam para a equipe de direção da escola tarefas que lhes caberiam.

Nas Escolas L e S, acolher e disciplinar não são objetivos excludentes no trabalho da direção. Somam-se a estes, as questões administrativas, pedagógicas e externas à escola. As demandas e o contexto de cada uma das escolas, acrescidas das características pessoais dos diretores, moldaram perfis de gestão que tenderam mais às relações pessoais e à construção do clima escolar, seja disciplinando ou acolhendo. Equilibrar as diferentes demandas no trabalho de dirigir uma escola não é uma tarefa fácil. Em seu levantamento de pesquisas sobre o trabalho do diretor escolar, Spillane e Lee (2014) sintetizam uma série de estudos que apontam o caráter de fragmentação, urgência e multiplicidade que ele pode apresentar. Os autores destacam que a tarefa requer longas horas de trabalho contínuo, lidando com demandas de diversas frentes.

Uma das questões do Survey GESQ 2014 foi elaborada para tentar captar a tendência da liderança do diretor através da identificação de sua principal meta de trabalho. A partir da categorização dos dados, a meta escolhida pelos diretores destas duas escolas estavam relacionadas à gestão administrativa (Escola L) e à gestão pedagógica (Escola S). Os dados coletados na pesquisa qualitativa, contudo, mostraram a relevância de outros aspectos da liderança destes diretores, voltados para a organização do ambiente e para as relações na escola. Possivelmente, as principais metas que consideram para o seu trabalho não estavam explícitas nas opções do item (Anexo 10, questão 4) ou houve uma tendência a escolher uma resposta socialmente desejável, como já foi comentado na construção do instrumento. Para ampliar a capacidade de mensuração deste item sugerimos a inserção de três outras opções de resposta:

4.10 Manter a disciplina e a organização da escola.

4.11 Garantir que os alunos da escola se sintam acolhidos. 
4.12 Outra:

Ao identificar sua principal meta de trabalho, o diretor está explicitando sua concepção de educação e da escola. Como ressaltaram Medeiros e colegas (2014), é possível pensarmos em uma relação entre o que pensam os gestores escolares sobre a função educacional da escola, as suas atividades e os resultados de aprendizagem dos alunos. Com efeito, outros estudos apontaram a importância de se ter metas claras na condução da gestão escolar (BOYD et al., 2011; HULPIA et al., 2011; MAYER et al., 2013; entre outros).

Finalmente, é importante lembrar que o trabalho da gestão escolar é, na rede municipal de ensino do Rio de Janeiro, desempenhado por uma equipe composta de Diretor, Adjunto e Coordenador Pedagógico, ainda que o primeiro seja quem responde pela escola. Cada unidade conta também com secretário (s), inspetor (es) e professores readaptados (professores que foram afastados da sala de aula mas não aposentados, que desempenham funções diversas na escola). Estas equipes devem trabalhar, sob a gestão do diretor, a partir de uma meta comum, a ser conhecida e adotada por estes atores.

\section{3 \\ O direito de aprender: qual o olhar do diretor?}

Uma das questões centrais propostas por esta pesquisa se referia às intervenções pedagógicas do diretor em sua relação com os professores. Um bloco de questões (para professores e diretores) foi elaborado, para tentar captar informações sobre a atuação do diretor no que se refere ao trabalho pedagógico do professor com vistas a favorecer a aprendizagem dos alunos. Os dados coletados no survey possibilitaram a criação do Índice de Intervenção Pedagógica do Diretor (percebida pelos professores), que apresentou associação positiva à Proficiência Média em Matemática e associação negativa ao Índice de Satisfação no Trabalho. Assim, vale a pena retomar os dados referentes às respostas dos diretores e dos professores para estas questões nas duas escolas analisadas.

$\mathrm{Na}$ percepção dos diretores das duas escolas, sua intervenção pedagógica é praticamente nula. As respostas individuais que deram para os itens que compõem o índice apontam que, nas duas escolas, os diretores nunca ou raramente assistem aulas, sugerem práticas pedagógicas para os professores ou outras situações de intervenção pedagógica. 
Com relação à percepção dos professores, as respostas para os itens que compuseram o índice revelam resultados semelhantes nas duas escolas (considerando as médias para cada item). Apenas na primeira opção, que se referia à prática do diretor de assistir às aulas ou parte delas, a média de frequência ficou entre às vezes e frequentemente. Para todas as outras possíveis intervenções pedagógicas do diretor, a resposta dos professores foi, em média, raramente ou nunca.

De fato, durante o período de observação nas escolas, poucas foram as intervenções com objetivo pedagógico entre o diretor e seus professores. Os quadros 21 e 22 apresentados, ao sintetizar todas as situações de interação entre os diretores e os professores em cada ambiente, apontam a predominância de questões disciplinares ou de ordem prática como centrais nestas interações.

Ainda que consideremos que outros integrantes da equipe possam se ocupar das questões pedagógicas e de aprendizagem dos alunos, consideramos importante compreender qual é a percepção dos diretores sobre o ensino que a escola oferece e sobre a aprendizagem de seus alunos. A ênfase dada à aprendizagem dos alunos é uma característica da Liderança Instrucional, uma das tipologias destacadas nas pesquisas norte-americanas sobre ao trabalho do diretor escolar. Os líderes instrucionais, naquele contexto, têm como prioridade trabalhar junto com os professores, enfatizando o currículo e a aprendizagem dos alunos. (URICK \& BOWERS, 2014, p. 101). Entretanto esta não foi uma característica predominante na gestão das Escolas L e S, ainda que os dois diretores tenham apresentado diferentes abordagens sobre a função de ensinar, expressas em seus discursos e práticas. Nas entrevistas, os diretores foram interrogados sobre o foco da aprendizagem na sua escola e sobre suas contribuições para a aprendizagem dos alunos, entre outras questões (ver Roteiro da Entrevista com o Diretor, Anexo 8). Na Escola L, a Diretora exemplificou a atuação de sua equipe priorizando, especialmente, a avaliação da aprendizagem:

Porque a Coordenadora Pedagógica, ela aplica as provas e digita, ela já tira as planilhas e aí já dá para você fazer um comparativo. Pra me dar um mapa [...] nós pontuamos e mostramos onde está mais fraco, onde nós temos que atuar.

[...] Eu costumo colocar para os professores o seguinte: "o que eu puder oferecer para vocês, é só me pedir", eu não dificulto, eu sou elemento facilitador do professor, então eu não dificulto o trabalho dele.

Eu participo dos COC's ativamente. Nós fechamos média juntos, eu e os professores.

Tenho professores que carregam mais a mão na caneta vermelha, e outros que aliviam mais, mas é aquela questão: "O aluno aprendeu? Você está em sala de aula, você está vendo. Não adianta você me mostrar um papel com um mar de nota vermelha ou com o céu azul, não adianta, não adianta. Mas ele aprendeu?", aí 
quando o professor [fala]: "Ah, coitadinho, mas ele é esforçado, né?", "Mas ele aprendeu com o esforço dele? A minha pergunta é essa, eu quero a resposta para essa pergunta. Ele aprendeu com o esforço dele? Ele alcançou o mínimo desejado? Ele sabe se expressar? Ele sabe se comunicar? Ele lê, ele interpreta?", "Não!", "Então ele não alcançou, então ele não pode passar de ano". [...] mas às vezes você tem, você tem esse professor que ele é mais mãezona e aí ser mãezona faz mal ao aluno, tem que ter aquele meio termo. (Trechos da entrevista com a Diretora, Escola L)

Sobre os resultados de sua escola nas avaliações externas, a Diretora da Escola L é consciente dos avanços e desafios de suas metas, dando prioridade à aprendizagem dos alunos:

Eu não me preocupo muito com a questão do prêmio não ${ }^{96}$. Eu me preocupo se o meu aluno aprendeu. Vocês, às vezes, para alcançar uma meta, você mascara algum resultado e eu digo pra mim o seguinte: "Nós vamos ganhar por merecimento e não por fingimento!", ano passado nós ganhamos por merecimento. (Trecho da entrevista com a Diretora, Escola L)

Na Escola S, de acordo com a Adjunta, o maior desafio que encontraram ao assumir a gestão foi "fazer uma escola mais feliz" e o apoio dado ao professor nas questões pedagógicas está relacionado ao planejamento de eventos:

\begin{abstract}
Primeiro eu combino com os professores, eu faço uma reunião com os professores: "Vamos fazer um evento tal, o que vocês acham? Quais são as propostas?". E, baseado no que os professores também pensam, aí a gente monta alguma coisa, monta, por exemplo, uma feira cultural, uma festa junina, uma festa de dia das mães, a gente gosta de fazer eventos aqui._São trabalhos sempre contextualizados, a gente sempre trabalha essa contextualização, o que está acontecendo, a gente jogo para esse aluno. As feiras culturais, tudo né... (Trecho da entrevista com a Adjunta, Escola $S$ )
\end{abstract}

$\mathrm{Na}$ entrevista com o Diretor e a Adjunta, as questões relacionadas à aprendizagem dos alunos e ao trabalho pedagógico desenvolvido na escola foram abordadas brevemente. As respostas para as questões citadas acabavam desviando de foco, recuperando o tema da inclusão ou acolhida dos alunos indisciplinados:

Varia [o nível de aprendizagem dos alunos]. Você tem alunos aqui... esse menino, inclusive ele era bom, muito bom, ele estava atrasado, turma de projeto, já tinha sido preso inclusive, e... mas era um bom aluno. A gente teve, por exemplo, agora aqui problemas de... foram cinco alunos que eles se juntaram e fizeram uma gangue dentro da escola ... (Trecho da entrevista com a Adjunta, Escola S)

\footnotetext{
${ }^{96}$ A diretora se refere à política de responsabilização (com ênfase na bonificação) adotada pela SME/RJ e descrita na Introdução deste trabalho.
} 
Durante a entrevista a impressão era de que a aprendizagem curricular era uma questão secundária para os entrevistados. E esta percepção parece ser também a dos professores, como pôde ser observado no comentário:

Eu às vezes esqueço completamente o conteúdo pra tá conversando mesmo, pra tá mostrando pra eles coisas que eles precisam, pra eles verem que eles não precisam ir por aquele caminho, pra aquelas coisas... Eles têm outros caminhos, que eles podem fazer outras coisas... (Trecho da entrevista com o Professor 2, Escola S)

No que se refere ao planejamento e organização da rotina escolar, o Diretor da Escola S comentou, no início do Centro de Estudos, que o COC do primeiro bimestre não havia sido feito. De acordo com ele e com os comentários dos professores, o tempo da reunião foi utilizado para resolver questões emergenciais da escola. Alguns professores queixaram-se do ocorrido, uma vez que o Conselho de Classe é o fórum privilegiado para a discussão e avaliação conjunta da aprendizagem dos alunos. $\mathrm{O}$ fato de não ter ocorrido no primeiro bimestre trouxe, como consequências, problemas na síntese da nota global dos alunos (que deveria ser feita com a presença de todos os professores) e pendências a serem discutidas sobre o rendimento coletivo e individual.

Em entrevista, os diretores da Escola $\mathrm{S}$ apresentaram sua percepção sobre os resultados da escola nas avaliações externas e a dificuldade em lidar com as faltas constantes de professores, trazendo como consequência alunos sem aula:

A escola é uma escola de inclusão, a gente recebe muitos alunos fracos, que vem de outras escola, então o nosso IDEB não é um IDEB alto, não é um IDEB alto e... estou sendo muito sincera. E a gente... não vou falar que a gente tem uma preocupação imensa em aumentar esse IDEB. Não vou dizer que a gente... não, não tem. A gente quer que o aluno aprenda, a gente utiliza os mecanismos pedagógicos que a gente pode... (Trecho da entrevista com a Adjunta, Escola S)

O professor pega uma licença de dois meses, e o aluno fica sem aula, não tem outro. Não tem. Fica sem aula. A gente não tem condição de ficar entrando, né? Então é complicado... (Trecho da entrevista com a Adjunta, Escola S)

As crianças ficam sem aula. A gente acaba arrumando um esquema aqui, interno... Ficaram aqui sem aula, a gente bota totó... e ficaram numa tranquilidade. Quer dizer, em outro momento isso aí geraria um tumulto, porque estão à toa, não estão fazendo nada. (Trecho da entrevista com o Diretor, Escola S) 
A questão da falta de professores é um problema real e complexo para a gestão escolar $^{97}$. A forma de lidar com essa questão depende, em grande parte, da equipe de apoio disponível na escola (uma vez que a SME/RJ não disponibiliza professores substitutos para os professores licenciados) e dos arranjos e iniciativas dos gestores. Mas, nem sempre os diretores contam com uma equipe completa ou preparada para auxiliá-lo, como destacou Paes de Carvalho (2013, p. 141) a partir dos dados de pesquisa realizada na mesma rede de ensino:

Possivelmente o exíguo apoio administrativo e pedagógico disponível nestas escolas se expresse numa atribuição de funções nem sempre clara e muitas vezes demasiado concentrada na própria diretora, tornando provavelmente sua liderança e capacidade de gestão ainda mais vital para a manutenção do trabalho pedagógico.

Neste sentido, uma prática que nos chamou a atenção para lidar com problemas de falta de professores, foi acompanhada no período de shadowing realizado na Escola L:

Sentada em sua mesa, a diretora preenche um caderninho onde cola tabelas de horário diário com cinco tempos de aulas para cada turma da escola. As aulas a serem dadas estão em branco e ela completa a tabela à lápis, consultando o horário fixo de cada turma. Às vezes para, pensa, consulta a tabela de horário dos professores. Ela me explica que faz isso diariamente: a partir das licenças ou reuniões já agendadas dos professores na CRE, reestrutura as grades de horários na véspera, remanejando as aulas dos professores ausentes para colegas que estariam em horário vago, para que nenhuma turma fique sem aula. Cita o exemplo de um professor que avisou que faltará amanhã devido à uma audiência. No início da aula os professores consultam esse caderninho e, também, o inspetor passa avisando as alterações. (Trecho do registro Shadowing a Diretora, Escola L)

Em um dos dias de observação, antes do início do horário escolar, a Diretora passou na sala dos professores com o caderninho de horários na mão e cumprimentou os professores que já estavam lá. Ao voltar para a sua sala, comentou com a Adjunta: “Graças a Deus, está todo mundo aí!". Parece haver uma preocupação cotidiana com o fato de que todos os alunos estejam realmente tendo aulas enquanto estão na escola. Usando a terminologia adotada por Slavin (2003), a direção da escola estaria se preocupando em garantir que o tempo alocado para as atividades acadêmicas dos alunos estivesse assegurado. Com efeito, durante nossa permanência na Escola L, em diferentes dias e horários, não presenciamos alunos sem aulas no pátio durante o horário de aula. $\mathrm{A}$ própria Diretora estava substituindo (por tempo indeterminado) uma professora de geografia no $9^{\circ}$ ano, apesar de ser licenciada em Pedagogia. Como ela mesma

\footnotetext{
${ }^{97} \mathrm{Em} 2013,47,7 \%$ dos diretores das escolas públicas brasileiras testadas pela Prova Brasil afirmaram terem vivenciado, naquele ano, inexistência de professores para alguma série (sendo que $18,5 \%$ afirmaram que foi um problema grave). (Fonte: INEP, 2015)
} 
argumentou, era "preferível garantir que eles estivessem lendo a matéria e fazendo os exercícios do que deixá-los à toa" (Trecho do registro Shadowing a Diretora, Escola L). Esta preocupação é compatível com o encontrado por Paes de Carvalho (2013) ao sintetizar as características da gestão de escolas públicas de sucesso na rede municipal do Rio de janeiro. Segundo a autora, chamou a atenção "a defesa aguerrida da garantia das aulas", sendo comum que diretores ou coordenadores substituíssem professores faltosos, mesmo que deixando outras atribuições de lado. O aproveitamento do tempo escolar para atividades de cunho realmente acadêmico é uma dos fatores-chave para a eficácia escolar:

Vários estudos mostraram correlações entre o foco em ensino e aprendizagem e a eficácia da escola e do professor. Em alguns casos, esse foco tem sido definido através da quantificação do uso tempo do aluno e do professor e, em outras, tem sido definido em termos de medidas alternativas da concentração da escola no processo de aprendizagem e no desempenho. (SAMMONS, 2008, p. 359-360)

No caso da Escola S esta é uma preocupação ainda em construção. O Diretor e a Adjunta tentam fazer com que os alunos estejam em sua sala de aula nos horários de entrada e após o recreio. Porém, uma conjunção de fatores dificulta esta organização: turmas sem professores cujos alunos permanecem no pátio ou quadra por um ou mais horários; insuficiência de profissionais para auxiliar no contato com os alunos; ausência de uma rotina organizacional (horários distintos para cada segmento subir para a sala ou formação de filas com os alunos menores, porexemplo). Como resultado, parece ser constante a dificuldade em concluir esta tarefa, fazendo com que os alunos percam vários minutos de aula, diariamente. Um dos desafios apontados pelas pesquisas em eficácia escolar sintetizadas por Sammons (2008) foi, justamente, a maximização do tempo de aprendizagem. Para tanto, é necessário que professores e auxiliares administrem a transição entre aulas de forma ativa e eficaz (op. cit., p. 360)

Neste capítulo procuramos apresentar as informações coletadas na pesquisa qualitativa realizada em duas das escolas que participaram do survey aplicado por esta pesquisa. Esta imersão qualitativa buscou aprofundar nossa compreensão sobre os resultados encontrados no Survey GESQ 2014. Conforme afirmou Brandão (2013) ao apresentar a metodologia de trabalho de seu grupo de pesquisa, a articulação entre um survey e um trabalho de campo possibilita diferentes "tomadas de cena da realidade social, mais compatíveis com o caráter complexo dos fenômenos estudados no campo da Sociologia da Educação" (p. 16). Considerando nossa proposta de ampliar as possibilidades de acessar as informações sobre o tema em estudo através da criação e testagem de novos instrumentos de pesquisa, voltar ao campo nos ofereceu a 
oportunidade de pensar em como estes instrumentos poderiam ser aprimorados. Ao longo do capítulo apresentamos algumas sugestões de itens a serem incorporados aos questionários, ampliando e refinando as possibilidades de acesso às informações em pesquisas futuras. Certamente, estes itens ainda necessitam ser testados, tanto em sua formulação quanto em sua operacionalização - tarefas para um futuro próximo.

No que se refere ao aprofundamento das questões levantadas pela pesquisa e investigadas pelo survey, encontramos características do trabalho do diretor, reconhecidas pelos professores, que não havíamos considerado detalhadamente nos questionários propostos. Ter um perfil predominantemente disciplinador ou acolhedor foram características importantes no reconhecimento da liderança do diretor, estando relacionadas com o tipo de interação que ele estabelece com sua equipe de trabalho. No caso da Escola L, o perfil disciplinador da diretora foi um importante e frequente fator reportado como determinante na satisfação do professor no trabalho. Ainda que o trabalho da gestão escolar não tenha efeito direto nos resultados de aprendizagem dos alunos (LEITHWOOD, 2009), vimos que, na amostra selecionada, o reconhecimento do trabalho da direção escolar e a satisfação do professor no trabalho foram fatores associados positivamente com os resultados de aprendizagem dos alunos.

Considerando que a variável sociodemográfica (NSE) foi isolada na escolha das duas escolas, passamos a tentar compreender como estes fatores escolares poderiam ser determinantes na variância dos resultados dos alunos entre elas. Para além do trabalho do diretor escolar na construção de um clima adequado para a aprendizagem dos alunos, que será retomado nas considerações finais, destacamos as diferentes formas dos educadores lidarem com o contexto em que atuam nas duas escolas. Como foi dito, as duas unidades atendem predominantemente alunos oriundos de complexos de favelas com contexto social e de segurança bastante complicados. A Diretora da Escola L, muito provavelmente em decorrência de sua origem (foi criada em uma das comunidades atendidas pela escola), tem um olhar sobre a realidade dos alunos que reflete sua crença no poder de mudança social através da educação escolar. Utilizando como exemplo sua própria história, deixa claro que espera dos alunos o melhor que eles podem dar, e que ninguém “os chame de coitadinhos! Eu odeio essa palavra!" (Trecho da entrevista com a Diretora, Escola L). A diretora ressalta que alguns alunos da escola foram selecionados para o Colégio Pedro II, para o Cap-UERJ e para a Fundação Oswaldo Cruz, como exemplos desta superação da origem social. Os professores também costumam destacar os resultados da escola nas avaliações externas e a aprovação de seus alunos em colégios considerados academicamente fortes, ressaltando o trabalho que realizam: 
Nós temos alunos aqui que foram, vão pro Pedro II. Muitos alunos nossos passam no Pedro II. Pedro II, Colégio Militar... Então, por quê? Porque nós procuramos dar mais subsídios pra ele, porque se nós ficarmos somente no que eles [SME] querem...

[...] É aonde está a diferença da L pras outras escolas, porque nós cobramos presença dos nossos alunos. Nós cobramos o estudo da criança, nós cobramos. (Trecho da entrevista com a Professora 4, Escola L)

A Escola $\mathrm{S}$ atende a uma clientela com perfil socioeconômico muito próximo ao da Escola L, que também experimenta a intrincada realidade territorial dos complexos de favelas do Rio de Janeiro. Os educadores da Escola S, contudo, parecem ter um olhar menos esperançoso para o futuro acadêmico de seus alunos. O discurso que encontramos estava muito preso às limitações e defasagens dos alunos, uma possível vitimização de sua condição:

A escola é pesada, é punk... a realidade que lidamos aqui... (Diretor) O problema é a matéria prima com que a gente lida, vêm do pântano e nunca chegarão a lótus (Professor 8)

[...] O P10 pede a palavra e comenta que os alunos das séries finais estão com pouca ambição de ir para o Ensino Médio, tem pouco vínculo com o estudo. (Trechos do registro do Centro de Estudos, Escola S)

E aí você tem que acabar se conformando de que aquele teu aluno, você vai estar preparando ele para a vida, mas você vai... você consegue ver que ele não vai chegar lá no finalzinho. Agora que tem aquela pergunta também que eu sempre me faço: "O que ele quer para a vida dele?" Tem gente que almeja uma faculdade, não sei o quê, para essa criança, e poucos chegam lá. Mas, ele quer isso para vida dele? [...] e a gente sabe que esse caminho dele vai ser outro. Que ele não vai chegar lá, mas se ele chegar feliz, se ele chegar com sucesso dentro da área dele... (Trecho da entrevista com o Professor 1, Escola S)

Quanto aos resultados nas avaliações externas e a dificuldade de atingir as metas de desempenho estipuladas, a fala da equipe de direção da Escola $S$ parece justificá-los com o argumento de serem uma escola "inclusiva".

Ainda que reconheçamos que a origem socioeconômica dos alunos é o principal fator a determinar a diferença de resultados acadêmicos entre as escolas, vários estudos já mostraram que os fatores intra-escolares podem minimizar este efeito social (CREEMERS and REEZGIT, 1996; SAMMONS, 2008; BROOKE e SOARES, 2008). A pesquisa qualitativa desenvolvida e apresentada neste capítulo ajudou a ampliar a percepção sobre a importância da construção de um clima acadêmico adequado à aprendizagem, que inclui as relações estabelecidas entre diretores e professores e, certamente, as habilidades de acolher e disciplinar, sem perder de foco o objetivo da escola: ensinar a todos. 


\section{8 \\ Considerações finais}

A questão central desta pesquisa abordou as possíveis relações entre as características do trabalho do diretor, as percepções dos professores sobre o clima escolar e o desempenho dos alunos. Entendendo a escola enquanto organização social, procuramos desenvolver o estudo de forma multifocalizada pois, como indica Lima (2001, p. 94) "as organizações são sempre as pessoas em interação social". Desta forma, a questão colocada apontava na direção de uma teia relacional que, além de envolver diferentes atores em diferentes contextos, está sujeita a determinações externas. Como aponta o mesmo autor, os sujeitos na escola não desempenham somente um papel préestabelecido cumprindo regras e hierarquias, mas dispõem de margens de autonomia relativa (LIMA, 2001, p. 94).

Foi nesse sentido que buscamos entender as diferentes formas de atuação dos diretores escolares em uma mesma rede de ensino, imersos na mesma política educativa. Os diretores das 42 escolas selecionadas nesta pesquisa estão inseridos no mesmo contexto político, sujeitos às mesmas regulamentações e decretos, participam das mesmas reuniões nos órgãos centrais e se comprometem anualmente a cumprir as metas de desempenho estabelecidas pela SME/RJ. Ainda que consideremos a estrutura da rede municipal que conta com 11 Coordenadorias (o survey contemplou escolas de 3 CREs, como foi explicitado), atuando como instâncias intermediárias entre a SME/RJ e as escolas, o cargo da direção escolar segue a mesma referência legal em toda a rede (SECRETARIA MUNICIPAL DE ENSINO DO RIO DE JANEIRO, 1998; 2010; 2011; 2013) No entanto, a forma como cada diretor conduz a gestão de sua escola difere bastante e, ao assumir diferentes demandas a frente da escola, o diretor assume, também, múltiplos papéis. Souza (2006) aponta esta multiplicidade de papéis do diretor como uma estratégia de sobrevivência:

[...] vimos que os diretores atendem aos interesses dos diferentes segmentos como estratégia política de sobrevivência, modificando inclusive suas aparentes concepções para se conservar no centro da cena política. Atender aos interesses dos superiores hierárquicos e aos da comunidade escolar faz parte desse jogo político (op. cit., p.281)

Esta pesquisa propôs uma reflexão sobre as características do trabalho do diretor escolar, levantando a hipótese de que algumas tarefas, posicionamentos e iniciativas do diretor influenciam diretamente o clima escolar, interferindo no trabalho do professor. A revisão de literatura e o levantamento das recentes pesquisas desenvolvidas sobre o tema, 
apontaram que, no âmbito nacional, foram poucos os trabalhos que se dedicaram a estudar a gestão escolar, especialmente aqueles que relacionaram o trabalho do diretor ao trabalho dos professores na escola. E, entre estes, a presença de estudos quantitativos é ainda escassa. Além da pouca tradição, no Brasil, de estudos quantitativos na área educacional ${ }^{98}$, é preciso considerar o levantamento e a disponibilização dos dados referentes ao tema. Apesar de contarmos atualmente com extensa disponibilização de dados educacionais (incluindo os Censos Escolares e as edições da Prova Brasil), encontramos limitações para a mensuração dos aspectos relacionados à gestão escolar através dos instrumentos disponíveis, como foi apresentado detalhadamente no Capítulo 4. Assim, propusemos a criação, testagem e aplicação de um novo instrumento de pesquisa que possibilitasse olhar para as especificidades da rotina escolar com mais profundidade e abrangência (Survey GESQ 2014). Alguns itens foram especialmente pensados para captar a percepção dos respondentes sobre a liderança e o trabalho do diretor, favorecendo a criação índices e indicadores. Selecionamos, como campo de estudo, as 163 escolas municipais do Rio de Janeiro que atendiam aos dois segmentos do ensino fundamental, tendo a intenção de acessar um grupo maior e mais diversificado de professores e por considerar que estas escolas poderiam ter uma gestão mais complexa. O levantamento de informações sobre este grupo específico de escolas, que no caso do município do Rio de Janeiro tende a não mais existir, oferece a possibilidade de estudos comparativos futuros em contextos e organizações escolares distintas. Os questionários foram então aplicados à diretores, coordenadores e professores em uma amostra de 42 escolas da rede municipal do Rio de Janeiro. Considerando o retorno obtido, trabalhamos com uma subamostra de 27 escolas.

$\mathrm{Na}$ análise dos dados, o indicador criado para captar a tendência da liderança do diretor encontrou que, nas escolas pesquisadas, os diretores apresentam uma percepção distribuída de sua liderança, que abrange diferentes dimensões (pedagógica, relacional, administrativa ou de contexto externo) dependendo da situação (estabelecimento de metas de trabalho, predominância do tempo de dedicação à uma das dimensões, identificação de desafios na gestão escolar, definição do papel da escola). Esta percepção corrobora a "integração" de diferentes estilos de liderança apontada pelo trabalho de Urick e Bowers (2014), em seu estudo com uma amostra de 7650 de diretores nos Estados Unidos. Propondo uma reflexão sobre a tipologia de liderança comumente utilizada nos estudos norte-americanos, os autores ressaltam que os diretores escolares tendem a adotar a combinação de diferentes estilos de liderança ao desempenharem sua função (op. cit., p. 121).

\footnotetext{
${ }^{98}$ Sobre este tema, ver GATTI, 2004.
} 
Polon (2009) também destaca esta combinação de perfis de liderança em seu estudo sobre as características da gestão em escolas no Rio de Janeiro:

[...] há distintos perfis de liderança e estas distinções se fazem por processos de combinação e recombinação de prioridades em face de: a) as qualidades pessoais e profissionais dos diretores e membros da equipe; b) as pressões exercidas pelas demandas próprias às diferentes frentes de atuação existentes na escola, a saber aspectos políticos-pedagógicos, administrativo-organizacionais e humanorelacionais; c) as condições materiais da escola e o nível socioeconômico do público atendido; d) o tipo de rede de ensino em que se inserem, pelo fato de estas redes serem em grande parte determinantes de valores, códigos próprios e condições de trabalho e e) principalmente pela cultura institucional estabelecida (op. cit. p. 304).

Ao tentar identificar possíveis perfis de liderança na nossa amostra, nossa principal intenção foi observar as diferentes dimensões de liderança do diretor, especialmente aquelas relacionadas com uma gestão pedagógica, analisando se estavam associadas ao trabalho docente e aos resultados de aprendizagem dos alunos. Como indicador da aprendizagem dos alunos utilizamos a Proficiência média em Matemática do $5^{\circ}$ ano na Prova Brasil e como indicador do comprometimento do professor no trabalho utilizamos o Índice de Satisfação no Trabalho. Buscamos medir o nível de satisfação dos professores através dos itens propostos entendendo que 1) questões contextuais relacionadas ao trabalho do diretor e ao clima escolar interferem neste nível de satisfação (BARRÈRE, 2014; BOYD et al., 2011; BRITO \& COSTA, 2010); e 2) professores mais satisfeitos no trabalho desempenham sua função instrucional de forma mais comprometida (PRICE, 2012; GOULART JUNIOR \& LIPP, 2011).

Chamamos de "gestão pedagógica" as tarefas desempenhadas pelo diretor com enfoque na aprendizagem dos alunos, passando pela interação com os professores. Luck (2009) identificou a dimensão pedagógica da gestão escolar como um conjunto de "atividades-meio" que deve contribuir para a organização do trabalho coletivo na escola com vistas à melhoria dos processos de ensino e aprendizagem. Esta dimensão da gestão escolar apresenta características muito parecidas à Liderança Instrucional (Instructional Leadership), identificada em estudos norte-americanos como aquela que prioriza o trabalho junto aos professores para guiar o cumprimento do currículo e a instrução ${ }^{99}$ (URICK e BOWERS, 2013). Este estudo levantou a hipótese de que algumas tarefas do diretor poderiam compor uma "gestão pedagógica da escola" através da interação com os professores e, consequentemente, relacionar-se ao desempenho acadêmico de seus alunos.

\footnotetext{
${ }^{99}$ na tradução literal, podemos entender como ensino.
} 
A análise dos dados do survey não encontrou nenhuma associação significativa entre alguns dos índices criados abordando o tema (Índice Liderança do Diretor em questões Pedagógicas, Indicador de Liderança Pedagógica, Índice de Monitoramento da Aprendizagem) e o indicador de aprendizagem dos alunos. Apenas o Índice de Intervenção Pedagógica do Diretor teve uma associação significativa no modelo estimado $(\alpha=2,11$, pvalue $<0,05)$ tendo como variável dependente a Proficiência Média em Matemática - $5^{\circ}$ ano (tendo sido controlada a variável indicativa de NSE médio da escola). Na fase seguinte da pesquisa, os dados qualitativos construídos a partir da observação da rotina do diretor e dos relatos dos entrevistados mostraram que os diretores interagem pouco com os professores e, menos ainda, para tratar de questões relacionadas ao ensino e aprendizagem.

No que se refere à associação entre a "gestão pedagógica" do diretor e o nível de satisfação dos professores, para a qual tínhamos uma expectativa de relação positiva, encontramos um resultado inesperado no survey. Nas escolas da nossa amostra, o Índice de Satisfação do Professor no trabalho estava inversamente associado à percepção docente sobre as intervenções pedagógicas do diretor e à percepção docente sobre a interação do diretor com os professores. Como foi discutido no Capítulo 6, esse "efeito negativo" das intervenções e interações do diretor no nível de satisfação dos professores no trabalho pode estar relacionado à representação que constroem dos limites de atuação do diretor escolar.

Coloca-se então a hipótese de que os professores interpretam as intervenções pedagógicas dos diretores como uma forma de controle ou cerceamento da sua autonomia profissional. Polon (2009) destacou algumas tensões na condução da gestão pedagógica nas escola analisadas em sua pesquisa. A autora considerou que os professores identificavam a intervenção dos gestores como mediação das políticas educativas dos órgãos centrais, que os colocavam como "meros executores" de uma proposta pedagógica planejada em outra instância (op. cit. p. 300). Além desta relação com a representação de liderança e com a hierarquia das relações na escola, consideramos também como possibilidade para esta relação negativa, a percepção dos professores de que os diretores não oferecem insumos para sua prática pedagógica.

Entre os estudos nacionais há poucos que se dedicaram a estudar as relações entre diretores e professores, como foi apresentado em nossa revisão de literatura, e não encontramos nenhum que identificasse quais eram as intervenções pedagógicas do diretor e como os professores a percebiam. Contudo, em um estudo de caso, Oliveira (2012) relatou a dificuldade encontrada pela diretora adjunta e pela coordenadora pedagógica em introduzir mudanças metodológicas na condução do trabalho escolar devido à resistência de alguns professores. Entre os trabalhos recentes desenvolvidos nos Estados Unidos, um 
estudo realizado em 12 escolas (LOUIS et al., 2010) encontrou que 83,3\% dos diretores e apenas $37,7 \%$ dos professores consideravam que o monitoramento do trabalho dos professores em sala de aula (por parte dos diretores) ajudaria a melhorar a aprendizagem na escola. Em nossa pesquisa, visualizamos a possibilidade de ampliar a coleta de informações sobre este aspecto, propondo novas questões ao questionário dos professores.

De acordo com a análise dos dados do survey, a relação que pode ser estabelecida entre a gestão escolar e os resultados de aprendizagem dos alunos vai além da intervenção pedagógica do diretor. A percepção do ambiente escolar e a satisfação que os professores reportam em trabalhar na sua escola mostraram ser, também, preditores significativos para explicar a variação nos resultados acadêmicos das escolas. Os dados apontaram, ainda, que o nível de satisfação dos professores no trabalho está relacionado positivamente ao reconhecimento do trabalho da direção da escola e à percepção sobre o ambiente escolar, e negativamente às intervenções pedagógicas e à interação do diretor. Esta indicação corrobora os estudos de Shapira-Lishinsky e Tsemach (2014, p.676-677) sobre a associação entre uma liderança autêntica do diretor e importantes resultados (outcomes) escolares, entre eles, a satisfação no trabalho.

Nos dois modelos estimados a variável que se associou mais positivamente com o Índice de Satisfação no Trabalho e com a Proficiência Média em Matemática no $5^{\circ}$ ano foi o Índice de percepção do Ambiente Escolar ( $\alpha=0,27$, pvalue < 0,01 no primeiro caso; $\alpha=5,8$, pvalue $<0,05$ no segundo caso). Podemos inferir destes resultados exploratórios que trabalhar em uma escola onde se reconheça um ambiente adequado para o trabalho escolar é positivamente significativo para o sentimento de pertencimento do professor e para o desejo de continuar trabalhando naquela escola, traduzido no seu nível de satisfação. Da mesma forma, estudar em uma escola onde há esta percepção positiva do ambiente escolar é positivamente significativo para os resultados dos alunos. O esquema a seguir sintetiza os resultados encontrados na análise quantitativa dos dados: 
Figura 5: Síntese dos resultados do estudo exploratório. Survey GESQ 2014, Subamostra.

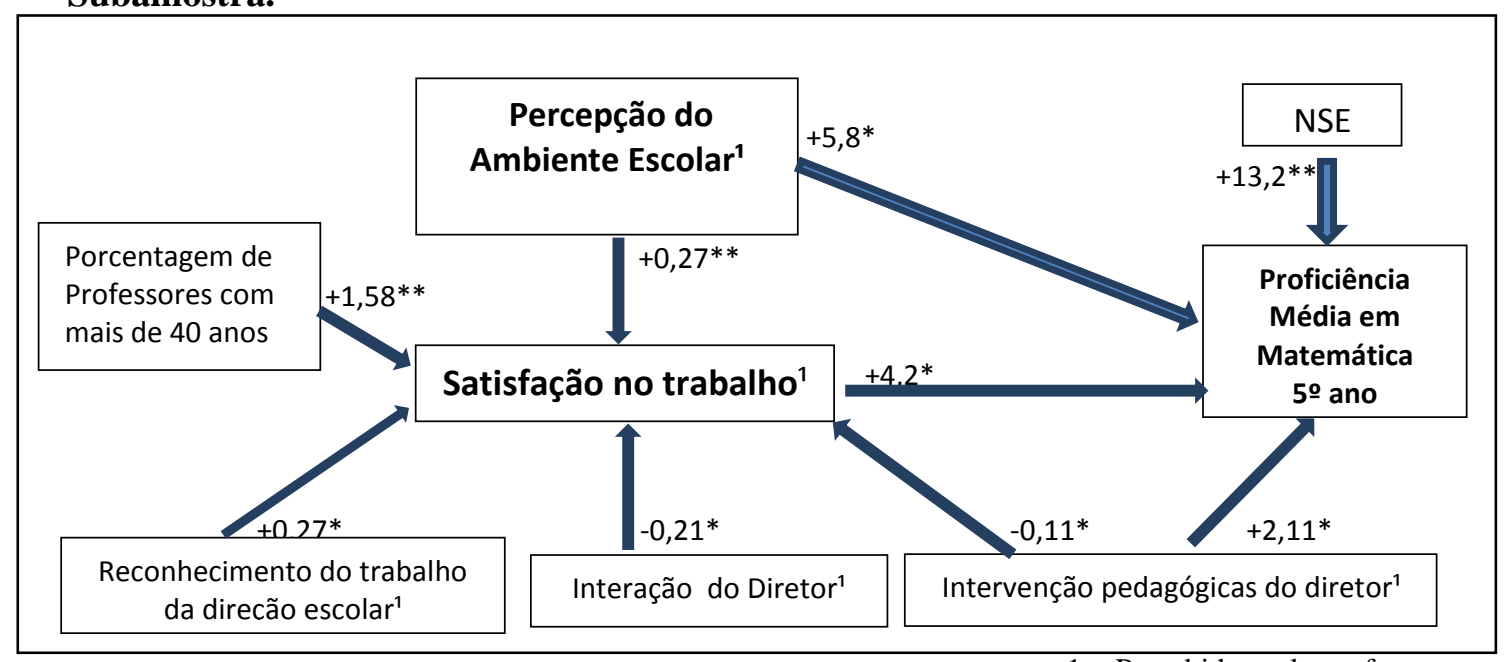

$1=$ Percebidos pelo professor

*.O coeficiente é significativo ao nível 0.05 (2-tailed).

**. O coeficiente é significativo ao nível 0.01 (2-tailed)

Elaborado pela autora.

Ainda que esses resultados não sejam representativos para a população (todas as escolas que atendem aos dois segmentos do ensino fundamental do município do Rio de Janeiro), é possível extrair deste estudo exploratório pistas significativas para a reflexão sobre as implicações das diferentes formas de gerenciar a escola. Metodologicamente é importante ressaltar que o estudo estatístico apresentado se limitou às possibilidades dos dados obtidos.

A volta ao campo após as análises estatísticas nos possibilitou ampliar a compreensão sobre as relações estabelecidas entre estas variáveis. Como se constrói a percepção de um ambiente adequado de aprendizagem? O que faz deste reconhecimento um fator influente para o desempenho de aprendizagem dos alunos, direta e indiretamente? O que é considerado, pelos professores, no reconhecimento da eficácia do trabalho da direção?

Através da atuação dos diretores em duas unidades escolares, selecionadas a partir de critérios previamente estabelecidos, identificamos que os professores (e os próprios diretores) reconhecem como característica principal do trabalho da direção aspectos relacionados à organização do ambiente escolar e às relações pessoais na escola (disciplinando ou acolhendo). Estes achados convergem com os resultados do estudo estatístico exploratório. Entre as diversas demandas que requerem do diretor uma flexibilização de papéis, as tarefas de disciplinar (na Escola L) e de acolher (na Escola S) foram reconhecidas como prioridades por seus diretores. Retomando a análise feita a partir do estudo quantitativo, poderíamos inferir que, nestas escolas, as características de 
disciplinar e acolher são importantes determinantes do reconhecimento do ambiente escolar que, por sua vez, tem um efeito direto e indireto no resultado dos alunos.

É fundamental que analisemos esses resultados sem buscarmos, contudo, uma relação causal entre eles. Inicialmente, é preciso problematizar o isolamento das características de NSE entre as escolas. Ainda que o indicador utilizado por esta pesquisa esteja em consonância com vários outros estudos que associam a escolaridade dos pais ao nível socioeconômico dos alunos, há uma infinidade de outros fatores referentes ao background social dos alunos que ficam de fora deste controle: a composição familiar, o efeito da vizinhança, o apoio e suporte dos pais ao estudo, entre outros.

No que se refere aos fatores escolares que poderiam ter um impacto positivo na aprendizagem dos alunos, priorizamos a gestão escolar. Ainda assim, como vimos, a própria dimensão do trabalho de gestão da escola tem inúmeras nuances e nem todas foram abordadas neste trabalho. $\mathrm{O}$ reconhecimento pela equipe docente de um ambiente escolar adequado para a aprendizagem, que está relacionado ao trabalho do diretor escolar, mostrou uma associação positiva com o resultado dos alunos nesta amostra e com o trabalho do professor (aqui medido apenas ao nível de satisfação).

Apesar disso, não podemos concluir que a diferença nos resultados entre as duas escolas seja decorrente dos diferentes perfis de liderança encontrados (e legitimados) nas escolas. Em primeiro lugar porque é impossível isolar a associação ou o efeito de cada elemento preditor para o resultado dos alunos. Em segundo lugar, porque esta pesquisa não trabalhou com a análise de valor agregado, ou seja, não foi feito um estudo longitudinal com controle inicial, para captar efeitos da atuação dos diretores em um determinado período de tempo. Tais pesquisas, utilizando procedimentos específicos para captar mudanças em um intervalo determinado e isolando o quanto possível as variáveis testadas, poderiam identificar com mais precisão, os efeitos da atuação do diretor para os resultados de aprendizagem de seus alunos. Assim, os resultados ora apontados não tratam de relações causais e determinísticas (que não caberiam em pesquisas nas ciências sociais) mas indicam importantes associações que merecem atenção e estudos posteriores.

Esta pesquisa teve um caráter metodológico e conceitual, propondo um novo instrumento de pesquisa ao campo e realizando um estudo exploratório a partir dele, a fim de buscar respostas para algumas de nossas questões. Nosso estudo exploratório se preocupou em realizar correlações e associações entre os índices criados. Encontramos no resultado da análise do survey associações significativas entre variáveis que se referem ao trabalho da gestão escolar. Tais associações nos remetem a uma retomada dos conceitos que nortearam nossa pesquisa: gestão, liderança e clima escolar.

Poderíamos dizer que identificamos uma combinação entre perfis de liderança e a atuação do diretor na gestão da escola, construindo um clima organizacional escolar 
favorável ao trabalho docente e à aprendizagem. Esta combinação de fatores atuando no interior da escola poderia compor o que Rutter e colegas (2008) chamaram de "efeito institucional". Ou seja, ainda que características do perfil de liderança do diretor ou determinadas tarefas que adote na condução da gestão da escola ou ainda características específicas do clima escolar atuem no nível de aprendizagem dos alunos, o "efeito combinado" destas especificidades (o ethos da escola) tem um poder de atuação mais poderoso.

Em seu estudo, publicado originalmente em 1979 (uma das reações ao Relatório Coleman e ao postulado de que a escola não fazia diferença na determinação das diferenças de aprendizagem dos alunos) os autores acompanham o trabalho de 12 escolas controlando as características iniciais ou de origem dos alunos. Os resultados reforçaram a tese de que as escolas fazem, sim, diferença sobre o desempenho e o comportamento dos alunos (o estudo utilizou como medida de resultado o comportamento dos alunos, a frequência, o sucesso nos exames e a delinquência juvenil). A variação dos resultados encontrada pelos autores estava fortemente associada às características das escolas enquanto instituições sociais.

Torna-se necessário, então, refletir sobre os conceitos de gestão, liderança e clima escolar enquanto integradores e não de forma isolada. No caso desta pesquisa, os dados pareceram indicar que a combinação de uma atuação presente do diretor especialmente na construção e manutenção de um clima adequado para a aprendizagem, e o seu reconhecimento enquanto líder são elementos importantes para a qualidade do trabalho docente e para a aprendizagem dos alunos. Entre as escolas analisadas, a manutenção da ordem e da disciplina na escola foi reconhecida como fundamental entre as tarefas do diretor.

Por fim, este trabalho procurou contribuir para a discussão sobre as características do trabalho do diretor e suas possíveis relações com o trabalho docente e a aprendizagem discente por três vias: 1) na realização de uma meta-análise, incluindo a revisão estruturada das recentes pesquisas sobre o tema; 2) da proposição e testagem de um novo instrumento de coleta de dados quantitativos sobre a gestão e o clima escolar; 3) da apresentação dos resultados de um estudo exploratório com os dados coletados, indicando importantes indícios para as questões levantadas. Sem a pretensão de esgotar o tema, este trabalho propôs ampliar a conversa, ampliar os olhares. 


\section{Referências Bibliográficas}

ABDIAN, G.; HERNANDES, E. Concepções de gestão e vivência da prática escolar democrática. RBPAE - Revista Brasileira de Política e Administração Escolar, v. 28, n. 1, p. 144-162, jan/abr. 2012.

AGRESTI, A.; FINLAY, B. Métodos estatísticos para Ciências Sociais. Porto Alegre: Penso, 2012.

AGUERRE, T. F. Clima organizacional en las escuelas: un enfoque comparativo para México y Uruguay. REICE - Revista Electrónica Iberoamericana sobre Calidad, Eficacia y Cambio en Educación, v. 2, n. 2, 2004. Disponível em: http://www.ice.deusto.es/rinace/reice. Acesso em 10 ago. 2012.

AGUIAR, G. Quem Ensina Matemática no Brasil? Um estudo dos perfis dos professores a partir dos dados do SAEB 1997 e 1999. Rio de Janeiro, 2001. Dissertação (Mestrado em Educação). Coordenação de Pós-Graduação, Pontifícia Universidade Católica do Rio de Janeiro.

ALERJ - Assembléia Legislativa do Estado do Rio de Janeiro, Notícias Online. Municipalização do ensino fundamental será concluída até 2015. Rio de Janeiro, 2011. Disponível em: http://www.alerj.rj.gov.br/common/noticia_corpo.asp?num=42228. Acesso em: 10 fev. 2015.

ALVES, F. Políticas educacionais e desempenho escolar nas capitais brasileiras. Cadernos de Pesquisa, São Paulo, v. 38, n. 134, ago. 2008. Disponível em http://www.scielo.br/scielo. Acesso em 15 ago. 2012.

ALVES, F.; ORTIGAO, I.; FRANCO, C. Origem social e risco de repetência: interação raça-capital econômico. Cadernos de Pesquisa, São Paulo, v. 37, n.

130, abr. 2007. Disponível em http://www.scielo.br/scielo. Acesso em 15 ago. 2012.

ALVES, F.; FRANCO, C.; RIBEIRO, L.C. Segregação residencial e desigualdade escolar no Rio de Janeiro. In: RIBEIRO, L. C. \& KAZTMAN, R. (Orgs) A cidade contra a escola: segregação urbana e desigualdades educacionais em grandes cidades da América Latina. Rio de Janeiro: Letra Capital, 2008.

ALVES,F.; LANGE, W.; BONAMINO, A. A geografia de oportunidades educacionais na cidade do Rio de Janeiro. In: RIBEIRO, L.C.Q.; KOSLINSKI, M.C.; ALVES, F.; LASMAR, C. (Orgs). Desigualdades urbanas, desigualdades escolares. Rio de Janeiro: Letra Capital: Observatório das Metrópoles: IPPUR/UFRJ, 2010.

ALVES, M.T.G.; SOARES, J.F. As pesquisas sobre o efeito das escolas: contribuições metodológicas para a Sociologia da Educação. Sociedade e Estado, Brasília, v. 22, n. 2, p. 435-473, maio/ago. 2007.

ALVES, M. T. G.; FRANCO, C. A pesquisa em eficácia escolar no Brasil: evidências sobre o efeito das escolas e fatores associados à eficácia escolar. In: BROOKE, Nigel; SOARES, José Francisco. (Orgs.) Pesquisa em eficácia escolar: origem e trajetórias. Belo Horizonte: Editora UFMG, 2008. 
ALVES, M.T. G.; NOGUEIRA, M. A.; MARTINS NOGUEIRA, C.M; RESENDE, T.F. Fatores Familiares e Desempenho Escolar: Uma abordagem Multimensional. Dados Revista de Ciências Sociais, v. 56, n. 3, p. 571 a 603, 2013.

ARRETCHE, M.T.S. Estado federativo e políticas sociais: Determinantes da descentralização. Rio de Janeiro/São Paulo: Revan/FAPESP, 2000.

ARRETCHE, M. T. S. Democracia, federalismo e centralização no Brasil. Rio de Janeiro: Editora FGV/Editora Fiocruz, 2012

BARRÈRE, A. Controlar ou avaliar o trabalho docente? estratégias dos diretores numa organização escolar híbrida. Revista Brasileira de Educação, Rio de Janeiro, v. 18, n. 53, jun. 2013. Disponível em http://www.scielo.br/scielo. Acesso em 13 fev. 2014.

BARROSO, J. A Administração Educacional e a Abordagem Sociológica das Organizações Educativas. In: BARROSO, J. Políticas Educativas e Organização Escolar. Lisboa: Universidade Aberta, 2005.

BARROSO, J. O Estado e a Educação: a regulação transnacional, a regulação nacional e a regulação local. In: BARROSO, J. (Org.) A regulação das políticas públicas de educação: espaços, dinâmicas e atores. Lisboa: Educa, 2006a.

BARROSO, J. A regulação interna das escolas: lógicas e actores. In: BARROSO, J. (Org.) A regulação das políticas públicas de educação: espaços, dinâmicas e atores. Lisboa: Educa, 2006b.

BARROSO, J. La direción escolar: tensiones em el presente, desafios para el futuro. Conferência proferida no III Congresso Ibero-Americano de Política e Administração da Educação. Zaragoza: Nov. 2012.

BOBBIO, N.; MATTEUCCI, N.; PASQUINO, G. Dicionário de Política. Brasília: Editora Universidade de Brasília, 12 $2^{\mathrm{a}}$ ed., 2004.

BOGDAN, R.; BIKLEN, S. Investigação qualitativa em educação. Porto: Porto Editora, 1994.

BONAMINO, A. M. C. Características da gestão escolar promotoras de sucesso. In: POLON, T. L. P.; BONAMINO, A. M. C.; PAES DE CARVALHO, C.; ALVES, F. Gestão do Currículo e Gestão e Liderança (Col. Gestão e Avaliação da Educação Pública, vol.3). Juiz de Fora: Editora do CAED, 2012.

BONAMINO, A. M. C.; SOUZA, S. Z. L. Três gerações de avaliação da educação básica no Brasil: interfaces com o currículo da/na escola. Educação e Pesquisa (USP. Impresso), v. 38, p. 373-388, 2012.

BONAMINO, A. M. C.; OLIVEIRA, L. H. G. Estudos longitudinais e pesquisa na educação básica. Linhas Críticas (Online), v. 19, p. 33-50, 2013.

BOURDIEU, P. Choses dites. Paris: Les Éditions de Minuit, 1987.

BOURDIEU, P. Sociologia. São Paulo: Ática, 1994.

BOURDIEU, P. Razões Práticas: sobre a teoria da ação. Campinas: Papirus, 1996. 
BOYD, D.; GROSSMAN, P.; ING, M.; LANKFORD, H.; LOEB, S.; WYCKOFF, J. The Influence of School Administrators on Teacher Retention Decisions. American Educational Research Journal, v. 48, n. 2, p. 303-333, 2011.

BRADBURN, N.; SEYMOUR, S.; WANSINK, B. Asking questions: the definitive guide to questionnaire design - for market research, political polls, and social and health questionnaires. San Francisco: Jossey-Bass, 2004.

BRANDAO, Z. Operando com conceitos: com e para além de Bourdieu. Educação e Pesquisa, São Paulo: v. 36, n. 1, Abr. 2010.

Introdução. In: XAVIER, A.; SILVA, M.L.C.Q.; BRANDÃO, Z. (orgs.)

Construção da Qualidade de Ensino: Achados e tensões de uma década de pesquisas. Rio de Janeiro: Forma e Ação Editora, 2013.

BRANDÃO, Z.; WALDHELM, A.P.S.; FELIPE, L.H.L. Sites escolares: uma nova estratégia na construção da imagem de excelência das instituições de ensino? Boletim SOCED, Rio de Janeiro: $n^{\circ}$ 6, p. 1-21, 2008.

BRASIL. Constituição Federal. Brasília, 1988. Versão atualizada disponível em: http://www.planalto.gov.br. Acesso em: 12 jun. 2013.

BRASIL. Lei de Diretrizes e Bases da Educação Nacional, Lei 9.394/96. Brasília, 1996. Disponível em: http://www.planalto.gov.br/ccivil_03/leis/19394.htm Acesso em: 08 mar. 2012.

BRASIL. Lei no 13.005, de 25 de junho de 2014. Plano Nacional de Educação. Aprova o Plano Nacional de Educação - PNE e dá outras providências. Disponível em: http://pne.mec.gov.br/ Acesso em: 08/04/2015.

BRASIL. Ministério da Educação, 2010. Programa Nacional Escola de Gestores da Educação Básica Pública. Curso de Especialização em Gestão Escolar (Projeto de Curso). Disponível em: http://portal.mec.gov.br Acesso em: 08/04/2015.

BRASIL. Senado Federal. Projeto de Lei do Senado, n. 328 de 2005. Acrescenta parágrafo ao art. 14 da Lei nº 9.394, de 20 de dezembro de 1996 - Lei de Diretrizes e Bases da Educação Nacional. (Dispõe sobre a escolha dos dirigentes escolares). Disponível em: http://www.senado.gov.br. Acesso em: 20/01/2015.

BRASIL. Senado Federal. Projeto de Lei do Senado, n. 344 de 2007. Acrescenta inciso ao art. 14 da lei $\mathrm{n}^{\circ}$ 9.394, de 20 de dezembro de 1996, que estabelece as Diretrizes e Bases da Educação Nacional (LDB), de forma a instituir a eleição direta para diretores de escolas públicas. Disponível em: http://www.senado.gov.br. Acesso em: 20/01/2015.

BRASIL. Senado Federal. Parecer s/n, de 2014, Gabinete do Relator (tramitação). Da COMISSÃO DE EDUCAÇÃO, CULTURA E ESPORTE, sobre o Projeto de Lei do Senado ${ }^{\circ} 328$, de 2005, do Senador Pedro Simon e sobre o Projeto de Lei do Senado $n^{\circ}$ 344, de 2007, da Senadora Ideli Salvatti. Disponível em: http://www.senado.gov.br. Acesso em: 20/01/2015.

BRESSOUX, P. As pesquisas sobre o efeito-escola e o efeito-professor. Educação em Revista, Belo horizonte. n. ${ }^{\circ}$ 38, p.17-88, dez. 2003 
BRITO, M. S. T.; COSTA, M. Práticas e percepções docentes e suas relações com o prestígio e clima escolar das escolas públicas do município do Rio de Janeiro. Revista Brasileira de Educação, v. 15, n. 45, p. 500- 510, set./dez. 2010.

BROOKE, N. O futuro das políticas de responsabilização educacional no Brasil. Cadernos de Pesquisa, São Paulo, v. 36, n. 128, p.377-401, maio/ago. 2006. Disponível em http://www.scielo.br/scielo. Acesso em: 20 out. 2011.

BROOKE, Nigel; SOARES, José Francisco. (Orgs.) Pesquisa em eficácia escolar: origem e trajetórias. Belo Horizonte: Editora UFMG, 2008.

BROOKE, N.; CUNHA, M. A.; FALEIROS, M. As avaliações externas como instrumento de gestão educacional nos estados. Estudos e Pesquisas Educacionais Fundação Victor Civita, v. 2, p. 3-64, 2011.

BRUGGENCATE, G.; LUYTEN, H.; SCHEERENS, J.; SLEEGERS, P. Modeling the Influence of School Leaders on Student Achievement: How Can School Leaders Make a Difference? Educational Administration Quarterly, v. 48, n. 4, p. 699-732, out. 2012.

BRUNET, L. El clima de trabajo en las organizaciones. México: Trillas, 1987.

BRUNET, L. Clima de trabalho e eficácia da escola. In: NÓVOA, A. (Org.) As organizações escolares em análise. Lisboa: Dom Quixote, 1992.

CAZELLI, S. Ciência, cultura, museus, jovens e escolas: quais as relações? Rio de Janeiro, 2005. Tese (Doutorado em Educação). Coordenação de Pós-Graduação, Pontifícia Universidade Católica do Rio de Janeiro.

CERDEIRA, D. G. S. Apropriações e usos de Políticas de Avaliação e Responsabilização Educacional pela Gestão Escolar. Rio de Janeiro, 2015. Tese (Doutorado em Educação). Coordenação de Pós-Graduação, Universidade Federal do Rio de Janeiro.

COHEN, J.; COHEN, P. Applied multiple regression/correlation analysis for the behavioral sciences. Hillsdale, NJ: Lawrence Erlbaum, 1975.

CONCEIÇÃO, S.; PARENTE, J. Um estudo multivariado do perfil do diretor das escolas públicas de Itabaiana - SE. RBPAE - Revista Brasileira de Política e Administração Escolar, v. 28, n. 2, p. 479-494, mai/ago. 2012.

CORREIA, J. A. Paradigmas e cognições no campo da administração educacional: das políticas de avaliação à avaliação como política. Revista Brasileira de Educação, v. 15, n. 45, p. 456- 497, set/dez. 2010.

COUPER, M.; MILLER, P. Web Survey Methods: Introduction. Public Opinion Quarterly, v. 72, n. 5, p. 831-835, 2008.

COUSIN, O. L'efficacité des collèges - sociologie de l'effet établissement. Paris: PUF, 1998.

CREEMERS, B.; REEZIGT, G. School level conditions affecting the effectiveness of instruction. In: School Effectiveness and School Improvement, v. 7, n. 3, p. 197-228, 1996. 
COSTA, E. Gestão pública escolar e avaliação do índice de desenvolvimento da educação básica: da reflexão à transformação da prática pedagógica. Lages, 2012. Dissertação (Mestrado Acadêmico em Educação). Coordenação de Pós-Graduação: Universidade do Planalto Catarinense.

COSTA, M.; KOSLINSKI, M. C. Quase-mercado oculto: disputa por escolas "comuns" no Rio de Janeiro. Cadernos de Pesquisa. 2011, vol.41, n.142, p. 246-266.

CUNHA, C. P. Prática docente sob pressão: Ações e percepções de professores sobre a política de responsabilização na rede municipal de ensino do Rio de Janeiro. Rio de Janeiro, 2015. Dissertação (Mestrado em Educação) Coordenação de Pós-Graduação, Universidade Federal do Rio de Janeiro.

CUNHA, E. O. A relação entre a gestão escolar o desempenho da escola medida pelo IDEB: um estudo em duas escolas municipais de Salvador. Salvador, 2012. Dissertação (Mestrado Acadêmico em Educação) Coordenação de Pós-Graduação, Universidade Federal da Bahia.

CUNHA, M. B. Rotatividade docente na rede municipal de ensino da cidade do Rio da Janeiro. Rio de Janeiro, 2015. Tese (Doutorado em Educação). Coordenação de PósGraduação, Pontifícia Universidade Católica do Rio de Janeiro.

DONALDSON, M. Principals' Approaches to Cultivating Teacher Effectiveness: Constraints and Opportunities in Hiring, Assigning, Evaluating, and Developing Teachers. Educational Administration Quarterly, v. 49, n. 5, p. 832-882, dez. 2013.

ELFERS, A.; STRITIKUS, T. How School and District Leaders Support Classroom Teachers' Work With English Language Learners. Educational Administration Quarterly, v. 50, n. 2, p. 305-344, abr. 2014.

FELIPE, L. H. L. Escolha de escola: homologias nas estratégias em jogo no campo educacional. In: XAVIER, A.; SILVA, M.L.C.Q.; BRANDÃO, Z. (orgs.) Construção da Qualidade de Ensino: Achados e tensões de uma década de pesquisas. Rio de Janeiro: Forma e Ação Editora, 2013.

FERNANDES, D. C. Estratificação educacional, origem socioeconômica e raça no brasil: as barreiras da cor In: PRÊMIO IPEA 40 anos. Brasília: IPEA, 2005. p. 21-72.

FERNANDES, E. M. A. Educação escolar, estado e município: análise da descentralização de ensino no estado do Rio de Janeiro durante a vigência do FUNDEF (1998 - 2006). Tese de Doutorado. Universidade Metodista de Piracicaba. Faculdade de Ciências Humanas. Programa de Pós Graduação em Educação, 2012.

FERREIRA, N.; TORRES, L. Perfil de liderança do diretor de escola em Portugal: modos de atuação e estratégias de regulação da cultura organizacional. RBPAE - Revista Brasileira de Política e Administração Escolar, v. 28, n. 1, p. 86-111, jan/abr. 2012.

FICHER, S.; GUIMARÃES, M. C. A construção da gestão autônoma das escolas públicas brasileiras: um estudo nas escolas de ensino fundamental em Santa Catarina. RBPAE - Revista Brasileira de Política e Administração da Educação, v. 29, n. 1, p. $97-115$, jan./abr. 2013.

FIELD, A. Descobrindo a estatística usando o SPSS. Porto Alegre: Artmed, 2009. 
FIGUEIREDO FILHO, D. B.; PARANHOS, R.; SILVA JÚNIOR, J. A.; ROCHA, E. C.; ALVES, D. P. O que é, para que serve e como se faz uma meta-análise? Teoria e Pesquisa: Revista de Ciência Política, v.23, n.2, p. 205- 248, 2014.

FORQUIN, J.C. Sociologia das desigualdades de acesso à educação: principais orientações, principais resultados desde 1965. In: FORQUIN, J.C. (org.). Sociologia da Educação - dez anos de pesquisa. Petrópolis, Vozes, 1995, p.19-37.

FULLER, E.; YOUNG, M.; BAKER, B. Do Principal Preparation Programs Influence Student Achievement Through the Building of Teacher-Team Qualifications by the Principal? An Exploratory Analysis. Educational Administration Quarterly, v. 47, n.1, p. 173-216, fev. 2011.

GATTI, B. A. Estudos quantitativos em educação. Educação e Pesquisa, São Paulo, v.30, n. 1, p.11-30, jan/abr 2004.

GIL, Antônio Carlos. Métodos e técnicas de pesquisa social. São Paulo: Atlas, 2008.

GILHAM, M., GRANBERG, D. Should we take don't know for an answer? Public Opinion Quartely, Vol. 57, No. 3. Autumn, 1993, pp. 348- 357.

GOMES, M. B. Monitoramento e gestão do Ensino Fundamental: práticas escolares em face de políticas indutoras. 2012. Dissertação (Mestrado Acadêmico em Educação) Coordenação da Pós-Graduação, Universidade Federal da Grande Dourados.

GOULART JUNIOR, E.; LIPP, M.E. Estilo de liderança e stress: uma pesquisa em escolas estaduais de ensino fundamental. RBPAE - Revista Brasileira de Política e Administração Escolar, v.27, n.2, p. 265-283, maio/ago. 2011.

GRISSOM, J.; LOEB, S. Triangulating Principal Effectiveness: How Perspectives of Parents, Teachers, and Assistant Principals Identify the Central Importance of Managerial Skills. American Educational Research Journal, v. 48, n. 5, p. 1091-1123, 2011.

GÜNTHER, H. Pesquisa Qualitativa versus Pesquisa Quantitativa: esta é a questão? Psicologia: Teoria e Pesquisa, Brasília, vol. 22 n. 2, p. 201-210, mai/ago 2006.

HARRIS, D.; INGLE, W.; RUTLEDGE, S. How Teacher Evaluation Methods Matter for Accountability: A Comparative Analysis of Teacher Effectiveness Ratings by Principals and Teacher Value-Added Measures. American Educational Research Journal, v. 51, n. 1, p. 73-112, 2014.

HASENBALG, C.; SILVA, N. V. Tendências de desigualdades educacional no Brasil. Dados, Revista de Ciências Sociais, v .43, n. 3, p. 423-445, 2000.

HIGGINS, J.; BONNE, L. Configurations of Instructional Leadership enactments that promote the teaching and learning of Mathematics in a New Zealand Elementary School. Educational Administration Quarterly, v. 47, n.5, p. 794-825, dez. 2011.

HOLBROOK, A.L.; GREEN, M.; KROSNICK, J. Telephone versus Face to-Face Interviewing of National Probability Samples with Long Questionnaires. Comparisons of Respondent Satisficing and Social Desirability Response Bias. Public Opinion Quarterly v. 67:p.79-125, 2003. 
HOUAISS, A. Dicionário Houaiss da Língua Portuguesa. Rio de Janeiro: Objetiva: 2001.

HULPIA, H.; DEVOS, G.; KEER, H. The Relation Between School Leadership From a Distributed Perspective and Teachers' Organizational Commitment: Examining the Source of the Leadership Function. Educational Administration Quarterly, v. 47, n.5, p. 728-771, dez. 2011.

INEP, INSTITUTO NACIONAL DE ESTUDOS E PESQUISAS EDUCACIONAIS ANÍSIO TEIXEIRA. Microdados da Aneb e da Anresc 2007. Brasília: Inep, 2008. Disponível em: http://portal.inep.gov.br/basica-levantamentos-acessar. Acesso em: $22 \mathrm{fev}$ 2014.

INEP, INSTITUTO NACIONAL DE ESTUDOS E PESQUISAS EDUCACIONAIS ANÍSIO TEIXEIRA. Microdados da Aneb e da Anresc 2009. Brasília: Inep, 2011. Disponível em: http://portal.inep.gov.br/basica-levantamentos-acessar. Acesso em: $22 \mathrm{fev}$ 2014.

INEP, INSTITUTO NACIONAL DE ESTUDOS E PESQUISAS EDUCACIONAIS ANÍSIO TEIXEIRA. Microdados da Aneb e da Anresc 2011. Brasília: Inep, 2012. Disponível em: http://portal.inep.gov.br/basica-levantamentos-acessar. Acesso em: $22 \mathrm{fev}$ 2014.

INEP, INSTITUTO NACIONAL DE ESTUDOS E PESQUISAS EDUCACIONAIS ANÍSIO TEIXEIRA. Microdados do Censo Escolar 2013. Brasília: Inep, 2014. Disponível em: http://portal.inep.gov.br/basica-levantamentos-acessar. Acesso em $12 \mathrm{mar}$ 2015.

INEP, INSTITUTO NACIONAL DE ESTUDOS E PESQUISAS EDUCACIONAIS ANÍSIO TEIXEIRA. Microdados da Aneb e da Anresc 2013. Brasília: Inep, 2015. Disponível em: http://portal.inep.gov.br/basica-levantamentos-acessar. Acesso em: 30 mai 2015.

JACKSON, K.; MARRIOT, C. The Interaction of Principal and Teacher Instructional Influence as a Measure of Leadership as an Organizational Quality. Educational Administration Quarterly, v. 48, n.2, p. 230-268, abr. 2012.

KARANXHA, Z. When the "Dream" Turns Into a Nightmare: Life and Death of Voyager Charter School. Educational Administration Quarterly, v. 49, n.4, p.576-609, out. 2013.

KOSLINSKI, M. C.; PAES DE CARVALHO, C.; ALVES, F.; MACEDO, F. What are schools learning with accountability and improvement policies? Exploring Rio de Janeiro's school system. In: UCEA Convention. Indianápolis, 2013.

KOSLINKI, M.; CUNHA, C. P.; ANDRADE, F. Accountability escolar: um estudo exploratório do perfil das escolas premiadas. Estudos em Avaliação Educacional. São Paulo, v. 25, n. 59, p. 108-137, set./dez. 2014.

LEITHWOOD, K. Leadership for school restructuring. Educational Administration Quarterly, n. 30, p. 498-518, 1994.

LEITHWOOD, K. \& Cómo liderar nuestras escuelas? Aportes desde la investigación. Santiago: Salesianos Impresores, 2009. 
LEITHWOOD, K.; JANTZI, D. Transformational school leadership effects: A replication. School effectiveness and school improvement, n.10 (4), p. 451-479, 1999.

LEITHWOOD, K.; LOUIS, K., ANDERSON, S.; WAHLSTROM, K. How leadership influences student learning: A review of the evidence linking leadership to student learning. New York: The Wallace Foundation, 2004.

LEITHWOOD, K., DAY, C., SAMMONS, P., HOPKINS, D.; HARRIS, A. Successful school leadership: What it is and how it influences pupil learning. London: Department of Education and Skills, 2006.

LEITHWOOD, K.; SLEEGERS, P. Transformational school leadership: Introduction. School Effectiveness and School Improvement, n. 17, p. 143-144, 2006.

LEITHWOOD, K., MASCALL, B., STRAUSS, T., SACKS, R., MEMON, N.; YASHKINA, A. Distributing leadership to make schools smarter: Taking the ego out of the system. Leadership and Policy in Schools, n. 6, p. 37-67, 2007.

LEITHWOOD, K.; PATTEN, S.; JANTZI, D. - Testing a Conception of How School Leadership Influences Student Learning. Educational Administration Quarterly, v. 46 n.5, p. 671-706, 2010.

LEITHWOOD, K.; SUN, J. Transformational school leadership effects on schools, teachers and students. In: HOY, W. K. e DIPAOLA, M. (Eds.), School improvement. New York: Information Age, p. 1-22, 2009.

LEEITHWOOD, K.; SUN, J. - The Nature and Effects of Transformational School Leadership: A Meta-Analytic Review of Unpublished Research. Educational Administration Quarterly, v. 48 n.3, p. 387-423, 2012.

LIMA, A. M. G. Fatores associados à eficácia escolar: um estudo de instituições educacionais públicas municipais de Fortaleza CE. Fortaleza, 2012. Dissertação (Mestrado Acadêmico em Educação) Coordenação de Pós-Graduação, Universidade Federal do Ceará.

LIMA, M. F. M. Conselhos escolares, gestão democrática e qualidade do ensino em quatro escolas da rede pública municipal do Rio de Janeiro, 2011. Dissertação (Mestrado Acadêmico em Educação) Coordenação de Pós-Graduação, Pontifícia Universidade Católica do Rio de Janeiro.

LIMA, M. F. M.; ALCANTARA, G.; ALMEIDA, M.A.O. O que potencialmente afeta a gestão escolar? Percepções de diretores de duas redes públicas de ensino do estado do Rio de Janeiro In: Anais da 36 ${ }^{\mathbf{a}}$ Reunião Nacional da ANPED, 2013, Goiânia. Sistema Nacional de Educação e Participação Popular: desafios para as políticas educacionais, 2013.

LIMA, N. C. M. Infraestrutura, gestão escolar e desempenho em leitura e matemática: um estudo a partir do Projeto GERES. Rio de Janeiro, 2012. Dissertação (Mestrado Acadêmico em Educação) Coordenação de Pós-Graduação, Pontifícia Universidade Católica do Rio de Janeiro.

LOUIS, K. S.; LEITHWOOD, K.; WALHLSTROM, K. L.; ANDERSON, S. E.; MICHLIN, M.; MASCALL, B.; GORDON, M.; STRAUSS, T.; THOMAS, E.; MOORE, 
S. Investigating the links to improved learning: Final report of research findings. Minneapolis, MN: Center for Applied Research and Educational Improvement, 2010.

LÜCK, H. Liderança em gestão escolar. $3^{\text {a }}$ ed. Petrópolis: Vozes, 2009. (Série Cadernos de Gestão).

MACHADO, M. F. E. Identidade com a profissão docente na trama da eficácia escolar. Brasília, 2012. Tese (Doutorado em Educação) Coordenação de Pós-Graduação, Universidade Católica de Brasília.

MACHADO, C.; ALAVARSE, O. Avaliação interna no contexto das avaliações externas: desafios para a gestão escolar. RBPAE - Revista Brasileira de Política e

Administração da Educação, v. 30, n.1, p. 97 -115, p. 63-78, jan./abr. 2014.

MAFRA, L. A sociologia dos estabelecimentos escolares: passado e presente de um campo de pesquisa em reconstrução. In ZAGO, N.; CARVALHO, M; VILELA, R. (orgs). Itinerários de pesquisa: Perspectivas em Sociologia da Educação. Rio de Janeiro: DP\&A, 2003.

MARCONDES, M. I. ; LEITE, V. F. ; OLIVEIRA, A.C.P. Reforma e recontextualização das políticas: o papel dos coordenadores pedagógicos nas escolas municipais do Rio de Janeiro. Revista Diálogo Educacional (PUC- PR, Impresso), v. 12, p. 185-207, 2012.

MARCONDES, M. I. ; OLIVEIRA, A. C. P. Novas Políticas Curriculares da SME do Rio de Janeiro; novos desafios para o coordenador pedagógico e os professores das séries iniciais.. In: Maria Zuleide Costa Pereira; Idelsuite de Souza Lima. (Org.). Currículo e Políticas Educacionais em Debate. 1ed.Campinas: Alínea, 2012, v. 1, p. 137-150.

MARKS, H. M.; PRINTY, S. M. Principal leadership and school performance: An integration of transformational and instructional leadership. Educational Administration Quarterly, v.39, n. 3, p. 370-397, ago. 2003.

MARQUES, R. N. Escolas bem-sucedidas: como são? Um estudo de caso de duas escolas públicas do Distrito Federal. Brasília, 2012. Dissertação (Mestrado Acadêmico em Educação) Coordenação de Pós-Graduação, Universidade Católica de Brasília.

MARTINS, A. M. Gestão e autonomia escolar: um estudo comparado Brasil/Portugal. Revista Brasileira de Educação, v. 16 n. 46, p. 69-98, jan/abr. 2011.

MAY, H.; SUPOVITZ, J. - The Scope of Principal Efforts to Improve Instruction. Educational Administration Quarterly, v. 47 n.2, p. 332-352, 2011.

MAYER, A.; DONALDSON, M.; LeCHASSEUR, K.; WELTON, A.; COBB, C. Negotiating Site-Based Management and Expanded Teacher Decision Making: A Case Study of Six Urban Schools. Educational Administration Quarterly, v. 49 n.5, p. 695731, dez.2013.

MEDEIROS, M.; FEROLLA, L.; PASSADOR, C. e PASSADOR, J. Gestão escolar: afinal, que fins estão sendo buscados? RBPAE - Revista Brasileira de Política e Administração da Educação, v. 30, n.1, p. 115-138, jan./abr. 2014.

MEDEIROS, V. G. de. Clima escolar: um estudo sociológico de uma instituição pública de excelência. 151 f. Dissertação (Mestrado em Educação Brasileira) - 
Departamento de Educação, Pontifícia Universidade Católica do Rio de Janeiro, Rio de Janeiro, 2007.

MIRANDA, J. A. A. Fatores de eficácia associados à gestão escolar e sua relação com os resultados de desempenho da escola Juiz de Fora,2012 (Mestrado Profissional Em Gestão e Avaliação da Educação Pública) Universidade Federal de Juiz De Fora.

MORTIMORE, P.; SAMMONS, P.; STOLL,L.; LEWIS, D.; ECOB, R. School matters. California: University of California Press, 1988.

NELSON, S.; GUERRA, P. Educator Beliefs and Cultural Knowledge: Implications for School Improvement Efforts. Educational Administration Quarterly, v.50, n.1, p. 6795, fev. 2014.

NEUMERSKI, C. Rethinking Instructional Leadership, a Review: What Do We Know About Principal, Teacher, and Coach Instructional Leadership, and Where Should We Go From Here? . Educational Administration Quarterly, v.49, n.2, p. 310-347, abr. 2013.

NEVES, K. H. IDEB: O caso de sucesso de uma escola do interior do estado do Rio de Janeiro. Juiz de Fora, 2012. Dissertação (Mestrado Profissional em Gestão e Avaliação da Educação Pública) Universidade Federal de Juiz De Fora.

NOGUEIRA, M. A. A Sociologia da Educação do final dos anos 60/início dos anos 70: o nascimento do paradigma da reprodução. Em Aberto, v. 46, p. 49-59, 1990.

OGAWA, R. T.; BOSSERT, S. T. Leadership as an organizational quality. Educational Administration Quarterly, v.31, n.2, p. 224-243, mai. 1995.

OLIVEIRA, A. C. P. Política pública e Prática docente: quando e como dialogam no espaço escolar- A experiência em uma escola municipal do Rio de Janeiro. Rio de Janeiro, 2012. Dissertação (Mestrado em educação). Coordenação de Pós-Graduação, Pontifícia Universidade Católica do Rio de Janeiro.

OLIVEIRA, A.C.P. Política pública e gestão escolar: um estudo de caso no Rio de Janeiro. In: III Congresso Ibero Americano de Política e Administração da Educação, 2012, Zaragoza. Cadernos ANPAE. Timbaúba: Biblioteca ANPAE - Cadernos ANPAE, $2012 b$.

OLIVEIRA, A.C.P. e WALDHELM, A. P. S. Questionários contextuais da Prova Brasil 2009: o que dizem os dados faltantes dos professores do $9^{\circ}$ ano? Trabalho não publicado (Doutorado em Educação). Coordenadoria de Pós-Graduação, PUC-Rio, 2012.

OLIVEIRA, A. C. P. e WALDHELM, A.P.S. Liderança do Diretor, Clima Escolar e desempenho dos alunos: qual a relação? (Artigo aceito para publicação, Revista Ensaio, Fund. Carlos Chagas)

OLIVEIRA, A.C.P.; PAES DE CARVALHO, C.; LIMA, F. School's democratic management and community participation: a study on two educational systems in Rio de Janeiro. In: UCEA Convention. Indianápolis, 2013.

PAES DE CARVALHO, C. Gestão, autonomia e liderança na escola: alguns conceitos e desafios atuais. In: POLON, T. L. P.; BONAMINO, A. M. C.; PAES DE CARVALHO, 
C.; ALVES, F. Gestão do Currículo e Gestão e Liderança (Col. Gestão e Avaliação da Educação Pública, vol.3). Juiz de Fora: Editora do CAED, 2012.

Gestão escolar em escolas públicas e privadas: liderança e condições de trabalho. In: XAVIER, A.; SILVA, M.L.C.Q.; BRANDÃO, Z. (orgs.) Construção da Qualidade de Ensino: Achados e tensões de uma década de pesquisas. Rio de Janeiro: Forma e Ação Editora, 2013.

PAES DE CARVALHO, C.; SILVA, M. L.C.Q. Estilos de gestão em escolas de prestígio na cidade do Rio de Janeiro. Boletim SOCED, v. 6, p. 1-30, 2008.

PAES DE CARVALHO, C.; LIMA, M. F. M. Conselhos Escolares, gestão democrática e Qualidade do ensino em escolas da rede pública municipal do Rio de Janeiro: percepções e pais e professores. Boletim SOCED, n. 8, 2012.

PAES DE CARVALHO, C.; WALDHELM, A. P. S.; ALVES, F. C. M.; KOSLINSKI, M. C. Gestão e Desempenho Escolar: um estudo nas redes municipais da Região Metropolitana do Rio de Janeiro a partir dos resultados da Prova Brasil 2009. In: III Congresso Ibero Americano de Política e Administração da Educação, 2012, Zaragoza. Cadernos ANPAE. Timbaúba: Biblioteca ANPAE - Cadernos ANPAE, 2012.

PAES DE CARVALHO, C.; OLIVEIRA, A.C.P. School management: principals' leadership and educational results in national assessments in Brazil. In: UCEA Convention. Washington, 2014.

PAES DE CARVALHO, C.; OLIVEIRA, A.C.P.; LIMA, M. F. M. Avaliações externas: tensões e desafios para a gestão escolar. Estudos em Avaliação Educacional. São Paulo, v. 25, n. 59, p. 50-76, set./dez. 2014.

PARO, V. H. Gestão democrática da escola pública. São Paulo: Ática, 2001.

Diretor escolar: educador ou gerente? São Paulo: Cortez, 2015.

PASTORE, J. ; SILVA, N. V. Mobilidade social no Brasil. São Paulo, Markron, 2000.

PAUL, Jean-Jacques; BARBOSA, Maria Ligia de Oliveira. Qualidade docente e eficácia escolar. Tempo Social, São Paulo, v. 20, n. 1, 2008. Disponível em $<$ http://www.scielo.br/scielo >Acesso em 01 jun. 2010.

POLON, T. L. P. Identificação dos Perfis de Liderança e características relacionadas a gestão pedagógica eficaz nas escolas participante do Projeto GERES Estudo Longitudinal - Geração Escolar 2005 - Pólo Rio de Janeiro. Rio de Janeiro, 2009. Tese (Doutorado em Educação) Coordenação de Pós-Graduação, Pontifícia Universidade Católica do Rio de Janeiro.

POLON, T. L. P. Perfis de liderança e características relacionadas à gestão em escolas eficazes. In: POLON, T. L. P.; BONAMINO, A. M. C.; PAES DE CARVALHO, C.; ALVES, F. Gestão do Currículo e Gestão e Liderança (Col. Gestão e Avaliação da Educação Pública, vol.3). Juiz de Fora: Editora do CAED, 2012.

POLLOCK, K.; MINDIZACK, M.; HAUSEMAN, C.; BRISCOE, P. Principals' work and workload in the contemporary era: A view from Ontario.

Seminário Apresentado em: UCEA Convention. Washington, 2014. 
PRICE, H. Principal-Teacher Interactions: How Affective Relationships Shape Principal and Teacher Attitudes. Educational Administration Quarterly, v. 48 n.1, p. 39-85, 2012.

RAMOS, G. P. A política educacional paulista (1995-2010) e seus impactos na identidade da escola e do professor. RBPAE - Revista Brasileira de Política e Administração da Educação, v. 29, n.3, p. 537-556, set/dez. 2013.

RODRIGUES, M. A. Gestão da sala de aula em uma escola pública de qualidade Rio de Janeiro, 2011. Dissertação (Mestrado Acadêmico em Educação). Coordenação de PósGraduação, Pontifícia Universidade Católica do Rio de Janeiro.

RIBEIRO, L.C.Q.; KOSLINSKI, M.C.; ALVES, F.; LASMAR, C. (Orgs).

Desigualdades urbanas, desigualdades escolares. Rio de Janeiro: Letra Capital: Observatório das Metrópoles: IPPUR/UFRJ, 2010.

RIBEIRO, L. C. Q.; KOSLINSKI, M. C. Fronteiras urbanas da democratização das oportunidades educacionais: o caso do Rio de Janeiro. In: RIBEIRO, L.C.Q.; KOSLINSKI, M.C.; ALVES, F.; LASMAR, C. (Orgs). Desigualdades urbanas, desigualdades escolares. Rio de Janeiro: Letra Capital: Observatório das Metrópoles: IPPUR/UFRJ, 2010.

ROSISTOLATO, R.; PRADO, A.; FERNÁNDEZ, S. Cobranças, estratégias e "jeitinhos": avaliações em larga escala no Rio de Janeiro. Estudos em Avaliação Educacional. São Paulo, v. 25, n. 59, p. 78-107, set./dez. 2014.

RUSSO, M. Trabalho e administração da escola: desenvolvimento e apropriação do sentido que assumem no processo de produção pedagógica. RBPAE - Revista Brasileira de Política e Administração Escolar, v.27, n.3, p. 361-588, set./dez. 2011.

RUTTER, M.; MAUGHAN, B.; MORTIMORE, P.; OUSTON, J.; SMITH, A. Fifteen Thousand hours: Secondary Schools and their Effects on Children. London: Open Books, 1979.

RUTTER, M.; MAUGHAN, B.; MORTIMORE, P.; OUSTON, J.; SMITH, A. Estudos anteriores. In: BROOKE, Nigel; SOARES, José Francisco. (Orgs.) Pesquisa em eficácia escolar: origem e trajetórias. Belo Horizonte: Editora UFMG, 2008.

SAMMONS, P. As características-chave das escolas eficazes. In: BROOKE, Nigel; SOARES, José Francisco. (Orgs.) Pesquisa em eficácia escolar: origem e trajetórias. Belo Horizonte: Editora UFMG, 2008.

SANDER, B. O estudo da administração da educação na virada do século. In: MACHADO, L. M. e FERREIRA, N. S. C. (Orgs.) Política e gestão da educação: dois olhares. Rio de Janeiro: DP\&A, 2002.

SANDER, B. Políticas públicas e Gestão Democrática da Educação. Brasília: Liber Livro Editora, 2005.

SCANLAN, M. A learning architecture: how school leaders can design for learning social justice. Educational Administration Quarterly, Online first, p. 1-44, 2012. 
SEBASTIAN, J.; ALLENSWORTH, E. - The Influence of Principal Leadership on Classroom Instruction and Student Learning: A Study of Mediated Pathways to Learning. Educational Administration Quarterly, v. 48, n.4, p. 626-663, out.2012.

SECRETARIA ESTADUAL DE EDUCAÇÃO DO RIO DE JANEIRO. Resolução no 1.411/SEE, de 03 de dezembro de 1987. Institui o Programa de Municipalização do Ensino do Estado do Rio de Janeiro, PROMURJ.

$1.411 / 87$.

Resolução no 1.488/ SEE, 08 de março de 1989. Altera a Resolução ${ }^{\circ}$ $1.488 / 89$

Resolução no 1.658/ SEE, 25 de março de 1992. Altera a Resolução no

SECRETARIA MUNICIPAL DE EDUCAÇÃO. Lei 2.619 de 16 de janeiro de 1998. Dispõe sobre a estrutura organizacional, pedagógica e administrativa da rede pública municipal de educação. Diário Oficial do Rio, Rio de Janeiro, 19 jan 1998. Disponível em http://cm-rio-de janeiro.jusbrasil.com.br Acesso em 23/02/2015.

Resolução SME no 1074 de 14 de abril de 2010. Dispõe sobre o Regimento Escolar Básico do Ensino Fundamental da Rede Pública do Município do Rio de Janeiro. Disponível em http://www.mprj.mp.br/documents/112957/1485448. Acesso em 23/02/2015.

Lei Municipal 5225, de 05/11/2010. Disponível no Diário Oficial de 08 de novembro de 2010 . maio de 2011.

Resolução 1132, de 12 de maio de 2011. Disponível no Diário Oficial de 13 de

Decreto 36978, de 09 de abril de 2013. Disponível no Diário Oficial de 11 de abril de 2013.

Resolução SME no 1133 , de 16 de maio de 2011. Dispõe sobre o procedimento de consulta à Comunidade Escolar para escolha da direção das Unidades Escolares da Rede Pública do Sistema Municipal de Ensino da Cidade do Rio de Janeiro e dá outras providências. Diário Oficial do Rio, Rio de Janeiro, n. 44, 17 mai 2011. Disponível em http://webapp.sme.rio.rj.gov.br Acesso em 02/03/2015.

Lei 5623 de 01 de outubro de 2013. Dispõe sobre o Plano de Cargos, Carreiras e Remuneração dos funcionários da Secretaria Municipal de Educação e dá outras providências. Diário Oficial do Rio, Rio de Janeiro 02 out 2013. Disponível em http://smaonline.rio.rj.gov.br/ConLegis/ato.asp?45130 Acesso em: 20/02/2015.

SHAPIRA-LISHCHINSKI, O. and TSEMACH, S. Psychological Empowerment as a Mediator Between Teachers' Perceptions of Authentic Leadership and Their Withdrawal and Citizenship Behaviors. Educational Administration Quarterly, v. 50, n.4, p. 675712, out. 2014.

SHEERENS, J. A mensuração da liderança escolar. (Série Documental: textos para discussão) Brasília, DF: INEP, 2005.

SHEN, J.; LESLIE, J.; SPYBROOK, J.; MA, X. Are Principal Background and School Processes Related to Teacher Job Satisfaction? A Multilevel Study Using Schools and 
Staffing Survey 2003-04. American Educational Research Journal, v. 49, n. 2, p. 200$230,2012$.

SILVA, I. F. A efetividade da 'política de fundos' no financiamento da educação no Brasil 2007-2011. Curitiba, 2014. Tese (Doutorado em Educação) Coordenação de PósGraduação, Universidade Federal do Paraná.

SILVA, J. S. F. Modelagem de Equações Estruturais: apresentação de uma metodologia. Porto Alegre, 2006. Dissertação (Mestrado em Engenharia de Produção). Departamento de Pós-Graduação, Universidade Federal do Rio Grande do Sul.

SILVA, M. L.C.Q. Um olhar a partir das famílias. In: XAVIER, A.; SILVA, M.LC.Q.; BRANDÃO, Z. (orgs.) Construção da Qualidade de Ensino: Achados e tensões de uma década de pesquisas. Rio de Janeiro: Forma e Ação Editora, 2013.

SILVA, L.; ALVES, M. Gerencialismo da escola pública: contradições e desafios concernentes à gestão, à autonomia e à organização do trabalho escolar. RBPAE Revista Brasileira de Política e Administração Escolar, v. 28, n. 3, p. 665-681, set/dez. 2012 .

SILVA, M. L.C.Q.; MUYLAERT, N.; RESINENTTI, P. Relacionamento do Gestor com o corpo docente: o olhar do diretor. In: II Congresso Ibero-Americano de Política e Administração da Educação, 2011, São Paulo. Políticas Públicas e Gestão da Educação, 2011.

SILVA, N. V.; BARBOSA, M.L.O. Desempenho individual e Organização escolar na realização educacional. Sociologia \& Antropologia, v.02.04: p. 159-184, 2012.

SILVA, V. G. et al. Uso da avaliação externa por equipes gestoras e profissionais docentes: um estudo em quatro redes de ensino público. Relatório de Pesquisa. São Paulo: Fundação Itaú Social, 2013. Disponível em: Acesso em: nov. 2014.

SPILLANE, J.; PARISE, L.; SHERER, J. Organizational Routines as Coupling Mechanisms: Policy, School Administration, and the Technical Core. American Educational Research Journal, v. 49, n. 2, p. 200-230, 2012. American Educational Research Journal, v. 48, n. 3, p. 586-619, 2011.

SPILLANE, J.; LEE, L. Novice School Principals' Sense of Ultimate Responsibility: Problems of Practice in Transitioning to the Principal's Office. Educational Administration Quarterly, v. 50, n.3, p. 431-465, 2014.

SOARES, J. F. Melhora do desempenho cognitivo dos alunos do ensino fundamental. Cadernos de Pesquisa, v. 37, n. 130, p. 135-160, jan./abr. 2007.

SOARES, J. F.; ANDRADE, R. J. Nível socioeconômico, qualidade e eqüidade das escolas de Belo Horizonte Ensaio: avaliação e políticas públicas em Educação, Rio de Janeiro, v.14, n.50, p. 107-126, jan./mar. 2006.

SOARES, J. F.; ANDRADE, R. J. Medida da heterogeneidade das escolas brasileiras de educação básica. In: III Reunião da ABAVE - Associação Brasileira de Avaliação Educacional. Belo Horizonte: ABAVE, 2007. 
SOARES, T. M.; TEIXEIRA, L. H. G. Efeito do perfil do diretor na gestão escolar sobre a proficiência do aluno. Estudos em Avaliação Educacional, v. 17, n. 34, maio/ago. 2006.

SOMECH, A. Participative Decision Making in Schools: A Mediating-Moderating Analytical Framework for Understanding School and Teacher Outcomes. Educational Administration Quarterly, v. 46, n.2, p. 174-209, 2010.

SOUZA, A. R. Perfil da Gestão Escolar no Brasil. Tese de Doutorado (Educação). São Paulo: PUC-SP, 2006.

SOUZA, A. R. A natureza política da gestão escolar e as disputas pelo poder na escola. Revista Brasileira de Educação, vol.17, n.49, pp. 159-174, jan./abr. 2012.

SUN, M.; FRANK, K.; PENUEL, W.; KIM, C. How External Institutions Penetrate Schools Through Formal and Informal Leaders. Educational Administration Quarterly, v. 49, n.4, p. $610-644,2013$.

SUPOVITZ, J.; SIRINIDES, P.; MAY, H. How Principals and Peers Influence Teaching and Learning. Educational Administration Quarterly, v. 46, n.1, p. 31-56, 2010.

TEIXEIRA, B.B. Diretores de escola: reflexões sobre a função e provimento do cargo. In: Congressos Ibero-Luso-Brasileiros de Política e Administração da Educação de 2010, ANPAE. Disponível em: http://www.anpae.org.br/iberolusobrasileiro2010/cdrom/18.pdf. Acesso em: 20/04/2015.

TEROSKY, A. From a Managerial Imperative to a Learning Imperative: Experiences of Urban, Public School Principals. Educational Administration Quarterly, v. 50, n.1, p. 3-33, 2014.

THOONEN, E.; SLEEGERS, P.; OORT, F. PEETMAT, T.; GEIJSELF, F. How to Improve Teaching Practices: The Role of Teacher Motivation, Organizational Factors, and Leadership Practices. Educational Administration Quarterly, v. 47, n.3, p. 496536, 2011.

TORRECILLA, F. J. M. Um panorama da pesquisa Ibero-americana sobre a eficácia escolar. In: In: BROOKE, Nigel; SOARES, José Francisco. (Orgs.) Pesquisa em eficácia escolar: origem e trajetórias. Belo Horizonte: Editora UFMG, 2008.

URICK, A.; BOWERS, A. What Are the Different Types of Principals Across the United States? A Latent Class Analysis of Principal Perception of Leadership. Educational Administration Quarterly, v. 50, n.1, p. 96-134, 2014.

WEBER, M. Ensaios de Sociologia. Rio de Janeiro, 1971, $2^{\text {a }}$ ed.

WEBER, M. ¿Qué es la burocracia? Buenos Aires: Editorial la Pléyade, 1977.

WEBER, M. Sociologia. São Paulo: Ática, 2008, $7^{\mathrm{a}}$ ed.

WILLMS, J.D. Monitoring School Performance: a Guide for Educators. London: The Falmer Press, 1992. 


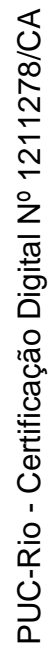

ANEXOS 


\section{Anexo 1}

\section{A pesquisa acadêmica: recentes tendências nacionais e internacionais a partir de 2010}

O quadro a seguir apresenta os 42 artigos selecionados e lidos para a revisão de literatura desta tese organizados por categorias apresentando, também, a metodologia adotada por cada um deles. Na sequência, oferecemos uma breve apresentação comentada de cada um dos artigos, material que certamente contribuirá para futuras pesquisas sobre o tema. 
Quadro 23: Categorização dos artigos selecionados na revisão de literatura ${ }^{100}$

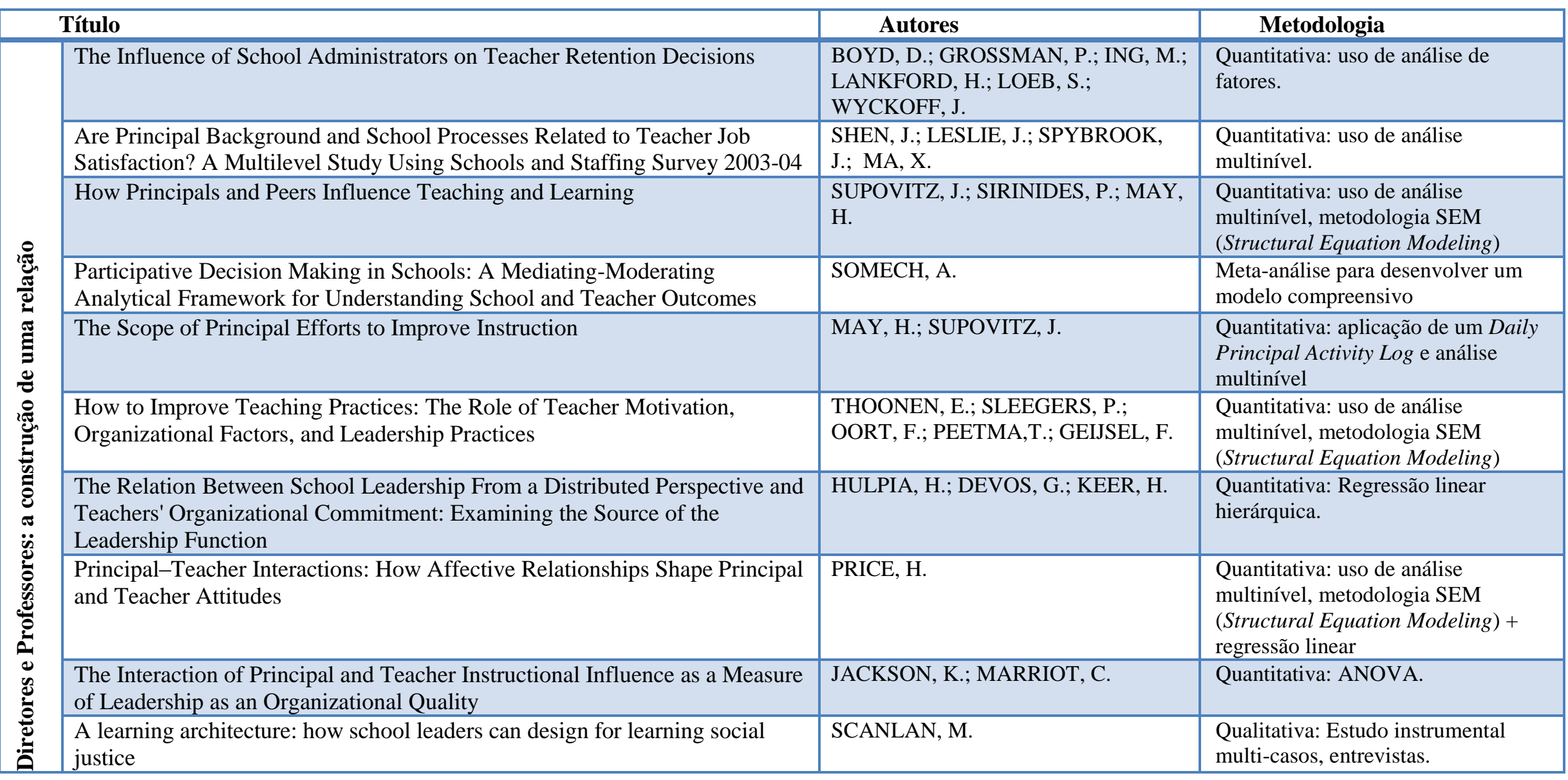

${ }^{100}$ Todos os artigos constam nas Referências Bibliográficas 


\begin{tabular}{|c|c|c|}
\hline Título & Autores & Metodologia \\
\hline Um estudo multivariado do perfil do diretor das escolas públicas de Itabaiana & CONCEIÇÃO, S.; PARENTE, J. & $\begin{array}{l}\text { Quantitativa: Questionários, análise } \\
\text { descritiva }\end{array}$ \\
\hline $\begin{array}{l}\text { Estilo de liderança e stress: uma pesquisa em escolas estaduais de ensino } \\
\text { fundamental }\end{array}$ & GOULART JUNIOR, E.; LIPP, M. & $\begin{array}{l}\text { Quantitativa: Questionários e uso do } \\
\text { Inventário do Sintomas de Stress } \\
\text { para Adultos }\end{array}$ \\
\hline $\begin{array}{l}\text { Práticas e percepções docentes e suas relações com o prestígio e clima escolar } \\
\text { das escolas públicas do município do Rio de Janeiro }\end{array}$ & BRITO, M.; COSTA, M. & $\begin{array}{l}\text { Quanti-quali: Análise descritiva de } \\
\text { dados para seleção + Entrevistas }\end{array}$ \\
\hline $\begin{array}{l}\text { Controlar ou avaliar o trabalho docente? Estratégias dos diretores numa } \\
\text { organização escolar híbrida. }\end{array}$ & BARRÈRE, A. & Qualitativa: observação e entrevistas \\
\hline $\begin{array}{l}\text { How Teacher Evaluation Methods Matter for Accountability: A Comparative } \\
\text { Analysis of Teacher Effectiveness Ratings by Principals and Teacher Value- } \\
\text { Added Measures }\end{array}$ & $\begin{array}{l}\text { HARRIS, D.; INGLE, W.; } \\
\text { RUTLEDGE, S. }\end{array}$ & Qualitativa: Entrevisats \\
\hline $\begin{array}{l}\text { Educator Beliefs and Cultural Knowledge: Implications for School } \\
\text { Improvement Efforts. }\end{array}$ & NELSON, S.; GUERRA, P. & $\begin{array}{l}\text { Qualitativa: observação + ‘cases’ } \\
\text { (discussão a partir de cenários } \\
\text { fictícios) }\end{array}$ \\
\hline $\begin{array}{l}\text { Psychological Empowerment as a Mediator Between Teachers' Perceptions } \\
\text { of Authentic Leadership and Their Withdrawal and Citizenship Behaviors. }\end{array}$ & $\begin{array}{l}\text { SHAPIRA-LISHCHINSKI, O.; } \\
\text { TSEMACH, S. }\end{array}$ & Quantitativa: análise multinível \\
\hline $\begin{array}{l}\text { Negotiating Site-Based Management and Expanded Teacher Decision } \\
\text { Making: A Case Study of Six Urban Schools. }\end{array}$ & $\begin{array}{l}\text { MAYER, A.; DONALDSON, M.; } \\
\text { LeCHASSEUR, K.; WELTON, A.; } \\
\text { COBB, C. }\end{array}$ & $\begin{array}{l}\text { Quanti-quali: Entrevista + observação } \\
\text { +dados do survey anual com } \\
\text { professores }\end{array}$ \\
\hline $\begin{array}{l}\text { Principals' Approaches to Cultivating Teacher Effectiveness: Constraints and } \\
\text { Opportunities in Hiring, Assigning, Evaluating, and Developing Teachers. }\end{array}$ & DONALDSON, $\mathrm{M}$ & $\begin{array}{l}\text { Qualitativa: entrevistas } \\
\text { semiestruturadas }\end{array}$ \\
\hline Concepções de gestão e vivência da prática escolar democrática & ABDIAN, G.; HERNANDES, E. & Pesquisa-ação \\
\hline
\end{tabular}




\begin{tabular}{|c|c|c|c|}
\hline \multicolumn{2}{|c|}{ Título } & Autores & Metodologia \\
\hline \multirow{11}{*}{ 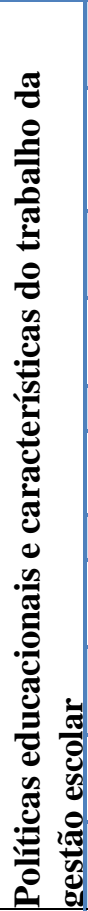 } & $\begin{array}{l}\text { Organizational Routines as Coupling Mechanisms: Policy, School } \\
\text { Administration, and the Technical Core }\end{array}$ & SPILANE, J.; PARISE, L.; SHERER,J. & $\begin{array}{l}\text { Qualitativa: Estudo de caso com } \\
\text { entrevistas e observação }\end{array}$ \\
\hline & $\begin{array}{l}\text { How School and District Leaders Support Classroom Teachers’ Work With } \\
\text { English Language Learners. }\end{array}$ & ELFERS, A.; STRITIKUS, T. & $\begin{array}{l}\text { Qualitativa: Estudo de caso com } \\
\text { entrevistas, observação, análise } \\
\text { documental }\end{array}$ \\
\hline & $\begin{array}{l}\text { Gerencialismo da escola pública contradições e desafios concernentes à } \\
\text { gestão, à autonomia e à organização do trabalho escolar }\end{array}$ & SILVA, L.; ALVES, M & $\begin{array}{l}\text { Qualitativa: Estudo de caso com } \\
\text { entrevistas. }\end{array}$ \\
\hline & $\begin{array}{l}\text { Trabalho e administração da escola: desenvolvimento e apropriação do } \\
\text { sentido que assumem no processo de produção pedagógica }\end{array}$ & RUSSO, M. & Levantamento teórico \\
\hline & Paradigmas e cognições no campo da administração educacional & CORREIA, J.A. & Levantamento teórico \\
\hline & Gestão e autonomia escolar: um estudo comparado Brasil / Portugal & MARTINS, A. M. & $\begin{array}{l}\text { Levantamento teórico e documental } \\
\text { (legislações), comparativo. }\end{array}$ \\
\hline & A natureza política da gestão escolar e as disputas pelo poder na escola & SOUZA, A. R. & Levantamento teórico \\
\hline & $\begin{array}{l}\text { When the "Dream" Turns Into a Nightmare: Life and Death of Voyager } \\
\text { Charter School. }\end{array}$ & KARANXHA, Z. & $\begin{array}{l}\text { Qualitativa: Estudo de caso em } \\
\text { profundidade }\end{array}$ \\
\hline & $\begin{array}{l}\text { Avaliação interna no contexto das avaliações externas: desafios para a gestão } \\
\text { escolar. }\end{array}$ & MACHADO, C.; ALAVARSE, O. & Pesquisa-ação \\
\hline & $\begin{array}{l}\text { A política educacional paulista (1995-2010) e seus impactos na identidade da } \\
\text { escola e do professor. }\end{array}$ & RAMOS, G. P. & $\begin{array}{l}\text { Levantamento bibliográfico e } \\
\text { documental }\end{array}$ \\
\hline & $\begin{array}{l}\text { How External Institutions Penetrate Schools Through Formal and Informal } \\
\text { Leaders. }\end{array}$ & $\begin{array}{l}\text { SUN, M.; FRANK, K.; PENUEL,W.; } \\
\text { KIM, C. }\end{array}$ & $\begin{array}{l}\text { Quantitativa: Longitudinal, análise de } \\
\text { fatores e regressão linear }\end{array}$ \\
\hline & $\begin{array}{l}\text { Configurations of Instructional Leadership Enactments That Promote the } \\
\text { Teaching and Learning of Mathematics in a New Zealand Elementary School }\end{array}$ & HIGGINS, J.; BONNE, L. & $\begin{array}{l}\text { Qualitativa: Estudo de caso com } \\
\text { entrevistas. }\end{array}$ \\
\hline 窇 & $\begin{array}{l}\text { The Nature and Effects of Transformational School Leadership: A Meta- } \\
\text { Analytic Review of Unpublished Research }\end{array}$ & LEEITHWOOD, K.; SUN, J. & $\begin{array}{l}\text { Revisão meta-analítica de pesquisas } \\
\text { não-publicadas }\end{array}$ \\
\hline 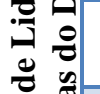 & $\begin{array}{l}\text { Perfil de liderança do diretor de escola em Portugal modos de atuação e } \\
\text { estratégias de regulação da cultura organizacional }\end{array}$ & FERREIRA, N. ; TORRES, L. & $\begin{array}{l}\text { Qualitativa: Estudo de caso } \\
\text { sincrônico }\end{array}$ \\
\hline 总 & Gestão escolar: afinal, que fins estão sendo buscados? & $\begin{array}{l}\text { MEDEIROS, M.; FEROLLA, L.; } \\
\text { PASSADOR, C.; PASSADOR, J. }\end{array}$ & $\begin{array}{l}\text { Qualitativa: Entrevistas em } \\
\text { profundidade, Atlas-Ti }\end{array}$ \\
\hline
\end{tabular}




\begin{tabular}{|c|c|c|c|}
\hline \multicolumn{2}{|r|}{ Título } & \multirow{2}{*}{$\begin{array}{l}\text { Autores } \\
\text { FICHER, S.; GUIMARÃES, M. C. }\end{array}$} & \multirow{2}{*}{$\begin{array}{l}\text { Metodologia } \\
\text { Qualitativa: Estudo de caso }\end{array}$} \\
\hline & $\begin{array}{l}\text { A construção da gestão autônoma das escolas públicas brasileiras: um estudo } \\
\text { nas escolas de ensino fundamental em Santa Catarina. }\end{array}$ & & \\
\hline & $\begin{array}{l}\text { Rethinking Instructional Leadership, a Review: What Do We Know About } \\
\text { Principal, Teacher, and Coach Instructional Leadership, and Where Should } \\
\text { We Go From Here? }\end{array}$ & NEUMERSKI, C. & Revisão bibliográfica \\
\hline & $\begin{array}{l}\text { From a Managerial Imperative to a Learning Imperative: Experiences of } \\
\text { Urban, Public School Principals. }\end{array}$ & TEROSKY, A. & Qualitativa: Estudo de caso \\
\hline & $\begin{array}{l}\text { What Are the Different Types of Principals Across the United States? A } \\
\text { Latent Class Analysis of Principal Perception of Leadership. }\end{array}$ & URICK, A.; BOWERS, A. & Quantitativo \\
\hline & $\begin{array}{l}\text { Novice School Principals' Sense of Ultimate Responsibility: Problems of } \\
\text { Practice in Transitioning to the Principal's Office. }\end{array}$ & SPILLANE, J.; LEE, L. & $\begin{array}{l}\text { Quanti-quali: Longitudinal, } \\
\text { Entrevistas + análise estatística de } \\
\text { dados }\end{array}$ \\
\hline \multirow{5}{*}{ 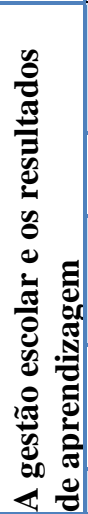 } & $\begin{array}{l}\text { Triangulating Principal Effectiveness : How Perspectives of Parents, } \\
\text { Teachers, and Assistant Principals Identify the Central Importance of } \\
\text { Managerial Skills }\end{array}$ & GRISSOM, J.; LOEB, S. & $\begin{array}{l}\text { Quantitativa: análise de fatores e } \\
\text { análise multivariada. }\end{array}$ \\
\hline & Testing a Conception of How School Leadership Influences Student Learning & $\begin{array}{l}\text { LEITHWOOD, K.; PATTEN, S.; } \\
\text { JANTZI, D. }\end{array}$ & $\begin{array}{l}\text { Quantitativa: análise de fatores e } \\
\text { covariância }\end{array}$ \\
\hline & $\begin{array}{l}\text { Do Principal Preparation Programs Influence Student Achievement Through } \\
\text { the Building of Teacher-Team Qualifications by the Principal? An } \\
\text { Exploratory Analysis }\end{array}$ & $\begin{array}{l}\text { FULLER, E.; YOUNG, M.; BAKER, } \\
\text { B. }\end{array}$ & $\begin{array}{l}\text { Quantitativa: regressão dos } \\
\text { quadrados mínimos (OLS) }\end{array}$ \\
\hline & $\begin{array}{l}\text { Modeling the Influence of School Leaders on Student Achievement: How } \\
\text { Can School Leaders Make a Difference? }\end{array}$ & $\begin{array}{l}\text { BRUNGECATE, G.; LUYTEN, H.; } \\
\text { SHEERENS, J.; SLEEGERS, P. }\end{array}$ & $\begin{array}{l}\text { Quantitativa: uso de análise } \\
\text { multinível, metodologia SEM } \\
\text { (Structural Equation Modeling) }\end{array}$ \\
\hline & & & \\
\hline
\end{tabular}




\title{
Apresentação dos artigos
}

\section{Diretores e Professores: a construcão de uma relacão}

\begin{abstract}
ABDIAN, G.; HERNANDES, E. Concepções de gestão e vivência da prática escolar democrática.

A partir de uma pesquisa-ação em um contexto em que são, também, professoras de um curso de formação continuada em Gestão escolar, as autoras procuraram identificar relatos de gestão democrática no discurso dos diretores pesquisados.
\end{abstract}

BARRÈRE, A. Controlar ou avaliar o trabalho docente? Estratégias dos diretores numa organização escolar híbrida.

Relato de um estudo qualitativo realizado na França, sobre as tensões no trabalho do diretor escolar envolvendo a avaliação do trabalho desempenhado pelos professores. A autora apresenta uma importante contextualização sobre a interferência externa na rotina escolar, especialmente reconfigurando o trabalho do diretor. A partir dos dados, propõe uma tipologia de perfis de diretores com base na forma como incorporam, conforme prescrição externa, a tarefa de avaliar os professores em sua rotina.

BOYD, D.; GROSSMAN, P.; ING, M.; LANKFORD, H.; LOEB, S.; WYCKOFF, J. The Influence of School Administrators on Teacher Retention Decisions.

Os autores dedicam especial atenção aos fatores contextuais da escola (incluindo o que chamam de Administração) e seus impactos nas decisões dos professores em permanecer ou deixar a escola. A pesquisa de falta de follow-up, realizada uma não após as primeiras entrevistas, apontou o fator Administração (que envolve o relacionamento com a equipe de direção da escola) como importante preditor da decisão do professor em continuar na escola, assim como o apoio desta equipe foi apontado como aspecto que influenciou a decisão do professor em deixar a escola.

BRITO, M.; COSTA, M. Práticas e percepções docentes e suas relações com o prestígio e clima escolar das escolas públicas do município do Rio de Janeiro.

Os autores se voltaram para a compreensão do clima escolar, abordando o papel da gestão para a construção do mesmo. Apontam que a gestão da escola foi indicada pelos professores como segundo fator de diferenciação entre a oferta educacional (melhor ou pior resultado acadêmico) nas unidades onde trabalham. Esta percepção aponta para a relevância do trabalho da gestão escolar para o resultado escolar, inclusive do ponto de vista dos professores, que são mais diretamente responsáveis pelo mesmo..

DONALDSON, M. Principals' Approaches to Cultivating Teacher Effectiveness: Constraints and Opportunities in Hiring, Assigning, Evaluating, and Developing Teachers.

A partir de um estudo qualitativo com os resultados de entrevistas semiestruturadas com 30 diretores, o autor apresenta as principais barreiras que estes líderes encontram nas tarefas de selecionar/contratar, avaliar, atribuir tarefas e favorecer o desenvolvimento profissional dos professores. Metodologicamente, traz boas sugestões para validação e categorização em entrevistas semiestruturadas.

GOULART JUNIOR, E.; LIPP, M. Estilo de liderança e stress: uma pesquisa em escolas estaduais de ensino fundamental.

$\mathrm{O}$ stress provocado pela necessidade de atingir metas traz para o diretor a responsabilidade pelo controle do processo escolar, resultando em medidas de cobrança de resultados com "efeito em cascata" para o trabalho dos professores. Os autores apontam que as características do trabalho da gestão escolar podem ser associadas ao quadro de stress dos professores, sendo este mais comum em escolas nas quais o perfil de 
liderança do diretor é percebido como liberal (de acordo com a classificação utilizada pelo estudo)

HARRIS, D.; INGLE, W.; RUTLEDGE, S. How Teacher Evaluation Methods Matter for Accountability: A Comparative Analysis of Teacher Effectiveness Ratings by Principals and Teacher Value-Added Measures

Os autores abordam o tema da avaliação do trabalho docente baseada nos instrumentos da Política Race to the Top (RttT) que medem a eficiência do trabalho docente (expressa nos resultados dos alunos) a partir da ideia de valor-agregado. Discutem, com base nos dados levantados pela pesquisa, as divergências entre os resultados deste tipo de avaliação e de uma avaliação mais subjetiva, conduzida pelos diretores. $\mathrm{O}$ artigo traz também, uma importante discussão sobre as implicações desta avaliação para a carreira e o trabalho do professor e suas relações com agentes externos (políticas, proteção sindical).

HULPIA, H.; DEVOS, G.; KEER, H. The Relation Between School Leadership From a Distributed Perspective and Teachers' Organizational Commitment: Examining the Source of the Leadership Function.

Os autores analisam o comprometimento dos professores a partir das estratégias adotadas por uma gestão que aplica a proposta de "Liderança Distribuída". Tal prática implica no reconhecimento de que a tarefa de liderar a escola deve ser repartida entre membros da equipe de gestão e não centralizada na mão de uma só pessoa. Os autores propõem a operacionalização do conceito de "Liderança Distribuída" em três diferentes áreas: a) os diferentes membros da equipe que desempenham tarefas de liderança; b) a participação dos professores e c) a cooperação entre os membros da equipe de direção.

JACKSON, K.; MARRIOT, C. The Interaction of Principal and Teacher Instructional Influence as a Measure of Leadership as an Organizational Quality. O estudo propõe uma medida da liderança escolar através da interação entre a influência instrucional do diretor e do professor. Utiliza as respostas aos questionários de diretores, professores e alunos do SASS (School and Staffing Survey) do ano escolar de 2003-2004. Os autores utilizam as quatro condições de liderança apontadas pelo Modelo da Liderança Organizacional (OLM, no original).

MAY, H.; SUPOVITZ, J. The Scope of Principal Efforts to Improve Instruction.

Os autores desenvolveram uma metodologia especialmente para captar as tendências neste campo. $\mathrm{O}$ estudo procura medir qual é a frequência das tarefas do diretor que visam instruir seus professores sobre o trabalho a ser desenvolvido na escola e qual é o peso desta instrução nas mudanças didáticas relatadas pelos professores. Abordam, assim, uma relação de aceitação e reconhecimento, por parte do professor, da instrução dada pelo diretor e, por parte deste, a priorização (ou não) desta tarefa.

MAYER, A.; DONALDSON, M.; LeCHASSEUR, K.; WELTON, A.; COBB, C. Negotiating Site-Based Management and Expanded Teacher Decision Making: A Case Study of Six Urban Schools.

Os autores discutem duas estratégias adotadas a partir da Comprehensive School Reform: maior autonomia da gestão da escola e maior participação dos professores nas decisões. Em um estudo quanti-quali, os autores analisam as implicações de uma maior autonomia dos diretores na gestão escolar, principalmente no empoderamento dos professores, favorecendo a construção de um clima escolar mais colaborativo.

NELSON, S.; GUERRA, P. Educator Beliefs and Cultural Knowledge: Implications for School Improvement Efforts.

Os autores relatam um estudo qualitativo sobre as crenças e conhecimentos culturais dos professores e diretores de escolas de dois distritos. Destacam a importância das expectativas dos educadores com relação ao sucesso de seus alunos, dando especial 
relevância às questões relacionadas às diferenças culturais entre alunos. Metodologicamente, apresenta uma interessante proposta de "cenários" (casos) fictícios para discussão com os respondentes nas entrevistas realizadas.

PRICE, H. Principal-Teacher Interactions: How Affective Relationships Shape Principal and Teacher Attitudes.

A autora analisa as relações organizacionais na escola e como elas se manifestam em diferentes níveis de satisfação, coesão e comprometimento entre diretores e professores. A pesquisa busca, também, medir como as atitudes dos diretores (tais como divisão de tarefas, interações com os professores, comunicação de expectativas) contribuem para atitudes positivas dos professores (que refletem a satisfação e o comprometimento com a escola e a coesão em grupo).

SCANLAN, M. A learning architecture: how school leaders can design for learning social justice.

$\mathrm{O}$ estudo pretende ajudar na compreensão sobre como a aprendizagem sociocultural promove mudanças práticas. Traz como questão central: Como as comunidades de práticas afetam a aprendizagem através do trabalho de professores em uma escola que defende uma comunidade mais justa socialmente? Os autores concluem que líderes escolares devem atender às interconexões de todas as quatro dualidades da arquitetura da aprendizagem, citadas no texto, para auxiliar na aprendizagem, dos professores.

SHAPIRA-LISHCHINSKI, O.; TSEMACH, S. Psychological Empowerment as a Mediator Between Teachers' Perceptions of Authentic Leadership and Their Withdrawal and Citizenship Behaviors.

Em um estudo quantitativo realizado em Israel, os autores usam uma medida de "empoderamento psicológico" como mediadora da relação entre a variável criada para medir a percepção dos professores sobre a liderança do diretor (liderança autêntica) e os comportamentos negativos (de atraso, faltas e intenção de sair da escola) e positivos (relacionados à colaboração e trabalho coletivo) dos professores. Destaca-se a relevância do trabalho na definição dos conceitos, no desenho da pesquisa e na metodologia empregada.

SHEN, J.; LESLIE, J.; SPYBROOK, J.; MA, X. Are Principal Background and School Processes Related to Teacher Job Satisfaction? A Multilevel Study Using Schools and Staffing Survey 2003-04.

Os autores questionam a relação entre as variáveis - o nível de formação do diretor e sua experiência no trabalho - com o nível de satisfação dos professores na escola. Destacam a importância do diretor na manutenção do clima de trabalho na escola, e nas atitudes de reconhecimento, respeito e apreciação do trabalho do professor como determinantes do nível de satisfação demonstrado pelos professores em atuarem em determinada escola.

SOMECH, A. Participative Decision Making in Schools: A Mediating-Moderating Analytical Framework for Understanding School and Teacher Outcomes.

$\mathrm{O}$ estudo pretendeu desenvolver um modelo compreensivo para entender os distintos impactos do Participative Decision Making - PDM nos resultados das escolas e dos professores. O quadro analítico do estudo sugere que a relação entre o PDM e os resultados dos professores e da escola devem ser mediados por mecanismos motivacionais ou cognitivo. Os mecanismos cognitivos demonstraram ser mais vantajosos, especialmente para melhorar os resultados escolares. 
SUPOVITZ, J.; SIRINIDES, P.; MAY, H. How Principals and Peers Influence Teaching and Learning.

Os autores levantam quais são as principais atividades dos diretores que produzem mudanças nas salas de aula a partir do comportamento dos professores. Os autores apontam para a influência indireta da atuação do diretor na prática dos professores, favorecendo a colaboração e a comunicação no ambiente escolar.

THOONEN, E.; SLEEGERS, P.; OORT, F.; PEETMA,T.; GEIJSEL,F. How to Improve Teaching Practices: The Role of Teacher Motivation, Organizational Factors, and Leadership Practices.

O estudo analisa o impacto das práticas de Liderança Transformacional, das condições organizacionais da escola e de fatores motivacionais nas práticas dos professores. Os autores abordam ainda a colaboração docente e sua influência para o engajamento dos professores nas atividades de formação.

\section{Políticas educacionais e o trabalho da gestão escolar}

CORREIA, J.A. Paradigmas e cognições no campo da administração educacional.

O levantamento teórico destaca o papel central que as questões administrativas passaram a ter nas políticas educacionais. $\mathrm{O}$ autor aborda a relação entre as políticas educacionais recentes em Portugal e o trabalho do gestor escolar.

ELFERS, A.; STRITIKUS, T. How School and District Leaders Support Classroom Teachers' Work With English Language Learners.

A partir de uma pesquisa qualitativa em 4 distritos, os autores procuram levantar as estratégias através das quais os diretores e gestores dos distritos auxiliam os professores que atendem alunos não fluentes na língua inglesa. São destacadas as responsabilidades e desafios dos diretores na tarefa de oferecer suporte aos professores, através de uma liderança com foco na instrução/aprendizagem.

KARANXHA, Z. When the "Dream" Turns Into a Nightmare: Life and Death of Voyager Charter School.

O texto trata do universo das charters schools na Flórida, ressaltando, especialmente, a alta taxa destas escolas que são fechadas por não cumprirem as exigências e metas legais. A autora ressalta a maior autonomia dos gestores destas escolas nas definições pedagógicas e nas relações profissionais, que incorporam elementos da responsabilização na qual estão mais fortemente inseridos. Em um estudo de caso em profundidade, analisa a trajetória de uma charter school, na qual destacamos as tensões da gestão para lidar com sua autonomia e responsabilidades.

MACHADO, C.; ALAVARSE, O. Avaliação interna no contexto das avaliações externas: desafios para a gestão escolar.

Os autores trazem a tona uma discussão sobre a tarefa do gestor escolar em instruir os professores da escola sobre a melhor utilização dos dados levantados a partir das avaliações externas. A pesquisa-ação desenvolvida pelos autores revela a incongruência entre resultados nos dois tipos de avaliação (interna e externa) para os mesmos alunos. Ressalta a importância de o professor ampliar a avaliação externa com instrumentos próprios e buscar compreender os resultados alcançados por seus alunos e destacam o papel fundamental dos gestores escolares nesse processo. 
MARTINS, A. M. Gestão e autonomia escolar: um estudo comparado Brasil / Portugal.

A autora faz um estudo comparativo entre as legislações brasileira e portuguesa sobre a gestão e autonomia escolar, analisando seus reflexos nos diferentes contextos. Apresenta uma importante contextualização da política e legislação dos dois países.

RAMOS, G. P. A política educacional paulista (1995-2010) e seus impactos na identidade da escola e do professor.

A autora faz, a partir de um levantamento bibliográfico e documental, uma análise das mudanças na política educacional paulista no período de 1995 a 2010, quando prevaleceu o foco na racionalização organizacional, na mudança nos padrões de gestão, e na qualidade do ensino. Aborda, brevemente, os possíveis impactos destas políticas na identidade da escola e do professor atual.

RUSSO, M. Trabalho e administração da escola: desenvolvimento e apropriação do sentido que assumem no processo de produção pedagógica.

$\mathrm{O}$ autor realiza um levantamento teórico sobre o tema e destaca que se, por um lado notase uma relativa autonomia da escola na consecução e ação de seu projeto escolar, por outro lado se assiste a uma crescente postura intervencionista do Estado na educação.

SILVA, L.; ALVES, M. Gerencialismo da escola pública contradições e desafios concernentes à gestão, à autonomia e à organização do trabalho escolar.

Os autores apontam a contrariedade sobre as atuais determinações para a gestão escolar: apesar de se propagar a abertura para maior participação e democracia nos processos escolares, percebe-se a intensificação da responsabilização pelos resultados alcançados.

\section{SOUZA, A. R. A natureza política da gestão escolar e as disputas pelo poder na escola. \\ O autor realiza um estudo sobre a natureza política da gestão escolar, analisando as ações e reações do trabalho dos dirigentes escolares evidenciando a natureza política do mesmo. $\mathrm{O}$ autor propõe que pensar sobre "alternativas na condução da política educacional, particularmente no que concerne à democratização do direito à educação e a sua gestão", pressupõe a compreensão sobre a margem de poder e controle dos dirigentes escolares.}

SUN, M.; FRANK, K.; PENUEL, W.; KIM, C. How External Institutions Penetrate Schools Through Formal and Informal Leaders.

A partir de um estudo quantitativo longitudinal, os autores ressaltam o papel central que líderes formais (diretores) e informais exercem na mediação das demandas das políticas educacionais, especialmente no que se refere às mudanças na prática docente. Os resultados indicaram uma associação estatisticamente significativa entre a exposição à influência de líderes formais (diretores) e as práticas dos professores voltadas para o ensino de leitura (foco do estudo) de acordo com o recomendado pela implementação do $\mathrm{NCLB}^{101}$.

${ }^{101}$ Lei No Child Left Behind, U.S. 2001. 
Tipos de Lideranca e Tarefas do Diretor

CONCEIÇÃo, S.; PARENTE, J. Um estudo multivariado do perfil do diretor das escolas públicas de Itabaiana.

O estudo "indicou o peso de variáveis de natureza administrativa, pedagógica, humana e financeira, as quais influenciam em diferentes perspectivas no processo de gestão das instituições escolares" (p. 491). As autoras esclarecem o caráter exploratório e metodológico do estudo, que se limitou a determinar se e em que medida as características pessoais e as estratégias de trabalho dos diretores interferem no processo de gestão escolar.

FERREIRA, N.; TORRES, L. Perfil de liderança do diretor de escola em Portugal modos de atuação e estratégias de regulação da cultura organizacional.

O estudo traz, como questão central, o desempenho do trabalho do diretor sofre a influência de determinações e pressões externas, vindas das políticas educacionais propostas pelas instâncias governamentais que, atualmente, tendem às avaliações em larga escala com possível responsabilização das escolas pelos resultados alcançados. Os autores concluem que, frente às pressões das políticas externas, cabe ao diretor escolar adotar uma posição e esta posição revela e constrói seu perfil de liderança.

FICHER, S.; GUIMARÃES, M. C. A construção da gestão autônoma das escolas públicas brasileiras: um estudo nas escolas de ensino fundamental em Santa Catarina.

A partir de um estudo qualitativo realizado em 6 cidades catarinenses, os autores propõem uma reflexão sobre a amplitude da autonomia na gestão escolar. Os dados coletados são analisados a partir das seguintes dimensões: autonomia financeira, autonomia administrativa e autonomia pedagógica.

HIGGINS, J.; BONNE, L. Configurations of Instructional Leadership Enactments That Promote the Teaching and Learning of Mathematics in a New Zealand Elementary School.

Os autores exploram como a liderança do diretor pode desenvolver uma melhor instrução dos professores influenciando a melhora nos resultados dos alunos. Dedicam especial atenção às tarefas da liderança escolar em suas configurações hierárquica, horizontal e híbrida. Esta dupla categorização da liderança escolar traz uma nova abordagem dos conceitos relativos às tarefas de liderança, que podem ser observados em sua tipologia e intensidade de controle.

LEEITHWOOD, K. and SUN, J. The Nature and Effects of Transformational School Leadership: A Meta-Analytic Review of Unpublished Research.

Em um levantamento meta-analítico de pesquisas ainda não publicadas (teses e dissertações defendidas), os autores buscam identificar as práticas associadas à liderança transformacional na escola (TSL, no original); descrever os estados e comportamentos internos que as práticas de TSL assumidamente influenciam e em que extensão esta influência é manifestada; identificar as condições da escola influenciadas pela TSL e a extensão dessa influência; acessar a influência da TSL nos resultados dos alunos.

MEDEIROS, M.; FEROLLA, L.; PASSADOR, C.; PASSADOR, J. Gestão escolar: afinal, que fins estão sendo buscados?

Os autores propõem uma análise sobre o que pensam os gestores escolares a respeito da função educacional da escola e as possíveis relações entre esta percepção e os resultados dos alunos. Para tanto, utilizam dados coletados em 4 escolas de dois municípios paulistas (entrevistas em profundidade). Através de uso de software específico, são observadas as relações entre as concepções educacionais reportadas pelos gestores e sua percepção 
sobre a finalidade de seu trabalho. Estas informações são, então, relacionadas aos resultados das escolas.

NEUMERSKI, C. Rethinking Instructional Leadership, a Review: What Do We Know About Principal, Teacher, and Coach Instructional Leadership, and Where Should We Go From Here?

A autora faz um levantamento sobre as pesquisas que se dedicaram a examinar a Instructional Leaderhip a partir do trabalho dos diretores, dos professores-líderes e dos coaches $^{102}$, separadamente. Traz, como proposta, a integração entre as pesquisas sobre liderança instrucional para que questões que envolvem os três agentes sejam interrelacionadas. Importante revisão de literatura sobre o tema.

SPILLANE, J.; LEE, L. Novice School Principals' Sense of Ultimate Responsibility: Problems of Practice in Transitioning to the Principal's Office.

O texto trata sobre os desafios que os novos diretores (primeiros 3 meses no cargo) enfrentam, que são complexificados pelo contexto de políticas de responsabilização, na transição da sala de aula para o escritório da direção. Entre eles, o mais expressivo foi o sentimento de "responsabilidade por tudo" (Ultimate Responsability). O objetivo do estudo, que mesclou métodos quantitativos e qualitativos, foi oferecer pistas para melhor preparar e apoiar os novos diretores, afim de que continuem no cargo.

TEROSKY, A. From a Managerial Imperative to a Learning Imperative: Experiences of Urban, Public School Principals.

A autora destaca a predominância de atividades mais administrativas na condução do trabalho do diretor (managerial imperative) e a importância da valorização de estratégias mais voltadas para o ensino-aprendizagem (instructional leadership). No contexto de 18 escolas em Nova Iorque os diretores reportaram alguma frustração em designar mais tempo e atenção para as tarefas administrativas do que nas tarefas mais voltadas para a instrução, realidade intensificada com as demandas da legislação atual naquele contexto. Discute-se, ainda, um novo conceito: o "imperativo da aprendizagem".

URICK, A. and BOWERS, A. What Are the Different Types of Principals Across the United States? A Latent Class Analysis of Principal Perception of Leadership. Os autores problematizam a tipologia de perfis de liderança comumente adotada nos estudos norte-americanos, propondo uma classificação que contemple a interação com o contexto onde a escola está inserida e a relação com os outros agentes escolares. A partir de um estudo quantitativo com os dados do SASS, os autores chegam a três tipos de liderança: o diretor controlador, o diretor "balkanizing" - que divide para conquistar- e o diretor integrador. Os autores destacam a importância do contexto onde a escola está inserida na definição/escolha do diretor pelas estratégias de liderança que vai adotar.

\footnotetext{
${ }^{102}$ Mentores ou especialistas profissionais na área educacional, internos ou externos à escola, contratados para trabalhar diretamente com os professores em aspectos pontuais ou acompanhando o projeto da escola, a longo prazo.
} 
Diretores e Alunos: A gestão escolar e os resultados de aprendizagem

BRUGGENCATE, G.; LUYTEN, H.; SHEERENS, J.; SLEEGERS, P. Modeling the Influence of School Leaders on Student Achievement: How Can School Leaders Make a Difference?

Como os diretores de escola se tornam efetivos e "fazem a diferença"? A partir desta pergunta os autores desenvolvem uma ampla pesquisa quantitativa a partir das respostas de professores e diretores de 97 escolas da Holanda. Entre os achados, destacamos: Os líderes escolares têm uma grande influência em desenvolver orientações nas escolas, em manter o que pode ser chamado de organização para a aprendizagem. O comportamento dos diretores afeta os resultados dos alunos direta e indiretamente. Os resultados apontam uma pequena mas positiva e significativa relação de efeitos mediados entre as quatro dimensões estudadas e a média de promoção dos alunos através do desenvolvimento orientado da organização escolar e do trabalho dos professores (que afeta a taxa de promoção da escola diretamente).

FUlLER, E.; YOUNG, M.; BAKER, B. Do Principal Preparation Programs Influence Student Achievement Through the Building of Teacher-Team Qualifications by the Principal? An Exploratory Analysis.

O estudo aborda a relação entre o nível de qualificação dos professores e as mudanças no nível de resultados dos alunos da escola elementar (após controlar por variáveis sócio demográficas). Investigam, também, a relação entre as características do programa de formação do diretor e as mudanças na qualificação do time de professores da escola (após controlar pelas características individuais do diretor, NSE dos alunos, resultados acadêmicos da escola e características do mercado de trabalho local).

GRISSOM, J.; LOEB, S. Triangulating Principal Effectiveness : How Perspectives of Parents, Teachers, and Assistant Principals Identify the Central Importance of Managerial Skills.

Estudando a eficácia do diretor através da análise das diferentes tarefas que exerce, os autores apontam cinco dimensões das funções dos diretores que são efetivas na escola: Gestão da Instrução, Relações Internas, Gestão da Organização, Administração e Relações Externas. As questões do survey, que passaram pela análise fatorial resultando em tais dimensões, são apresentadas no texto (p.1099). A escolha dos nomes dos fatores a partir de suas variáveis, com base especialmente na literatura sobre Liderança Instrucional, constitui leitura interessante para os estudos sobre as funções do diretor escolar.

LEITHWOOD, K.; PATTEN, S.; JANTZI, D. Testing a Conception of How School Leadership Influences Student Learning

Pensando sobre as práticas dos líderes escolares, os autores levantam as tarefas do diretor classificando-as a partir dos Quatro Caminhos de Liderança (The Four Paths Model): Racional, Organizacional, das Emoções e da Família. A partir deles, as práticas dos diretores foram categorizadas e seus efeitos analisados nos resultados dos alunos. 


\section{Anexo 2}

\section{Questionário do School and Staff Survey (SASS), uma contribuição internacional.}

O SASS trata-se de um sistema de questionários relacionados aplicados a diretores, professores, escolas e distritos, a cada quatro anos em regime amostral nos Estados Unidos. Os dados disponibilizados pelo SASS tornaram-se importante ferramenta para a pesquisa na área educacional naquele país. A grande abrangência dos itens dos questionários, tratando temas como formação profissional, práticas pedagógicas, nível socioeconômico e cultural, estilos de liderança e formas de gestão, possibilita múltiplos olhares sobre as relações entre fatores escolares associados ao desempenho dos alunos. A partir deste instrumento, foram desenvolvidos e divulgados inúmeros trabalhos que relacionam as informações dos questionários entre si e/ou com os níveis de proficiência dos alunos. Entre eles, destacamos o trabalho de Price (2012), que investigou como a variação nas relações organizacionais manifestam diferentes níveis de satisfação, coesão e comprometimento entre diretores e professores; o estudo de Jackson e Marriot (2012), sobre a medida de liderança nas escolas como qualidade organizacional e os reflexos de seus diferentes níveis nos resultados da unidade de ensino; a pesquisa de Shen e colegas (2012), que abordou a relação entre a gestão e a satisfação do professor no trabalho, a partir do cruzamento das características dos diretores e das escolas e as respostas dos professores.

A leitura dos artigos citados acima ressaltou as possibilidades de uso das informações geradas pelo SASS. Julgamos ser interessante analisar os instrumentos de coleta de dados do SASS, principalmente os questionários destinados a diretores, com o intuito de conhecer diferentes formas de propor itens para os temas a serem abordados por esta pesquisa. Para tanto, levantamos os itens propostos pelo instrumento a partir de suas temáticas e, em seguida, o mesmo levantamento foi realizado no questionário contextual da Prova Brasil. Procuramos quantificar as questões em cada temática a fim de realçar a atenção dirigida a cada uma delas. A intenção principal foi perceber quais informações são passíveis de serem capturadas por estes dois instrumentos e quais podem ser ampliadas. Os resultados deste levantamento inicial são apresentados nos quadros que se seguem: 
Quadro 24: SASS: Temas abordados no questionário dirigido ao diretor escolar

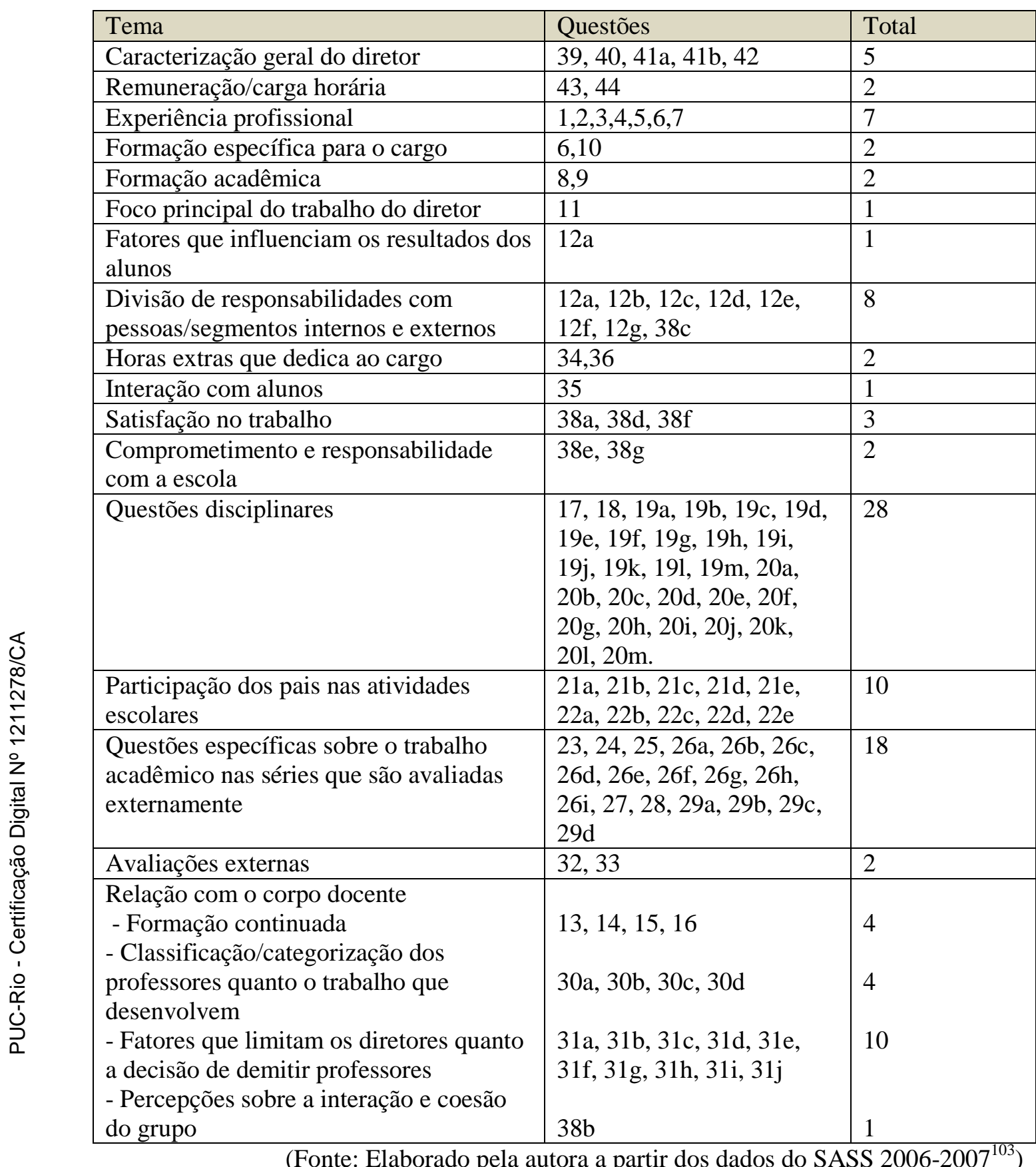

\footnotetext{
${ }^{103}$ Disponibilizados em: http://nces.ed.gov/surveys/sass
} 
Quadro 25: Prova Brasil: Temas abordados no questionário dirigido ao diretor escolar

\begin{tabular}{|c|c|c|}
\hline Tema & Questões & Total \\
\hline Caracterização geral do diretor & $1,2,3$ & 5 \\
\hline Escolaridade/Formação & $\begin{array}{l}4,5,6,7,8,9,10,11,12 \\
13\end{array}$ & 10 \\
\hline Rendimentos/Carga horária & $14,15,16,20$ & 4 \\
\hline Seleção/ acesso ao cargo & 21 & 1 \\
\hline $\begin{array}{l}\text { Atividades desenvolvidas com relação ao } \\
\text { Conselho de Escola }\end{array}$ & $24,25,2627,28$ & 5 \\
\hline Acesso dos alunos às vagas da escola & 31,32 & 2 \\
\hline Enturmação dos alunos & 33 & 1 \\
\hline $\begin{array}{l}\text { Relação com os professores } \\
\text { - Atividades de formação continuada } \\
\text { - Participação nos Conselhos de Classe e } \\
\text { na Elaboração do PP } \\
\text { - Distribuição de turmas/professor } \\
\text { - Vínculo de trabalho dos professores } \\
\text { - Absenteísmo } \\
\text { - Rotatividade } \\
\text { - Escolha de material didático }\end{array}$ & $\begin{array}{l}22,23 \\
29,30 \\
34 \\
35,45 \\
50 \\
52 \\
94\end{array}$ & $\begin{array}{l}2 \\
2 \\
1 \\
2 \\
1 \\
1 \\
1\end{array}$ \\
\hline $\begin{array}{l}\text { Desafios do trabalho } \\
\text { - Abandono dos alunos } \\
\text { - Reprovação } \\
\text { - Absenteísmo dos alunos } \\
\text { - Reforço à aprendizagem } \\
\text { - Problemas disciplinares e violência }\end{array}$ & $\begin{array}{l}36 \\
37 \\
38,39,40,41,42,51 \\
43 \\
53,99,100,101,102,103 \\
104,105,106,107,108 \\
109,110,111,112,113 \\
114,115,116,117,118 \\
119,120,121,122,123 \\
124,125,126,127,128\end{array}$ & $\begin{array}{l}1 \\
1 \\
6 \\
1\end{array}$ \\
\hline $\begin{array}{l}\text { Questões de administração financeira e } \\
\text { de pessoal }\end{array}$ & $44,46,47,49,91,92,93$ & 7 \\
\hline Infraestrutura e recursos & $\begin{array}{l}48,58,59,60,61,62,63, \\
64,65,66,67,69,70,71, \\
72,73,74,75,76,77,78, \\
79,80,81,95,96,97,98\end{array}$ & 29 \\
\hline $\begin{array}{l}\text { Relações exógenas - autonomia na gestão } \\
\text { da escola }\end{array}$ & $54,55,56,94$ & 4 \\
\hline Relação escola e comunidade & $\begin{array}{l}57,82,83,84,85,86,87 \\
88,89,90\end{array}$ & 10 \\
\hline $\begin{array}{l}\text { Conhecimento sobre a participação da } \\
\text { escola e seus resultados nos resultados } \\
\text { das avaliações externas }\end{array}$ & 129,130 & 2 \\
\hline
\end{tabular}

(Fonte: Elaborado pela autora. INEP, 2012)

Os quadros acima apresentam um levantamento dos temas abordados pelos itens dos questionários destinados aos diretores escolares no contexto dos Estados Unidos (SASS) e do Brasil (Prova Brasil). Nossa intenção neste levantamento não foi estabelecer uma comparação entre os instrumentos, o que não faria sentido considerando o 
distanciamento contextual e teórico que motivaram a elaboração de cada um deles. Procuramos somente buscar indícios de uma abordagem diferente para os temas aos quais nos dedicamos.

Um primeiro ponto que chama a atenção é a presença de itens específicos sobre a satisfação do diretor no desempenho do seu trabalho no questionário do SASS. Este um é um conceito que nos parece importante para as relações que se estabelecem no interior da escola, especialmente aquelas entre o diretor e os professores, e não é abordado no questionário contextual da Prova Brasil. A insatisfação no desempenho de suas funções, possivelmente captada pelas questões apontadas, interfere no perfil de liderança deste diretor. Assim, resolvemos elaborar itens que tratassem sobre o nível de satisfação do diretor na escola pensando na possibilidade de relacioná-lo a outras medidas captadas pelo instrumento.

O questionário do SASS traz uma questão de escolha hierárquica forçada (tipo de questão que pede ao respondente que escolha uma ordem entre várias opções) para captar o principal foco/meta do seu trabalho. Este tópico não é abordado no questionário da Prova Brasil e nos pareceu bastante pertinente incluí-lo em nosso instrumento para nos ajudar a refletir sobre os diferentes perfis de liderança. No nosso caso, elaboramos uma questão de escolha forçada, mas com uma só opção, sobre a principal meta de trabalho do diretor. Nossa intenção, como será discutido mais adiante, será relacionar as respostas a outras variáveis, com vistas a identificar tendências de liderança entre os diretores das escolas de nossa pesquisa.

As questões sobre o contexto de avaliações externas no questionário do diretor da Prova Brasil se limitam a medir o conhecimento do diretor sobre a participação e classificação de sua escola na última edição da Prova Brasil. O questionário do SASS apresenta duas questões específicas sobre o tema, que buscam medir também o conhecimento do diretor sobre o resultado de sua escola na classificação da aprendizagem de seu estado ${ }^{104}$. Propomos, em nosso instrumento, uma ampliação desta reflexão trazendo alguns itens que buscam captar os reflexos das avaliações externas para a rotina escolar.

Quanto às relações intra-escolares, os questionários contextuais da Prova Brasil trazem alguns itens sobre respeito mútuo e compartilhamento das decisões escolares, mas somente no questionário dos professores. As questões sobre este tema no questionário contextual do diretor da Prova Brasil se limitam a questões administrativas (vínculo de professores, absenteísmo, designação, entre outros). Sentimos a falta de questões que buscassem captar as intervenções pedagógicas do diretor, influenciando o trabalho

\footnotetext{
${ }^{104}$ Trata-se da política chamada "Adequate Yearly Progress" (AYP).
} 
docente. O questionário do SASS nos trouxe algumas pistas, mas sua atenção se volta para as intervenções do diretor nas séries que são avaliadas nacionalmente. Há, também, uma forte valorização da avaliação do diretor sobre o trabalho do professor, com vistas à seleção, retenção ou demissão, o que não cabe para o contexto brasileiro.

De forma geral, o estudo sobre o questionário do SASS trouxe, para esta pesquisa, a possibilidade de dialogar com outras experiências de mensuração dos aspectos relacionados ao universo escolar, especialmente aqueles relacionados às questões levantadas. 


\title{
Anexo 3
}

\section{A pesquisa acadêmica: recentes teses e dissertações defendidas sobre o tema}

\author{
Nosso segundo movimento de atualização das pesquisas desenvolvidas \\ recentemente sobre a gestão escolar (especialmente em relação ao trabalho dos \\ professores) envolveu o levantamento das recentes teses e dissertações defendidas no
} Brasil sobre o tema. A intenção inicial era dar continuidade ao levantamento realizado por Souza (2006), que fez este levantamento para o período de 1987 a 2004, selecionando assim o período de 2005 a 2015 como recorte temporal. No entanto, após vários meses fora de funcionamento, o banco de teses e dissertações da Capes ${ }^{105}$ voltou ao ar em uma nova versão da plataforma de consulta, disponibilizando até o momento da finalização do levantamento, apenas os trabalhos defendidos no período de 2011 a 2012. De acordo com informações do site, os dados estão sendo inseridos gradualmente. Assim, nos limitamos a este período de consulta. Utilizando a ferramenta de busca do portal, selecionamos "área de conhecimento = educação" e "palavra-chave = gestão". A princípio, considerouse usar o termo "gestão escolar" como palavra-chave de busca, contudo, como evidenciou-se posteriormente na leitura dos resumos, ainda há uma inconsistência no uso do termo (gestão escolar/gestão da escola/ gestão educacional são, muitas vezes, usados como sinônimos). Obtivemos um resultado de 213 trabalhos defendidos no período, sendo 37 teses de doutorado, 148 dissertações de mestrado acadêmico e 28 de mestrado profissional. Chama a atenção a distribuição dos trabalhos por instituição, com o predomínio da Universidade Federal de Juiz de Fora - UFJF como instituição de origem da maior número de trabalhos (31), seguida pela PUC de São Paulo (14). O restante dos trabalhos está distribuído em outras 58 instituições. Após a leitura de todos os resumos, foram excluídos 15 trabalhos por serem da área de Educação Física ou Educação para a saúde. As 198 pesquisas foram, então categorizadas ${ }^{106}$ conforme apresentado no quadro a seguir:

\footnotetext{
${ }^{105} \mathrm{http}: / /$ bancodeteses.capes.gov.br/

106 A categorização das pesquisas foi realizada somente a partir da leitura dos resumos e levou em consideração a intenção do trabalho, a referência teórica apontada e os resultados e articulações encontrados. Vale ressaltar a dificuldade encontrada em alguns casos devido à baixa qualidade do texto apresentado e à ausência de uma padronização para os resumos de teses e dissertações (exemplo: alguns não apresentam seus referenciais teóricos ou seus resultados ou, ainda, nem mesmo mencionam qual foi o trabalho empreendido).
} 
Quadro 26: Categorização do Levantamento de Teses e Dissertações

\begin{tabular}{|l|c|}
\hline \multicolumn{1}{|c|}{ Tema central da pesquisa } & $\begin{array}{c}\text { Quantidade de } \\
\text { trabalhos }\end{array}$ \\
\hline Gestão e Políticas educacionais & 66 \\
\hline Gestão Democrática e descentralização & 50 \\
\hline Gestão da escola e resultados acadêmicos & 26 \\
\hline Formação e Capacitação dos gestores Educacionais & 13 \\
\hline Gestores escolares: O Diretor, e/ou o Coordenador, e/ou o Supervisor & 10 \\
\hline Gestão do Ensino Superior & 9 \\
\hline Gestão de Educação à Distância & 5 \\
\hline Gestão e Organização/Clima escolar & 5 \\
\hline Gestão e Diversidade cultural & 5 \\
\hline Gestão e Tecnologias da Informação e Comunicação (TICs) & 5 \\
\hline Revisão de literatura e definição do conceito & 4 \\
\hline
\end{tabular}

Fonte: Classificação realizada pela autora, com base nos dados disponibilizados pelo Banco de Teses e Dissertações da CAPES.

Observa-se a diluição do tema em 11 categorias, heterogeneidade também encontrada por Souza (2006, p. 100) que, em um período de observação bem mais amplo, encontrou 13 temas principais. Ressalta-se, nesta distribuição, a predominância (33\%) dos trabalhos que se dedicaram ao estudo de políticas educacionais envolvendo, de alguma forma, o trabalho da gestão. É Importante considerar que a opção por não utilizar o termo "gestão escolar" na ferramenta de busca trouxe como consequência a inclusão de trabalhos que citavam a palavra-chave "gestão educacional", como foi o caso de muitos dos trabalhos categorizados neste grupo. Estes estudos abordavam, principalmente, as relações entre os entes federados, a gestão de políticas e programas nacionais (Plano de Desenvolvimento da Educação - PDE, Plano de Ações Articuladas - PAR, Mais Educação, Proalfa, Programa Dinheiro Direto na Escola - PDDE, entre outras) e locais (transferências de recursos, parcerias público/privado, sistemas de avaliação local do desempenho, entre outras).

Como não é intuito deste trabalho aprofundar a discussão sobre as tendências das pesquisas realizadas em cada uma das categorias levantadas, nos ativemos ao processo de identificação da abordagem dos temas relevantes para o nosso trabalho. Um primeiro olhar sobre as categorias construídas acima, poderia indicar que os trabalhos agrupados em Gestão e Organização/Clima escolar poderiam abordar as relações entre diretores e professores no ambiente escolar. Porém, os trabalhos categorizados neste grupo se dedicaram mais especificamente ao aspecto estrutural da escola, ao planejamento 
estratégico e ao plano de trabalho do diretor. Apenas um deles aborda de forma mais explícita a relação Diretor/professor, porém, a partir de um marco referencial psicocomportamental, ao estudar o trabalho coletivo para tratar das questões disciplinares na escola.

A leitura dos resumos indicou que no grupo Gestão da escola e resultados acadêmicos foi mais frequente encontrar pesquisas que abordassem as relações entre diretores e professores na escola. A presença desta discussão em trabalhos que se voltam para a associação entre a gestão escolar e os resultados dos alunos reforça a compreensão de que esta associação passa pela relação entre diretores e professores. As contribuições destas pesquisas se encontram no escopo do trabalho. 


\section{Anexo 4}

(Trecho da Lei Ordinária 2619, do município do Rio de Janeiro)

\section{ATRIBUIÇÕES ESPECÍFICAS \\ I - DO DIRETOR DE UNIDADE ESCOLAR:}

- cumprir e fazer cumprir a legislação específica vigente, a Lei Orgânica e o Estatuto do Funcionalismo Público Municipal do Rio de Janeiro e as determinações emanadas do nível central e intermediário da Secretaria Municipal de Educação, bem como o Regulamento e o Regimento da unidade escolar;

- implementar a proposta pedagógica emanada da Secretaria Municipal de Educação; - organizar e manter atualizado o Regimento Interno da escola, promovendo, para isso, intercâmbio entre os membros da comunidade escolar;

- responsabilizar-se pelo desenvolvimento dos recursos humanos da unidade escolar;

- delegar poderes, distribuir tarefas e atribuir responsabilidades aos seus funcionários, tomando decisões com base em instrumentos e propostas decorrentes de processo participativo;

- aprovar normas para o desenvolvimento das atividades e estimular o desempenho dos diferentes setores da escola;

- divulgar assuntos de interesse da comunidade escolar;

- trabalhar as relações interpessoais entre os membros da comunidade escolar;

- promover a integração da escola com a comunidade, buscando parceria constante;

- responsabilizar-se pelo patrimônio público sob sua guarda;

- gerenciar as ações orçamentário-financeiras da unidade escolar;

- gerenciar Programa de Alimentação da unidade escolar;

- responder pela execução dos serviços realizados por funcionário ou mediante contratação de terceiros;

- responsabilizar-se pela documentação escolar de alunos e ex-alunos da unidade escolar. 


\section{Anexo 5}

\section{Construindo uma Amostra}

Algumas limitações de pesquisa foram encontradas durante o processo de acesso ao campo, como o tempo de aprovação e liberação da pesquisa junto à SME/RJ (tornando possível o acesso às escolas somente no segundo semestre de 2014) e o número de pesquisadores no grupo disponíveis para auxiliar no trabalho de campo. Tais limitações dificultaram o acesso às 163 escolas de nosso universo, sendo necessário realizar um procedimento de amostragem. Para isso, inicialmente seguimos o cálculo para a definição do tamanho ideal da amostra (com intervalo de confiança de 95\%, erro máximo igual a 3 e considerando o desvio padrão da distribuição no que se refere ao número de professores por escola). Com estes procedimento encontramos que nossa amostra deveria ter 42 casos.

Com esta amostragem pretendeu-se colher as informações em um número viável, mas também representativo, do universo das escolas selecionadas. Cabe assinalar aqui a questão referente à distribuição geográfica das escolas. Inicialmente, foi considerada a possibilidade de estratificarmos a amostra pela distribuição das escolas nas CREs. Porém, considerando as características territoriais do Rio de Janeiro, percebemos que cada CRE se constitui em um micro universo do município. É comum, por exemplo, termos uma grande variância nos indicadores sociais dentro de uma mesma CRE. Neste sentido, Alves, Franco e Ribeiro (2008) ressaltam o caráter híbrido da interação inter-classes presente no município do Rio de Janeiro, destacando que "sua principal marca é a proximidade territorial de atores que ocupam posições sociais distantes" (op. cit., p. 94). Assim, as escolas pertencentes à uma mesma CRE podem apresentar características socioeconômicas muito distintas já que cada Coordenadoria pode ser considerada uma micro-cidade com diferentes contextos. "[...] uma característica do Rio de Janeiro é a presença de favelas, com baixo desenvolvimento social, em áreas nobres. No entanto, encontramos também, nas áreas de baixo desenvolvimento social, regiões com alto desenvolvimento" (ALVES et al., 2010, p, 70). Optamos então por não considerar a distribuição das escolas entre as Coordenadorias Regionais de Educação (CREs) e utilizar uma estratificação que considerasse a diferenciação no público atendido (NSE médio de cada unidade) e a distribuição da complexidade na composição do corpo docente nas escolas selecionadas.

Assim, para selecionar as 42 unidades dentro do universo das 163 escolas, optamos pela estratificação probabilística, a partir de dois estratos: a nossa medida de proxy do NSE entre as escolas (a porcentagem de pais com formação superior ao ensino médio, em 
faixas, como já foi apresentado ${ }^{107}$ ) e a distribuição da quantidade de professores que atendiam aos anos iniciais ou aos anos finais do ensino fundamental por escola. Assim, nosso trabalho de amostragem envolveu a replicação das porcentagens destes dois indicadores do universo para a amostra a ser construída. As tabelas a seguir detalham esse processo de construção:

Tabela 20: Estratificação da amostra a partir da primeira referência: Proxy de NSE

\begin{tabular}{lcrr}
\hline & População (N, \%) & Amostra (n) \\
\hline Baixo NSE & $76(46,5 \%)$ & 19 \\
Médio NSE & $79(48,2 \%)$ & 21 \\
Alto NSE & & $8(5,3 \%)$ & 2 \\
& Total & $163(100 \%)$ & 42 \\
\hline
\end{tabular}

Fonte: Elaborado pela autora. INEP, 2012

Para construir a segunda referência da estratificação, analisamos a razão da quantidade de professores que atendiam aos anos iniciais ou aos anos finais do ensino fundamental por escola. Para este estudo utilizamos os dados disponibilizados pelo Censo Escolar (base dos docentes) identificando segmento para o qual o professor lecionava em 2013 e agregando as informações por escola. Os dados foram então levados para a base de dados dos diretores, nas variáveis: Professores que atuam nos anos iniciais; Professores que atuam nos anos finais e Professores que atuam nos dois segmentos. Para pensar sobre a complexidade da distribuição destes profissionais por escola, realizamos um cálculo a partir da expressão:

\section{[Professores que atuam nos anos iniciais + Professores que atuam nos dois segmentos] Professores que atuam nos anos finais}

Quanto menor a razão entre os grupos de professores, mais equilibrada é a divisão proporcional entre tipos de professores na equipe docente. Uma maior razão indica a predominância de professores dos anos iniciais. Então, classificamos as escolas em duas faixas a partir da variável criada com o resultado da expressão (razão): Composição do corpo docente mais equilibrada (Razão entre professores $<2,00$ ) e Composição do corpo docente menos equilibrada (Razão entre professores $>2,01$ ), cujas distribuições se vêm no quadro abaixo:

${ }^{107}$ Ver capítulo 3, p. 66-67. 
Tabela 21: Referência para estratificação da amostra a partir da distribuição dos professores por escola

\begin{tabular}{lrr}
\hline & População & \\
\hline & N & $\%$ \\
Composição do corpo docente mais equilibrada & 148 & $90,8 \%$ \\
Composição do corpo docente menos equilibrada & 15 & $9,2 \%$ \\
Total & 163 & $100 \%$ \\
\hline
\end{tabular}

Fonte: Elaborado pela autora. Censo Escolar, INEP 2014.

O próximo passo foi aplicar esta referência percentual na distribuição quantitativa das faixas de NSE já construída, conforme mostra a tabela a seguir:

Tabela 22: Reestratificação da amostra a partir da segunda referência: distribuição dos professores por escola

\begin{tabular}{rlr}
\hline & \multicolumn{1}{c}{ Amostra } \\
\hline Baixo NSE & Composição do corpo docente mais equilibrada (94,3\%) & 17 \\
& Composição do corpo docente menos equilibrada (5,7\%) & 2 \\
\hline \multirow{2}{*}{$\begin{array}{c}\text { Médio NSE } \\
\text { n=21 }\end{array}$} & Composição do corpo docente mais equilibrada (94,3\%) & 19 \\
& Composição do corpo docente menos equilibrada (5,7\%) & 2 \\
\hline Alto NSE & Composição do corpo docente mais equilibrada (94,3\%) & 2 \\
& Composição do corpo docente menos equilibrada (5,7\%) & -- \\
\hline
\end{tabular}

De volta à listagem das 163 escolas, selecionamos aquelas 42 que cumpriam as características da estratificação probabilística, segundo a base de dados da Prova Brasil 2013. Nesta decisão, privilegiou-se uma menor distribuição pelas CREs com o objetivo de facilitar o acesso às escolas, embora isso não tenha evitado uma considerável amplitude territorial do trabalho de campo, envolvendo grandes deslocamentos nas repetidas visitas a cada unidade escolar. Um mapa da distribuição territorial das 42 escolas pode ser consultado no Anexo a seguir. Foram escolhidas 42 escolas que atendiam aos requisitos da estratificação entre as unidades da $2^{\mathrm{a}}, 3^{\mathrm{a}}$ e $4^{\mathrm{a}} \mathrm{CREs}$. Esclarecer esta decisão faz parte do processo de reconhecimento das limitações da pesquisa, ainda que se considere que esta escolha não produza vieses significativos nos resultados, conforme a variação nas características sociais dentro de uma mesma CRE. Neste processo de escolha, também foram selecionadas "escolas reserva" para cada quadrante da estratificação amostral, com o intuito de preparar qualquer substituição que se fizesse necessária. Assim, foram delimitadas as 42 escolas da amostra, nas quais seriam aplicados os questionários propostos por esta pesquisa. 
Anexo 6

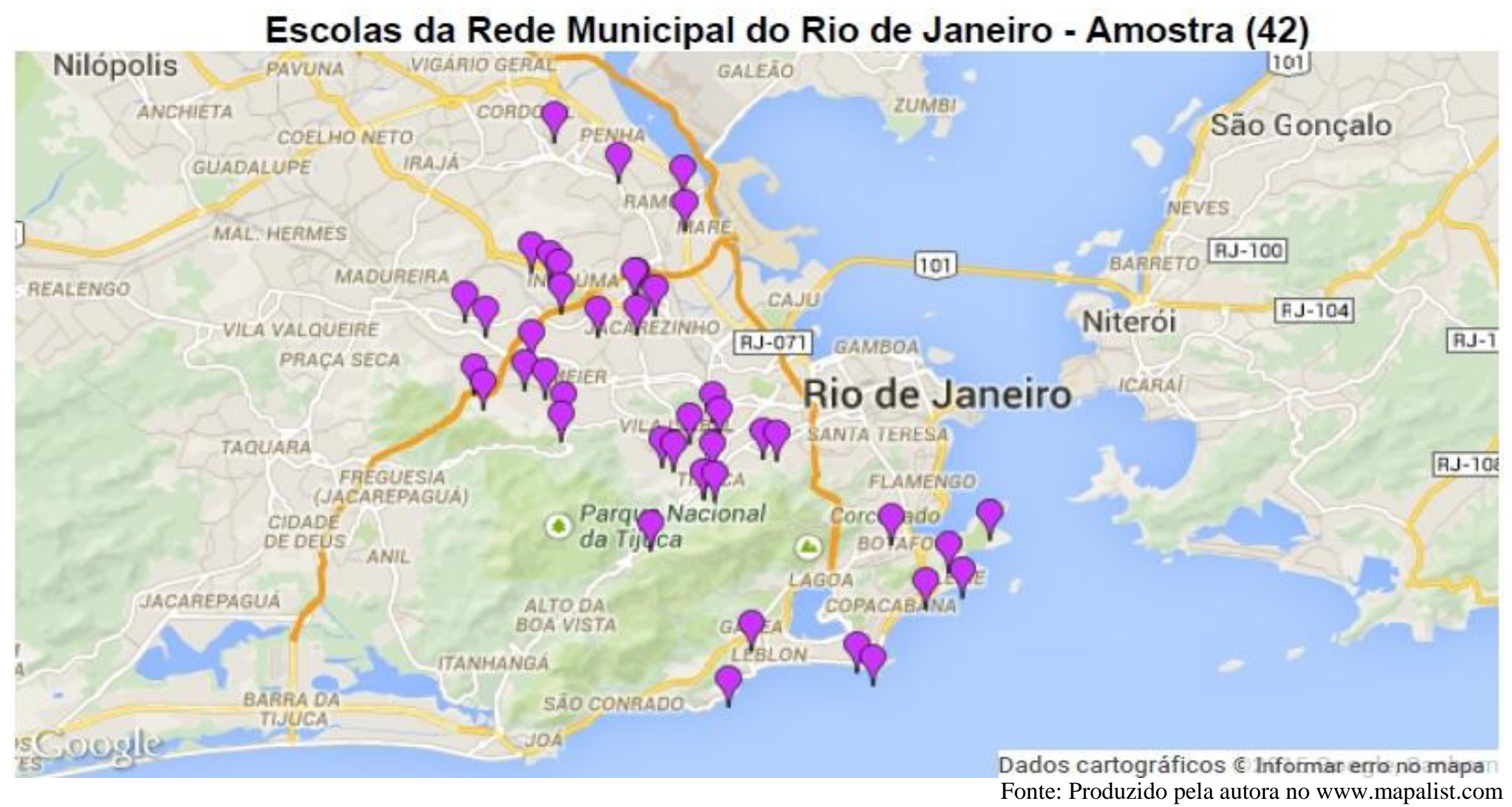




\section{Anexo 7 \\ Dos itens aos índices: processo de criação, itens e cargas fatoriais}

\section{1) Indicador de tendência da Gestão do Diretor}

Procuramos criar uma variável indicativa do perfil de gestão dos diretores com o objetivo de ressaltar o foco do seu trabalho na direção escolar. Para compor este indicador, utilizamos os itens elaborados com esta finalidade (conforme exposto no Capítulo 5 desta tese): a principal meta da direção escolar (D4); o aspecto da gestão escolar que mais ocupa o tempo de trabalho do diretor na escola (D34); a percepção do diretor sobre o papel da escola na sociedade (D33) e sobre o maior desafio do trabalho na direção escolar (D60). O primeiro item teve suas respostas recodificadas, uma vez que cada uma das metas apresentadas correspondia à identificação de um perfil de gestão, conforme apresentado no quadro abaixo:

Quadro 27 : Recodificação das respostas: Indicador de tendência da Gestão do Diretor

\begin{tabular}{|c|c|}
\hline Resposta & Recodificação \\
\hline $\begin{array}{l}1 \text {-Desenvolvimento dos melhores métodos para } \\
\text { favorecer a aprendizagem }\end{array}$ & 3 - Gestão Pedagógica \\
\hline $\begin{array}{l}2 \text { - Promover o desenvolvimento profissional do corpo } \\
\text { docente }\end{array}$ & 1 - Gestão Pessoal/Relacional \\
\hline 3 - Zelar pela segurança dos alunos e funcionários & 2- Gestão Administrativa \\
\hline $\begin{array}{l}4 \text { - Proporcionar o desenvolvimento do relacionamento } \\
\text { humano entre o grupo de trabalho }\end{array}$ & 1 - Gestão Pessoal/Relacional \\
\hline $\begin{array}{l}5 \text { - Assegurar o cumprimento das metas de avaliação } \\
\text { estabelecidas externamente }\end{array}$ & 3 - Gestão Pedagógica \\
\hline $\begin{array}{l}6 \text { - Conhecer e solucionar os principais problemas de } \\
\text { aprendizagem dos alunos da escola }\end{array}$ & 3 - Gestão Pedagógica \\
\hline $\begin{array}{l}7 \text { - Estabelecer a mediação entre as demandas da } \\
\text { secretaria de ensino e o trabalho escolar }\end{array}$ & $\begin{array}{l}4 \text { - Gestão das Relações } \\
\text { Externas }\end{array}$ \\
\hline $\begin{array}{l}8 \text { - Garantir a boa administração financeira, focando o } \\
\text { funcionamento de todos os setores da escola. }\end{array}$ & 2- Gestão Administrativa \\
\hline 9 - Garantir a participação das famílias & $\begin{array}{l}4 \text { - Gestão das Relações } \\
\text { Externas }\end{array}$ \\
\hline
\end{tabular}

O segundo item que compõe este indicador já trazia, entre as opções de respostas, as quatro categorias de gestão utilizadas acima. Os dois últimos itens eram dissertativos e foi necessário categorizar as respostas válidas, utilizando as mesmas quatro categorias. Como em outras situações equivalentes, as categorias foram criadas somente a partir da leitura e interpretação dos dados. Por fim, os dados relativos aos quatro itens foram agregados 
quanto à predominância das respostas, indicando uma possível tendência de gestão no trabalho do diretor na escola. Quando não havia uma predominância de reposta aos itens, ou seja, quando as respostas do diretor para os quatro itens se distribuía entre as categorias, sua tendência de gestão foi caracterizada como "Gestão Distribuída". Para que a variável pudesse entrar nos modelos a serem estimados futuramente, foi necessário transformá-la em duas variáveis $d u m m y^{108}$, considerando nossas intenções de pesquisa: Tendência de Gestão Pedagógica e Tendência de Gestão Distribuída. É importante notar que a medida criada pelos indicadores propostos nesta fase é um indicativo da percepção do diretor sobre seu próprio trabalho. Outras medidas, incluindo o trabalho com os dados relativos aos professores, serão utilizadas na construção de uma percepção mais aprofundada sobre a tendência da gestão do diretor. Como para a nossa amostra este indicador não apresentou associações significativas a outras variáveis, ele não foi incluído no modelo.

\section{2) Indicador de Interlocução com a equipe (percebida pelo Diretor e Professor)}

Os itens que compuseram este indicador se referiam à frequência das reuniões na escola, em seus diferentes arranjos de participação. As respostas foram recodificadas, criando 3 medidas de frequência: Alta, Média e Baixa, conforme apresentado no quadro abaixo:

Quadro28: Recodificação das respostas: Indicador de Interlocução

\begin{tabular}{|l|l|}
\hline Resposta & Recodificação \\
\hline 1 - Semanal & 3 - Alta frequência \\
\hline 2 - Quinzenal & 3 - Alta frequência \\
\hline 3 - Mensal & 2 - Média frequência \\
\hline 4 - Bimestral & 2 - Média frequência \\
\hline 5 - Semestral & 1 - Baixa frequência \\
\hline 6 - Anual & 1 - Baixa frequência \\
\hline 7 - Não se aplica & 1 - Baixa frequência \\
\hline
\end{tabular}

Os dados provenientes dos 4 itens foram computados em uma única variável, propondo uma medida da frequência média das reuniões (interlocução) entre a equipe (percebida pelos professores e pelos diretores): Indicador médio da frequência de

\footnotetext{
${ }^{108}$ A codificação dummy é uma forma de representar variáveis categóricas em uma ou mais variáveis codificadas em 0 e 1 . No nosso caso, Tendência de Gestão Pedagógica (categoria "Gestão Pedagógica" $=1$ e demais categorias $=0$ ) e Tendência de Gestão Distribuída (categoria "Gestão Distribuída" $=1$ e demais categorias $=0$ ).
} 
interlocução $(D)$ e Indicador médio da frequência de interlocução $(P)$. Como para a nossa amostra este indicador não apresentou associações significativas a outras variáveis, ele não foi incluído no modelo.

3) Índice da percepção docente sobre sua participação

As questões elaboradas para medir a percepção dos professores sobre sua própria participação em questões importantes da escola (Didáticas, Curriculares e Administrativas) foram trabalhadas de duas formas: na primeira, os itens (P10) foram condensados em um índice através da análise fatorial. O Índice foi então agregado por escola criando um índice médio da percepção dos professores sobre o tema: Índice de Participação docente. As cargas fatoriais das variáveis que compuseram o índice são apresentadas no quadro abaixo:

Quadro 29: Cargas Fatoriais das Variáveis Relativas à Participação Docente Índice de Participação Docente

\begin{tabular}{|l|l|}
\hline Variável & Carga Fatorial \\
\hline
\end{tabular}

\begin{tabular}{|l|c|}
\hline Nas diferentes questões da rotina escolar, apresentadas abaixo, com & 0,878
\end{tabular} que frequência você é consultado para tomar decisões? Questões Didáticas (calendário de avaliações, distribuição de pontos, volume de exercícios e atividades)

Nas diferentes questões da rotina escolar, apresentadas abaixo, com que frequência você é consultado para tomar decisões? Questões Curriculares (definição dos conteúdos a serem trabalhados em cada série, planejamento anual dos conteúdos)

Nas diferentes questões da rotina escolar, apresentadas abaixo, com que frequência você é consultado para tomar decisões? Questões Administrativas (decisões financeiras, alocação de pessoal)

Extraction Method: Principal Component Analysis.

Porém, interessava-nos também saber se os professores percebiam que eram mais convidados a participar de decisões referentes a uma dimensão do que outra. Assim, os itens foram recodificados em uma variável binária, onde $0=$ "não me sinto incluído" (Respostas Raramente e Nunca) e 1= "sinto-me incluído" (Respostas Às vezes e Frequentemente). De forma geral, os professores se sentiram mais incluídos nas questões curriculares ou didáticas do que nas questões administrativas da escola. As variáveis criadas para esta análise foram então agregadas por escola, indicando a porcentagem de professores que se sentiam incluídos em cada tipo de decisão escolar. As variáveis finais foram: Participação em Questões Didáticas, Participação em Questões Curriculares, Participação em Questões Administrativas. Como para a nossa amostra estes indicadores 
não apresentaram associações significativas a outras variáveis, eles não foram incluídos no modelo.

4) Índice de intervenção pedagógica do Diretor (percebida pelo Diretor e pelos Professores)

(Apresentado no corpo do capítulo 6)

\section{5) Índice de monitoramento da aprendizagem pelo Diretor}

Alguns itens do questionário do diretor foram pensados para captar as estratégias de monitoramento da aprendizagem que efetua em sua rotina na escola, algumas incluindo intervenções diretas ao professor e outras passando pela equipe de gestão da escola. A análise fatorial, que não incluiu todos os itens pensados para esta medida (Capítulo 5), resultou no Índice de Monitoramento da Aprendizagem (D). As cargas fatoriais dos itens que compuseram o índice são apresentadas no quadro abaixo:

Quadro 30: Cargas Fatoriais das Variáveis Relativas ao Monitoramento da Aprendizagem pelo Diretor

\begin{tabular}{|l|r|}
\hline Índice de Monitoramento da Aprendizagem (D) \\
\hline Variável & Carga Fatorial \\
\hline $\begin{array}{l}\text { Eu converso com os professores sobre o desempenho de seus alunos } \\
\text { nas avaliações internas da escola. }\end{array}$ & 0,820 \\
\hline $\begin{array}{l}\text { Eu converso com os professores sobre a preparação de seus alunos } \\
\text { para as avaliações externas. }\end{array}$ & 0,766 \\
\hline $\begin{array}{l}\text { Eu solicito à equipe gestora que acompanhe os resultados internos dos } \\
\text { alunos. }\end{array}$ & 0,775 \\
\hline $\begin{array}{l}\text { Eu solicito à equipe gestora que acompanhe os resultados dos alunos } \\
\text { nas avaliações externas. }\end{array}$ & 0,757 \\
\hline
\end{tabular}

Extraction Method: Principal Component Analysis

Ao elaborarmos os itens tínhamos a hipótese de que eles fossem gerar dois índices relacionados ao monitoramento da aprendizagem através das avaliações externas e através das avaliações internas, considerando que os respondentes teriam padrões de respostas diferentes para cada tipo de avaliação. Porém, no caso dos diretores desta amostra, verificou-se que os itens se resumem, a partir da análise fatorial, em apenas um índice, refletindo um possível padrão no monitoramento da aprendizagem pelo diretor, independente do tipo de avaliação. Como para a nossa amostra estes índices não apresentaram associações significativas a outras variáveis, eles não foram incluídos no modelo. 
6) Índice de Influência do Diretor (percebida pelo diretor)

Como foi discutido na construção do Quadro de Referência conceitual dos questionários (Capítulo 5), algumas pesquisas têm utilizado a medida de influência como proxy para medir a liderança dos sujeitos na escola. Um bloco de questões do questionário do diretor foi proposto para captar a percepção do diretor sobre sua própria influência na escola. Os valores dos dados foram recodificados para que a escala de significância obtivesse um sentido positivo. $\mathrm{Na}$ análise fatorial com os dados dos diretores de nossa amostra, encontramos dois índices, o primeiro reunia itens sobre a influência do diretor em questões pedagógicas (metas de ensino, conteúdos, avaliação de professores) e por isso foi nomeado de Índice de Liderança Pedagógica. O segundo índice agrupou itens relacionados à influência do diretor em questões relacionadas à organização administrativo-burocrática da escola (matrícula, encaminhamento de alunos) e foi nomeado de Índice Liderança Administrativa. Os quadros a seguir apresentam as cargas fatoriais dos itens que compuseram cada um destes índices:

Quadro 31: Cargas Fatoriais das Variáveis Relativas à influência do diretor na Liderança Pedagógica da escola

Índice de Liderança Pedagógica

\begin{tabular}{|l|l|}
\hline Variável & Carga Fatorial \\
\hline Sta
\end{tabular}

\begin{tabular}{|l|r|}
\hline Sua influência enquanto DIRETOR: Definição de metas de & 0,903
\end{tabular} desempenho para os alunos da escola

Sua influência enquanto DIRETOR: Definição dos conteúdos a serem $\quad 0,792$ trabalhados em cada série/disciplina

\begin{tabular}{l|c}
\hline Sua influência enquanto DIRETOR: Sistemas de avaliação dos & 0,813
\end{tabular} professores

\begin{tabular}{l|l} 
Sua influência enquanto DIRETOR: Decisões sobre a aprovação ou & 0,742
\end{tabular} reprovação de alunos

Extraction Method: Principal Component Analysis

Quadro 32: Cargas Fatoriais das Variáveis Relativas à influência do diretor na Liderança Administrativa da escola

Índice de Liderança Administrativa

\begin{tabular}{|l|l|}
\hline Variável & Carga Fatorial \\
\hline
\end{tabular}

\begin{tabular}{|l|c|}
\hline Sua influência enquanto DIRETOR: Definição e organização de & 0,556
\end{tabular}

turmas regulares da unidade escolar.

\begin{tabular}{l|l} 
Sua influência enquanto DIRETOR: Decisões sobre a matrícula de & 0,781
\end{tabular} alunos

Sua influência enquanto DIRETOR: Decisões sobre o

encaminhamento de alunos para outras unidades

Extraction Method: Principal Component Analysis

Como para a nossa amostra estes índices não apresentaram associações significativas a outras variáveis, eles não foram incluídos no modelo. 


\section{7) Índice de Participação Docente na Liderança (percebida pelos professores)}

A medida de influência foi utilizada como proxy da participação dos professores no fluxo de definições e decisões na escola. Os itens foram recodificados e, através da análise fatorial, reduzidos a um só fator, sendo em seguida, agregado por unidade escolar. O índice foi denominado Índice de Liderança do Professor e o quadro a seguir apresenta as cargas fatoriais dos itens que o compuseram:

Quadro 33: Cargas Fatoriais das Variáveis Relativas à influência do professor na Liderança da escola

Índice de Liderança do Professor

\begin{tabular}{|l|l|}
\hline Variável & Carga Fatorial \\
\hline
\end{tabular}

\begin{tabular}{|l|r|}
\hline Em sua opinião, atualmente, qual é o nível de influência dos & 0,781
\end{tabular}

PROFESSORES na rotina desta escola, em cada um dos seguintes aspectos: Definição de metas de desempenho para os alunos da escola

Em sua opinião, atualmente, qual é o nível de influência dos PROFESSORES na rotina desta escola, em cada um dos seguintes aspectos: Definições sobre os conteúdos curriculares Em sua opinião, atualmente, qual é o nível de influência dos PROFESSORES na rotina desta escola, em cada um dos seguintes aspectos: Definição dos temas dos programas de desenvolvimento profissional (formação continuada)

Em sua opinião, atualmente, qual é o nível de influência dos PROFESSORES na rotina desta escola, em cada um dos seguintes aspectos: Decisões sobre a aprovação ou reprovação de alunos Em sua opinião, atualmente, qual é o nível de influência dos PROFESSORES na rotina desta escola, em cada um dos seguintes aspectos: Decisões sobre o encaminhamento de alunos para outras unidades

Extraction Method: Principal Component Analysis

Como para a nossa amostra este índice não apresentou associações significativas a outras variáveis, ele não foi incluído no modelo.

Os diretores foram questionados sobre sua percepção quanto ao nível de influência dos professores na rotina escolar. A análise fatorial, contudo, não apresentou a sintetização dos itens de forma significativa $(\mathrm{KMO}=0,429$ e Alpha de Conbrach=0,515). Assim, não foi criado nenhum índice para sintetizar a percepção do diretor sobre a influência dos professores na liderança da escola.

\section{8) Índice do reconhecimento do trabalho da direção escolar pelos professores}

Alguns itens distribuídos no questionário do professor visavam medir o nível de reconhecimento, pelos professores, de que a equipe de direção desempenha um bom trabalho na escola. Estes itens se apresentavam em uma escala de concordância e foram submetidos à análise fatorial, para serem, em seguida, agregados por escola, resultando 
no Índice do Reconhecimento do trabalho da Direção. As cargas fatoriais dos itens que foram sintetizados neste índice são apresentadas no quadro a seguir:

Quadro 34: Cargas Fatoriais das Variáveis Relativas ao reconhecimento dos professores quanto ao trabalho da Direção

Índice do Reconhecimento do trabalho da Direção

\begin{tabular}{|l|l|}
\hline Variável & Carga Fatorial \\
\hline
\end{tabular}

\begin{tabular}{|l|r|}
\hline Nesta escola a equipe de gestão é reconhecida por realizar um bom & 0,796
\end{tabular} trabalho.

A equipe de gestão da escola tem uma postura encorajadora e solidária com os professores.

O diretor da escola valoriza e reforça o trabalho desenvolvido pelos professores.

Extraction Method: Principal Component Analysis

Este índice apresentou associações significativas a outras variáveis da nossa amostra, sendo assim incluído no modelo estimado.

\section{9) Índice de Percepção do Ambiente Escolar}

Para analisarmos questões relacionadas ao Clima Escolar, foi proposto um bloco de questões específicas para captar a percepção dos respondentes sobre a adequação do ambiente escolar para a aprendizagem. Entre os itens propostos (Capítulo 4), alguns deles (além de outros que não haviam sido inicialmente pensados para este índice), foram sintetizados em um único fator, no caso das respostas dos diretores da nossa amostra. Antes do processo de análise fatorial, os dados foram recodificados para garantir o sentido positivo da escala. As cargas fatoriais do Índice de Percepção do Ambiente Escolar $(D)$ são apresentadas no quadro abaixo:

Quadro 35: Cargas Fatoriais das Variáveis Relativas à percepção dos Diretores sobre o Ambiente Escolar

\begin{tabular}{|l|r|}
\hline Índice de Percepção do Ambiente Escolar (D) \\
\hline Variável & Carga Fatorial \\
\hline $\begin{array}{l}\text { Como você avalia os seguintes aspectos da sua escola: } \\
\text { Disciplina/comportamento dos alunos }\end{array}$ & 0,810 \\
\hline $\begin{array}{l}\text { Como você avalia os seguintes aspectos da sua escola: Relação dos } \\
\text { alunos com os professores }\end{array}$ & 0,926 \\
\hline $\begin{array}{l}\text { Como você avalia os seguintes aspectos da sua escola: Relação dos } \\
\text { professores com os alunos }\end{array}$ & 0,837 \\
\hline $\begin{array}{l}\text { Como você avalia os seguintes aspectos da sua escola: Relação entre } \\
\text { os alunos e os funcionários }\end{array}$ & 0,787 \\
\hline
\end{tabular}

Extraction Method: Principal Component Analysis 
No caso dos dados dos questionários respondidos pelos professores, da mesma forma outros itens vieram compor o índice sobre sua percepção do Ambiente escolar. Os dados também foram recodificados e analisados fatorialmente, para depois serem agregados por escola, originando o Índice de Percepção do Ambiente Escolar (P). O quadro a seguir apresenta as cargas fatoriais de suas variáveis:

Quadro 36: Cargas Fatoriais das Variáveis Relativas à percepção dos Professores sobre o Ambiente Escolar

\begin{tabular}{|l|r|}
\hline Índice de Percepção do Ambiente Escolar (P) \\
\hline Variável & Carga Fatorial \\
\hline $\begin{array}{l}\text { Como você avalia os seguintes aspectos da sua escola: } \\
\text { Disciplina/comportamento dos alunos }\end{array}$ & 0,767 \\
\hline $\begin{array}{l}\text { Como você avalia os seguintes aspectos da sua escola: Relação dos } \\
\text { alunos com os professores }\end{array}$ & 0,909 \\
\hline $\begin{array}{l}\text { Como você avalia os seguintes aspectos da sua escola: Relação dos } \\
\text { professores com os alunos }\end{array}$ & 0,842 \\
\hline $\begin{array}{l}\text { Como você avalia os seguintes aspectos da sua escola: Relação entre } \\
\text { os alunos e os funcionários }\end{array}$ & 0,847 \\
\hline
\end{tabular}

Extraction Method: Principal Component Analysis

Como para a nossa amostra o Índice de Percepção do Ambiente Escolar (P). apresentou associações significativas a outras variáveis, eles foi incluído no modelo.

10) Índice das relações interpessoais (percebidas pelo diretor e pelos professores)

Um dos aspectos relativos ao clima escolar que pretendíamos mensurar era a percepção dos respondentes sobre as relações interpessoais na escola (conforme relatado no Capítulo 5). Um bloco de questões indagava a avaliação dos respondentes sobre diferentes arranjos relacionais (professores e diretor, professores entre si, professores e funcionários). As respostas, em escala de Muito ruim a Muito boa, foram recodificadas e depois reduzidas em análise fatorial aos seguintes fatores: Índice de Relações Interpessoais $(D)$ e Índice de Relações Interpessoais $(P)$. As cargas fatoriais dos itens de cada índice são apresentadas nos quadros que se seguem: 
Quadro 37: Cargas Fatoriais das Variáveis Relativas à percepção dos Diretores sobre as Relações Interpessoais

\begin{tabular}{|l|r|}
\hline Índice de Relações Interpessoais (D) & Carga Fatorial \\
\hline Variável & 0,815 \\
\hline $\begin{array}{l}\text { Como você avalia os seguintes aspectos da sua escola: Relação entre } \\
\text { os professores do mesmo segmento }\end{array}$ & 0,808 \\
\hline $\begin{array}{l}\text { Como você avalia os seguintes aspectos da sua escola: Relação entre } \\
\text { os professores de forma geral }\end{array}$ & 0,606 \\
\hline $\begin{array}{l}\text { Como você avalia os seguintes aspectos da sua escola: Relação entre } \\
\text { os professores e a coordenação pedagógica }\end{array}$ & 0,807 \\
\hline $\begin{array}{l}\text { Como você avalia os seguintes aspectos da sua escola: Relação entre } \\
\text { os professores e a direção }\end{array}$ & 0,853 \\
\hline $\begin{array}{l}\text { Como você avalia os seguintes aspectos da sua escola: Relação entre } \\
\text { os professores e os funcionários }\end{array}$ & \\
\hline
\end{tabular}

Extraction Method: Principal Component Analysis

Quadro 38: Cargas Fatoriais das Variáveis Relativas à percepção dos Professores sobre as Relações Interpessoais

Índice de Relações Interpessoais (P)

\begin{tabular}{|l|r|}
\hline Variável & Carga Fatorial \\
\hline Como você avalia os seguintes aspectos da sua escola: Relação entre & 0,819
\end{tabular}

os professores do mesmo segmento

\begin{tabular}{l|l} 
Como você avalia os seguintes aspectos da sua escola: Relação entre & 0,859
\end{tabular}

os professores de forma geral

Como você avalia os seguintes aspectos da sua escola: Relação entre $\quad 0,872$

os professores e a coordenação pedagógica

Como você avalia os seguintes aspectos da sua escola: Relação entre $\quad 0,778$

os professores e a direção

Como você avalia os seguintes aspectos da sua escola: Relação entre

os professores e os funcionários

Extraction Method: Principal Component Analysis

Como para a nossa amostra estes índices não apresentaram associações

significativas a outras variáveis, eles não foram incluídos no modelo.

11) Índice de coesão e comprometimento do corpo docente (percebido pelo diretor, coordenador e professores)

Um bloco de questões foi pensado para analisar a percepção de todos os respondentes sobre a coesão do corpo docente e seu comprometimento com a escola enquanto manifestações do Clima Escolar. As questões envolviam atitudes como compartilhar responsabilidades, formar um grupo coeso, confiar e motivar os alunos, entre outras. No caso dos diretores, estes itens foram aplicados duas vezes, uma para captar a percepção dos respondentes quanto aos professores dos anos iniciais (D37) e outra quanto aos professores dos anos finais do ensino fundamental (D38). Para os professores o item foi construído referindo-se aos professores em geral (P25). Ainda neste conceito, foram propostos itens sobre o alinhamento do trabalho de todos os professores 
entre si, com a equipe de gestão e com o PPP da escola (D39, D40 e D41). O resultado foi expresso nos seguintes índices: Índice de Coesão e Comprometimento EF1 (D), Índice de Coesão e Comprometimento EF2 (D), Índice de Coesão e Comprometimento $(P)$ e Índice do Alinhamento do trabalho Docente (D).

As cargas fatoriais das variáveis que compuseram estes índices estão expressas nos quadros que se seguem:

Quadro 39: Cargas Fatoriais das Variáveis Relativas à percepção dos Diretores sobre a Coesão e o Comprometimento dos Professores EF1

\begin{tabular}{|l|c|}
\hline Índice de Coesão e Comprometimento EF1 (D) \\
\hline Variável & $\begin{array}{l}\text { Carga } \\
\text { Fatorial }\end{array}$ \\
\hline $\begin{array}{l}\text { Como você avalia os professores dos anos iniciais do ensino fundamental da } \\
\text { sua escola com relação à capacidade de: Compartilhar responsabilidades }\end{array}$ & 0,852 \\
\hline $\begin{array}{l}\text { Como você avalia os professores dos anos iniciais do ensino fundamental da } \\
\text { sua escola com relação à capacidade de: Formar um grupo coeso }\end{array}$ & 0,795 \\
\hline $\begin{array}{l}\text { Como você avalia os professores dos anos iniciais do ensino fundamental da } \\
\text { sua escola com relação à capacidade de: Comprometer-se com a política da } \\
\text { escola }\end{array}$ & 0,827 \\
\hline $\begin{array}{l}\text { Como você avalia os professores dos anos iniciais do ensino fundamental da } \\
\text { sua escola com relação à capacidade de: Motivar os alunos para a } \\
\text { aprendizagem }\end{array}$ & 0,867 \\
\hline $\begin{array}{l}\text { Como você avalia os professores dos anos iniciais do ensino fundamental da } \\
\text { sua escola com relação à capacidade de: Confiar na capacidade dos alunos }\end{array}$ & 0,836 \\
\hline $\begin{array}{l}\text { Como você avalia os professores dos anos iniciais do ensino fundamental da } \\
\text { sua escola com relação à capacidade de: Buscar novas estratégias que } \\
\text { melhorem a aprendizagem dos alunos. }\end{array}$ & 0,777 \\
\hline
\end{tabular}

Extraction Method: Principal Component Analysis

Quadro 40: Cargas Fatoriais das Variáveis Relativas à percepção dos Diretores sobre a Coesão e o Comprometimento dos Professores EF2

\begin{tabular}{|l|r|}
\hline Índice de Coesão e Comprometimento EF2 (D) \\
\hline Variável & $\begin{array}{l}\text { Carga } \\
\text { Fatorial }\end{array}$ \\
\hline $\begin{array}{l}\text { Como você avalia os professores dos anos finais do ensino fundamental da } \\
\text { sua escola com relação à capacidade de: Compartilhar responsabilidades }\end{array}$ & 0,815 \\
\hline $\begin{array}{l}\text { Como você avalia os professores dos anos finais do ensino fundamental da } \\
\text { sua escola com relação à capacidade de: Formar um grupo coeso }\end{array}$ & 0,715 \\
\hline $\begin{array}{l}\text { Como você avalia os professores dos anos finais do ensino fundamental da } \\
\text { sua escola com relação à capacidade de: Comprometer-se com a política da } \\
\text { escola }\end{array}$ & 0,927 \\
\hline $\begin{array}{l}\text { Como você avalia os professores dos anos finais do ensino fundamental da } \\
\text { sua escola com relação à capacidade de: Motivar os alunos para a } \\
\text { aprendizagem }\end{array}$ & 0,904 \\
\hline $\begin{array}{l}\text { Como você avalia os professores dos anos finais do ensino fundamental da } \\
\text { sua escola com relação à capacidade de: Confiar na capacidade dos alunos }\end{array}$ & 0,826 \\
\hline $\begin{array}{l}\text { Como você avalia os professores dos anos finais do ensino fundamental da } \\
\text { sua escola com relação à capacidade de: Buscar novas estratégias que } \\
\text { melhorem a aprendizagem dos alunos. }\end{array}$ & 0,901 \\
\hline
\end{tabular}


Quadro 41: Cargas Fatoriais das Variáveis Relativas à percepção dos Professores sobre a Coesão e o Comprometimento Docente

\begin{tabular}{|l|r|}
\hline Índice de Coesão e Comprometimento $(\mathbf{P})$ & Carga Fatorial \\
\hline Variável & 0,856 \\
\hline $\begin{array}{l}\text { Como você avalia os professores da sua escola com relação à } \\
\text { capacidade de: Compartilhar responsabilidades }\end{array}$ & 0,836 \\
\hline $\begin{array}{l}\text { Como você avalia os professores da sua escola com relação à } \\
\text { capacidade de: Formar um grupo coeso }\end{array}$ & 0,877 \\
\hline $\begin{array}{l}\text { Como você avalia os professores da sua escola com relação à } \\
\text { capacidade de: Comprometer-se com a política da escola }\end{array}$ & 0,860 \\
\hline $\begin{array}{l}\text { Como você avalia os professores da sua escola com relação à } \\
\text { capacidade de: Motivar os alunos para a aprendizagem }\end{array}$ & 0,777 \\
\hline $\begin{array}{l}\text { Como você avalia os professores da sua escola com relação à } \\
\text { capacidade de: Confiar na capacidade dos alunos }\end{array}$ & 0,836 \\
\hline $\begin{array}{l}\text { Como você avalia os professores da sua escola com relação à } \\
\text { capacidade de: Buscar novas estratégias que melhorem a } \\
\text { aprendizagem dos alunos. }\end{array}$ & \\
\hline
\end{tabular}

Extraction Method: Principal Component Analysis

Quadro 42: Cargas Fatoriais das Variáveis Relativas à percepção dos Diretores sobre o Alinhamento do trabalho docente

\begin{tabular}{|l|r|}
\hline Índice do Alinhamento do trabalho Docente (D) \\
\hline Variável & Carga Fatorial \\
\hline $\begin{array}{l}\text { Você considera que os professores desta escola estão alinhados com o } \\
\text { PPP? }\end{array}$ & 0,805 \\
\hline $\begin{array}{l}\text { Você considera que os professores desta escola estão alinhados com o } \\
\text { trabalho desenvolvido pela equipe de gestão (direção e coordenação)? }\end{array}$ & 0,869 \\
\hline $\begin{array}{l}\text { Você considera que, nesta escola, o trabalho desenvolvido pelos } \\
\text { professores dos anos iniciais está alinhado com o trabalho } \\
\text { desenvolvido pelos professores dos anos finais do ensino } \\
\text { fundamental? }\end{array}$ & 0,786 \\
\hline
\end{tabular}

Extraction Method: Principal Component Analysis

Destacamos, na construção deste índice, os resultados altos para o Alpha de Cronbach dos índices de Coesão e Comprometimento Docente (em todos os casos), conforme indicado no Quadro18, o que indica uma boa confiabilidade dos índices.

Como para a nossa amostra estes índices não apresentaram associações significativas a outras variáveis, eles não foram incluídos no modelo.

12) Índice de Interação do diretor com o corpo docente

O questionário dos professores trouxeram alguns itens para captar a percepção docente sobre a interação entre o diretor e os professores, em diferentes situações (apoio em situações problema, expectativas de trabalho, motivação, entre outras). Os dados 
necessitaram de recodificação de seus valores para que a escala de frequência admitisse um sentido positivo. $\mathrm{O}$ resultado da análise fatorial sintetizou os itens no índice que chamamos Índice de Interação do Diretor $(P)$, cujas variáveis apresentaram as seguintes cargas fatoriais:

Quadro 43: Cargas Fatoriais das Variáveis Relativas à percepção dos Professores sobre a Interação do Diretor com o corpo docente

\begin{tabular}{|l|r|}
\hline Índice de Interação do Diretor (P) \\
\hline Variável & Carga Fatorial \\
\hline $\begin{array}{l}\text { Quando um professor tem problemas em sua classe, o diretor toma a } \\
\text { iniciativa de discutir o problema. }\end{array}$ & 0,640 \\
\hline $\begin{array}{l}\text { Quando um professor leva um problema sobre sua classe à direção } \\
\text { escolar, este é resolvido com a sua participação. }\end{array}$ & 0,618 \\
\hline $\begin{array}{l}\text { O diretor desta escola deixa claro para os professores o que é } \\
\text { esperado de seu trabalho. }\end{array}$ & 0,718 \\
\hline O diretor desta escola se preocupa com o bem estar dos professores. & 0,754 \\
\hline $\begin{array}{l}\text { O diretor desta escola me encoraja a melhorar o meu trabalho em sala } \\
\text { de aula. }\end{array}$ & 0,896 \\
\hline $\begin{array}{l}\text { O diretor desta escola garante que existam momentos para discussões } \\
\text { coletivas sobre o trabalho desenvolvido na escola. }\end{array}$ & 0,833 \\
\hline
\end{tabular}

Extraction Method: Principal Component Analysis

Este índice apresentou associações significativas a outras variáveis da nossa amostra, sendo assim incluído no modelo estimado.

13) Índice de Satisfação no trabalho (percebido pelos diretores e professores)

Os instrumentos traziam questões sobre o nível de satisfação dos respondentes no trabalho, envolvendo o excesso de demanda, autonomia, motivação, entre outros aspectos. Foi necessário recodificar os itens criados para este bloco com atenção, uma vez que alguns tinham escala de concordância invertida. Como síntese destes itens, foram criados o Índice de Satisfação no Trabalho (D) e o Índice de Satisfação no Trabalho (P), sendo que este último foi agregado por escola. As cargas fatoriais destes índices são apresentadas nos quadros a seguir: 
Quadro 44: Cargas Fatoriais das Variáveis Relativas à percepção dos Diretores sobre sua Satisfação no trabalho

\begin{tabular}{|l|r|}
\hline Índice de Satisfação no Trabalho (D) \\
\hline Variável & Carga Fatorial \\
\hline $\begin{array}{l}\text { Sinto-me estressado (a) com o volume de demandas que o trabalho da } \\
\text { direção escolar me exige. }\end{array}$ & 0,723 \\
\hline $\begin{array}{l}\text { Sinto-me insatisfeito (a) com a irregularidade da rotina e com as } \\
\text { constantes mudanças que interferem na gestão escolar. }\end{array}$ & 0,631 \\
\hline $\begin{array}{l}\text { Eu não tenho o mesmo entusiasmo que eu tinha quando comecei a } \\
\text { trabalhar na direção escolar. }\end{array}$ & 0,749 \\
\hline $\begin{array}{l}\text { Sinto-me frustrado (a) pelo pouco controle e baixa interferência que } \\
\text { tenho sobre os projetos encaminhados pela CRE/SME para a escola. }\end{array}$ & 0,791 \\
\hline
\end{tabular}

Extraction Method: Principal Component Analysis

Quadro 45: Cargas Fatoriais das Variáveis Relativas à percepção dos Professores sobre sua Satisfação no trabalho

\begin{tabular}{|l|r|}
\hline Índice de Satisfação no Trabalho (P) \\
\hline Variável & Carga Fatorial \\
\hline Eu estou satisfeito com o tamanho da minha turma. & 0,675 \\
\hline Às vezes considero perda de tempo dar o melhor de mim nesta escola. & 0,710 \\
\hline Eu me sinto satisfeito em trabalhar nesta escola. & 0,643 \\
\hline Eu penso em me transferir para outra escola. & 0,653 \\
\hline Se eu pudesse, escolheria outra carreira. & 0,710 \\
\hline
\end{tabular}

Extraction Method: Principal Component Analysis

O Índice de Satisfação no Trabalho (P) apresentado acima foi utilizado como indicador do compromisso do professor no trabalho na escola e, assim, assumiu a função de variável dependente em um dos modelos estimados. 


\section{Anexo 8}

\section{Roteiro para Entrevista Semiestruturada: Diretores}

Características sócio demográficas

\begin{tabular}{|l|l|}
\hline Sexo & \\
\hline Idade; Mês/Ano de nascimento & \\
\hline Formação acadêmica: Curso Superior / IES & \\
\hline Pós-Graduação (tipo e área): & \\
\hline Formação Específica em gestão escolar & \\
\hline Número de anos como diretor escolar & \\
\hline Número de anos como diretor nesta escola & \\
\hline $\begin{array}{l}\text { Ocupou algum cargo na gestão escolar antes } \\
\text { de ser diretor? }\end{array}$ & \\
\hline $\begin{array}{l}\text { Experiência profissional fora do campo } \\
\text { educacional }\end{array}$ & \\
\hline
\end{tabular}

1. Conte um pouco sobre a história desta escola?

- o entorno, o posicionamento na comunidade, a trajetória acadêmica da escola.

2. Por favor, descreva quais são, atualmente, a missão e os valores desta escola.

3. Por favor, descreva qual é o foco dado à aprendizagem nesta escola.

4. Quais foram as razões que o levaram a querer ser diretor escolar?

- Quais foram suas primeiras impressões sobre a escola? Como você percebia o foco que era dado à aprendizagem?

- Quais foram as suas primeiras impressões sobre a escola? Nos primeiros meses de sua gestão, quais foram as suas estratégias voltadas para a aprendizagem dos alunos? (Exemplos)

- Como você acredita que estará a escola em 5 anos? E em 10 anos?

5. Quais são as suas maiores contribuições na liderança para esta escola?

6. Quais são as suas contribuições para aprimorar a aprendizagem nesta escola?

7. Quais são as suas contribuições para melhorar o desempenho individual e coletivo da escola?

- Como você influencia/apoia o trabalho dos professores para a aprendizagem dos alunos? Há outros aspectos voltados ao desempenho nos quais o trabalho da direção escolar contribui?

8. Quais são as metas a serem alcançadas em longo prazo pela escola?

-acadêmicas 
-outras (sócio emocionais)

9. Quais são as barreiras e desafios que a escola enfrenta para desenvolver e fortalecer uma cultura de aprendizagem?

- A manutenção ou criação de uma cultura de aprendizagem pode estar em diferentes níveis de implementação.

10. Como você acha que o clima escolar pode afetar a aprendizagem nesta escola?

- O que funciona/ o que está faltando?

11. Como o ambiente externo (pais, comunidade, política, sistema, nível educacional central) pode afetar a aprendizagem nesta escola?

- O que funciona/ o que está faltando?

12. Por favor, nos dê exemplos de como a aprendizagem é enfocada nesta escola.

- Aprendizagem dos alunos, dos professores, a própria aprendizagem.

13. Como as decisões relacionadas à liderança/gestão são compartilhadas na sua escola? Forneça dois exemplos.

14. Quais são as suas metas (em curto e longo prazo) para capacitar os professores e funcionários?

15. Como você contribui para desenvolver a capacidade de sua equipe para atingir as metas da escola?

16. Por favor, nos conte alguns exemplos de situações que demonstram que a escola está atingindo as suas metas, ou buscando atingi-las.

17. Como você acha que o clima escolar pode afetar a gestão desta escola (estrutura, prática e processos)?

- O que funciona/ o que está faltando?

18. Como você acha que o contexto externo (pais, comunidade, política, sistema educacional) pode afetar a gestão desta escola (estrutura, prática e processos)?

- O que funciona/ o que está faltando?

19. Você considera que os professores desta escola são satisfeitos em trabalhar aqui? Por quê?

20. Na sua opinião, quais são as características da gestão desta escola que são mais reconhecidas por sua equipe?

21. Pergunta final: há outras ideias ou comentários que não foram mencionados e você gostaria de expor? 


\section{Anexo 9}

\section{Roteiro para Entrevista Semiestruturada: Professores}

\section{Características sócio demográficas}

\begin{tabular}{|l|l|}
\hline Sexo & \\
\hline Idade; Mês/Ano de nascimento & \\
\hline Formação acadêmica: Curso Superior / IES & \\
\hline Pós-Graduação (tipo e área): & \\
\hline Número de anos trabalhando nesta escola & \\
\hline $\begin{array}{l}\text { Experiência profissional fora do campo } \\
\text { educacional }\end{array}$ & \\
\hline $\begin{array}{l}\text { Trabalhou em outras escolas? Quantas e de } \\
\text { que tipo (pública ou privada)? }\end{array}$ & \\
\hline $\begin{array}{l}\text { Está trabalhando atualmente em outras } \\
\text { escolas? Quantas e de que tipo (pública ou } \\
\text { privada)? }\end{array}$ & \\
\hline
\end{tabular}

1. O que você sabe/conhece sobre a história desta escola?

2. Por favor, descreva quais são, atualmente, a missão e os valores desta escola.

3. Por favor, descreva qual é o foco dado à aprendizagem nesta escola.

4. Que tipo de apoio/suporte é oferecido (e por quem) para impactar a aprendizagem nesta escola?

5. Por favor, nos dê alguns exemplos de apoio/suporte à aprendizagem dos alunos nesta escola?

- Apoio interno/apoio externo

6. Como você contribui para a aprendizagem dos alunos nesta escola?

7. Como as decisões relacionadas à liderança/gestão são compartilhadas na sua escola? Forneça dois exemplos

- Quem você considera como líderes nesta escola? Explique sua escolha.

8. Como você vê o seu papel nesta escola? Que suporte/apoio existe para favorecer sua participação nas decisões mais importantes da escola?

9. Como os líderes/gestores apoiam e sustentam a aprendizagem nesta escola?

- O que mais você acha que pode ser feito?

10. Você acha que a gestão desta escola desenvolve e encoraja a aprendizagem contínua dos alunos? Como? 
11. Quais são as barreiras e desafios que a escola enfrenta para desenvolver e fortalecer uma cultura de aprendizagem?

- A manutenção ou criação de uma cultura de aprendizagem pode estar em diferentes níveis de implementação.

12. Como você acha que o clima escolar pode afetar a aprendizagem nesta escola?

- O que funciona/ o que está faltando?

13. Como o ambiente externo (pais, comunidade, política, sistema, nível educacional central) pode afetar a aprendizagem nesta escola?

- O que funciona/ o que está faltando?

14. Como você acha que o clima escolar pode afetar a gestão nesta escola?

- O que funciona/ o que está faltando?

15. Como o ambiente externo (pais, comunidade, política, sistema, nível educacional central) pode afetar a gestão/liderança nesta escola?

- O que funciona/ o que está faltando?

16. Você considera que os professores desta escola são satisfeitos em trabalhar aqui? Por quê?

17. Quais são as características da gestão desta escola que você acha mais importantes?

18. Pergunta final: há outras ideias ou comentários que não foram mencionados e você gostaria de expor? 


\section{Anexo 10}

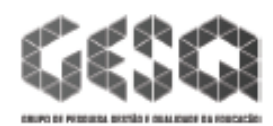

Pesquisa Gestắo Q Qualldade do Ensino na

Educaçăo Báslca/Gestăo, Llderança • Cllma Escolar

\section{Questionário do Diretor}

Convidamos o/a Sr./Sra. Diretor/a a participar de nossa pesquisa, através do preenchimento deste questionário. Nosso objetivo é colaborar para uma educaçāo de qualidade e contribuir para políticas equalizadoras, pelo estudo das características da direçāo escolar e de sua relação com o trabalho docente.

Esta investigaçāo integra a pesquisa "Desigualdades de Oportunidades Educacionais e Dimensōes da Alfabetizaçāo da Educaçāo Básica no Estado do Rio de Janeiro" do Observatório Educaçāo e Cidade, desenvolvida por pesquisadores da UFRJ, PUC-Rio e UERJ sob a coordenação do Prof. Dr. Márcio da Costa da FE-UFRJ, apoiada pela CAPES e a pesquisa pela Prof. Dra. Cynthia Paes de Carvalho da PUC-Rio, apoiada pela FAPERJ. Para algum questionamento, dúvida ou relato de algum acontecimento os pesquisadores poderāo ser contatados a qualquer momento.

Sua colaboração será de grande importância para nós. Asseguramos a confidencialidade das informaçōes que nos serão fornecidas. Os dados serão utilizados somente para fins cientificos, sem identificação de respondentes individuais ou das escolas em que atuam.

Apenas para efeito de controle da quantidade de respondentes por instituiçāo escolar, solicitamos que registre Apo o nome da escola em que recebeu o presente convite para participar da pesquisa e assinale sua concordância com esta participaçāo.

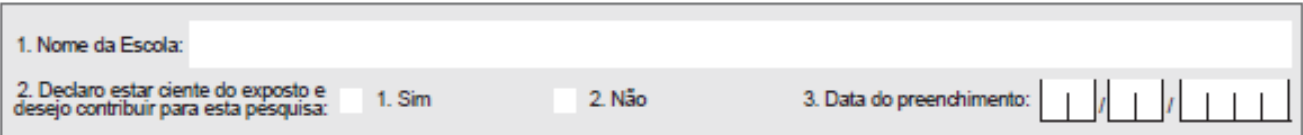

\begin{tabular}{|c|c|c|c|}
\hline $\begin{array}{l}\text { 2. Declaro estar ciente do exposto e } \\
\text { desejo contribuir para esta pesquisa: }\end{array}$ & 1. Sim & 2 Nằ & 3. Data do preenchimento: \\
\hline
\end{tabular}

\begin{tabular}{|c|c|c|}
\hline \multicolumn{3}{|c|}{ 4. Entre as metas elencadas abaixo, selecione aquela que vocé considera mais importante para o seu trabaho na direção da escolax. } \\
\hline $\begin{array}{l}\text { 1. Desenwolvimento dos melhores métodos } \\
\text { para favorecer a aprendizagem. }\end{array}$ & $\begin{array}{l}\text { 4. Proporcionar o desenwolvimento do } \\
\text { relacionamento humano entre o grupo } \\
\text { de trabaho. }\end{array}$ & $\begin{array}{l}\text { 7. Estabelecer a mediação entre as } \\
\text { demandas da secretaria de ensino e o } \\
\text { trabalho escolar. }\end{array}$ \\
\hline $\begin{array}{l}\text { 2. Promover o desenvolvimento profissional } \\
\text { do corpo docente. }\end{array}$ & $\begin{array}{l}\text { 5. Assegurar o cumprimento das metas de } \\
\text { avaliação estabelecidas externamente. }\end{array}$ & $\begin{array}{l}\text { 8. Garantir a boa administraçäo financeira, } \\
\text { focando o funcionamento de todos os } \\
\text { setores da escolla. }\end{array}$ \\
\hline $\begin{array}{l}\text { 3. Zelar pela segurança dos alunose } \\
\text { funcionarios. }\end{array}$ & $\begin{array}{l}\text { 6. Conhecer e solucionar os principais } \\
\text { problemas de aprendizagem dos alunos } \\
\text { da escola. }\end{array}$ & 9. Garantir a participaçäo das familias. \\
\hline
\end{tabular}

5. Qual é a frequência dos seguintes tipos de reunibes na sua escola?

\begin{tabular}{|c|c|c|c|c|c|c|c|}
\hline & Semanal & Cuinzenal & Mensal & Bimestral & Semestral & Anual & Năo se aplica \\
\hline $\begin{array}{l}5.1 \text { Somente entre a equipe } \\
\text { gestora }\end{array}$ & & $2 \mathrm{O}$ & 3.0 & 4. $\mathrm{O}$ & 5. $\mathrm{O}$ & & \\
\hline $\begin{array}{l}5.2 \text { Equipe gestora e professores do } \\
\text { primeiro segmento }\end{array}$ & & & & & & & \\
\hline $\begin{array}{l}5.3 \text { Equipe gestora e professores do } \\
\text { segundo segmento }\end{array}$ & & & & & & & \\
\hline $\begin{array}{l}\text { 5.4 Equipe gestora e todos os } \\
\text { professores }\end{array}$ & & & 3. & & & & \\
\hline
\end{tabular}

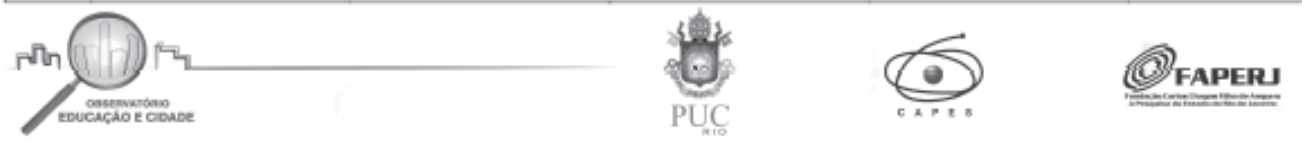




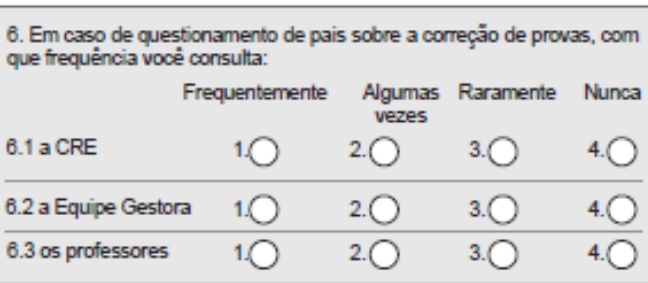

7. Em caso de baixo desempenho académico de uma turmalsérie, com que frequéncia vocé consulta:

8. Em casso de faltas de professores, com que frequência você consulta:

\begin{tabular}{|c|c|c|c|c|}
\hline 6.1 a CRE & Frequentemente & Algumas vezes & Raramente & Nunca \\
\hline a Equipe Gestora & 1. $\mathrm{O}$ & 2. $\mathrm{O}$ & 3. $\mathrm{O}$ & 4. $C$ \\
\hline os professores & 1. $\mathrm{O}$ & 2. $\mathrm{O}$ & 3. $\mathrm{O}$ & 4. $C$ \\
\hline
\end{tabular}

9. Indique com que frequência vocè realiza as seguintes atividades no seu trabalho na direção escolar.

Frequentemente Algumas Raramente Nunca

9.1 Eu assisto às aulas (ou parte delas

9.2 Eu acompanho os "Passeios Pedagógicos".

9.3 Eu acompanho a aplicação de provas.

9.4 Eu dou sugestôes aos professores sobre como eles podem mehorar suas aulas.

9.5 Eu dialogo com os professores sobre os problemas que surgem em suas turmas.

9.6 Eu informo os professores sobre possiveis formas de ampliarem sua formaçäo para o trabalho na escola.

9.7 Eu dou aulas quando algum professor falta.

9.8 Eu acompanho a escolha do material dídático adotado pelos professores na escola.

Frequentemente Algumas Raramente Nunca

7.1 a CRE

1. $\quad 2 \mathrm{O} \quad 3 \mathrm{O} \quad 4 \mathrm{O}$

$\begin{array}{lllll}7.2 \text { a Equipe Gestora } \quad 10 & 2 \bigcirc & 3 . & & \end{array}$

$\begin{array}{lllll}7.3 \text { os professores } \quad 1 . & 2 & 0 & 3 . & 4 .\end{array}$

10. Quando um professor lhe relata uma briga de alunos em sua turma, qual é o encaminhamento mais comumente adotado? tado em sua turma, qual è o encaminhamento mais comumente adotado?

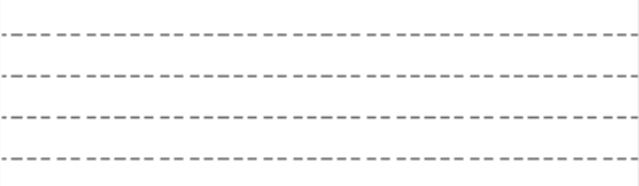
tuma, qual é o encaminhamento mais comumente adotado?

13. Quando um professor lhe relata um problema de aprendizagem de seus alunos qual é o encaminhamento mais comumente adotado?

1 sugiro alguma estratégia de trabalho a ser realizado.

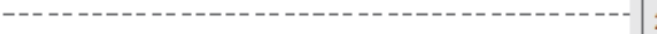

dou-the autonomia para resolver a situaçäo.

o encaminho à Coordenação Pedagógica

proponho uma reunäo com a Equipe de Gestäo.

levo o tema para a reuniảo de professores.

14. Quando um professor dos anos iniciais do ensino fundamental fata, sem avisar, qual é o encaminhamento mais comumente adotado?

1 Eu o substituo.

6 Os alunos realizam tarefas autonomamente.

2 O Coordenador Pedagógico o substitui.

3 O Diretor Adjunto o substtui.

4 Um funcionário administrativo o substtui.

7 Os alunos permanecem na escola fazendo outras atividades.

Um professor especializado o substitui.

8 os alunos são dispensados da aula e encaminhados para

retomarem às suas casas

9 Os alunos sảo distribuídos em outras tumas. 


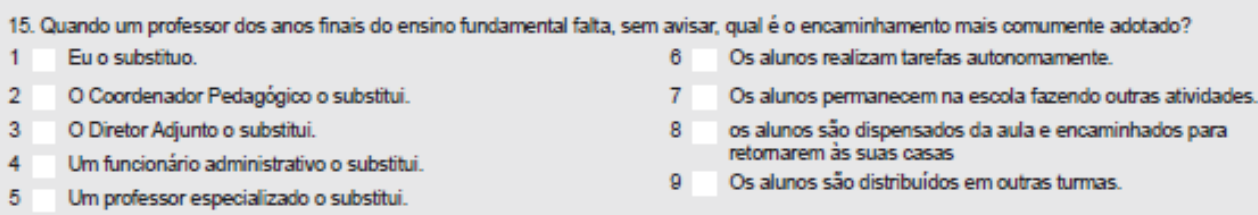

\begin{tabular}{|c|c|c|c|}
\hline $\begin{array}{l}16.1 \text { Eu solicito ao coordenador uma descrição do desempenho } \\
\text { acadêmico bimestral de cada turma. }\end{array}$ & $\begin{array}{c}\text { Frequentemente } \\
1.0\end{array}$ & $\begin{array}{c}\text { Algumas vezes } \\
2 \bigcirc\end{array}$ & $\begin{array}{c}\text { Raramente } \\
3 . \bigcirc\end{array}$ \\
\hline $\begin{array}{l}\text { 16.2 Eu converso com os professores sobre o desempenho de seus } \\
\text { alunos nas avaliaģeses interas da escola. }\end{array}$ & 1.0 & 20 & 3. $\mathrm{O}$ \\
\hline $\begin{array}{l}\text { 18.3 Eu converso com os professores sobre a preparaçăo de seus alunos } \\
\text { para as avaliaģes extemas. }\end{array}$ & 1. 0 & $2 \mathrm{O}$ & 3. $\mathrm{O}$ \\
\hline $\begin{array}{l}16.4 \text { Eu solicito à equipe gestora que acompanhe os resultados internos } \\
\text { dos alunos. }\end{array}$ & 1. $\mathrm{O}$ & 20 & 3. $\mathrm{O}$ \\
\hline $\begin{array}{l}16.5 \text { Eu solicto à equipe gestora que acompanhe os resultados dos } \\
\text { alunos nas avaliaģes externas. }\end{array}$ & 1.0 & $2 \mathrm{O}$ & 3. $\mathrm{O}$ \\
\hline $\begin{array}{l}16.6 \text { Eu utlizo o argumentito da bonificaçáa para estimular os professores } \\
\text { a mehorar os resultados dos alunos nas avaliaģoes extermas. }\end{array}$ & $1 . \mathrm{O}$ & 20 & 3. $\mathrm{O}$ \\
\hline $\begin{array}{l}16.7 \text { Eu acompanho os resultados dos } \\
\text { de corregäo de fluxo. }\end{array}$ & 1.0 & $2 \mathrm{O}$ & 3. $\mathrm{O}$ \\
\hline
\end{tabular}

17. Sobre os resultados da sua escola na última avaliaçäo externa (Prova Brasi), indique o seu grau de concordància com as afimativas abaixo:

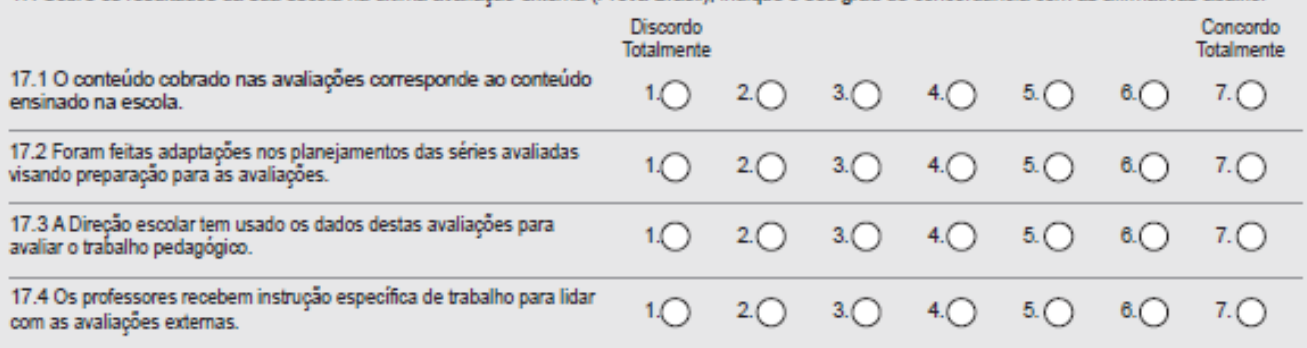

18. Em sua opiniäo, quais são os principais fatores que influenciamvexplicam o resultado dessa escola nas avaliaçöes externas (Prova Brasi)? Cite ate très fatores

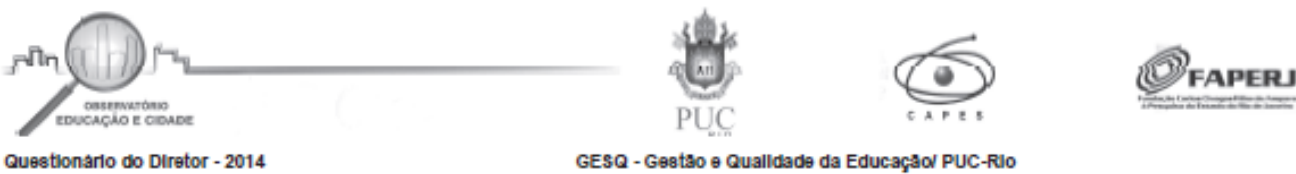




\begin{tabular}{|c|c|c|c|c|}
\hline & $\begin{array}{l}\text { Intuencis } \\
\text { sigrifcativa }\end{array}$ & $\begin{array}{l}\text { Intutencis } \\
\text { Moderada }\end{array}$ & $\begin{array}{l}\text { Roucs } \\
\text { impuencla }\end{array}$ & $\begin{array}{l}\text { Nentums } \\
\text { Influtencla }\end{array}$ \\
\hline 19.1 Defniçlo de metas de desempenho para os alunos da escola & 10 & $2 . \mathrm{O}$ & 3. $\mathrm{O}$ & 4.0 \\
\hline 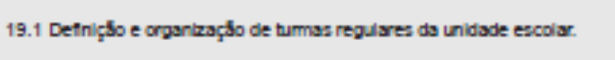 & 10 & $2 . \mathrm{O}$ & 3. $\mathrm{O}$ & 4.0 \\
\hline 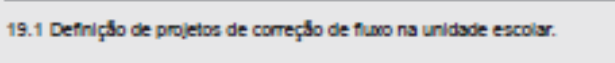 & 1.0 & 2.0 & 3. 0 & 4.0 \\
\hline 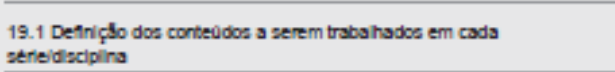 & $1 . \mathrm{O}$ & 2.0 & 3. 0 & 4.0 \\
\hline 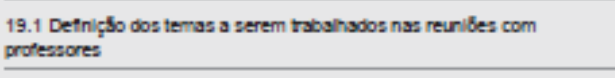 & 1.0 & 2.0 & 3. $\mathrm{O}$ & 4.0 \\
\hline 19.1 astemas de aval splo dos protessores & 1.0 & 2.0 & 3. $\mathrm{O}$ & $4 . \mathrm{O}$ \\
\hline 19.1 Decibbes sobre a maricua de alinos & 1.0 & 2.0 & 3. $\mathrm{O}$ & 4.0 \\
\hline 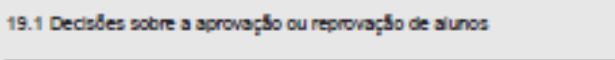 & ${ }^{1} \mathrm{O}$ & $2 . \mathrm{O}$ & 3. $\mathrm{O}$ & $4 . \mathrm{O}$ \\
\hline 19. 1 Decibbes sobre o encaminhamento de alunos pars outras unilades & $1 . \mathrm{O}$ & $2 . \mathrm{O}$ & 3. $\mathrm{O}$ & $4 . \mathrm{O}$ \\
\hline \multicolumn{5}{|c|}{$\begin{array}{l}\text { 20. Em sua opinilSo, stualmente, qual t o nivel de infuencla do COORDENADOR PEDAGOGICO na rotha desta escola, em cada um dos seguir- } \\
\text { tea aspectos. }\end{array}$} \\
\hline & $\begin{array}{l}\text { Intuencis } \\
\text { sloniticativa }\end{array}$ & $\begin{array}{l}\text { Intuencia } \\
\text { Modersoda }\end{array}$ & $\begin{array}{l}\text { Proucs } \\
\text { irnuenclas }\end{array}$ & $\begin{array}{l}\text { Nentuma } \\
\text { Influencis }\end{array}$ \\
\hline 20.1 defniçlo de metas de desempenho para os alunos da escola & 1. $\mathrm{O}$ & $2 . \mathrm{O}$ & 3. $\mathrm{O}$ & \\
\hline 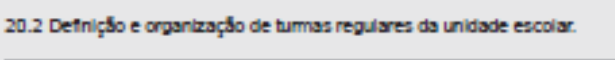 & 1. $\mathrm{O}$ & $2 . \mathrm{O}$ & 3. $\bigcirc$ & $4 . \mathrm{O}$ \\
\hline 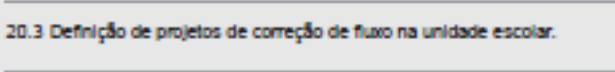 & 1.O & $2 . \mathrm{O}$ & 3. $\mathrm{O}$ & \\
\hline $\begin{array}{l}20.4 \text { Defrichlo dos contevodos a serem trabshadse em cads } \\
\text { stenediacipins }\end{array}$ & $1 . \bigcirc$ & 2.0 & 3. $\mathrm{O}$ & $4 . \mathrm{O}$ \\
\hline 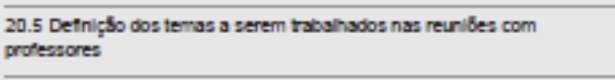 & $1 . \mathrm{O}$ & 2.0 & 3. $\mathrm{O}$ & $4 . \mathrm{O}$ \\
\hline 20.6 antemas de avalsplo dos proteseores & 1. $\mathrm{O}$ & $2 . \mathrm{O}$ & 3. $\mathrm{O}$ & 4.0 \\
\hline 20.7 decibles sobre a maricula de atinos & 1. $\mathrm{O}$ & 2.0 & 3. $\mathrm{O}$ & $4 . \mathrm{O}$ \\
\hline 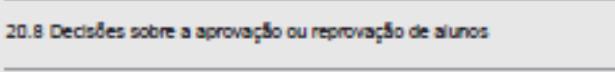 & 1. $\mathrm{O}$ & 2.0 & 3. $\mathrm{O}$ & $4 . \mathrm{O}$ \\
\hline 20.9 Decibbes sobre o encaminhamerno de alunos para outras unildades & 1. $\mathrm{O}$ & 2.0 & 3. $\mathrm{O}$ & 4.0 \\
\hline \multicolumn{5}{|c|}{ 21. Em sua opiniso, stualmente, qual to onivel de infuencia dos PROFEssOREs na rotina desta escols, em cads um dos seguintes aspectos: } \\
\hline & $\begin{array}{l}\text { Intuencis } \\
\text { abrificativa }\end{array}$ & $\begin{array}{l}\text { Intuencla } \\
\text { Modersods }\end{array}$ & $\begin{array}{l}\text { Poucs } \\
\text { infuencls }\end{array}$ & $\begin{array}{l}\text { Nentuma } \\
\text { Infuenclas }\end{array}$ \\
\hline 21.1 Defnlçlo de metas de desempenho para os alunos da escola & 1.0 & 2.0 & $3 . \mathrm{O}$ & 4.0 \\
\hline 212 Deenightes sobre os corteudse curricuares & 1. $\mathrm{O}$ & 2.0 & 3. $\mathrm{O}$ & 4.0 \\
\hline 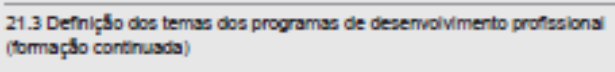 & 1.0 & 2.0 & 3. $\mathrm{O}$ & 4.0 \\
\hline 21. 4 Decibles sobre a serrovaģto ou reprovaçbo de aunos & 1.0 & 2.0 & 3. $\mathrm{O}$ & $4 . \mathrm{O}$ \\
\hline 215 Deciabes sobre o encaminhamento de alunos para outras unicades & 1. $\mathrm{O}$ & 2.0 & 3. $\mathrm{O}$ & 4.0 \\
\hline
\end{tabular}




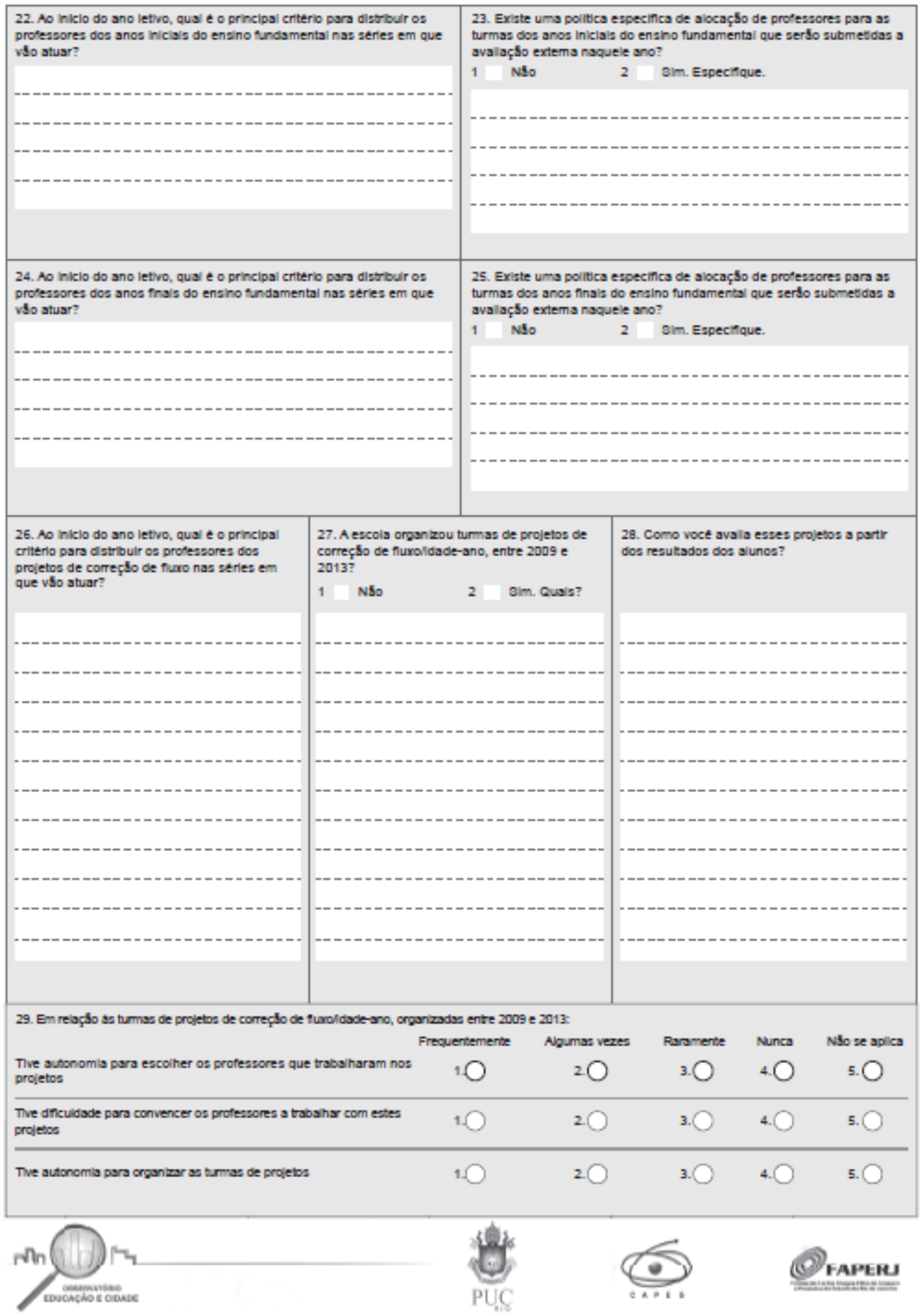




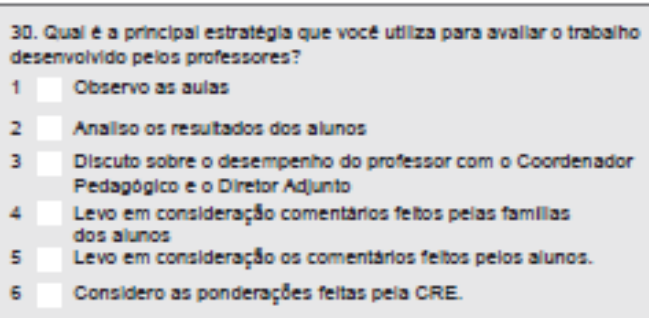

$\begin{array}{lllllll}10 & 2.0 & 3.0 & 4.0 & 5.0 & 6.0 & 7.0\end{array}$

32.2 As demandsa de trabsiho na drep̧lo escols sto rasabvela.

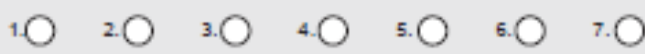

32.3 anto-me estrescasio (a) com o volume de demandas que o trabaho da dreplo escolsr me exipe.

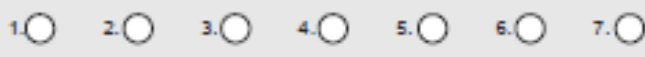

32.4 anto-me nastsfeto (a) com a iregulandsde da rotha e com as

constantes mudropas que interferem na gestlo escoly:

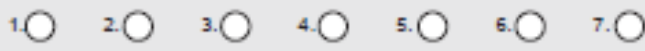

325 Eu nfo tenho o mesmo entuslsamo que eu thing quando

comecel s trabs har na direfto eacoler.

$\begin{array}{llllllll}1 . & 2.0 & 3.0 & 4.0 & 5.0 & 6.0 & 7.0\end{array}$

32.6 anto-me turtado (a) peio pouco controie e baina intertertncis que tenho sobre os projelos encamintados pela CFESME para a ercola.

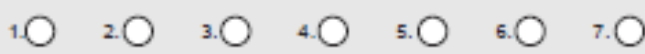

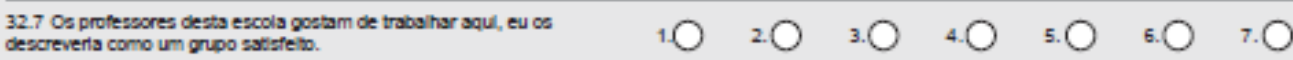

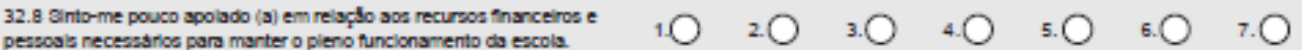

C)

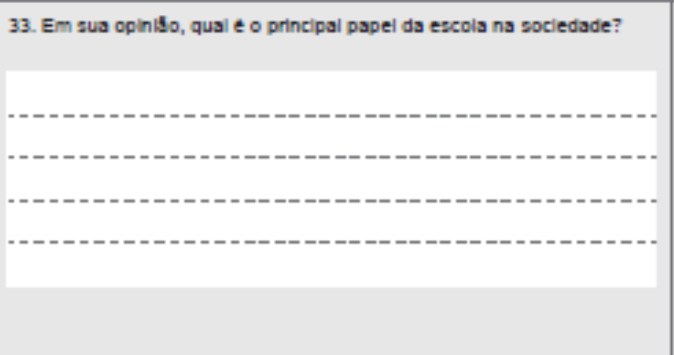

34. Entre oa aspectoa abaixo, com qual voce gasta mala do seu tempo de trabaho na escols?

1 Gestlo de pessoal (administraçlo das relaçles entre professores e entre funcionarioa, controle de faltas e Icenças, etc.)

2 Gestlo sdministrativa (prestaç5o de contas, coleta de orçamentos, organizaçlo de horarios, controles inanceiros)

3 Aspectos pedagogicos (dlacusablo sobre cumiculo, metodolog/a de ensino, avalis palo de desempenho dos alunos, dlsciplinaicomportamento dos aunoa)

4 RelaçBes extemas (reunibes com pals, reunides na CRE/aME, organizaçlo e moniboramento de parcerias)

35. Como voct avala a sua relaç̧o com:

35.1 Os professores

Mulb bos Bas Regulsr fuim Muto rum

35.20 coordenador pedagogice

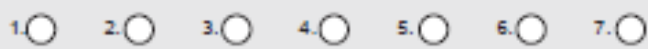

35.20 coordenador pedagobica

$\begin{array}{lllllll}1.0 & 2.0 & 3.0 & 4.0 & 5.0 & 6.0 & 7.0\end{array}$

35.4 Os a vunce

$\begin{array}{lllllll}1 . & 2.0 & 3.0 & 4.0 & 5.0 & 6.0 & 7.0\end{array}$

35.5 Os pala dos alunos

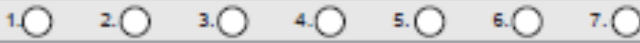

35.6 Conseino Escols:

$\begin{array}{lllllll}1 . & 2 . \mathrm{O} & 3 . \mathrm{O} & 4 . \mathrm{O} & 5 . \mathrm{O} & 6 . \mathrm{O} & 7 . \mathrm{O}\end{array}$

35.7 As escolas do entomo

$\begin{array}{lllllll}10 & 2 . \mathrm{O} & 3 . \mathrm{O} & 4 . \mathrm{O} & 5 . \mathrm{O} & 6 . \mathrm{O} & 7 . \mathrm{O}\end{array}$

35.. ACRE

$\begin{array}{lllllll}1.0 & 2 . & 3.0 & 4.0 & 5.0 & 6.0 & 7.0\end{array}$

$\begin{array}{lllllll}1 . & 2.0 & 3.0 & 4.0 & 5.0 & 6.0 & 7.0\end{array}$ 


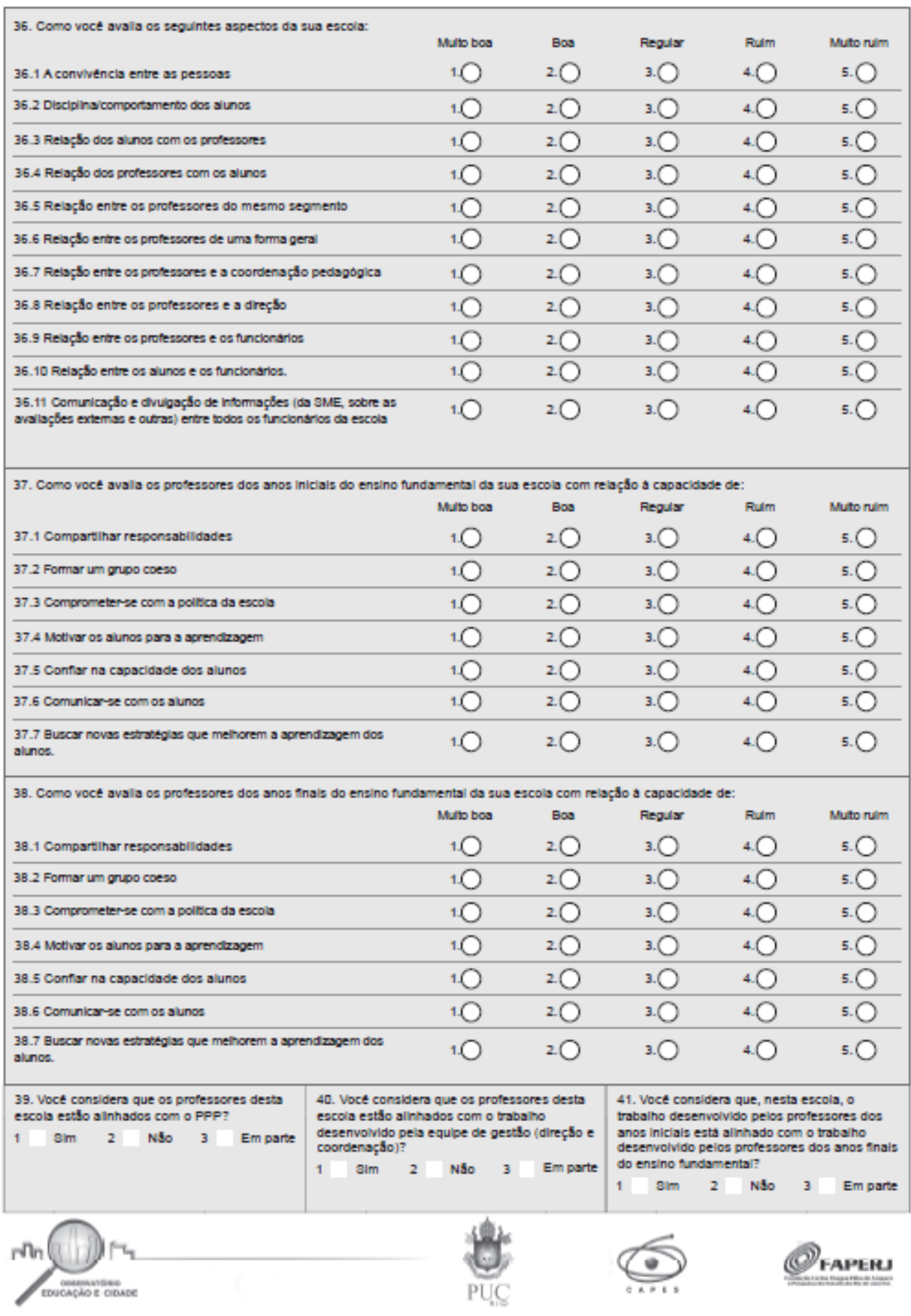




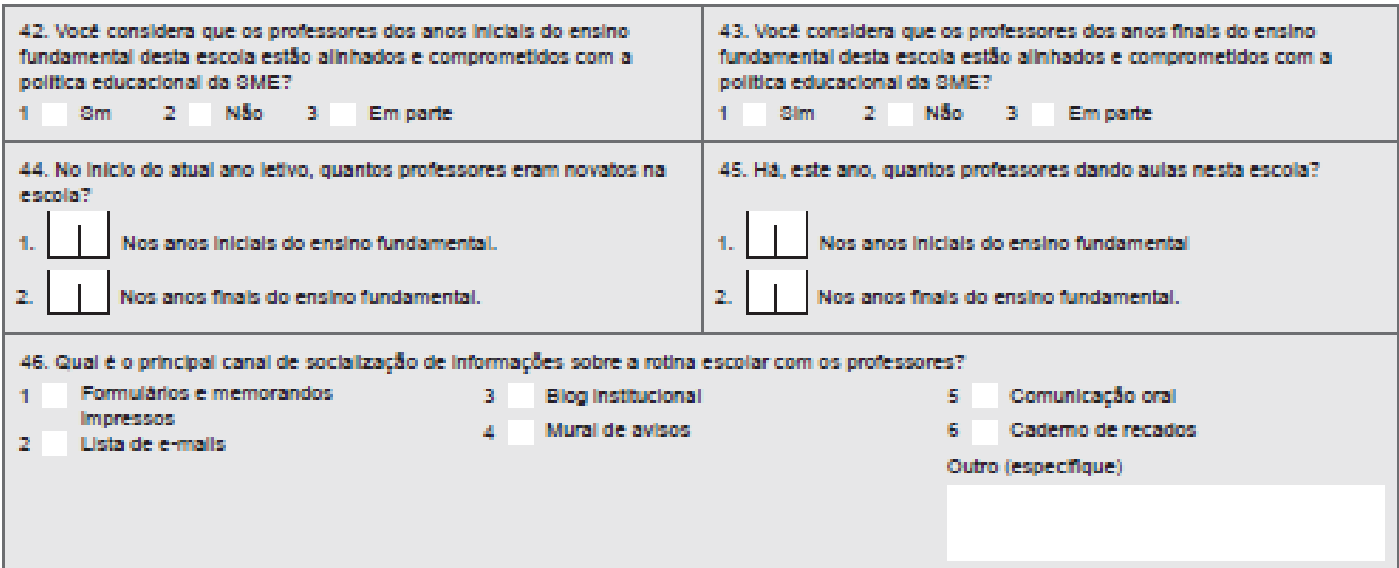

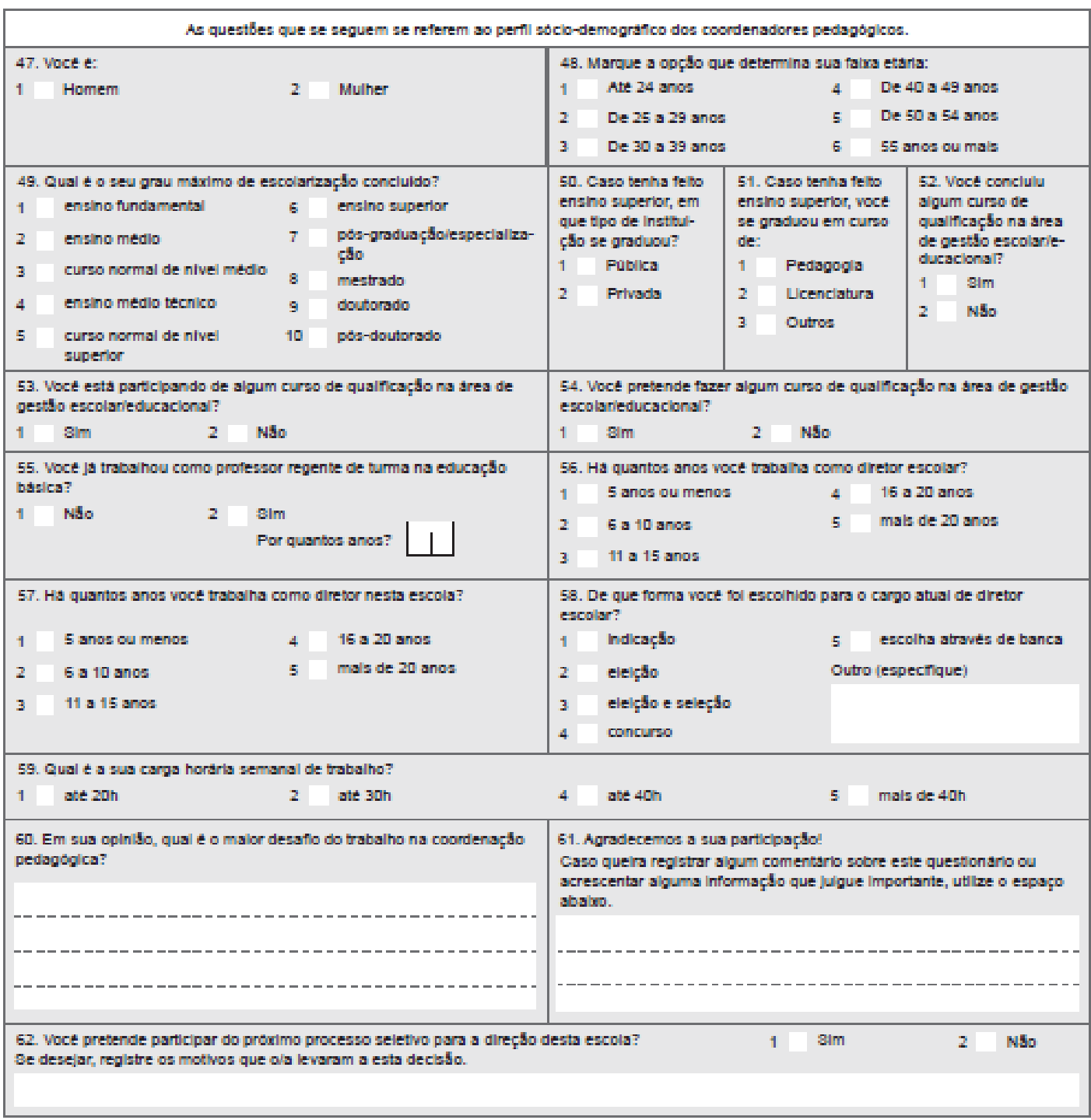




\section{Anexo 11}

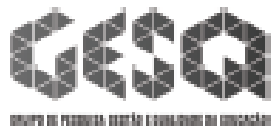

\section{P•squlsa Gestäo • Qualldade do Enslno na}

\section{Educaçăo Bäslca/Gıstäo, Lldørança • Cllma Escolar}

Questionário do Coordenador Pedagógico

Convidamos o/a Sr/Sra. Coordenador/a a participar de nossa pesquisa, através do preenchimento deste questiońrio. Nosso objetivo é colaborar para uma educação de qualidade e contribuir para politicas equalizadoras, pelo estudo das caracteristicas da direção escolar e de sua relação com o trabalho docente.

Esta investigaç̄o integra a pesquisa "Desigualdades de Oportunidades Educacionais e Dimensōes da Alfabetização da Educação Básica no Estado do Rio de Janeiro" do Observatório Educação e Cidade, desenvolvida por pesquisadores da UFRJ, PUC-Rio e UERJ sob a coordenação do Prof. Dr. Márcio da Costa da FE-UFRJ, apoiada pela CAPES e a pesquisa "Gestão e Qualidade do Ensino na Educação Búsica" do grupo Gestão e Qualidade da Educação - GESQ, coordenada pela Prof. Dra. Cynthia Paes de Carvalho da PUC-Rio, apoiada pela FAPERJ. Para algum questionamento, dúvida on relato de algum acontecimento os pesquisadores poderão ser contatados a qualquer momento.

Sua colaboraçăo será de grande importância para nós. Asseguramos a confidencialidade das informaçōes que nos ser Jo formecidas. Os dados serāo utilizados somente para fins cientificos, sem ident ificaçāo de respondentes individuais ou das escolas em que atuam.

Apenas para efeito de controle da quantidade de respondentes por instituiço escolar, solicitamos que registre abaixo o nome da escola em que recebeu o presente convite para participar da pesquisa e assinale sua concordancia com esta participação.

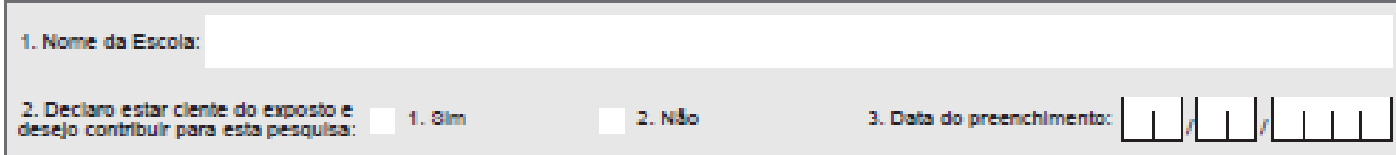

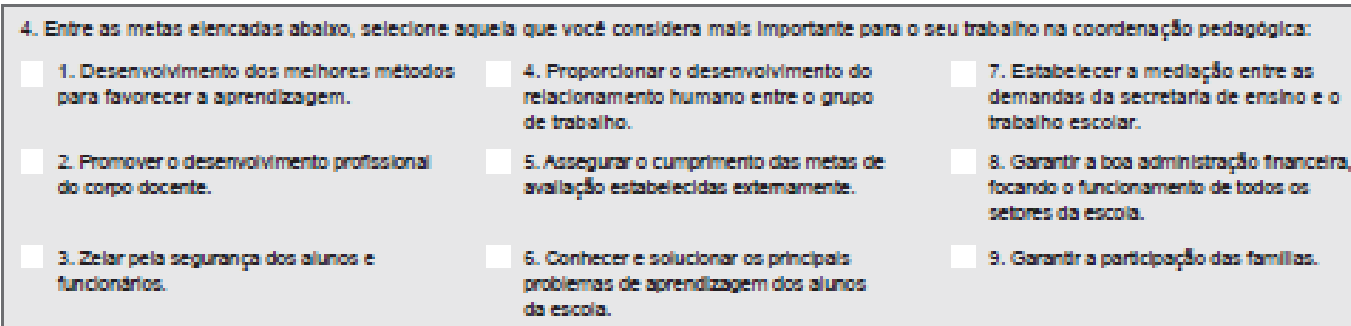

5. Gual e a frequencla doa seguintes tpos de reunides na sua eacols?

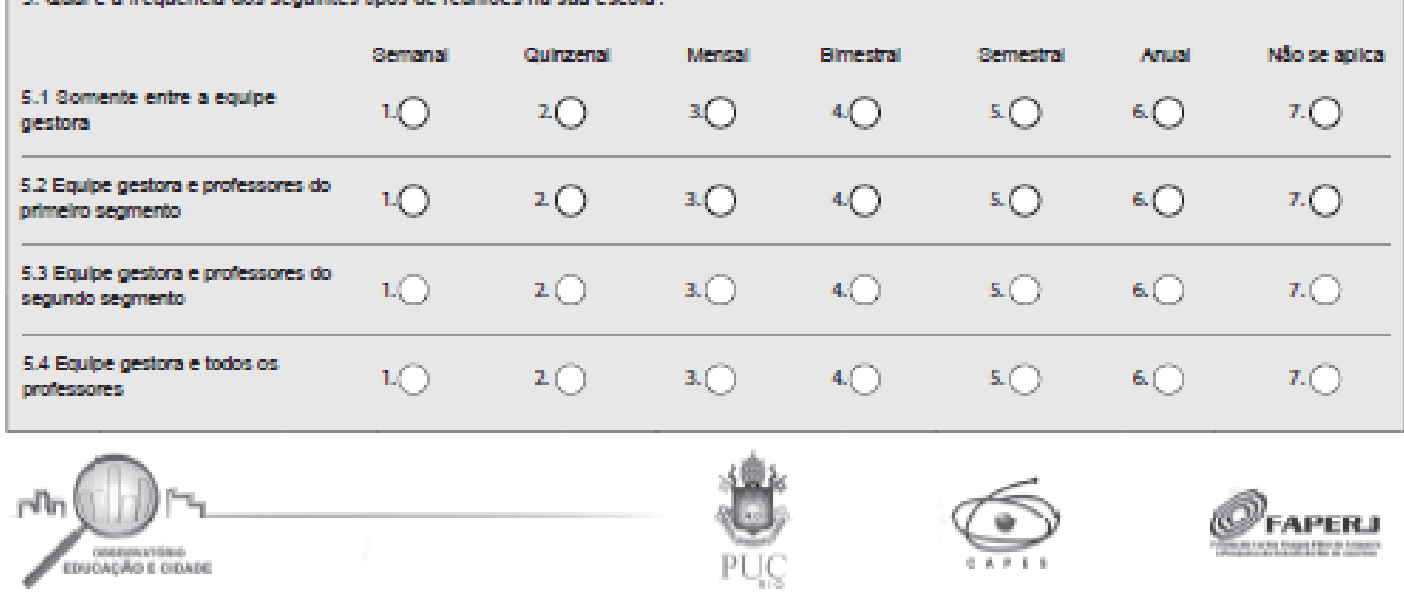




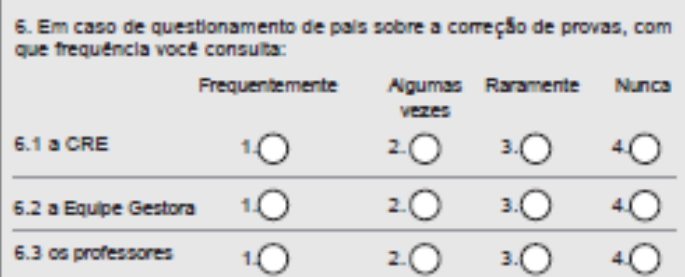

7. Em caso de baiko desempenho academico de uma turmastrie, con que frequencla voct consulta:

\begin{tabular}{lllll}
$7.1 \mathrm{a} \mathrm{CRE}$ & Frequentemente & $\begin{array}{c}\text { Ngumas } \\
\text { vezes }\end{array}$ & Raramente & Nunca \\
$7.2 \mathrm{a}$ Equipe Gestors & $1 . \mathrm{O}$ & $2 . \mathrm{O}$ & $3 . \mathrm{O}$ & $4 . \mathrm{O}$ \\
\hline $7.3 \mathrm{ces}$ professores & $1 . \mathrm{O}$ & $2 . \mathrm{O}$ & $3 . \mathrm{O}$ & $4 . \mathrm{O}$ \\
\hline
\end{tabular}

8. Em caso de fa tas de profeasores, com que frequencla voct consutta:

\begin{tabular}{|c|c|c|c|c|}
\hline 8.1 a CRE & $\begin{array}{c}\text { Frequentemente } \\
1 .(\mathrm{O}\end{array}$ & $\begin{array}{c}\text { Agumse vezes } \\
20\end{array}$ & Raramente & $\begin{array}{l}\text { Nunca } \\
4 . \mathrm{O}\end{array}$ \\
\hline 8.2 a Equipe Gestora & & & & \\
\hline $8.3 \mathrm{ce}$ professores & & & ${ }^{3}$. & \\
\hline
\end{tabular}

9. Indque com que frequencia voct realiza as seguintes atividades no seu trabalho na coordenaçlo pedagogica: Frequentemente Agumss Faramente Nunca

9.1 Eu assigto ss aulsa (ou parte delas).

9.2 Eu acompanho ce "Paszeica Pedagogicos"

veres

10

2.0

3. $\mathrm{O}$

9.3 Eu acomparho a aplicaplo de provas.

10

$3 \quad \mathrm{O} \cdot \mathrm{O}$

9.4 Eu dou supesties sos professores sobre como eies podem mehorr suas aulas.

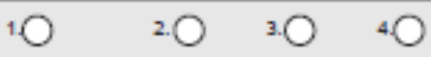

9.5 Eu dlaiogo com os professores sobre os problemas que surgem em suss tumas.

10

3.0

9.6 Eu informo of protessores sobre possivels formas de amplisrem sua formachlo para o trabsiho na escols.

9.7 Eu dou sulsa quando algum professor fats.

$\begin{array}{lllll}1 . & 2 . & 3 & 3 . & 4\end{array}$

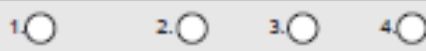

9.8 Eu acompsrho a escolha do material didatico soctado peics professores na escols.

10

$2 . \mathrm{O}$

3. $\mathrm{O} \quad 4 . \mathrm{O}$

10. Quando um professor line relata uma briga de alunos em sua tuma, qual to encaminhamento mals comumente adotado?

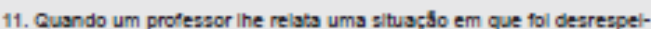
tado em sua turma, qual to encaminhamento mals comumente adotado?

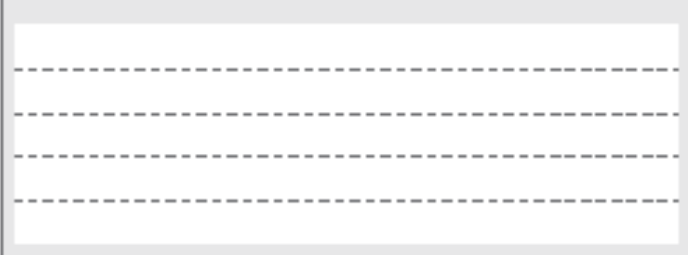

12. Quando um professor lhe relata uma difculdade no manejo de sus turma, qual to encaminhamento mals comumente adotado?

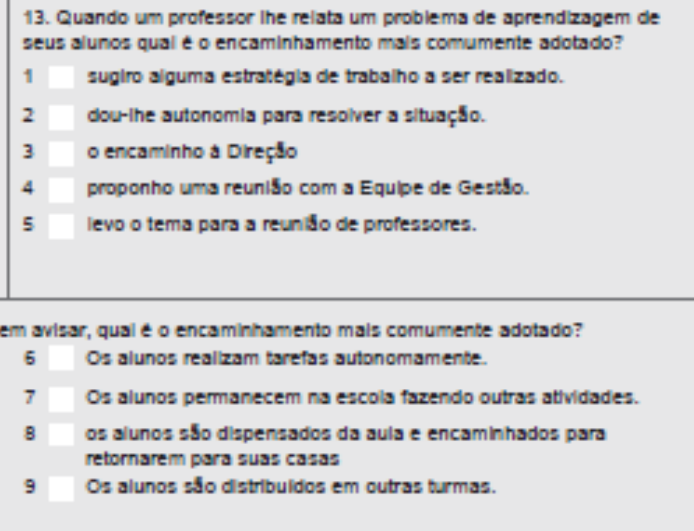

13. Quando um profesgor the relata um problema de aprendizagem de seus alunos qual to encaminhamento mals comumente adotado? 1 sugiro aguma eatrattgls de trabalho a ser realzado. proponho uma reunl\$o com a Equipe de Gestlo. evo tema para a reun lo de profeseores.

14. Quando um professor dos anos iniclas do ensino fundamental fata, sem avisar, qusl e o encaminhamento mals comumente adotado? Eu o substhus.

O Diretor o subettul.

o Diretor Adiunto o substhu.

Um funcionario administrativo o subatitul.

Um professor especializado o substtul. 


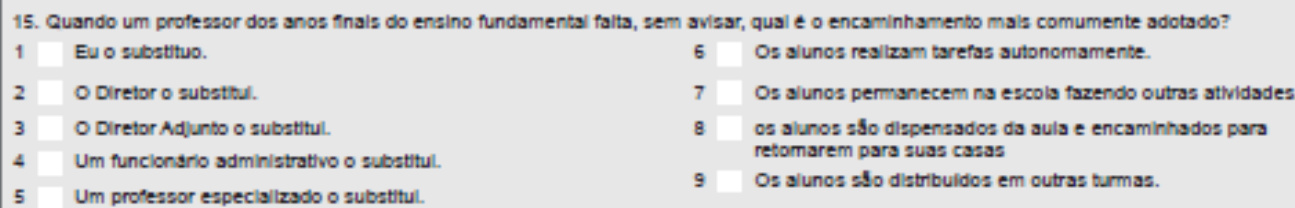

(1)

17. acbre os resutados da sua escola na uttma avalaçlo entema (Prova Erasil), indlque o seu grau de concordancia com as aflmastvas abalxo: Decordo Concordo Totaimente Totamente

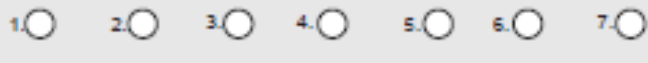

18. Em sus opiniso, quals aso os principals fatores que infuenciam/explcam o resultado dessa escola nas avalaçbes extemas (Prova Brasil0? Clte att trets fatore:

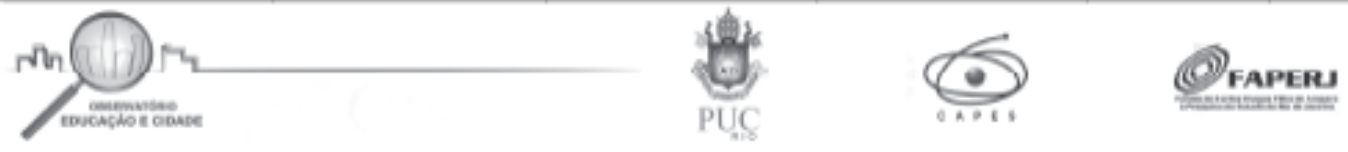




\begin{tabular}{|c|c|c|c|c|}
\hline & $\begin{array}{l}\text { Imauencia } \\
\text { sonncatva }\end{array}$ & $\begin{array}{l}\text { matuencis } \\
\text { Moderdas }\end{array}$ & $\begin{array}{l}\text { Pouca } \\
\text { Influencis }\end{array}$ & $\begin{array}{l}\text { Nernums } \\
\text { intuluncle }\end{array}$ \\
\hline 19.1 Definlz̧so de metsas de desempentho para os alunos da escols & 1.0 & $2 . \mathrm{O}$ & $3 . \mathrm{O}$ & 4. $\mathrm{O}$ \\
\hline 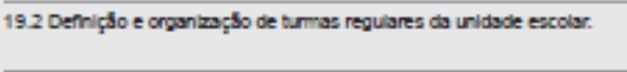 & 1. $\mathrm{O}$ & 2.0 & ${ }^{3} \mathrm{O}$ & 4.0 \\
\hline 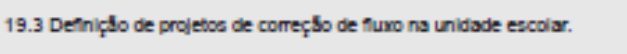 & $1 . \mathrm{O}$ & $2 . \mathrm{O}$ & ${ }^{3} \mathrm{O}$ & 4. $\mathrm{O}$ \\
\hline 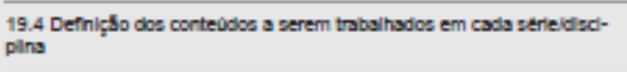 & $1 . \mathrm{O}$ & $2 . \mathrm{O}$ & ${ }^{3} \mathrm{O}$ & \\
\hline 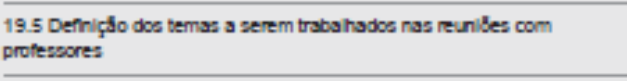 & & 2.0 & 3. $\mathrm{O}$ & \\
\hline 19.6 sistemas de avalaç̧o doe profesosres & 1. $\mathrm{O}$ & 2.0 & ${ }^{3} . \mathrm{O}$ & \\
\hline 19.7 Deciebes sobre a matricula de asunse & 1.0 & 2.0 & 3. $\mathrm{O}$ & 4.0 \\
\hline 19.8 Deciabes socre a aprovachlo ou reprovaplo de alunos & $1 . \mathrm{O}$ & $2 . \mathrm{O}$ & 3.0 & 4. $\mathrm{O}$ \\
\hline 19.9 Decisbes sobre o encamirhamento de sunos pars oursas unidsses & 1.0 & 2.0 & $3 . \mathrm{O}$ & \\
\hline
\end{tabular}

20. Em sus opin/So, ahusimente, qual e o seu nivel de infuencla na rotna desta escola, enquanto COORDENADOR PEDAGOGICO, em cada Um dos seguintes aspectoa: Infuencia mouca Nerisuma Sonncativa Moderada Influencis intukncis

20.1 Definlz̧̧o de metsa de desempenho para os alunos da escola

20.2 Defniçlo e organizą̧lo de tumas regulares da uridade escolar.

\begin{tabular}{|c|c|c|c|c|}
\hline 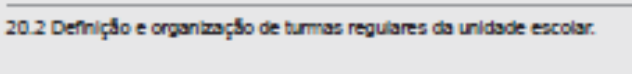 & 10 & 20 & 30 & 4.0 \\
\hline 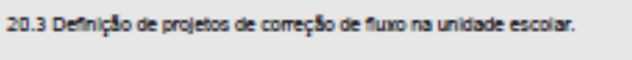 & 10 & 20 & 30 & 4.0 \\
\hline 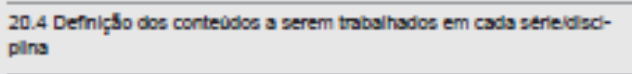 & 10 & 2.0 & 30 & ${ }^{4} \mathrm{O}$ \\
\hline 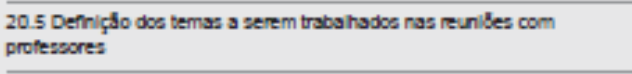 & 1.0 & 2.0 & 30 & 4.0 \\
\hline 20.6 satemas de aval aço dos proferesorea & 10 & 2.0 & ${ }^{3} \mathrm{O}$ & 4.0 \\
\hline 20.7 Decibbers score a matricus de sumses & 1. & 2.0 & 30 & 4.0 \\
\hline 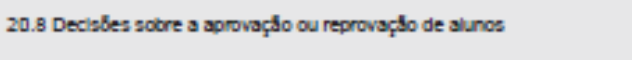 & 10 & 2.0 & 30 & 4. 0 \\
\hline 20.9 Decibbes sobre o encamirhsmento de sunos pras our & 10 & 2.0 & 30 & 4.0 \\
\hline
\end{tabular}

(1)

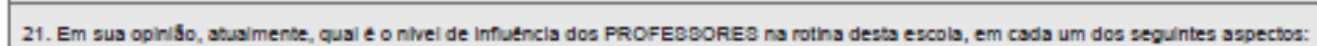

\begin{tabular}{|c|c|c|c|c|}
\hline & $\begin{array}{l}\text { Infuencia } \\
\text { agnincativa }\end{array}$ & $\begin{array}{l}\text { Intuencia } \\
\text { Moderada }\end{array}$ & $\begin{array}{l}\text { Poucs } \\
\text { Infuenclas }\end{array}$ & $\begin{array}{l}\text { Nerhums } \\
\text { Infuthcla }\end{array}$ \\
\hline 21.1 Definlę̧o de metas de desempento para os alunos da escola & & & & \\
\hline 21.2 Defniçbles sobre os conteudos cumculares & & & & \\
\hline $\begin{array}{l}\text { 21.3 Defniçlo dos temas dos programas de desenvolimento profosions } \\
\text { (formaçlo continuada) }\end{array}$ & & & & \\
\hline 21.4 Deciabes sobre a aprovap̧lo ou reprovaçbo de siunse & & & & \\
\hline 21.5 Dedigles sobre o encaminhamento de alunos para cutras unidades & & & & \\
\hline
\end{tabular}




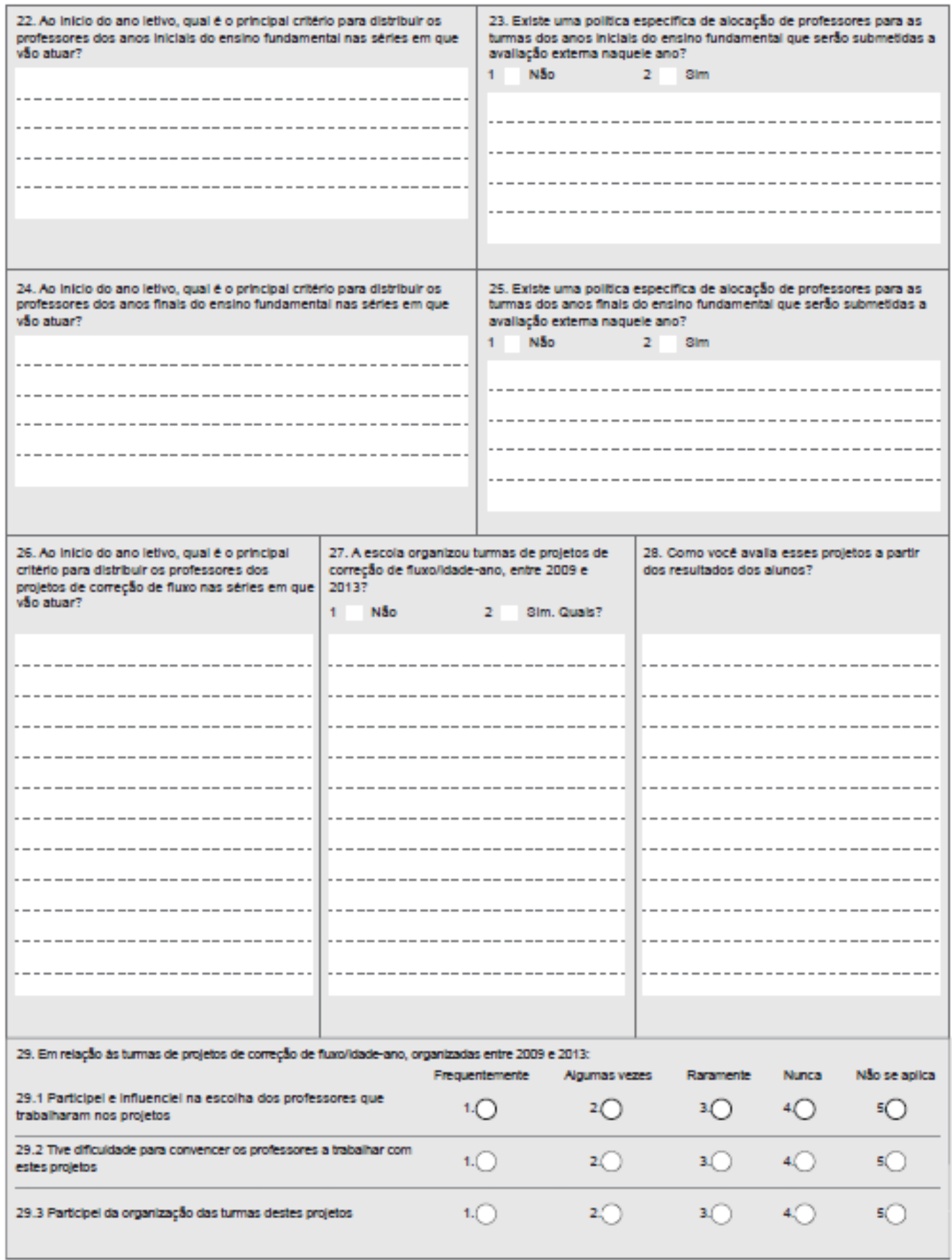

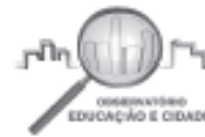

Quectlonario do Coordenador Podagcoloo - 2014
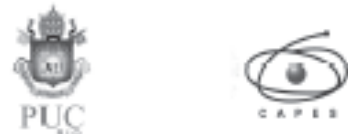

(9) FAPER 


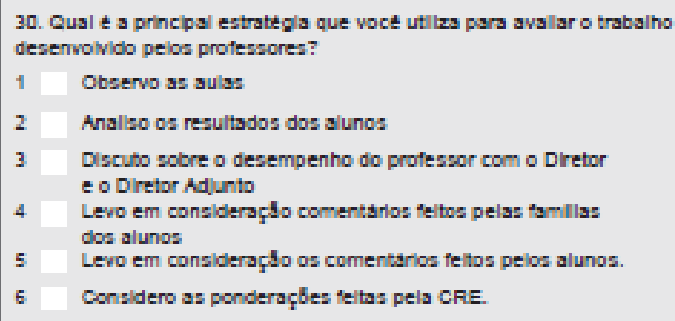

32. Sobre o seu trabaino na coordenaçso pedagogica desta escola, marque qual t o seu nivel de concordsncla com cada uma das afrmativas ababro:

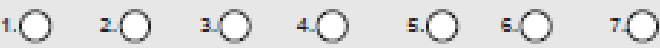

33. Em sus opinilso, qual to princlpal papel da eacola na sociedade?

34. Entre os aspectos abalro, com qual voce gasta mala do seu tempo de trabalho na eacola?

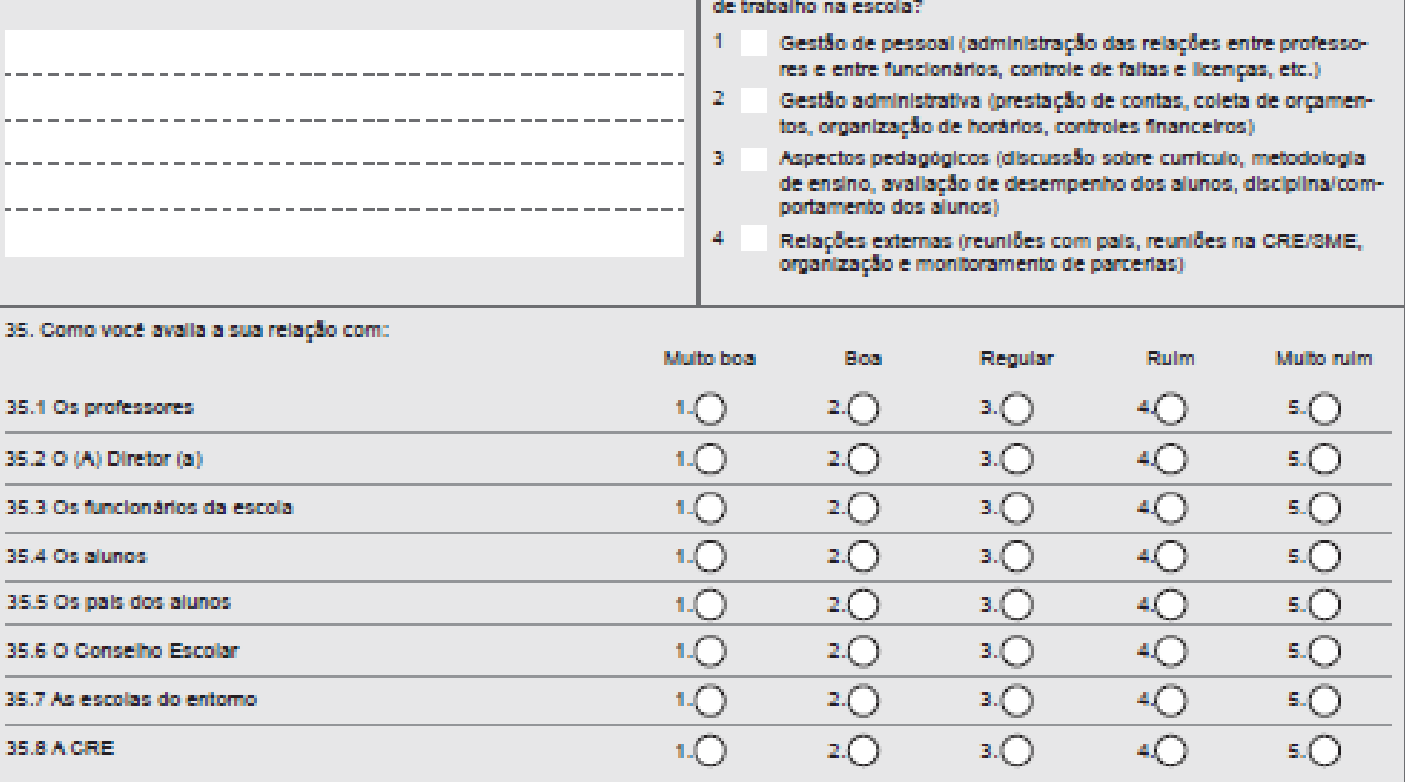




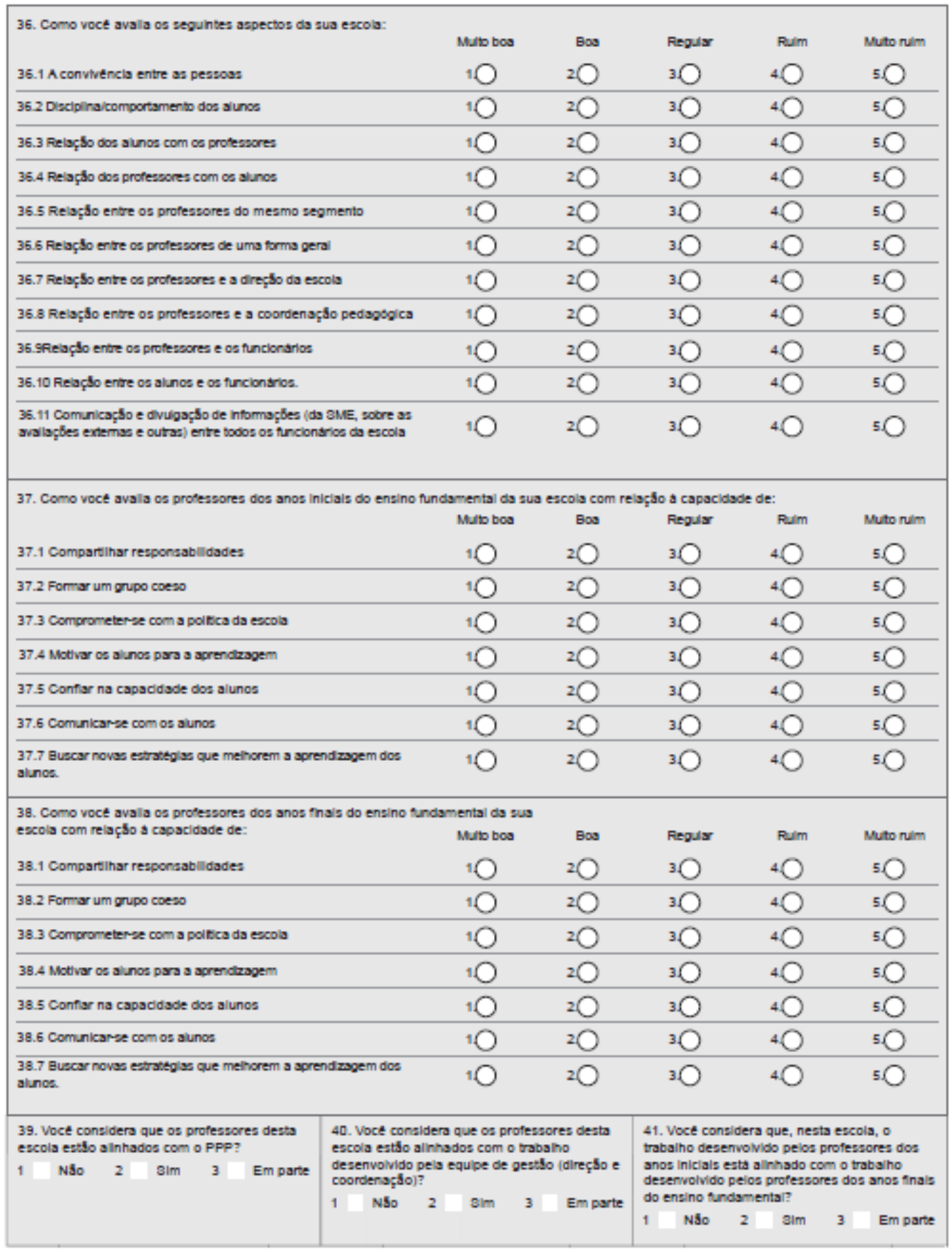

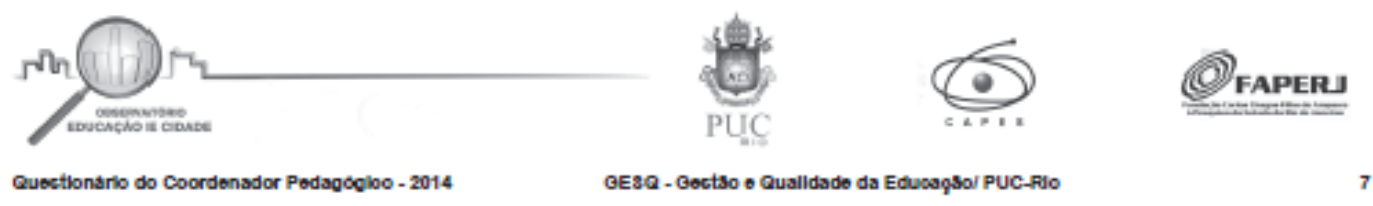




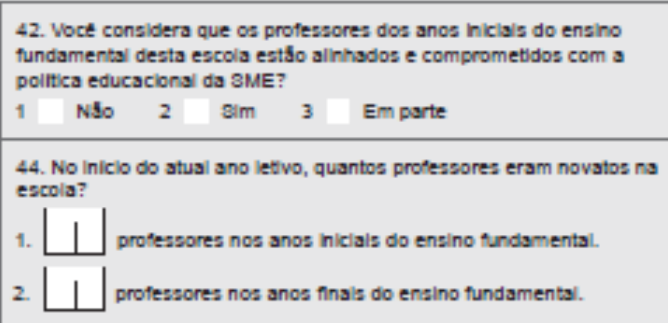

43. Voct considera que os protessores dos anos finals do ensino fundamental desta escols estbo alinhadoa e comprometidoa com a poilfca educacional da $3 \mathrm{ME}$ ?

1 NSo 2 aim 3 Emparte

45. Qual e o principal canal de socialzzaç5o de informaçbes sobre a rotina escolar com os protessores?

1 Formularios e memorandios 4 Mural de avisos impreseos

2 Lista de e-mals 5 Comunicaçlo oral

\begin{tabular}{ll|l|l}
3 & Blog Insthucional & 6 & Caderno de recados
\end{tabular}

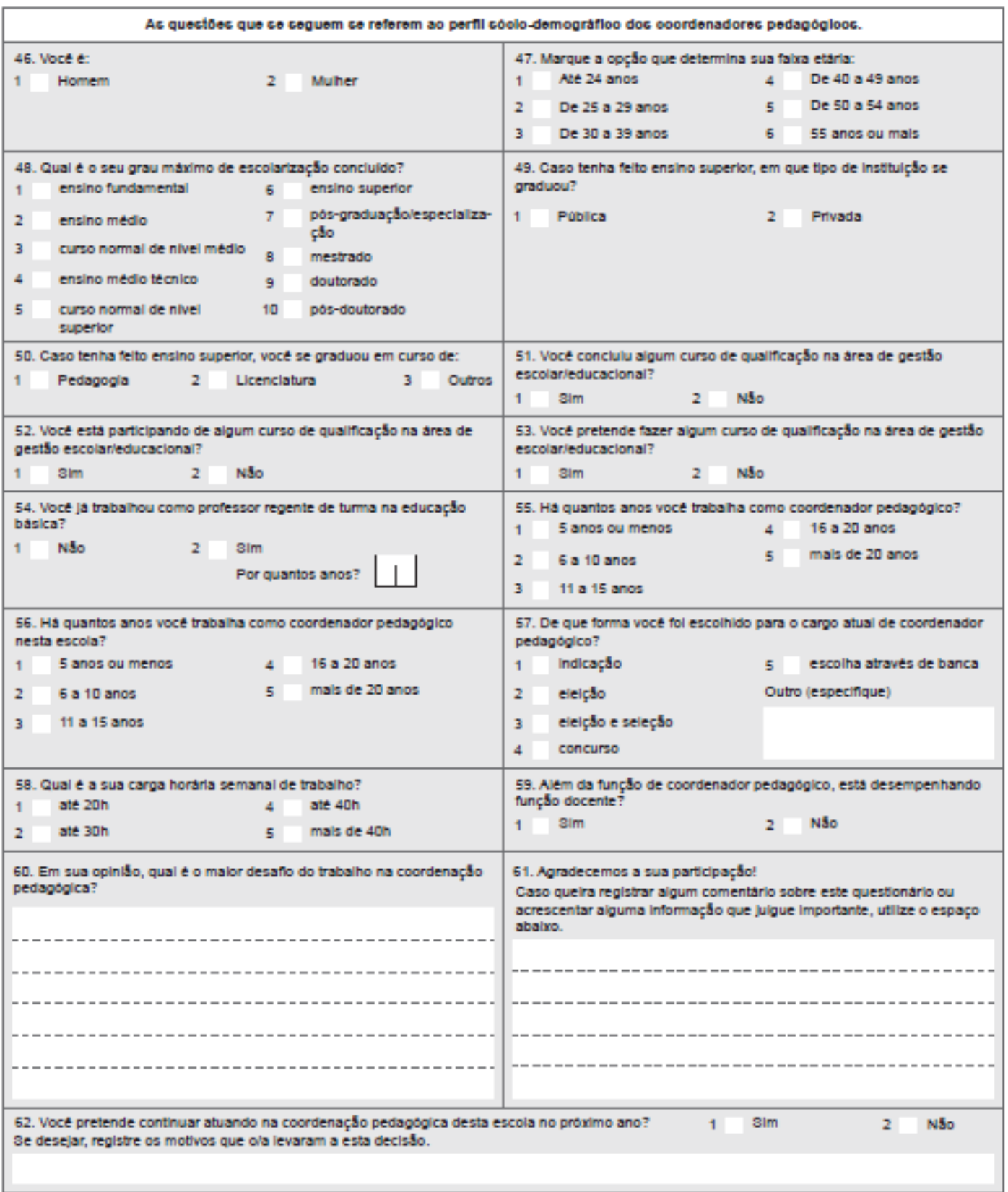




\section{Anexo 12}

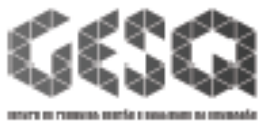

Nimeroo questionaro $\lfloor\perp \perp|\perp| \perp \mid \bigsqcup \perp \perp$

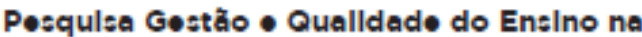 Educaçäo Bäslca/Gıstäo, Llderança • Cllma Escolar}

Questionário do Professor

Convidamos o/a Sr./Sra. Professor/a a participar de nossa pesquisa, através do preenchimento deste questionário. Nosso objetivo é colaborar para uma educacăo de qualidade e contribuir para politicas equalizadoras, pelo estudo das caracteristicas da direção escolar e de sua relação com o trabalho docente.

Esta investigaç̃o integra a pesquisa "Desigualdades de Oportunidades Educacionais e Dimensões da Alfabetizaç̃o da Educaç̃o Básica no Estado do Rio de Janeiro" do Observatório Educacão e Cidade, desenvolvida por pesquisadores da UFRJ, PUC-Rio e UERJ sob a coordenação do Prof. Dr. Márcio da Costa da FE-UFRJ, apoiada pela CAPES e a pesquisa "Gestão e Qualidade do Ensino na Educaçāo Básica" do grupo Gestāo e Qualidade da Educaçāo - GESQ, coordenada pela Prof. Dra. Cynthia Paes de Carvalho da PUC-Rio, apoiada pela FAPERJ. Para algum questionarnento, dúvida ou relato de algum acontecimento os pesquisadores poderão ser contatados a qualquer momento.

Sua colaboração será de grande importáncia para nós. Asseguramos a confidencialidade das informaçōes que nos ser ão fornecidas. Os dados seräo utilizados somente para fins científicos, sem ident ificaçăo de respondentes individuais ou das escolas em que atuam.

Apenas para efeito de controle da quantidade de respondentes por instituição escolar solicitamos que registre abaixo o nome da escola em que recebeu o presente convite para participar da pesquisa e assinale sua concordåncia com esta participaç̄o.

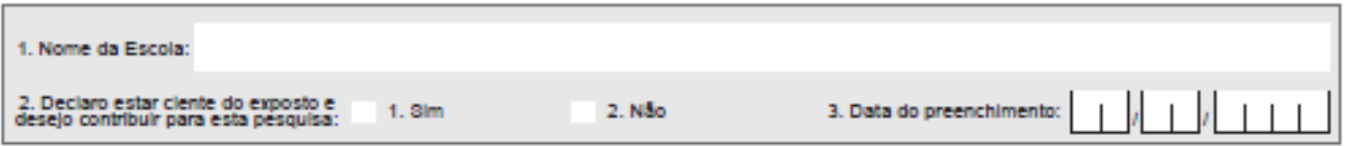

\begin{tabular}{|c|c|c|}
\hline 4. Para qual segmento da escola voce leciona? & \multicolumn{2}{|c|}{ 5. Voct considera a qualidsde do ensino na sua eacola } \\
\hline 1. Anos inicisls do ensino tundamental ( $1^{\circ}$ so $5^{\circ}$ ano) & 1. Multo bos & 4. Rulm \\
\hline 2. Anos finals do ensino tundamental (6" as $9^{\circ}$ ano) & 2. Bos & 5. Muto rulm \\
\hline 3. Os dols segmentos. & 3. Regular & \\
\hline
\end{tabular}

6. Sobre os resultados da sus escols na ûtma avalaçşo extema (Prova Brasl), indque o seu grau de concordsncia com as affrmativas abairo:

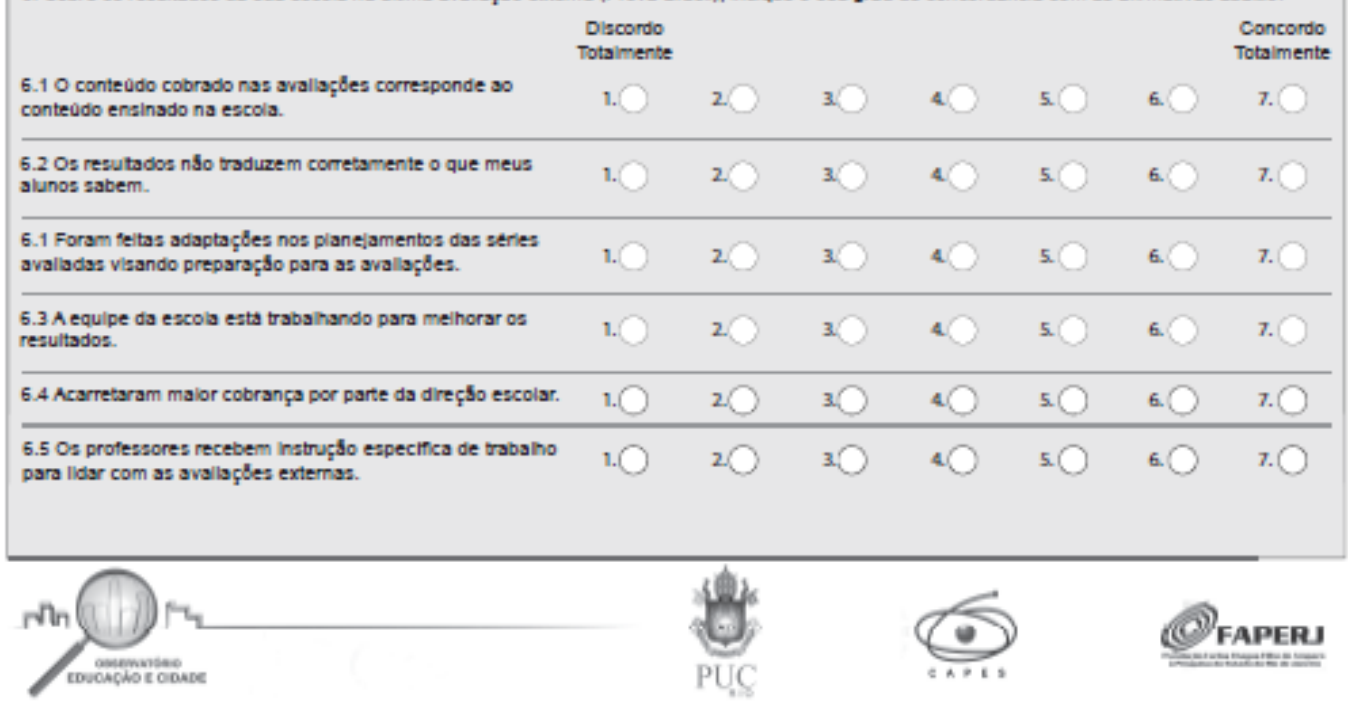




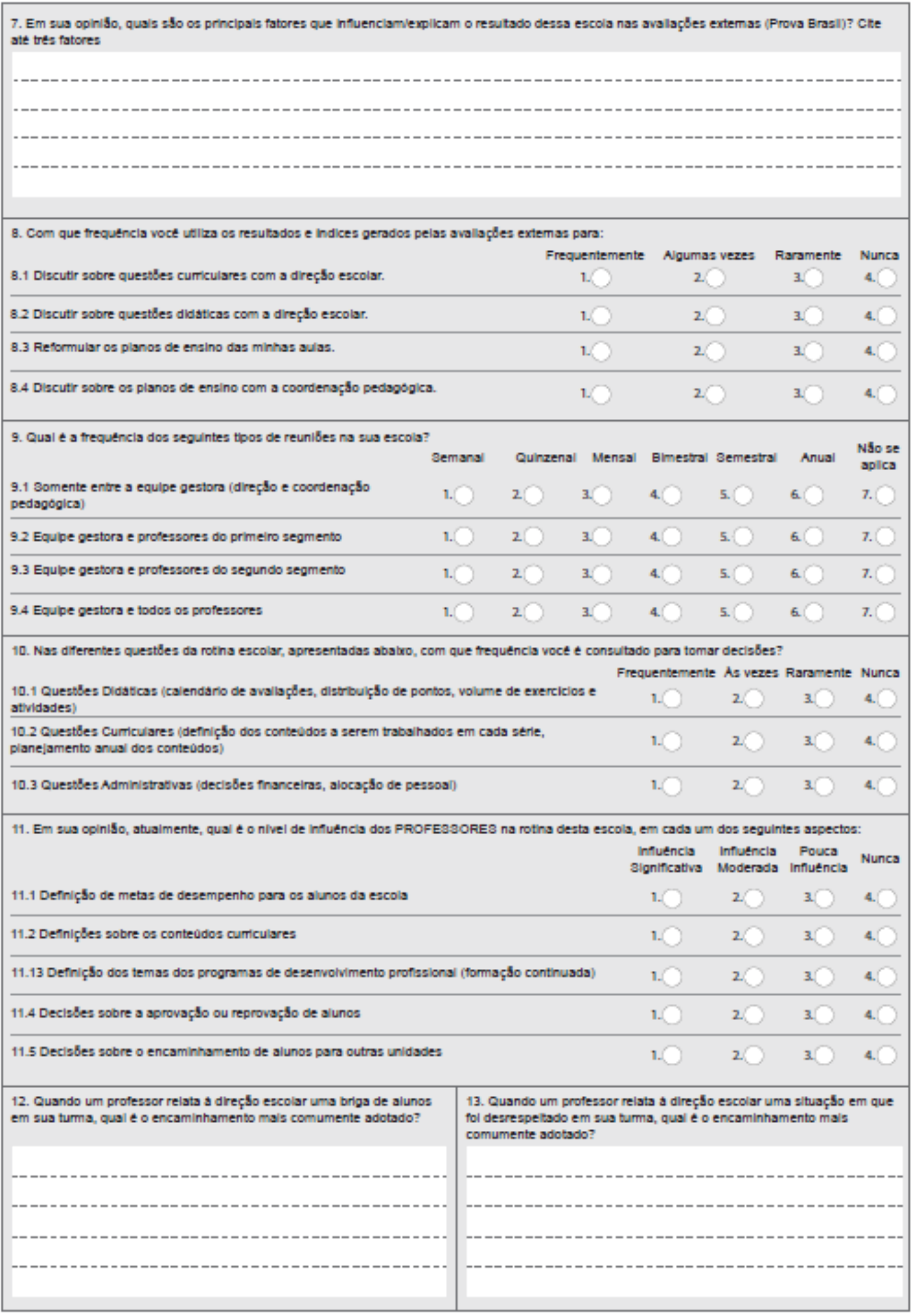


14. Quando um protessor relista a dreçlo escolsr uma dificuldade no manejo de sua turma, qual to encaminhamento mals comumente dotado?
15. Guando um protessor relata a dreçlo eacolar um probiema de aprendizapem de seus alunos qual to encaminhamento mals comumente adotado?
16. Cuando um professor doa anos iniciass do ensino tundamental fata, sem avisar, qual t o encaminhamento mals comumente adotado?

1 O Diretor o substtul.

2. Diretor Ad lunto o substitul.

O coordenador o subattul.

Um funcionario administrativo o subatitul.

Um professor eapecis/zado o subatitul.

Os alunos realzam tarefas aubonomamente.

Os alunos permanecem na escola fazendo outras atvidades.

Os alunos ablo dlspenaados da aula e sfo encaminhsdos para retomarem as suas casse

9 Os alunos abo dletrbuidos em outras tumas.
17. Guando um profeseor doa anos fraig do engino fundamental ta sem avisar, qusl e o encaminhamento mals comumente adotado?

1 O Direbor o substtul.

2 O Diretor Ad unto o substhul.

3 O Coordenador o subattul.

4 Um funcionario administrativo o subatilu.

5 Um professor eapecialzado o subattil.

6 Os alunos realzam taretas aubonomaments.

7 Os alunos permanecem na escola fazendo outras atvidades.

8 Os alunos afo dlspenaadoa da aula e sSo encaminhados para retomarem as suas casas.

9 Os alunos afo dletrbuldos em outras tumss. criterio para dlstrbuir os professores do se segmento nas stries em que vSo atuar?
18. Ao Inicio do ano lettivo, qual e o principa

19. Eviste uma poititica eapecifica de alocaçlo extema naqueie ano?

1 NSo

2 Sim. Especinque
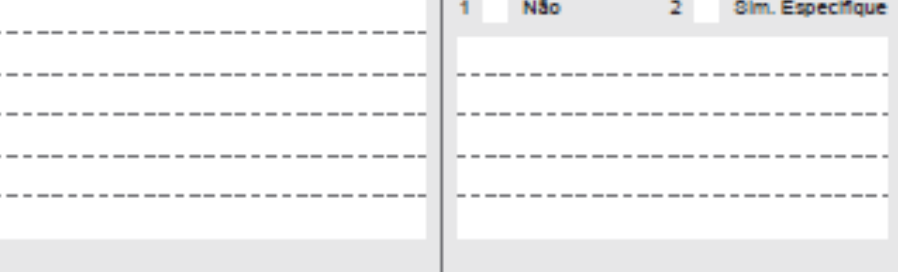
de protessores para as turmas do ensino fundamental que serlo aubmetdas a avalaçlo

20. Ao inicio do ano letivo, qual e o principal criterio para diatribuir os professores dos projetos de correç\$o de fluro nas stries em que vilo atuar?

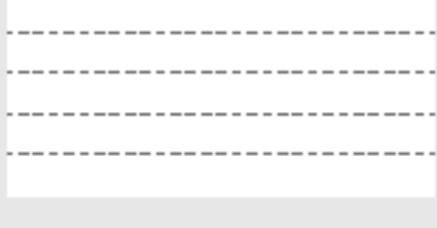

21. A seguir eatlo alguna ltens que se referem so trabaho de geatso da escols. Indlque a frequencla das seguintes atividades no trabaho do dretor de sus eacols: Frequentemente As vezes Faramente Nunca

21.10 direbor assiate ts aulas (ou parte delas)

21.10 dretor ds sugestles aos professores sobre como eles podem melhorar suss aulas.

21.10 diretor avala o trabaho dos professores.

21.10 dretor montora os resultados doa alunos.

1.

21.1 Quando um professor tem probiemas em sua classe, o direbor toma a iniclativa de discuatro probiems.

21.1 Quando um professor leva um problema sobre sus classe a dreçlo escolar, este et resolvido com a sua participaçso.

21.10 direbor desta escols deira claro para os professores o que e esperado de seu trabalho.

21.10 dretor desta escols oferece suporte indlvidual sos professores.

21.10 direbor desta escola $\approx$ preocupa com o bem estar doa professores.

21.10 direbor desta escola me encorala a meihorar o meu trabaino em sala de aja.

21.1 0 direbor desta escola me encorala a meihorar o meu trabaino em sala de aula.
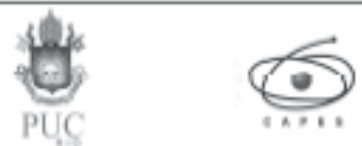


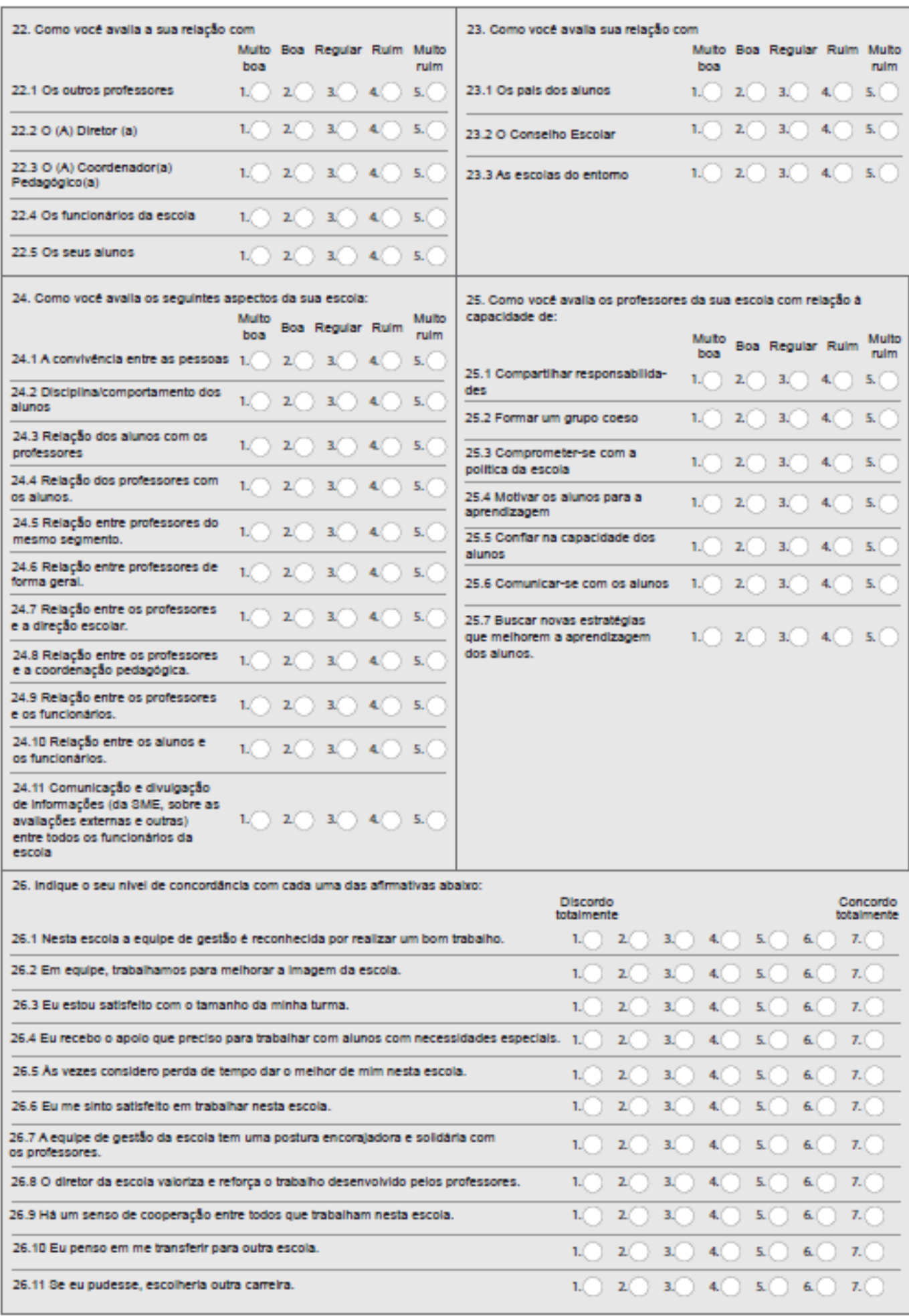


27. Em sua opiniso, qual te o principal papel da eacola na rociedade?

Ac quecteec que ce ceguem ce referem ao perfil coolo-demografloo doc profeccorec.

28. Vocte:

Homem

2 Mulher

29. Marque a opç5o que determina sua tåxa etaria:

1 Ate 24 anos 4 De 40 a 49 anos

2 De 25 a 29 anos 5 De 50 a 54 anos

3 De 30 a 39 anos 6 anos ou male

30. Gual to seu grau mtrimo de escolarzaçso conciuldo?

1 ensino fundamental 5 cureonomal de nivet \begin{tabular}{l|l|l} 
B mestrado & $\begin{array}{l}\text { 31. Caso tenha felto enaino } \\
\text { superior, em que tpo de insthu- }\end{array}$
\end{tabular}

2 ensino medo

curso normal de nivel
superior

ensino medlo 6 ensino superior

10 pos-doutorado

3 curso normal de nivel med çlo $x$ graduou?

4 ensino medlo tecnico ça do

\begin{tabular}{l|l} 
32. Caso tenha feto enaino & 33. Quals drociplinas voct lecions atusimente nesta escols?
\end{tabular}

superior, voct se graduou en

curso de:

1 Pedspogla

2 Ucenciatura

3 Outros

1. Todas as digciplinge

(professor pollvalente dos anos iniciala do ensino

fundsmenta?

2 Lingua Portuguesa ianos finals do enaino fundamenta)

3 Matematica (anos finala do ensino tundamental)

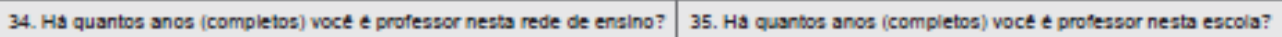

1 Menos de 1 ano. 4 De 7 a 9 anos $\quad 1$ Menos de 1 ano. 4 De 7 a anos

2 De 1 a 3 anos 5 De 10,14 anos

3 De 4 a 6 anos 6 Mals de 15 anos

\begin{tabular}{l}
5 \\
6 De 10 a 14 anos \\
\hline Mals de 15 anos
\end{tabular}

36. De que forma voct fol alocado nesta escola?

1 Indlcaçlo da CRE

2 minha solicitaçlo

3 solleitaçlo do diretor

4 realocaça

5 Outras (especinque)

2 De 1 a 3 anos

5 De 10 a 14 anoe

3 De 4 a 6 anos 6 Mas de 15 anos \begin{tabular}{l|l}
$\begin{array}{l}\text { 37. Qual e o seu regime de } \\
\text { trabalho nesta escola? }\end{array}$ & $\begin{array}{l}\text { 38. Cual e a sua carga horaria } \\
\text { semanal de trabaino nesta escola? }\end{array}$
\end{tabular} \begin{tabular}{l|l|l|l|l|}
1 & Professor concursado & $20 \mathrm{~h}$
\end{tabular}

realocagaso

2 Contrato temporario

2 ate 30 h

1 ate $40 h$

2 mas de 4 ah

39. Em sua jornads de trabalho nesta escola esta prevista carga hordris remunerada para a realzaclo de reuniles com a equipe gestora eiou professores da escols?

$1 \quad 3 \mathrm{~m}$ 2 NSo

20.Voct possul outro cargo de professor?

41. Em sua opiniso, qual to malor desaflo do traba/ho na coordenaç, to pedsgogica?

42. Agradecemos a sua participaç̧o!

Caso queira reglatrar algum comentario sobre eate questionario ou acreacentar alguma informaçbo que julgue importante, uflize o espaço abalivo.

$\ln$

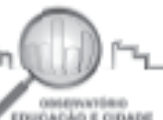

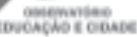

Quectionario do Protececor - 2014

GEsQ - Gectso o Qualldade da Edusaghsol PUC-Flo 


\section{Anexo 13}
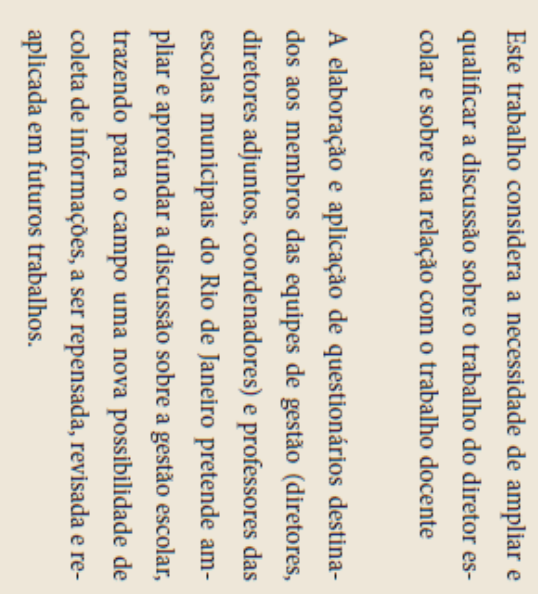

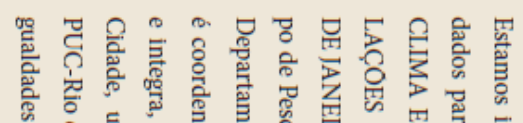

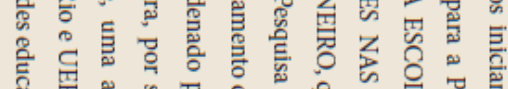

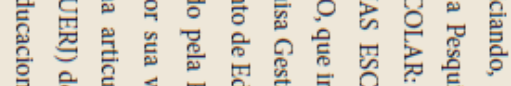

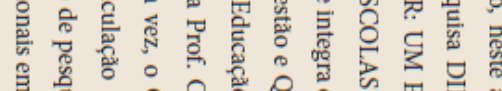

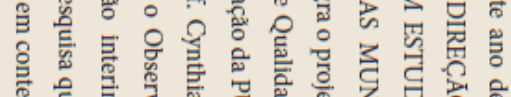

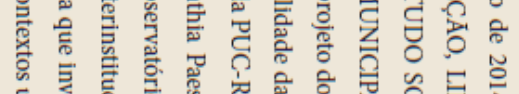

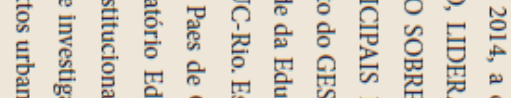

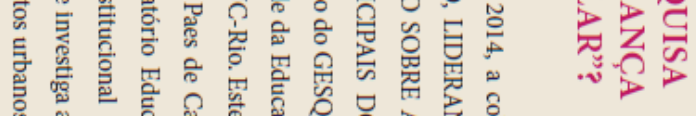

ㅍำ

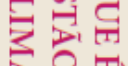

50 전

范藏

음용

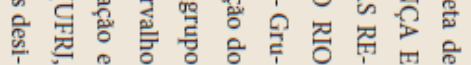

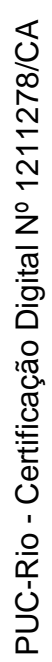
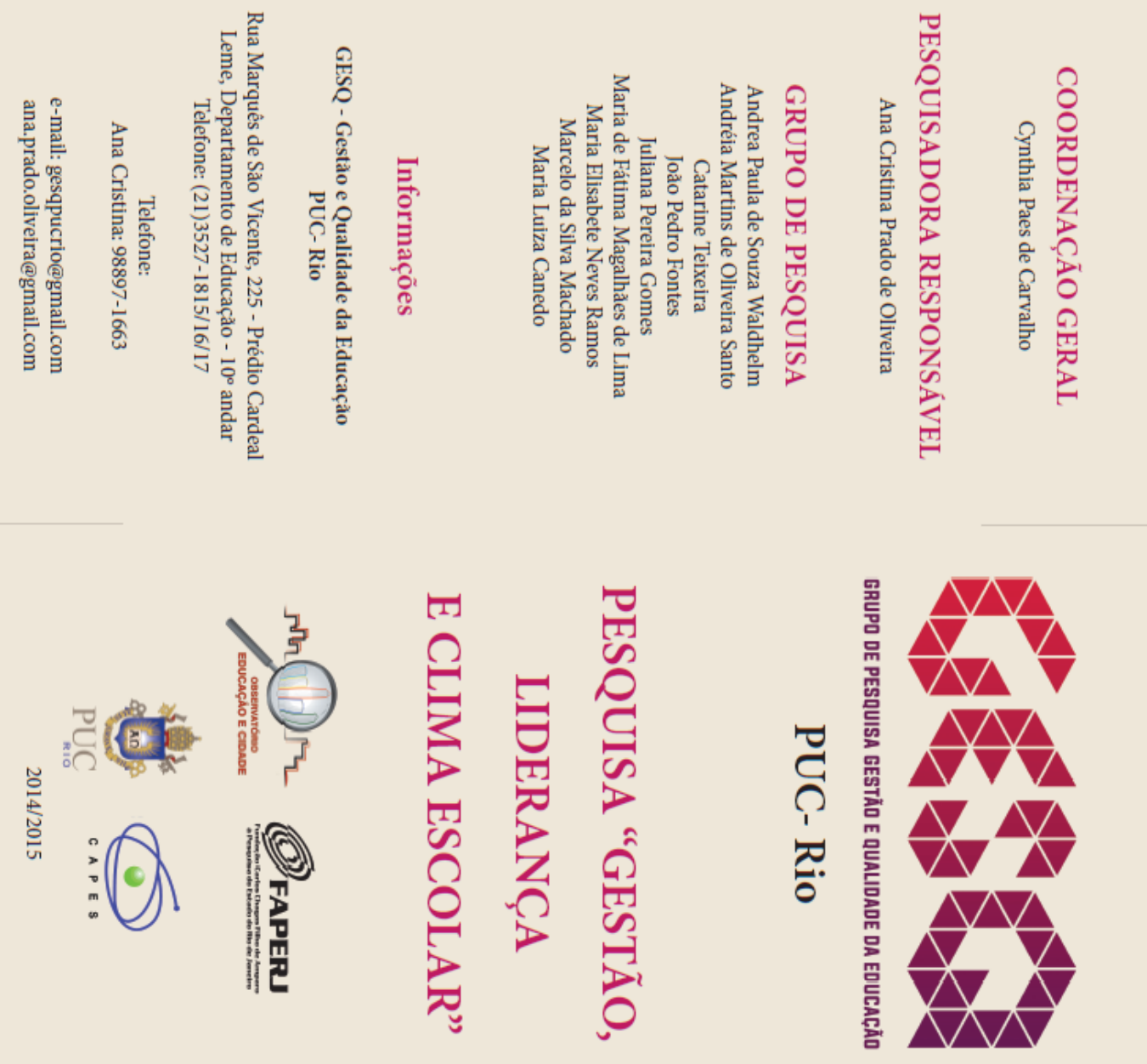

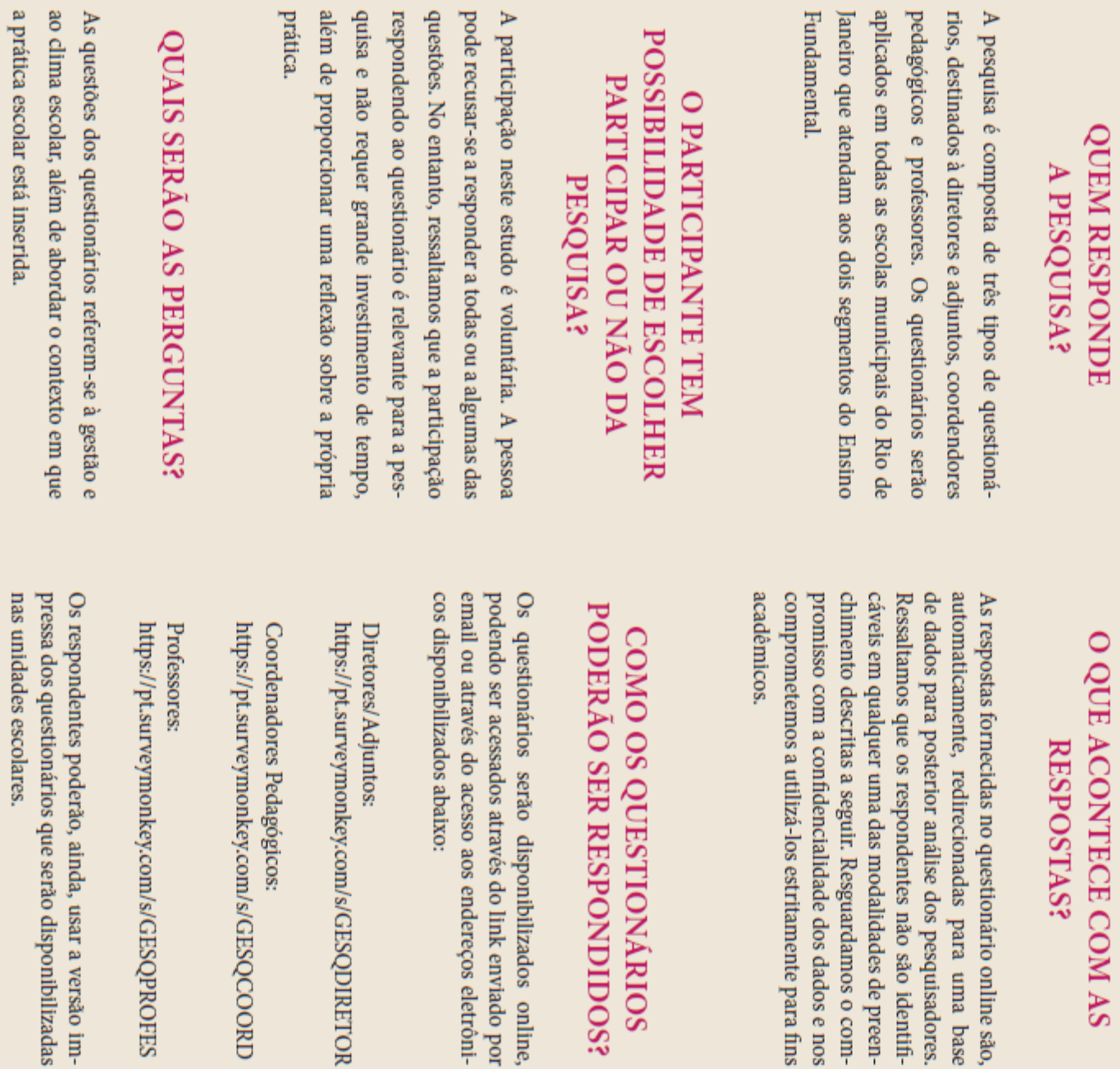

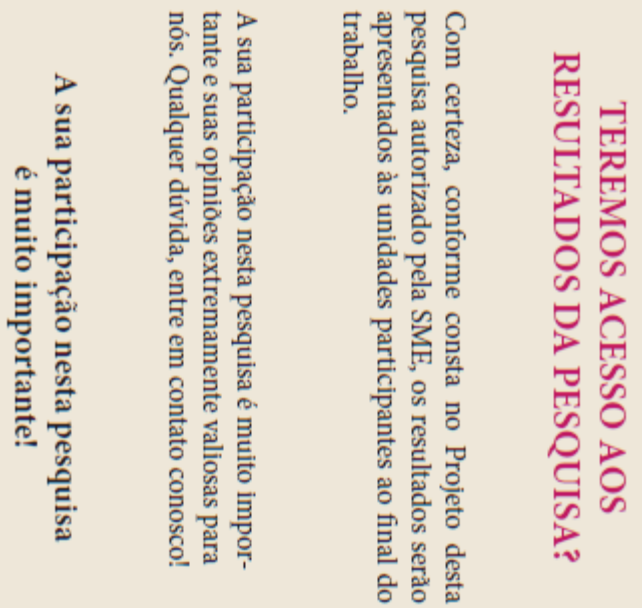

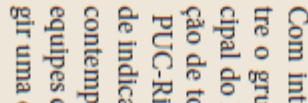

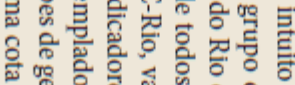

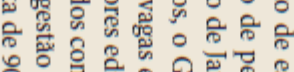

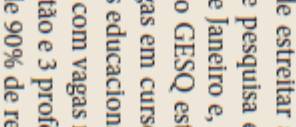

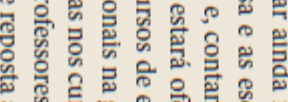

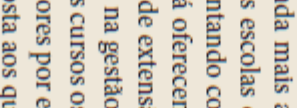

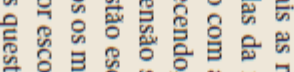

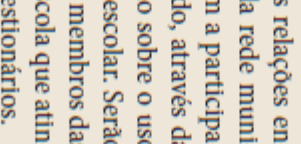

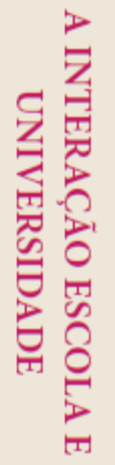

